\author{
UNIVERSIDADE DE SÃO PAULO \\ ESCOLA DE ENGENHARIA DE SÃO CARLOS \\ DEPARTAMENTO DE GEOTECNIA
}

ARTHUR COUTO MANTESE

\begin{abstract}
ANÁLISE DO COMPORTAMENTO DA FUNDAÇÃO DAS ESTRUTURAS DE CONCRETO DE UMA BARRAGEM SOBRE METACALCÁRIOS/ METASILTITOS E DRENOS DE FUNDAÇÃO COM INTENSA CARBONATAÇÃO - ESTUDO DE CASO
\end{abstract}

SÃO CARLOS 



\section{Análise do comportamento da fundação das estruturas de concreto de uma barragem sobre metacalcários/ metasiltitos e drenos de fundação com intensa carbonatação - estudo de caso}

\section{Versão Corrigida}

Original encontra-se disponível na unidade que aloja o programa

Dissertação apresentada ao Programa de Pós Graduação em Geotecnia da Escola de Engenharia de São Carlos, da Universidade de São Paulo, para obtenção do título de Mestre em Ciências.

Área de concentração: Geotecnia

Prof $^{\circ}$. Dr. Lázaro Valentin Zuquette 


\begin{abstract}
AUTORIZO A REPRODUČ̃̃O TOTAL OU PARCIAL DESTE TRABALHO, POR QUALQUER MEIO COONVENCIONAL OU ELETROONICO, PARA FINS DE ESTUDO E PESQUISA, DESDE QUE CITADA A FONTE.
\end{abstract}

Ficha catalográfica elaborada pela Biblioteca Prof. Dr. Sérgio Rodrigues Fontes da EESC/USP com os dados inseridos pelo(a) autor(a).

Mantese, Arthur Couto
M291a ANÁLISE DO COMPORTAMENTO DA FUNDAÇĀo DAS

ESTRUTURAS DE CONCRETO DE UMA BARRAGEM SOBRE

METACALCÁRIOS/ METASILTITOS E DRENOS DE FUNDAÇÃO COM

INTENSA CARBONATAÇÃo - ESTUDO DE CASO / Arthur Couto

Mantese; orientador Lázaro Valentin Zuquette. São

Carlos, 2021.

Dissertação (Mestrado) - Programa de

Pós-Graduação e Área de Concentração em Geotecnia --

Escola de Engenharia de Säo Carlos da Universidade de São Paulo, 2021.

1. Barragem de concreto. 2. Fundaçăo de barragem. 3. Carbonatação de drenos. 4. Metacalcário. 5.

Metassiltito. I. Título.

Eduardo Graziosi Silva - CRB - 8/8907 


\section{FOLHA DE JULGAMENTO}

Candidato: Engenheiro ARTHUR COUTO MANTESE.

Título da dissertação: "Análise do comportamento da fundação das estruturas de concreto de uma barragem sobre metacalcários/metasiltitos e drenos de fundação com intensa carbonatação - estudo de caso".

Data da defesa: 24/09/2021.

Comissão Julgadora

Resultado

Prof. Titular Lázaro Valentin Zuquette

Aprovado

(Orientador)

(Escola de Engenharia de São Carlos/EESC-USP)

Profa. Dra. Katia Vanessa Bicalho

Aprovado

(Universidade Federal do Espírito Santo/UFES)

Profa. Dra. Denise Balestrero Meneze

Aprovado

(Universidade Federal de São Carlos/UFSCar)

Coordenadora do Programa de Pós-Graduação em Geotecnia:

Profa. Associada Valéria Guimarães Silvestre Rodrigues

Presidente da Comissão de Pós-Graduação:

Prof. Titular Murilo Araujo Romero 



\section{AGRADECIMENTOS}

Agradeço primeiramente a Deus por me guiar, me dar sabedoria, força e perseverança para que pudesse realizar este trabalho.

À minha família, em especial à minha mãe por ser o centro, a força, o amor. Ao meu pai (in memoriam), ao lembrar dos seus olhos brilhando ao comemorar nossas conquistas, aos meus irmãos Evandro e Gabriel, por compartilhar os momentos e o crescimento, à Ana, pela força, coragem e motivação para melhorar a cada dia e ao recém-chegado sobrinho Pedro, por trazer mais alegria para nossa família.

Ao meu orientador Prof. Lázaro pela disposição, orientação, paciência e compreensão ao longo da jornada, a qual em grande parte foi à distância devido à pandemia. À Prof ${ }^{a}$ Kátia Bicalho e ao Prof ${ }^{\circ}$ Rogério Ribeiro pelas sugestões apresentadas no exame de qualificação.

Aos professores, funcionários e colegas do Departamento de Geotecnia da Escola de Engenharia de São Carlos, da Universidade de São Paulo, EESC-USP, pelos conhecimentos, trocas de experiência e ajuda de sempre durante o mestrado.

Ao Engenheiro João Francisco A. Silveira, pela oportunidade desde o estágio, e pelos valiosos ensinamentos na área de instrumentação e auscultação de barragens ao longo de quase 10 anos.

À CPFL por incentivar a qualificação e o desenvolvimento, em especial aos colegas da área de Segurança de Barragens e O\&M. Aos amigos de Taquaritinga e de São Carlos, dos tempos de universidade, pelas alegrias e por todos os momentos compartilhados. 

"Palco iluminado... Roupas coloridas... É mais um show... Que eu faço sem ... Você" 



\section{RESUMO}

MANTESE, A. C. Análise do comportamento da fundação das estruturas de concreto de uma barragem sobre metacalcários/ metasiltitos e drenos se fundação com intensa carbonatação - estudo de caso. 2021. 262p. Dissertação (Mestrado em Geotecnia) - Escola de Engenharia de São Carlos, Universidade de São Paulo, São Carlos, 2021.

As barragens estão relacionadas ao crescimento e ascensão das civilizações, com elevado potencial de risco devido à possibilidade de ruptura e consequências catastróficas. O monitoramento das barragens e suas fundações permite a detecção de eventuais anomalias/ocorrências. O presente estudo analisou o comportamento das fundações das estruturas de concreto da Barragem Principal da PCH Mata Velha, no rio Preto, estado de Minas Gerais, tendo como motivação as observações junto aos drenos de fundação: altas vazões durante o enchimento do reservatório, seguida de rápida redução e intensa deposição de carbonato nos drenos, sem reflexo nas subpressões. Foram analisadas as características e o tratamento da fundação, os dados dos instrumentos de auscultação, realizando-se a avaliação e testes nos drenos de fundação, o monitoramento das águas e a análise paramétrica de estabilidade. $\mathrm{O}$ maciço rochoso de fundação pode ser inserido em um contexto cárstico e as observações no período de operação podem estar associadas a uma ou mais ocorrências, destacando-se: i- piezômetros afetados pela carbonatação; ii- "fechamento" dos caminhos preferenciais de percolação (d processo de carbonatação/colmatação da fundação ou deposição de sedimentos finos no reservatório); iii- ocorrência de novos caminhos de percolação, com eventual carreamento de finos de preenchimento das descontinuidades/juntas da fundação e ou dissolução. Os resultados dos estudos de estabilidade demonstram a influência da cortina de drenagem no alívio das subpressões e a importância em mantê-la operante/eficiente, assim como a sensibilidade em termos de variação dos parâmetros geomecânicos das juntas de alívio do maciço de fundação. O monitoramento ao longo do tempo e a realização de eventuais estudos complementares ainda são necessários para melhor entendimento do comportamento das estruturas.

Palavras-Chave: Barragem de concreto, fundação de barragem, carbonatação de drenos, metacalcário, metassiltito. 



\begin{abstract}
MANTESE, A. C. Analysis of the behavior of the concrete structure foundation of a dam on metalimestones /metasiltites and foundation drains with intense carbonation - case study. 2021. 262p. Master Thesis, School of Engineering of Sao Carlos, University of Sao Paulo, Sao Carlos, 2021.

Dams are related to the growth and rise of civilizations, with high risk potential due to the possibility of rupture and catastrophic consequences. The monitoring of dams and their foundations allows the detection of eventual anomalies/occurrences. The present study analyzed the behavior of the foundations of the concrete structures of the Main Dam of the SPP Mata Velha, in Rio Preto, state of Minas Gerais, as a function of the observations in the foundation drains: high flows during the filling of the reservoir, followed by rapid reduction and intense deposition of carbonate in the drains, with no effect on subpressures. The characteristics and treatment of the foundation were analyzed, as well as the data from the auscultation instruments, carrying out the evaluation and tests in the foundation drains, the monitoring of the waters and the parametric stability analysis. The foundation on rock mass can be inserted in a karstic context and observations in the period of operation can be associated with one or more occurrences: i- piezometers affected by carbonation; ii- "closure" of the preferential percolation paths (carbonation process / filling of the foundation or deposition of fine sediments in the reservoir); iii- occurrence of new percolation paths, with eventual carriage of fines filling of discontinuities/foundation joints and/or dissolution. The results of the stability studies demonstrate the influence of the drainage curtain in the relief of subpressures and the importance of keeping it operational/efficient, as well as the sensitivity in terms of variation of the geomechanical parameters of the relief joints in the foundation massif. Monitoring over time and carrying out any additional studies are still needed to better understand the behavior of structures.
\end{abstract}

KEYWORDS: Concrete dam, dam foundation, drain carbonation, metalimestone, metasiltstone. 



\section{LISTA DE FIGURAS}

Figura 1 - Evolução do cadastro de barragens.

Figura 2 - Uso principal das barragens no Brasil submetidas à Política Nacional de Segurança de Barragens - PNSB

Figura 3 - Evolução da quantidade de regulamentos emitidos sobre segurança de barragens.40

Figura 4 - Distribuição regional de barragens considerando a altura (m). 43

Figura 5 - Barragens de terra. 48

Figura 6 - Barragem do Vigário (Terzaghi), Piraí RJ. 48

Figura 7 - Barragem Jati - Barragem de terra zoneada, construída com saprolito compactado (a montante e jusante) e núcleo de solo saprolítico compactado.

Figura 8 - Barragens de enrocamento.

Figura 9 - Foto mostrando o uso dos materiais de transição em barragem de enrocamento com núcleo de argila, nas proximidades das estruturas de concreto. .50

Figura 10 - Vista aérea da barragem de Campos Novos. ...........................................................51

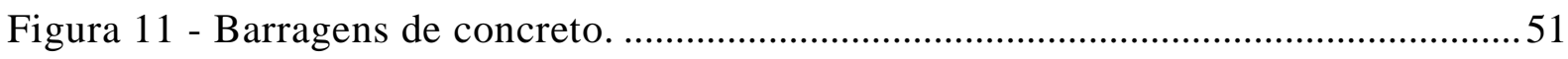

Figura 12 - Vista da PCH Americana - barragem de concreto gravidade. .............................52

Figura 13 - Barragem em Gravidade Aliviada - UHE Itaipu Binacional, PR.........................53

Figura 14 - Barragem principal do tipo gravidade aliviada da UHE Itaipu. ...........................54

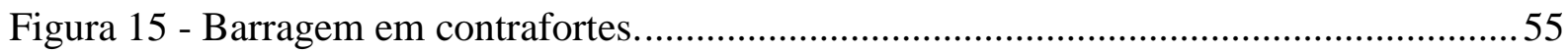

Figura 16 - Barragem em Contraforte Trecho D - UHE Itaipu Binacional, PR......................55

Figura 17 - Praça Típica da Construção da Barragem em CCR da UHE Castro Alves, RS. ...56

Figura 18 - Barragem de Caraíbas em Gravidade em CCR. .................................................56

Figura 19 - Barragem em arco Glen Canyon Dam............................................................57

Figura 20- Barragem em Arco, Karun-3 Dam, Irã: a) Paramento de montante; b) Paramento de

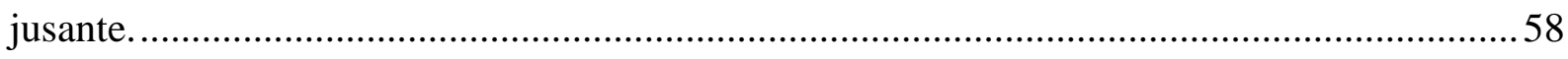

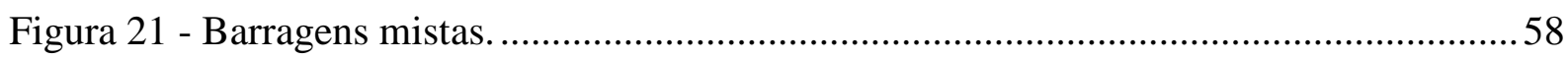

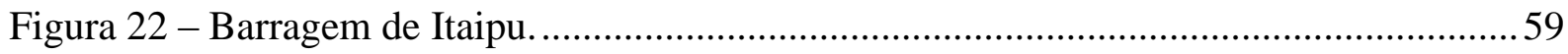

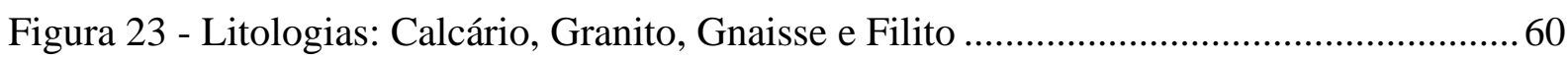

Figura 24 - Estruturas planares favoráveis e desfavoráveis considerando uma seção transversal

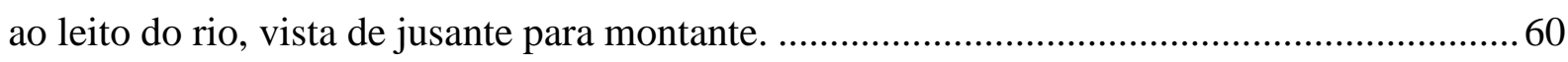

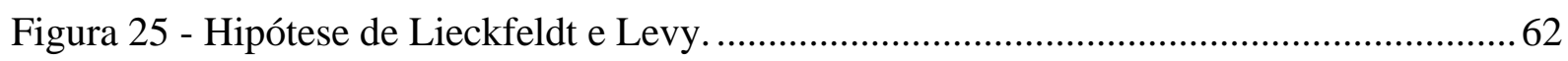

Figura 26 - Drenos de alívio e injeções a partir da galeria de drenagem. ................................65 
Figura 27 - Comparação das subpressões em 3 barragens com injeção e sem drenagem........66

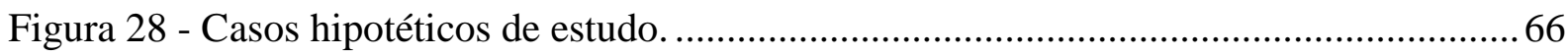
Figura 29 - Comparação das subpressões nas Barragens de Wheeler, Wilson e Fontana.........67 Figura 30 - Subpressões considerando: (a) Apenas injeção, (b) Apenas drenagem, (c) Injeção e

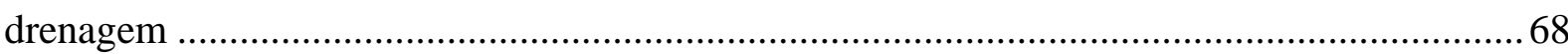

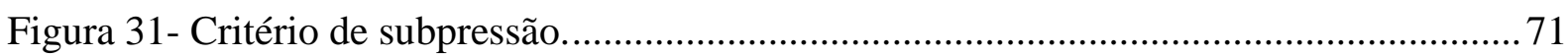

Figura 32 - Subpressões (a) No contato das estruturas de concreto com a fundação, (b) Com contato aberto, (c) Com uma linha de drenos operantes, (d) com drenos inoperantes. .72 Figura 33 - Representação de corpo rígido de estrutura complexa: a) Vista em corte da estrutura a ser analisada; b) Fundação de estrutura rígida; c) Diagrama de corpo livre para o método de

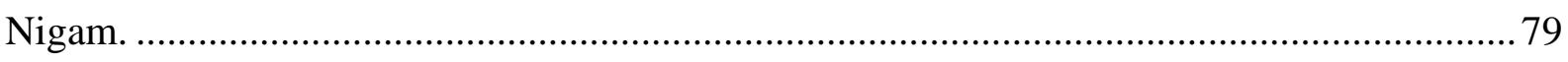

Figura 34 - Acidente/Ruptura Barragem de Bouzey ............................................................ 84

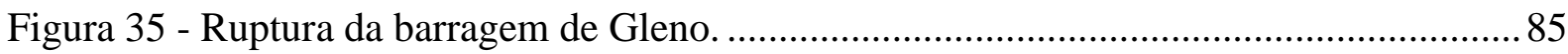

Figura 36 - Vista geral da Barragem de Malpasset antes da ruptura....................................... 86 Figura 37 - Seção transversal da barragem e fundação na altura média do lado esquerdo: a pressão hidrostática total na fundação da barragem criada pela barragem em arco pode empurrar o diedro para cima ao longo da falha.....

Figura 38 - Fases da falha na vista a jusante e no perfil A-A. (1) a água penetra na fissura de tração ao longo do contato Concreto/Rocha a montante; (2) o diedro da fundação é empurrado ao longo da falha, para cima e para a direita; (3) todo o impulso do arco concentra-se no bloco, que não pode suportar e rompe; (4) o efeito do arco é interrompido e rompe; (5) e (6) os blocos da margem direita falham por flexão.

Figura 39- Estrutura remanescente da Barragem de Malpasset, .......................................... 88

Figura 40 - Detalhe da ombreira esquerda após falha. ....................................................... 88

Figura 41 - Vista da região da ombreira esquerda, após ruptura da Barragem de Camará. .... 89

Figura 42 - Vista após desmoronamento do "arco" da Barragem de Camará. ......................... 89

Figura 43 - Interpretação da falha da ombreira esquerda na fase de projeto. ...........................90

Figura 44 - Esquema da falha na ombreira esquerda e projeção da zona de cisalhamento.....91 Figura 45 - Esquema com injeções de cimento complementares ao tratamento da falha da ombreira esquerda, notando-se também o muro de proteção em concreto.

Figura 46 - Zona de cisalhamento na ombreira esquerda. a) Vista do orifício preenchido com solo residual; b) Vista após execução da solução proposta para contenção............................. 92

Figura 47 - Representação esquemática do modelo geológico do local da barragem..............92 
Figura 48 - Esquema representando a laje de rocha acima da zona de cisalhamento (falha da OE) em vista frontal e em seção transversal. Indicam-se também o NA da percolação na falha e as forças atuantes na laje superior.

Figura 49 - Vista aérea da Barragem de Zeuzier, na Suíça. .................................................. 95

Figura 50 - Barragem de Zeuzier - Deslocamentos observados. ......................................... 95

Figura 51 - Galeria de investigação do túnel rodoviário próximo à Barragem Zeuzier. .........96

Figura 52 - Relações entre instrumentação e a deterioração observada na barragem..............97

Figura 53 - Etapas de confecção e instalação de piezômetro "standpipe"................................99

Figura 54 - Esquema de instalação de dois piezômetros em um mesmo furo de sondagem a

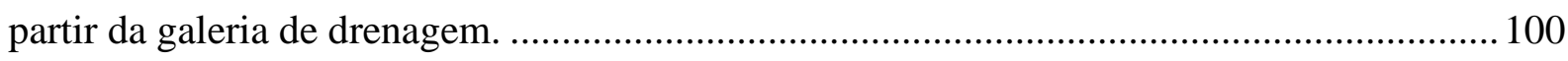

Figura 55 - Medidor tipo triortogonal de junta e orientação dos respectivos eixos. .............. 108

Figura 56 - Exemplo de um perfil típico de um extensômetro múltiplo de haste................... 110

Figura 57 - Localização dos extensômetros da UHE Tucuruí. ................................................111

Figura 58 - Síntese da dissolução do carbonato de cálcio em água. ...................................... 114

Figura 59 -Relação entre o $\mathrm{CaCO}_{3}$ e o pH.................................................................... 115

Figura 60 - Vista aérea das Barragens de Monte Claro e Castro Alves............................... 120

Figura 61 - Profundidade dos drenos da UHE Monte Claro - Antes da limpeza. .................. 121

Figura 62 - Porcentagem das etapas de limpeza.............................................................. 121

Figura 63 - Vista aérea do barramento da PCH Mata Velha.................................................. 122

Figura 64 - Porção do Mapa geológico de Minas Gerais e estratigrafia da região da PCH na

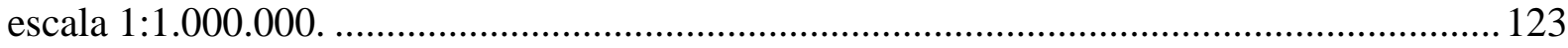

Figura 65 - Aspecto da rocha com intercalação de meta siltito e calcário no leito do rio de

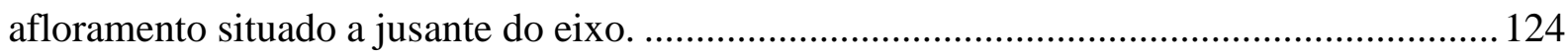

Figura 66 - Mapa Geológico-Geotécnico do local do aproveitamento. ................................. 126

Figura 67 - Planta de locação das sondagens e seções geológico-geotécnicas ...................... 127

Figura 68 - Seções geológico geotécnica da barragem de concreto “como construído"........ 128 Figura 69 - Seções geológico geotécnica da margem esquerda e casa de força "como construído".

Figura 70 - Sondagem rotativa SR-103 na seção da Tomada d'Água, com indicação da numeração das caixas (1 a 8) e divisões geológicas/geotécnicas (A a D) obtidas do log de sondagem.

Figura 71 - Diagrama de contorno dos pontos polares dos planos das estruturas presentes nas superfícies escavadas. Ao lado as concentrações das isolinhas. A seta indica a atitude média das 
juntas de alívio.

Figura 72 - Localização das seções em que foram extrapoladas as juntas de alívio na fundação das estruturas de concreto

Figura 73 - Seção modelo estaca 3+15,00 m . 134

Figura 74 - Escavação na região da Tomada de Água (T.A.) e Casa de Força (C.F.): a) T.A. Vista geral; b) T.A. - Mergulho para jusante e juntas fechadas; C.F. - Juntas com mergulho para jusante; d) C.F. - Detalhe de Zona Cisalhada a montante 134 Figura 75 - Seção modelo estaca 5+15,00 m 135 Figura 76 - Escavação na região dos Blocos 4 e 5: a) Vista em direção a jusante com escavação em expondo as superfícies planas das juntas; b) Vista em direção à ombreira direita com escavação em degraus (sentido do Leito do Rio) e juntas com paredes justapostas e sãs...... 135 Figura 77 - Seção modelo estaca 6+7,50 m. 136 Figura 78 - Escavação na região do Vertedouro: a) Vista geral; b) Junta horizontal com contato rocha-rocha fechado c) Junta horizontal com material fragmentado; d) Trecho com mergulho para jusante; e) Junta horizontal com zona cisalhada, com material pétreo; f) Talude Esquerdo da fossa de erosão com jusante onduladas e mergulho médio para jusante. 137 Figura 79 - Seção geológica-geotécnica com extrapolação das juntas de alívio da fundação

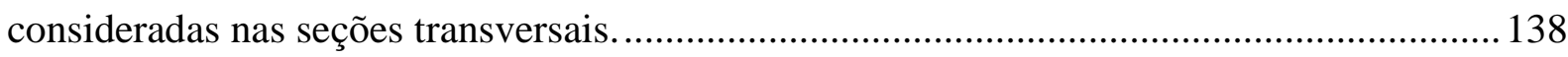

Figura 80- Planta esquemática da PCH Mata Velha............................................................. 139

Figura 81 - Seção típica da barragem de concreto compactado a rolo - CCR....................... 140

Figura 82 - Seção típica da barragem de terra/enrocamento 140

Figura 83 - Planta e Corte das estruturas de concreto com locação dos drenos de fundação a partir da galeria de drenagem da Barragem Principal 142

Figura 84 - Fluxograma das atividades a serem desenvolvidas 143

Figura 85 - Leitura de vazão empregando-se o recipiente graduado. 145 Figura 86 - Medição de nível d'água e profundidade dos drenos de fundação. a) realização de leitura. b) Detalhe do sensor de nível d'água empregado, com torpedo metálico na extremidade inferior. 146

Figura 87 - Foto aérea com localização dos pontos de coleta de água. Os drenos de fundação da barragem (DR) estão localizados na galeria de drenagem.

Figura 88 - Detalhe típico do tratamento superficial rigoroso.

Figura 89 - Vista da escavação na região da margem direita. 150

Figura 90 - Fundação da barragem de CCR da margem direita e local com pequena caverna, 
nas proximidades da El. 620,00 m.

Figura 91 - Detalhe da pequena caverna $(\sim 50 \mathrm{~cm})$, característica de regiões cársticas.

Figura 92 - Limpeza e preparo de fundação na região da tomada d'água.

Figura 93 - Vista da limpeza da fundação e região de regularização (seta) do vertedouro.... 151

Figura 94 - Concreto de regularização da fundação da barragem margem direita.

Figura 95 - Vista da região da margem direita com fundação já regularizada.

Figura 96 - Vista da barragem a partir da margem direita, com lançamento do CCR.

Figura 97 - Esquema de injeção de calda de cimento: a) Impermeabilização em linha tripla; b) Impermeabilização em linha única; c) Consolidação.

Figura 98 - Seções típicas das estruturas com as linhas de injeção triplas e de consolidação, na região da ombreira direita e tomada d'água.

Figura 99 - Injeções de calda de cimento na margem direita: a) Trecho regularizado com furos das injeções de consolidação. d) Injeção de consolidação por gravidade. c) Execução de furos. d) Injeção de calda de cimento de impermeabilização sob pressão.

Figura 100 - Resultados das injeções da fundação. a) Consumo dos furos de consolidação na margem direita (em cores). b) Seção longitudinal com consumo dos furos de impermeabilização (linha de injeção mais a montante)

Figura 101 - Sobreposição dos consumos de cimento dos furos de injeção de impermeabilização de montante em relação à seção geológico-geotécnica. 158 Figura 102 - Sobreposição das juntas inferidas na fundação à seção longitudinal com os dos consumos de cimento dos furos de injeção de impermeabilização de montante. 159

Figura 103 - Seção longitudinal e plano de instrumentação da barragem de concreto. 161

Figura 104 - Seção típica e posicionamento dos instrumentos. 162

Figura 105 - Seção típica com locação dos piezômetros 163 Figura 106 - Vista do terminal dos piezômetros antes do enchimento, com várias conexões e apenas um manômetro para leitura de quatro piezômetros. 164 Figura 107 - Gráfico das leituras dos piezômetros localizados no Bloco B-4 da barragem de concreto durante o enchimento do reservatório. Em tracejado são indicadas as projeções possíveis das subpressões

Figura 108 - Exemplo dos tipos de leituras utilizadas nos piezômetros 165

Figura 109 - Gráfico das leituras dos piezômetros localizados no Bloco B-3 da barragem de concreto. 166

Figura 110 - Comparação entre níveis piezométricos medidos (Abril/19) e Valores de Controle 
(Atenção e Alerta).

Figura 111 - Medidores de vazão afogados durante o enchimento do reservatório

Figura 112 - Gráfico das leituras dos Medidores de Vazão instalados na galeria de drenagem da barragem de concreto

Figura 113 - Condição do dreno de fundação do Dreno 25 da barragem de concreto: a) Abril/2016 (pós enchimento); b) Abril/2017; c) Outubro/2017; d) Fevereiro/2018 169

Figura 114 - Depósitos de carbonato nos drenos: a) Conexão de dreno de fundação 6 meses após enchimento; b) Detalhe da saída de dreno de fundação com o depósito de carbonato, cerca de 1 ano após o enchimento. c) e d) Dreno do depósito de carbonato nas paredes, abaixo do nível d'água.

Figura 115 - Foto aérea e local de instalação do medidor de vazão MV-4, para controle das infiltrações pelo talude de ombreira direita. 171

Figura 116 - Gráfico das leituras do Medidor de Vazão MV-4 instalado para controle da vazão pelo talude em rocha da ombreira direita. 172

Figura 117 - Medidor triortogonal instalado na junta entre blocos, a partir da galeria de drenagem

Figura 118 - Deslocamentos registrados junto ao medidor triortogonal de junta entre blocos MT-01, localizado na crista da barragem, na junta entre blocos B-1/B-2

Figura 119- Deslocamentos registrados junto ao medidor triortogonal de junta entre blocos MT03, localizado na galeria de drenagem na junta dos Blocos B-3/B-4. 174

Figura 120 - Deslocamentos registrados junto ao medidor triortogonal de junta entre blocos do MT-06 localizado na galeria de drenagem na junta dos Blocos B-6/B-7

Figura 121 - Esquema típico de instalação dos Extensômetros de Hastes a partir da galeria 176 Figura 122 - Detalhe das ancoragens, hastes e cabeça do extensômetro antes da instalação. 176 Figura 123 - Deslocamentos medidos pelo extensômetro de hastes EH-01.......................... 178 Figura 124 - Deslocamentos medidos pelo extensômetro de hastes EH-03. 178 Figura 125 - Deslocamentos medidos pelo extensômetro de hastes, com a haste "b" indicando compressão durante o período construtivo.

Figura 126 - Planta galeria de drenagem da Barragem Principal com a locação dos drenos. 181 Figura 127 - Dreno 33: a) antes do tamponamento com vazão; b) devidamente tamponado durante o teste. 181

Figura 128 - Seção transversal com locação dos piezômetros e da cortina de drenagem. ..... 183 Figura 129 - Variação dos níveis piezométricos de Bloco 3 da barragem de concreto no decorrer 
do teste de tamponamento.

Figura 130 - Gráfico comparativo das subpressões medida durante o teste de tamponamento dos drenos.

Figura 131 - Seção longitudinal com indicação das profundidades dos drenos e vazões. ..... 187

Figura 132 - Seção longitudinal da Barragem em CCR com locação dos instrumentos ........ 188 Figura 133 - Verificação das condições do dreno 19 -Bloco 4: a) Remoção do terminal e emaranhado de tela (seta); b) Detalhe do carbonato junto ao terminal; .c) Carbonato junto à tubulação abaixo do terminal (abaixo do piso). d) Carbonato em cerca de $1,1 \mathrm{~m}$, com os primeiros 0,55 m bastante consolidados; e) Detalhe do carbonato junto à tela; f) Detalhe do carbonato em tubulação a cerca de 2,5 $\mathrm{m}$ de profundidade.

Figura 134 - Verificação das condições dos drenos do Bloco 5: a) Dreno 23- Condições iniciais com carbonato nas paredes; b) Dreno 23- material coletado; c) Dreno 24 - vista a partir do topo do terminal. D) Dreno 24 - carbonato removido do terminal. E) Dreno 24 - carbonato junto à tela. F) Dreno 24 - Trecho da tubulação removido com 2,30 m, totalmente obstruída por carbonato.

Figura 135 - Verificação das condições dos drenos do Bloco 7:. a) Dreno 37 - limpeza com jato de água; b) Dreno 37 - detalhe do material coletado; c) Dreno 39 - material coletado; d) Dreno 39 - detalhe do material, com fragmento de maior tamanho.

Figura 136 - Drenos 35 e 36, observando redução em relação a Abril/2016 (enchimento)... 194 Figura 137 - a) Sistema desenvolvido com talha elétrica para remoção da tubulação interna dos drenos. b) Boroscópio utilizado, Modelo END 23F50MHD. 195 Figura 138 - Seção longitudinal com indicação das profundidades dos drenos e vazões, medidas em Dez/2019 (Fase 1) e Set/2020 (Fase 2) 196 Figura 139 - Observações da remoção da tubulação do Dreno 10 - Bloco 3 da estrutura de concreto: a) Carbonato fechando a tubulação no trecho superior. b) trecho inferior da tubulação com carbonato junto às paredes. 198 Figura 140 - Observações da remoção da tubulação do Dreno 11- Bloco 3 da estrutura de concreto: a). Material branco e fino (seco) junto ao terminal, semelhante a cal. b) Material fechando a tubulação no trecho superior. c) Material de obstrução após remoção. d) Detalhe do material.

Figura 141 - Observações da remoção da tubulação do Dreno 23 - Bloco 5 da estrutura de concreto: a) Material junto à tela de nylon. b) Detalhe do material fino junto à tela. c)Carbonato internamente à tubulação. d) "Cap" inferior com material fino acinzentado 200 
Figura 142 - Observações da remoção da tubulação do Dreno 24 - Bloco 5 da estrutura de concreto: a) Carbonato junto à tela de nylon. b) Tubulação totalmente obstruída.

Figura 143 - Observações da remoção da tubulação do Dreno 25 - Bloco 5 da estrutura de concreto. a) Carbonato nas laterais bastante consolidado. b) Trechos com maior deposito de carbonato internamente

Figura 144 - Observações da remoção da tubulação do Dreno 38- Bloco 7 da estrutura de concreto: a) Vista geral e vazão. b) Detalhe das bolhas de ar. 202 Figura 145 - Observações da remoção da tubulação do Dreno 42 - Bloco 7 da estrutura de concreto: a) Tubulação travada, impossibilitando a remoção. b) Carbonato terminal. 202 Figura 146 - Observações da remoção da tubulação do Dreno 45 - Bloco 8 da estrutura de concreto: a) Tubulação sendo removida. b) Detalhe de material fino junto à tela de nylon. . 203 Figura 147 - Observações da remoção da tubulação do Dreno 47 - Bloco 8 da estrutura de concreto: a) Tubulação sendo removida. b) Detalhe do carbonato junto à tela. 203 Figura 148 - a) Tubulações removidas dos Drenos 45,43,49 e 48 (da esquerda para a direita). b) Detalhe das tubulações com material removido da tubulação do Dreno 48 . .204 Figura 149 - Registro da câmera endoscópica no Dreno 1, no Bloco 2 da estrutura de concreto: a) Indícios de carbonato junto às ranhuras internas da tubulação. b) Fundo do tubo com carbonato depositado. 205

Figura 150 - Registro da câmera endoscópica nos Drenos 14 e 17, no Bloco 4 da estrutura de concreto: a) Dreno 14 sem indícios de carbonato. b) Dreno 17 com algum material no fundo do tubo. .205

Figura 151 - Registro da câmera endoscópica nos Drenos 19 e 21, nos Blocos 4 e 5 da estrutura de concreto, após remoção da tubulação interna: a) Dreno 19 observando-se aspecto da rocha com material nas paredes. b) Dreno 21 aspecto da rocha.

Figura 152 - Registro da câmera endoscópica no Dreno 22 no Bloco 5 da estrutura de concreto. a) Trecho superior da tubulação. b) Carbonatação a cerca de 1,0 de profundidade. c) Intensa carbonatação a cerca de 1,6 m. d) Carbonatação impedindo a passagem do boroscópio, a cerca de $2,5 \mathrm{~m}$. 206

Figura 153 - Registro da câmera endoscópica no Dreno 23 no Bloco 5 da estrutura de concreto: a) Intensa carbonatação; b) Aspecto da rocha após remoção da tubulação. 206 Figura 154 - Registro da câmera endoscópica nos Drenos 24 e 27, nos Blocos 5 e 6 da estrutura de concreto: a) Dreno 24 após remoção da tubulação interna; b) Dreno 27 com indícios de carbonato junto às ranhuras internas da tubulação. .206 
Figura 155 - Registro da câmera endoscópica nos Drenos 28 e 33 no Bloco 6 da estrutura de concreto: a) Dreno 28 com material aparentemente de origem biológica; b) Dreno 33 com indícios de carbonato junto às ranhuras internas da tubulação. 207 Figura 156 - Registro da câmera endoscópica nos Drenos 36 e 37 no Bloco 7 da estrutura de concreto: a) Dreno 36 com intensa carbonatação; b) Dreno 37 com intensa carbonatação ... 207 Figura 157 - Registro da câmera endoscópica no Dreno 38 no Bloco 7 da estrutura de concreto: a) Presença de bolhas de ar e material junto às ranhuras; b) Formação de bolhas de ar a cerca de $12 \mathrm{~m}$ de profundidade, observando carbonatação nas ranhuras abaixo. 207 Figura 158 - Registro da câmera endoscópica no Dreno 40 no Bloco 7 da estrutura de concreto: a) Intensa cabonatação a cerca de 1,7 m de profundidade; b) Carbonação menos intensa a cerca de $10,2 \mathrm{~m}$. 208

Figura 159 - Registro da câmera endoscópica nos Drenos 44 e 45 no Bloco 8 da estrutura de concreto: a) Dreno 44 com indícios de carbonato junto às ranhuras internas da tubulação; b) Dreno 45 após remoção da tubulação. 208 Figura 160 - Registro da câmera endoscópica nos Drenos 46 e 48 no Bloco 8 da estrutura de concreto: a) Dreno 46 com carbonato em suspensão em função descida do boroscópio; b) Dreno 48 com carbonato. 208 Figura 161 - Registro da câmera endoscópica no Dreno 50 no Bloco 8 da estrutura de concreto: a) Trecho inicial do com carbonato; b) Material aparentemente de origem biológica, sem obstruir a tubulação, a cerca de 7,5 m.

Figura 162 - Amostras coletadas dos drenos, para eventual análise. 209 Figura 163 - Resultados das análises físico-químicas. a) pH. b) Temperatura. c) Condutividade. d) Oxigênio dissolvido. e) Sulfato Total. f) Sólidos dissolvidos

Figura 164 - Resultados das análises físico-químicas. a) Sólidos suspensos. b) Ferro total. c) Manganês total. d) Cálcio total. e) Ferro dissolvido. f) Ferro particulado. 216 Figura 165 - Resultados das análises físico-químicas. a) Manganês dissolvido. b) Manganês particulado. c) Cálcio dissolvido. d) Cálcio particulado. e) Sódio Dissolvido. f) Sódio particulado.

Figura 166 - Resultados das análises físico-químicas. a) Sódio total. b) Potássio dissolvido. c) Potássio particulado. d) Potássio particulado.

Figura 167 - Seção longitudinal geológica geotécnica e indicação das profundidades dos drenos e vazões (Medição Dez/2019) Fonte: Adaptado de Mata velha Energética S.A. (2016).......219 Figura 168 - Seção longitudinal com consumo dos furos de impermeabilização e indicação das 
profundidades dos drenos e vazões (Medição Dez/2019).

Figura 169 - Ações atuantes junto ao contato concreto/rocha para as condições de drenos inoperantes e operantes: a) e b) Tomada d'Água; c) e d) Barragem Margem Direita; e) e f) Vertedouro

Figura 170 - Ações atuantes no bloco da Tomada d'Água: a) Junta J4; b) Junta J5; c) Junta J6, drenos inoperantes; d) Junta J6, drenos operantes; e) Junta J7, drenos inoperantes; f) Junta J7, drenos operantes. 225 Figura 171 - Ações atuantes no bloco da Barragem da Margem Direita: a) Junta J1, drenos inoperantes; b) Junta J1, drenos operantes; c) Junta J2, drenos inoperantes; d) Junta J2, drenos operantes; e) Junta J3, drenos inoperantes; f) Junta J3, drenos operantes; 226

Figura 172 - Ações atuantes na fundação no Bloco do Vertedouro, junta J1 227 Figura 173 - Ações atuantes no bloco do Vertedouro: a) Junta J2, drenos inoperantes; b) Junta J2, drenos operantes; c) Junta J3, drenos inoperantes; d) Junta J3, drenos operantes; e) Junta J4, drenos inoperantes; f) Junta J4, drenos operantes; 228 



\section{LISTA DE TABELAS}

Tabela 1 - Ano de construção das barragens mais antigas em alguns países. ......................... 46

Tabela 2 - Orientação para análise de absorção de cimento nas injeções ...............................64

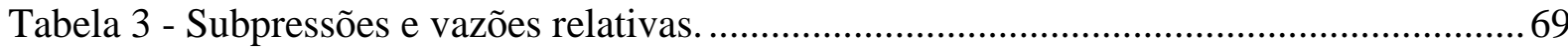

Tabela 4 - Fatores de Segurança ao Tombamento FST e Flutuação FSF................................. 76

Tabela 5 - Fatores de Redução da Resistência do Atrito e da Coesão FSD $ø$ e FSDc. ............. 76

Tabela 6 - Tensão admissível do concreto a compressão......................................................... 78

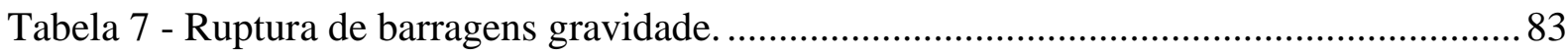

Tabela 8 - Vazões específicas em barragens dotadas de túneis de drenagem na fundação.... 104

Tabela 9 - Vazões específicas através de barragens de concreto nos E.U.A.......................... 105

Tabela 10 - Vazões específicas através de barragens de concreto no Brasil.......................... 105

Tabela 11 - Vazões específicas de barragens e estruturas de Concreto................................... 107

Tabela 12 - Deslocamentos diferenciais máximos observados entre blocos de barragens de concreto.

Tabela 13 - Quantidades de carbonato de cálcio solúvel em água (mg/l) em função da quantidade de dióxido de carbono livre $\left(\right.$ para $\mathrm{T}=17^{\circ}$ ) .................................................. 114

Tabela 14 - Quantidade de $\mathrm{CO}_{2}$ dissolvido na água (mg/l) em função da pressão parcial de $\mathrm{CO}_{2}$

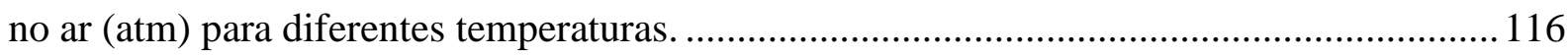

Tabela 15 - Observações em 100 barragens construídas em região cárstica......................... 117

Tabela 16 - Traços A/C e volumes empregados................................................................... 154

Tabela 17 - Registro das injeções: comprimento perfurado e consumo de cimento. ............. 156

Tabela 18 - Remoção de tubulação interna dos drenos......................................................... 197

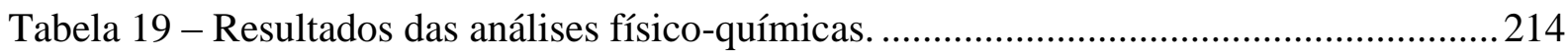





\section{LISTA DE QUADROS}

Quadro 1 - Classificação de Barragens........................................................................... 47

Quadro 2 - Cálculos das propriedades geométricas. .......................................................... 81

Quadro 3 - Tipos de medidores de vazão - mureta e triangular............................................ 102

Quadro 4 - Tipos de medidores de vazão - retangular e trapezoidal. .................................... 103

Quadro 5 - Compilação de dados de vazão observados em galerias de concreto. .................. 106

Quadro 6 - Lista de instrumentos instalados nas estruturas de concreto. .............................. 160

Quadro 7 - Síntese dos deslocamentos máximos medidos nos MTs até Abril/2019............. 175

Quadro 8 - Deslocamentos máximos dos Extensômetros de Hastes até Abril/2019.............. 179

Quadro 9 - Acréscimos máximos observados no decorrer do teste de tamponamento.......... 185

Quadro 10 - Resultados da análise de estabilidade pelo contato concreto/rocha ...................224

Quadro 11 - Resultados da análise de estabilidade pela fundação do bloco da Tomada de Água

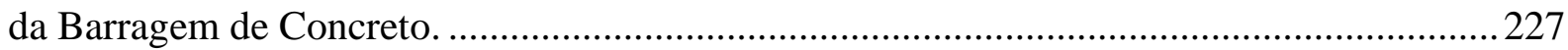

Quadro 12 - Resultados da análise de estabilidade pela fundação do bloco da Barragem da

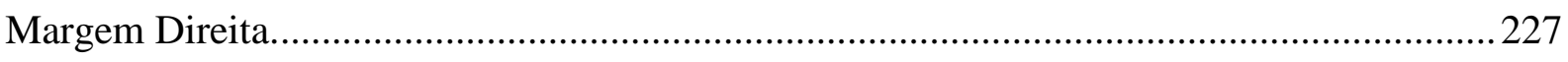

Quadro 13 - Resultados da Análise de estabilidade pela fundação do bloco do Vertedouro. 229 



\section{SUMÁRIO}

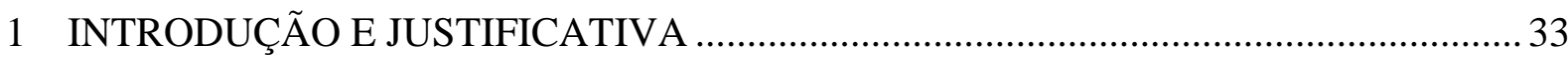

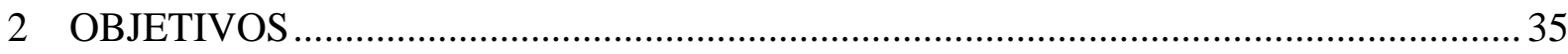

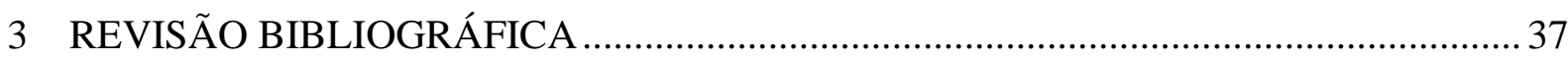

3.1 A POLÍTICA NACIONAL DE SEGURANÇA DE BARRAGENS .......................... 37

3.2 SEGURANÇA DE BARRAGENS E SUA EVOLUÇÃO NO CONTEXTO

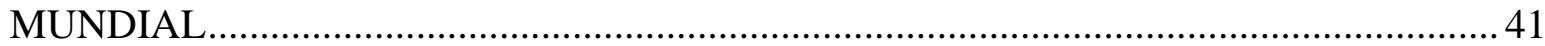

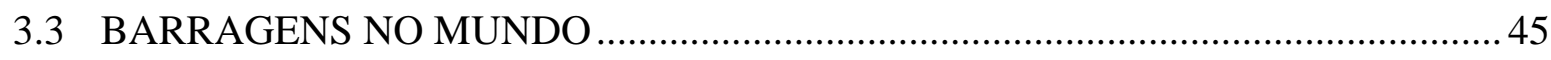

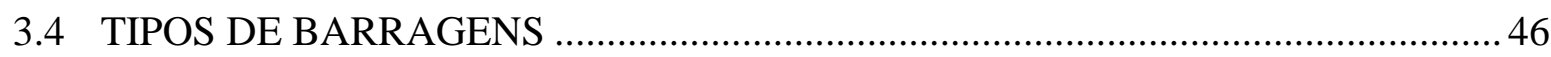

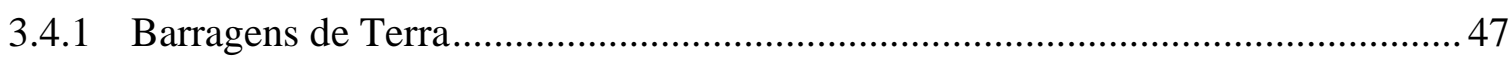

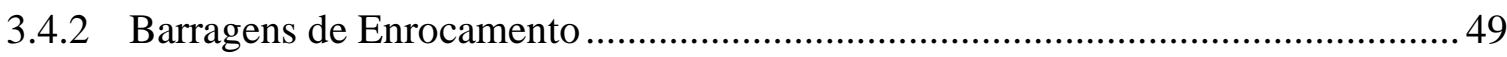

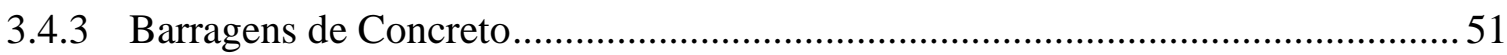

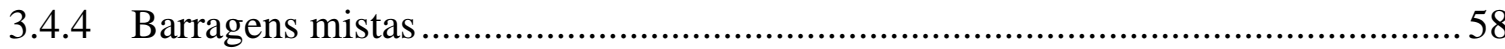

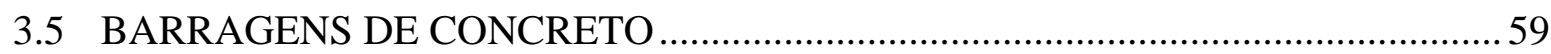

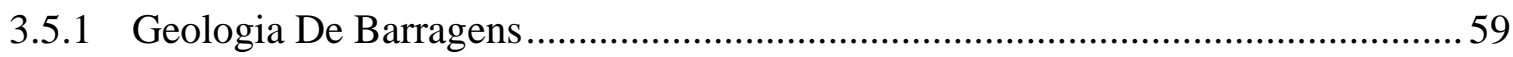

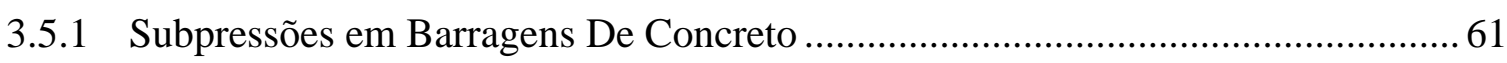

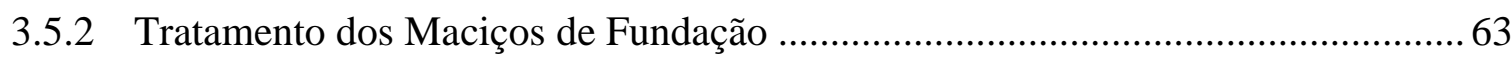

3.5.3 Critérios de Subpressão para Análise de Estabilidade........................................... 69

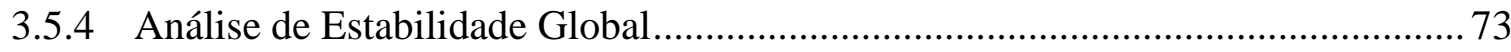

3.6 ACIDENTES E INCIDENTES COM BARRAGENS GRAVIDADE ....................... 82

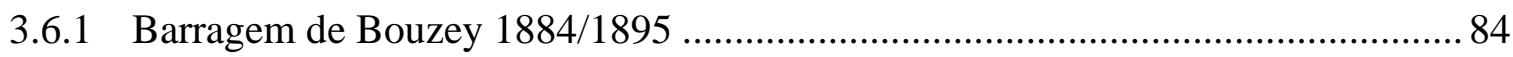

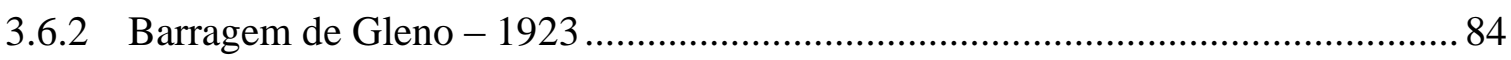

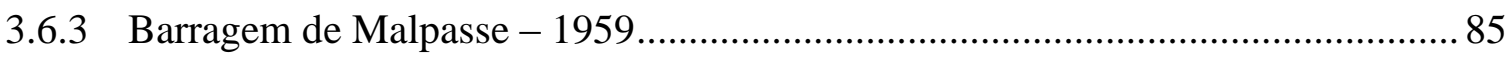

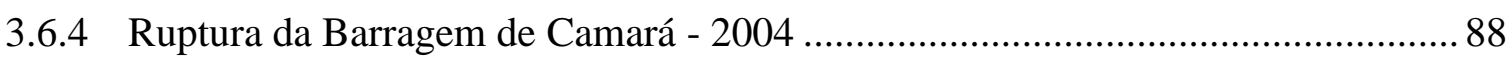

3.6.5 Barragem De Zeuzier - Deslocamentos Anormais Detectados Pela Instrumentação

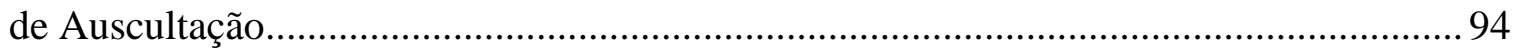

3.7 AUSCULTAÇÃO DE BARRAGEM DE CONCRETO ......................................... 96

3.7.1 Instrumentação de Barragens de Concreto ........................................................ 98

3.8 BARRAGENS EM REGIÕES CÁRSTICAS ......................................................... 112

3.8.1 Carbonatação e Colmatação de Drenos de Fundação.......................................... 118

3.8.2 Instrumentação x Colmatação de Drenos ......................................................... 119

4 ÁREA DE ESTUDO - CARACTERIZAÇÃO GEOLÓGICO-GEOTÉCNICA DO MACIÇO ROCHOSO DE FUNDAÇÃO .................................................................. 122 


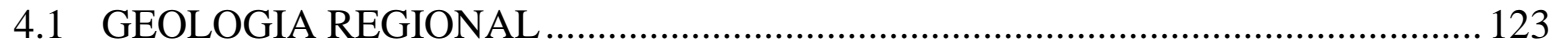

4.2 GEOLOGIA DA ÁREA DO APROVEITAMENTO ............................................. 124

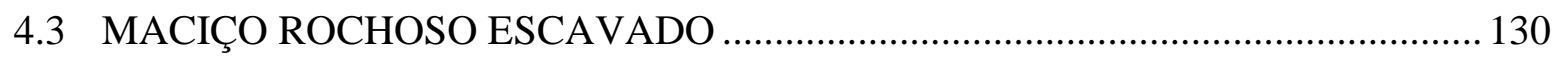

4.3.1 Tomada de Água - Margem Direita (Estaca 3+15,00) ...................................... 133

4.3.2 Barragem Margem Direita - Bloco 5 (Estaca 5+15,00) ................................... 135

4.3.3 Vertedouro e Adufas de Desvio (Estaca 6+7,5) ................................................ 136

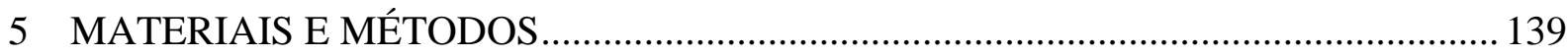

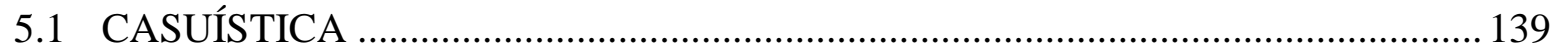

5.2 CARACTERÍSTICAS E TRATAMENTO MACIÇO ROCHOSO DE FUNDAÇÃO

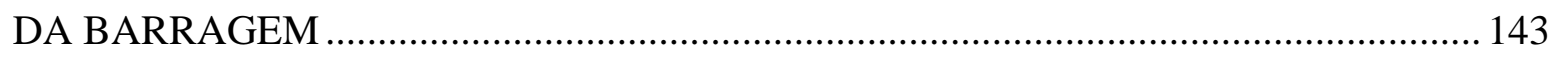

5.3 ANÁLISE DA INSTRUMENTAÇÃO DE AUSCULTAÇÃO ................................ 144

5.4 TESTE DE TAMPONAMENTO DOS DRENOS DE FUNDAÇÃO ....................... 144

5.5 AVALIAÇÃO DAS CONDIÇÕES DE OPERAÇÃO DOS DRENOS DE

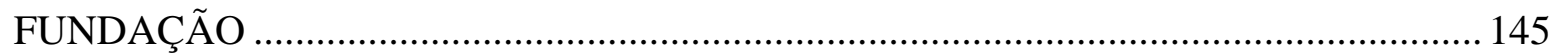

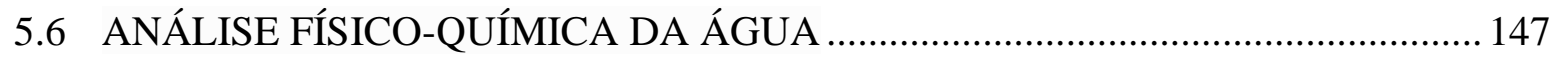

5.7 ANÁLISES DA ESTABILIDADE GLOBAL - MODELOS ANALÍTICOS .......... 148

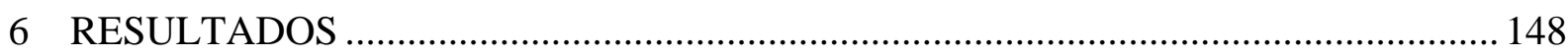

6.1 CARACTERÍSTICAS E TRATAMENTO DA FUNDAÇÃO DAS ESTRUTURAS

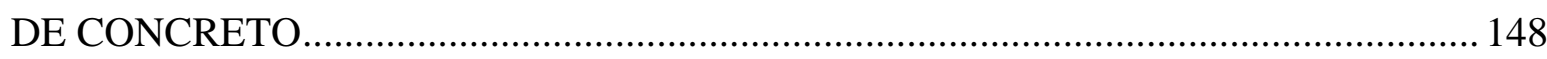

6.1.1 Regularização e Limpeza da Fundação .............................................................. 148

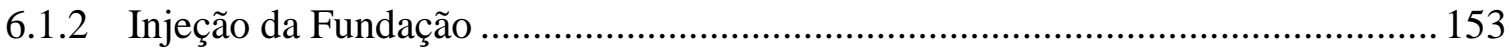

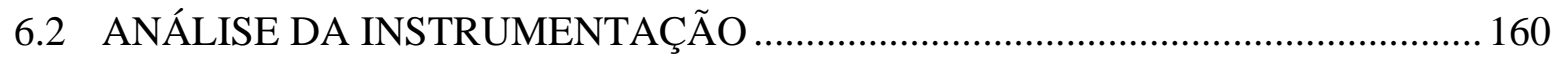

6.2.1 Piezômetros Standpipe (tubo aberto) .................................................................. 162

6.2.2 Vazões de Drenagem - Medidores de Vazão ...................................................... 167

6.2.3 Medidores Triortogonais de Junta entre Blocos da Estrutura de Concreto .......... 172

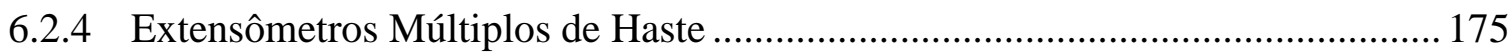

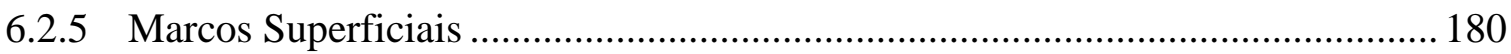

6.3 TESTE DE TAMPONAMENTO DOS DRENOS DE FUNDAÇÃO ....................... 180

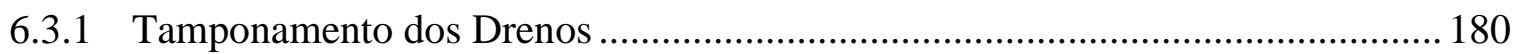

6.3.2 Análise da Instrumentação Durante os Testes de Tamponamento ....................... 182

6.4 AVALIAÇÃO DAS CONDIÇÕES DE OPERAÇÃO DOS DRENOS DE

FUNDAÇÃO DAS ESTRUTURAS DE CONCRETO - TESTE 1 ................................... 186

6.4.1 Bloco 4 - Principais Observações ........................................................................ 189 
6.4.2 Bloco 6 - Principais Observações

6.4.3 Outros Blocos - Principais Observações ............................................................ 191

6.4.4 Comentários Gerais

6.5 AVALIAÇÃO DAS CONDIÇÕES DE OPERAÇÃO DOS DRENOS DE

FUNDAÇÃO DAS ESTRUTURAS DE CONCRETO - FASE 2 ................................. 195

6.5.1 Remoção das Tubulações Internas do Drenos ..................................................... 197

6.5.2 Inspeção dos Furos e Tubulações Internas dos Drenos Utilizando Boroscópio .. 204

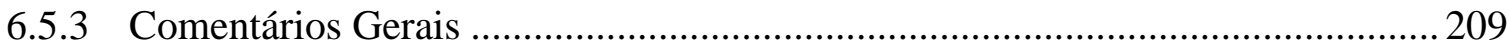

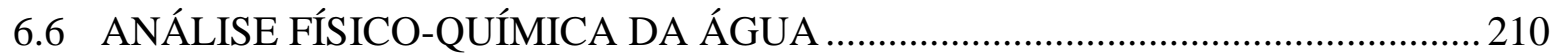

6.7 COMPARAÇÃO DA SEÇÃO GEOLÓGICO GEOTÉCNICA E CONSUMO DE CALDA DE CIMENTO DAS CAMPANHAS DE INJEÇÃO COM AS MEDIÇÕES DE OBSTRUÇÃO DOS DRENOS

6.8 ANÁLISES DA ESTABILIDADE DA BARRAGEM DE CONCRETO - MODELOS ANALÍTICOS

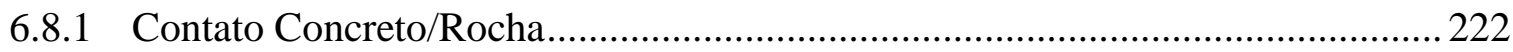

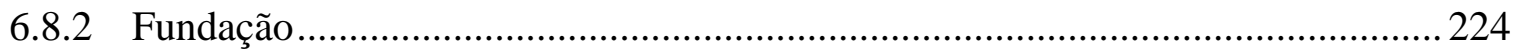

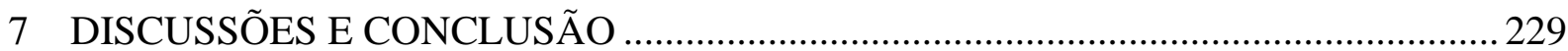

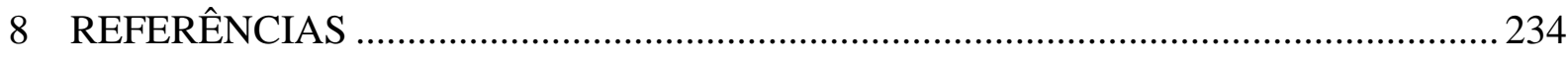

APÊNDICE A - PLANILHAS DE CÁLCULO DE ESTABILIDADE ............................... 241 


\section{INTRODUÇÃO E JUSTIFICATIVA}

A história da civilização está diretamente ligada à construção de barragens. Tais estruturas estão relacionadas com o crescimento e a ascensão de muitas civilizações, principalmente as dependentes da irrigação. As barragens vêm sendo utilizadas pelo homem há mais de 5.000 anos (JANSEN, 1983).

Após a Revolução Industrial, a necessidades se ampliaram e passaram a ser utilizadas barragens também como um recurso no combate a enchentes, geração de energia elétrica e para prover recreação (SCHNITTER, 1994)

Conforme Zuffo (2005), as barragens são geralmente obras associadas a um elevado potencial de risco devido à possibilidade de ruptura, com consequências catastróficas para as próprias estruturas, para o meio ambiente, com destruição de flora e fauna, prejuízos econômicos e, principalmente, pela perda de vidas humanas.

Sendo a Geologia a ciência que estuda a origem, a formação, a estrutura e a composição da crosta terrestre e a Geotecnia um ramo dedicado à interferência da geologia com as obras de engenharia, o conhecimento dessas disciplinas é de fundamental importância para o projeto, construção e manutenção da segurança de barragens. (GIL, 2013).

Conhecer as condições geológicas do local no qual será inserida uma barragem, possibilita um projeto executado de forma mais eficiente em vários aspectos. O papel da Geologia na otimização de um projeto de barragem é essencial e abrange garantir uma obra segura, econômica e com inserção ambiental de menor impacto, assim como, desde o início dos estudos, analisar a própria viabilidade do projeto. (COSTA, 2012)

Os conhecimentos de mecânica das rochas se aplicam especialmente nos estudos, projetos e construção de grandes obras civis como, por exemplo, nas fundações de barragens, taludes naturais e de corte remanescente, túnel hidráulico ou viário, poços largos e profundos, cavernas amplas, na mineração, etc. (GIL, 2013).

Julga-se que a Geologia tem contribuição essencial na aplicação da Mecânica das rochas, estando intimamente ligadas no caso de projetos barragens, assim como no entendimento do comportamento das barragens e estruturas secundárias durante as fases de construção, enchimento e operação. A comunicação e a sinergia entre Geólogos e Engenheiros Geotécnicos, assim como uma linguagem comum entre ambos, são de extrema importância, visando sempre as melhores práticas dentro da geotécnica.

Conforme Cruz et al. (2015), a arte de um bom projeto de barragem é manter o corpo 
da barragem estável, controlando as deformações e a quantidade de água que percola pelo do corpo da barragem, ombreiras e fundações. Barragens de qualquer tipo (concreto e terra) apresentaram vazamentos e às vezes falhas progressivas devido ao fluxo excessivo de água das ombreiras, altos gradientes através das imperfeições do aterro e da fundação.

Para tanto, o julgamento da validade das hipóteses de projeto, a avaliação dos reais fatores de segurança, a realização de inspeções periódicas e a análise dos dados da instrumentação de auscultação, são de fundamental importância para a segurança de uma barragem. Análises de estabilidade de estruturas hidráulicas têm sido realizadas com formulações clássicas analíticas de verificações quanto à segurança ao deslizamento, ao tombamento e à flutuação, bem como avaliação das tensões atuantes na fundação. Entretanto, também podem ser feitos estudos com modelagem em elementos finitos para consideração mais real da estrutura e de seu entorno (BORGES, 2016).

No Brasil, foi instituída em Setembro/2010 a Lei Federal 12.334, estabelecendo a Política Nacional de Segurança de Barragens (PNSB) e criando o Sistema Nacional de Informações sobre Segurança de Barragens (SNISB), tendo sido regulamentada pelos órgãos/entidades fiscalizadoras estaduais e federais. Após casos mais recentes de ruptura de barragens de rejeitos no Brasil, como de Mariana, em 2015, e o de Brumadinho, em 2019, levando à morte de cerca de 20 e 250 pessoas, respectivamente, com elevado dano ambiental e grande comoção nacional, a Lei Federal 12.334/2010 ganhou ainda mais força, dada a sua devida importância.

Toda barragem necessita de uma permanente supervisão de seu comportamento, objetivando a detecção de todas as eventuais anomalias/ocorrências e a análise de suas causas, para verificar a necessidade de medidas corretivas a curto, médio e longo prazo.

Nesse contexto, a observação e análise do desempenho das barragens em construção, em fase de enchimento do reservatório e em operação permite um grande aprendizado, tendo em vista a possibilidade de associação e comparação de comportamentos entre casos semelhantes.

Particularmente no caso da $\mathrm{PCH}$ Mata Velha, localizada no rio Preto, entre os Municípios Unaí e Cabeceira Grande, Estado de Minas Gerais, o aprendizado se torna muito valioso, tendo em vista o maciço rochoso de fundação onde a mesma foi implantada, constituindo um grande desafio para a Engenharia de Barragens, devido à sua variabilidade, dobramentos, intercalações de rochas metassedimentares carbonáticas, interfaces, falhas tectônicas e feições persistentes de menor resistência e condições de fluxo desfavoráveis. 
Ressalta-se que não há relatos de carbonatação tão intensa em drenos de fundação e redução tão rápida e considerável de vazão (de aproximadamente 1.500 l/min para 130 1/min) através dos drenos de fundação das estruturas de concreto como aquela observada na PCH Mata Velha, sendo está uma grande contribuição para a literatura.

Conforme Cruz et al. (2015), fluxos imprevisíveis devido à singularidade das fundações, interfaces ou materiais utilizados nos tratamentos de fundação ou no corpo da barragem surpreenderam até projetistas e construtores conhecidos na história das barragens. O fluxo de água pelo corpo das barragens e suas fundações pode se tornar uma verdadeira paixão e um desafio para os engenheiros de barragens que dedicam suas vidas a entender e tentar explicar esses fenômenos.

\section{OBJETIVOS}

$\mathrm{O}$ presente trabalho tem como objetivo estudar o comportamento da fundação e estabilidade das estruturas de concreto da PCH Mata Velha, localizada no rio Preto, entre os Municípios Unaí e Cabeceira Grande, Estado de Minas Gerais, realizando-se, também, o estudo de estabilidade das estruturas de concreto e eventuais ações a serem implementadas a curto, médio e longo prazo para a manutenção das condições de segurança das estruturas, atentandose para a ocorrência/mecanismos e as eventuais implicações da intensa carbonatação e redução das vazões observada nos drenos de fundação.

A Barragem Principal da usina é constituída por uma estrutura de concreto em CCR Concreto Compactado a Rolo, com 37 m de altura máxima e 183,60 m de comprimento, seguida de uma barragem de enrocamento com núcleo argiloso, com $44 \mathrm{~m}$ de altura máxima e cerca de $171,70 \mathrm{~m}$ de comprimento, fechando o barramento junto à ombreira esquerda. A fundação das estruturas é constituída predominantemente por metaritimitos, neste caso uma alternância de camadas de metacalcário e de metassiltito.

Julga-se que para que o objetivo principal seja atingido, alguns pontos chaves devem ser estudados/avaliados, comparando-se e associando-se, sempre que possível, com outras barragens de concreto e comportamentos semelhantes com fundações apoiadas em rochas carbonáticas. Dos objetivos específicos destacam-se:

$\checkmark$ Análise das investigações, sondagens e documentação para caracterização geológica e geotécnica da fundação; 
$\checkmark$ Avaliação da instrumentação durante o período de enchimento e operação, avaliando-se particularmente as subpressões, deslocamentos e vazões de drenagem.

$\checkmark$ Realização de testes de tamponamento dos drenos de fundação e seu reflexo nas subpressões registradas pelos piezômetros;

$\checkmark$ Avaliação das condições gerais dos drenos de fundação, através da medição de profundidade, nível d'água e vazão;

$\checkmark$ Associar o comportamento dos drenos de fundação com consumo de calda de cimento das campanhas de injeção;

$\checkmark$ Implementação de medidas de acompanhamento/controle de curto prazo que possam subsidiar uma melhor compreensão das observações já realizadas. Exemplo: controle de sólidos carreados através dos drenos; análise da água e sólidos dissolvidos da água dos drenos; medição de $\mathrm{PH}$, temperatura e pressão nos drenos.

$\checkmark$ Levantamento das principais hipóteses que podem ter levado à intensa carbonatação e rápida redução da vazão dos drenos de fundação, observada em poucos meses após o enchimento,

$\checkmark$ Avaliação da possibilidade de carreamento de material pela fundação, formação de "vazios" e possibilidade de ocorrência de "piping";

$\checkmark$ Realizar análises de estabilidade global empregando-se modelos analíticos, conforme critérios definidos pela Eletrobrás (2003), para avaliação da implicação da obstrução e eventual perda de eficiência dos drenos, levando em conta tanto o contado concreto/rocha como a fundação, através das juntas de alívio no maciço rochoso de fundação, considerando a análise paramétrica dos parâmetros, a fim de avaliar os Fatores de Segurança - FS para conjuntos de parâmetros distintos;

$\checkmark$ Análise de medidas de médio e longo prazo:

- Necessidade de limpeza dos drenos com frequência pré-determinada;

- Necessidade de reperfurar drenos existentes ou perfurar drenos adicionais e se poderá ocorrer aumento repentino de vazão;

- Avaliar a utilização de tubulação revestida internamente para evitar carreamento de finos;

- Necessidade de realizar sondagem para obtenção de amostras da fundação e realização de ensaios;

- Etc; 
$\checkmark$ Eventuais recomendações para acompanhamento da segurança da barragem e da instrumentação de auscultação:

- Frequências das inspeções e de leitura dos instrumentos;

- Necessidade de novos instrumentos;

- Medições adicionais nos drenos de fundação (vazão dreno a dreno, temperatura, pressão) e eventuais inspeções com câmera endoscópica;

- Automação dos instrumentos;

- Estimar o comportamento da instrumentação tendo por base o comportamento da fundação;

- Etc.

\section{REVISÃO BIBLIOGRÁFICA}

\subsection{A POLÍTICA NACIONAL DE SEGURANÇA DE BARRAGENS}

Em 2003 foi elaborado o Projeto de Lei $n^{\circ} 1.181$, o qual visava estabelecer a Política Nacional de Segurança de Barragens (PNSB), criar o Conselho Nacional de Segurança de Barragens (CNSB) e o Sistema Nacional de Informações sobre Segurança de Barragens (SNISB).

Apenas em 2010 foi sancionada a Lei 12.334, a qual conforme Art. $1^{\circ}$, estabelece a Política Nacional de Segurança de Barragens (PNSB) e cria o Sistema Nacional de Informações sobre Segurança de Barragens (SNISB).

Conforme Lei 12.334, "Parágrafo único. Esta Lei aplica-se a barragens destinadas à acumulação de água para quaisquer usos, à disposição final ou temporária de rejeitos e à acumulação de resíduos industriais que apresentem pelo menos uma das seguintes características:

I - altura do maciço, contada do ponto mais baixo da fundação à crista, maior ou igual a $15 \mathrm{~m}$ (quinze metros);

II - capacidade total do reservatório maior ou igual a $3.000 .000 \mathrm{~m}^{3}$ (três milhões de metros cúbicos);

III - reservatório que contenha resíduos perigosos conforme normas técnicas aplicáveis;

IV - categoria de dano potencial associado, médio ou alto, em termos econômicos, 
sociais, ambientais ou deperda de vidas humanas, conforme definido no art. 6o."

Conforme Art. $3^{\circ}$ da Lei 12.334, "são objetivos da Política Nacional de Segurança de Barragens (PNSB):

I - Garantir a observância de padrões de segurança de barragens de maneira a reduzir a possibilidade de acidente e suas consequências;

II - Regulamentar as ações de segurança a serem adotadas nas fases de planejamento, projeto, construção, primeiro enchimento e primeiro vertimento, operação, desativação e de usos futuros de barragens em todo o território nacional;

III - promover o monitoramento e o acompanhamento das ações de segurança empregadas pelos responsáveis por barragens;

IV - Criar condições para que se amplie o universo de controle de barragens pelo poder público, com base na fiscalização, orientação e correção das ações de segurança;

V - Coligir informações que subsidiem o gerenciamento da segurança de barragens pelos governos;

VI - Estabelecer conformidades de natureza técnica que permitam a avaliação da adequação aos parâmetros estabelecidos pelo poder público;

VII - Fomentar a cultura de segurança de barragens e gestão de riscos”

Conforme apresentado no Relatório de Segurança de Barragens - RSB 2018, e publicado pela ANA (2019), existiam no país 44 entidades potencialmente fiscalizadoras de segurança de barragens, das quais 32 são efetivamente fiscalizadoras, por terem registros de barragens. Em seus cadastros constam 17.604 barragens para os mais diversos usos, das quais se sabe que 4.830 (28\%) submetem-se à Política Nacional de Segurança de Barragens - PNSB e que 10.812 $(61 \%)$ das barragens cadastradas não informam o suficiente para se saber se elas se submetem à PNSB. Na Figura 1 é mostrada a evolução do número de barragens cadastradas pelos órgãos fiscalizados. Em relação aos RSBs anteriores, houve uma redução no número de barragens cadastradas, relacionada, principalmente, à revisão do cadastro do DAEE-SP, que iniciou um novo trabalho de identificação de barragens no estado

$\mathrm{Na}$

Figura 2 apresenta-se o uso principal das barragens submetidas à Política nacional de segurança de barragens, observando-se a maior quantidade de barragens para irrigação, seguido de barragens para abastecimento humano, hidrelétricas e de contenção de rejeitos de mineração. 
Figura 1 - Evolução do cadastro de barragens.

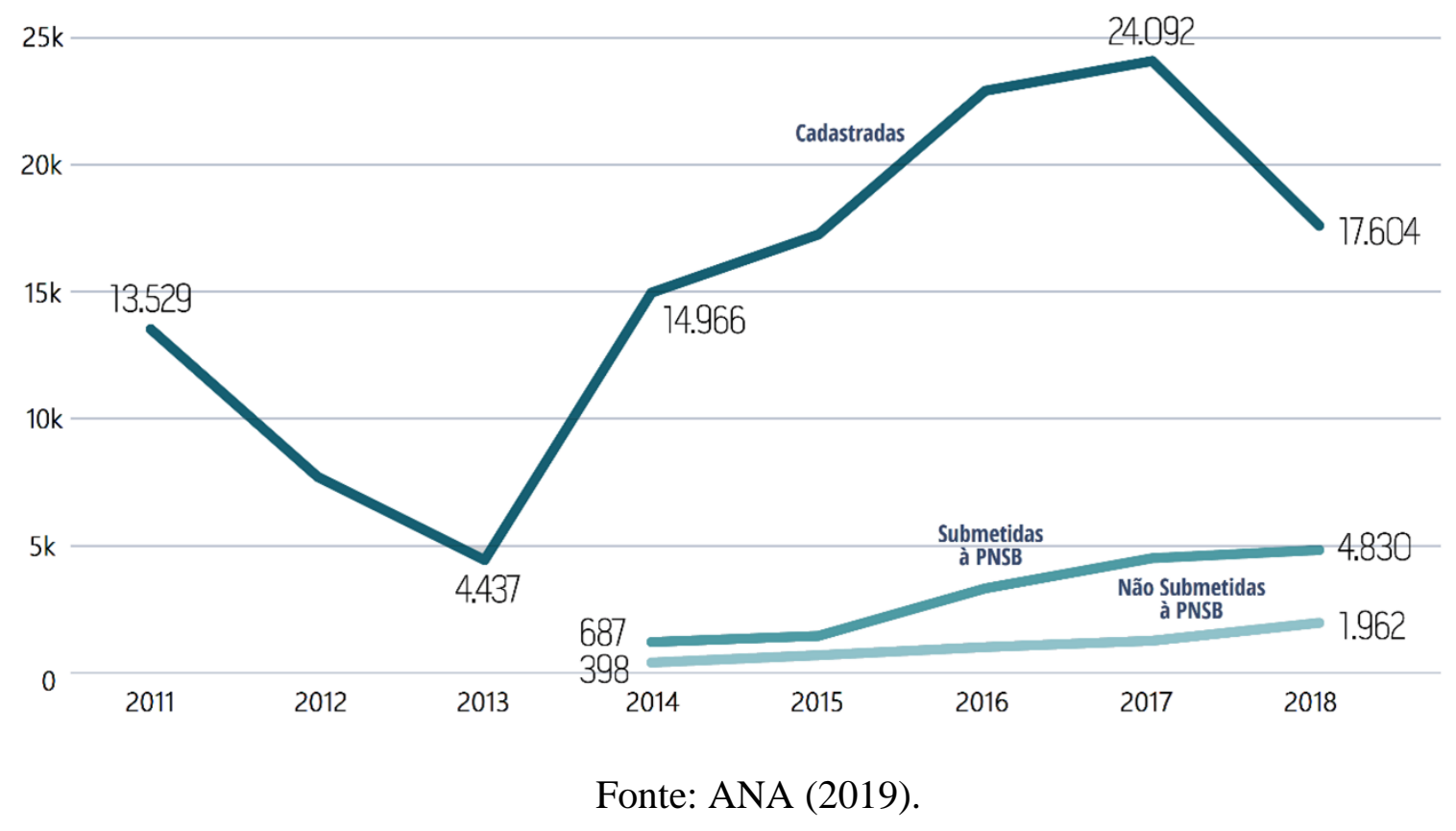

Figura 2 - Uso principal das barragens no Brasil submetidas à Política Nacional de Segurança de Barragens - PNSB

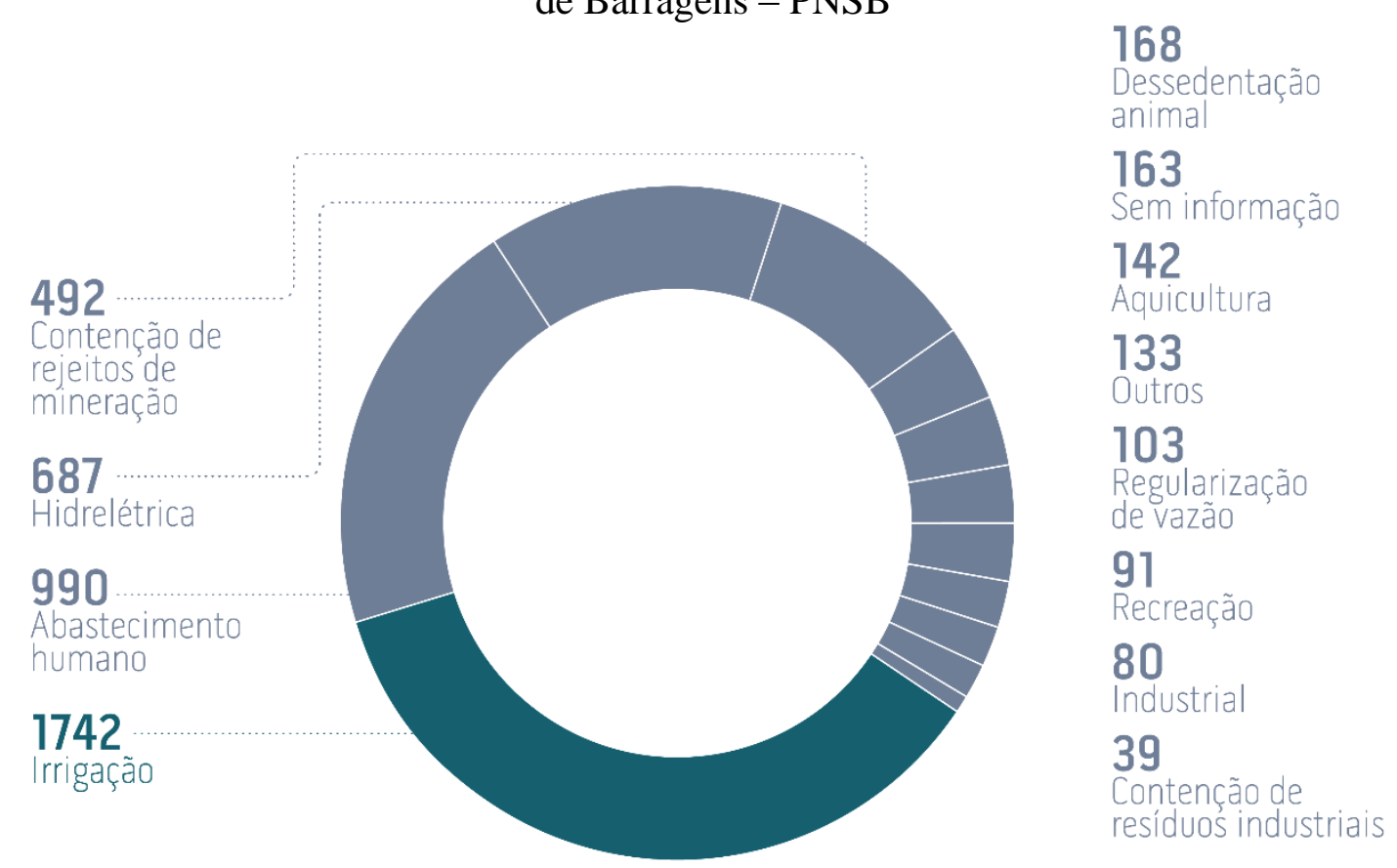

Fonte: ANA (2019).

Segundo ANA (2019), é importante frisar que muitos órgãos fiscalizadores interpretam que só devem enviar informações para o RSB das barragens que se submetem à PNSB, baseando-se no art. $1^{\circ}$ da Lei $n^{\circ} 12.334 / 2010$. Este entendimento sobre quais barragens devem compor o cadastro (todas ou só as que apresentam as características citadas no art. $1^{\circ}$ da Lei $n^{\circ}$ 
12.334/2010) não se restringe somente aos três órgãos fiscalizadores citados anteriormente.

Conforme Art. 10. da Lei 12.334, “Deverá ser realizada Revisão Periódica de Segurança de Barragem com o objetivo de verificar o estado geral de segurança da barragem, considerando o atual estado da arte para os critérios de projeto, a atualização dos dados hidrológicos e as alterações das condições a montante e a jusante da barragem"

A Figura 3 (ANA, 2019) mostra a evolução anual da quantidade de regulamentos emitidos, conforme abreviações: PSB - Plano de Segurança de Barragem; RPSB - Revisão Periódica de Segurança de Barragem; ISR - Inspeção de Segurança Regular; ISE - Inspeção de Segurança Especial; PAE - Plano de Ação de Emergência. Verifica-se que, em 2018, mantevese a tendência de crescimento verificada nos anos anteriores, com um aumento no número de regulamentos emitidos, demonstrando o esforço dos órgãos fiscalizadores nessa área. Ressaltase, entretanto, que seis órgãos efetivamente fiscalizadores ainda não publicaram regulamento algum da Lei $\mathrm{n}^{\mathrm{o}}$ 12.334/2010.

Figura 3 - Evolução da quantidade de regulamentos emitidos sobre segurança de barragens.

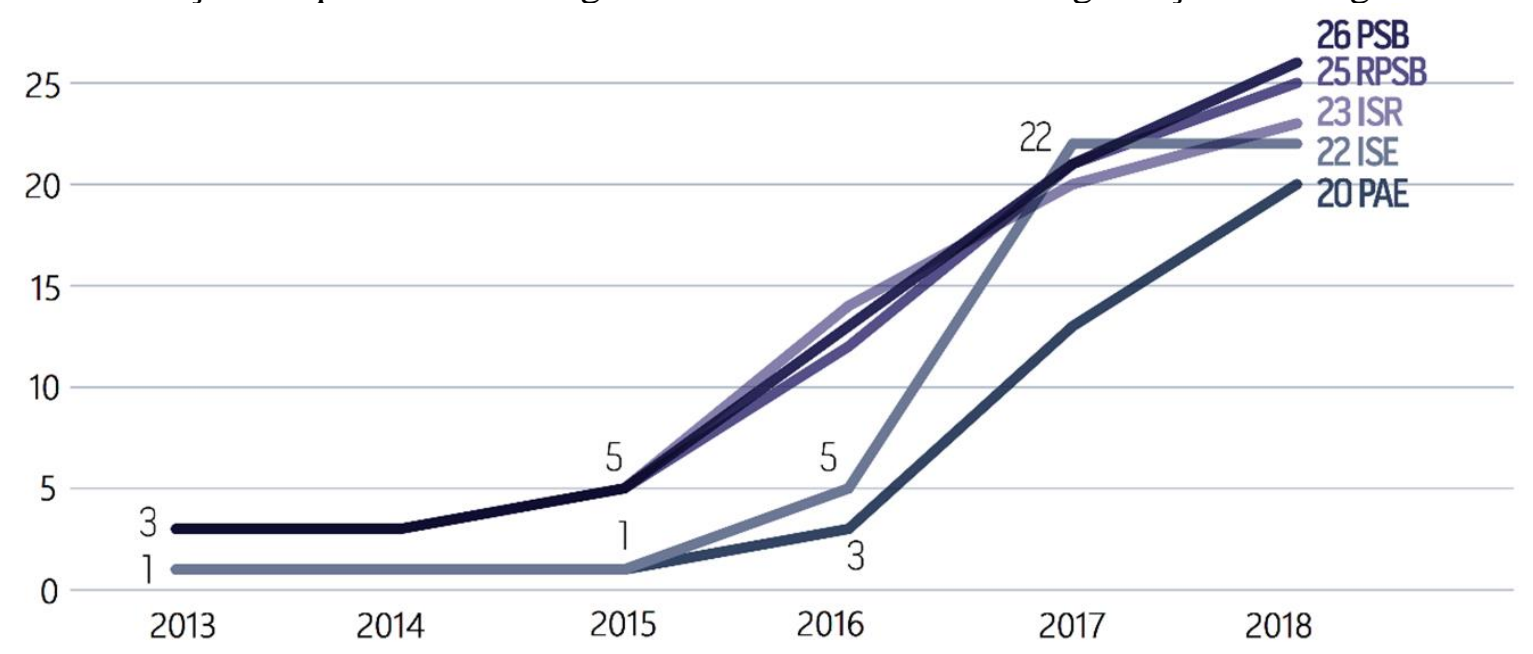

Fonte: ANA (2019).

As periodicidades em relação à RPSB levam em consideração a classificação das barragens em função da categoria de risco e dano potencial, conforme regulamentação dos respectivos órgãos/entidades. No geral as revisões periódicas devem ter periodicidade entre 4 anos a 10 anos, o que deverá gerar uma grande demanda de trabalhos dessa natureza nos próximos anos, dos quais há muitas barragens de pequeno porte, algumas construídas de forma pouco criteriosa e dotadas de poucas informações em relação ao projeto e construção, no caso daquelas mais antigas. 
Após o rompimento da Barragem do Córrego Feijão (Brumadinho), em 25 de janeiro 2019, levando à morte mais de 240 pessoas, em função da grande comoção mundial e circunstâncias em que o mesmo ocorreu, houve uma maior celeridade/movimentação dos órgãos de fiscalização e maior cobrança da sociedade:

- Foi criado o Conselho Ministerial de Supervisão de Respostas a Desastres;

- Foi criado o Subcomitê de Elaboração e Atualização Legislativa, para atualização da PNSB;

- Foram realizadas fiscalizações pelas entidades fiscalizadoras;

- Foi apresentado ao Senado Federal o Projeto de Lei 550/2019, para atualização da PNSB.

A eventual aprovação do Projeto de Lei 550/2019 deverá exigir ainda mais dos empreendedores, em termos de comprometimento e adequação à Política de Segurança de Barragens.

\subsection{SEGURANÇA DE BARRAGENS E SUA EVOLUÇÃO NO CONTEXTO MUNDIAL}

Em média, a cada década, ocorrem dez rompimentos significativos de barragens em algum lugar do mundo, isso sem mencionar, as "quase rupturas". As falhas mais comuns que podem ocorrer em barragens são devidas a: enchentes extremas, incertezas geológicas do local de implantação, infiltrações através das fundações e aterros, defeitos de construção e projeto e sismicidade. No século XX houve 200 casos notáveis de falhas em reservatórios ao redor do mundo e mais de 250.000 pessoas perderam suas vidas em desastres deste tipo (MCCULLY, 2001).

Pelo menos 60 desastres com barragens foram registrados no mundo nos últimos 50 anos. Entre os mais devastadores estão as rupturas da Barragem de Fundão (Mariana-M.G.), em 2015, e do Córrego Feijão (Brumadinho-M.G.), em 2019 (UOL, 2019), levando à morte de cerca de 20 e 250 pessoas, respectivamente, com elevado dano ambiental e grande comoção nacional.

Contudo, como a Engenharia de Barragens não é uma ciência exata a ponto de se poder eliminar completamente o risco de um acidente ou incidente, a segurança de barragens deve ser a prioridade máxima em todas as fases de seu desenvolvimento e uso, incluindo o planejamento, projeto, construção e fases de operação e manutenção. 
Conforme Zuffo (2005), em vários países, a partir da década de 70, ou até antes disso, como Canadá, Portugal, Reino Unido, Estados Unidos e Austrália, a preocupação com a segurança de barragens se tornou um ponto chave para o desenvolvimento específico de legislações relacionadas ao assunto e, assim, motivando um aumento e melhoria na avaliação da segurança das barragens.

Jansen (1983) afirma que o risco de falha de barragens é um dos pesos inevitáveis que a humanidade deve carregar. Os programas de segurança de barragens são de vital importância para toda a sociedade. Os engenheiros têm que trabalhar em conjunto, como por exemplo, com geólogos, em ações coordenadas, de tal forma a reduzir as incertezas.

Devem ser realizadas reavaliações periódicas das barragens existentes, vindo assegurar que estas apresentem condições seguras. Com os conhecimentos hidrológicos, geológicos e de sismologia atuais, as barragens que foram consideradas seguras no passado, podem passar a não ser.

Exames de barragens existentes devem focar a detecção de qualquer condição que possa ameaçar a integridade vital da estrutura. Essas situações podem ser atribuídas à inadequação de materiais construtivos, condições adversas no entorno, falhas na fundação, deficiências de projeto ou operação e manutenção impróprios.

Segundo o Bureau of Reclamation (1987), a avaliação e revisão periódica de barragens e reservatórios é de suma importância para a segurança da população, sendo possível detectar situações/condições que venham prejudicar as operações ou ameaçar a segurança da barragem, cedo o suficiente para que se possa corrigi-los.

McCully (2001) cita que segundo o ICOLD - International Commission on Large Dams, cerca de 2,2\% de todas as barragens construídas antes de 1950 falharam e 0,5\% das barragens que falharam, foram construídas após este período. A maioria das falhas ocorre com barragens de pequeno porte e elas constituem a maiorias das barragens construídas.

Na Figura 4 é apresentada, em termos percentuais, uma distribuição regional das barragens, classificadas conforme sua altura, sendo que, em média, 60\% das barragens apresentam até $30 \mathrm{~m}$ de altura, as quais dependendo da classificação, seriam consideradas de pequeno porte. 
Figura 4 - Distribuição regional de barragens considerando a altura (m).

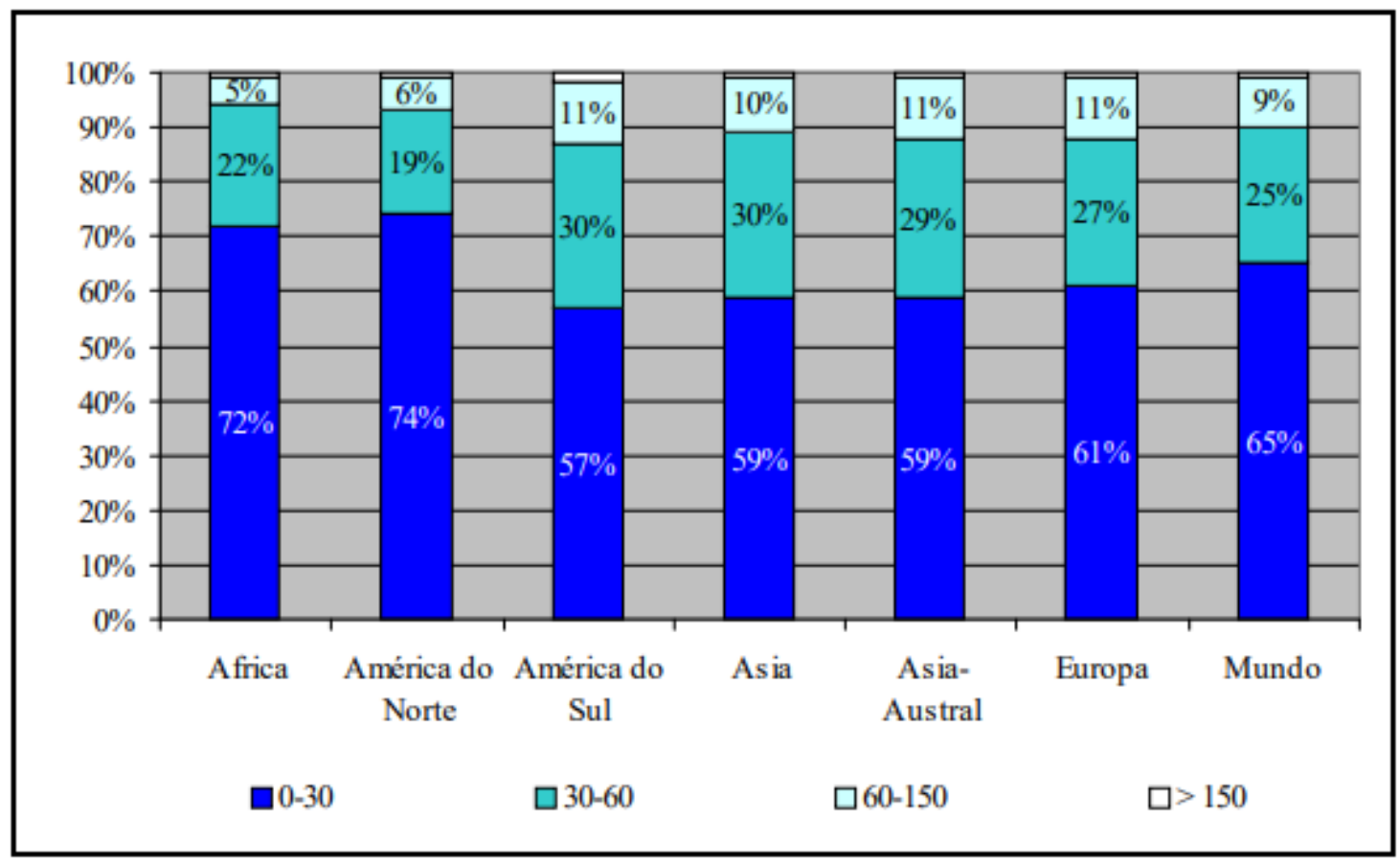

Fonte: Zuffo (2005).

Zuffo (2005) cita o histórico da situação relativa à segurança de barragens no mundo apresentado pela EMAE - Empresa Metropolitana de Águas e Energia (2001), de São Paulo. Durante o Congresso Internacional de Grandes Barragens do ICOLD em 1979, investiu-se maiores esforços no âmbito da segurança de barragens por três motivos: diversos incidentes envolvendo barragens, com grandes consequências; aumento das dimensões das barragens e envelhecimento de outras; aumento na construção de barragens em países sem nenhuma tradição e experiência em engenharia de barragens.

$\mathrm{Na}$ Inglaterra a preocupação com a segurança de barragens data do início do século XX (década de 30), que facilitou o aparecimento de base legal e ações propostas em 1975. Na França, um decreto de 1968 impôs a preparação de um plano de emergência para barragens com mais de 18 metros de altura e reservatório acima de $15 \times 10^{6} \mathrm{~m}^{3}$. Outros países como o Canadá, Noruega e Itália também possuem legislação própria para as atividades de segurança de barragens.

No Brasil, o CBGB - Comitê Brasileiro de Grandes Barragens - citado na EMAE (2001), hoje CBDB - Comitê Brasileiro de Barragens, seguindo a tendência mundial, editou em 1979 e 1983 as Diretrizes para Inspeção e Avaliação de Segurança de Barragens em Operação. Diversas outras publicações seguiram, como "Auscultação e Instrumentação de Barragens no Brasil”, em 1996. Em 1997, foi criada, no CBGB, pela Comissão de Deterioração 
e Reabilitação de Barragens, a minuta para a formação do Conselho Nacional de Segurança de Barragens. Em 1998, o Núcleo São Paulo do CBGB finalizou o "Guia Básico de Segurança de Barragens", o qual teve por finalidade orientar os proprietários de barragens quanto aos padrões e procedimentos de segurança a serem seguidos. (ZUFFO, 2005).

Em 2002, o Ministério de Integração Social, por meio da Secretaria de Infraestrutura Hídrica publicou o "Manual de Segurança e Inspeção de Barragens", com o objetivo estabelecer parâmetros e um roteiro básico para orientar os procedimentos de segurança a serem adotados em novas barragens e manter aquelas já construídas em um estado de segurança compatível com seu interesse social e desenvolvimento.

Segundo Manual de Segurança e Inspeção de Barragens (2002), uma barragem segura é aquela cujo desempenho satisfaça as exigências de comportamento necessárias para evitar incidentes e acidentes que se referem a aspectos estruturais, econômicos, ambientais e sociais. A segurança das barragens existentes deve ser avaliada regularmente pelas reavaliações de segurança de todas as estruturas e instalações.

Segundo o Manual de Segurança e Inspeção de Barragens (2002), o objetivo de uma avaliação de segurança é determinar as condições relativas à segurança estrutural e operacional das barragens, identificando os problemas e recomendando tanto reparos corretivos, restrições operacionais e/ou modificações, quanto as análises e os estudos para determinar as soluções dos problemas.

Em 2005, a Associação Canadense de Barragens (Canadian Dam Association) publicou o Dam Safety Guidelines - Manual de Segurança de Barragens - produto da revisão do primeiro exemplar, lançado em 1995 e revisado, também, em 1999. Há um capítulo dedicado às revisões da segurança de uma barragem que pode ser definida como: uma revisão formal e compreensível, feita em intervalos de tempo regulares para se determinar se uma barragem existente é segura ou não, a fim de se poder melhorar a segurança das estruturas associadas.

Mais recentemente, tendo em vista a Lei 12.334, de Segurança de Barragens, a ANA Agência Nacional de Águas elaborou um conjunto de oito manuais, com o intuito de estabelecer orientações gerais quanto às metodologias e procedimentos a serem adotados pelos empreendedores de barragens, visando a assegurar adequadas condições de segurança para as barragens pelas quais são responsáveis, ao longo das diversas fases da vida das obras, designadamente, as fases de planejamento e projeto, de construção e primeiro enchimento, de operação e de descomissionamento (desativação). 


\subsection{BARRAGENS NO MUNDO}

A história da civilização está diretamente ligada à construção de barragens. Tais estruturas estão relacionadas com o crescimento e a ascensão de muitas civilizações, principalmente as dependentes da irrigação. As barragens vêm sendo utilizadas pelo homem há mais de 5.000 anos e ruínas de barragens podem ser encontradas em locais considerados berços da civilização, tais como Pérsia, Egito, Babilônia, Índia e em países situados no oriente (JANSEN, 1983).

As ruínas encontradas na Índia e Sri Lanka revelam como as barragens eram construídas antigamente. Tratavam-se de barreiras de terra ao longo de rios e eram basicamente construídas utilizando-se materiais como solo e pedras. Porém, como as técnicas adotadas na construção eram bastante rudimentares, muitas vezes as estruturas falhavam em sua finalidade, levando à sua ruptura. A construção bem sucedida da barragem mais antiga se deu no Rio Nilo, no Egito, em algum período entre 5.700 e 2.700 a.C.., a qual era de alvenaria (JANSEN, 1983).

Desde esse período até o final do século XIX, as barragens desempenharam um papel fundamental no desenvolvimento econômico das nações, na irrigação, para repor perdas em canais de navegação e abastecimento de água, entre outros (VELTROP, 1991 apud ZUFFO, 2005). Após a Revolução Industrial, as necessidades foram ampliadas e as barragens passaram a ser utilizadas também como um recurso no combate a enchentes, geração de energia elétrica e para prover recreação (SCHNITTER, 1994). As barragens, entretanto, podem alterar e desviar os cursos d'água, afetando o acesso à água e os direitos existentes, com a possibilidade de haver impactos significativos nos meios de sustento e no meio ambiente (WORLD COMISSION ON DAMS, 2001). A Tabela 1 indica a data de construção das barragens mais antigas em alguns países.

Para que a demanda atual e futura de água seja suficientemente disponibilizada, mais reservatórios de superfície são necessários devido à distribuição irregular de água no tempo. Estruturas hidráulicas de condução são necessárias para suprir a má distribuição da mesma, no espaço. Neste contexto, as barragens desempenham um papel de múltipla finalidade. Elas foram e continuarão a ser as grandes propulsoras de atividades de desenvolvimento, pois com suas finalidades ajudam a nação a se tornar auto-suficiente na produção de alimentos e a prover energia necessária a sua industrialização, entre outras ZUFFO (2005). 
Tabela 1 - Ano de construção das barragens mais antigas em alguns países.

\begin{tabular}{cc}
\hline País & Ano de Construção \\
\hline China & 833 \\
Estados Unidos & 1810 \\
Japão & Século II \\
Espanha & Século II \\
Îndia & 1664 \\
Grã-Bretanha & 1794 \\
Coréia & 1915 \\
Suíça & 1895 \\
Itália & 1830 \\
França & 1675 \\
Canadá & 1832 \\
México & 1730 \\
Brasil & 1901 \\
Áustria & 1911 \\
Austrália & 1857 \\
Irãa & 1962 \\
\hline
\end{tabular}

Fonte: Zuffo (2005).

\subsection{TIPOS DE BARRAGENS}

De acordo com Azevedo (2005), as barragens dividem-se, quanto a sua finalidade, em barragens de regularização, que tem como objetivo regularizar o regime hidrológico dos rios, ou seja, equilibrar a demanda com o consumo de água e barragens de retenção, as quais tem por objetivo reter água, geralmente para controle de cheias. Além disto, quanto ao tipo, Azevedo (2005) divide as barragens em homogêneas (terra), zonadas, enrocamento e concreto.

Já Costa (2012), divide os tipos de barragens convencionais, que são aquelas mais utilizadas e cujo mecanismo é de amplo conhecimento na literatura especializada, conforme a seguir:

- Barragens de terra:

- Homogêneas;

- Zonadas;

- Barragens de enrocamento:

- Com núcleo impermeável;

- Com face impermeável;

- Barragens de concreto:

- Gravidade;

- Gravidade aliviada;

- Em contraforte; 
- De concreto rolado ou compactado;

- Abóbada.

- Barragens mistas (de concreto e/ou terra).

Conforme Possan (2015), existem diferentes tipos de barragens, sendo que a classificação pode ser dada pela rigidez, forma (geometria) ou tipo de material empregado na construção, conforme apresentado no Quadro 1.

\begin{tabular}{|c|c|c|}
\hline \multicolumn{1}{|c|}{ Quadro 1 - Classificação de Barragens. } \\
\hline Rigidez & Material de construção & Forma \\
\hline Rígida & Concreto & $\begin{array}{c}\text { Gravidade } \\
\text { Gravidade aliviada } \\
\text { Arco } \\
\text { Arco Gravidade } \\
\text { Contrafortes }\end{array}$ \\
\hline Não Rígida & $\begin{array}{c}\text { Terra } \\
\text { Terra e enrocamento }\end{array}$ \\
\hline
\end{tabular}

Fonte: Possan (2015).

\subsubsection{Barragens de Terra}

Segundo Quintas (2002, apud CAMARGO, 2014), são consideradas barragens de terra aquelas cuja estrutura é constituída fundamentalmente por terra. Neste caso, é adequado, quando possível, utilizar o solo da área de implantação da barragem. As barragens de terra são as mais utilizadas e numerosas, devido a vantagens econômicas e construtivas que elas proporcionam, em muitos casos, em relação às de concreto.

As barragens de aterro comportam-se de maneira razoável em praticamente todos os tipos de fundação, uma vez que os esforços transmitidos à fundação por unidade de área são menores que nas barragens de concreto, e os assentamentos verificados durante e após a construção não são significativos para comprometer a estabilidade da barragem, devido à fácil adaptabilidade do material do aterro (ALMEIDA, 2010).

As características geológicas e topográficas da fundação são, também, importantes fatores da economia das seções da barragem, principalmente porque as características de resistência da fundação podem condicionar a declividade dos taludes da barragem (a utilização de taludes mais íngremes, possibilitada pelos enrocamentos, exige melhores características de 
resistência dos materiais de fundação). A deformabilidade e permeabilidade da fundação podem igualmente influenciar a seleção do tipo de barragem (barragens de seção homogênea impõem menor grau de exigência). (ANA, 2016). Na Figura 5 são apresentadas seções transversais de barragens de terra, conforme Costa (2012), descritas nos subitens seguintes.

Figura 5 - Barragens de terra.

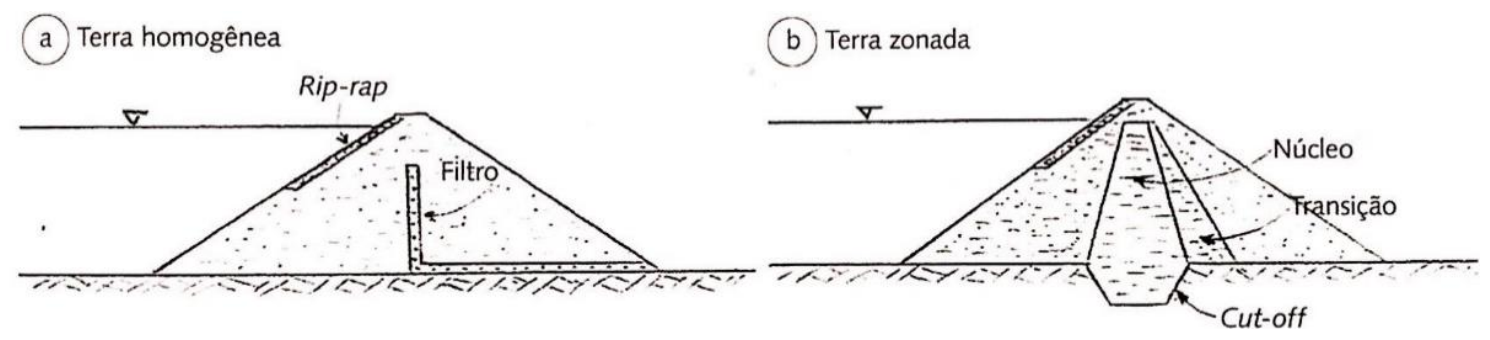

Fonte: Costa (2012).

\subsubsection{Barragens de Terra Homogêneas}

Conforme Costa (2012), a barragem é considerada homogênea quando há predominância de um único material, embora possam ocorrer elementos diversificados, como filtros, rip-rap, etc. As barragens homogêneas podem ser executadas com solos compactados com diferentes características (AZEVEDO, 2005). Na Figura 6 é apresentada uma seção típica de uma barragem de terra homogênea.

Figura 6 - Barragem do Vigário (Terzaghi), Piraí RJ.

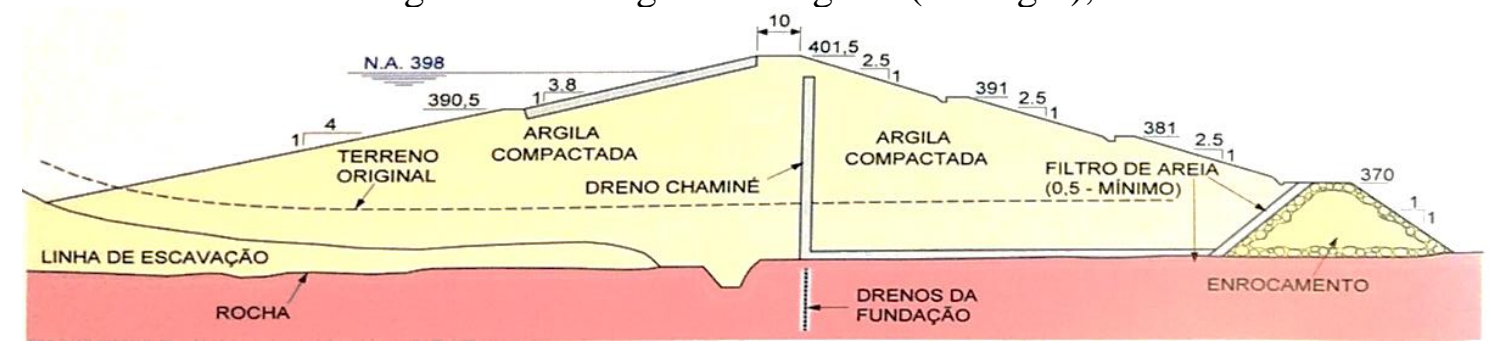

Fonte: Cruz (2004 apud ABRAHÃO e CRUZ, 2018).

\subsubsection{Barragens de Terra Zonadas}

Este tipo de barragem é caracterizado por apresentar um zoneamento de elementos terrosos que variam em função de suas propriedades de materiais e/ou permeabilidade (COSTA, 2012). Na Figura 7 é apresentada a seção da barragem Jati, a qual pode ser considerada como barragem de terra zonada. 
Figura 7 - Barragem Jati - Barragem de terra zoneada, construída com saprolito compactado (a montante e jusante) e núcleo de solo saprolítico compactado.

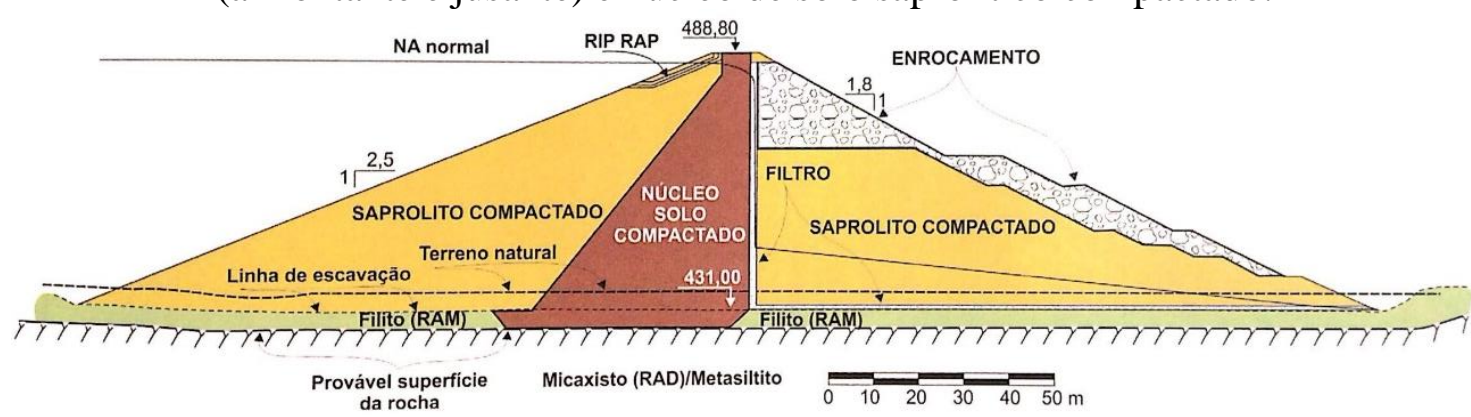

Fonte: Abrahão e Cruz (2018).

\subsubsection{Barragens de Enrocamento}

Barragens de enrocamento são barragens em que se faz o emprego de blocos de rocha de vários tamanhos juntamente com uma membrana impermeável sobre a face de montante do talude construído ou um núcleo impermeável. Geralmente, esse empreendimento é viável em regiões com altos custos para obtenção de concreto, terra e fácil obtenção de rochas. O tipo de rocha de fundação que tolera uma obra de barragem de enrocamento, nem sempre tolera obras de concreto (MARANGON, 2004).

Na Figura 8 são apresentadas seções transversais de alguns tipos de barragens de enrocamento, conforme Costa (2012).

Figura 8 - Barragens de enrocamento.
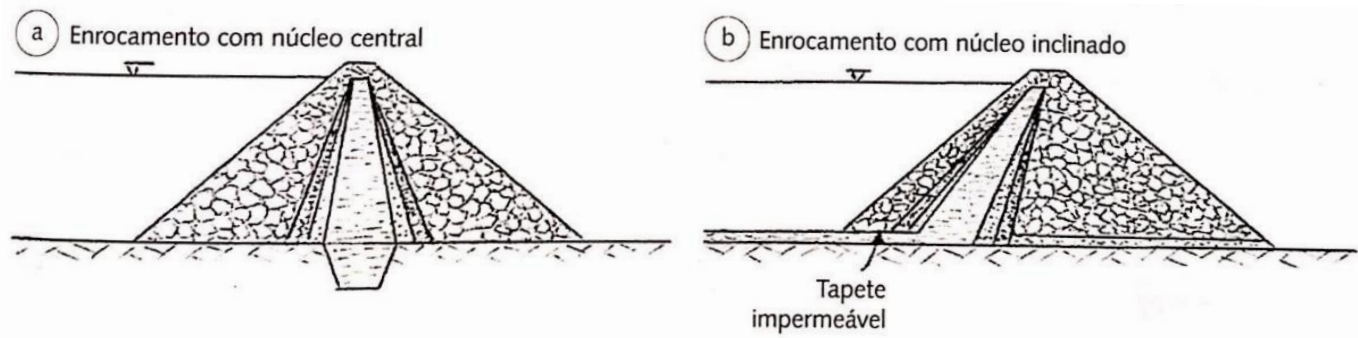

(c) Enrocamento com face de concreto

(d) Enrocamento com chapa de aço
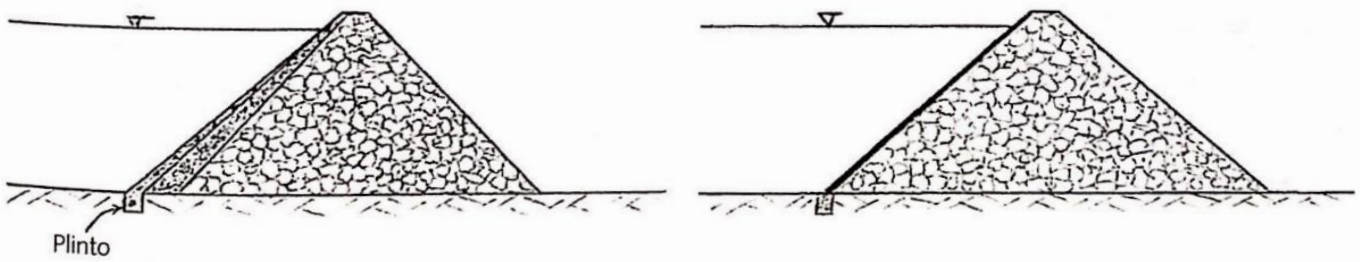

Fonte: Costa (2012). 


\subsubsection{Barragens de Enrocamento Com Núcleo Impermeável}

$\mathrm{Na}$ barragem de enrocamento com núcleo impermeável o material rochoso é predominante, e a vedação da água é feita por meio de um núcleo argiloso. O núcleo pode ser centralizado ou inclinado para a montante. Ele também é separado do material rochoso por meio de uma camada de transição para evitar o carregamento do material fino para o interior do enrocamento (COSTA, 2012), conforme Figura 8 e Figura 9.

Figura 9 - Foto mostrando o uso dos materiais de transição em barragem de enrocamento com núcleo de argila, nas proximidades das estruturas de concreto.

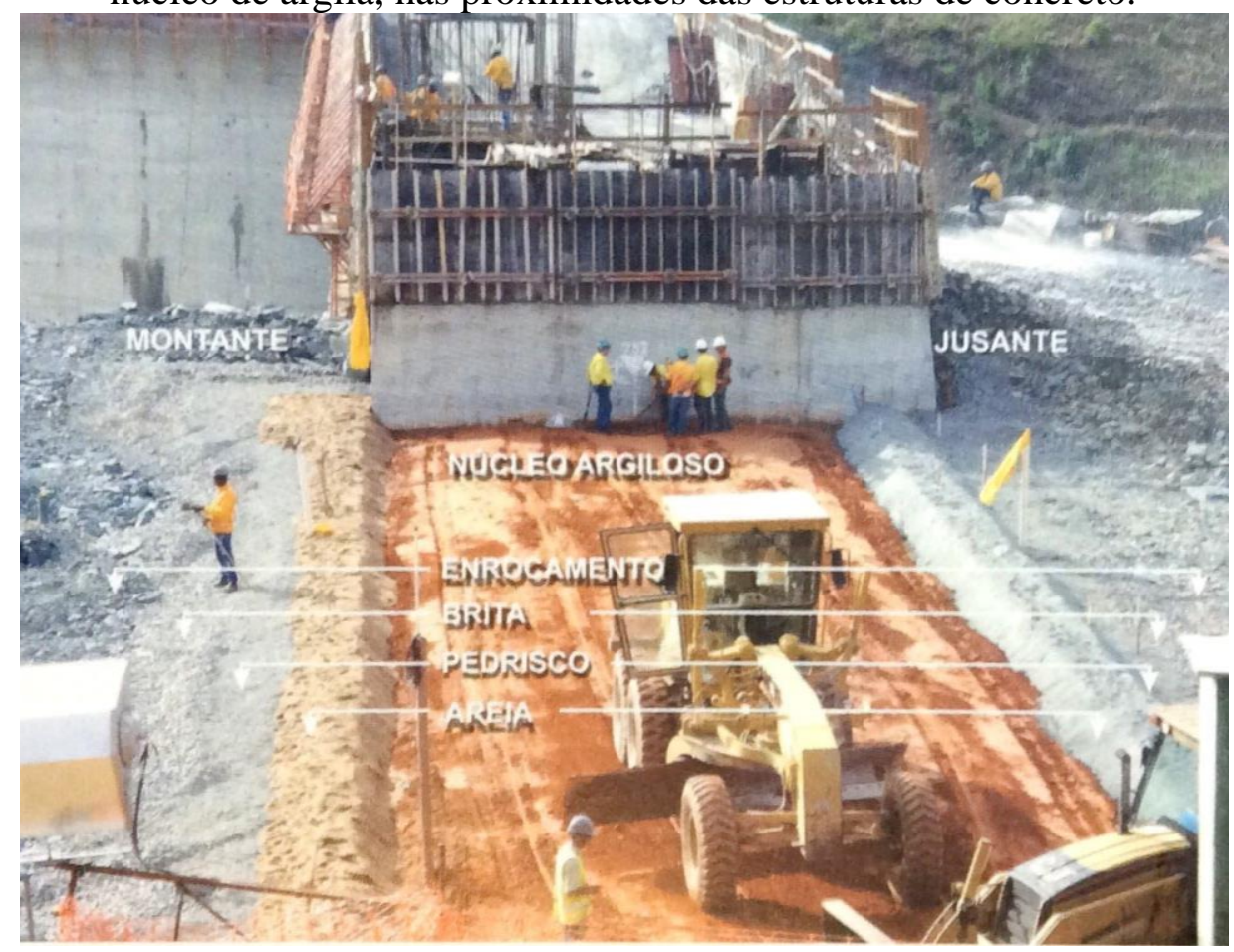

Fonte: Abrahão e Cruz (2018).

\subsubsection{Barragem de Enrocamento Com Face Impermeável}

Nesse tipo de barragem, o material predominante também é rochoso, porém a formação do reservatório e estanqueidade do barramento são garantidas por uma membrana externa impermeável (AZEVEDO, 2005), como pode ser observado na Figura 8 e na Figura 10. 
Figura 10 - Vista aérea da barragem de Campos Novos.

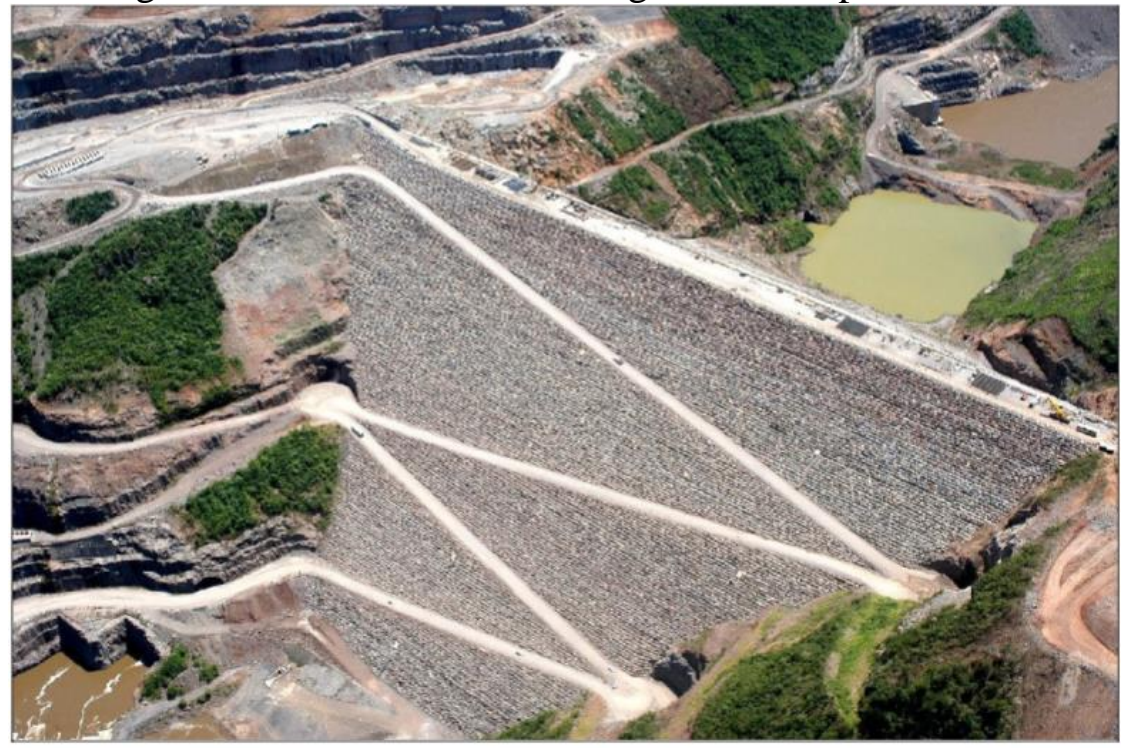

Fonte: CNEC (2004 apud AZEVEDO, 2005).

\subsubsection{Barragens de Concreto}

Conforme Marangon (2004), barragens de concreto são as constituídas basicamente de materiais granulares produzidos artificialmente aos quais se acrescentam cimento e aditivos químicos. Por este motivo, são as barragens que tem o maior custo de produção.

Figura 11 - Barragens de concreto.

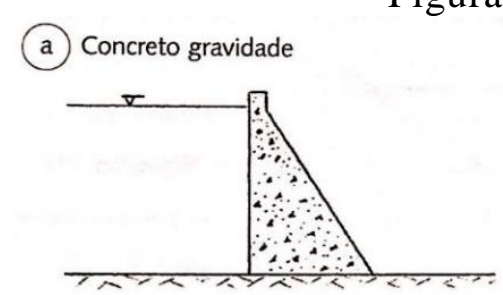

(C) Concreto em contraforte

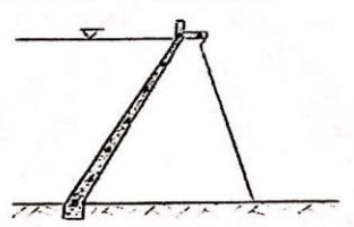

(e) Concreto de abóbada

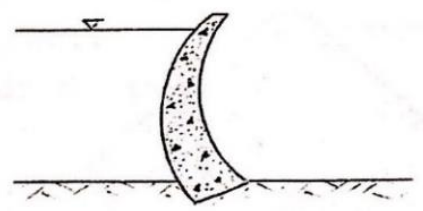

(b) Concreto aliviada
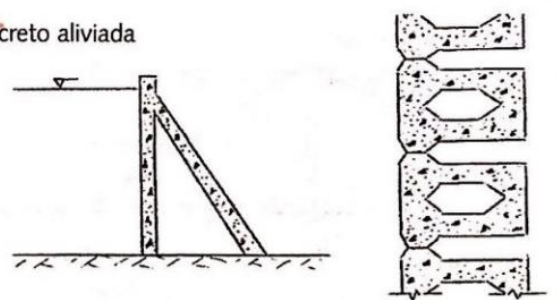

(d) Concreto rolado

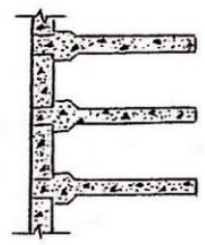

(f) Arco simples

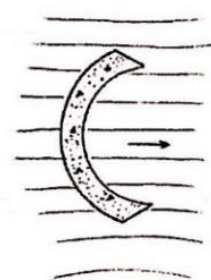

Fonte: Costa (2012).

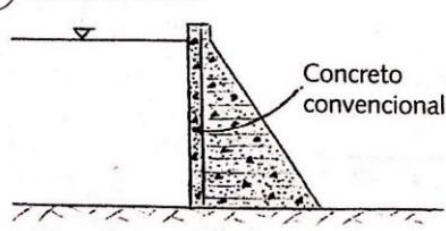

(g) Arcos múltiplos

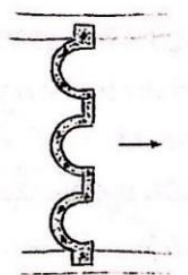




\subsubsection{Barragens de concreto de gravidade}

O U. S. Army Corps of Engineers (1995) define as barragens de concreto gravidade como estruturas sólidas de concreto que mantém a sua estabilidade contra as cargas a que está sujeita pela sua forma, massa e resistência do concreto.

As barragens de concreto gravidade são em geral maciças e pouco armadas, onde as forças atuantes predominantes são de compressão. Em relação ao seu traçado, ele pode ser retilíneo ou em arco. Seu elevado peso próprio é o fator que mantem a sua estabilidade, transmitindo as forças das águas a montante para o solo (COSTA, 2012).

Estas barragens são as mais resistentes e com o menor custo de manutenção, porém, elas apresentam o maior custo de produção em relação às de terra ou de enrocamento (MARANGON, 2004). Na Figura 12 é apresentada uma vista da PCH Americana, cuja barragem é do tipo concreto gravidade.

Figura 12 - Vista da PCH Americana - barragem de concreto gravidade.

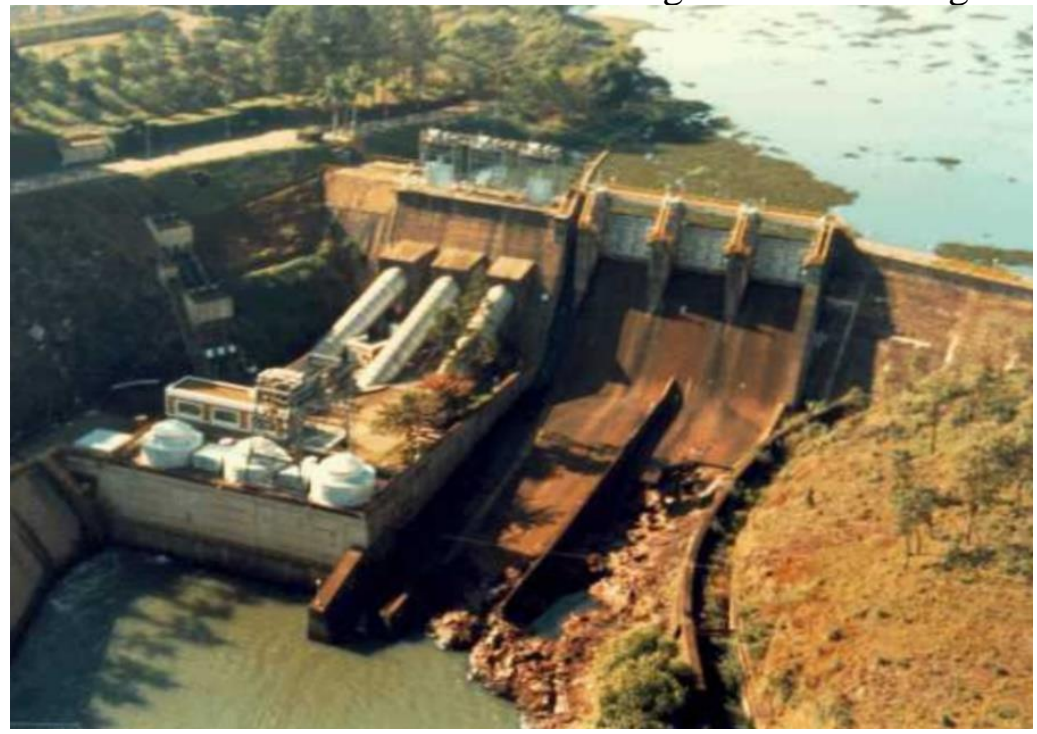

Fonte: CBDB (2005 apud AZEVEDO, 2005).

\subsubsection{Barragens de concreto de gravidade aliviada}

Costa (2012) se refere às barragens de concreto gravidade aliviada como uma variação da barragem de concreto gravidade, porém com a diferença de que a de gravidade aliviada é vazada, ou oca, para assim promover economia de concreto ou diminuir a carga no maciço de fundação. Ela também sofre maior tensão de tração, sendo necessário o uso de armação para resistir a este esforço.

Estas barragens são utilizadas quando a fundação dispões de alta resistência e baixa 
deformabilidade, pois os esforços na fundação são maiores que aqueles aplicados por barragens gravidade (ABRAHÃO; CRUZ, 2018). Na Figura 13 e Figura 14 são apresentadas uma seção transversal e foto da barragem de Itaipu.

Figura 13 - Barragem em Gravidade Aliviada - UHE Itaipu Binacional, PR.

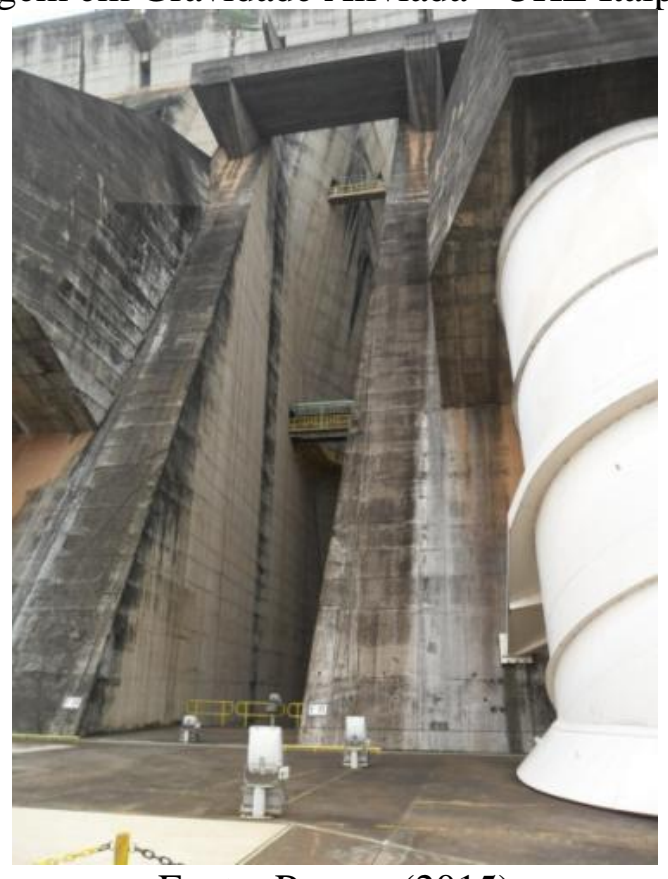

Fonte: Possan (2015). 
Figura 14 - Barragem principal do tipo gravidade aliviada da UHE Itaipu.

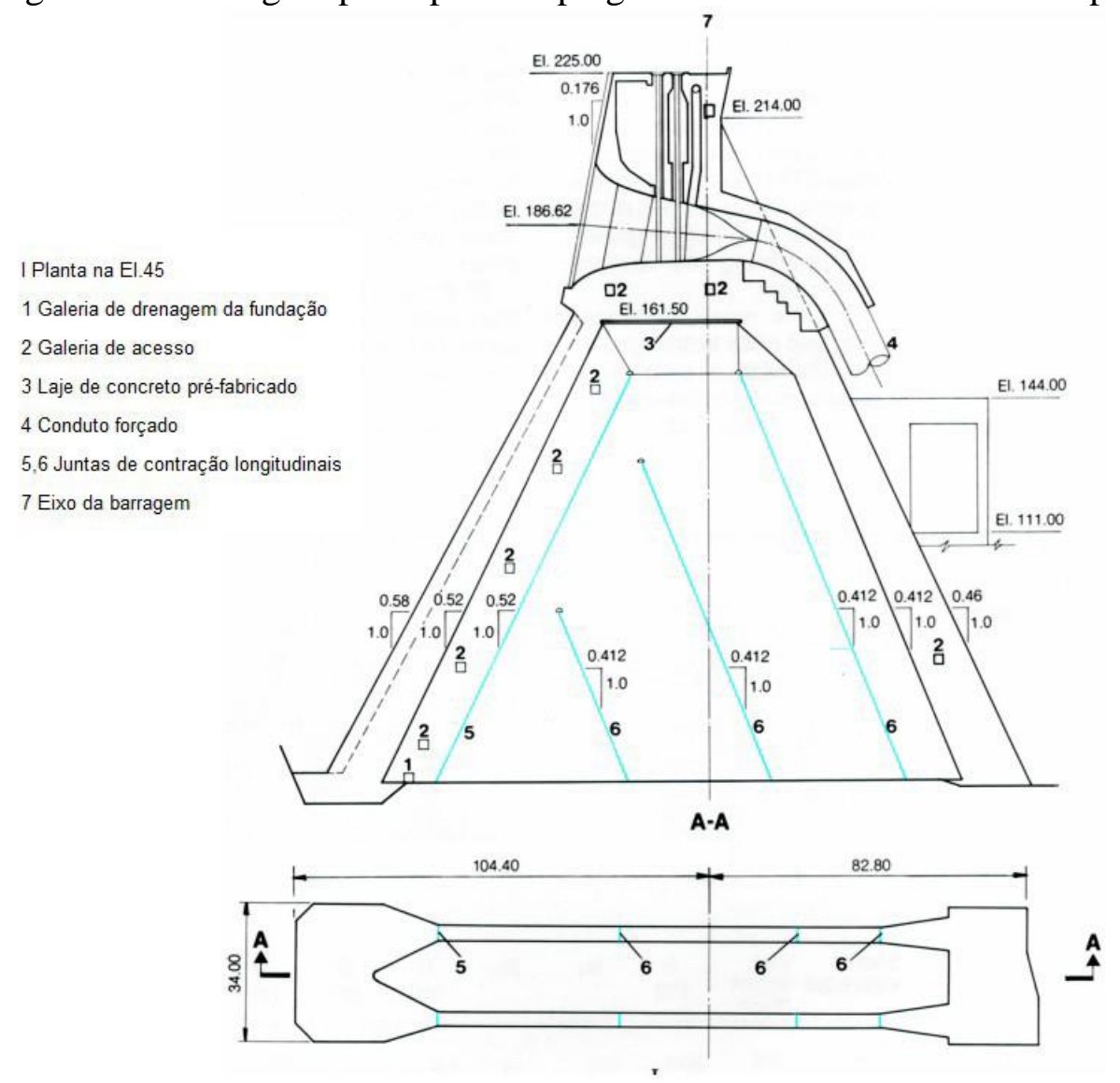

Fonte: Usina Hidrelétrica de Itaipu (2009 apud POSSAN, 2015).

\subsubsection{Barragens de concreto em contraforte}

Barragens em contraforte constituem um tipo de barragem onde o esforço no paramento montante é transmitido à fundação através de uma série de contrafortes perpendiculares ao eixo do paramento de montante. (POSSAN, 2015)

Os contrafortes são estruturas tipo "pilares" que recebem o esforço do empuxo do paramento de montante descarregando-o para as fundações. A parede vedante é formada por lajes de concreto armado apoiadas nos contrafortes, ou por abóbodas cilíndricas, em geral, em forma de semicírculo (SCHREIBER, 1977 apud POSSAN, 2015). Na

Figura 15 e Figura 16 são apresentados casos de barragens em contrafortes. Quintas (2002), cita alguns exemplos de características das barragens de contraforte:

- O equilíbrio da barragem aumenta com a força de água atuante no parâmetro oblíquo de montante;

- Pequenas infiltrações de água não colocam em risco a segurança da barragem, exceto se a fundação for de material erodível; 
- A necessidade de mão de obra de alta qualificação aumenta consideravelmente os custos de construção, porém se desconsidera a quantidade de materiais necessários.

- É complexa a distribuição dos esforços nos contrafortes quando a barragem tem dimensão longitudinal grandiosa.

Figura 15 - Barragem em contrafortes.

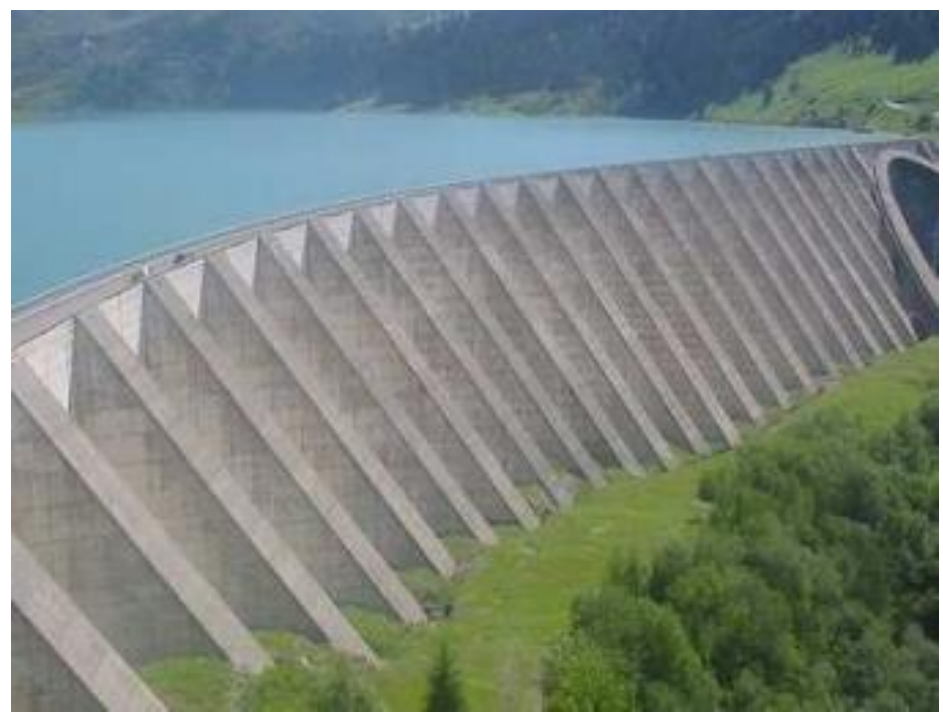

Fonte: França (2014 apud CAMARGO, 2014)

Figura 16 - Barragem em Contraforte Trecho D - UHE Itaipu Binacional, PR.

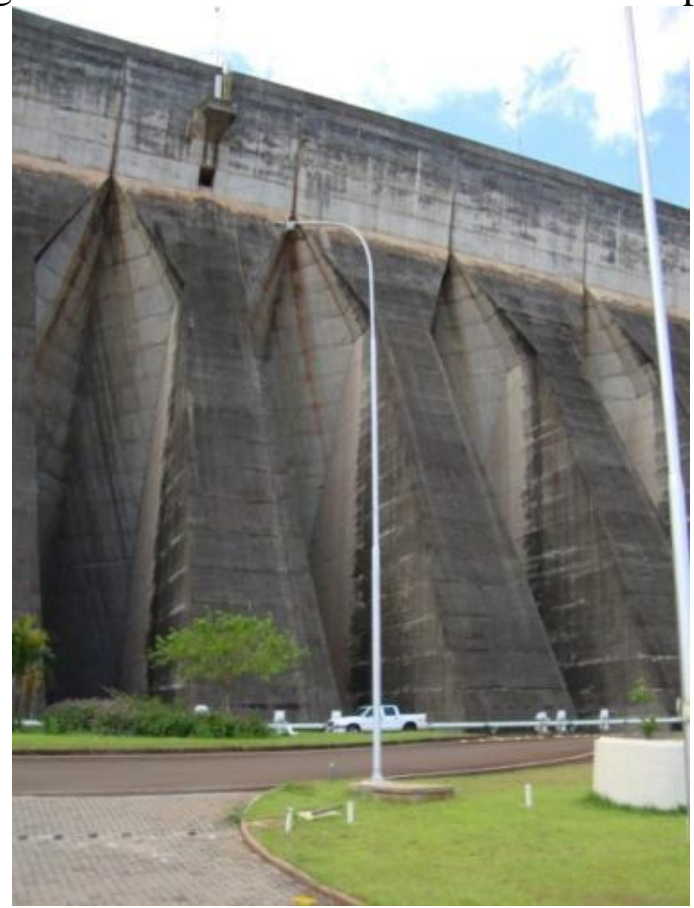

Fonte: Possan (2015). 


\subsubsection{Barragens de Concreto Compactado a Rolo - CCR}

Costa (2012), afirma que a barragem de concreto compactado a rolo - CCR é uma barragem de gravidade onde o concreto é espalhado com trator e logo após é compactado., conforme Figura 17. Neste método, o concreto não é vibrado, fazendo-se necessário a utilização de uma camada de concreto convencional construída no paramento de montante para garantir a estanqueidade da barragem. Na Figura 18 a título de ilustração é apresentada a barragem de Caraíbas, executada em concreto compacto a rolo.

Figura 17 - Praça Típica da Construção da Barragem em CCR da UHE Castro Alves, RS.

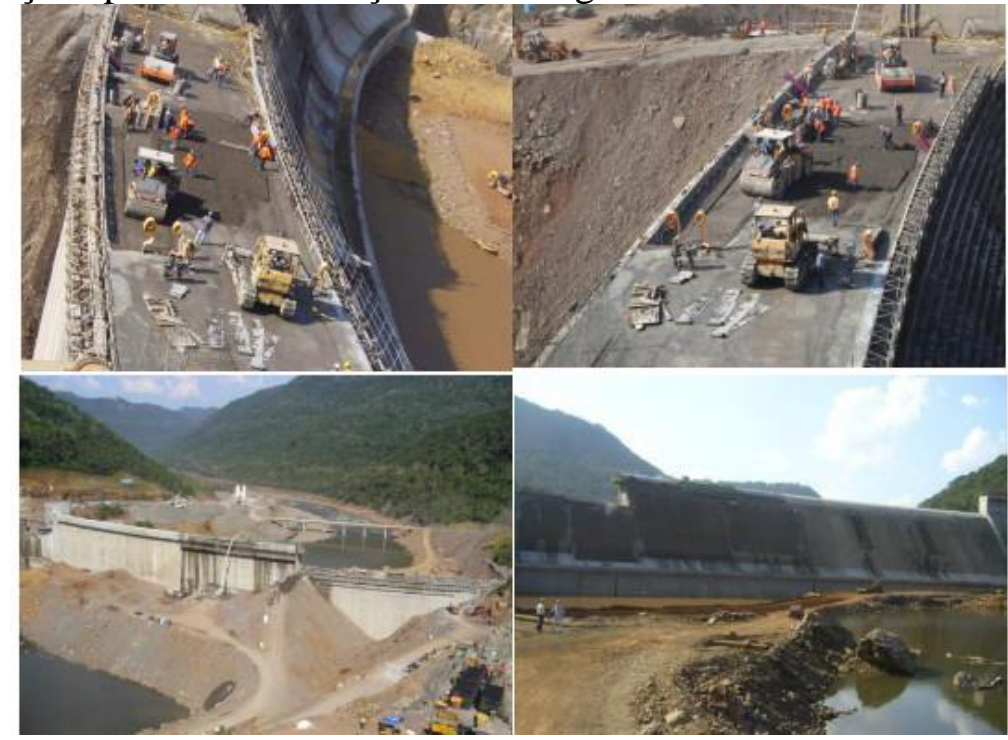

Fonte: Possan (2015).

Figura 18 - Barragem de Caraíbas em Gravidade em CCR.

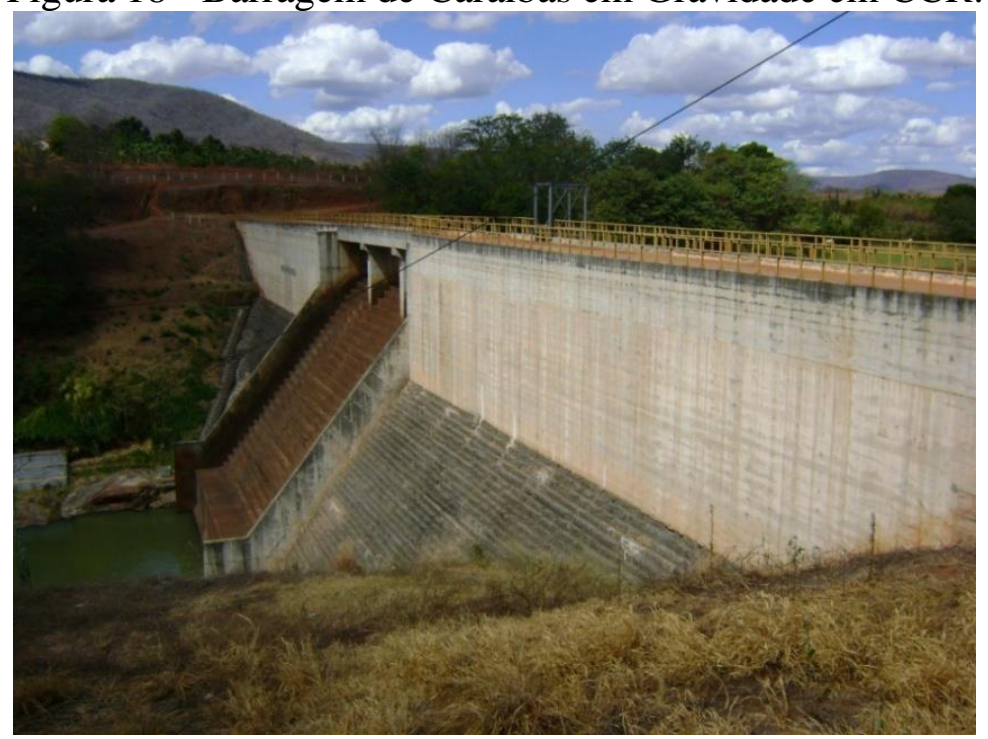

Fonte: Possan (2015). 


\subsubsection{Barragens de concreto do tipo Arco}

Conforme Marangon (2004), barragens de concreto do tipo arco (Figura 19 e Figura 20) são as mais raras pois seu comprimento deve ser pequeno em relação à sua altura, desta forma é necessária à presença de material rochoso de alta resistência nas encostas do vale, que possa suportar os esforços a elas transmitidos, sendo mais comum na Europa, ondem há vales profundos e estreitos

Essas barragens são construídas com uma seção bastante delgada com curvaturas nos planos horizontal e vertical, formando uma abóbada. A característica da barragem em arco é que a aplicação dos esforços resultantes do empuxo hidrostático se dá em todas as direções na fundação e não só na vertical, portanto nas ombreiras existe uma com- ponente do esforço na direção horizontal. Trata-se de uma estrutura complexa, que demanda um modelo geomecânico bem detalhado, com base em investigações geológicas e geotécnicas extensivas e abrangentes (ABRAHÃO; CRUZ, 2018).

Segundo Gusmão Filho (2006 apud CAMARGO, 2014), quando a distribuição das cargas for dividida de forma semelhante entre as ombreiras engastadas por arco e a fundação da barragem, a mesma é chamada de arco-gravidade, enquanto que quando as cargas são quase totalmente transmitidas por efeito arco a barragem é chamada apenas de tipo em arco.

Figura 19 - Barragem em arco Glen Canyon Dam.

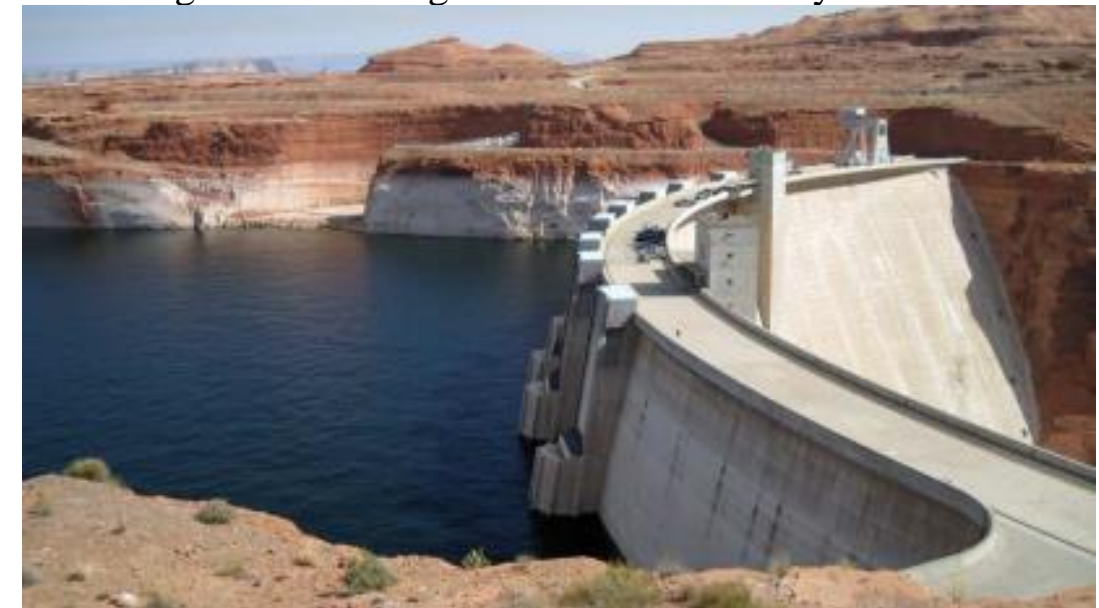

Fonte: Glen (2014 apud CAMARGO, 2014). 
Figura 20- Barragem em Arco, Karun-3 Dam, Irã: a) Paramento de montante; b) Paramento de jusante.

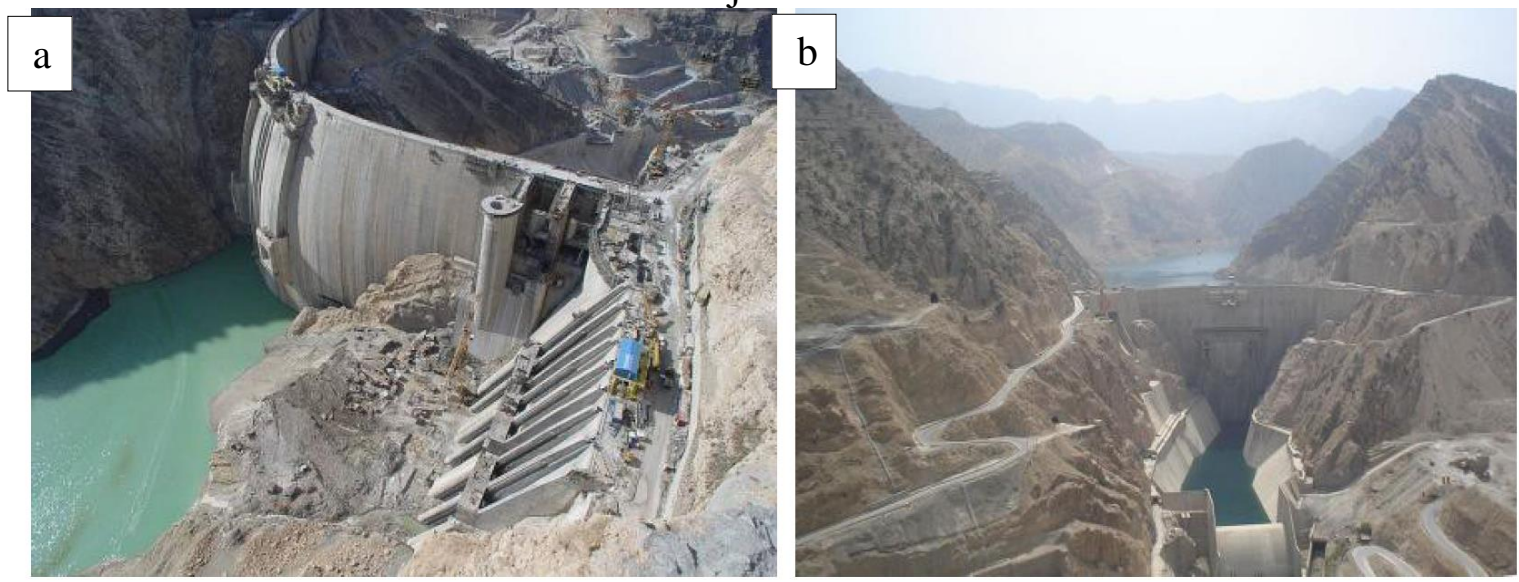

Fonte: Wikipedia (2015 apud POSSAN, 2015).

\subsubsection{Barragens mistas}

Uma barragem pode ser considerável mista quando se utiliza em sua constituição mais de um tipo de material. Podendo ser considerada mista em relação a seção transversal (Figura 21) ou em relação a seu traçado longitudinal. Não se considera barragem mista a que em seu corpo principal é de terra ou enrocamento e o vertedouro é de concreto, mesmo que exista uma continuidade do traçado, conforme (COSTA, 2012).

Figura 21 - Barragens mistas.

(a) Terra/enrocamento

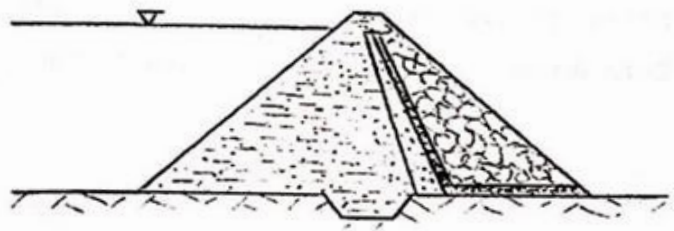

(b) Terra/concreto

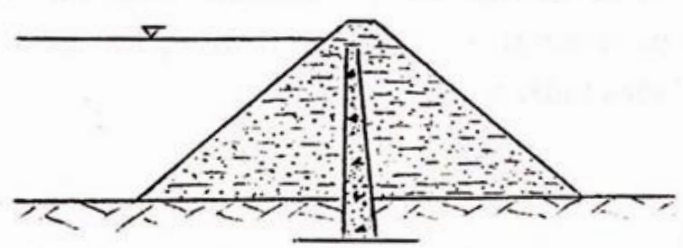

(c) Enrocamento/concreto

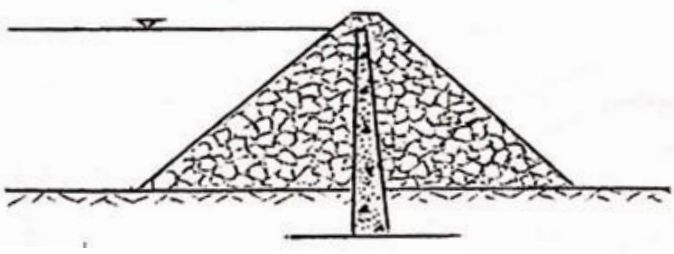

Fonte: Costa (2012).

Conforme Camargo (2014), um bom exemplo de barragem mista em relação a seu traçado longitudinal é o da barragem de Itaipu. Está barragem é composta por trechos com 
diferentes tipos de materiais (tipos de barragem), conforme Figura 22.

Figura 22 - Barragem de Itaipu.

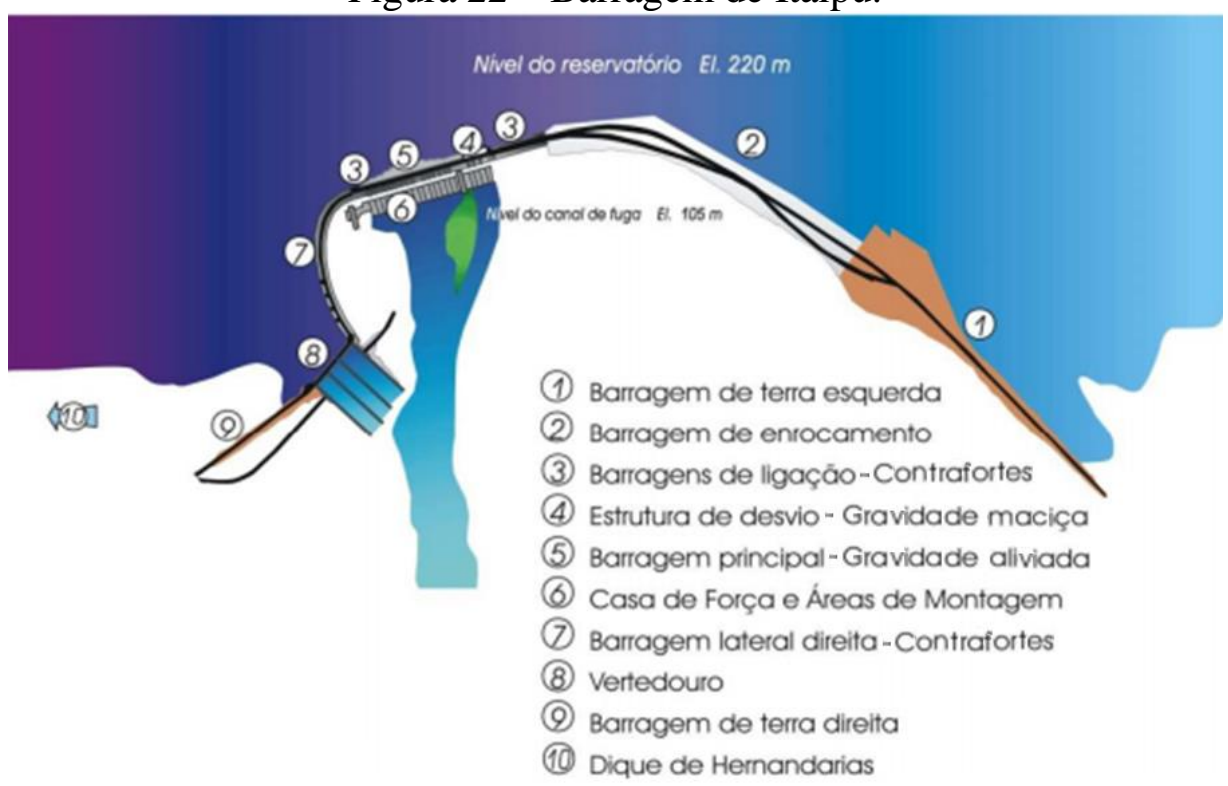

Fonte: Adaptado de Camargo (2014).

\subsection{BARRAGENS DE CONCRETO}

\subsubsection{Geologia De Barragens}

Para um estudo adequado das características geológicas e geotécnicas que interessam ao empreendimento é necessário o conhecimento prévio da geologia da região bem como da topografia para que sejam adotados tipos de barragens e arranjo das estruturas compatíveis com a vocação do sítio.

Em se tratando de barragens de concreto, o conhecimento de geologia envolve informações das litologias, estruturas e coberturas de solo. Além disso, informações relativas à sismicidade, estanqueidade e estabilidade de taludes marginais ao reservatório e nas proximidades do barramento são também importantes para a segurança da obra.

Conforme GIL (2013), merecem cuidados as rochas carbonáticas, as quais podem ser parcialmente dissolvidas facilitando a percolação e ampliando aberturas e consequentemente aumentando a permeabilidade pelas fundações e ombreiras. Rochas como granitos, gnaisses, xistos, basaltos geralmente indicam boas características geomecânicas e consequente bom comportamento quanto às fundações e baixa permeabilidade (Figura 23). Rochas sedimentares como arenitos e siltitos podem apresentar permeabilidade elevada exigindo tratamentos para 
reduzir a permeabilidade e percolação pelas fundações e ombreiras. Os filitos, muitas vezes com presença de quartzitos, são rochas com baixas características geomecânicas e podem se apresentar friáveis porosas.

Figura 23 - Litologias: Calcário, Granito, Gnaisse e Filito

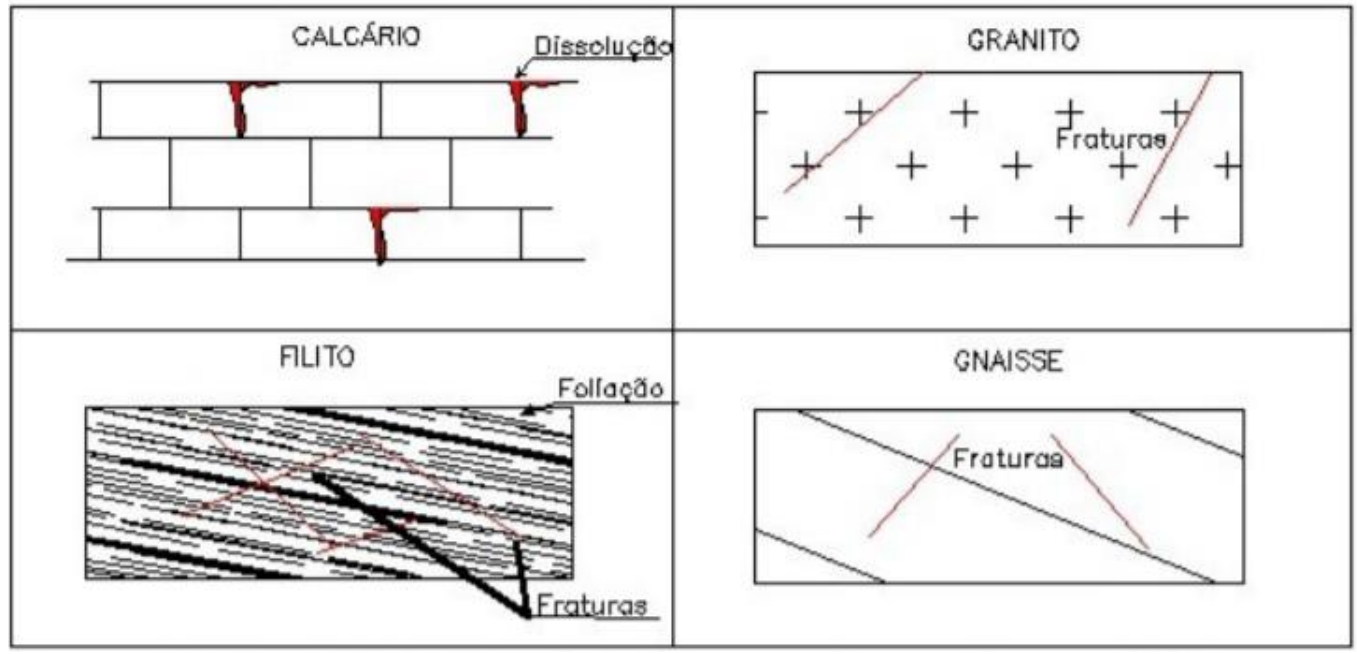

Fonte: Gil (2013).

Ainda conforme GIL (2013), a geometria mais favorável das estruturas é a transversal ao leito do rio com mergulho das camadas para montante e, em relação às ombreiras, as estruturas mais favoráveis são as que mergulham para dentro do maciço rochoso e para montante, conforme Figura 24. Essas condições favorecem a estabilidade e a estanqueidade das fundações da barragem e estruturas hidráulicas.

Figura 24 - Estruturas planares favoráveis e desfavoráveis considerando uma seção transversal ao leito do rio, vista de jusante para montante.

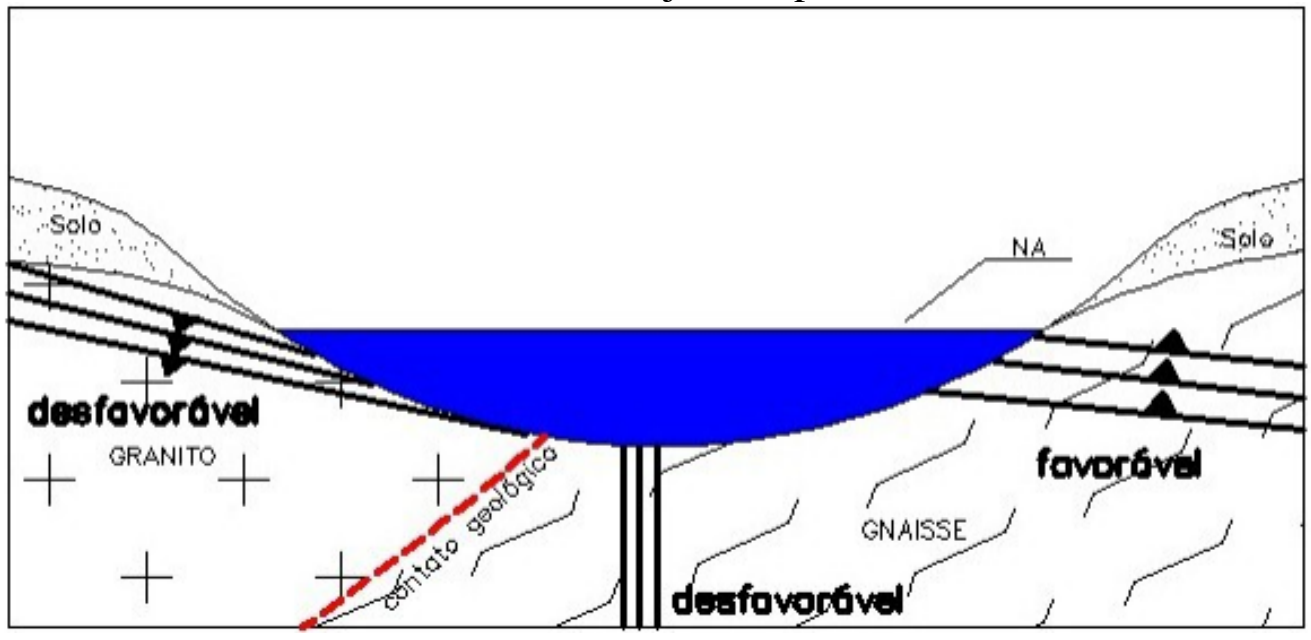

Fonte: Gil (2013). 
No estudo de arranjo, as estruturas de concreto devem ser posicionadas em locais de menor espessura de solo, devendo este material ser escavado e as fundações ficarem assentadas em rocha de boa qualidade e tratadas em subsuperfície (GIL, 2013).

Dependendo da estrutura da rocha, assim como a qualidade, levando-se em consideração seu faturamento (frequente/persistente) e a abertura, alteração e/ou preenchimento das fraturas, poderá ser necessário a realização de um determinado tratamento, visando melhorar a estanqueidade da fundação e ombreiras bem como a consolidação do maciço rochoso ou eventual estabilização de uma ombreira, por exemplo.

Apesar de sua ocorrência mais rara que os fraturamentos, as falhas apresentam geralmente baixas características geomecânicas, podendo apresentar zonas preferenciais de percolação. Maciços rochosos com alta deformabilidade podem exigir como solução a redução do esforço ou da espessura da camada, e/ou aumento do módulo de deformação da rocha, requerendo o emprego de tirantes de alta resistência, controle da subpressão, aumento da coesão e o ângulo de atrito, ou injeções de consolidação.

Problemas geotécnicos em barragens de concreto estão geralmente relacionados às fundações, que necessitam atender essencialmente às solicitações impostas pela estrutura e manter o fluxo de percolação a níveis adequados. São estruturas mais suscetíveis à deformabilidade do maciço de fundação devido à sua rigidez e questões de suporte, portanto precisam estar assentes sobre maciço rochoso (SILVEIRA, 2003).

\subsubsection{Subpressões em Barragens De Concreto}

As barragens de concreto gravidade têm sua estabilidade dependente do peso próprio e largura de base. Partindo desse conceito, o esforço de subpressão causado pela percolação através do maciço da fundação, que atua em sentido ascendente, atua como força instabilizante reduzindo o peso efetivo da estrutura, podendo causar deslocamentos e consequente colapso da estrutura (VOLKMER, 2011).

A estabilidade das barragens de concreto deve ser calculada de forma a garantir segurança quanto ao deslizamento, tombamento e flutuação, semelhante a uma estrutura de contenção em concreto. A grande diferença é a carga de água e a subpressão que ela exerce sob a barragem, tanto na superfície de apoio do concreto como em qualquer plano de fraqueza que exista no terreno (rocha, em geral) de fundação.

O entendimento da ação da subpressão no final do século XIX revolucionou o futuro dos 
tratamentos de fundações de barragens. Até então as hipóteses de cálculo de projetos de barragens não consideravam a existência da subpressão no corpo da barragem. Assim, tanto o corpo da barragem quanto a fundação eram considerados impermeáveis. Conforme Osako (2002), quando se tomou consciência da existência da subpressão, a maior preocupação era voltada ao contato estrutura-fundação, à ausência de segurança quanto à completa impermeabilização. Nesta época, quando a fundação era constituída de "rocha-dura", a preocupação era impermeabilizar e não aliviar os esforços de subpressão.

Após o acidente de Bouzey, em 1895, Maurice Lévy indicou que as causas da catástrofe se deviam às pressões de água instaladas na rocha e a força de subpressão atuante sob a fundação, colocando em evidência a importância da subpressão na estabilidade global destas estruturas.

Inicialmente, em 1898, Lieckfeldt considerava a possibilidade da subpressão se estabelecer retangularmente, conforme a Figura 25, pois se admitia que na altura do paramento de jusante a barragem resistiria por peso, não permitindo que as infiltrações fossem até jusante. Já em 1899, Levy propôs que a subpressão variava linearmente de montante para jusante. (ANDRADE, 1982).

Figura 25 - Hipótese de Lieckfeldt e Levy.
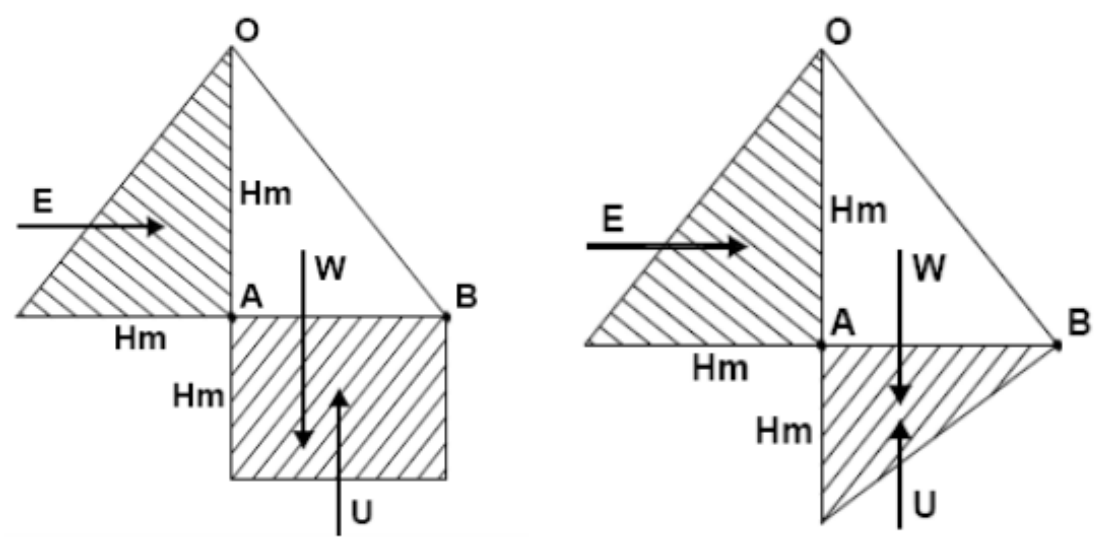

Fonte: Andrade (1982).

Posteriormente, várias pesquisas continuaram a ser realizadas, destacando-se os trabalhos de Casagrande, ASCE - American Society of Civil Engineers, TVA - Tennessee Valley Authority, USACE - U.S. Army Corps of Engineers, USBR - U.S. Bureau of Reclamation.

Conforme LOPES (2015), para Azevedo e Albuquerque Filho (1998), a presença de descontinuidades, a sua orientação e abertura, o estado de tensão atuante no maciço e a porosidade da matriz rochosa, interferem na área de atuação da subpressão, e Lagos Filho e Geraldo (1998) concluem que a subpressão pode atuar não somente na base da barragem, mas 
em qualquer descontinuidade presente na fundação.

\subsubsection{Tratamento dos Maciços de Fundação}

Conforme COSTA (2012), o maciço natural que constitui a fundação sofrerá intensas modificações com a construção de uma obra de barramento. Como nem sempre as características originais desse maciço natural são suficientes para suportar as modificações a serem impostas pela obra projetada, é necessário melhorar ou reforçar essas características por meio de técnicas e procedimentos visando a uma melhor adequação das fundações à obra projetada.

O tratamento dos maciços de fundação das barragens de concreto visa, essencialmente, melhorar as características mecânicas e hidráulicas desses maciços, por intermédio de injeções de consolidação e impermeabilização do maciço ou de ligação na interface estrutura fundação e por sistemas de drenagem, tendo em atenção que as cargas transferidas pelas barragens de gravidade atingem em maior escala a zona central do vale, e que as barragens em arco transferem as cargas essencialmente às ombreiras (ANA, 2016).

\subsubsection{Injeções}

Conforme COSTA (2012), o tratamento das fundações de uma barragem por meio de injeções consiste em fazer penetrar nos vazios do maciço natural (solo ou rocha) um produto líquido que tenha a propriedade de endurecer depois de certo tempo de aplicado. O produto cimentante injetado é denominado calda de injeção.

As injeções dos maciços devem ser estudadas, tendo em conta as características destes, como por exemplo, as superfícies de compartimentação, de modo a preencher de forma adequada os vazios e as descontinuidades existentes. Quando as características do maciço de fundação ou a dimensão da barragem o justificar, deve ponderar-se a realização de blocos de ensaio, incluindo ensaios de injetabilidade, na fase anterior à instalação do canteiro ou no início dos trabalhos, visando definir, para cada zona do maciço, os produtos, os métodos, as pressões e as técnicas a utilizar (ANA, 2016).

Existem três tipos de injeções: de colagem, de consolidação e cortina de injeções. As injeções de colagem objetivam eliminar os vazios existentes entre um maciço de concreto e as fundações rochosas; as injeções de consolidação visam melhorar as condições de resistência das fundações, embora tenham também uma função impermeabilizante; e as cortinas de 
injeção têm corno principal objetivo controlar a percolação da água através das fundações ou no entorno de Obras subterrâneas (COSTA, 2012).

Deere (1977) propõe um critério para avaliação da absorção/consumo de cimento dos furos de injeção, conforme Tabela 2.

Tabela 2 - Orientação para análise de absorção de cimento nas injeções

\begin{tabular}{cc} 
Absorção & $\begin{array}{c}\text { Peso de cimento absorvido por } \\
\text { metro de furo }(\mathbf{k g} / \mathbf{m})\end{array}$ \\
\hline Muito baixa & 0 a 12,5 \\
Baixa & 12,5 a 25 \\
Moderadamente baixa & 25 a 50 \\
Moderada & 50 a 100 \\
Moderadamente alta & 100 a 200 \\
Alta & 200 a 400 \\
Muito Alta & mais de 400 \\
\hline
\end{tabular}

Fonte: Deere (1977).

\subsubsection{Sistemas de Drenagem}

As injeções de calda de cimento devem ser complementadas com a execução de drenos, visando reduzir as subpressões nas zonas do maciço em que, mesmo nos casos em que as injeções são eficientes, os respectivos valores possam pôr em risco as condições de estabilidade da barragem (ANA, 2016).

Conforme COSTA (2012) as pressões hidrostáticas que atuam na base de uma barragem (subpressões), constituem um problema mais significativo nas barragens de concreto, onde a relação H/ B (altura/comprimento da base) é muito maior que nas barragens granulares (terra e enrocamento). Por isso, a drenagem subterrânea das fundações é aplicada apenas às barragens de concreto e realizada por meio de drenos de alívio.

Segundo Porto (2002 apud LEVIS 2006), as cortinas de drenagem são constituídas de furos igualmente espaçados e dispostos logo a jusante da cortina de injeção. Seu objetivo consiste em drenar as águas que fluem através do maciço e aliviar as supressões impostas pela carga hidráulica do reservatório.

Complementando, esses drenos são abertos no maciço rochoso com a utilização de equipamentos de rotopercussão geralmente com diâmetro de $75 \mathrm{~mm}$. sua maior parte, são 
executados a partir de uma galeria existente no corpo da barragem, localizada nas proximidades do pé de montante dessa obra. A profundidade dos drenos deve ser suficiente para interceptar os principais veículos de percolação do maciço rochoso, e o espaçamento entre os drenos geralmente varia entre $3 \mathrm{~m}$ e $5 \mathrm{~m}$. Caso seja projetada uma cortina de injeção a partir da mesma galeria em que forem projetados os drenos, como mostrado na Figura 26, a injeção deve preceder aos drenos, para evitar a colmatação destes no caso de serem executados primeiramente (COSTA, 2012).

Figura 26 - Drenos de alívio e injeções a partir da galeria de drenagem.

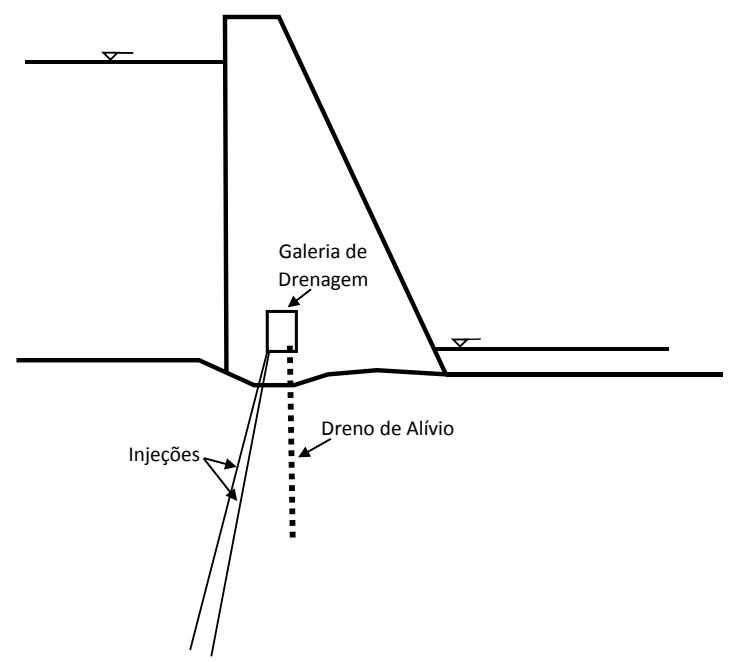

Fonte: Adaptado de Costa (2012).

\subsubsection{A Influência dos Tratamentos}

Visando a redução da subpressão sob barragens de concreto, passou-se a executar drenos a partir de galerias internas à estrutura, executando adicionalmente cortinas de injeção para reduzir as vazões nos drenos, visando melhorar as condições de segurança das estruturas e a construção de obras menos onerosas, em função da diminuição do volume de material de construção.

Na Figura 27, ASCE (1952 apud SANDRONI, 2006) mostra as subpressões em 3 barragens (Willwood, Wheeler e Neye) com injeções e sem drenagem e as compara com as médias das barragens com drenos e com injeções do USBR (8 barragens) e da TVA (4 barragens).

Casagrande (1961 apud LEVIS, 2006) estudou casos hipotéticos de situações com cortinas de drenagem e de injeções eficientes e ineficientes, como ilustrado na Figura 28. A Figura 29 mostra o caso da barragem Wheeler, na qual os drenos foram perfurados com a obra em operação, observando-se a expressiva queda da subpressão depois da instalação dos drenos. 
Figura 27 - Comparação das subpressões em 3 barragens com injeção e sem drenagem.

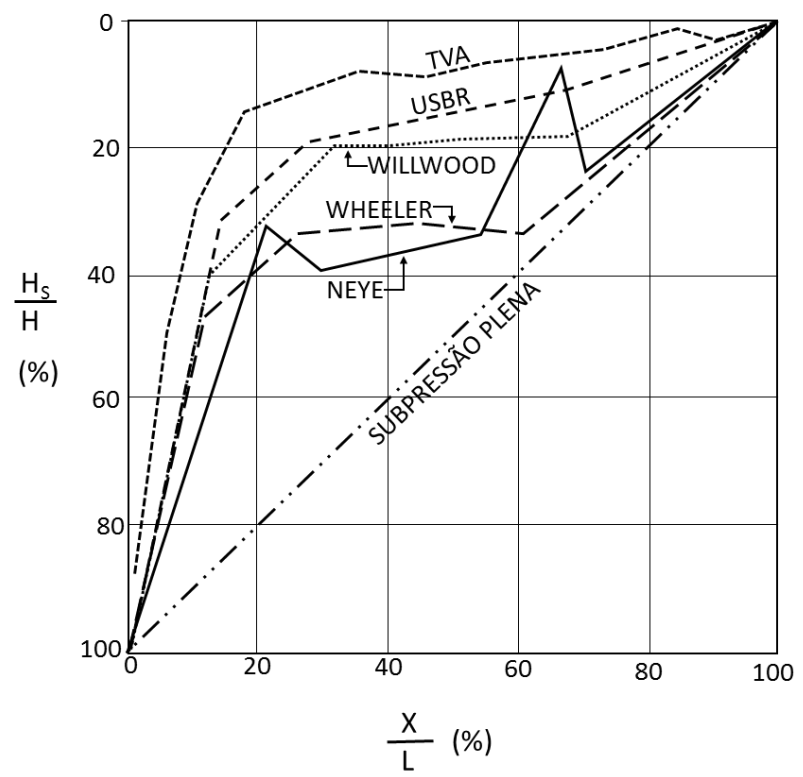

Fonte: ASCE (1952 apud SANDRONI, 2006).

Figura 28 - Casos hipotéticos de estudo.

(a) CORTINA DE INJEÇŌES PERFEITA

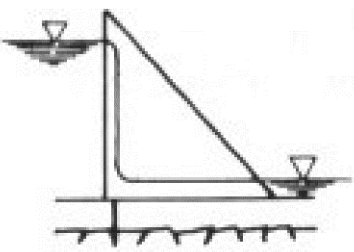

(d) DRENAGEM EFICIENTE. NIVEL NOS DRENOS ABALIXO DO NIVEL DE JUSANTE

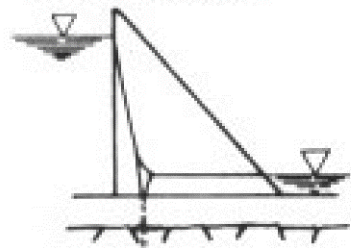

(9) CONDICOEES GEOLÓGICAS ORIGINAM SUBPRESSARO EXCESSIVA. PROFLNDI DADE INSUFICIENTE DOS DRENOS

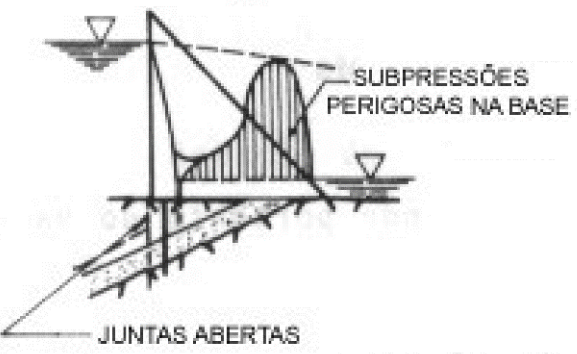

(b) CORTINA DE INJECÓES RAZOAVELMENTE EFICIENTE SEM DRENOS

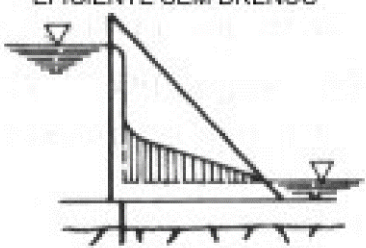

(e) DRENAGEM EFICIENTE. NIVE NOS DRENOS ACIMA DO NIVEL DE JUSANTE

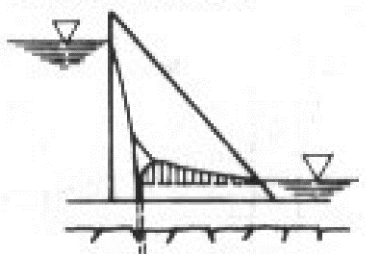

(6) CORTINA DE INJECOOES RAZOAVELMENTE EFICIENTE COM DRENOS

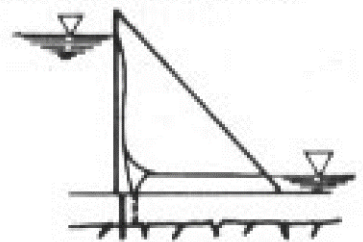

(f) DRENAGEM DEFICIENTE. FUROS NATO SUCIENTE MUITO PRO FUNDOS PARA AS CONDICÓES DA ROCHA

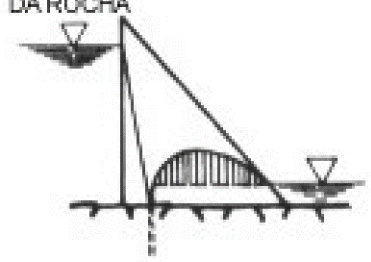

(1) CONDICÓES GEOLOGICAS CAUSAM PRESSOES INTERSTICLAIS PERIGO_ SAS NA ROCHA

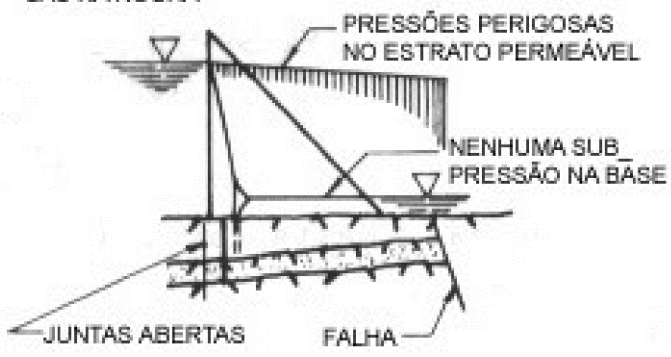

Fonte: Casagrande (1961 apud LEVIS, 2006). 
Figura 29 - Comparação das subpressões nas Barragens de Wheeler, Wilson e Fontana.

(A)

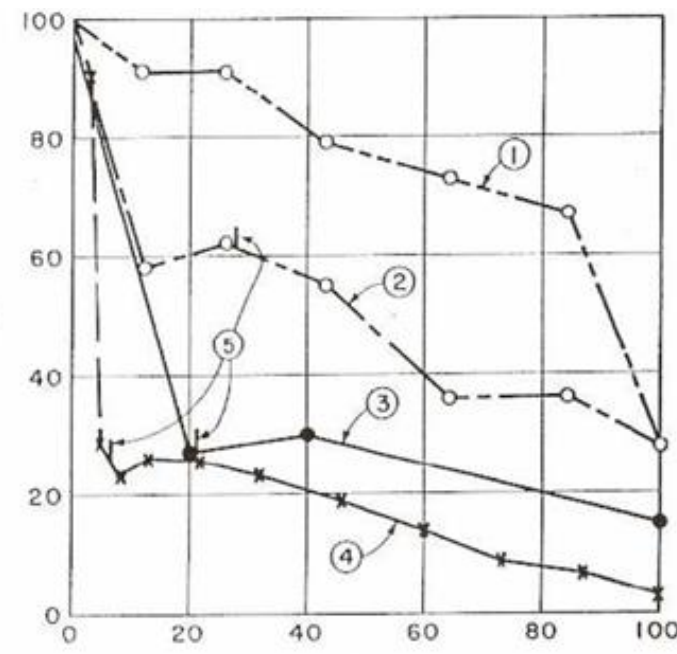

Legenda

A - Subpressão em porcentagem da diferença de nível entre montante e jusante;

B - Distância porcentagem da largura total da base;

C - face de montante;

D - face de jusante;

1 - Subpressão na barragem de Wheeler antes dos drenos;

2 - Subpressão na barragem de Wheeler depois dos drenos;

3 - Subpressão na barragem de Wilson;

4 - Subpressão na barragem de Fontana;

5 - Posição dos drenos.

Outro caso interessante é o da barragem de Chief Joseph (Rhodes e Dixon, 1976), vindo ressaltar a importância do espaçamento entre drenos para a eficiência do sistema de drenagem. A barragem entrou em operação em 1954 e o espaçamento dos drenos foi reduzido em duas ocasiões: de 6 para 3 m, em 1959, e para 1,5 m, em 1961. Após 1 ano da diminuição do espaçamento dos drenos para $3 \mathrm{~m}$, as subpressões voltaram a subir, entretanto, depois que o espaçamento foi diminuído para 1,5 m a subpressão se manteve baixa.

Conforme CRUZ, 2004, o fluxo em rocha é comandado pela natureza da rocha e estado de alteração, assim como pelas juntas, fraturas e falhas presentes na estrutura do maciço, tornando a determinação da permeabilidade aceitável para esse tipo de fundação complexa. Entretanto, pode-se considerar que maciços que apresentam permeabilidade média acima de 5 x $10^{-4} \mathrm{~cm} / \mathrm{s}$ necessitam de tratamento para redução desses valores, geralmente empregando a utilização de injeção de calda ou argamassa de cimento.

Cruz (2004) apresenta seções esquemáticas com as reduções de subpressão em uma feição permeável de uma barragem de concreto hipotética apoiada em rocha. São considerados casos de tratamento só com drenagem, só com injeção e drenagem injeção, desprezando a perda de carga no maciço rochoso, por se trata de uma feição rasa (Figura 30). 
Figura 30 - Subpressões considerando: (a) Apenas injeção, (b) Apenas drenagem, (c) Injeção e drenagem

a)

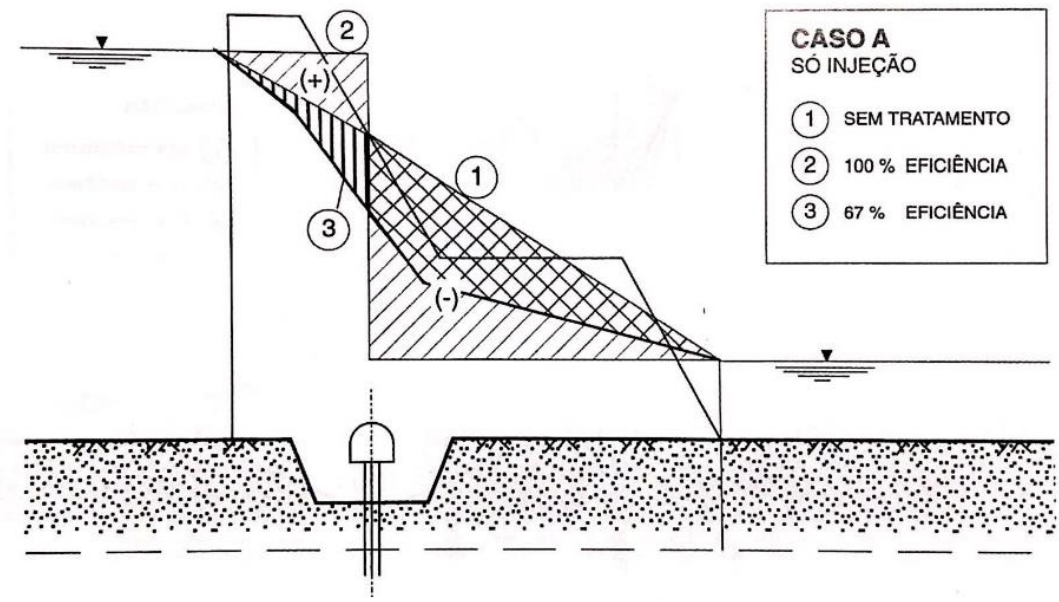

b)

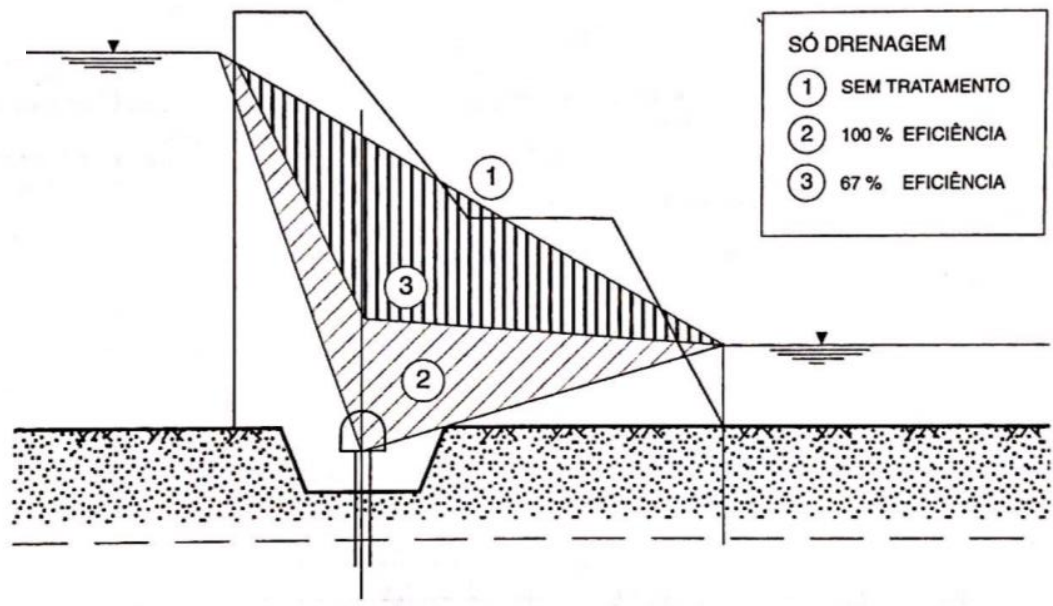

c)

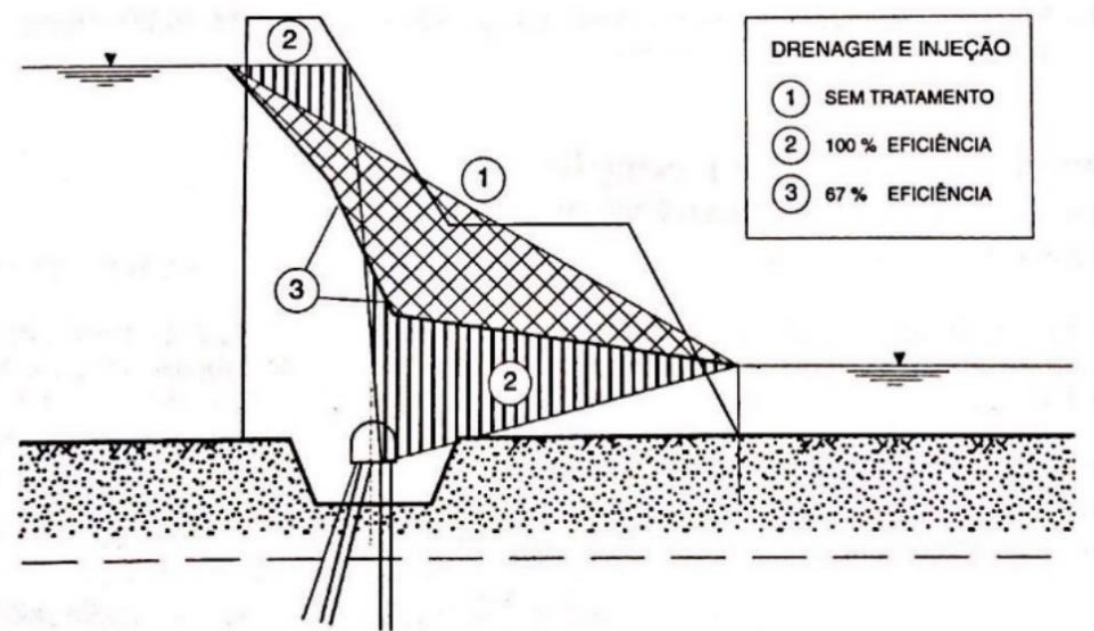

Fonte: Cruz (2004).

DRENAGEM E INJECCĀO

1) sem tratamento

(2) $100 \%$ EFICIÉNCIA

(3) $67 \%$ EFICIENCIA

(1) SeM tratamento

(2) $100 \%$ EFICIÊNCIA

(3) $67 \%$ EFICIÉNCIA 
$\mathrm{Na}$ Tabela 3 apresentam-se os valores das subpressões totais no plano da descontinuidade, e as reduções previstas. Partindo de uma vazão Q, admitido gradiente linear na fundação para a condição I (sem tratamento), pode-se estimar a redução ou o aumento das vazões resultantes. Conforme CRUZ (2004). Algumas observações são pertinentes:

a) a drenagem é mais eficiente na redução da subpressão do que a injeção;

b) a drenagem resulta num aumento de vazões, especialmente quando a galeria de montante está muito próxima do pé de montante da barragem;

c) a condição 3, usual em projeto, pode estar subdimensionada para a vazão nos drenos das galerias e, por outro lado, resulta em subpressões maiores do que as observadas;

d) se a perda de carga pelo maciço rochoso for considerada, as reduções das subpressões serão indicadas na segunda coluna.

Tabela 3 - Subpressões e vazões relativas.

\begin{tabular}{cccccc}
\hline \multirow{2}{*}{ Caso } & \multirow{2}{*}{$\begin{array}{c}\text { Subpressão } \\
\text { Total }\end{array}$} & $\begin{array}{c}\mathbf{1 0 0} \text { Supressão } \\
\text { Eficiência }\end{array}$ & $\begin{array}{c}\mathbf{6 7 \%} \\
\text { Eficiência }\end{array}$ & $\begin{array}{c}\mathbf{1 0 0} \% \\
\text { Eficiência }\end{array}$ & $\begin{array}{c}\mathbf{6 7 \%} \\
\text { Eficiência }\end{array}$ \\
\hline $\mathrm{A}$ & $\mathrm{U}$ & $0,83 \mathrm{U}$ & $0,85 \mathrm{U}$ & 0 & $0,34 \mathrm{Q}$ \\
$\mathrm{B}$ & $\mathrm{U}$ & $0,53 \mathrm{U}$ & $0,71 \mathrm{U}$ & $5,2 \mathrm{Q}$ & $3,6 \mathrm{Q}$ \\
$\mathrm{C}$ & $\mathrm{U}$ & $0,52 \mathrm{U}$ & $0,73 \mathrm{U}$ & $0,4 \mathrm{Q}$ & $0,7 \mathrm{Q}$ \\
\hline
\end{tabular}

Notas:

Na condição (1) Q é a vazão pela fundação sem tratamento;

Na condição (2) Q é a vazão para os drenos;

Na condição (3) Q é a vazão para os drenos e para jusante.

Fonte: Cruz (2004).

Conforme Terzaghi et al., (1996), drenos de alívio a jusante das cortinas de injeções apresentam melhor eficiência na redução de pressões, entretanto cortinas de injeções quando bem executadas podem diminuir consideravelmente as vazões pela fundação da barragem.

\subsubsection{Critérios de Subpressão para Análise de Estabilidade}

Conforme já comentado, após a proposta de Levy em 1899, de que a subpressão variava linearmente de montante para jusante, várias outras pesquisas continuaram a ser realizadas, considerando, ou não, casos com drenagem da fundação e cortina de injeção, que por consequência, levaram à proposição de critérios para a consideração da subpressão nos projetos e cálculos de estabilidade de barragem de concreto. 
Conforme Levis (2006), cada órgão controlador procura apresentar seus critérios de projeto, os quais fixam valores máximos de supressões a serem admitidos nas diferentes fases do projeto. Estes critérios levam ou não em consideração os dispositivos de injeção e drenagem. Levis (2006), apresenta ainda em seu trabalho uma série de critérios adotados em diversos países, dentre eles:

- Critério Sueco;

- Critério Italiano;

- Critério Alemão;

- Critério do U.S. Army Corps of Engeniers (Estados Unidos);

- Critério do U.S. Bureau of Reclamation (Estados Unidos);

- Critério de Cruz e Silva - 1978 (Brasil);

- Critério de Cruz e Barbosa - 1981 (Brasil);

- Critério de Azevedo - 1993 (Brasil);

- Critério de Cruz -1996 (Brasil);

- Critério da Eletrobrás - 2003 (Brasil).

O critério de projeto sugerido pelo U.S. Bureau of Reclamation (1976) propõe que a distribuição de tensões em uma seção horizontal da barragem sem cortina de drenagem deve ser assumida com variação linear entre a coluna de água de montante e a coluna d'água de jusante, zerando neste ponto quando inexiste coluna de água a jusante, semelhante à proposição de Levy. Recomenda-se, ainda, que seja adotada uma redução de $2 / 3$ da diferença de níveis hidrostáticos de montante e jusante na linha de drenos, na falta de outras análises. Esta redução é baseada na observação do comportamento das obras construídas pelo órgão e é ilustrada na Figura 31. 
Figura 31- Critério de subpressão.

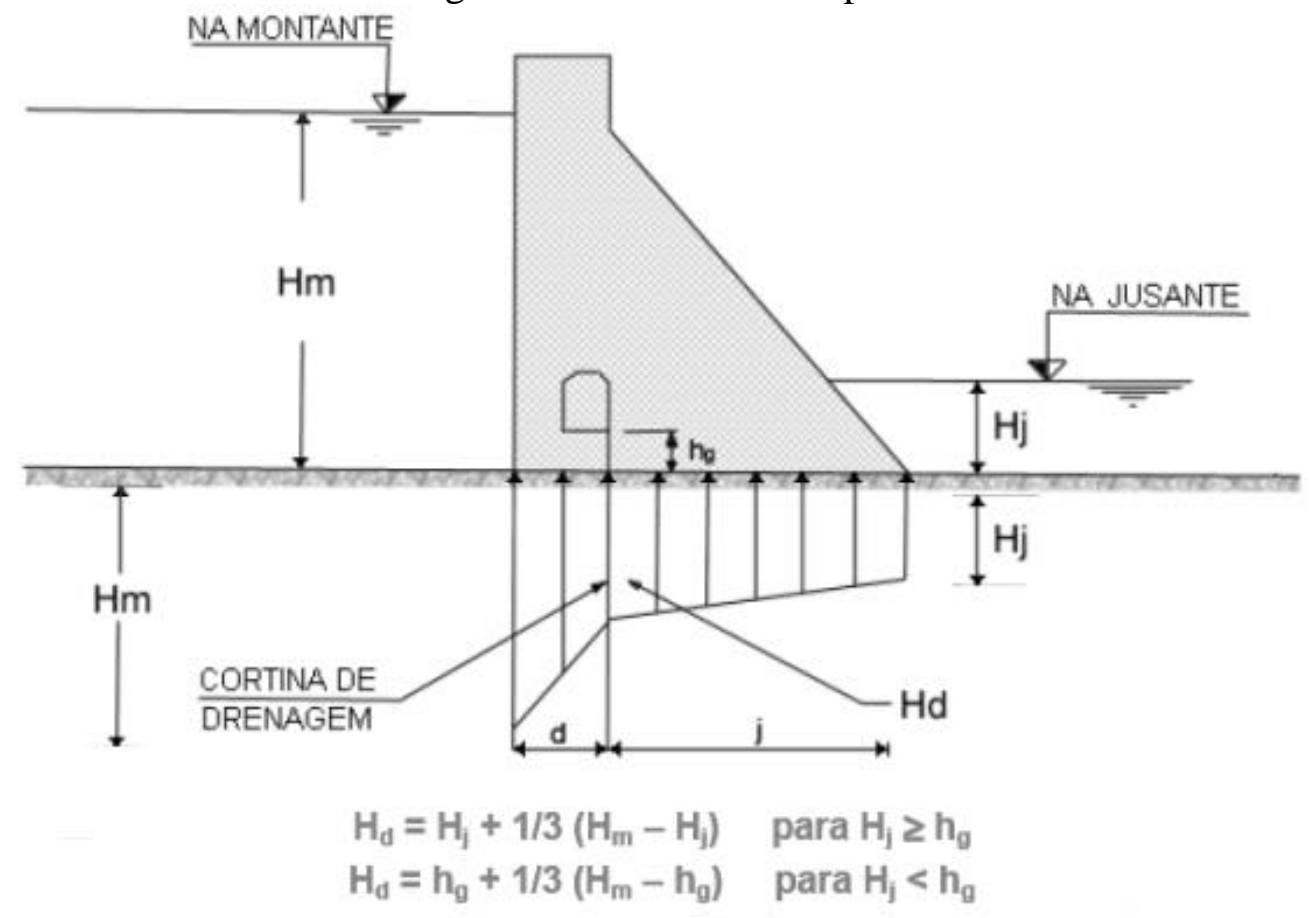

Fonte: USBR (1976 apud VOLKMER, 2011).

No Brasil, a Eletrobrás (2003) na publicação "Critérios de Projeto Civil de Usinas Hidrelétricas" visa uniformizar e definir os critérios a serem utilizados no desenvolvimento de projetos em nível de Viabilidade, Básico e Executivo de Usinas Hidrelétricas.

Estes critérios foram elaborados nos moldes daqueles produzidos pelo USBR-Bureau of Reclamation. Procurou-se chegar a critérios que atendessem as condições indispensáveis de segurança com o menor custo possível, mantendo a qualidade e o desempenho dos empreendimentos hidrelétricos (ELETROBRÁS, 2003). Na Figura 32 são apresentados exemplos dos critérios de projeto. 
Figura 32 - Subpressões (a) No contato das estruturas de concreto com a fundação, (b) Com contato aberto, (c) Com uma linha de drenos operantes, (d) com drenos inoperantes.
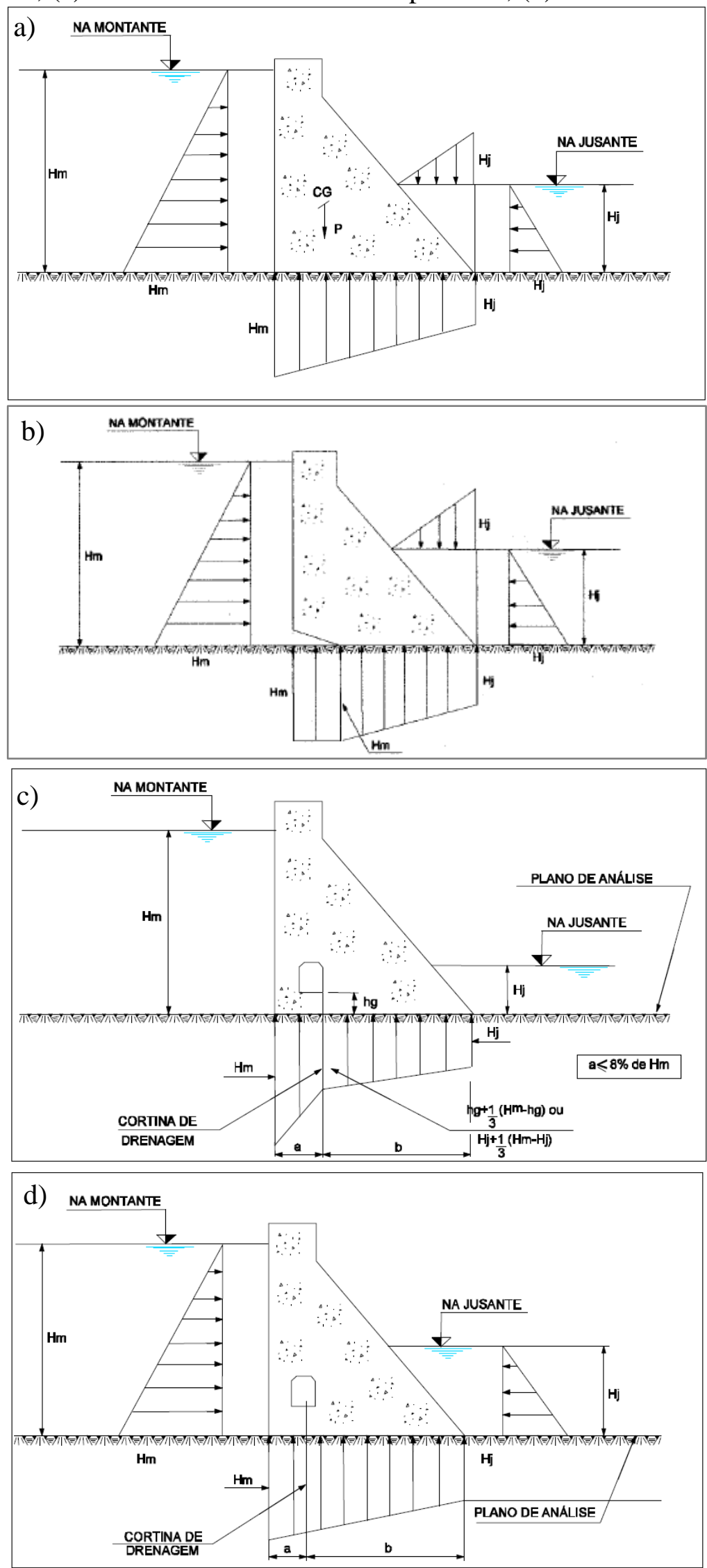

Fonte: Eletrobrás (2003). 
A definição do diagrama de subpressões em cada caso deve se basear, na prática, em precedentes e em avaliações geológicas. Não existe uma maneira padronizada para o diagrama de subpressões nas situações mais complexas, por exemplo, a ocorrência ou não de "trincas de tração" no pé de montante, que permitiriam a comunicação integral da pressão de montante abaixo da superfície.

Devem ser realizados estudos detalhados da geologia da fundação e, a partir destes, da geometria da obra e das experiências disponíveis, devem ser definidos os níveis das galerias, a posição, a profundidade e a geometria das linhas de drenos e das cortinas de injeção.

\subsubsection{Análise de Estabilidade Global}

Conforme já mencionado, cada órgão controlador procura apresentar seus critérios de projeto. No Brasil, a Eletrobrás (2003) elaborou um documento com os "Critérios Gerais de Projeto Civil" para o desenvolvimento de projetos de Usinas Hidrelétricas em todas as suas etapas. Estes critérios foram baseados em análises teóricas e experimentais de utilização consagrada, com finalidade orientar as condições exigíveis na verificação da segurança das estruturas de Usinas Hidrelétricas e estabelecer as definições, normas, diretrizes e critérios de quantificação das ações e das resistências a considerar no projeto das estruturas, que permitam a máxima eficiência, durabilidade e confiabilidade da geração energética.

Conforme Eletrobrás (2003), a análise de segurança global deve ser feita para todas as estruturas principais, elementos estruturais e sistemas de interação entre as fundações e as estruturas submetidas aos diversos casos de carregamentos e englobará a análise de estabilidade no contato concreto-rocha, a análise de estabilidade em planos superiores e inferiores ao da fundação, a análise de tensões e deformações, a definição dos coeficientes de segurança e a verificação entre as tensões atuantes e as tensões admissíveis dos materiais.

\subsubsection{Condições de Carregamento}

Conforme Eletrobrás (2003), as seguintes condições de carregamentos devem ser consideradas nos estudos de estabilidade global:

- Condição de Carregamento Normal (CCN) Corresponde a todas as combinações de ações que apresentem grande probabilidade de ocorrência ao longo da vida útil da estrutura, durante a operação normal ou manutenção de rotina da obra, em condições hidrológicas normais; 
- Condição de Carregamento Excepcional (CCE ) Corresponde a uma situação de combinação de ações com baixa probabilidade de ocorrência ao longo da vida útil da estrutura. Em geral, estas combinações consideram a ocorrência de somente uma ação excepcional, tais como, condições hidrológicas excepcionais, defeitos no sistema de drenagem, manobras de caráter excepcional, efeitos sísmicos, etc. com as ações correspondentes a condição de carregamento normal;

- Condição de Carregamento Limite (CCL) Corresponde a uma situação de combinação de ações com muito baixa probabilidade de ocorrência ao longo da vida útil da estrutura. Em geral, estas combinações consideram a ocorrência de mais de uma ação excepcional, tais como, condições hidrológicas excepcionais, defeitos no sistema de drenagem, manobras de caráter excepcional, efeitos sísmicos, etc. com as ações correspondentes a condição de carregamento normal;

- Condição de Carregamento de Construção (CCC) Corresponde a todas as combinações de ações que apresentem probabilidade de ocorrência durante a execução da obra. Podem ser devidas a carregamentos de equipamentos de construção, a estruturas executadas apenas parcialmente, carregamentos anormais durante o transporte de equipamentos permanentes, e quaisquer outras condições semelhantes, e ocorrem durante períodos curtos em relação à sua vida útil.

\subsubsection{Fator de Segurança à Flutuação (FSF)}

O fator de segurança à flutuação é definido como a relação entre o somatório das forças gravitacionais e o somatório das forças de subpressão (ELETROBRÁS, 2003), dado por:

$$
\mathrm{FSF}=\sum \mathrm{V} / \sum \mathrm{U}
$$

Onde,

FSF = Fator de segurança à flutuação;

$\sum \mathrm{V}=$ Somatório das forças gravitacionais;

$\sum \mathrm{U}=$ Somatório das forças de subpressão 


\subsubsection{Fator de Segurança ao Tombamento (FST)}

O fator de segurança ao tombamento em qualquer direção, conforme Eletrobrás (2003), é definido como a relação entre o momento estabilizante (devido ao peso próprio da estrutura, as cargas permanentes mínimas e o peso próprio dos equipamentos permanentes, se instalados) e o momento de tombamento (devido a atuação de cargas desestabilizante, tais como, pressão hidrostática, subpressão, empuxos de terra, etc.), em relação a um ponto ou uma linha efetiva de rotação, calculado da seguinte maneira:

$$
\mathrm{FST}=\sum \mathrm{Me} / \sum \mathrm{Mt}
$$

Onde,

$\mathrm{FST}=$ Fator de segurança ao tombamento;

$\sum \mathrm{Me}=$ Somatório dos momentos estabilizantes atuantes sobre a estrutura;

$\sum \mathrm{Mt}=$ Somatório dos momentos de tombamento. Deverão ser desprezados os efeitos estabilizantes de coesão e de atrito despertados nas superfícies em contato com a fundação.

\subsubsection{Fator de Segurança ao Deslizamento (FSD)}

Para a verificação da estabilidade das estruturas ao deslizamento (escorregamento), deve-se selecionar as superfícies de ruptura de modo a incluir todos os planos de menor resistência possível, ou os submetidos a tensões críticas na estrutura, na fundação e no contato estrutura-fundação, sobre as quais a estrutura possa sofrer movimento de deslizamento como corpo rígido. As análises dos fatores de segurança contra o deslizamento deverão incluir a coesão na resistência ao cisalhamento dos materiais rochosos, ou no contato concreto-rocha, (ELETROBRÁS, 2013).

Conforme Eletrobrás (2003) o cálculo do Fator de Segurança ao Deslizamento é dado pela equação geral:

$$
\frac{\frac{\sum N i \operatorname{tg}(\varnothing i)}{F S D \emptyset}+\frac{\sum C i A i}{F S D C}}{\sum T i} \geq 1,0
$$


Onde,

FSD $=$ Fator de segurança ao deslizamento;

FSD $\varnothing=$ Fator de redução da resistência ao atrito;

FSDc $=$ Fator de redução da resistência à coesão;

$\sum \mathrm{Ni}=$ Somatório das forças normais à superfície de deslizamento em análise;

$\varnothing \mathrm{i}=$ Ângulo de atrito característico da superfície de deslizamento em análise;

$\mathrm{Ci}$ = Coesão característica ao longo da superfície de deslizamento;

$\mathrm{Ai}=$ Área efetiva comprimida da estrutura no plano em análise;

$\sum \mathrm{Ti}=$ Somatório das forças paralelas à superfície de deslizamento

\subsubsection{Coeficientes De Segurança - Valores Mínimos Admissíveis}

Nas Tabelas Tabela 4 e Tabela 5 são indicados os valores mínimos admissíveis dos coeficientes de segurança ao tombamento FST e à flutuação FSF, assim como os fatores de redução da resistência por atrito e da coesão FSD $\varnothing$ e FSDc. Estes valores devem ser majorados nos casos em que tal conhecimento é precário ou os materiais não apresentam constância de comportamento, cujos valores são apresentados entre parênteses.

Tabela 4 - Fatores de Segurança ao Tombamento FST e Flutuação FSF

\begin{tabular}{ccccc}
\hline \multirow{2}{*}{ Coeficiente de Segurança } & \multicolumn{5}{c}{ Casos de Carregamento } \\
\cline { 2 - 5 } & CCN & CCE & CCL & CCC \\
\hline Flutuação - FSF $>$ & 1,3 & 1,1 & 1,1 & 1,2 \\
Tombamento -FST $>$ & 1,5 & 1,2 & 1,1 & 1,3 \\
\hline
\end{tabular}

Fonte: Eletrobrás (2013).

Tabela 5 - Fatores de Redução da Resistência do Atrito e da Coesão FSD $\varnothing$ e FSDc.

\begin{tabular}{ccccc}
\hline \multirow{2}{*}{ Coeficiente de Segurança } & \multicolumn{5}{c}{ Casos de Carregamento } \\
\cline { 2 - 5 } & CCN & CCE & CCL & CCC \\
\hline FSDc & $3,0(4,0)$ & $1,5(2,0)$ & $1,3(2,0)$ & $2,0(2,5)$ \\
FSD $\varnothing$ & $1,5(2,0)$ & $1,1(1,3)$ & $1,1(1,3)$ & $1,3(1,5)$ \\
\hline
\end{tabular}

Fonte: Eletrobrás (2013). 


\subsubsection{Análise das Tensões}

A estrutura ao ser solicitada, transfere os esforços à sua base de fundação, fazendo valer a capacidade e resistência desta aos esforços de compressão e tração.

Vários são os métodos aplicados para a análise de tensões na fundação e na base da estrutura, desde métodos simplificados, baseados na teoria da Resistência dos Materiais até métodos maiselaborados como os baseados em Elementos Finitos.

Conforme Souza (2008), em estruturas hidráulicas pequenas e médias, a análise de tensões na base pode ser verificada através de diferentes métodos que adotam a teoria clássica da Resistência dos Materiais, como o Método de Gravidade, admitindo contribuições lineares na estrutura e na sua base, transversal da barragem considerando-a um corpo rígido monolítico. As máximas tensões na base da estrutura podem então ser obtidas pela equação 4

$$
\sigma_{\text {máx }}=\frac{N}{A} \pm \frac{M}{W}=\frac{N}{l . b} \pm \frac{6 M}{l . b^{2}}
$$

Onde:

$N$ : Soma das forças verticais normais à base da fundação;

$A$ : Área da seção na base da fundação;

W: Módulo de rigidez; W=1/y, sendo I o momento de inércia e y a distância em relação ao ponto onde se deseja calcular as tensões;

M: Momento fletor das forças atuantes em relação ao centroide da área;

$b$ : Dimensão da seção na base no sentido transversal;

$l$ : Dimensão da seção da base no sentido longitudinal, usualmente igual a 1,0 m.

As tensões obtidas devem atender aos limites de tensões admissíveis. No contato concreto-rocha as tensões admissíveis do concreto podem ser consideradas como as préestabelecidas nos critérios Eletrobrás (2003).

Para o caso CCN é necessário que a base esteja completamente comprimida, ou seja, que a resultante dos esforços esteja dentro do núcleo central de inércia. Já para os casos CCE e CCL é permitido que parte da base esteja tracionada, permitindo abertura de contatos.

Nos Quadros 4 e 5 são apresentadas as tensões admissíveis à compressão e a tração efetivas, respectivamente. 
Tabela 6 - Tensão admissível do concreto a compressão.

\begin{tabular}{ccc}
\hline Caso de Carregamento & $\begin{array}{c}\text { Tensão admissível à } \\
\text { compressão }\end{array}$ & $\begin{array}{c}\text { Tensão admissível à } \\
\text { tração }\end{array}$ \\
\hline CCN & $0,50 \mathrm{f}_{\mathrm{ck}}$ & $0,050 \mathrm{f}_{\mathrm{ck}}$ \\
$\mathrm{CCC}$ & $0,55 \mathrm{f}_{\mathrm{ck}}$ & $0,055 \mathrm{f}_{\mathrm{ck}}$ \\
$\mathrm{CCE}$ & $0,60 \mathrm{f}_{\mathrm{ck}}$ & $0,060 \mathrm{f}_{\mathrm{ck}}$ \\
$\mathrm{CCL}$ & $0,65 \mathrm{f}_{\mathrm{ck}}$ & $0,065 \mathrm{f}_{\mathrm{ck}}$ \\
\hline
\end{tabular}

Fonte: Eletrobrás (2013).

\subsubsection{Método do Centro de Rotação de Nigam (1979)}

Para o cálculo de estruturas com vários níveis de fundação, é possível utilizar o método do centro de rotação proposto por Nigam (1979). Nesse método considera-se que o movimento de uma estrutura rígida pode ser reduzido a uma rotação instantânea em torno de um centro de rotação. O método do centro de rotação é válido para estruturas rígidas em que as deformações podem ser desconsideradas, com reações da fundação proporcionais à distância deste centro, levando-se em conta a consideração da fundação com comportamento elástico.

Tendo por base Souza (2008, apud MASSON, 1988), descreve-se a seguir o método do centro de rotação de Nigam (1979) para estruturas de gravidade complexas. Na Figura 33 é apresentada uma estrutura rígida de largura "b", cuja linha de fundação é representada pela poligonal KLMN (Figura 33-a) e projeção K'L’M’N’N"“ $M^{\prime \prime} L^{\prime \prime} K^{\prime \prime}$ (Figura 33-b). 
Figura 33 - Representação de corpo rígido de estrutura complexa: a) Vista em corte da estrutura a ser analisada; b) Fundação de estrutura rígida; c) Diagrama de corpo livre para o método de Nigam.

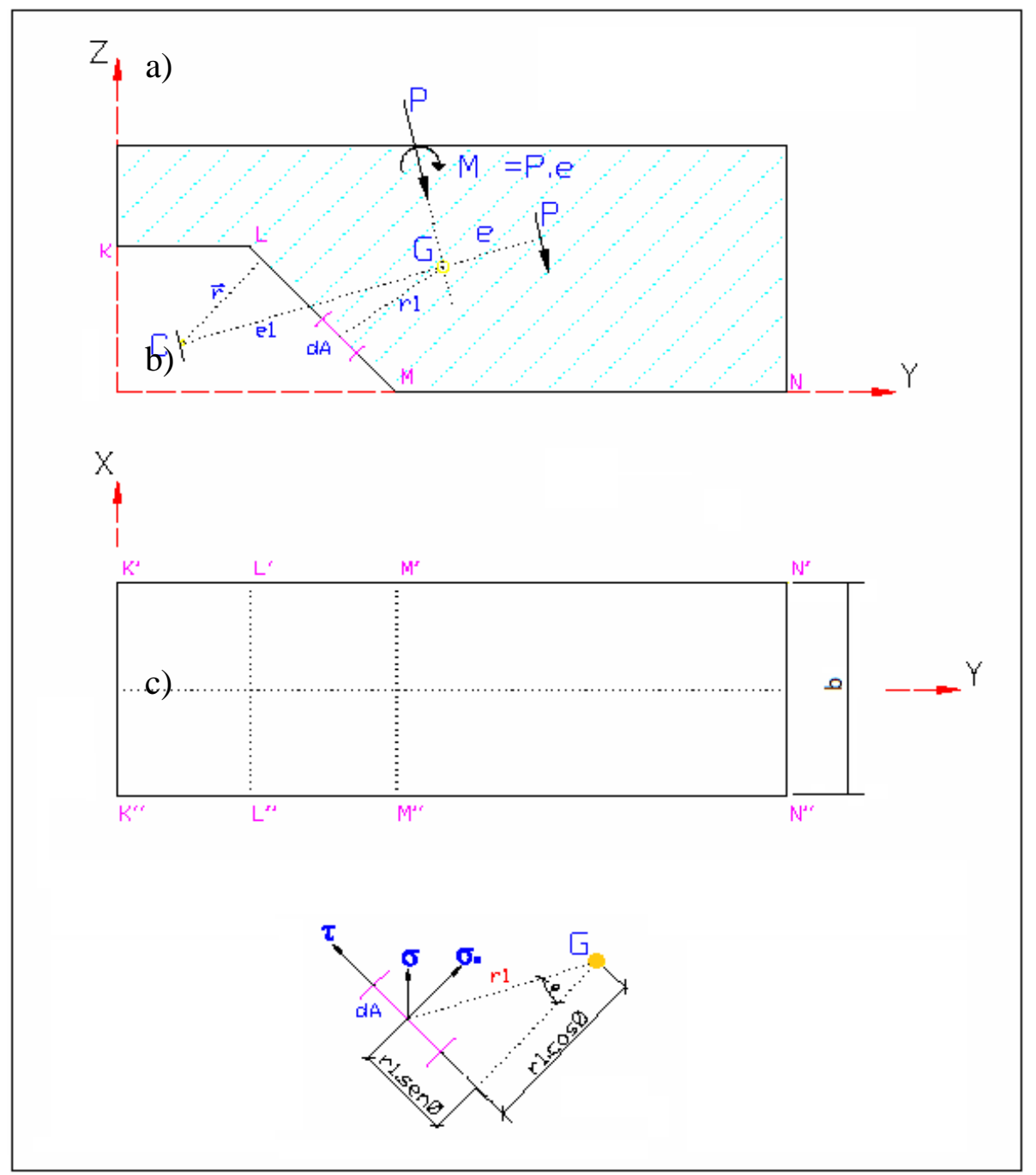

Fonte: Souza (2008).

O ponto $G$ representa o centro de gravidade da área da superfície da fundação e os carregamentos externos, que são resumidos na força $P$, tem o seu ponto de aplicação à distância $e$ de $G$. A força resultante dos carregamentos externos exerce um momento $M$ sobre a fundação, já que está a uma distância $e$ do centro de gravidade $G$.

Para um elemento de área infinitesimal $d A$ e com distância até $G$ igual a $r_{1}$, a força resultante considerando o corpo rígido será dada pela equação 5, normal a $r_{l}$, sendo $k$ uma constante de proporcionalidade e $\sigma$ a tensão normal a $r_{l}$. As tensões normal $\left(\sigma_{n}\right)$ e tangencial $(\tau)$ no elemento de área dA, são calculadas conforme equações 6 e 7. 


$$
\begin{gathered}
\sigma \cdot d A=k \cdot r_{1} \cdot d A \\
\sigma_{n}=k \cdot r_{1} \cdot \operatorname{sen} \varnothing \\
\tau=k \cdot r_{1} \cdot \cos \varnothing
\end{gathered}
$$

Para determinação da constante de proporcionalidade $k$, parte-se da premissa que a somatória dos momentos elementares da equação 5 em relação a $G$ deve ser equivalente ao momento externo resultante P.e $=M$, conforme equações 8 e 9.

$$
\begin{gathered}
\sum k \cdot r_{1}^{2} \cdot d A=P \cdot e=M \\
k=\frac{P \cdot e}{\sum r_{l}^{2} \cdot d A}=\frac{M}{\sum r_{l}^{2} \cdot d A}
\end{gathered}
$$

O momento polar de inércia da área da superfície de fundação, em relação a $G$, é dado pela equação 10. Substituindo o do momento polar de inércia nas equações 5, 6 e 7, tem-se as equações 11,12 e 13.

$$
\begin{gathered}
I p=\sum r_{l^{2}} \cdot d A \\
\sigma=\frac{M \cdot r_{1}}{I p} \\
\sigma_{p}=\frac{P}{\sum d A}
\end{gathered}
$$

A equação compacta, que reúna $M$ e $P$, pode então ser obtida mediante o conceito do Centro de Rotação (CR), definido como o ponto de tensão nula, ou seja, o ponto para o qual a tensão devida a $P$ é igual e contrária aquela devida a $M=P . e$.

A partir da Figura 33-a, por considerações elementares, pode-se concluir que o centro de rotação $C$ situa-se no prolongamento $G C$ de $G P$, perpendicular à direção de $P$, sendo $G C=$ $e_{1}$, obtendo-se a equação 15 . 


$$
k \cdot e_{1}=\frac{P}{\sum d A}
$$

Tendo por base as equações 7 e 8 anteriores, obtém-se a equação 16, enquanto a tensão resultante $\vec{\sigma}$, no elemento $d A$ da Figura 33 -a, pode ser expressa pela equação 17 , em que $\vec{r}$ é um vetor cujo módulo é dado pela distância normal $r$ de $C$ a $d A$, e $\vec{\sigma}$ é normal a $\vec{r}$.

$$
\begin{gathered}
e_{1}=\frac{P}{\sum d A \cdot k}=\frac{I p}{\sum d A \cdot e} \\
\vec{\sigma}=\frac{P \cdot e}{I p} \cdot \vec{r}
\end{gathered}
$$

Conforme Souza (2008), o cálculo prático pode ser realizado, de preferência, em forma tabular, conforme exemplo do Quadro 2, sendo o uso das equações referidas a $G$ mais direto,

\begin{tabular}{|c|c|c|c|c|c|}
\hline Segmento & Área & Ym,i & $\mathrm{Zm}, \mathrm{i}$ & Ym,i. A & $\mathrm{Zm}, \mathrm{i} . \mathrm{A}$ \\
\hline KL & $\mathrm{AKL}$ & \multirow{3}{*}{$\begin{array}{c}\text { Distância até o } \\
\text { centro de } \\
\text { gravidade em Y }\end{array}$} & \multirow{3}{*}{$\begin{array}{c}\text { Distância até o } \\
\text { centro de gravidade } \\
\text { em } Z\end{array}$} & \multirow{3}{*}{ Produto } & \multirow{3}{*}{ Produto } \\
\hline LM & AllM & & & & \\
\hline $\mathrm{MN}$ & AMN & & & & \\
\hline Segmento & $\mathrm{Ym}, \mathrm{i}-\mathrm{Ym}, \mathrm{G}$ & $\mathrm{Zm}, \mathrm{i}-\mathrm{Zm}, \mathrm{G}$ & $(Y m, i-Y m, G)^{2}$ & $(Y m, i-Y m, G)^{2}$ & $\mathrm{r}^{2} \cdot \mathrm{A}$ \\
\hline \multicolumn{5}{|l|}{ KL } & \multirow{3}{*}{ Produto } \\
\hline \multicolumn{5}{|l|}{ LM } & \\
\hline $\mathrm{MN}$ & & & & & \\
\hline
\end{tabular}
com adoção de um sistema de coordenadas.

Quadro 2 - Cálculos das propriedades geométricas.

Notas: r2 - Raio de Giração; Ym,G e Zm,G - Centróides;

Fonte: Souza (2008).

Ao final, as relações a serem calculadas em cada ponto para a tensão normal e para tensão cisalhante respectivamente pelas equações 18 e 19.

$$
\begin{gathered}
\sigma_{i}=\frac{V}{\sum d A} \pm \frac{M \cdot(y m-y g)}{I p} \\
\tau_{i}=\frac{H}{\sum d A} \pm \frac{M \cdot(z m-z g)}{I p}
\end{gathered}
$$




\subsection{ACIDENTES E INCIDENTES COM BARRAGENS GRAVIDADE}

Existem vários estudos sobre acidentes/incidentes com barragens. Um dos mais completos foi publicado pelo U. S. Bureau of Reclamation, tendo sido redigido por Jansen (1983), no qual foram listadas e discutidas falhas significativas de diversas barragens, incluindo barragens de gravidade.

Conforme Bartholomew (1989), durante o século 20, houve cerca de 200 falhas notáveis, resultando na perda de mais de 8000 vidas. Dessas 200 falhas de barragens, menos de 40 foram de barragens de concreto ou alvenaria. Na Tabela 7, são listadas rupturas significativas de barragens de concreto e alvenaria, mostrando que (eliminando atos de guerra) quase todas essas rupturas resultaram direta ou indiretamente de problemas de fundação ou ombreiras.

Ainda segundo Bartholomew (1989), o fato de ocorreram muito mais rupturas de barragens de terra barragens do que de concreto é devido principalmente a três fatores:

- Existem muito mais barragens de terra;

- Barragens de concreto são tipicamente construídas em fundações mais estáveis;

- O concreto é mais resistente que o aterro.

Entretanto, deve-se considerar que rupturas de barragens de concreto podem ocorrem e normalmente resultam em altos danos e perda significativa de vidas, devendo-se identificar condições peculiares da fundação e a auscultação adequada para permitir a detecção de comportamentos anômalos. 
Tabela 7 - Ruptura de barragens gravidade.

\begin{tabular}{|c|c|c|c|c|c|}
\hline $\begin{array}{l}\text { Nome da } \\
\text { Barragem }\end{array}$ & Localização & $\begin{array}{l}\text { Altura } \\
(\mathrm{m})\end{array}$ & $\begin{array}{l}\text { Ano da } \\
\text { Ruptura }\end{array}$ & $\begin{array}{l}\text { Idade até a } \\
\text { Ruptura } \\
\text { (anos) }\end{array}$ & Provável causa da Ruptura \\
\hline $\begin{array}{l}\text { Alla Sella } \\
\text { Zerbino }\end{array}$ & Itália & 12 & 1935 & 12 & $\begin{array}{l}\text { Percolação pela fundação, } \\
\text { escorregamento e tombamento }\end{array}$ \\
\hline Austin & $\begin{array}{l}\text { Pensilvânia } \\
\text { (EUA) }\end{array}$ & 15 & 1911 & 1,8 & $\begin{array}{l}\text { Deslizamento da fundação e fissuração } \\
\text { do concreto }\end{array}$ \\
\hline Bouzey $^{1}$ & França & 22 & 1895 & 14 & $\begin{array}{l}\text { Subpressões e pressões hidrostáticas } \\
\text { internas }\end{array}$ \\
\hline Dukeprostoj & Rússia & 40 & 1941 & - & Destruída na Guerra \\
\hline Eder & Alemanha & 48 & 1943 & 29 & Destruída na Guerra \\
\hline Eigiau & País de Gales & 11 & 1925 & 17 & Percolação sob a barragem \\
\hline Khadakwasia $^{1}$ & Índia & 40 & 1961 & 82 & Subpressões e fissuração interna \\
\hline Mohne & Alemanha & 40 & 1943 & 32 & Destruída na Guerra \\
\hline Puentes $^{1}$ & Espanha & 50 & 1802 & 11 & Percolação sob a barragem \\
\hline Tigra $^{1}$ & Índia & 26 & 1917 & 0,25 & Galgamento e deslizamento \\
\hline Gleno $^{2}$ & Itália & 44 & 1923 & 0,5 & Projeto e mão de obra de baixa qualidade \\
\hline Malpasset $^{3}$ & França & 61 & 1959 & 5 & $\begin{array}{l}\text { Rocka da ombreira com baixa resistência } \\
\text { e altas pressões de água na ombreira }\end{array}$ \\
\hline St. Francis ${ }^{4}$ & $\begin{array}{l}\text { Califórnia } \\
\text { (EUA) }\end{array}$ & 62 & 1928 & 2 & $\begin{array}{l}\text { Fundação de baixa qualidade e } \\
\text { fissuração interna }\end{array}$ \\
\hline Vaiont $^{3}$ & Itália & 265 & 1963 & 3 & $\begin{array}{c}\text { Galgamento causado por deslizamento } \\
\text { de grande volume de rocha do Monte } \\
\text { Toc no reservatório }\end{array}$ \\
\hline Vea de Tera $^{5}$ & Espanha & 34 & 1959 & 2 & $\begin{array}{l}\text { Percolação em juntas e deslizamento da } \\
\text { fundação }\end{array}$ \\
\hline
\end{tabular}

Nota: 1- Bloco de rocha argamassado; 2- Arco múltiplo e gravidade; 3- Arco; 4- Arco/gravidade; 5- Bloco de rocha argamassado, laje e contrafortes.

Fonte: Bartholomew (1989)

$\mathrm{Na}$ sequência são resumidos alguns casos de rupturas de barragem gravidade, assim como o incidente com a barragem de Zeuzier, que de certa forma tiveram sua relevância, tanto em relação à evolução dos critérios de projeto e auscultação, como no seu impacto em termos de danos e vítimas fatais, trazendo grandes lições para a engenharia de barragens, no estudo, projeto, implantação, construção e auscultação (inspeção e instrumentação) de barragens. 


\subsubsection{Barragem de Bouzey 1884/1895}

A barragem de Bouzey (Figura 34), na França, foi finalizada 1880, tendo ocorrido um acidente estrutural em 1884 e, após reparos, sofreu uma ruptura em 1895, levando à morte de 300 pessoas. Conforme Sandroni (2006), o primeiro acidente consistiu numa separação entre a cortina incorporada de montante e o corpo da barragem, a jusante da cortina (seção 1 da Figura 34). Os reparos consistiram em lançamento de material impermeabilizante a montante e na construção de um apoio no pé de jusante. O segundo acidente, levou à ruptura, por cisalhamento através do corpo da barragem (seção 2 da Figura 34). A análise de acidentes como este trouxe à tona as questões de pressão de água no interior e na base de estruturas de concreto.

Figura 34 - Acidente/Ruptura Barragem de Bouzey

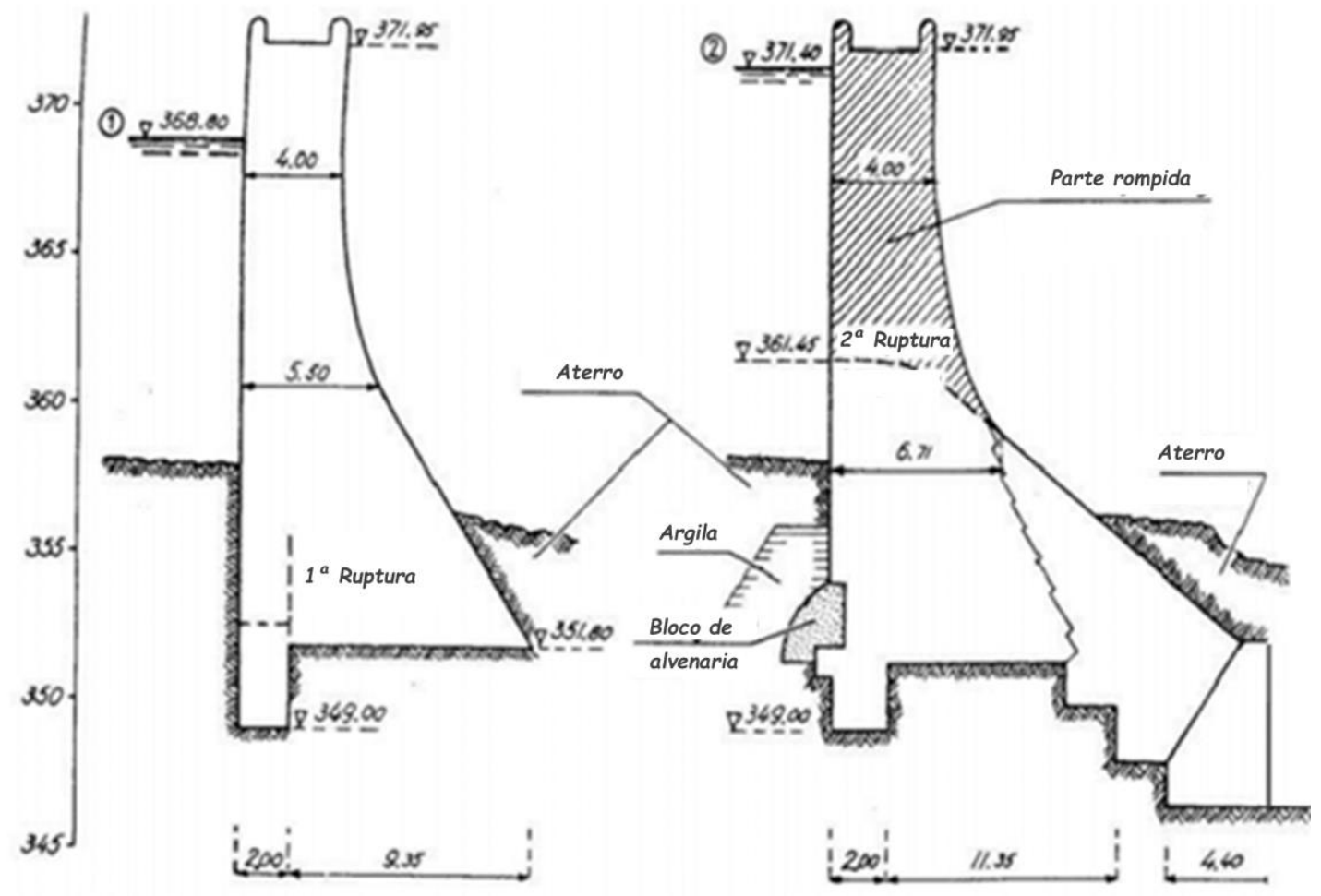

Fonte: FERC (2014).

\subsubsection{Barragem de Gleno - $\mathbf{1 9 2 3}$}

Na manhã de $1^{\circ}$ de dezembro de 1923, a barragem de Gleno (localizada nos Alpes italianos centrais) rompeu repentinamente alguns dias após o primeiro enchimento completo do reservatório. Cerca de 4,5 × $10^{6} \mathrm{~m}^{3}$ de água foram liberados. A consequente inundação causou destruição significativa ao longo do vale a jusante e a morte de pelo menos 356 pessoas, Pilotti 
et al. (2011).

Conforme Sandroni (2006), a barragem foi originalmente concebida como uma estrutura maciça de concreto e a correspondente base de apoio foi construída. Sobre a base, porém, foi construída uma barragem de arcos múltiplos, muito mais leve, sem que providenciassem o correspondente indispensável alívio de subpressões. A barragem rompeu bruscamente por tombamento no primeiro enchimento, cuja resultante das forças incidiu praticamente na aresta externa da base de apoio (Figura 35), levando à morte cerca de 350 pessoas.

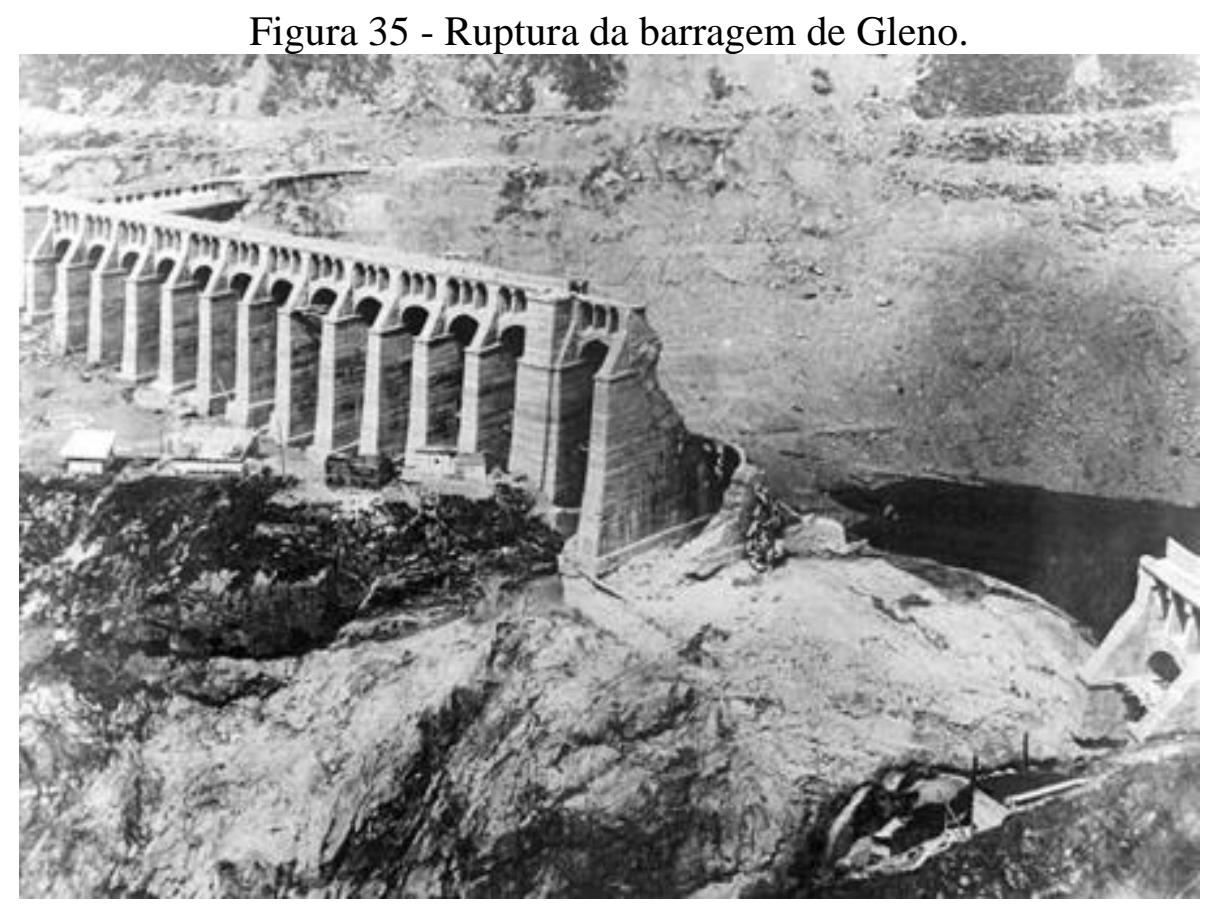

Fonte: Pilotti et al. (2011).

\subsubsection{Barragem de Malpasse - 1959}

A barragem de concreto de Malpasset foi construída em 1954, em arco, com 66 metros de altura máxima e 222 metros de altura, conforme Figura 36. A ruptura ocorreu de forma quase instantânea em 2 de dezembro de 1959, ocasionando na morte de 421 pessoas (JANSEN,1983).

O contato da fundação foi injetado a partir de furos rasos a uma profundidade de cerca de $5 \mathrm{~m}$. Uma cortina de injeção não foi considerada necessária devido à baixa permeabilidade da rocha abaixo da profundidade de $5 \mathrm{~m}$. Nenhuma drenagem foi executada na barragem ou fundação, e nenhum instrumento, exceto os pontos de medição de superfície, foi instalado. (ANDERSON et al., 1998)

Conforme Goodman (2013), uma série de deficiências de fundações e supervisão humana levou a problemas de instabilidade na barragem de Malpasset. Antes da construção, 
pouco esforço foi dedicado à análise da geologia da fundação na qual a barragem seria localizada.

Figura 36 - Vista geral da Barragem de Malpasset antes da ruptura.

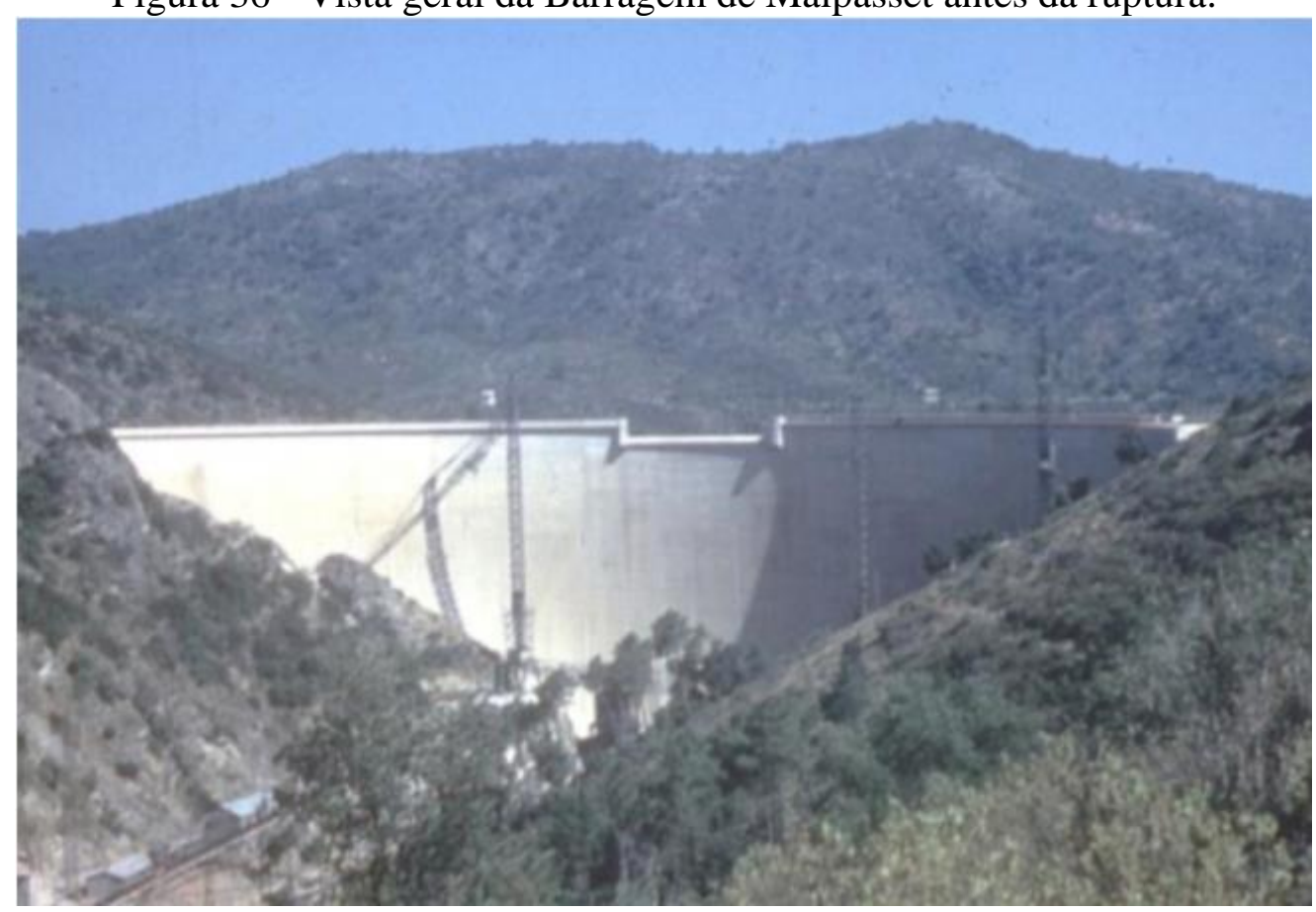

Fonte: Duffaut (2013).

O acidente ocorreu em função de uma associação de fatores, cuja atuação simultânea não foi prevista. Havia uma falha, cujo plano se constituía numa superfície impermeável, praticamente perpendicular ao vale mergulhando cerca de 45 graus de jusante para montante. Agravando a presença da falha, a estrutura de foliação, contendo planos de fraqueza, mergulhava de montante para jusante com disposição praticamente paralela à tangente do arco na ombreira esquerda (SANDRONI, 2006).

As estruturas de foliação fizeram com que as forças induzidas pela barragem ao invés de se espalharem pela massa de rocha, ficassem concentradas em um prisma de espessura constante transmitindo compressões elevadas até grande profundidade. Tais pressões fizeram com que a massa de gnaisse, já de baixa permeabilidade, se comportasse como uma cortina impermeável criando uma barreira sob a qual passou a atuar a pressão hidrostática total de montante. Deu-se então o levantamento do diedro de rocha de fundação na região ombreira esquerda e a ruptura catastrófica do conjunto, conforme Figura 37 e Figura 38. Os pedaços de concreto da barragem aderidos à rocha de fundação encontrados a jusante, evidenciam que a ruptura não ocorreu na superfície de contato concreto-rocha, conforme Figura 39 e Figura 40 (SANDRONI, 2006). 
Figura 37 - Seção transversal da barragem e fundação na altura média do lado esquerdo: a pressão hidrostática total na fundação da barragem criada pela barragem em arco pode empurrar o diedro para cima ao longo da falha.

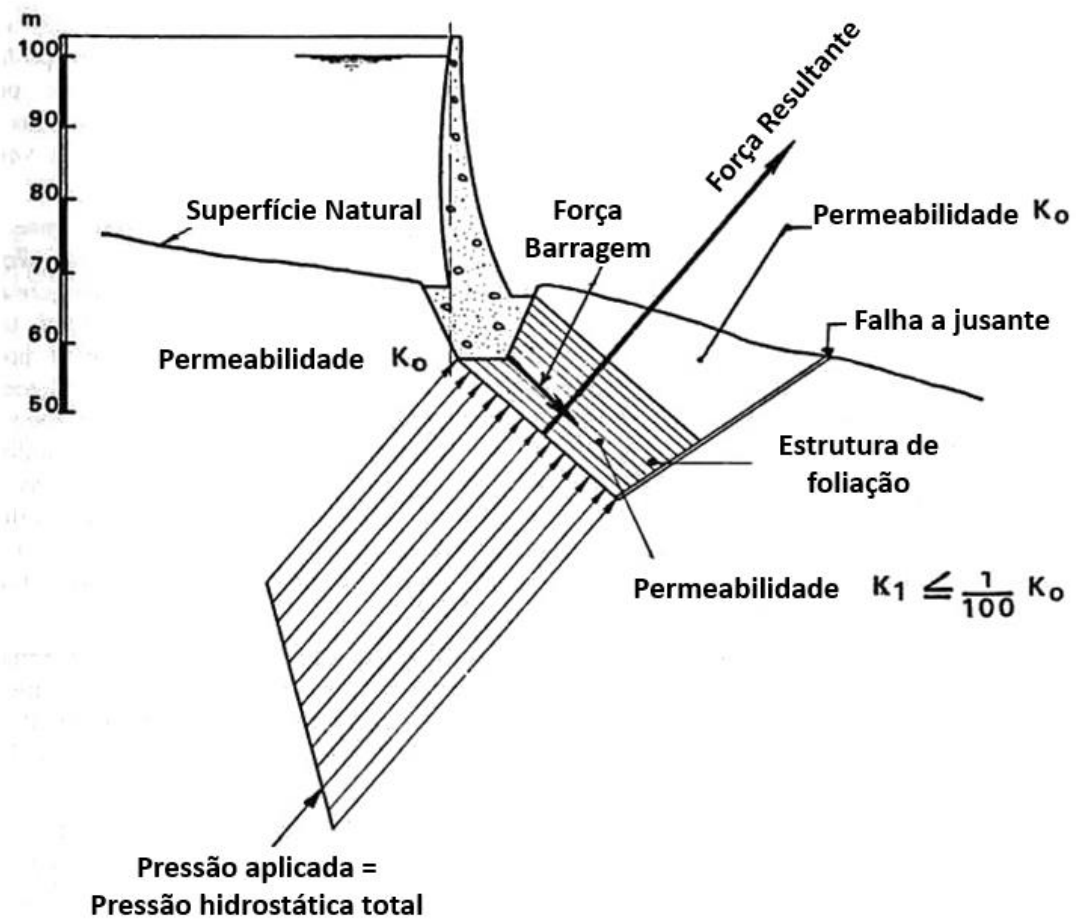

Fonte: Duffaut e Larouzee (2019).

Figura 38 - Fases da falha na vista a jusante e no perfil A-A. (1) a água penetra na fissura de tração ao longo do contato Concreto/Rocha a montante; (2) o diedro da fundação é empurrado ao longo da falha, para cima e para a direita; (3) todo o impulso do arco concentra-se no bloco, que não pode suportar e rompe; (4) o efeito do arco é interrompido e rompe; (5) e (6) os blocos da margem direita falham por flexão.

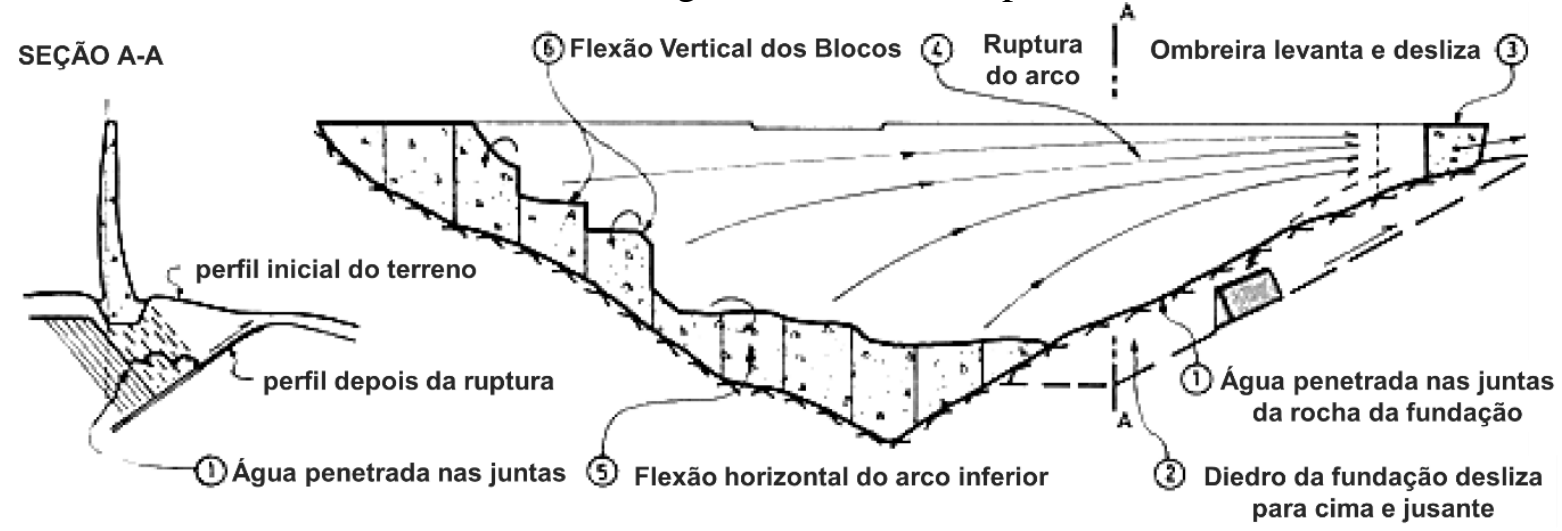

Fonte: Duffaut e Larouzee (2019). 
Figura 39- Estrutura remanescente da Barragem de Malpasset,

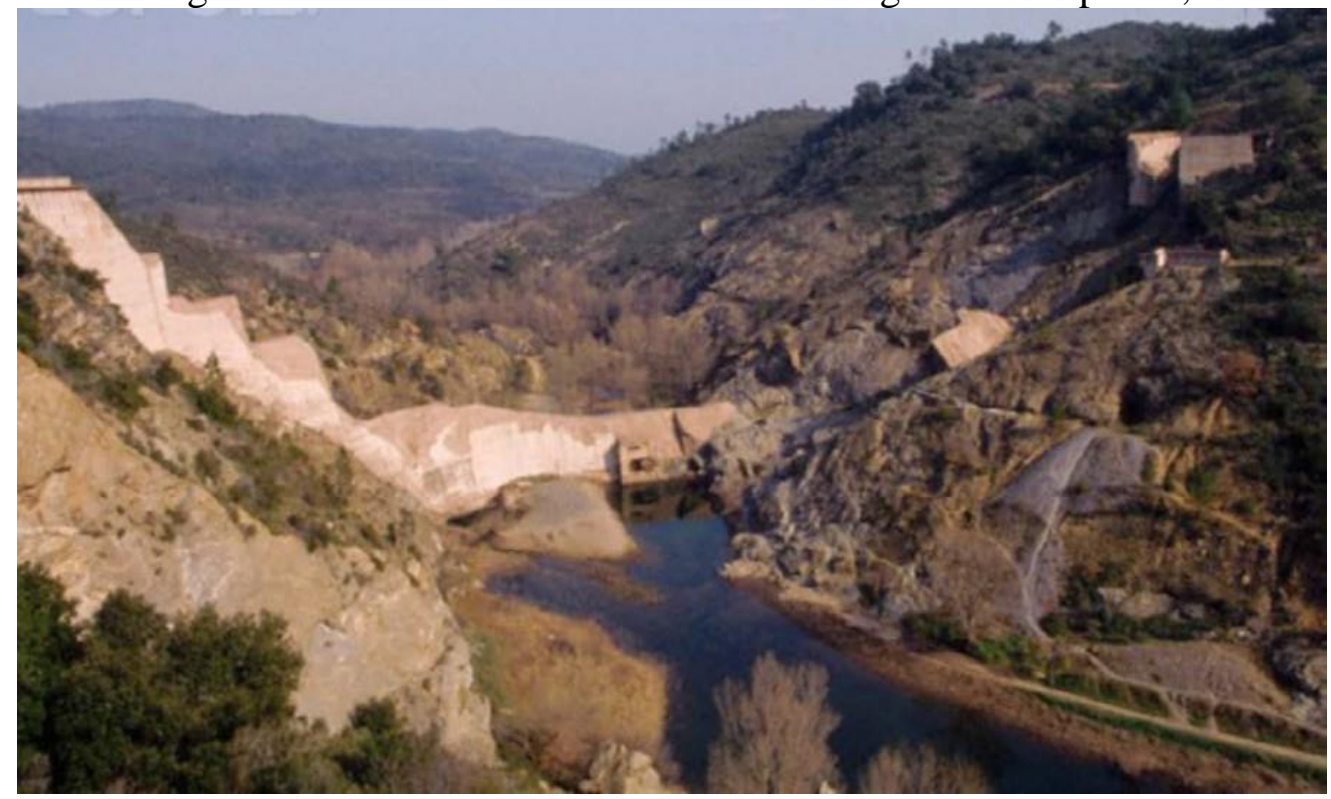

Fonte: Goodman (2013).

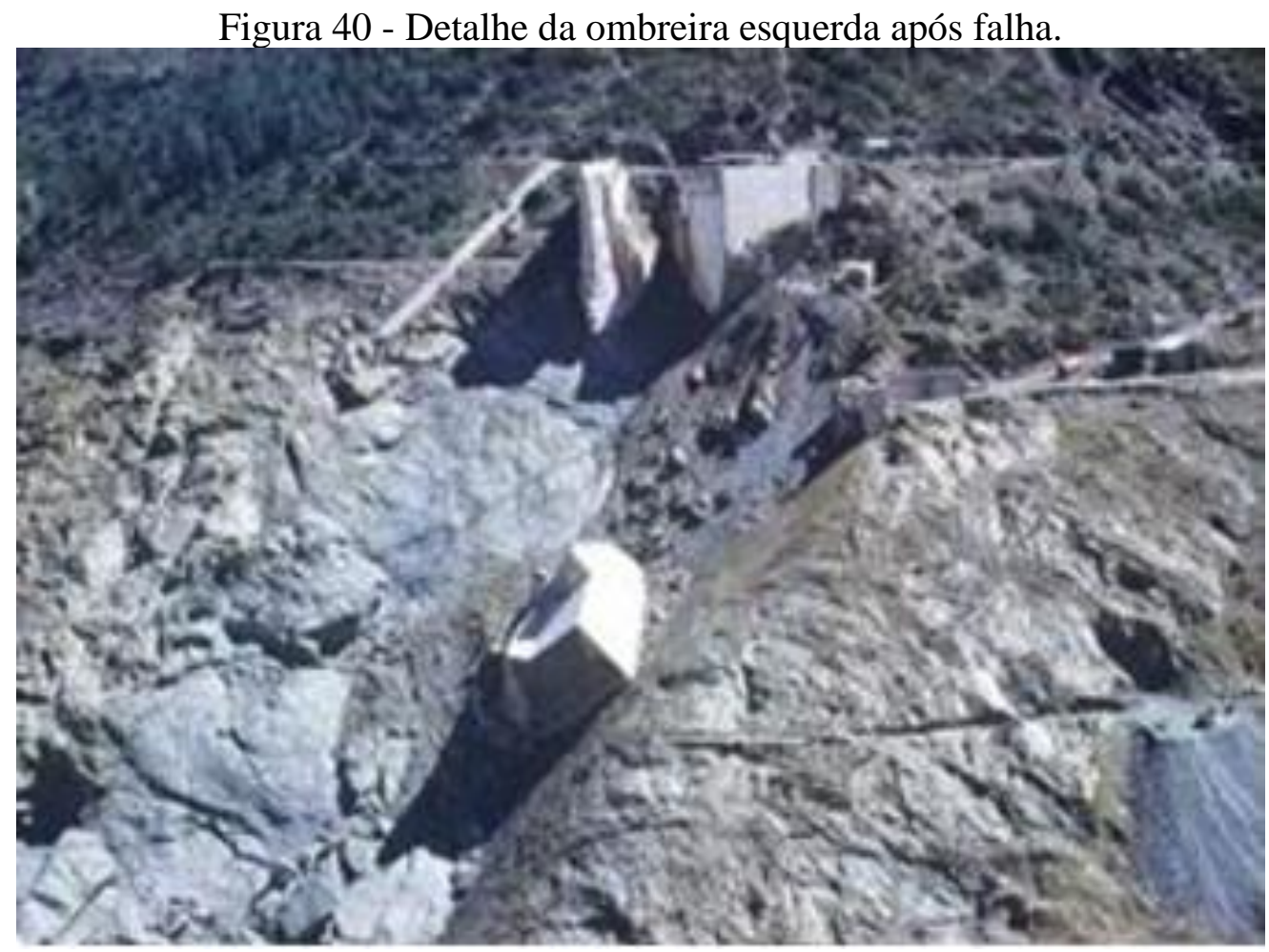

Fonte: Duffaut (2013).

\subsubsection{Ruptura da Barragem de Camará - 2004}

A barragem de Camará, construída no rio Riachão, na divisa entre os municípios de Alagoa Nova e Areia - PB, rompeu no dia 17/06/04, com N.A. do reservatório 6,50 m abaixo 
da soleira do vertedouro. A barragem encontrava-se em operação há 27 meses, porém o reservatório permaneceu baixo em decorrência da falta de chuvas. Esta ruptura implicou na morte de 5 pessoas e danos materiais a jusante.

A ruptura ocorreu na ombreira esquerda, pela rocha de fundação, junto à base da barragem (Figura 41), em local onde havia sido observado um grande bloco de rocha fraturado, em posição instável, sobre uma falha. Alguns dias depois, o trecho do CCR - Concreto Compactado a Rolo, que formava um arco, veio a desabar (Figura 42).

Figura 41 - Vista da região da ombreira esquerda, após ruptura da Barragem de Camará.

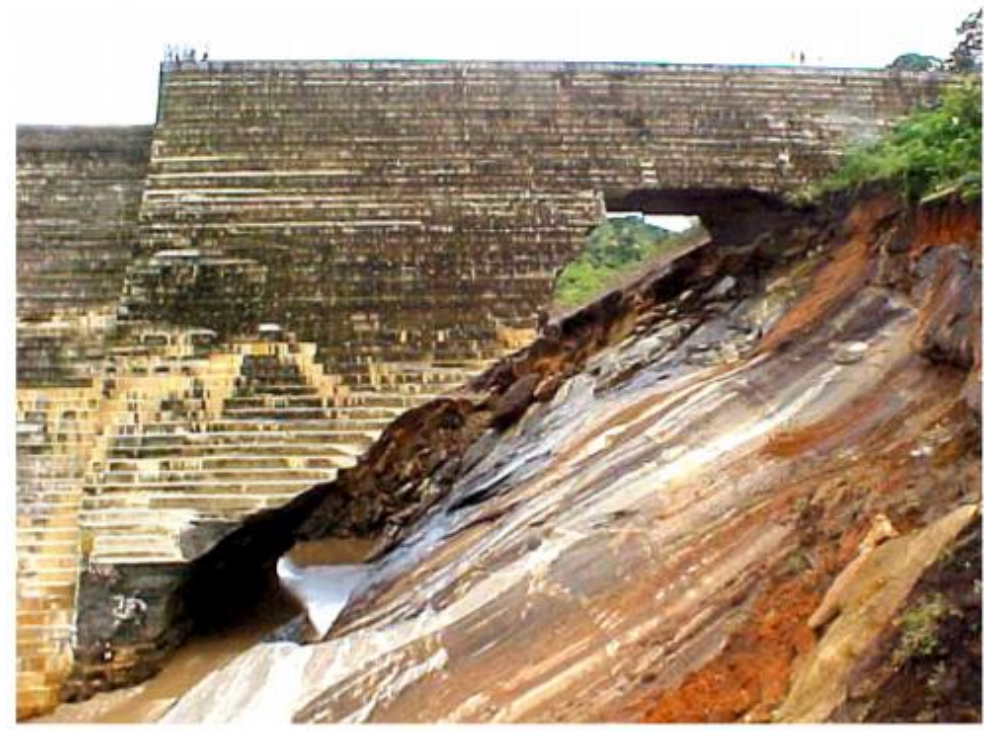

Fonte: Abrahão e Degaspare (2016).

Figura 42 - Vista após desmoronamento do "arco" da Barragem de Camará.

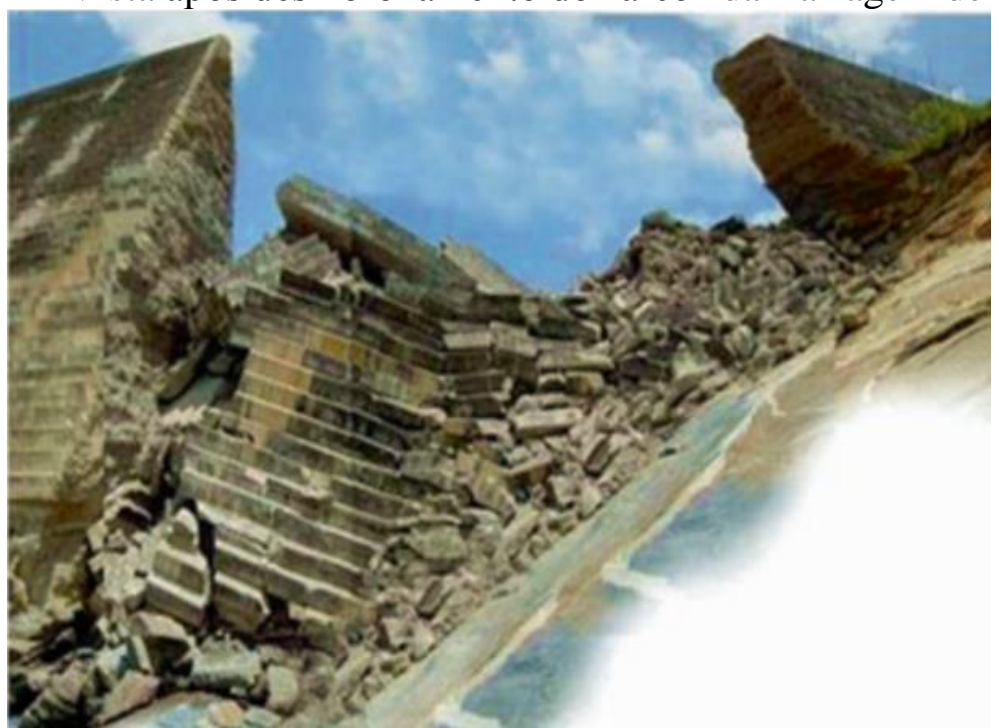

Fonte: Abrahão (2020). 


\subsubsection{O problema geológico e suas consequências}

O projeto básico tinha previsto a construção de uma barragem de terra, tendo sido alterada para uma barragem de concreto. Não se tem informação de estudos geológicos adicionais além dos realizados anteriormente, para uma barragem de terra.

Durante o período construtivo foi encontrada a chamada falha da $\mathrm{OE}$ - ombreira esquerda, tendo-se interpretado essa feição como sendo limitada e não contínua em profundidade, conforme ilustrado na Figura 43 (BARBOSA et. al., 2004), o que foi apoiado pela prospecção expedita realizada através de perfurações a roto-percussão, na qual não se notou a continuidade da zona de cisalhamento (ZC), devido a ondulações e estreitamento da mesma, conduzindo a um julgamento inadequado das características da feição geológica (Figura 44) (KANJI, 2004).

Foram realizados intensos trabalhos de tratamento para sanar a feição encontrada, consistindo de escavação e substituição do solo da fratura, realizada por partes para não descalçar e instabilizar a laje de rocha superior, preenchimento de concreto e injeções de contato, além da construção de espesso muro de concreto (Figura 45) (NIEBLE, 2004).

Figura 43 - Interpretação da falha da ombreira esquerda na fase de projeto.

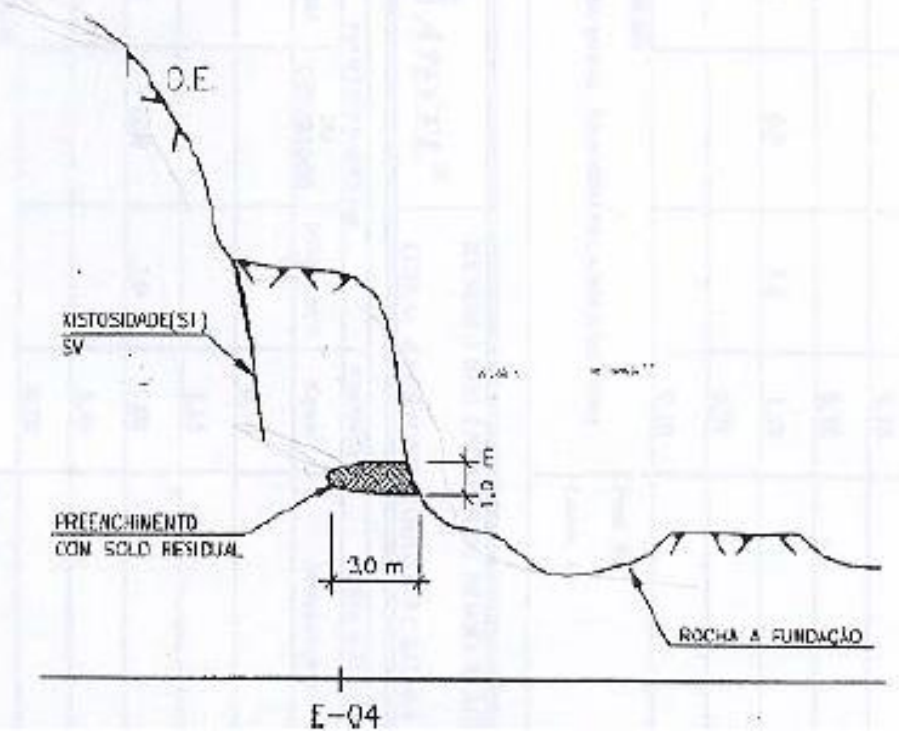

Fonte: Barbosa et al. (2004). 
Figura 44 - Esquema da falha na ombreira esquerda e projeção da zona de cisalhamento.

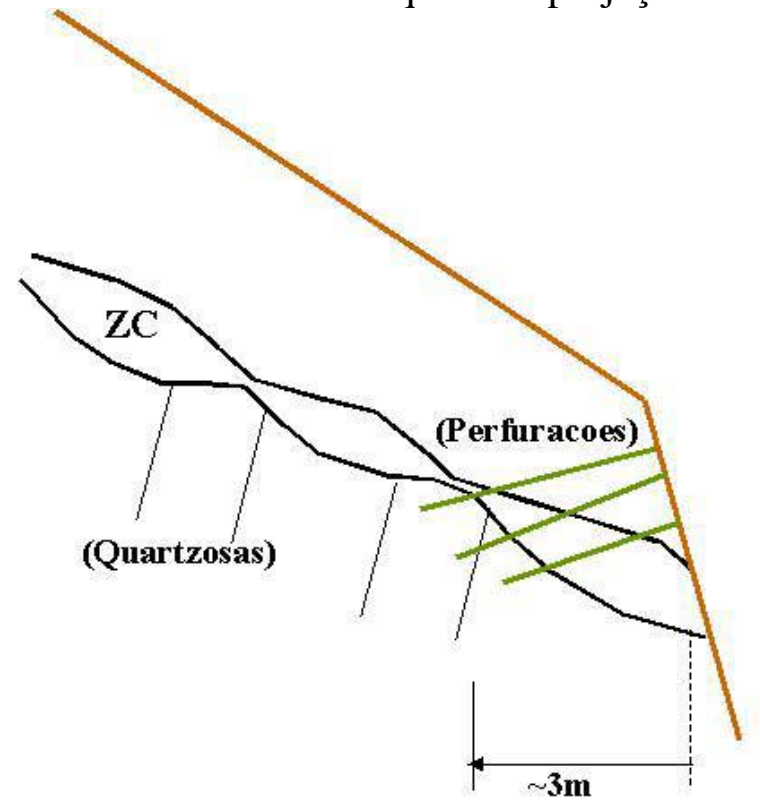

Fonte: Kanji (2004).

Figura 45 - Esquema com injeções de cimento complementares ao tratamento da falha da ombreira esquerda, notando-se também o muro de proteção em concreto.

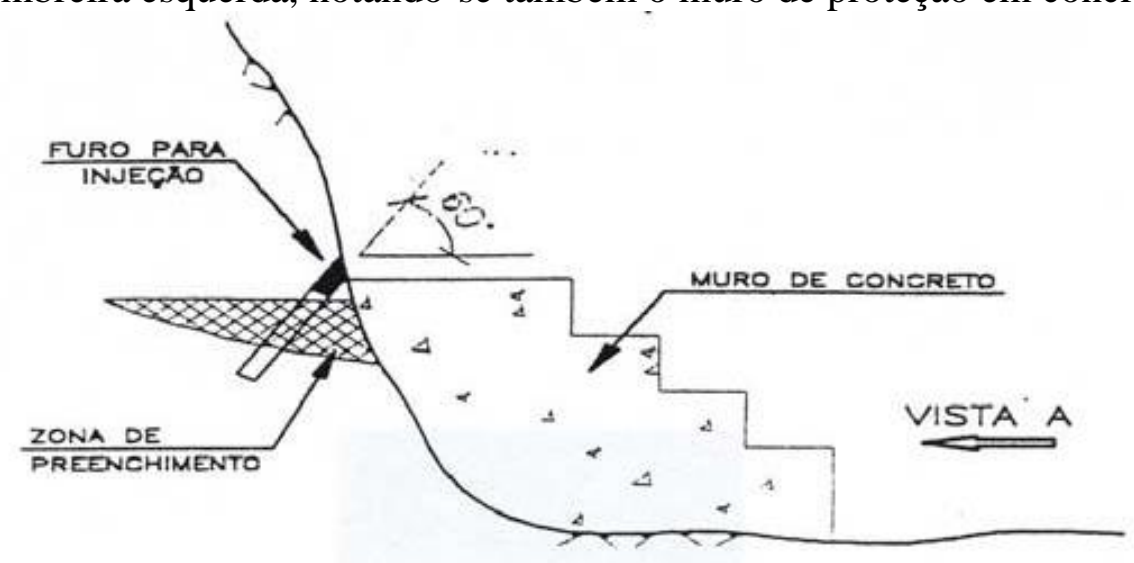

Fonte: Nieble (2006) 
Figura 46 - Zona de cisalhamento na ombreira esquerda. a) Vista do orifício preenchido com solo residual; b) Vista após execução da solução proposta para contenção.

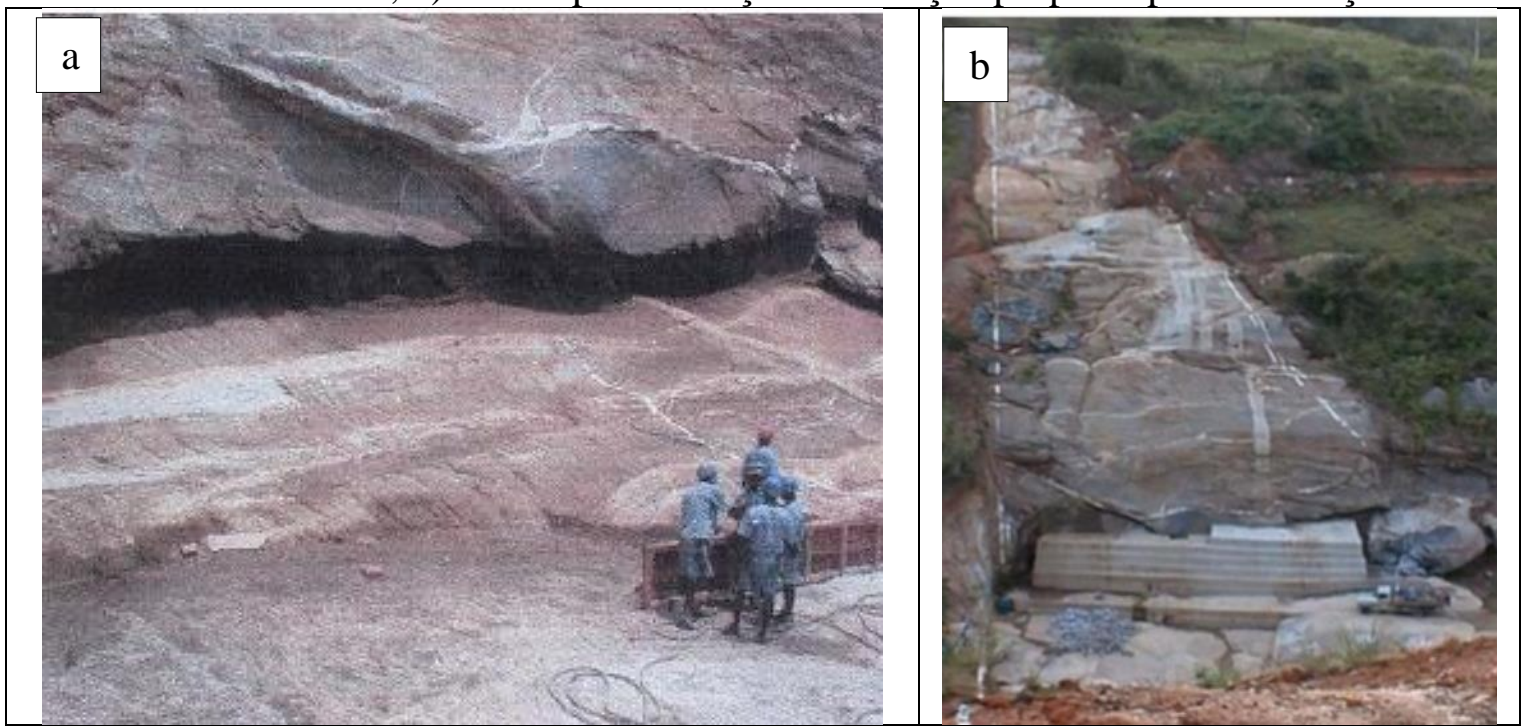

Fonte: Barbosa et al. (2004).

Segundo Kanji (2004) e Nieble (2004), a solução proposta foi ineficaz porque houve julgamento inadequado na interpretação geológica da extensão da falha. A partir de uma visita de campo, tomando-se várias fotos da ombreira esquerda, Kanji, 2004 realizou um retro análise, caracterizando a região, sendo possível a representação esquemática do modelo geológico do local da barragem (Figura 47).

Figura 47 - Representação esquemática do modelo geológico do local da barragem.

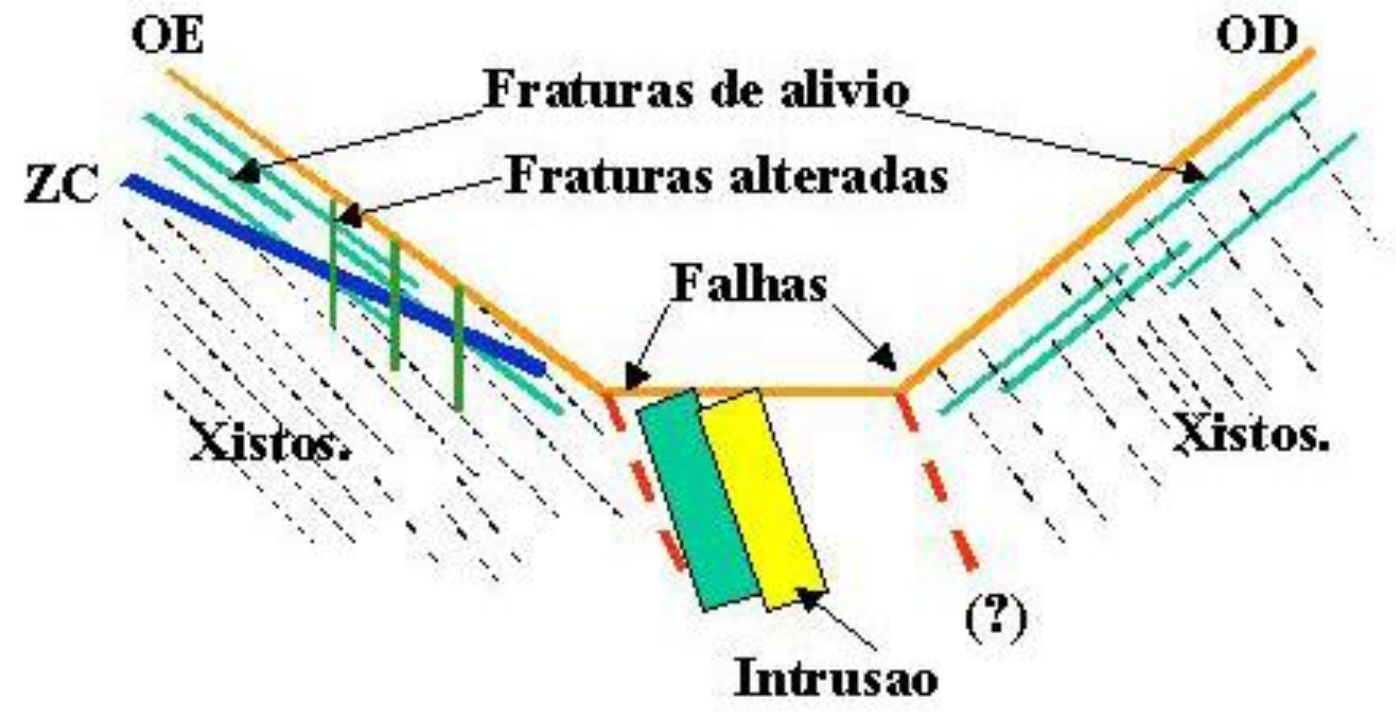

Fonte: Kanji (2004). 


\subsubsection{Mecanismo da Ruptura}

A ruptura provavelmente se iniciou na laje de rocha da margem esquerda imediatamente a jusante da barragem. Com o alteamento do NA do reservatório, estabeleceu-se um regime de percolação de água ao longo da zona de cisalhamento, de montante para jusante, com gradativa perda de carga, conforme esquema da Figura 48.

Figura 48 - Esquema representando a laje de rocha acima da zona de cisalhamento (falha da OE) em vista frontal e em seção transversal. Indicam-se também o NA da percolação na falha e as forças atuantes na laje superior

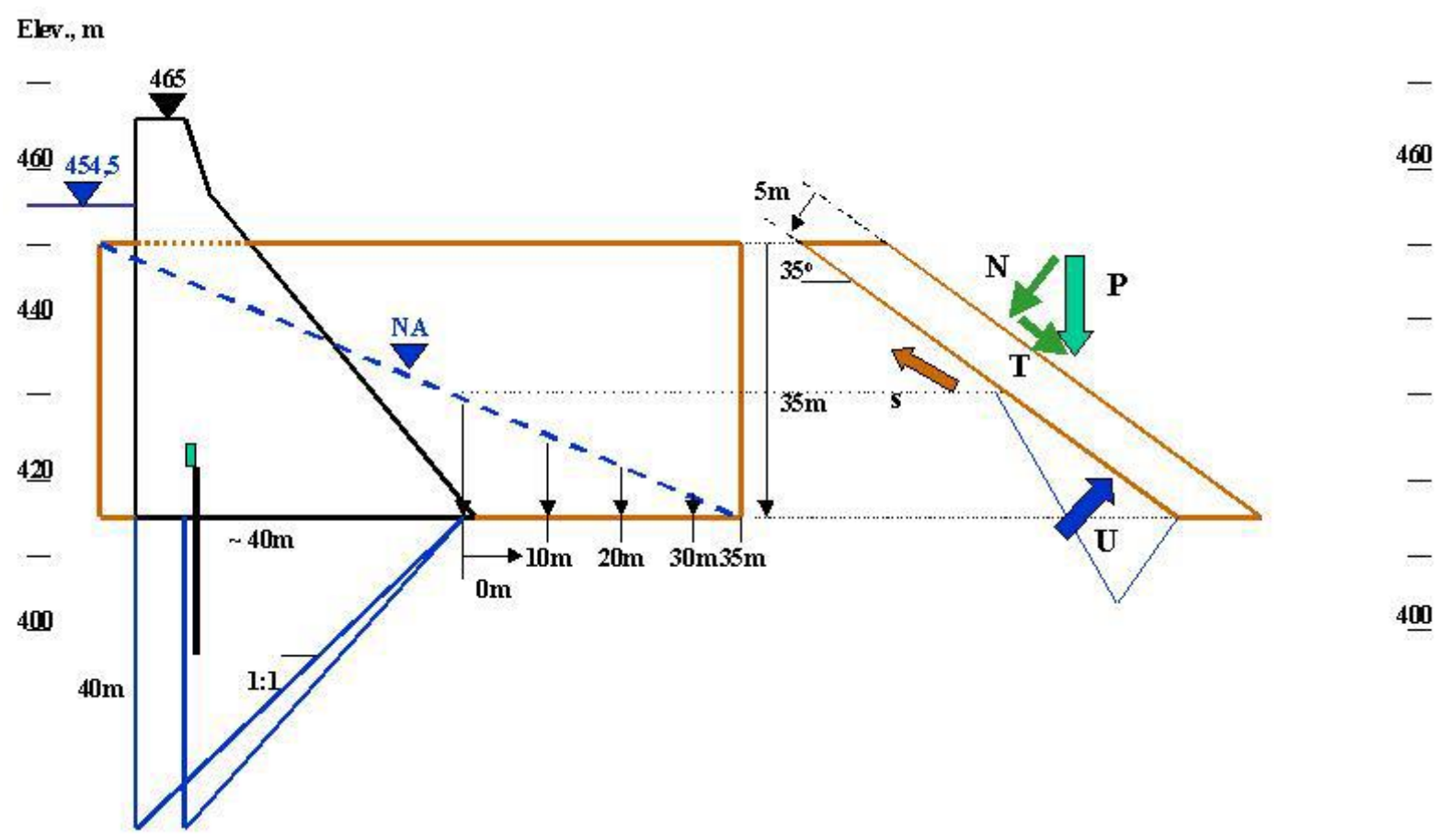

Fonte: Kanji (2004).

Trata-se de situação de exceção, causada pelas peculiares condições geológicas do local, assim como à natureza do preenchimento, reduzindo a resistência ao deslizamento (baixo coeficiente de atrito e orientação dos minerais).

Pode-se concluir pela análise que a elevada subpressão (resultante das pressões hidrostáticas atuantes sob a laje) e o baixo ângulo de atrito disponível na falha, causaram condições de instabilidade, comprovando que a ruptura se iniciou na laje a jusante da barragem, provocando o seu deslocamento e fraturamento em grandes blocos.

Em seguida, o processo de erosão interna já instalado no preenchimento da falha sob a barragem desenvolveu-se com maior intensidade, pois o gradiente hidráulico aumentou, 
causando a erosão completa do preenchimento. Isto deu passe livre à água do reservatório pela fratura, culminando com a ruptura do bloco de rocha ligado à barragem.

\subsubsection{As Conclusões do Acidente}

O histórico da barragem apresentou uma sucessão de julgamentos inadequados, que superpostos uns ao outros causaram a ruptura da mesma, não se podendo imputar o evento da ruptura a uma só causa. Não houve qualquer tipo de seguimento e observação sistemática do comportamento da barragem durante o enchimento da represa. Não houve atitudes e decisões da proprietária ou de seus delegados sobre providências para investigação das causas e condições das observações de ocorrências. A mudança de tipo de barragem de terra para CCR não representou a causa da ruptura, pois o local apresentava feições propícias para o tipo adotado, caso não existisse a falha da ombreira esquerda ou se a mesma tivesse sido removida. Houve julgamento inadequado na interpretação geológica da extensão da falha, já que ela não foi totalmente removida (KANJI, 2004 e NIEBLE, 2004)

A Justiça Federal na Paraíba responsabilizou unicamente o governo estadual, "Não consta que o Estado da Paraíba manteve equipe de monitoração e observação do comportamento do reservatório durante o seu enchimento, pelo contrário, abandonou à sua própria sorte o destino da represa, em que pese a constatação de anomalias que sinalizavam uma ruptura".

\subsubsection{Barragem De Zeuzier - Deslocamentos Anormais Detectados Pela Instrumentação de Auscultação}

No início de Dezembro de 1978, após cerca de 20 anos, as medições regulares passaram a indicar deformações anormais da Barragem em Arco de Zeuzier (Figura 49), na Suíça, com 156 m de altura máxima. (POUGATSCH et al., 2011). 
Figura 49 - Vista aérea da Barragem de Zeuzier, na Suíça.

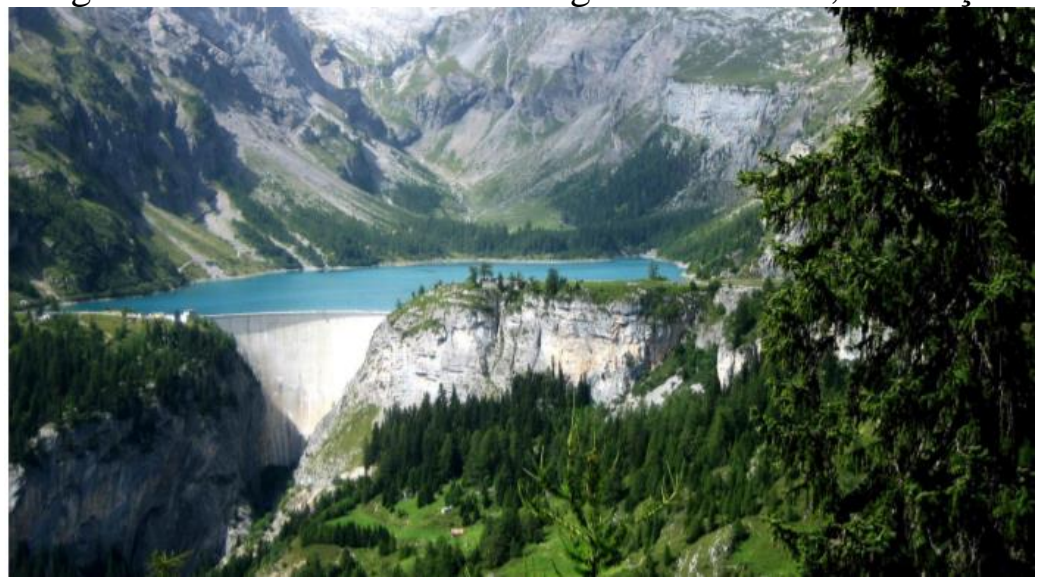

Fonte: Zuculin (2013).

As observações demandaram o rebaixamento do reservatório até seu nível mínimo operacional, com intensificação das inspeções de campo e das frequências de leitura da instrumentação.

Medições geodésicas mostraram que ocorria uma zona de recalques na região da barragem de Zeuzier, levando a deslocamentos das estruturas e consequentemente fissuras no paramento de jusante, conforme Figura 50.

Conforme Silveira (2003) resultados das investigações revelaram que as deformações eram provocadas provavelmente pela escavação de uma galeria de prospecção e drenagem de um túnel rodoviário que estava sendo escavado a cerca de $1,5 \mathrm{~km}$ da barragem e que teria provocado a drenagem de uma espessa camada de calcário, que ocorre a cerca de $450 \mathrm{~m}$ na fundação da barragem (Figura 51).

A supervisão contínua do comportamento das barragens, incluindo inspeções periódicas e leitura/análise da instrumentação, possibilitou a detecção imediata de um sério problema com a barragem e sua fundação.

Figura 50 - Barragem de Zeuzier - Deslocamentos observados.

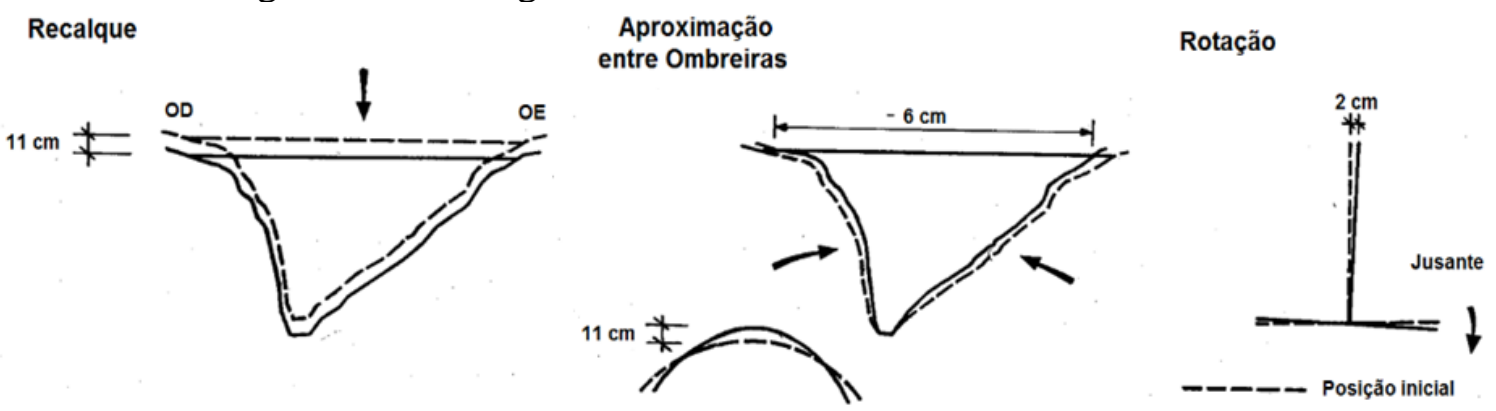

Fonte: Silveira (2003). 
Figura 51 - Galeria de investigação do túnel rodoviário próximo à Barragem Zeuzier.

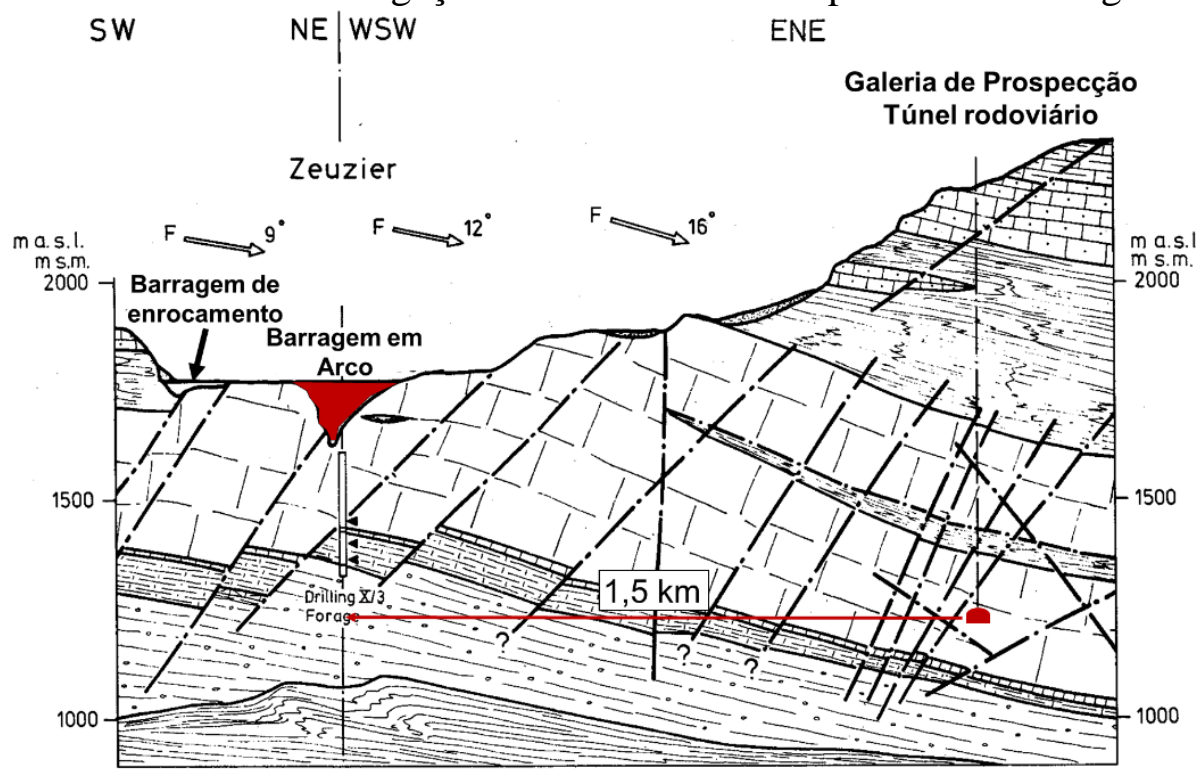

Fonte: Lombardi (2004).

\subsection{AUSCULTAÇÃO DE BARRAGEM DE CONCRETO}

A auscultação de barragens engloba desde o plano de instrumentação, com a especificação dos instrumentos a serem instalados, cuidados a serem tomados na instalação, metodologia de leitura e manutenção dos instrumentos, frequências de leituras, etc., passando pela definição de valores de referência para futura comparação com os valores medidos, e também a definição das rotinas e frequência das inspeções visuais. (ELETROBRÁS, 2003)

Segundo Brasil (2002), as boas condições de segurança de uma barragem não dependem apenas de um bom projeto de instrumentação de auscultação, devendo ser complementado com inspeções visuais periódicas de campo que tem por objetivo detectar deteriorações em potencial e alertar sobre aas condições que podem comprometer a segurança das estruturas associadas. Devem ser incluídas na inspeção local, a barragem, sua fundação, dispositivos de descarga, dispositivos de saída, reservatório, áreas imediatamente a jusante, dispositivos de auscultação e as vias de acesso.

Dentre os principais benefícios da instrumentação de uma barragem e fundações, os seguintes:

Supervisionar o comportamento da barragem em suas diferentes fases: construção, enchimento e operação;

$\checkmark$ Comprovar as hipóteses de projeto, assim como os parâmetros empregados nos modelos matemáticos de análise;

$\checkmark$ Permitir o diagnóstico de situações anômalas, que possam afetar a segurança da 
barragem;

$\checkmark$ Aprimorar o "feeling" dos engenheiros, através da comparação com os resultados de outras seções da barragem ou de outras barragens;

$\checkmark$ Monitorar o desempenho das obras de reparo eventualmente realizadas;

$\checkmark$ "Forçar" os leituristas a percorrer as várias partes de uma barragem, complementando com as inspeções visuais de campo

Ressalta-se que os reais benefícios da instrumentação estão intimamente ligados a um projeto bem elaborado, à aquisição de instrumentos de boa qualidade, a uma instalação por técnicos experientes, assim como por uma manutenção eficiente e leituras bem realizadas.

Dentre os instrumentos básicos destacam-se os piezômetros de fundação, para medição das subpressões junto ao contato concreto/rocha e juntas da fundação, e medidores de vazão, para acompanhamento das vazões através dos drenos de fundação

Na Figura 52, Silveira (2003), apresenta uma relação entre os tipos de instrumentos usualmente empregados na auscultação de barragens de concreto, conjuntamente as inspeções visuais, e os principais tipos de deterioração que podem ser detectados tanto pela instrumentação como inspeções.

Figura 52 - Relações entre instrumentação e a deterioração observada na barragem.

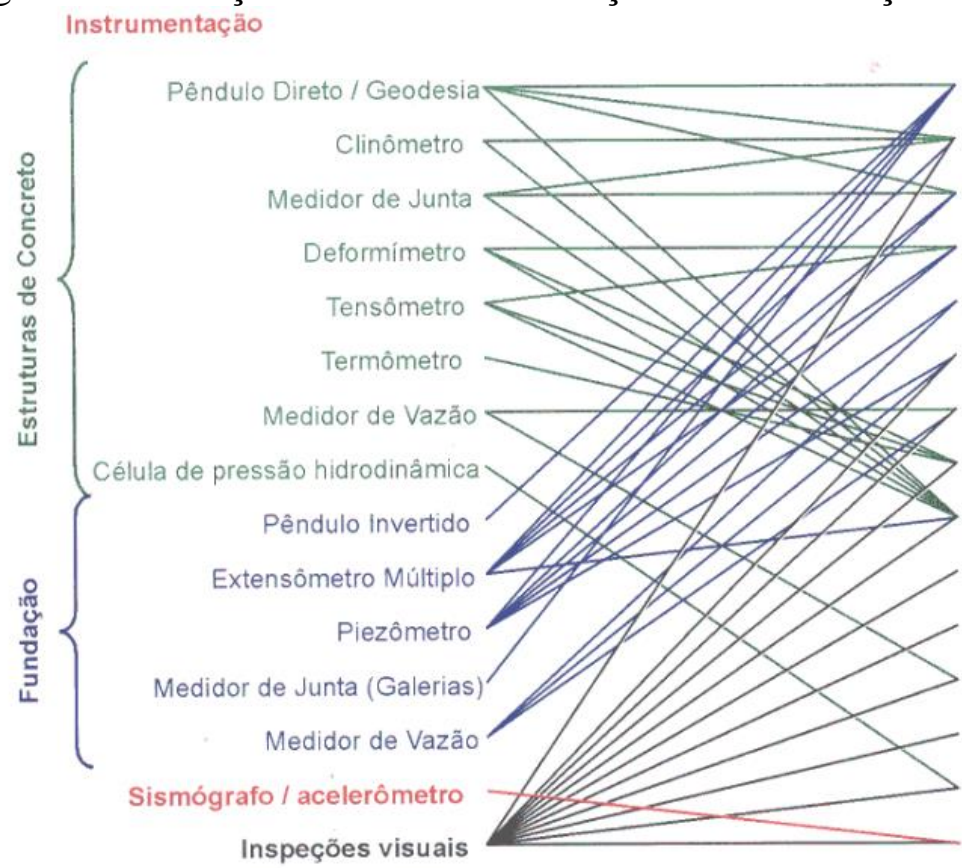

Fonte: Silveira (2003). Escorregamento (descontinuidades na fundaçăo) Recalque Diferencial Subsidência do terreno Distençăo no pé de montante Cortina de injeçăo deficiente Obstruçăo dos drenos de fundaçăo Obstruçăo dos drenos no concreto Fissuraçăo térmica RAA - Reatividade Álcali-Agregado Ataque de sulfatos Gelo / degelo Infiltraçăo excessiva pelo concreto Erosäo por abrasăo Erosăo por cavitaçăo Fissuraçăo devida a sismo

Conforme Figura 52, as inspeções visuais podem detectar grande parte das deficiências encontradas em barragens, tais como fissurações devidas a sismos e erosões, em fundações e 
barragens de aterro, e recalques diferenciais e fissurações térmicas, em barragens de concreto. Entretanto, estas informações são apenas qualitativas e não quantitativas, ficando evidente a importância tanto da instrumentação como das inspeções visuais, e de como elas caminham juntas e se complementam.

Conforme Costa (2012), a inspeção visual é o método mais simples, porém exige certa experiência do observados para detectar indícios, muitas vezes imperceptíveis, de anormalidades que possam denotar o início de um problema significativo no futuro, com risco de afetar a segurança da obra.

As inspeções, associadas a uma análise criteriosa dos dados fornecidos pela instrumentação de auscultação da barragem, formam a mais importante e eficiente ferramenta para avaliação do comportamento das estruturas do barramento (MACHADO, 2007).

\subsubsection{Instrumentação de Barragens de Concreto}

No que se refere a instrumentação de uma barragem, ela deve ser entendida como um processo de aquisição, registro e processamento sistemático dos dados obtidos dos diversos instrumentos de controle instalados no concreto ou maciço rochoso da fundação. Além de assegurar um controle da segurança da obra, a instrumentação hidrogeotécnica permite verificar as hipóteses, os critérios e os parâmetros adotados no projeto, adequando-os aos métodos construtivos de forma a assegurar sempre condições mais econômicas sem comprometer a segurança da obra (DOS SANTOS, 2018)

Conforme Costa (2012) a interpretação periódica e sistemática dos valores medidos na instrumentação é fundamental para o êxito do monitoramento, sua ausência pode tornar até mesmo nocivo todo procedimento, pois poderá levar uma falsa sensação de segurança em relação à obra, quando nem sempre isso está acontecendo. É importante se a ter consciência de que a segurança de uma barragem depende fundamentalmente de seu projeto e de sua construção e o monitoramento constitui um método de observação que apenas diagnostica a tempo eventuais problemas decorrentes de falhas de projeto ou de construção, mas que não aumenta intrinsicamente a segurança da obra.

\subsubsection{Piezômetros}

Piezômetros são instrumentos que possibilitam a medição de pressões neutras em 
maciços de solo ou rocha, assim como as subpressões em contato com estruturas de concreto. Existem diversos tipos de piezômetros, dos quais os mais utilizados são: piezômetro de tubo aberto ("standpipe" ou piezômetro Casagrande), piezômetro pneumático, piezômetro hidráulico e piezômetro elétrico (CRUZ, 2004).

Os piezômetros usualmente mais utilizados são aqueles do tipo "tubo aberto" ("standpipe"), com bulbos da ordem de 2,0 a 3,0 m de comprimento. O trecho perfurado destes piezômetros, geralmente com 1,0 m de comprimento, devem ser envoltos por uma a duas camadas de BIDIM, para evitar que haja entrada de partículas sólidas ou outros materiais carreados pela água, no interior do tubo piezométrico, conforme Figura 53 e Figura 54.

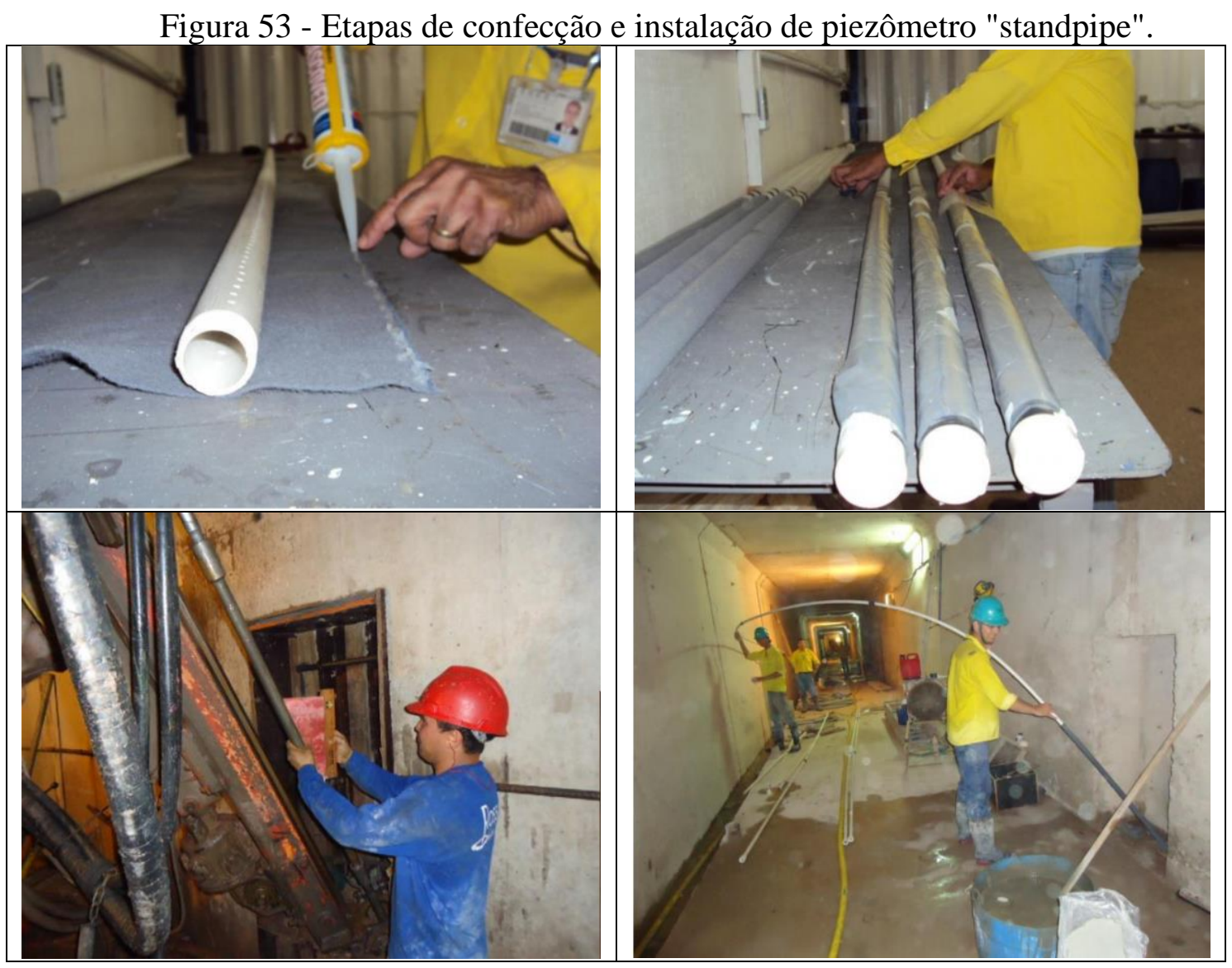

Fonte: ANA (2017). 
Figura 54 - Esquema de instalação de dois piezômetros em um mesmo furo de sondagem a partir da galeria de drenagem.

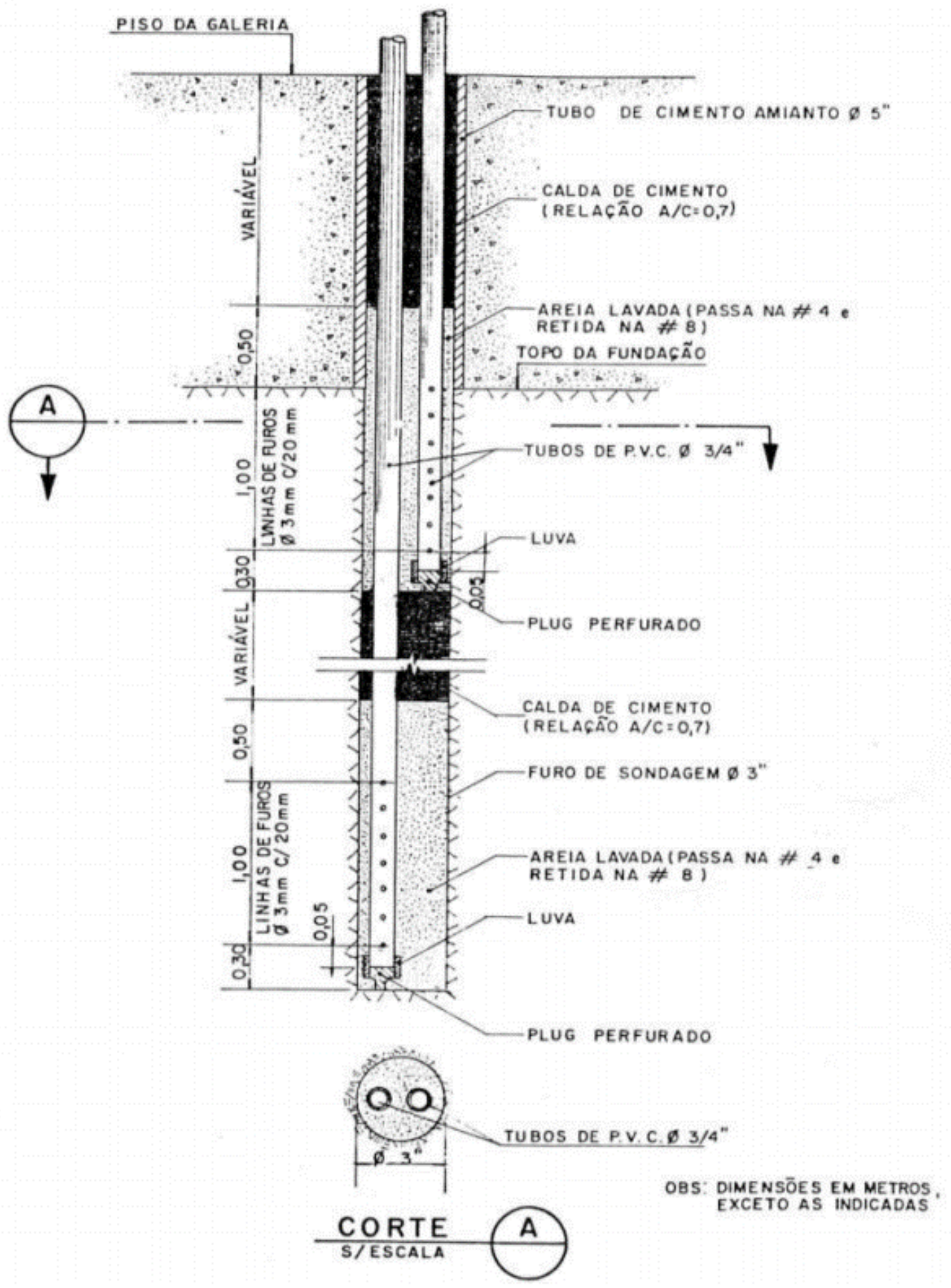

Fonte: ANA (2017).

A observação das subpressões na fundação das barragens de concreto é de suma importância para a boa supervisão de suas condições de segurança, tendo em vista que a estabilidade destas estruturas, seja em termos de escorregamento, tombamento ou flutuação, é diretamente afetada pelo nível das pressões piezométricas na interface concreto-rocha e nas 
descontinuidades sub-horizontais de baixa resistência existentes na fundação (SILVEIRA, 2003).

Conforme Silveira (2003), a análise das subpressões na fundação das barragens de concreto, medidas após certa estabilização, que normalmente ocorre alguns meses após o término do enchimento do reservatório, pode ser realizada tendo por base os seguintes critérios principais:

Analisar a variação temporal das subpressões em função do N.A. de montante, N.A. de jusante e, eventualmente, da temperatura ambiente, para o caso dos piezômetros da interface concreto-rocha;

$\checkmark$ Comparação com as subpressões estabelecidas pelos critérios de projeto, para a condição de drenos operantes e inoperantes;

$\checkmark$ Comparação com as subpressões medidas em posições similares, em outros blocos da barragem e em feições geológicas semelhantes;

$\checkmark$ Comparação com as subpressões medidas em outras barragens do mesmo tipo e, preferencialmente do mesmo porte;

Silveira (2003) ainda destaca que as subpressões na fundação das barragens de concreto devem ser sempre analisadas de forma integrada com as vazões de drenagem, no trecho em questão, visto que uma elevação de subpressões associada à uma redução de vazões, pode constituir indícios da perda de eficiência do sistema de drenagem da fundação, vindo a requerer uma investigação minuciosa do problema e, eventualmente, a implementação de obras de reparo.

É importante observar que a drenagem constitui em geral um dos meios mais eficientes para assegurar coeficientes de segurança adequados para as estruturas de concreto de uma barragem, devendo-se verificar quais os reais níveis piezométricos na fundação, para comparar com as hipóteses de projeto, assim como supervisionar durante todo o período operacional de uma barragem qual a eficiência do sistema de drenagem e como o mesmo está variando com o tempo. A experiência com algumas barragens do TVA - Tennessee Valley Autority, após algumas décadas de operação, vieram revelar aumentos significativos de subpressão, em decorrência da colmatação e obstrução de muitos dos drenos de fundação por partículas sólidas carreadas pelas águas de drenagem, o que veio exigir com o tempo a limpeza dos drenos de fundação e a reperfuração de novos drenos, para assegurar condições adequadas de estabilidade. (Silveira, 2003) 


\subsubsection{Medidores de Vazão}

Conforme Silveira (2003), a medição das vazões de drenagem através da fundação e das infiltrações através do concreto de uma barragem, constitui uma das grandezas mais importantes a ser supervisionadas nas fases de enchimento do reservatório e período de operação, em decorrência de refletir imediatamente muitos dos problemas que soem acontecer com este tipo de estrutura.

As vazões podem ser medidas conforme Quadro 3 e Quadro 4. Nas barragens de concreto, geralmente as vazões são medidas através da instalação de medidores de vazão do tipo triangular, retangular e trapezoidal, ao longo das canaletas da galeria de drenagem. Entretanto para medição de vazões individuais dos drenos de fundação das estruturas de concreto, podem ser empregados recipientes graduados e cronômetros, semelhante ao tipo de medidor "mureta" do Quadro 3.

Quadro 3 - Tipos de medidores de vazão - mureta e triangular.

\begin{tabular}{|c|c|c|c|}
\hline $\begin{array}{l}\text { Tipo de } \\
\text { medidor }\end{array}$ & Figura & Equação & $\begin{array}{l}\text { Faixa } \\
\text { de } Q\end{array}$ \\
\hline Mureta & $\begin{array}{c}\text { Medidor de vazão na barragem } \\
\text { de Canastra }\end{array}$ & $\begin{array}{l}\text { Equação } 1 \\
\begin{array}{l}Q=\frac{V}{t} \\
\text { Onde: } \\
\mathrm{V}=\text { volume coletado (litros) } \\
\mathrm{t}=\text { intervalo de tempo } \\
\text { (minutos ou segundos) }\end{array}\end{array}$ & - \\
\hline Triangular & $\begin{array}{c}\text { Medidor de vazão triangular no } \\
\text { túnel da barragem de Itaúba }\end{array}$ & $\begin{array}{l}\text { Equação } 2 \\
Q=\frac{8}{15} C d \sqrt{2 g} \operatorname{tg}(\alpha / 2) h^{5 / 2} \\
\text { Onde: } \\
\mathrm{g}=\text { aceleração da gravidade } \\
\alpha=\text { ângulo de abertura do } \\
\text { medidor } \\
\mathrm{h}=\text { altura da lâmina vertente }\end{array}$ & $\begin{array}{c}0 \text { a } 600 \\
\mathrm{~L} / \mathrm{min}\end{array}$ \\
\hline
\end{tabular}

Fonte: Smirdele (2014) 
Quadro 4 - Tipos de medidores de vazão - retangular e trapezoidal.

\begin{tabular}{|c|c|c|c|}
\hline $\begin{array}{c}\text { Tipo de } \\
\text { medidor de } \\
\text { vazão }\end{array}$ & Figura & Equação & $\begin{array}{c}\text { Faixa } \\
\text { de } \\
\text { Vazão }\end{array}$ \\
\hline Retangular & $\begin{array}{c}\text { Medidor de vazão retangular no } \\
\text { túnel da barragem de Itaúba }\end{array}$ & $\begin{array}{l}\text { Equação } 3 \\
Q=\frac{2}{3} C d \sqrt{2 g} L h^{3 / 2} \\
\text { Onde: } \\
\mathrm{g}=\text { aceleração da gravidade } \\
\mathrm{L}=\text { Largura do canal } \\
\mathrm{h}=\text { altura da lâmina vertente } \\
\text { Cd = os valores deste } \\
\text { coeficiente podem ser obtidos } \\
\text { a partir das fórmulas de Bazin } \\
\text { (1889), Rehbock (1929), } \\
\text { Francis (1905) ou Kindsvater e } \\
\text { Carte (1957). }\end{array}$ & $\begin{array}{c}0 \mathrm{a} \\
40.000 \\
\mathrm{~L} / \mathrm{min}\end{array}$ \\
\hline Trapezoidal & 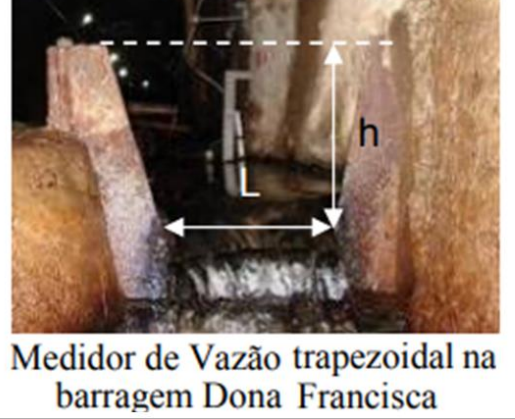 & $\begin{array}{l}\text { Equação } 4 \\
\qquad Q=1,861 L h^{3 / 2} \\
\text { Onde: } \\
\mathrm{L}=\text { Base do trapézio } \\
\mathrm{h}=\text { altura da lâmina vertente }\end{array}$ & $\begin{array}{l}0 \quad \mathrm{a} \\
40.000 \\
\mathrm{~L} / \mathrm{min}\end{array}$ \\
\hline
\end{tabular}

Fonte: Smirdele (2014).

Conforme Silveira (2003), a análise das vazões de drenagem através da fundação das barragens de concreto, medidas após atingirem os valores máximos, que normalmente ocorrem alguns meses após o término do enchimento do reservatório, podem ser realizadas tendo por base os seguintes critérios:

$\checkmark$ Analisar a variação temporal das vazões em função do N.A. de montante e do N.A. de jusante, assim como da eventual influência das precipitações pluviométricas;

$\checkmark$ Comparação com as vazões calculadas ou previstas em projeto;

$\checkmark$ Comparação com as vazões medidas em outros trechos da barragem, em feições geológicas semelhantes;

$\checkmark$ Comparação com as vazões medidas em outras barragens do mesmo tipo e, preferencialmente, do mesmo porte;

Ainda conforme Silveira (2003), uma boa técnica para a análise das vazões de drenagem 
consiste em se calcular as vazões específicas, dividindo-se a vazão total pelo comprimento da barragem no trecho em consideração, obtendo-se desta forma a vazão específica em 1/min/m. $\mathrm{Na}$ Tabela 8 apresentam-se valores das vazões de drenagem específicas observadas em barragens de concreto dotadas de túneis de drenagem na fundação, onde os valores observados são geralmente de maior intensidade, tendo em vista os maiores gradientes hidráulicos, associados geralmente à características da fundação mais desfavoráveis em termos de percolação. Na Tabela 9 e Tabela 10, Silveira (2003) apresenta, respectivamente, as vazões específicas registradas em barragens de concreto nos Estados Unidos e no Brasil.

Meireles et al, 2015 contribuem também com registros de vazões específicas de barragens de concreto (Quadro 5) e observam que grande parte das vazões provenientes das estruturas de concreto ficam em torno de $1,01 / \mathrm{min} / \mathrm{m}$ a $2,01 / \mathrm{min} / \mathrm{m}$, com exceção dos maciços que apresentam alta permeabilidade, como o caso da UHE Estreito, assente em arenito.

Tabela 8 - Vazões específicas em barragens dotadas de túneis de drenagem na fundação

\begin{tabular}{|c|c|c|c|c|c|c|}
\hline \multirow[t]{2}{*}{ Barragem } & \multirow{2}{*}{$\begin{array}{c}\text { Altura } \\
\text { maxima } \\
(\mathbf{m})\end{array}$} & \multirow{2}{*}{$\begin{array}{l}\text { Extensão } \\
\text { (m) }\end{array}$} & \multirow{2}{*}{$\begin{array}{l}\text { Rocha de } \\
\text { fundação }\end{array}$} & \multirow{2}{*}{$\begin{array}{c}\text { Vazão } \\
\text { inicial (l/s) }\end{array}$} & \multicolumn{2}{|c|}{$\begin{array}{c}\text { Vazão específica } \\
(1 / \mathrm{min} / \mathrm{m})\end{array}$} \\
\hline & & & & & Inicial & 2002 \\
\hline \multirow{3}{*}{ Itaipu } & \multirow{3}{*}{190} & $660(\mathrm{El} .20)$ & basalto & 21,7 & 2,0 & 1,37 \\
\hline & & $210(\mathrm{E} 1.55)$ & basalto & 9,8 & 2,8 & 1,53 \\
\hline & & $180(\mathrm{El} .60)$ & basalto & 5,7 & 1,9 & 1,59 \\
\hline Itaipu & 100 & $200(\mathrm{El} .125)$ & basalto & 10,9 & 3,3 & 1,41 \\
\hline Água Vermelha & 60 & 600 & basalto & 94,4 & $9,4(*)$ & - \\
\hline
\end{tabular}

Nota: (*) Em decorrência essencialmente da "estrutura geológica circular" existente na fundação do Vertedouro, extremamente permeável.

Fonte: Silveira (2003). 
Tabela 9 - Vazões específicas através de barragens de concreto nos E.U.A.

\begin{tabular}{|c|c|c|c|c|c|c|}
\hline $\begin{array}{c}\text { Nome do } \\
\text { Projeto }\end{array}$ & $\begin{array}{l}\text { Altura } \\
\text { Máxima } \\
\text { (m) }\end{array}$ & $\begin{array}{c}\text { Compri- } \\
\text { mento } \\
\text { (m) }\end{array}$ & Tipo de Fundação & $\begin{array}{c}\text { Vazão } \\
\text { Média } \\
\text { Inicial } \\
(\mathbf{l} / \mathbf{m i n} / \mathbf{m}) \\
\end{array}$ & $\begin{array}{c}\text { Vazão } \\
\text { Média } \\
\text { Final } \\
(\mathbf{l} / \mathbf{m i n} / \mathbf{m}) \\
\end{array}$ & $\begin{array}{l}\text { Número } \\
\text { de Anos }\end{array}$ \\
\hline Hiwasse & 94 & 420 & Gnaisse e quartzito & 0,45 & 0,07 & --- \\
\hline Fontana & 146 & 541 & Quartzito e filito & 0,25 & 0,11 & --- \\
\hline Green Peter & 100 & 462 & Basalto & 1,39 & 1,05 & 3 \\
\hline Conemaugh & 42 & 332 & Arenito denso & 0,40 & 0,16 & 12 \\
\hline Watts Bar & 34 & 328 & Arenito e folhelho & 0,07 & 0,02 & --- \\
\hline Greefs Ferry & 74 & 519 & Arenito e folhelho & 3,06 & 1,00 & 9 \\
\hline Mt. Morris & 76 & 313 & Folhelho fraturado & 0,04 & 0,11 & 19 \\
\hline Norfolk & 70 & 800 & Calcário e folhelho & 0,02 & 0,02 & 9 \\
\hline Kentucky & 63 & 504 & Calcário & 0,14 & 0,04 & --- \\
\hline Pickwick & 34 & 560 & Calcário & 0,02 & 0,10 & --- \\
\hline Cherokee & 53 & 517 & Calcário e folhelho & 0,82 & 0,07 & --- \\
\hline Mickajack & 25 & 298 & Calcário e folhelho & 0,43 & 0,10 & --- \\
\hline Wheeler & 22 & 1882 & Calcário & 0,18 & 0,17 & --- \\
\hline Wilson & 42 & 1336 & Calcário & 0,05 & 0,02 & --- \\
\hline Bull Shoals & 87 & 688 & Dolomito denso & 0,34 & 0,07 & 22 \\
\hline Table Rock & 77 & 488 & Dolomito, lentes areia & 1,48 & 1,08 & 12 \\
\hline Douglas & 62 & 520 & Dolomito & 0,26 & 0,01 & --- \\
\hline Boone & 49 & 238 & Dolomito e calcário & 0,22 & 0,05 & --- \\
\hline
\end{tabular}

Fonte: Silveira (2003).

Tabela 10 - Vazões específicas através de barragens de concreto no Brasil.

\begin{tabular}{|c|c|c|c|c|c|c|}
\hline Nome do Projeto & $\begin{array}{c}\text { Tipo de } \\
\text { Construção }\end{array}$ & $\begin{array}{l}\text { Altura } \\
\text { Máxima } \\
\text { (m) }\end{array}$ & $\begin{array}{c}\text { Compri- } \\
\text { mento } \\
\text { (m) }\end{array}$ & $\begin{array}{l}\text { Tipo de } \\
\text { Fundação }\end{array}$ & $\begin{array}{c}\text { Vazão } \\
\text { Média } \\
\text { Inicial } \\
(\mathbf{l} / \mathbf{m i n} / \mathbf{m})\end{array}$ & $\begin{array}{c}\text { Vazão } \\
\text { Média } \\
\text { Final } \\
(\mathbf{l} / \mathbf{m i n} / \mathbf{m})\end{array}$ \\
\hline $\begin{array}{c}\text { Itaipu } \\
\text { (Vertedouro) }\end{array}$ & Gravidade & 190 & 374 & Basalto & & 0,07 \\
\hline $\begin{array}{l}\text { Itaipu (Barragens } \\
\text { Laterais) }\end{array}$ & Contrafortes & 190 & 1500 & Basalto & & 0,35 \\
\hline $\begin{array}{l}\text { Itaipu (Estrutura } \\
\text { de Desvio) }\end{array}$ & Gravidade & 190 & 170 & Basalto & 4,20 & 1,62 \\
\hline Itaipu (Total) & $\begin{array}{l}\text { Gravidade } \\
\text { Aliviada }\end{array}$ & 190 & 2550 & Basalto & 1,38 & 1,24 \\
\hline Ilha Solteira & Gravidade & 74 & 1288 & Basalto & 2,40 & --- \\
\hline Jupiá & Gravidade & 31 & 1303 & Basalto & 0,60 & --- \\
\hline Promissão & Gravidade & 35 & 384 & Basalto & 3,10 & --- \\
\hline A. S. Lima (Bariri) & Gravidade & 32,5 & 385 & Basalto & 0,04 & --- \\
\hline Ibitinga & Gravidade & 31,7 & 509 & Basalto & 0,08 & --- \\
\hline Xavantes & $\begin{array}{l}\text { Enrocamento e } \\
\text { Concreto }\end{array}$ & 98 & 235 & Basalto & 5,10 & --- \\
\hline $\begin{array}{l}\text { A. A. Laydner } \\
\text { (Jurumirin) }\end{array}$ & Gravidade & 50 & 313 & Basalto & 0,01 & --- \\
\hline $\begin{array}{l}\text { A. S. Oliveira } \\
\text { (Limoeiro) }\end{array}$ & Terra compactada & 41 & 51 & Gnaisse & 0,14 & --- \\
\hline Itumbiara & Gravidade & 106 & 123 & $\begin{array}{l}\text { Anfibolito } \\
\text { Gnaisse }\end{array}$ & 0,37 & --- \\
\hline Furnas & Gravidade & 127 & 550 & $\begin{array}{c}\text { Quartzitos e } \\
\text { Xistos }\end{array}$ & 0,45 & --- \\
\hline
\end{tabular}

Fonte: Silveira (2003). 
Quadro 5 - Compilação de dados de vazão observados em galerias de concreto.

\begin{tabular}{|c|c|c|c|c|c|c|c|}
\hline \multirow{2}{*}{ NOME DO PROJETO } & \multirow{2}{*}{$\begin{array}{l}\text { ALTURA } \\
\text { MÁXIMA } \\
\quad(\mathrm{m})\end{array}$} & \multirow{2}{*}{$\begin{array}{l}\text { COMPRIMENTO } \\
(\mathrm{m})\end{array}$} & \multirow{2}{*}{$\begin{array}{l}\text { TIPO DE } \\
\text { FUNDAÇÃO }\end{array}$} & \multicolumn{2}{|c|}{$\begin{array}{l}\text { VAZÃO ESPECÍFICA } \\
\text { PÓS-ENCHIMENTO }\end{array}$} & \multicolumn{2}{|c|}{$\begin{array}{l}\text { VAZÃO ESPECÍFICA } \\
\text { RESERVATÓRIO } \\
\text { ESTABILIZADO }\end{array}$} \\
\hline & & & & $\begin{array}{l}\text { MÉDIA } \\
(1 / \mathrm{min} / \mathrm{m})\end{array}$ & $\begin{array}{l}\text { MÁXIMA } \\
(1 / \mathrm{min} / \mathrm{m})\end{array}$ & $\begin{array}{c}\text { MÉDIA } \\
(1 / \mathrm{min} / \mathrm{m})\end{array}$ & $\begin{array}{l}\text { MÁXIMA } \\
(\mathrm{I} / \mathrm{min} / \mathrm{m})\end{array}$ \\
\hline $\begin{array}{c}\text { UHE ITÁ } \\
\text { (VERTEDOURO 1) }\end{array}$ & 44 & 132 & BASALTO & 0,43 & 1,28 & 0,40 & 2,52 \\
\hline $\begin{array}{c}\text { UHE ITÁ } \\
\text { (VERTEDOURO 2) }\end{array}$ & 44 & 90 & BASALTO & 3,56 & 5,19 & 1,37 & 2,43 \\
\hline $\begin{array}{c}\text { UHE MACHADINHO } \\
\text { (VERTEDOURO: } \\
\text { GALERIA DE } \\
\text { MONTANTE) }\end{array}$ & 47 & 155,5 & RIODACITO & 3,57 & 5,79 & 2,73 & 3,40 \\
\hline $\begin{array}{l}\text { UHE MACHADINHO } \\
\text { (VERTEDOURO - } \\
\text { GALERIA DE JUSANTE) }\end{array}$ & 47 & 143 & RIODACITO & 1,26 & 3,15 & 0,87 & 1,38 \\
\hline $\begin{array}{l}\text { UHE PASSO FUNDO } \\
\text { (VERTEDOURO - } \\
\text { GALERIA 1) }\end{array}$ & 35 & 111,32 & BASALTO & - & - & 0,20 & 0,62 \\
\hline $\begin{array}{l}\text { UHE PASSO FUNDO } \\
\text { (VERTEDOURO - } \\
\text { GALERIA 2) }\end{array}$ & 35 & 84,60 & BASALTO & - & - & 0,14 & 0,64 \\
\hline $\begin{array}{l}\text { UHE PASSO FUNDO } \\
\text { (VERTEDOURO } \\
\text { GALERIA 3) }\end{array}$ & 35 & 84,60 & BASALTO & & & 0,13 & 0,33 \\
\hline $\begin{array}{l}\text { UHE SALTO } \\
\text { SANTIAGO } \\
\text { (VERTEDOURO) }\end{array}$ & 40 & 154,40 & BASALTO & - & - & 0,01 & 0,05 \\
\hline $\begin{array}{l}\text { UHE SALTO OSÓRIO } \\
\text { (VERTEDOURO 2) }\end{array}$ & 32 & 73,20 & BASALTO & - & - & 0 & - \\
\hline $\begin{array}{l}\text { UHE CANA BRAVA } \\
\text { (BLOCOS B-1 A B-6) }\end{array}$ & 48 & 134 & $\begin{array}{l}\text { QUARTZO- } \\
\text { MICA XISTO }\end{array}$ & 0,62 & 1,67 & 0,21 & 0,38 \\
\hline $\begin{array}{l}\text { UHE CANA BRAVA } \\
\text { (BLOCOS V-4 A B-6) }\end{array}$ & 48 & 60 & $\begin{array}{l}\text { QUARTZO- } \\
\text { MICA XISTO }\end{array}$ & 0,19 & 0,64 & 0,13 & 0,52 \\
\hline $\begin{array}{l}\text { UHE CANA BRAVA } \\
\text { (BLOCOS V-4 A B-7) }\end{array}$ & 48 & 66 & $\begin{array}{l}\text { QUARTZO- } \\
\text { MICA XISTO }\end{array}$ & 0,19 & 0,62 & 0,16 & 0,33 \\
\hline $\begin{array}{l}\text { UHE CANA BRAVA } \\
\text { (BLOCOS B-7 A B-9) }\end{array}$ & 58 & 38 & $\begin{array}{l}\text { QUARTZO- } \\
\text { MICA XISTO }\end{array}$ & 0,24 & 0,46 & 0,19 & 0,48 \\
\hline $\begin{array}{l}\text { UHE CANA BRAVA } \\
\text { (BLOCOS B-9 A B-16) }\end{array}$ & 56 & 98 & $\begin{array}{l}\text { QUARTZO- } \\
\text { MICA XISTO }\end{array}$ & 0,31 & 0,77 & 0,14 & 0,30 \\
\hline $\begin{array}{l}\text { UHE CANA BRAVA } \\
\text { (BLOCOS B-16 A B-20) }\end{array}$ & 78 & 68 & $\begin{array}{l}\text { QUARTZO- } \\
\text { MICA XISTO }\end{array}$ & 0,43 & 0,79 & 0,22 & 0,58 \\
\hline $\begin{array}{l}\text { UHE SÃO SALVADOR } \\
\text { (BLOCOS 1,2E 3) }\end{array}$ & 31 & 49 & $\begin{array}{l}\text { QUARTZO- } \\
\text { MICA XISTO } \\
\end{array}$ & 0,98 & 1,41 & 0,58 & 0,97 \\
\hline $\begin{array}{l}\text { UHE SÃO SALVADOR } \\
\text { (BLOCOS } 4 \text { E 5) }\end{array}$ & 45,7 & 170 & $\begin{array}{l}\text { QUARTZO- } \\
\text { MICA XISTO }\end{array}$ & 0,78 & 2,14 & 0,41 & 0,71 \\
\hline $\begin{array}{l}\text { UHE SÃO SALVADOR } \\
\text { (TOMADA D'ÁGUA) }\end{array}$ & 45,7 & 60 & $\begin{array}{l}\text { QUARTZO- } \\
\text { MICA XISTO }\end{array}$ & 0,94 & 1,78 & 0,59 & 0,99 \\
\hline $\begin{array}{l}\text { UHE ESTREITO } \\
\text { (VERTEDOURO) }\end{array}$ & 43,70 & 328 & ARENITO & - & - & 15,8 & - \\
\hline UHE SALTO CAXIAS & 67 & 1050 & BASALTO & - & - & 1,31 & 3,52 \\
\hline ÁGUA VERMELHA & 60 & 610 & BASALTO & - & - & 0,14 & 10 \\
\hline CANOAS 1 & 30 & 200 & BASALTO & - & - & 0,48 & 14,3 \\
\hline DONA FRANCISCA & 50 & 640 & $\begin{array}{l}\text { BASALTO/ } \\
\text { ARENITO }\end{array}$ & - & - & 0,09 & 4,64 \\
\hline
\end{tabular}

Fonte: Meirelles et al. (2015).

Na Tabela 11, são apresentados outros valores de vazões especificas em barragens de concreto, para servir, também, como comparação. Conforme Terzaghi et al. (1996), com o 
tempo as vazões pelos drenos de fundação podem diminuir devido ao processo de colmatação dos vazios da fundação e assoreamento do reservatório, obstrução dos drenos devido ao acúmulo de material carreado ou ainda pela colmatação química.

Tabela 11 - Vazões específicas de barragens e estruturas de Concreto.

\begin{tabular}{ccccccc}
\hline $\begin{array}{c}\text { Nome do } \\
\text { Projeto }\end{array}$ & $\begin{array}{c}\text { Tipo de } \\
\text { Barragem }\end{array}$ & $\begin{array}{c}\text { Altura } \\
\text { Máxima } \\
(\mathbf{m})\end{array}$ & $\begin{array}{c}\text { Compri- } \\
\text { mento } \\
(\mathbf{m})\end{array}$ & $\begin{array}{c}\text { Rocha de } \\
\text { Fundação }\end{array}$ & $\begin{array}{c}\text { Vazão Pico } \\
\text { Enchimento } \\
(\mathbf{l} / \mathbf{m i n} / \mathbf{m})\end{array}$ & $\begin{array}{c}\text { Vazão } \\
\text { Período de } \\
\text { Operação } \\
(\mathbf{l} / \mathbf{m i n} / \mathbf{m})\end{array}$ \\
\hline 14 de Julho & Gravidade-CCR & 42,00 & 338,00 & Basalto & 2,30 & 0,18 \\
Castro Alves & Gravidade-CCR & 50,00 & 235,00 & Basalto & 0,90 & 0,26 \\
$\begin{array}{c}\text { Monte Claro } \\
\text { Barra Grande } \\
\text { (VT) }\end{array}$ & Gravidade-CCR & 27,00 & 192,00 & Basalto & 2,20 & 0,84 \\
$\begin{array}{c}\text { Campos Novos } \\
\text { (VT) }\end{array}$ & Gravidade & 36,50 & 120,00 & Basalto & 1,40 & 0,45 \\
$\begin{array}{c}\text { Santa Luzia } \\
\text { Ludesa }\end{array}$ & Gravidade-CCR & 37,00 & 227,00 & Basalto/Riodacito & 0,40 & 0,07 \\
Figueirópolis & Gravidade-CCR & 27,70 & 40,00 & Basalto & 0,07 & 0,05 \\
\hline
\end{tabular}

Fonte: do Autor (2020)

As vazões de drenagem através da fundação das barragens devem ser sempre analisadas em associação com os níveis piezométricos na região, visto que uma redução de vazão conjuntamente com a elevação das subpressões na área, viria indicar uma tendência de perda de eficiência do sistema de drenagem das fundações (SILVEIRA, 2003)

Nas fundações, o fenômeno de erosão interna pode ocorrer na presença de fraturas ou falhas causadas por descontinuidades do maciço, que uma vez preenchidas com materiais suscetíveis à erosão por percolação subterrânea, tais como solos residuais, podem causar a formação de vazios devido ao carreamento de material pelo fluxo, aumentando o gradiente hidráulico devido a redução da distância de percolação. Isso pode contribuir com o surgimento de tensões cisalhantes e altas cargas hidráulicas na base da barragem, causando o colapso da estrutura. (KANJI, 2004)

Silveira (2003) explica que o controle de carreamento de finos é feito por meio de comparação do teor de sólidos a partir de amostras coletadas no reservatório e drenagem das galerias de barragens de concreto, com o objetivo analisar a possibilidade de erosão interna, devendo ser empregado especialmente em locais com solos suscetíveis e em locais com grande infiltração. 


\subsubsection{Medidores Triortogonais}

Segundo Graça (2014), os medidores triortogonais de junta, são usualmente empregados para monitorar fissuras, trincas ou juntas de contração entre blocos, cuja medição é realizada com relógio comprador, com precisão das leituras de $\pm 0,01 \mathrm{~mm}$. Através dos medidores triortogonais podem ser determinados os deslocamentos diferenciais entre blocos segundo três direções ortogonais entre si (Figura 55):

- Abertura/fechamento da junta (Direção X);

- Recalque diferencial entre blocos ((Direção Z);

- Deslizamento horizontal entre blocos (Direção Y).

Os medidores triortogonais devem ser instalados imediatamente após a concretagem e desforma da galeria de drenagem das barragens de concreto, de modo a possibilitar a medição dos deslocamentos diferenciais desde a fase inicial de construção da barragem. Os recalques que ocorrem durante o período construtivo de uma barragem de concreto, são cerca de 3 a 4 vezes superiores aqueles que ocorrerão durante o período de enchimento do reservatório (SILVEIRA,2003).

Figura 55 - Medidor tipo triortogonal de junta e orientação dos respectivos eixos.

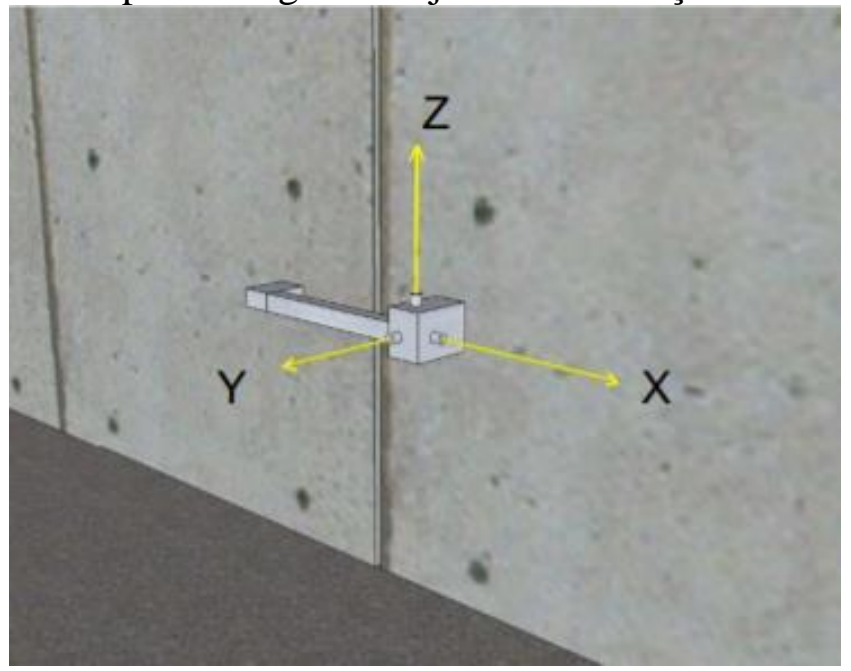

Fonte: Graça (2016).

Conforme Silveira (2003), a medição dos deslocamentos diferenciais entre os blocos de uma barragem de concreto apresenta, dentre outros, os seguintes objetivos:

Acompanhar a abertura das juntas de contração a serem injetadas, para permitir a escolha da época mais apropriada para as injeções, assim como acompanhar a 
eficiência das mesmas, através da determinação do volume de calda injetada;

$\checkmark$ Permitir o acompanhamento das regiões mais deformáveis da fundação, pelo acompanhamento dos recalques diferenciais entre blocos;

$\checkmark$ Verificar qual a ordem de grandeza dos deslocamentos diferenciais máximos entre blocos, para analisar sua influência sobre equipamentos e tubulações que atravessam as juntas de contração;

$\checkmark$ Verificar se os deslocamentos diferenciais entre blocos não foram excessivos, a ponto de danificar as chavetas de concreto existentes eventualmente nas juntas ou comprometer o sistema de veda-juntas, instalado nas proximidades dos drenos de junta entre blocos.

Na Tabela 12, Silveira (2003) apresenta os deslocamentos diferenciais máximos observados entre blocos de barragens de concreto, onde pode-se observar que os valores mais altos ocorreram nas barragem de São Simão e Itaipu, em função do porte das estruturas, e na barragem de Canoas I, em decorrência da existência de uma anomalia geológica na fundação das estruturas de concreto.

Tabela 12 - Deslocamentos diferenciais máximos observados entre blocos de barragens de concreto.

\begin{tabular}{ccccc}
\hline & \multicolumn{4}{c}{ Deslocamentos diferenciais máximos (mm) } \\
\cline { 2 - 5 } Barragem & Abertura & $\begin{array}{c}\text { Recalque } \\
\text { diferencial }\end{array}$ & Deslizamento cisalhante horizontal \\
\cline { 3 - 5 } & 1,85 & 1,21 & 0,76 & Crista \\
\hline Água Vermelha (total) & 0,90 & 0,47 & 0,37 & - \\
Água Vermelha (enchimento) & 1,31 & 0,73 & 2,58 & - \\
São Simão & 2,25 & 0,70 & 0,25 & - \\
Paulo Afonso IV & 0,66 & 0,50 & 0,86 & 2,27 \\
Xingó & 0,44 & 0,28 & 0,22 & - \\
Nova Avanhandava & 0,80 & 0,30 & 0,40 & - \\
Itá (CF) & 2,80 & 1,60 & 1,30 & - \\
Canoas I & 0,57 & 0,48 & 0,34 & - \\
Canoas II & 3,80 & 1,56 & 1,19 & $8,00\left(^{*}\right)$ \\
Dona Francisca & 0,65 & 0,70 & 0,60 & 1,00 \\
Itaipu (só enchimento) & 1,10 & 0,50 & 0,20 & 0,50 \\
Itaipu - Bar. Gravidade & 4,20 & 3,40 & 1,10 & 4,50 \\
Itaipu - Bar. Grav. Aliviada & 2,30 & 1,00 & 0,80 & 3,20 \\
Itaipu - Bar. Contrafortes &
\end{tabular}

Nota: (*) Observação realizada durante o inverno (barragem em CCR).

Fonte: Silveira (2003). 


\subsubsection{Extensômetros Múltiplos de Hastes}

Conforme ANA (2016), os extensômetros de fundação são constituídos por hastes metálicas ou cabos em fibra de vidro, instalados em furos de sondagem na fundação e ancorados a uma determinada profundidade. A medição da extensão da haste na sua extremidade superior, por intermédio relógio comparador, indica o deslocamento relativo segundo o eixo do furo, entre esta extremidade e as ancoragens na outra extremidade, com precisão de $\pm 0,01 \mathrm{~mm}$, conforme esquema da Figura 56.

Figura 56 - Exemplo de um perfil típico de um extensômetro múltiplo de haste.

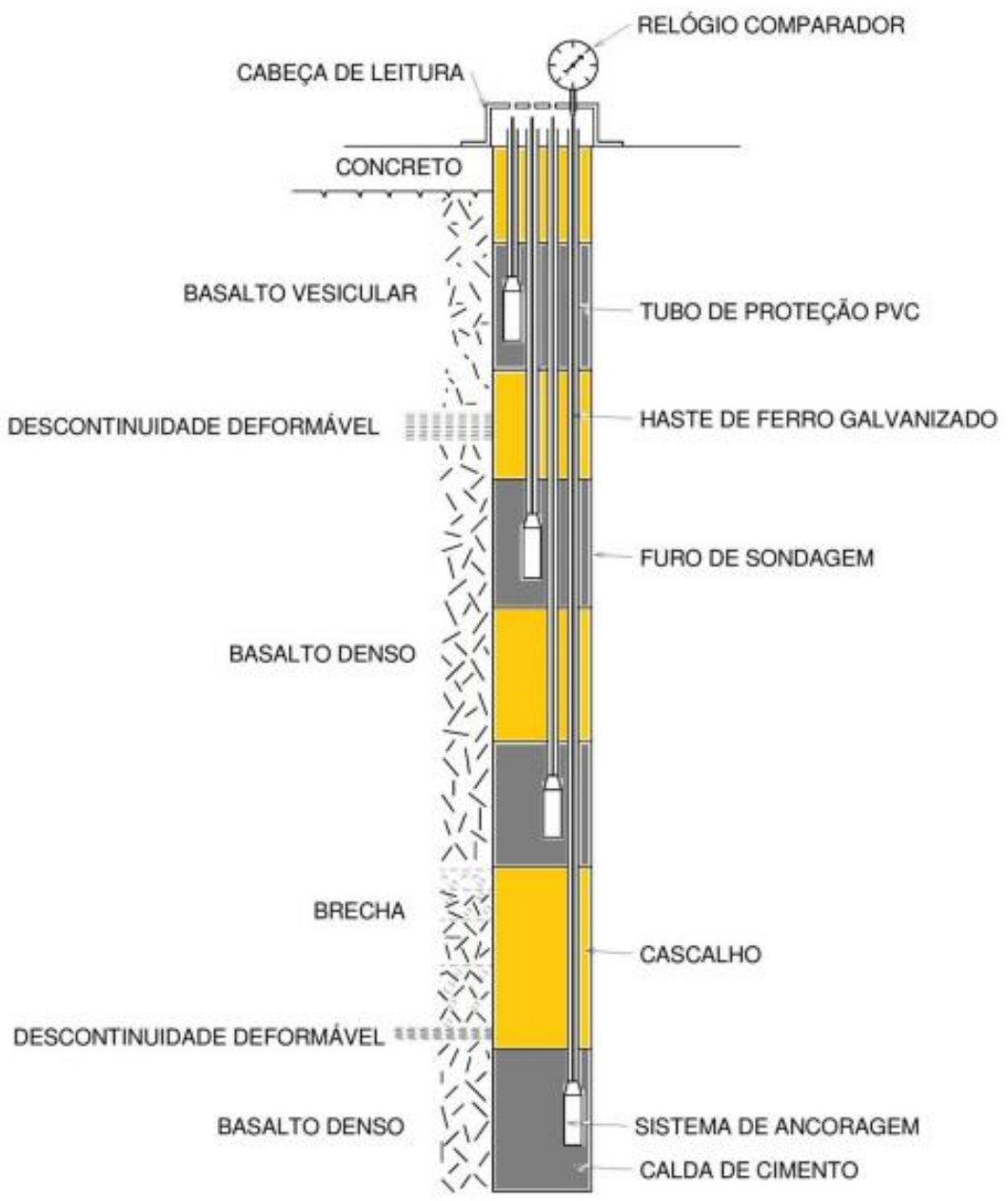

Fonte: Matos (2002 apud CAMARGO, 2014).

Conforme Matos (2002 apud CAMARGO, 2014), os extensores ou extensômetros múltiplos de haste são instrumentos usados para medir o deslocamento angular vertical em camadas profundas da fundação. Eles geralmente são instalados em grupos, um a jusante e outro 
a montante da barragem, e os dados obtidos são comparados a fim de se obter um resultado convergente.

Durante o período construtivo os extensômetros múltiplos permitem a medição dos recalques da barragem, possibilitando desta forma uma boa avaliação da deformabilidade do maciço rochoso de fundação, quando submetido às cargas verticais decorrentes do peso próprio da estrutura. (SILVEIRA, 2003). Além disso, podem ser instalados para acompanhamento das deformações de feições especificas na fundação, conforme Figura 57.

Figura 57 - Localização dos extensômetros da UHE Tucuruí.

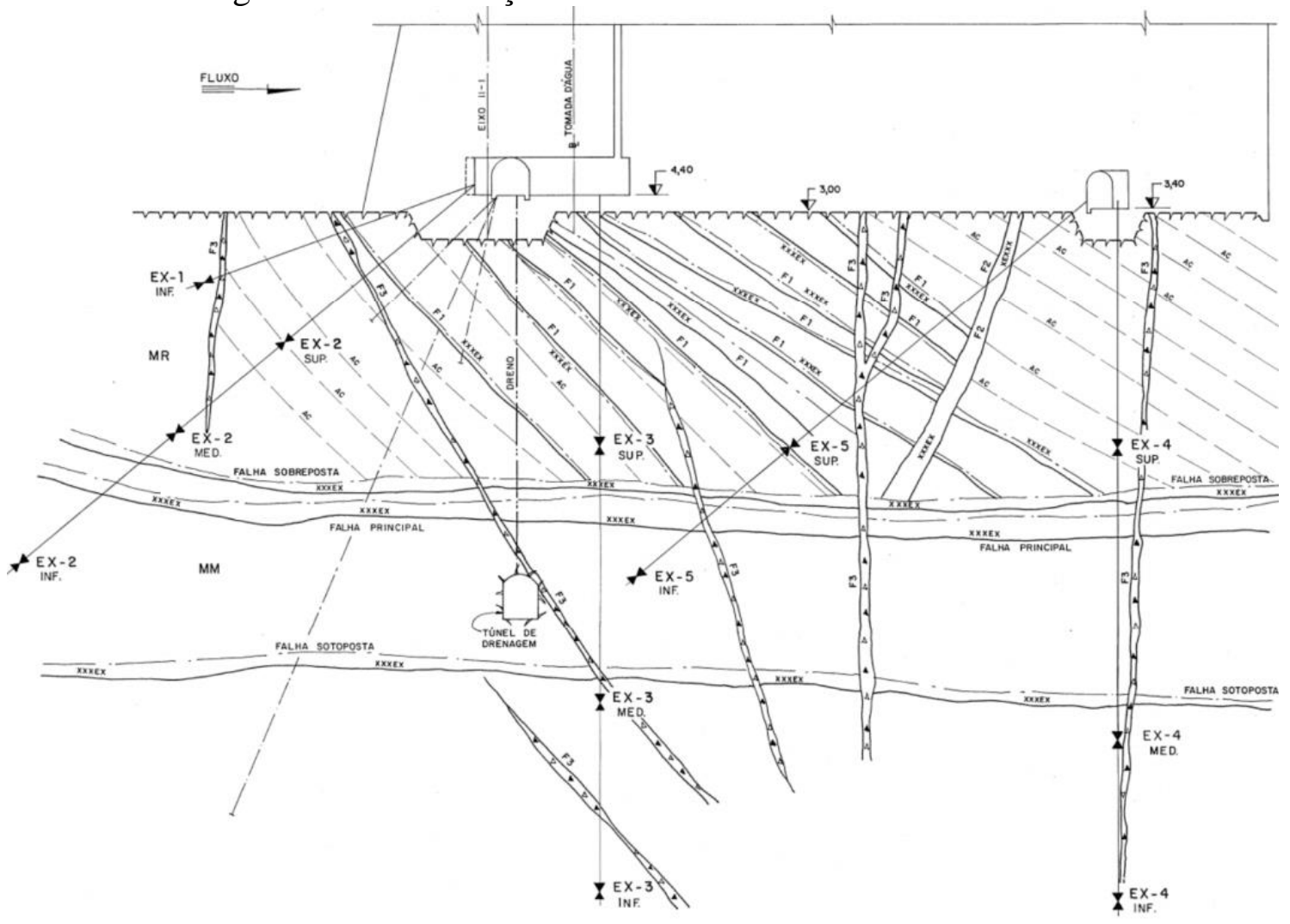

Fonte: Caldas e Luz (2013 apud CAMARGO, 2014).

Segundo Silveira (2003), os deslocamentos medidos pelas hastes dos extensômetros múltiplos, devem também ser analisados de uma forma mais completa e global, procurando-se proceder aos seguintes tipos de análise:

Comparar os deslocamentos das várias hastes de um determinado extensômetro múltiplo entre si, para verificar a consistência dos dados;

$\checkmark$ Comparar os deslocamentos medidos pelos extensômetros múltiplos instalados em posições similares, em blocos da barragem de mesma altura; 
$\checkmark$ Verificar a evolução dos recalques da barragem em função da subida dos blocos sobrejacentes;

$\checkmark$ Analisar a velocidade dos deslocamentos/deformações medidas, em função dos esforços aplicados;

$\checkmark$ Verificar eventuais influências térmicas sobre os deslocamentos medidos pelas várias hastes de cada extensômetro, particularmente para os instrumentos instalados mais superficialmente;

$\checkmark$ Analisar a ordem de grandeza dos módulos de deformabilidade obtidos, comparando-os com aqueles medidos "in situ" ou adotados em projeto.

\subsection{BARRAGENS EM REGIÕES CÁRSTICAS}

Praticamente todos os reservatórios construídos no mundo apresentam alguma perda de água e nem sempre é possível prever com precisão o comportamento hidráulico do corpo da barragem e das formações geológicas no seu entorno. Geralmente vazamentos e infiltrações são previstos no projeto, porém é difícil identificar os riscos associados e as consequências quando estes são excessivos, pois estes podem gerar erosão interna e levar à instabilidade da estrutura caso não sejam tomadas as medidas corretivas necessárias (BEDMAR E ARAGUÁS, 2002).

As duas principais características de aquíferos cársticos são anisotropia e heterogeneidade. Anisotropia significa que uma propriedade física varia com a direção e este termo quase se torna a primeira associação com a palavra "Carste”. Heterogeneidade como uma variação de uma propriedade de dois locais dentro da mesma formação. Tornar o carste e sua natureza sustentável para a humanidade não é uma tarefa fácil e vários tipos de intervenção às vezes são necessárias para adaptar tal ambiente às necessidades humanas. (STEVANOVIĆ; MILANOVIĆ, 2015).

Durante o século XX e especialmente na sua segunda metade, muitos projetos de sucesso foram implementados em diferentes regiões cársticas em todo o mundo. No entanto, uma série de falhas confirmam que o carste é um ambiente de risco para diferentes aspectos de utilização e controle da água (MILANOVIĆ 2015).

Conforme Stevanović e Milanović (2015), o bom planejamento e pesquisa extensa podem diminuir o risco, mas nunca podem garantir totalmente um resultado positivo em todas as obras 
em regiões cárticas. Para obter o melhor resultado das intervenções é, portanto, importante escolher métodos de investigações ideais e compreender e estudar bem o sistema cárstico local.

O relevo cárstico ocorre predominantemente em terrenos constituídos de rocha calcária, mas também pode ocorrer em outros tipos de rochas carbonáticas, como o mármore e rochas dolomíticas. Destacam-se como rochas solúveis as variedades de calcário $\left(\mathrm{CaCO}_{3}\right)$, dolomita $\left(\mathrm{CaMg}\left(\mathrm{CO}_{3}\right)_{2}\right)$, anidrita $\left(\mathrm{CaSO}_{4}\right)$, gesso $\left(\mathrm{CaSO}_{4} * 2 \mathrm{H}_{2} \mathrm{O}\right)$ e halita $(\mathrm{NaCl})$. A dissolução pode ocorrer por meio de reações com diferentes ácidos, mas mais comumente pelo ácido carbônico (JENNINGS, 1971), conforme exemplificado a partir do carbonato de cálcio, a seguir:

1. Carbonato de cálcio dissolvido em um estado iônico:

$$
\mathrm{CaCO}_{3} \text { (sólido) } \rightleftharpoons \mathrm{Ca}^{2+}{ }_{\text {(hidratado) }}+\mathrm{CO}_{3}{ }^{2-} \text { (hidratado) }
$$

2. O dióxido de carbono dissolvido reage com a água para produzir ácido carbônico em um estado iônico.

$$
\mathrm{CO}_{2} \text { (dissolvido) }+\mathrm{H}_{2} \mathrm{O} \rightleftharpoons \mathrm{H}^{+}+\mathrm{HCO}_{3}^{-}
$$

3. Os íons carbonato do calcário dissolvido reagem com os íons hidrogênio para produzir íons bicarbonato.

$$
\mathrm{CO}_{3}{ }^{2-}+\mathrm{H}^{+} \rightleftharpoons \mathrm{HCO}_{3}{ }^{-}
$$

4. A reação geral líquida para a dissolução de carbonato de cálcio é:

$$
\mathrm{CaCO}_{3}+\mathrm{CO}_{2}+\mathrm{H}_{2} \mathrm{O} \rightleftharpoons \mathrm{Ca}^{2+}+2 \mathrm{HCO}_{3}^{-}
$$

Na Figura 58, Fernandez et al. (1995), apresentam de forma didática as reações descritas anteriormente, sendo o dióxido de carbono $\left(\mathrm{CO}_{2}\right)$, o principal composto que atua na dissolução do carbonato de cálcio. $\left(\mathrm{CaCO}_{3}\right)$, apresentando-se na Tabela 13 algumas correlações para a condição em temperatura de $17^{\circ} \mathrm{C}$. 
Figura 58 - Síntese da dissolução do carbonato de cálcio em água.

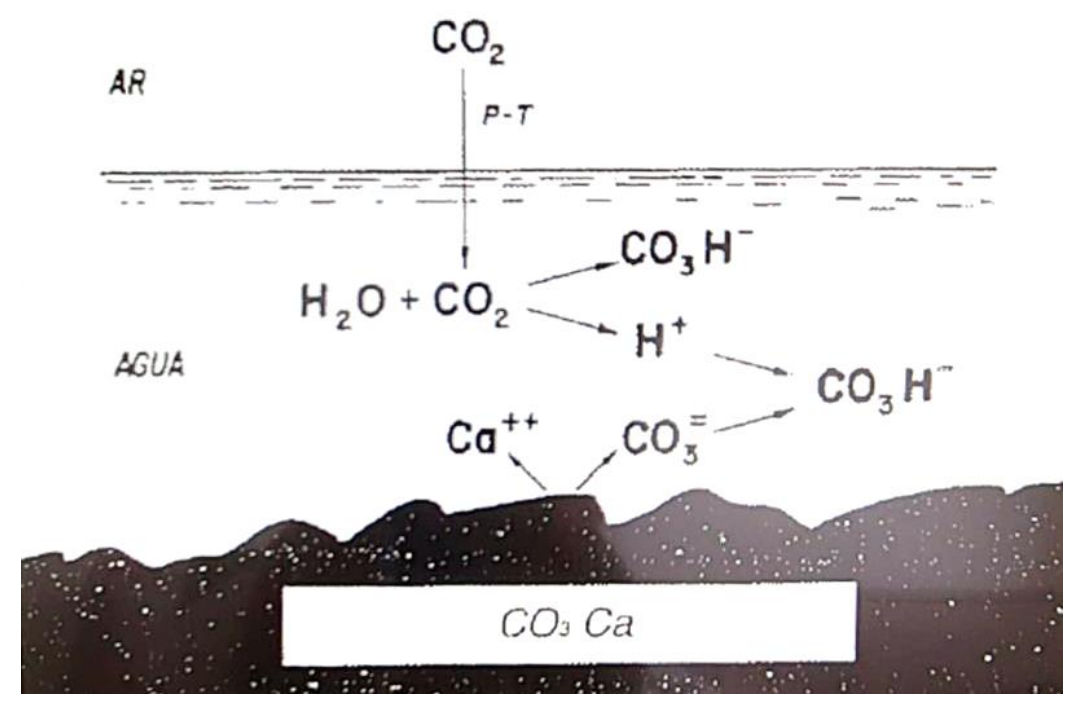

Fonte: Fernandez et al. (1995)

Tabela 13 - Quantidades de carbonato de cálcio solúvel em água (mg/l) em função da quantidade de dióxido de carbono livre (para $\mathrm{T}=17^{\circ}$ )

\begin{tabular}{cccccc}
\hline $\mathrm{CO}_{2}$ & $\mathrm{CO}_{3} \mathrm{Ca}$ & $\mathrm{CO}_{2}$ & $\mathrm{CO}_{3} \mathrm{Ca}$ & $\mathrm{CO}_{2}$ & $\mathrm{CO}_{3} \mathrm{Ca}$ \\
\hline 0.2 & 0.45 & 04.0 & 0.91 & 13.2 & 29.5 \\
0.4 & 0.91 & 04.5 & 10.2 & 14.2 & 31.8 \\
0.5 & 1.36 & 05.0 & 11.4 & 15.3 & 34.1 \\
0.8 & 1.82 & 06.0 & 13.6 & 16.3 & 36.4 \\
1.0 & 2.27 & 07.0 & 15.9 & 17.4 & 38.6 \\
1.5 & 3.40 & 08.0 & 18.2 & 18.4 & 40.9 \\
2.0 & 4.55 & 09.1 & 20.5 & 19.5 & 43.2 \\
2.5 & 5.70 & 10.1 & 22.7 & 20.5 & 45.5 \\
3.0 & 6.80 & 11.1 & 23.0 & 25.8 & 57.0 \\
3.5 & 7.90 & 12.1 & 27.3 & 31.8 & 68.0 \\
\hline
\end{tabular}

Fonte: Fernandez et al. (1995).

Segundo Fernandez et al. (1995) o carbonato de cálcio $\left(\mathrm{CaCO}_{3}\right)$, em todas as suas formas e a dolomita dolomita $\left(\mathrm{CaMg}\left(\mathrm{CO}_{3}\right)_{2}\right)$, são praticamente insolúveis em água pura; em temperatura ambiente a solubilidade da calcita oscila entre 10 e $15 \mathrm{mg} / \mathrm{l}$. No entanto certos compostos presentes na água alteram consideravelmente estes valores. Conforme Figura 59, a solubilidade do carbonato de cálcio está diretamente relacionada com o $\mathrm{pH}$ da água, cujos valores baixos (ácidos) favorecem a dissolução e para os valores altos (básicos) a solubilidade é muito baixa. 
Figura 59 -Relação entre o $\mathrm{CaCO}_{3}$ e o pH.

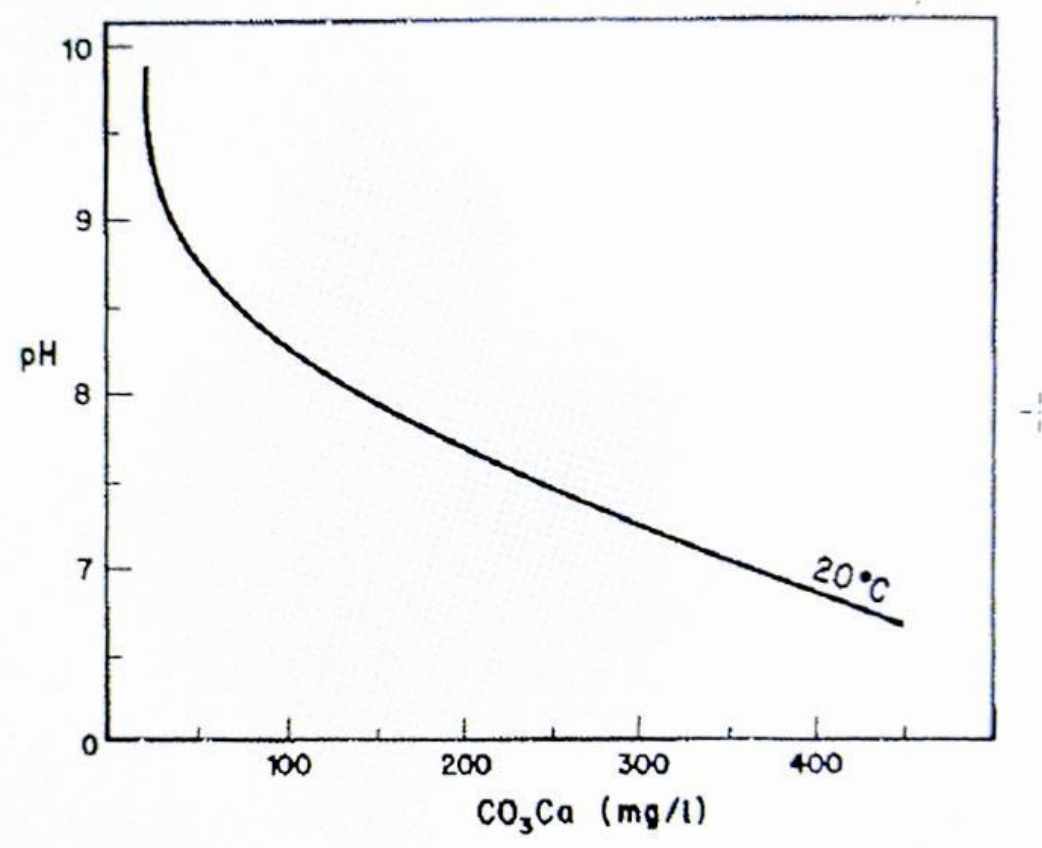

Fonte: Fernandez et al. (1995).

Conforme Lei de Henry aplicada à solução de carbonato: a quantidade total de calcário que pode ser dissolvido no equilíbrio de saturação por unidade de volume de água é, em geral, uma função direta da pressão parcial de dióxido de carbono do ar com a qual a água está em contato e é uma função inversa à temperatura da água devido ao controle desta no equilíbrio da saturação de $\mathrm{CO}_{2}$ dissolvido (JENNINGS, 1971).

Conforme Fernandez et al. (1995), quanto maior a quantidade de dióxido de carbono no ar (ou quanto maior sua pressão parcial), maior quantidade poderá passar do ar para água (Tabela 14). Na atmosfera o conteúdo normal de $\mathrm{CO}_{2}$ é de $0,0033 \%$ (que o mesmo que uma pressão parcial de 0,0003 atmosferas). Não obstante, a decomposição da matéria orgânica desprende grandes quantidades de gás, podendo nas proximidades do solo vegetal, alcançar valores de até $1 \%$ (300 vezes maiores), e o conteúdo de $\mathrm{CO}_{2}$ da água pode chegar a ser muito elevado, fato que também pode ocorrer em fundos de reservatórios.

Ao contrário, a água a maior temperatura pode conter menores quantidades de gás (Tabela 14). Se explica assim a grande agressividade da água nos carstes em montanhas elevadas, onde as águas muito frias alcançam solubilidades de $70 \mathrm{mg} / \mathrm{l}$ de $\mathrm{CaCO} 3$.

Dessa forma, Fernandez et al. (1995) define em quais são as circunstâncias que a água é especialmente agressiva em uma região cárstica: nos ambientes de degelo ou glaciares, devido ao elevado conteúdo de $\mathrm{CO}_{2}$ das águas frias, e em zonas tropicais, onde o solo e a cobertura vegetal aportam dióxido de carbono e outros compostos ácidos à água. 
Tabela 14 - Quantidade de $\mathrm{CO}_{2}$ dissolvido na água (mg/l) em função da pressão parcial de $\mathrm{CO}_{2}$ no ar (atm) para diferentes temperaturas.

\begin{tabular}{ccrrrr}
\hline $\mathrm{pCO}(\mathrm{atm})$ & \multicolumn{1}{c}{$0 \mathrm{OCC}$} & $100 \mathrm{C}$ & $17 \mathrm{OC}$ & $250 \mathrm{C}$ & $300 \mathrm{C}$ \\
\hline 0.0001 & 0.34 & 0.28 & 0.19 & 0.15 & 0.13 \\
0.0003 & 1.01 & 0.70 & 0.56 & 0.45 & 0.39 \\
0.01 & 3.36 & 2.34 & 1.88 & 1.49 & 1.31 \\
0.0025 & 8.40 & 5.85 & 4.70 & 3.73 & 3.28 \\
0.005 & 16.80 & 11.70 & 9.40 & 7.46 & 6.56 \\
0.0075 & 25.20 & 17.60 & 14.10 & 11.20 & 9.80 \\
0.001 & 33.80 & 23.50 & 18.80 & 14.90 & 13.10 \\
0.05 & 168.00 & 117.00 & 94.00 & 74.60 & 65.30 \\
0.10 & 336.00 & 235.00 & 188.00 & 149.00 & 131.00 \\
& & & & &
\end{tabular}

Fonte: Fernandez et al. (1995).

A permeabilidade é outro fator importante na determinação da quantidade de solução de calcário. Frequentemente, o desenvolvimento cárstico é mais dependente da permeabilidade secundária, ao invés da permeabilidade intergranular da rocha (JENNINGS, 1971). Os planos de acamamento e fraturas dentro do calcário expõem uma área de superfície maior para que a solução ocorra. Com o tempo, esses planos de fraqueza aumentam, formando condutos subterrâneos, cavernas e expressões de superfície cárstica (USACE, 1988).

Conforme Abrahão e Cruz (2018), a carstificação, pelo menos em calcários, é um fenômeno cuja velocidade não altera significativamente os maciços, no período de vida útil de uma obra. Assim, a preocupação maior é com os vazios já existentes num maciço, que podem formar uma rede de condutos subterrâneos intercomunicantes capaz de causar perdas d'água extremamente grandes. A obturação desses condutos pode ser muito complicada, exigindo a execução de cortinas profundas de injeção, eventualmente complementadas por paredesdiafragma e tampões de concreto.

Segundo Technos (2005 apud KYLA, 2013) a dissolução da rocha solúvel ocorre a uma taxa de aproximadamente uma polegada por 1000 anos. No entanto, existem muitos fatores contribuintes que podem afetar essa taxa. De maior importância são a temperatura e a pressão parcial do dióxido de carbono.

Milanović (2015) avaliou as condições de mais de 100 barragens construídas em regiões cársticas que apresentaram problemas de infiltração do reservatório, cujas observações são apresentadas na Tabela 15: 
Tabela 15 - Observações em 100 barragens construídas em região cárstica.

\begin{tabular}{cc}
\hline Constatação & $\begin{array}{c}\text { Quantidade de } \\
\text { Barragens }\end{array}$ \\
\hline Barragens construídas e reservatórios abandonados & 10 \\
Infiltrações muito altas $(2->50 \mathrm{~m} 3 / \mathrm{s})$ & 30 \\
Infiltrações altas e muito problemáticas & 13 \\
Barragens e reservatórios em rochas solúveis (evaporitos) & 38 \\
Grandes cavernas abaixo da fundação & 9 \\
Carstificação hipogênica e características do local da barragem & 7 \\
Tratamentos contra infiltração malsucedidos ou parcialmente bem- & 11 \\
sucedidos & 13 \\
Projetos congelados & 29 \\
Trabalhos bem-sucedidos de contra infiltrações & 27 \\
Infiltrações moderadas e aceitáveis & 9 \\
\hline
\end{tabular}

Fonte: Milanović (2015).

Segundo Abrahão e Cruz (2018), é muito difícil, durante as investigações, constatar com segurança a extensão e a geometria das dissoluções, sendo frequentes os casos em que a carstificação revelou-se maior do que o previsto. Como exemplo, cita-se o caso da Barragem Hales Bar (EUA), abandonada devido às infiltrações de mais de $50 \mathrm{~m} 3 / \mathrm{s}$, e o da Barragem de Keban (Turquia), que requereu mais de $570.000 \mathrm{~m}^{2}$ de cortinas de injeção e $50.000 \mathrm{~m}^{2}$ de diafragmas de concreto. Evidentemente, rochas de dissolução mais rápida, como alguns tipos particulares de calcário e, principalmente, rochas a base de sulfato de cálcio e outros evaporitos, podem constituir problemas bem mais importantes.

Os resultados de pesquisa complexa e posicionamento 3D de conduítes cársticos permitem o desenvolvimento de técnicas e soluções para a reabilitação permanente de infiltrações por tamponamento e injeção das cavidades e canais principais (MILANOVIĆ; VASIĆ 2014). A remediação bem-sucedida, portanto, requer sérias e abrangentes investigações, incluindo longo período monitoramento dos regimes de água subterrânea e (em muitos casos) obras corretivas durante a vida útil da estrutura, sendo que durante a construção, modificações e adaptações das estruturas são muito comuns. 


\subsubsection{Carbonatação e Colmatação de Drenos de Fundação}

Drenos são comuns em barragens e suas fundações, bem como para estruturas associadas e suas fundações. Em geral, todos os drenos cumprem o mesmo propósito - reduzem as pressões de infiltração dentro de uma estrutura ou fundação e melhoram a estabilidade da estrutura ou fundação. Existe uma variedade de tipos e configurações de drenagem. Fatores que influenciam o tipo e configuração dos drenos são o tipo de estrutura ou fundação, a localização esperada de águas subterrâneas e volume de fluxos de drenagem, facilidade de construção e acessibilidade. (FIEDLER et al., 2004).

Os drenos de fundação, tipicamente perfurados em um padrão fixo de espaçamento de furos e profundidade referido como cortina de drenagem, são usados para coletar infiltração que passam pelas fundações rochosas, sendo geralmente perfurados a partir de galerias dentro da barragem, pé da barragem, ou galerias escavadas na rocha. Como regra geral, uma cortina de drenagem de fundação está localizada a jusante da cortina de injeção e consiste em uma ou mais linhas de furos paralelos ao eixo da barragem. O diâmetro, o espaçamento e a profundidade dos drenos podem ser ajustados com base em um conhecimento prévio das descontinuidades de fundação e dos caminhos e quantidades de infiltração esperados. (FIEDLER et al., 2004).

Conforme Smith (2006), há uma série de mecanismos importantes na obstrução de drenos, incluindo obstrução físico-química e biológica. A água subterrânea, que possui teor relativamente alto de sólidos dissolvidos, pode contribuir para a obstrução devido à deposição de sais e à subsequente cimentação de meios granulares ao redor de telas, perfurações em tubos de drenagem e em geotêxtis.

A cimentação identificada pelo Bureau of Reclamation (1995) inclui carbonatos de ferro e cálcio, acúmulos de hidróxidos de ferro e manganês, e produtos de decomposição de leitos de lignita. Algumas deposições de carbonato são causadas pela liberação de dióxido de carbono à medida que a pressão diminui através do dreno ou paredes do furo (U.S. Army Corps of Engineers, 1992), em infiltrações e fissuras (FIEDLER et al., 2004) ou devido à oxidação de metano como muitas vezes ocorre em poços e túneis.

No estudo realizado pelo Electric Power Research Institute (1992), foram apresentados os resultados dos estudos de métodos de obstrução e limpeza de drenos, concluindo que a deposição de carbonato foi a forma dominante de colmatação, tendo por base os registros de 17 barragens, e que a pressão desempenhou um papel na formação de depósitos de carbonato de cálcio. 
Ruggeri (2004), afirma que o carbonato de cálcio é depositado em drenos de fundação através de uma reação química de três etapas. O carbonato de cálcio é dissolvido de uma fonte, transportado em solução, e depois redepositado nos drenos. O processo de dissolução começa quando a água absorve dióxido de carbono. O dióxido de carbono pode ser absorvido diretamente do ar, ou pode ser captado por águas subterrâneas. A alta pressão da água no fundo do reservatório pode fazer com que o gás dióxido de carbono dissolvido se combine com a água para formar ácido carbônico (esta reação é sensível à pressão). À medida que mais ácido carbônico se forma, o pH da solução diminui (ou seja, a acidez aumenta). Uma solução com um $\mathrm{pH}$ inferior a 8,2 pode dissolver carbonato de cálcio (de concreto da barragem, cortina de injeção e rocha de fundação) formando bicarbonato de cálcio. O bicarbonato de cálcio é então transportado em solução à medida que a água flui para a fundação. Mas o bicarbonato de cálcio é instável e se a pressão da água diminuir (o que ocorre quando a água flui para os drenos), isso faz com que a reação se reverta e o carbonato de cálcio dissolvido seja depositado nos drenos.

Conforme Ryan, Morris e Meisenheimer (1991), relata que as inspeções dos drenos com câmeras mostraram que os drenos eram muitas vezes livres de depósitos em profundidade. Ou seja, os depósitos de carbonato de cálcio pareciam estar confinados à parte superior (alguns metros) dos drenos, quando a pressão da água é mais baixa.

A taxa e a magnitude da diminuição da pressão afetam a densidade dos depósitos e a quantidade do precipitado que se forma. O tempo que um dreno leva para bloquear depende de um grande número de parâmetros: minerais solúveis em fundação e concreto, vazão, pH, etc. A dureza de um depósito pode variar, de um pouco macia a tão dura que a remoção só pode ser realizada por perfuração. Depósitos macios geralmente endurecem com o tempo. O caráter de um depósito muitas vezes muda com a localização. Os drenos podem ser severamente bloqueados em uma parte da barragem e completamente livres de depósitos em outra. Um único dreno pode ter depósitos que variam de macio a duro em todo ou em parte de seu comprimento (RUGGERI, 2004).

\subsubsection{Instrumentação x Colmatação de Drenos}

Fiedler et al. (2004) descrevem que a instrumentação é extremamente útil para detecção de problemas com a drenagem da fundação e que cada observação se relaciona diretamente com parâmetros de segurança de barragens (potenciais riscos geotécnicos), conforme a seguir:

- Pressão hidrostática e elevação (alterações que indicam potencial mau funcionamento do sistema de drenagem) 
- Níveis de água em piezômetros e na cortina de drenagem (relacionados à pressão hidrostática e obstrução);

- Vazões de drenagem (indica obstrução, especialmente se avaliadas em conjunto com as subpressões);

- Fluxos de infiltração;

- Profundidade dos drenos (obstrução);

- Observações visuais (documentadas com fotos e vídeos) que podem ser analisadas para obter informações sobre tipo de obstrução e seu progresso.

No Brasil, Silveira, Mantese e Melegari (2017) apresentam os resultados da operação de limpeza dos drenos de fundação das Barragens em Concreto Compactado a Rolo - CCR das UHE's Castro Alves e Monte Claro (Figura 60), localizadas no Estado do Rio Grande do Sul, juntamente com sua influência na instrumentação da barragem. O maciço rochoso de fundação de ambas barragens é constituído por derrames basálticos da Formação Serra Geral, de baixa deformabilidade.

Figura 60 - Vista aérea das Barragens de Monte Claro e Castro Alves.

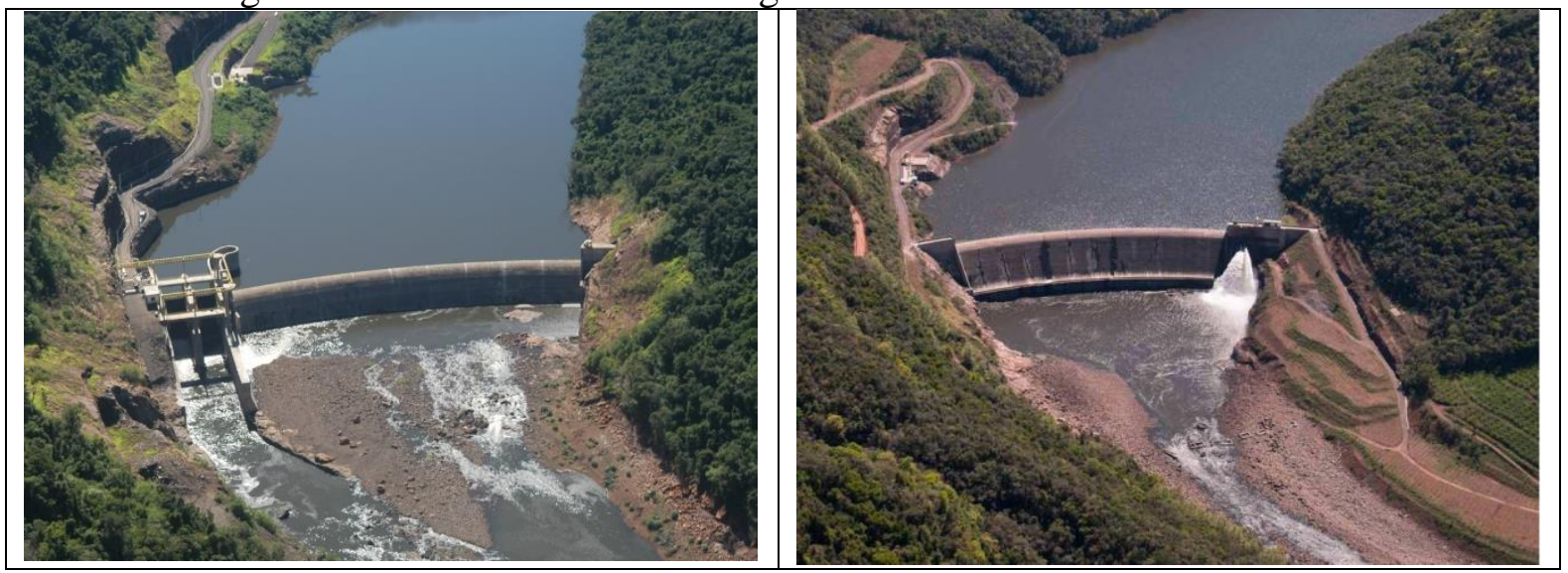

Fonte: Silveira, Mantese e Melegari (2017).

Os níveis piezométricos da barragem gravidade encontravam-se estabilizados e geralmente abaixo dos valores de controle, assegurando, portanto, boas condições de estabilidade. Entretanto, constatou-se que havia obstrução considerável, chegando a $69 \%$ do comprimento dos drenos na UHE Monte Claro, conforme Figura 61 e Figura 62. 
Figura 61 - Profundidade dos drenos da UHE Monte Claro - Antes da limpeza.

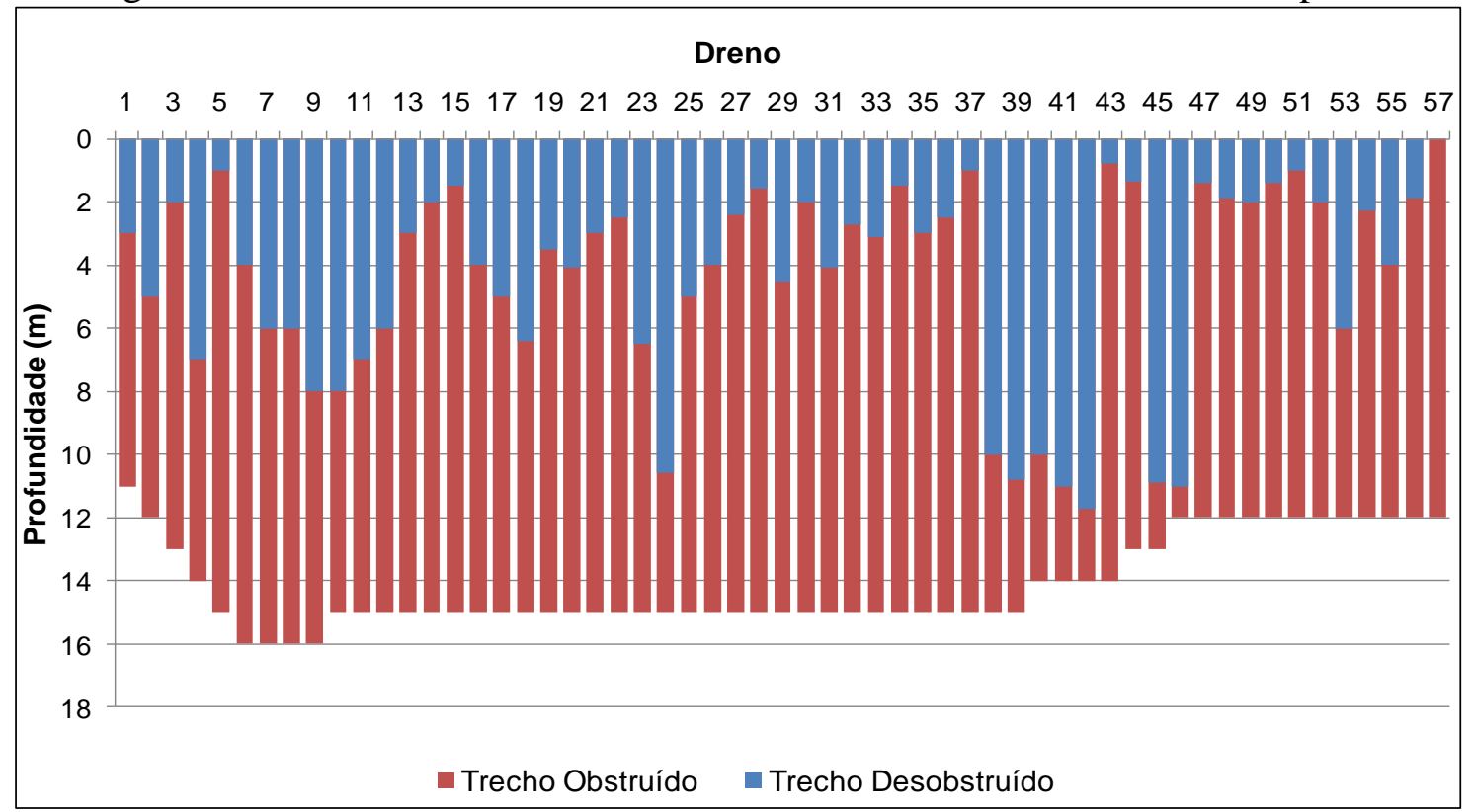

Fonte: Silveira, Mantese e Melegari (2017).

Figura 62 - Porcentagem das etapas de limpeza.

UHE Castro Alves

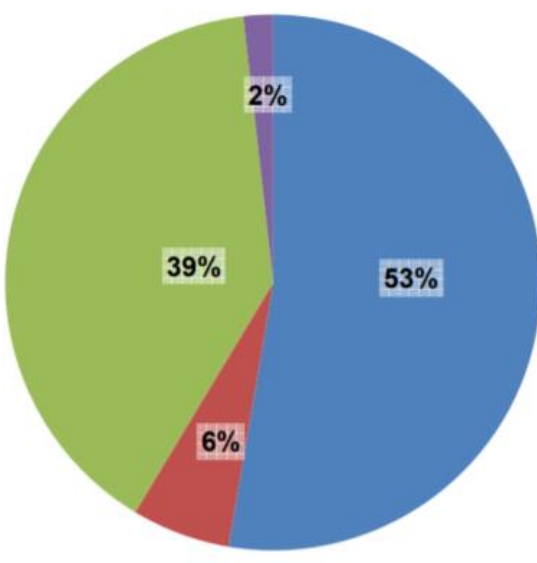

=Antes da Limpeza - 1210 m - $53 \%$

=Desobstruído c/ Jato de Água - 140 m - 6 \%

$=$ Reperfurado - $915 \mathrm{~m}-39 \%$

= Obstruído - 41 m - 2 \%

\section{UHE Monte Claro}

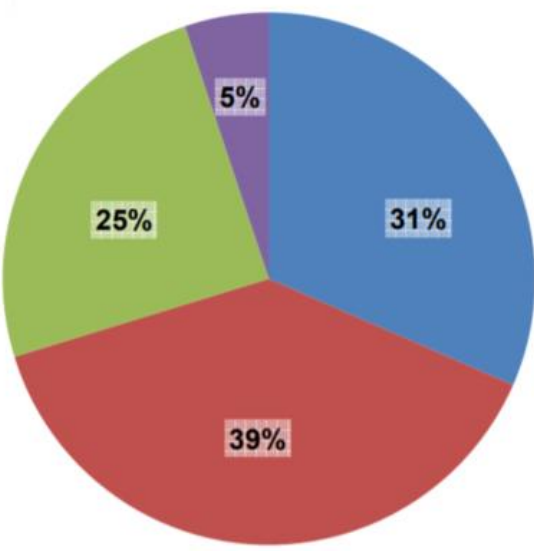

- Antes da Limpeza - 254 m - $31 \%$

=Desobstruído c/ Jato de Água - 312 m - 39 \%

$=$ Reperfurado - 198 m - $25 \%$

- Obstruído - 41 m - 5 \%

Fonte: Adaptado de Silveira, Mantese e Melegari (2017).

Conforme Silveira, Mantese e Melegari (2017), foi observada redução da subpressão na maioria dos piezômetros após a limpeza e reperfuração dos drenos, com reduções de 3,20 m na UHE Monte Claro, e algum aumento de vazão, chegando a 121\% (2,2 vezes) na UHE Castro Alves, porém em ambas, as vazões específicas ficaram abaixo de $21 / \mathrm{min} / \mathrm{m}$, considerado um valor adequado. 
Destaca-se que as vazões de drenagem através da fundação das barragens devem sempre ser analisadas em associação aos níveis piezométricos na região, visto que uma redução de vazão, conjuntamente à elevação das subpressões na área, indicaria uma tendência de perda de eficiência do sistema de drenagem das fundações (SILVEIRA, 2003).

\section{4 ÁREA DE ESTUDO - CARACTERIZAÇÃO GEOLÓGICO-GEOTÉCNICA DO MACIÇO ROCHOSO DE FUNDAÇÃO}

A Barragem Principal da PCH Mata Velha é constituída por uma estrutura de concreto, em CCR - Concreto Compactado a Rolo, com 37 m de altura máxima e 183,60 m de comprimento, seguida de uma barragem de enrocamento com núcleo argiloso, com $44 \mathrm{~m}$ de altura máxima e cerca de 101,70 m de comprimento, fechando o barramento junto à ombreira esquerda, conforme Figura 63. A fundação das estruturas é constituída predominantemente por metaritmitos, neste caso uma alternância de camadas de metacalcário e de metassiltito, que se intercalam com intensa e complexa estruturação geológica.

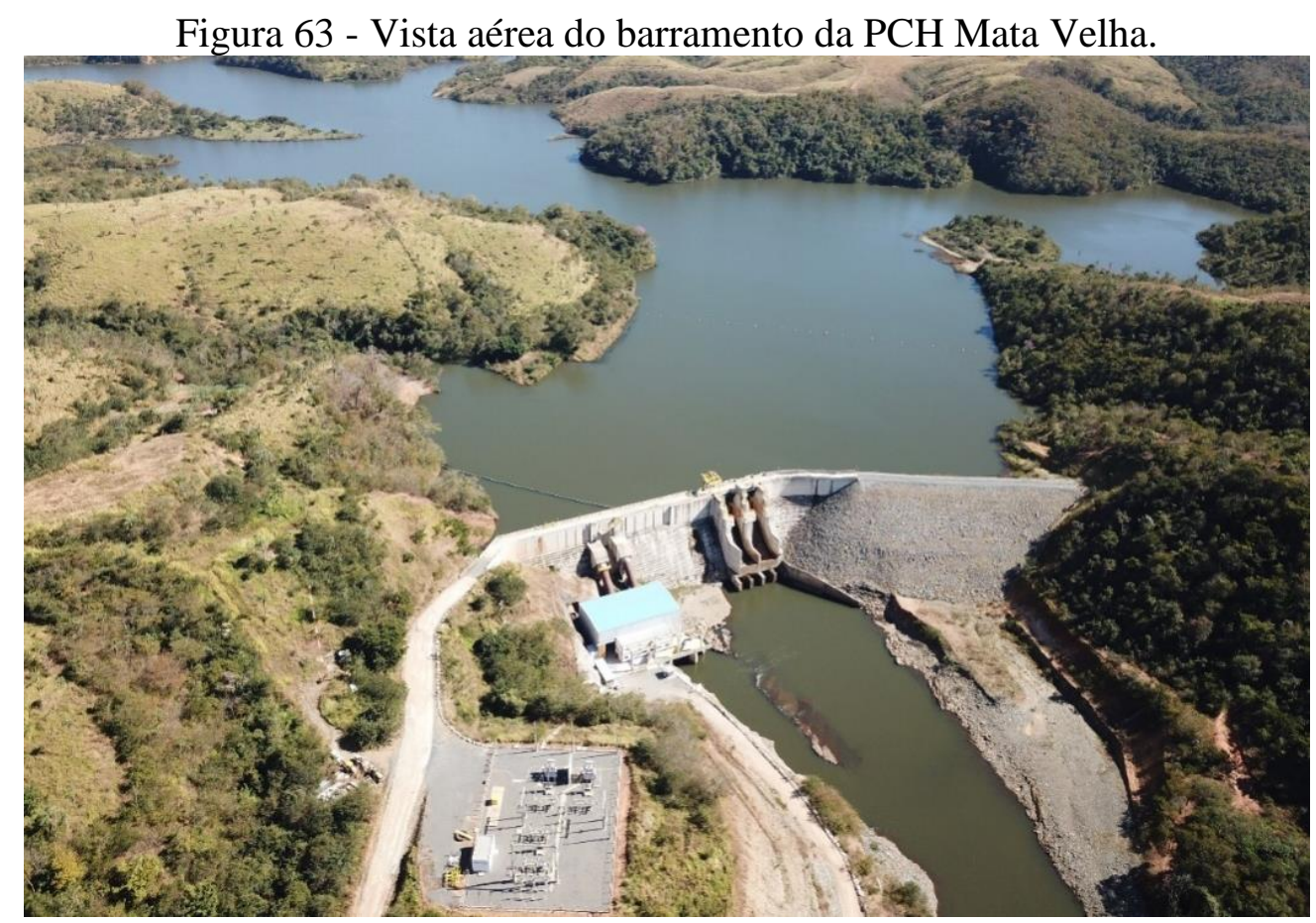

Fonte: do Autor (2020).

Incialmente previu-se a que todo o barramento seria executado em CCR, entretanto, após as investigações iniciais, em função da heterogeneidade do maciço rochoso definidas pelas intercalações de metassiltitos com metacalcários, da alta permeabilidade da fundação e devido 
às profundidades a serem escavadas e volumes de bota fora, foi realizada a alteração de trecho da Barragem de CCR para Barragem de Enrocamento com núcleo argiloso, na margem esquerda.

\subsection{GEOLOGIA REGIONAL}

O mapa geológico do estado de Minas Gerais mostra que a área do aproveitamento encontra-se na borda ocidental do Craton São Francisco, na área de influência da faixa de dobramento Brasília, no contexto geológico do Grupo Bambuí, Subgrupo Paraopeba (indiviso) de idade neoproterozóica (Figura 64).

Figura 64 - Porção do Mapa geológico de Minas Gerais e estratigrafia da região da PCH na escala 1:1.000.000.

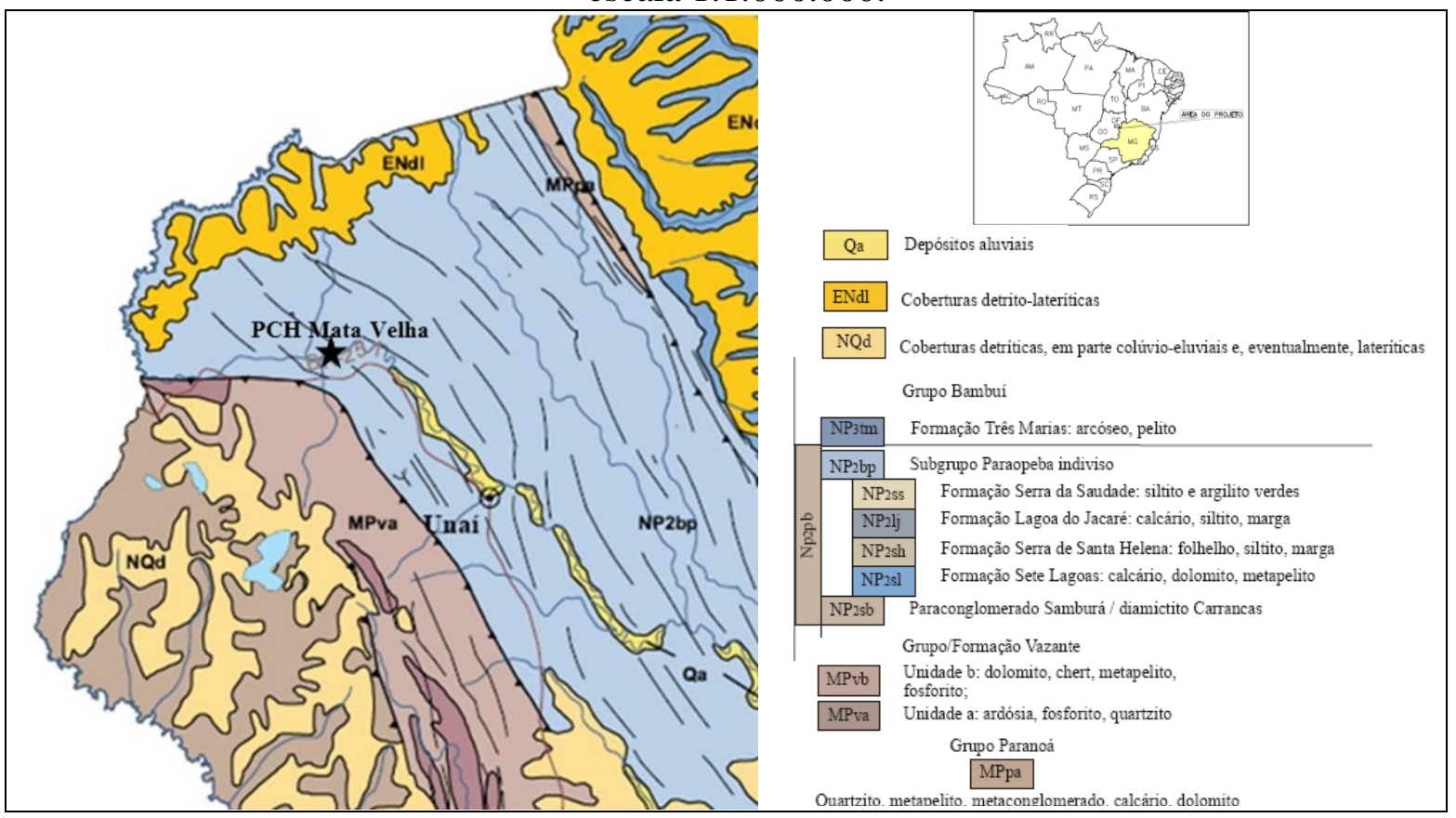

Fonte: Adaptado de COMIG (2003).

Entretanto, os mapeamentos geológicos de detalhamento desenvolvidos na região de Unaí, colocam as rochas da área da PCH Mata Velha no contexto da porção superior do Grupo Paranoá, que faz parte da estratigrafia da bacia Uruaçu de idade Meso-Proterozóica.

Conforme Laranjeira (1992) nas imediações da cidade de Unaí, ocorre uma sucessão de rochas de origem sedimentar, que foi dividida em 7 unidades litoestratigráficas (I a VII). Tais unidades sofreram deformação, acompanhada de aquecimento a temperaturas anquimetamórficas, durante o Ciclo Brasiliano (Proterozóico Superior). 
Conforme Laranjeira (1992) todas as unidades foram deformadas por esforço compressivo de direção NE, responsável por dobramentos em escala mega a mesoscópica, associados a falhamentos e fraturamentos.

As observações de campo no mapeamento da área, realizados na fase do Projeto Básico Consolidado - PBC, mostram uma concordância com os trabalhos que situam as rochas locais no contexto do Grupo Paranoá.

\subsection{GEOLOGIA DA ÁREA DO APROVEITAMENTO}

O mapeamento da área do aproveitamento, conforme documentos do Projeto Básico Consolidado - PBC revelou a ocorrência de litologias correspondentes às rochas do Grupo Paranoá, que são descritos nos trabalhos de abrangência regional. Durante os levantamentos foram encontradas rochas de grau metamórfico incipiente, classificados como meta siltitos e meta calcários

No início das investigações de campo já foi possível observar na região da calha do rio metacalcários e metassiltitos intercalados, conforme Figura 65.

Figura 65 - Aspecto da rocha com intercalação de meta siltito e calcário no leito do rio de afloramento situado a jusante do eixo.

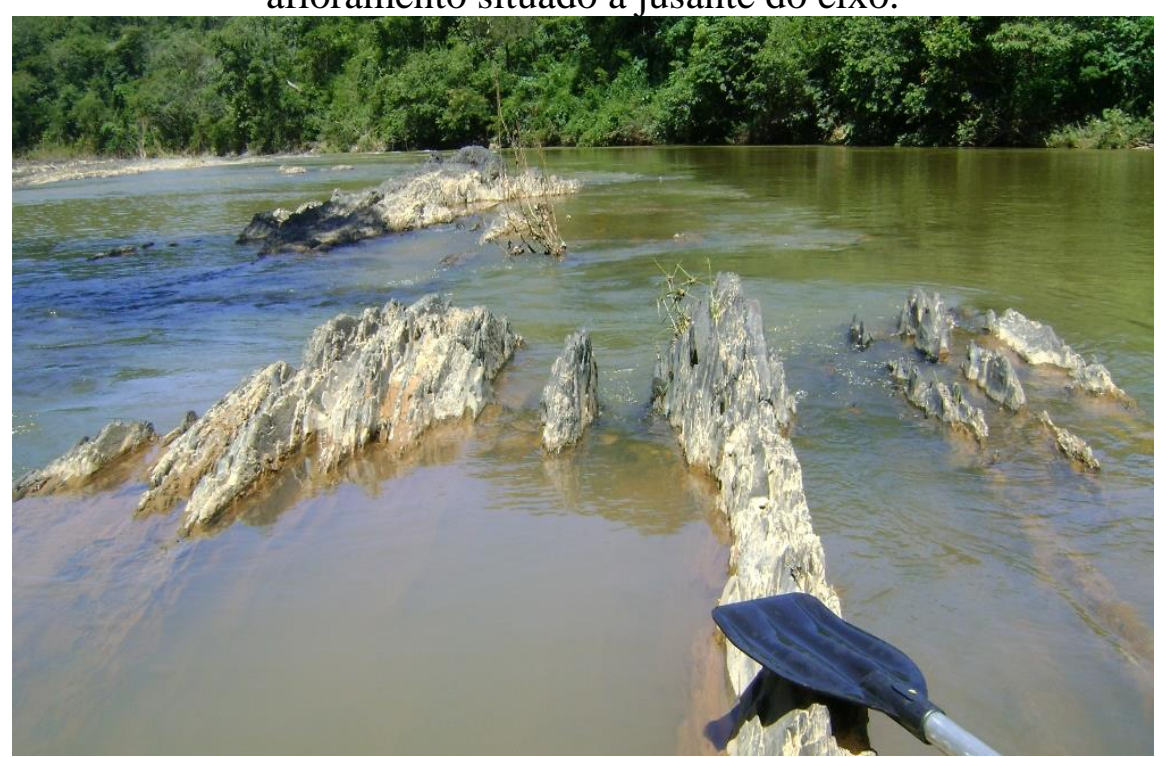

Fonte: Mata Velha Energética S.A. (2016).

Em praticamente todos os afloramentos nas calhas das drenagens, essas rochas apresentaram uma intercalação de camadas centimétricas a métricas, com direção NW-SE e 
mergulhos sub-verticais tanto para SW como para NE (Figura 66). Essa estruturação é encontrada a nível regional e reflete os esforços tectônicos compressivos com direção NE relatados na bibliografia regional.

Em testes realizados, as rochas calcárias apresentaram forte reação com solução de ácido clorídrico a $20 \%$, indicando a presença de calcita. Os metassiltitos, que não reagem com a solução ácida, apresentavam algumas vezes, veios e fraturas preenchidos por calcita branca que reagiram com esta solução.

A partir das investigações realizadas foram elaboradas as seções geológico-geotécnicas da barragem, conforme Figura 67 a Figura 69. Destaca-se que estas seções já constam a indicação do apoio das estruturas de concreto, tendo em vista as escavações/limpeza da fundação, as quais serão descritas adiante. 

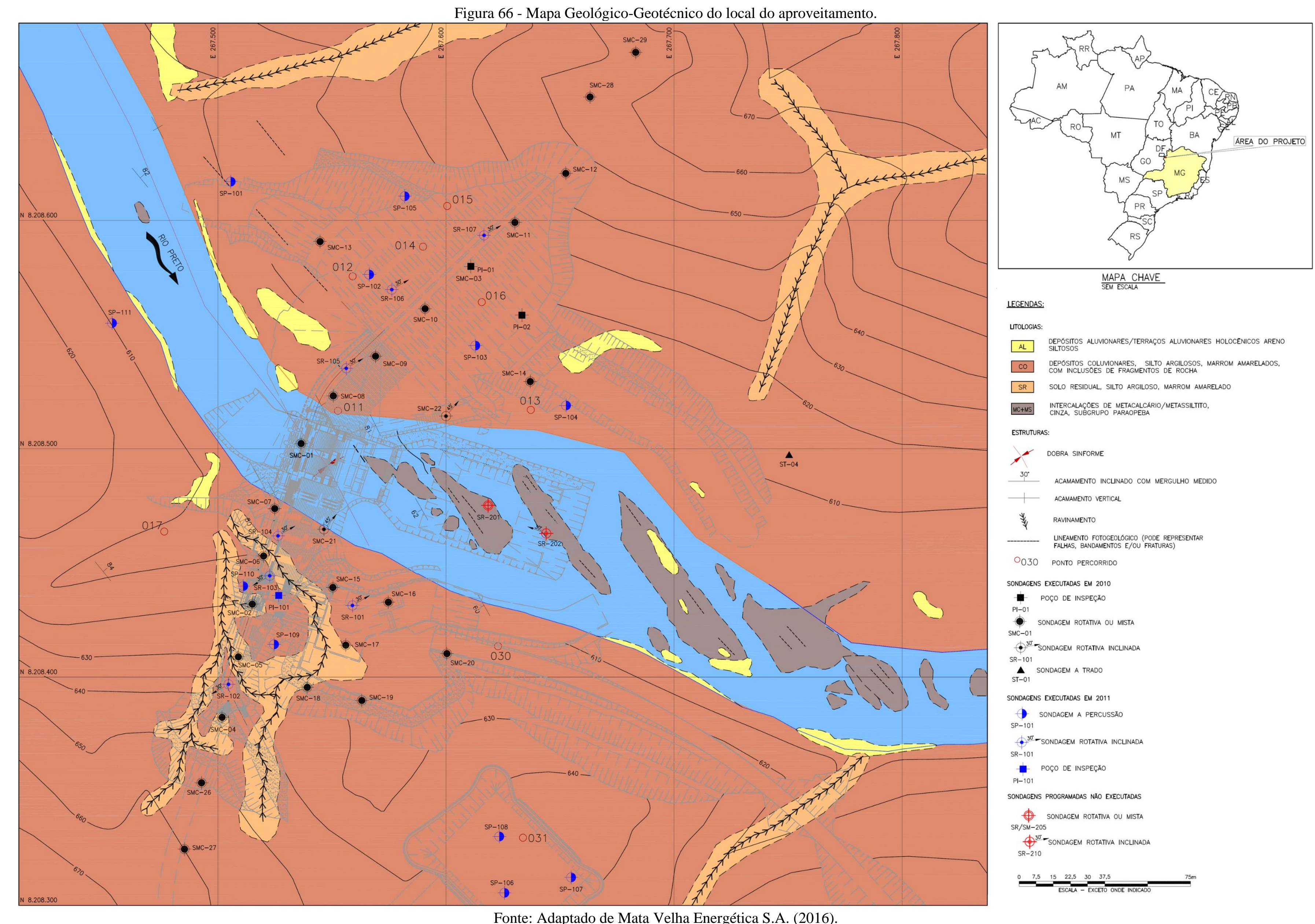

LEGENDAS:

urolocons:

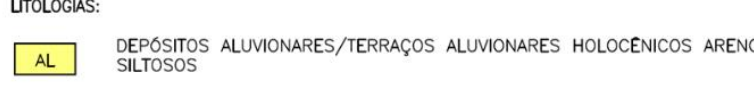

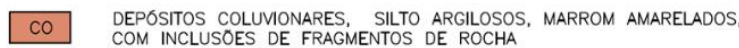

SR SOLO RESIOUAL, SLLTO ARGLLOSO, MARrom AMARELADO

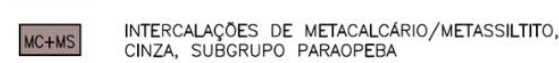

Estrutureas

DOBRA SIIFFRME

30. ACAMMEENTO INCUNADO COM MERGULHO MEODO

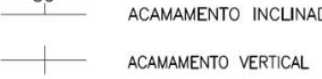

* RANNAMENTO

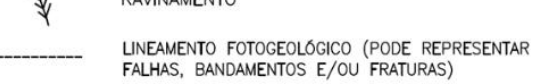

OO30 PONTO PERCORRDO

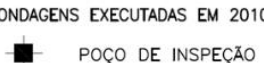

PI- PI POCOO DE INSEEGAO

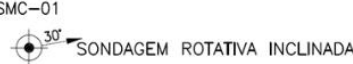

SR-101 SONDGEEM ROATINA IN

SONOAGENS EXECUTADS EM 2011

$\underset{\text { SP-101 }}{\text { SONDACEM A PERCUSSRO }}$

$\underset{\text { SR-101 }}{30}$ - SONDAGEM ROTATNA INCLNADA

- poģo de InSEEgá

SONDAGENS PROGRAMAOAS NAO EXECUTAAS

1. SONAGEEM ROTATINA OU MISTA

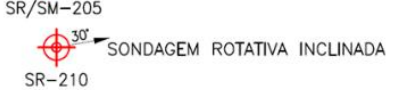




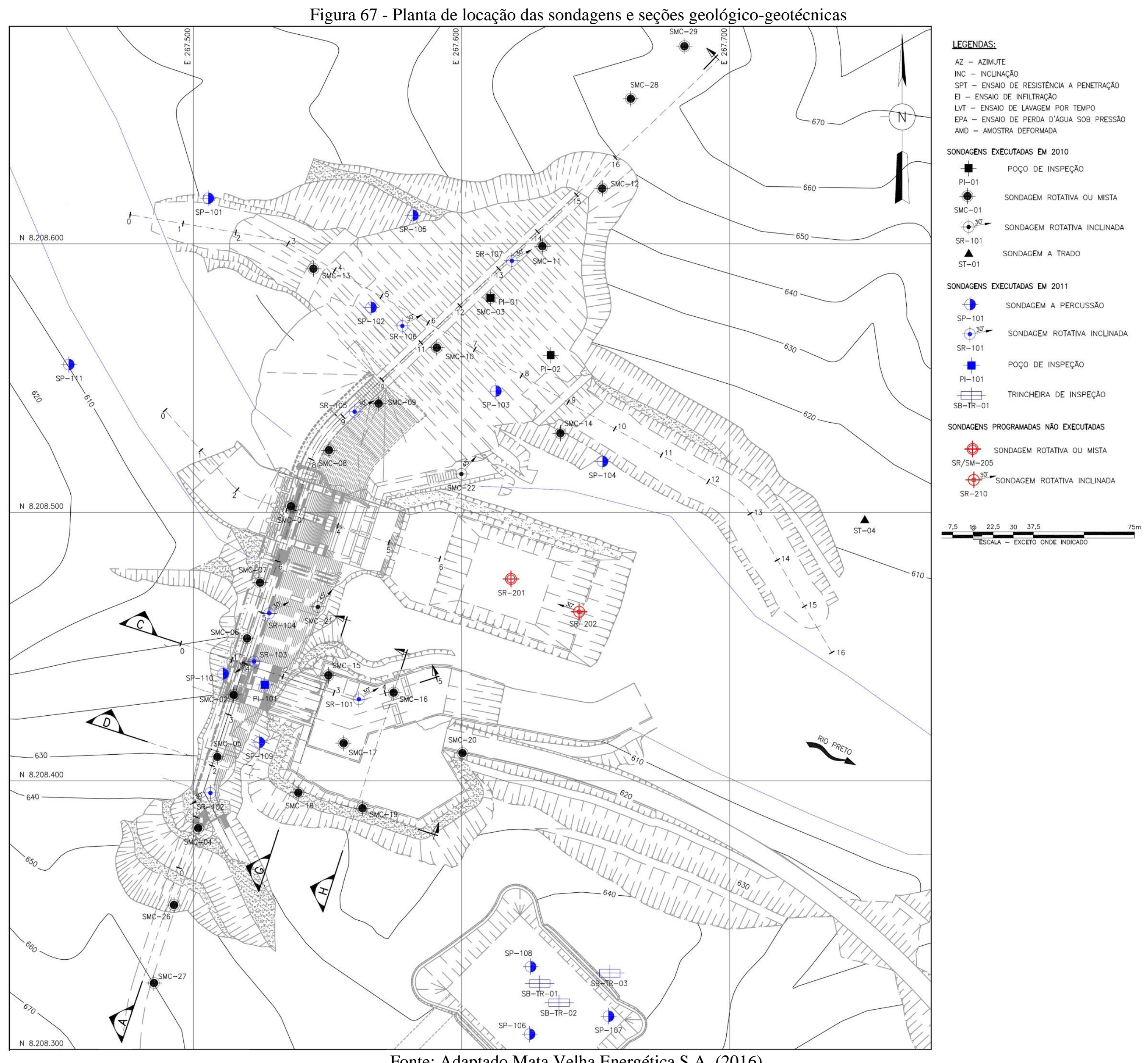

Fonte: Adaptado Mata Velha Energética S.A. (2016). 

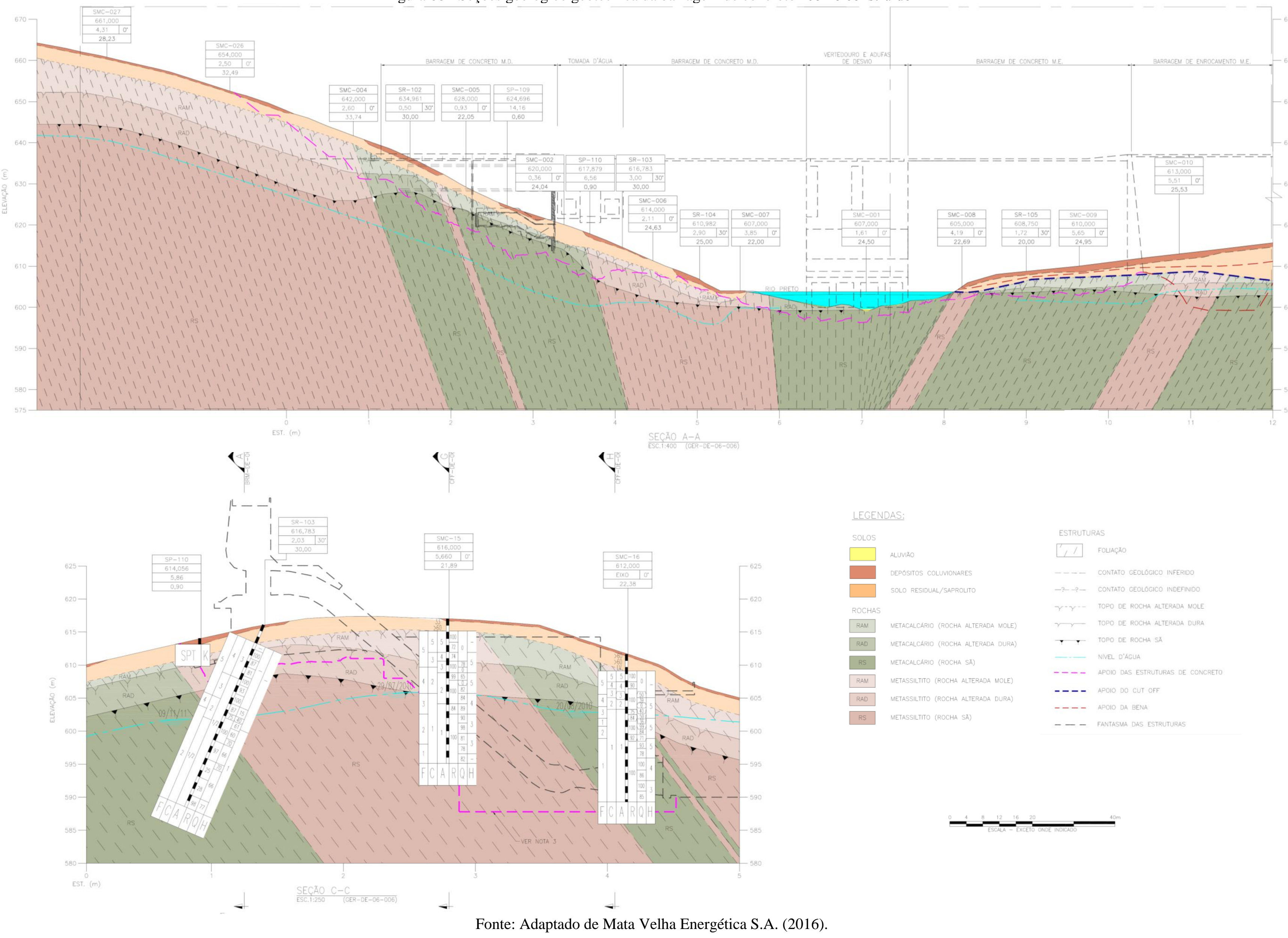


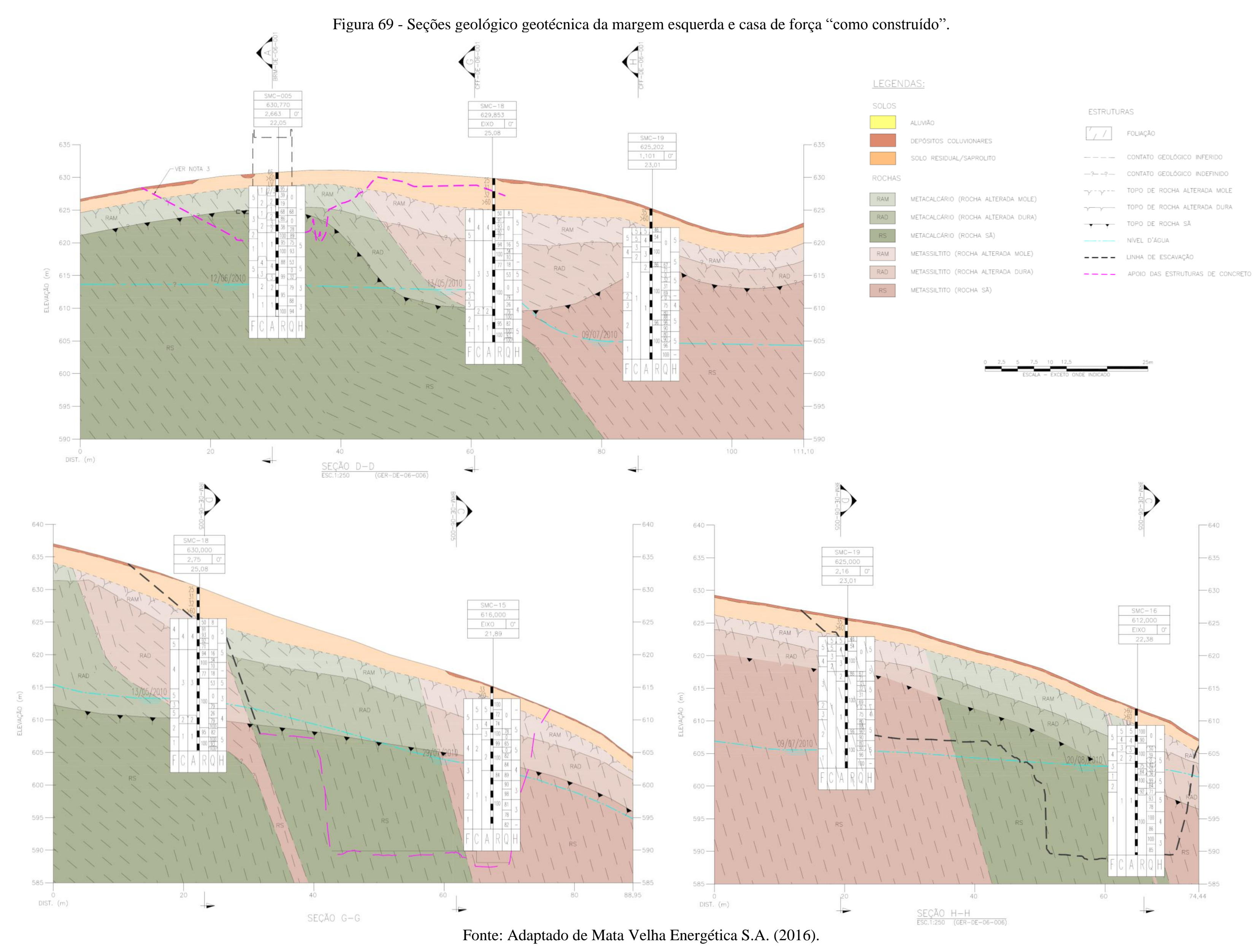


Os testemunhos de sondagens apresentaram um maciço com muitos trechos fraturados e graus de alteração e coerência que melhoram em profundidade, tudo isso devido ao contato frequente entre os metassiltitos e metacalcários. Na Figura 70, apresenta-se a título de ilustração os testemunhos da sondagem rotativa SR-103, na região da Tomada d'Água, conforme locação das Figuras Figura 67 a Figura 69 (Seção C-C), tendo atravessado camadas de metasiltito e metacalcário.

Figura 70 - Sondagem rotativa SR-103 na seção da Tomada d'Água, com indicação da numeração das caixas (1 a 8) e divisões geológicas/geotécnicas (A a D) obtidas do log de sondagem.

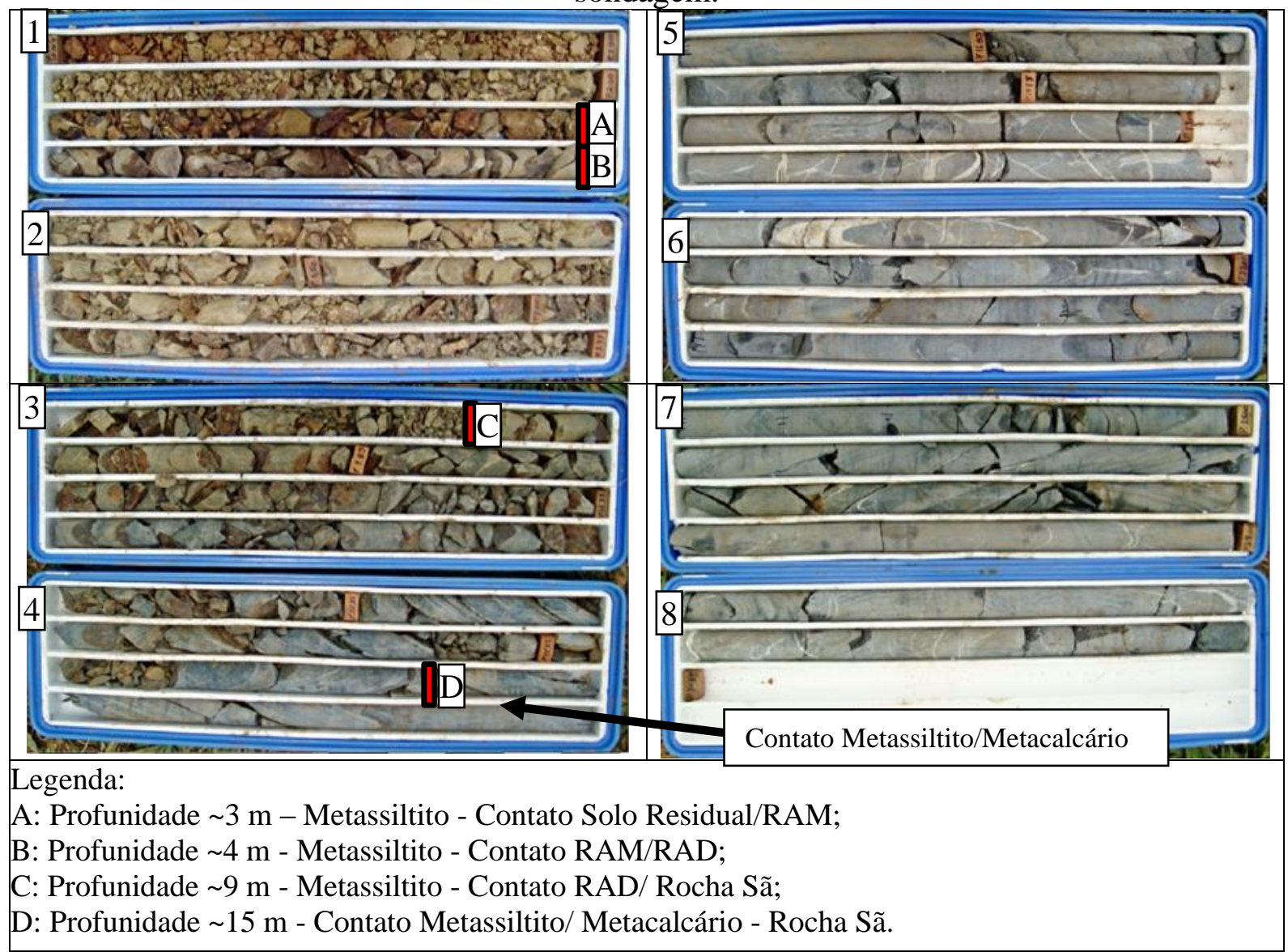

Fonte: Adaptado de Geosistema Geologia e Sondagens (2012).

\subsection{MACIÇO ROCHOSO ESCAVADO}

O maciço rochoso de fundação das estruturas de concreto da barragem e dos taludes de escavação é constituído predominantemente por metaritmitos, neste caso uma alternância de camadas de metacalcário e de metassiltitos, que se intercalam com intensa e complexa estruturação geológica, caracterizada pela presença de sucessivos dobramentos e falhamentos tectônicos, que tem grande influência na estanqueidade do barramento. Para elaboração desse 
item foram levadas em consideração as observações que constam nos relatórios do período de obra, conforme Mata Velha Energética S.A. (2016).

O maciço apresenta-se de maneira heterogênea, com a segregação de materiais de diferentes comportamentos geomecânicos, sendo o horizonte superior caracterizado pela presença de rochas alteradas e brandas (moles) (RAM - Rocha Alterada Mole) e o trecho subjacente, caracterizado por Rocha Alterada Dura (RAD) e rocha Sã.

Em geral, os trechos de RAM - Rocha Alterado Mole são constituídos pelos metassiltitos classificados com resistência R2 da ISRM - International Society for Rock Mechanics (1981), intervalo estimado de resistência entre 5 a $25 \mathrm{MPa}$, medianamente decompostos a decompostos (A3-A4) e medianamente fraturados a muito fraturados (F3-F4). Já o horizonte de RAD - Rocha Alterada Dura, mostra maior grau de competência e índice de resistência R3, 25 a $50 \mathrm{MPa}$ ou superior, sendo caracterizado por rocha pouco decomposta a sã (A2-A1), e pouco a medianamente fraturada (F2-F3).

A estruturação geral das camadas é representada pelos planos do acamamento sedimentar/xistosidade, exibindo direção em torno de NNW, com caimentos médios a acentuados $\left(>60^{\circ}\right)$ para o quadrante NE, preferencial, e SW, nos flancos invertidos dos dobramentos.

Além dos planos de foliação, o maciço contém várias famílias de descontinuidades, destacam-se entre estas, as juntas de alívio de tensões sub-horizontais. Foram identificadas nos mapeamentos a presença de juntas de alívio sub-horizontais, representadas por planos abertos com contato rocha até planos cisalhados. Vale destacar que, entre as famílias de descontinuidades presentes no maciço rochoso, as juntas sub-horizontais são as que têm potencial influência na estabilidade das estruturas.

No horizonte de rocha alterada dura e de rocha sã, as juntas apresentam-se descontínuas a contínuas e anastomosadas, com caimentos em geral sub-horizontais a suavemente inclinados, mas com persistência de vários metros. A principal área de ocorrência das juntas de alívio encontra-se na região do Bloco 5, onde as juntas de alívio exibem atitudes em torno de $\mathrm{N} 50^{\circ} \mathrm{E} / 05^{\circ} \mathrm{SE}$.

As juntas de alívio quando associadas ao cisalhamento, apresentam em termos gerais espessuras da ordem de 10 a 15 centímetros. Tais juntas de alívio são predominantemente de contato rocha/rocha, com paredes sãs a alteradas, e raramente com preenchimento/filmes de partículas arenosas ou areno-siltosas. Têm inclinações da ordem de $5^{\circ}$ a $7^{\circ}$ em média, e por 
suas características anastomosadas, podem ocorrer caindo ora para montante, ora para jusante, assim como no sentido do leito do rio ou para o interior das encostas.

Cerca de $90 \%$ da estrutura foi assentadada em rocha alterada dura (RAD), com apenas os $10 \%$ de jusante apoiados em rocha alterada mole (RAM).

A partir do modelo geológico do maciço de fundação das principais estruturas (MATA VELHA ENERGÉTICA S.A., 2016), considerando de forma esquemática e simplificada o acamamento e as principais descontinuidades presentes, apresentou algumas seções considerando a presença de descontinuidade na fundação, tendo por base extrapolações a partir das estruturas geológicas observadas em campo, em especial quanto à continuidade das estruturas geológicas.

Foram consideradas descontinuidades/juntas de atitude sub-horizontal, com mergulho para jusante e atitude média $160^{\circ} / 07^{\circ}$ (Figura 71), constituídas desde rocha sã a rocha pouco alterada até cisalhada/fragmentada.

Figura 71 - Diagrama de contorno dos pontos polares dos planos das estruturas presentes nas superfícies escavadas. Ao lado as concentrações das isolinhas. A seta indica a atitude média das juntas de alívio.

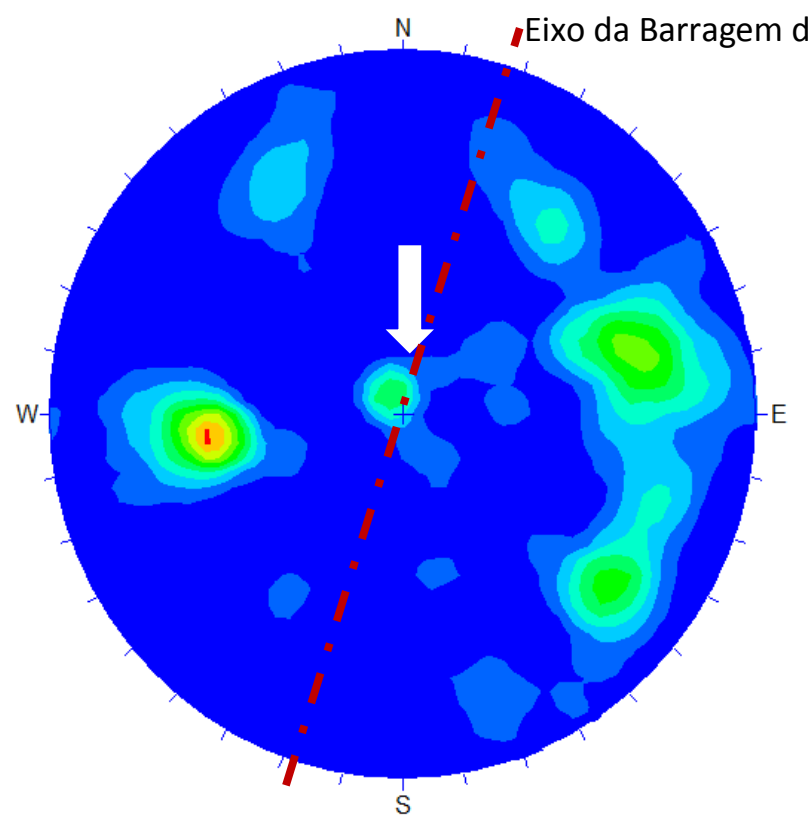

Fonte: adaptado de Mata Velha Energética S.A. (2016). 
Figura 72 - Localização das seções em que foram extrapoladas as juntas de alívio na fundação das estruturas de concreto

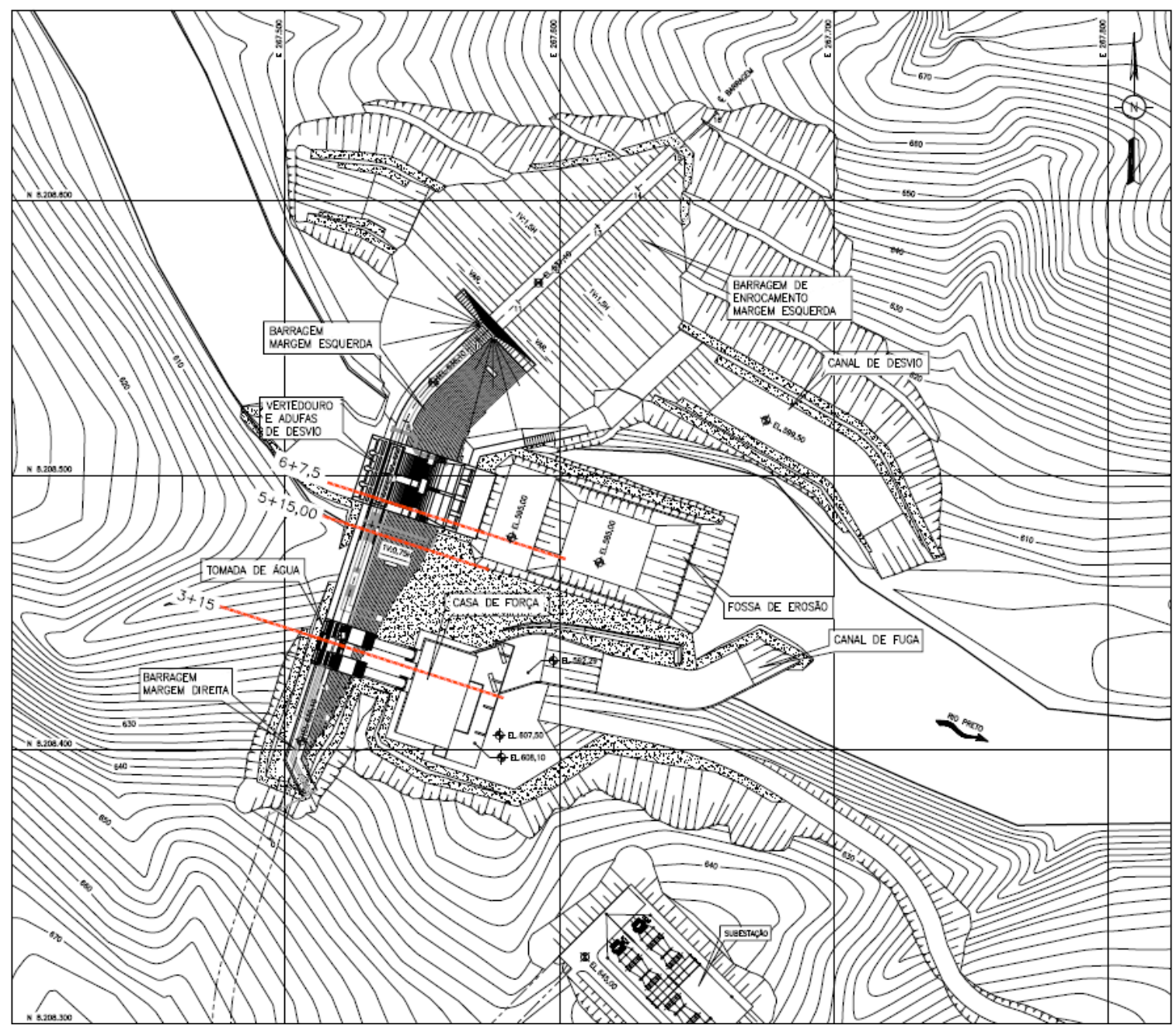

Fonte: Mata Velha Energética S.A. (2016).

\subsubsection{Tomada de Água - Margem Direita (Estaca 3+15,00)}

O modelo geológico foi extrapolado adotando juntas de alívio planares e contínuas que não foram identificadas na superfície de apoio da Tomada de Água. As juntas foram notadas pela letra "J" e numeradas de 1 a 7 , com numeração crescente da cota mais baixa para a cota mais alta.

Na Figura 73 a seguir, é apresentado o modelo geológico-geotécnico para a região da Tomada de Água e Casa de Força e na Figura 74 são apresentadas fotografias representativas das condições geológico-geotécnicas no trecho avaliado. 
Figura 73 - Seção modelo estaca 3+15,00 m

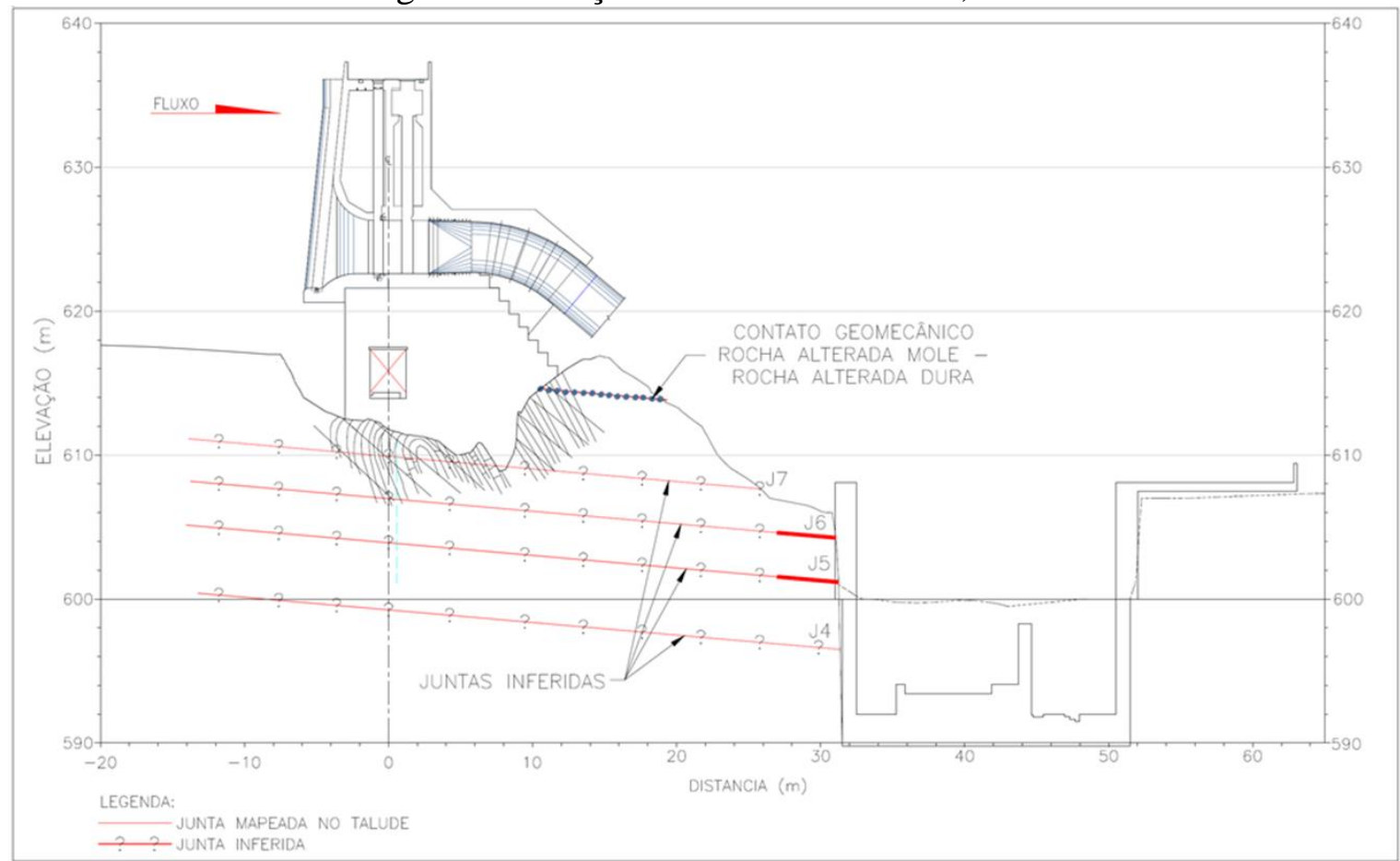

Fonte: Mata velha Energética S.A. (2016).

Figura 74 - Escavação na região da Tomada de Água (T.A.) e Casa de Força (C.F.): a) T.A. Vista geral; b) T.A. - Mergulho para jusante e juntas fechadas; C.F. - Juntas com mergulho para jusante; d) C.F. - Detalhe de Zona Cisalhada a montante.

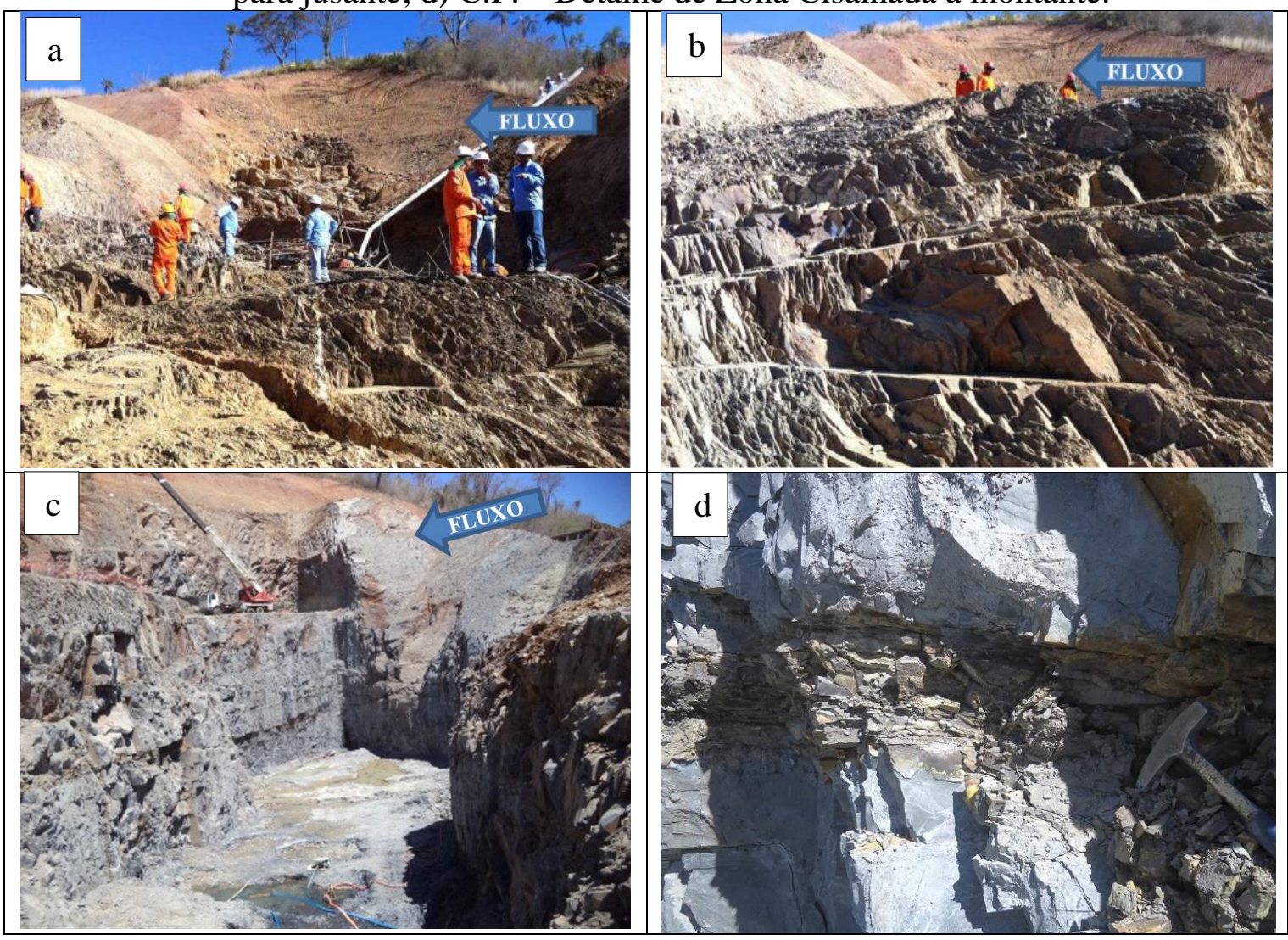

Fonte: Mata velha Energética S.A. (2016). 


\subsubsection{Barragem Margem Direita - Bloco 5 (Estaca 5+15,00)}

Na Figura 75 a seguir, é apresentado o modelo geológico-geotécnico para a região da Barragem de Concreto da Margem Direita - Bloco 5. O modelo geológico foi extrapolado adotando juntas de alívio planares e contínuas embora tais características não persistem em toda a superfície escavada de apoio da Barragem de Concreto da Margem Direita. Na Figura 76 são apresentadas fotografias representativas das condições geológico-geotécnicas no trecho avaliado.

Figura 75 - Seção modelo estaca 5+15,00 m

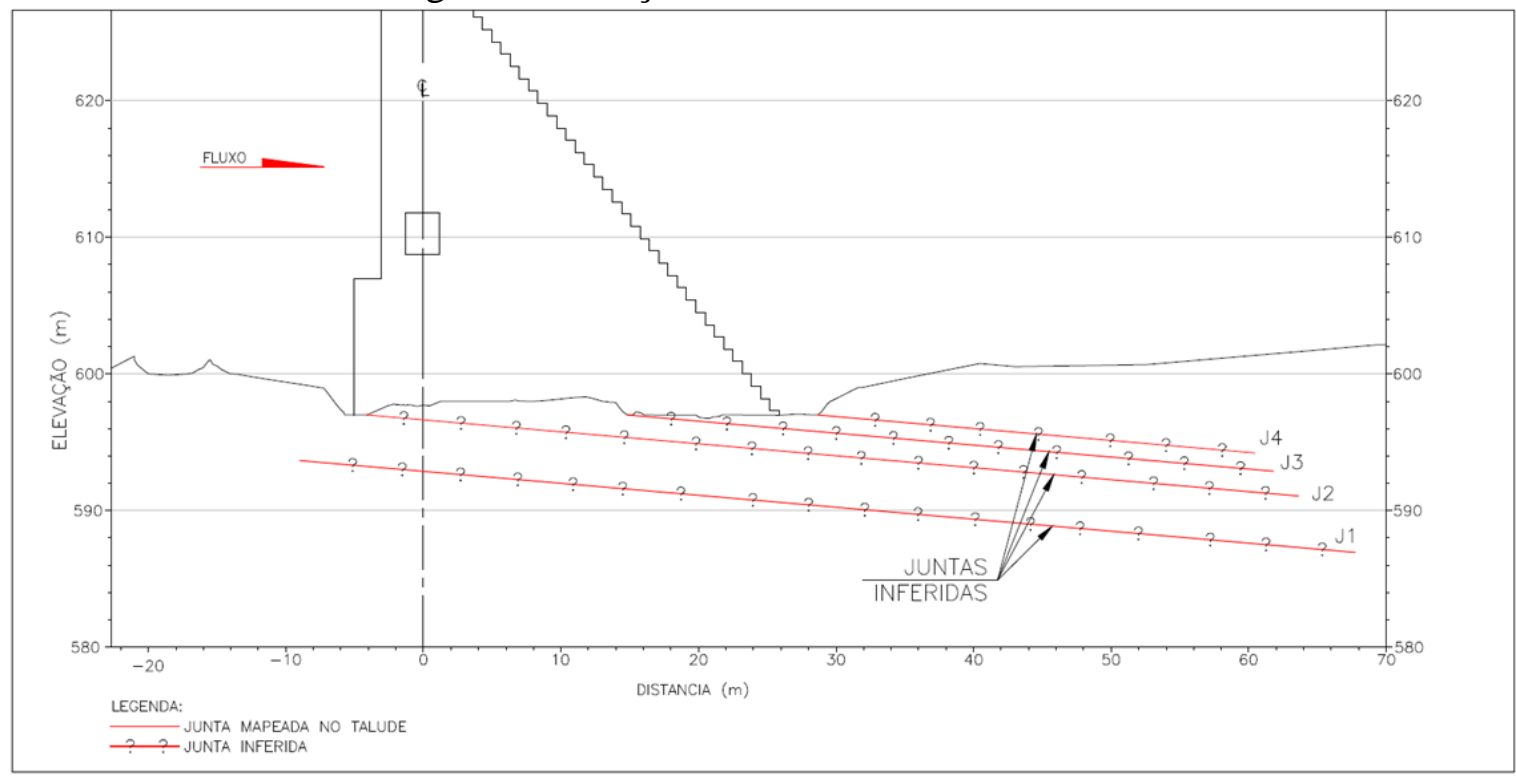

Fonte: Mata velha Energética S.A. (2016).

Figura 76 - Escavação na região dos Blocos 4 e 5: a) Vista em direção a jusante com escavação em expondo as superfícies planas das juntas; b) Vista em direção à ombreira direita com escavação em degraus (sentido do Leito do Rio) e juntas com paredes justapostas e sãs.

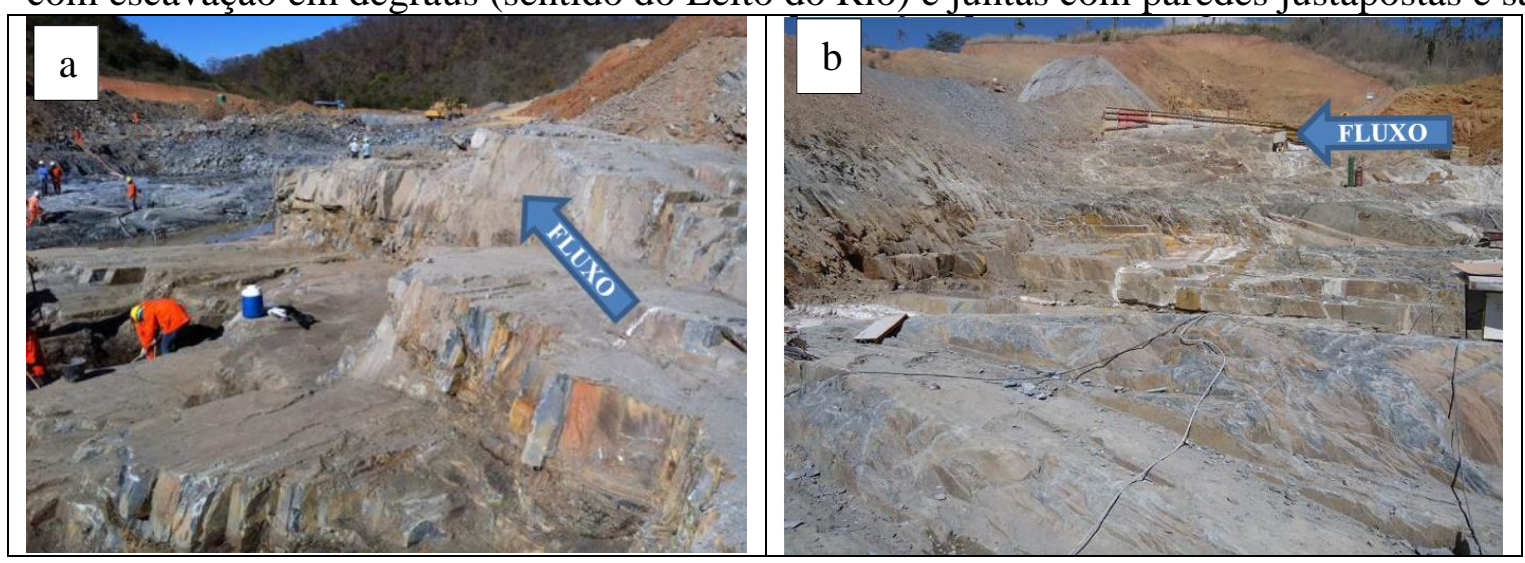

Fonte: Mata velha Energética S.A. (2016). 


\subsubsection{Vertedouro e Adufas de Desvio (Estaca 6+7,5)}

Na Figura 77 é apresentado o modelo geológico-geotécnico para a região do Vertedouro e Adufas de Desvio. O modelo geológico foi extrapolado adotando juntas de alívio planares e contínuas embora tais características não persistem em toda a superfície escavada do Vertedouro e Adufas de Desvio. Na Figura 78 são apresentadas fotografias representativas das condições geológico-geotécnicas no trecho avaliado.

Figura 77 - Seção modelo estaca 6+7,50 m.

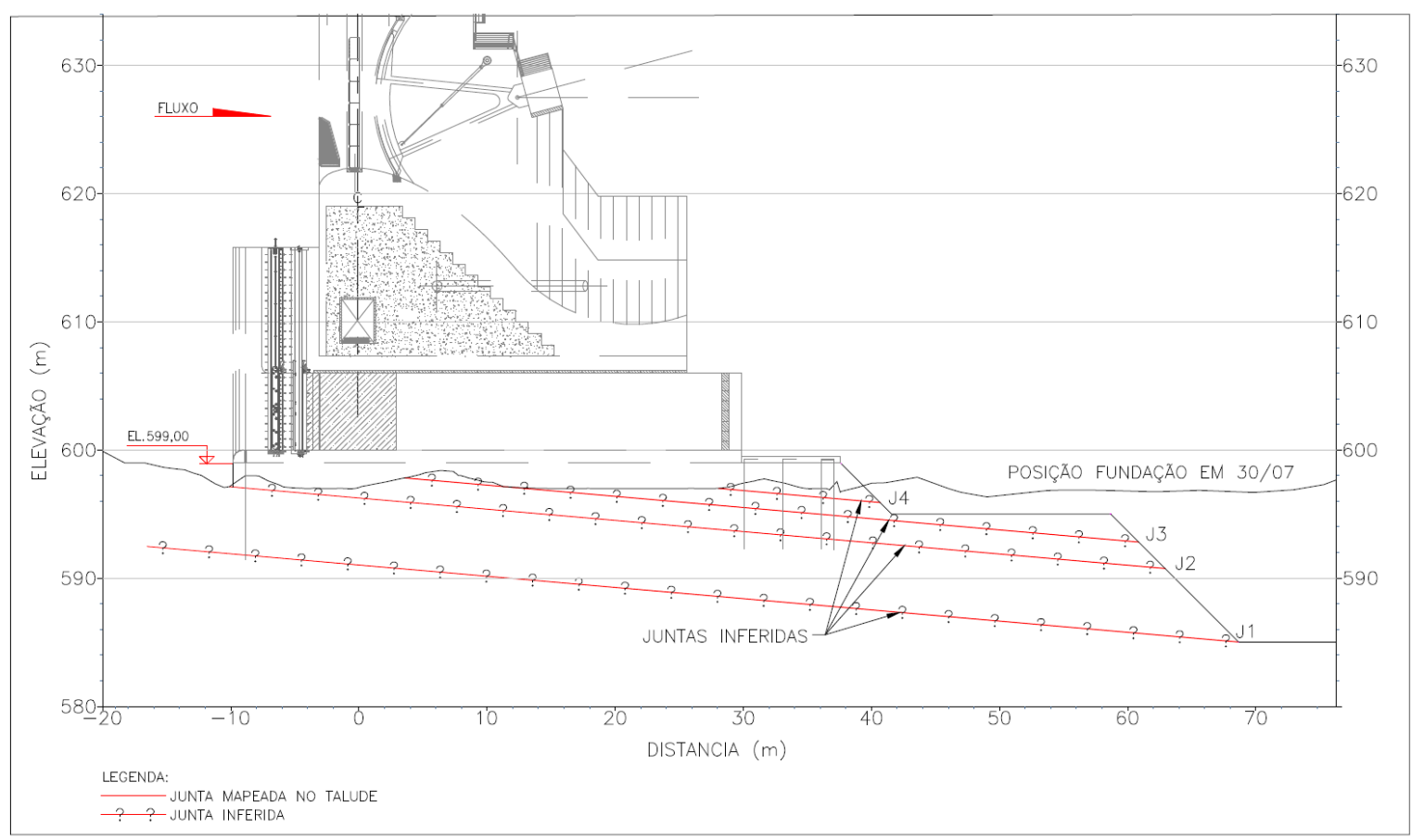

Fonte: Mata velha Energética S.A. (2016). 
Figura 78 - Escavação na região do Vertedouro: a) Vista geral; b) Junta horizontal com contato rocha-rocha fechado c) Junta horizontal com material fragmentado; d) Trecho com mergulho para jusante; e) Junta horizontal com zona cisalhada, com material pétreo; f) Talude Esquerdo da fossa de erosão com jusante onduladas e mergulho médio para jusante.

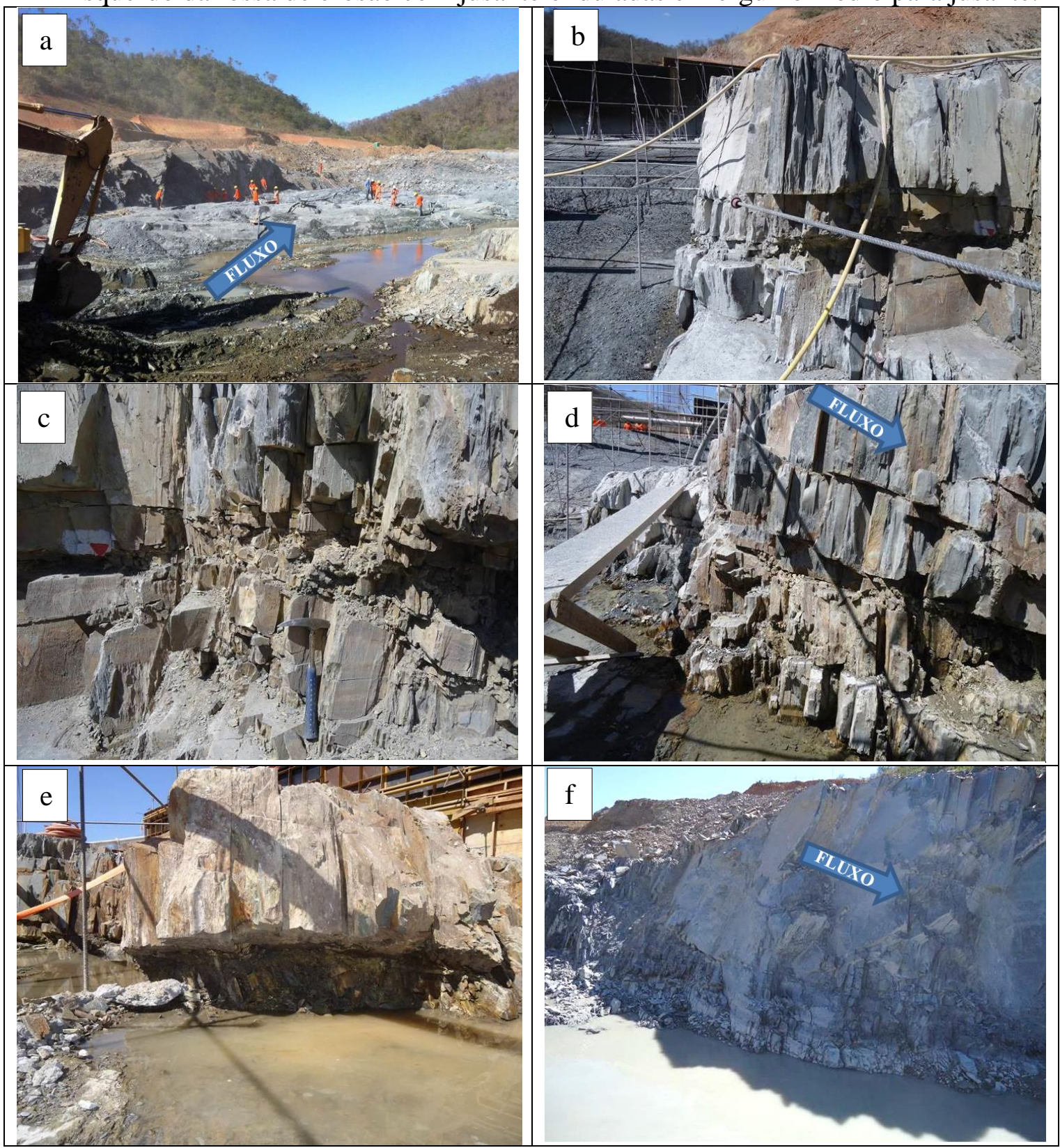

Fonte: Mata velha Energética S.A. (2016).

Tendo por base a extrapolação das descontinuidades/juntas de atitude sub-horizontal apresentadas nas seções transversais, na Figura 79 fez-se a extrapolação das mesmas, considerando a seção geológica geotécnica. 
Figura 79 - Seção geológica-geotécnica com extrapolação das juntas de alívio da fundação consideradas nas seções transversais
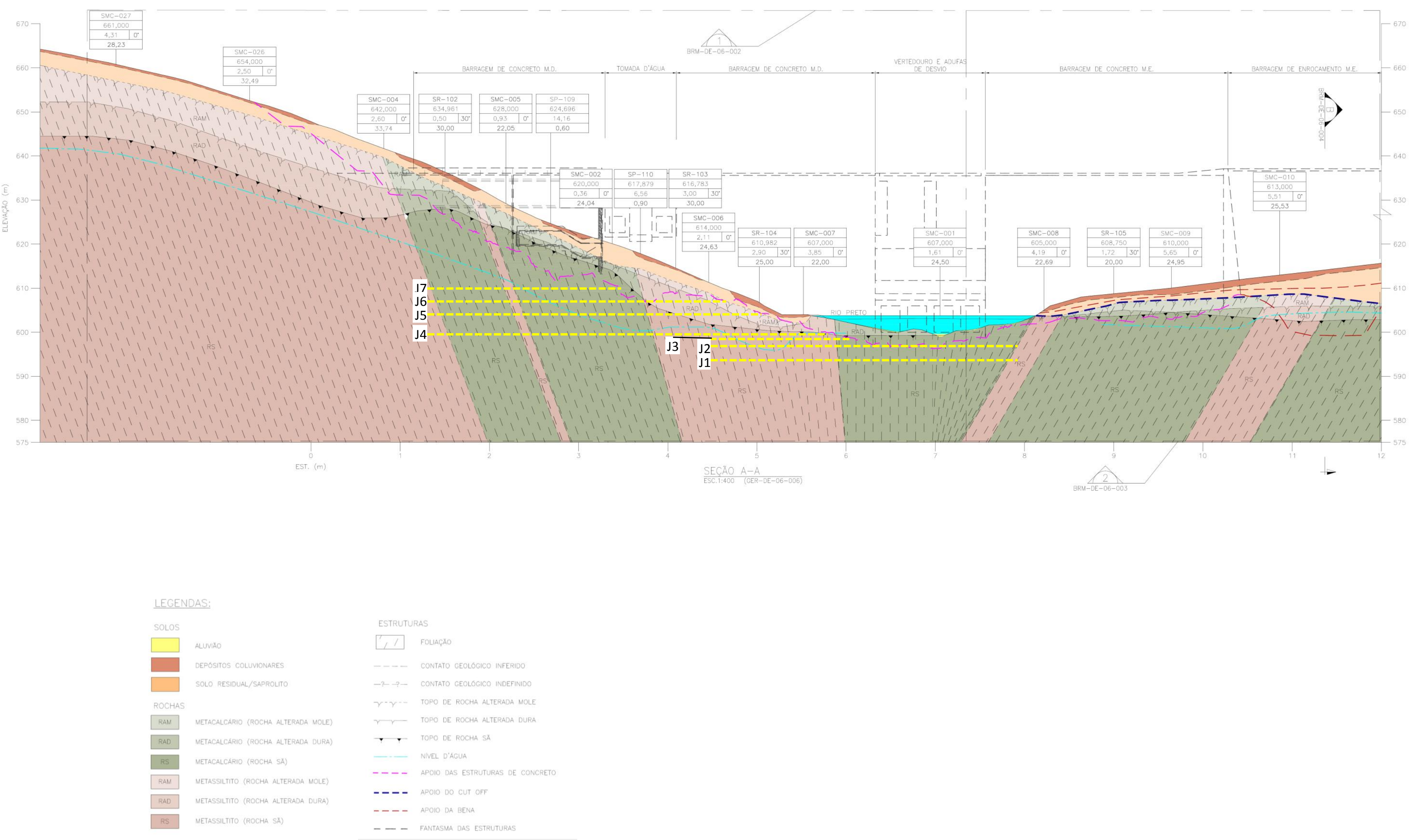


\section{MATERIAIS E MÉTODOS}

\subsection{CASUÍSTICA}

A barragem PCH Mata Velha é constituída de um trecho em concreto compactado a rolo CCR na margem direita e, na margem esquerda, em enrocamento com núcleo de argila, conforme Figura 80 a Figura 82.

Figura 80- Planta esquemática da PCH Mata Velha.

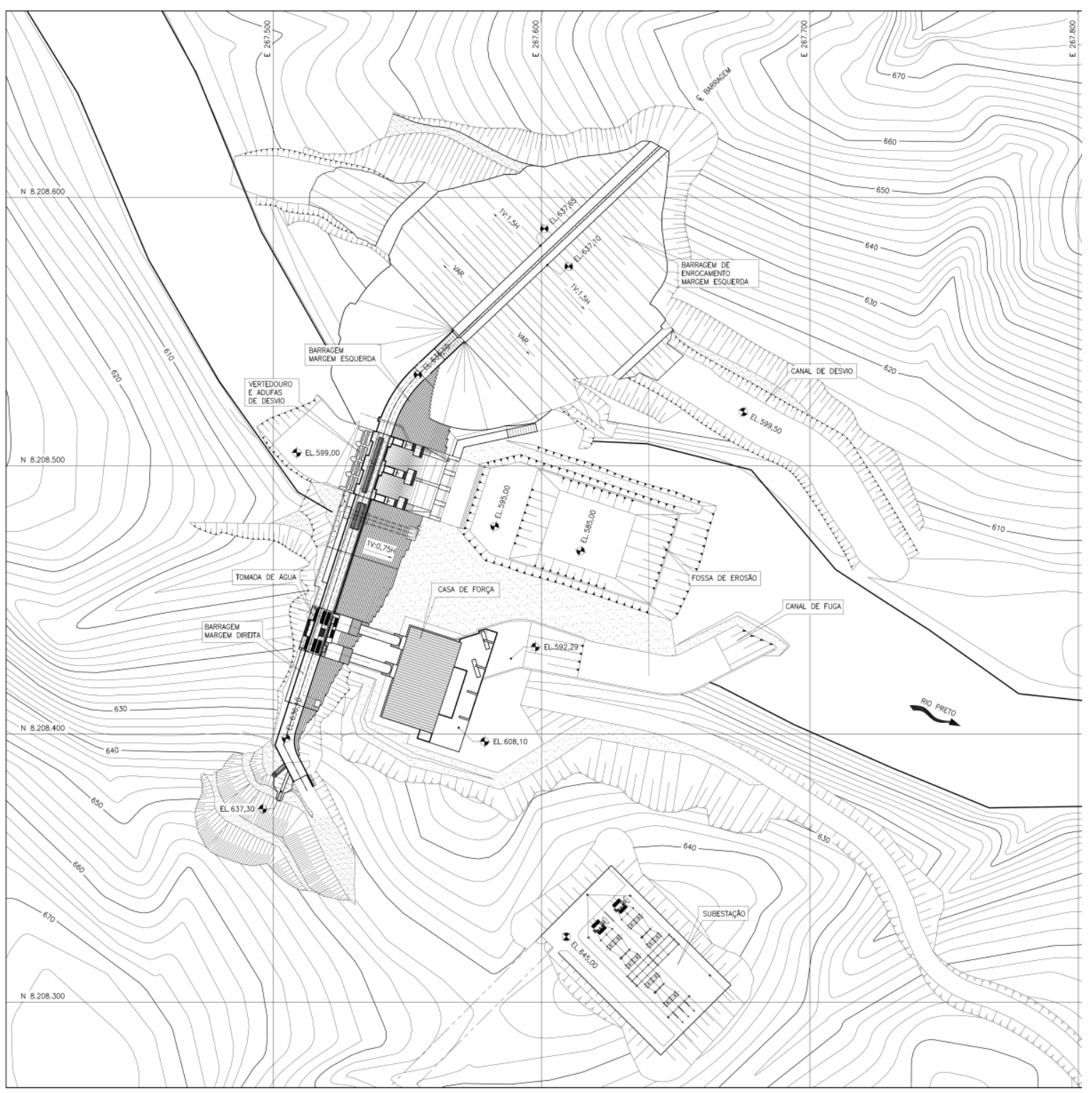

Fonte: Adaptado de Mata Velha Energética S.A. (2016). 
Figura 81 - Seção típica da barragem de concreto compactado a rolo - CCR.

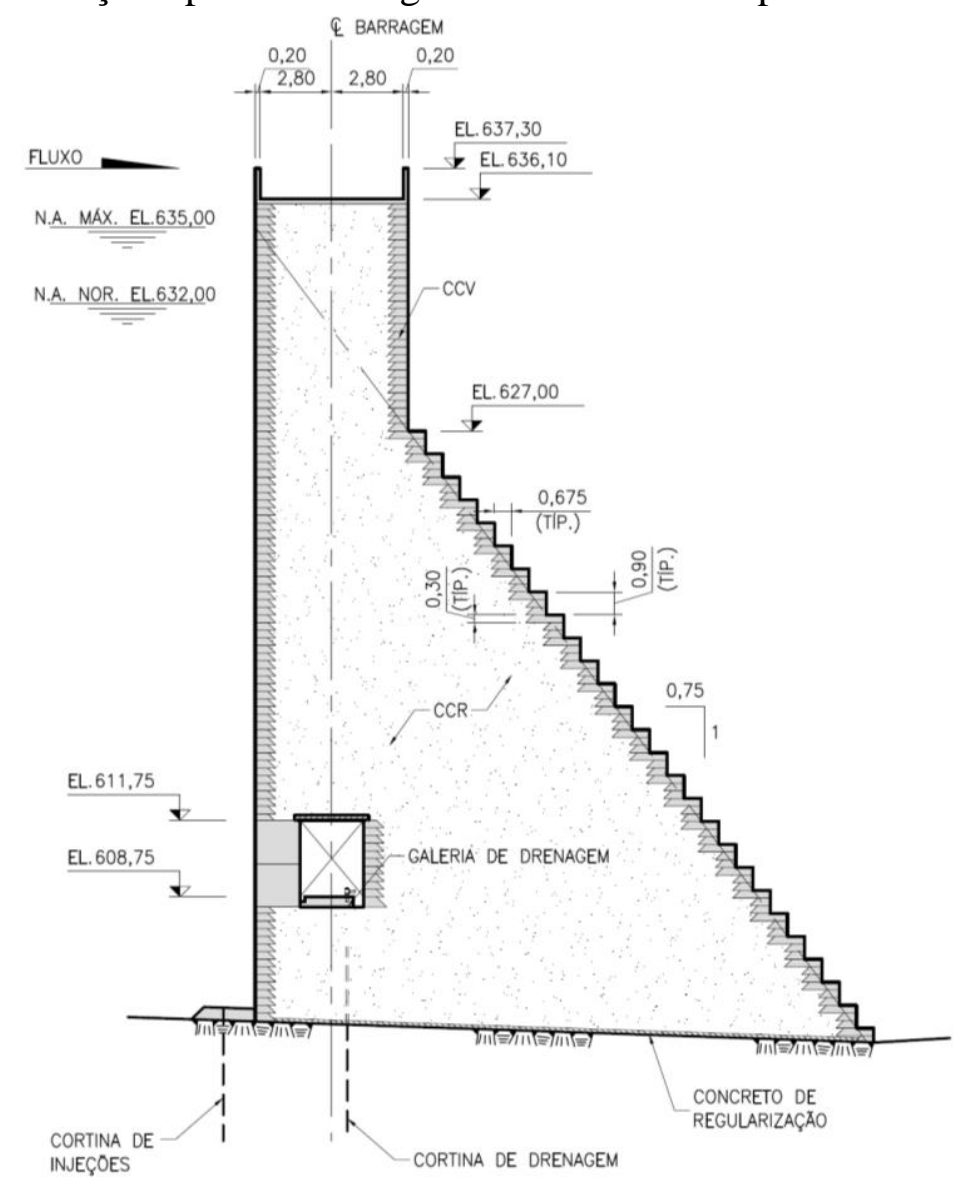

Fonte: Adaptado de Mata Velha Energética S.A. (2016).

Figura 82 - Seção típica da barragem de terra/enrocamento

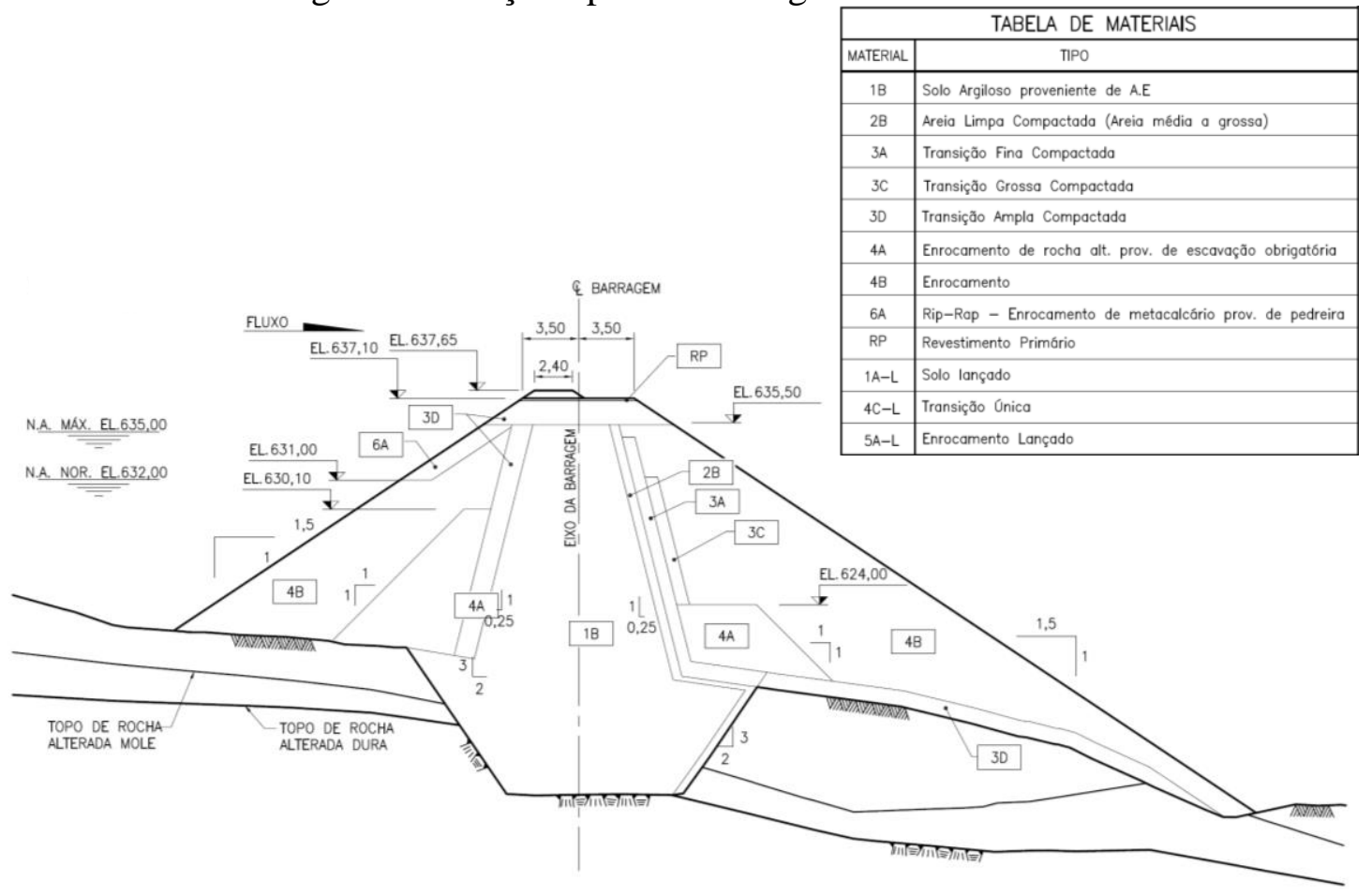

Fonte: Adaptado de Mata Velha Energética S.A. (2016). 
As estruturas de concreto do barramento desenvolvem-se ao longo de 183,60 metros de extensão, sendo integradas por 9 blocos, contemplando também a Tomada de Água e Vertedouro Controlado/Adufas de Desvio. Os blocos do Vertedouro/Adufas de Desvio apresentam vãos rebaixados, destinados a viabilizar o desvio do rio durante a segunda fase do período construtivo. Dos 9 (nove) blocos existentes, 7 (sete) são dotados de galeria de drenagem da fundação, com piso da galeria de drenagem variando entre as EL. 608,75m e EL. 619,95m.

A partir da galeria de drenagem foram executados 50 drenos de fundação, com intuito de reduzir as subpressões na região do contato concreto/rocha e pelo maciço rochoso de fundação. Os drenos de alívio da fundação foram executados com espaçamento de 3,0 m e com 5,0 m de profundidades na rocha, conforme Figura 83. Os drenos são dotados de tubulações geomecânicas de PVC ranhurado com diâmetro de $50 \mathrm{~mm}$ e espessura de corte de $0,5 \mathrm{~mm}$, envolvidos por 3 camadas de tela de nylon de $0,9 \mathrm{~mm}$.

A partir da galeria, foram instalados também os instrumentos de auscultações, a saber, piezômetros, medidores de vazão, medidores triortogonais e extensômetros múltiplos de hastes. O enchimento foi realizado em Abril/2016, com reservatório iniciando na El. 614,11m e finalizando na El. 632,00m, com duração de 8 (oito) dias, com uma velocidade média de 2,24 $\mathrm{m} /$ dia.

Durante o enchimento do reservatório foram observadas altas vazões através dos drenos de fundação (vazão específica $=15 \mathrm{l} / \mathrm{min} / \mathrm{m}$ ), com rápida redução das mesmas (vazão específica = 1,0 1/min/m), observando-se também intensa carbonatação dos drenos de fundação, sem reflexos de aumento de subpressões. 
Figura 83 - Planta e Corte das estruturas de concreto com locação dos drenos de fundação a partir da galeria de drenagem da Barragem Principal

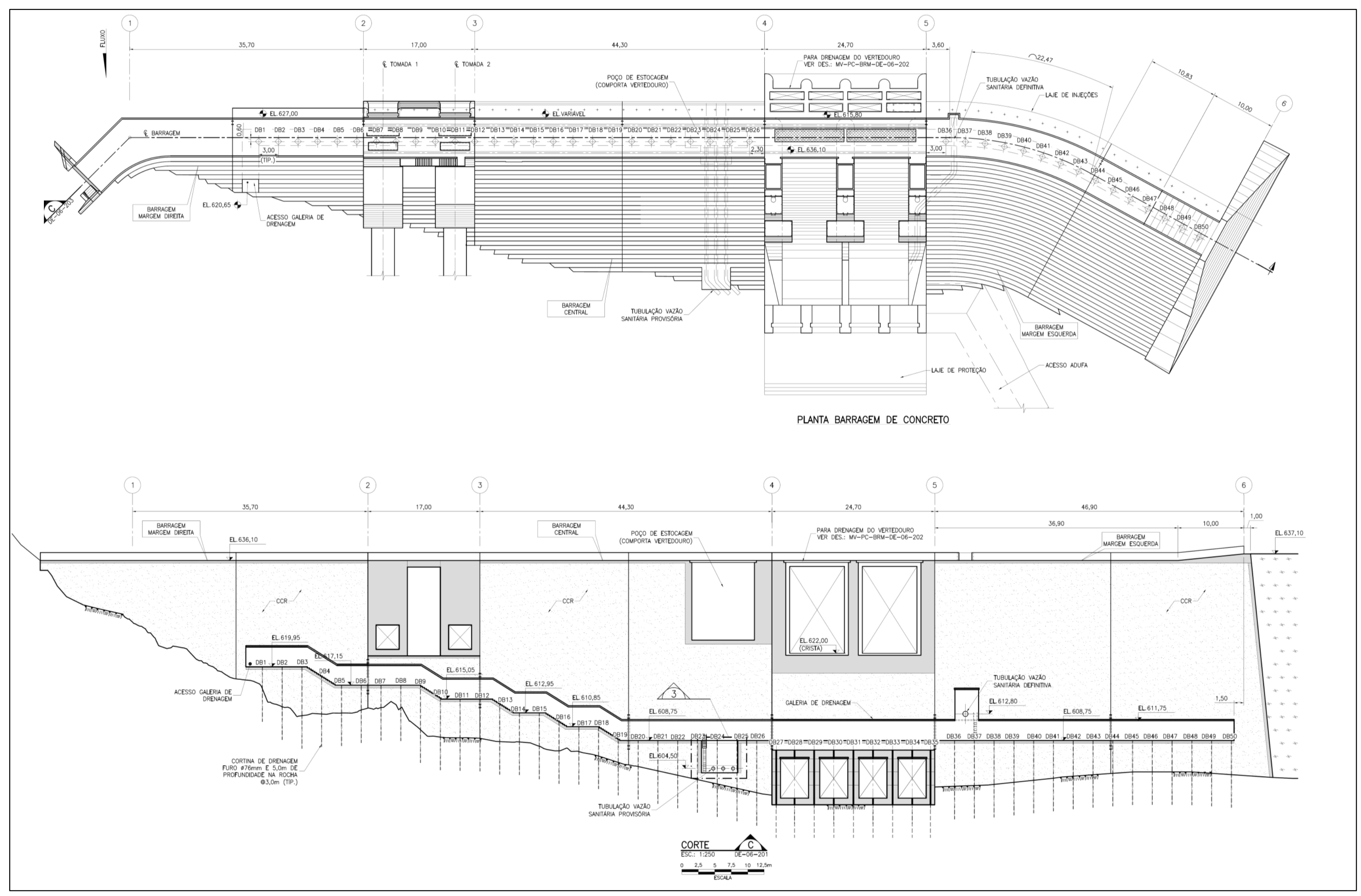

Fonte: adaptado de Mata Velha Energética S.A. (2016). 
Tendo por base a estrutura da dissertação, apresenta-se na Figura 84 o fluxograma das atividades desenvolvidas.

Figura 84 - Fluxograma das atividades a serem desenvolvidas.

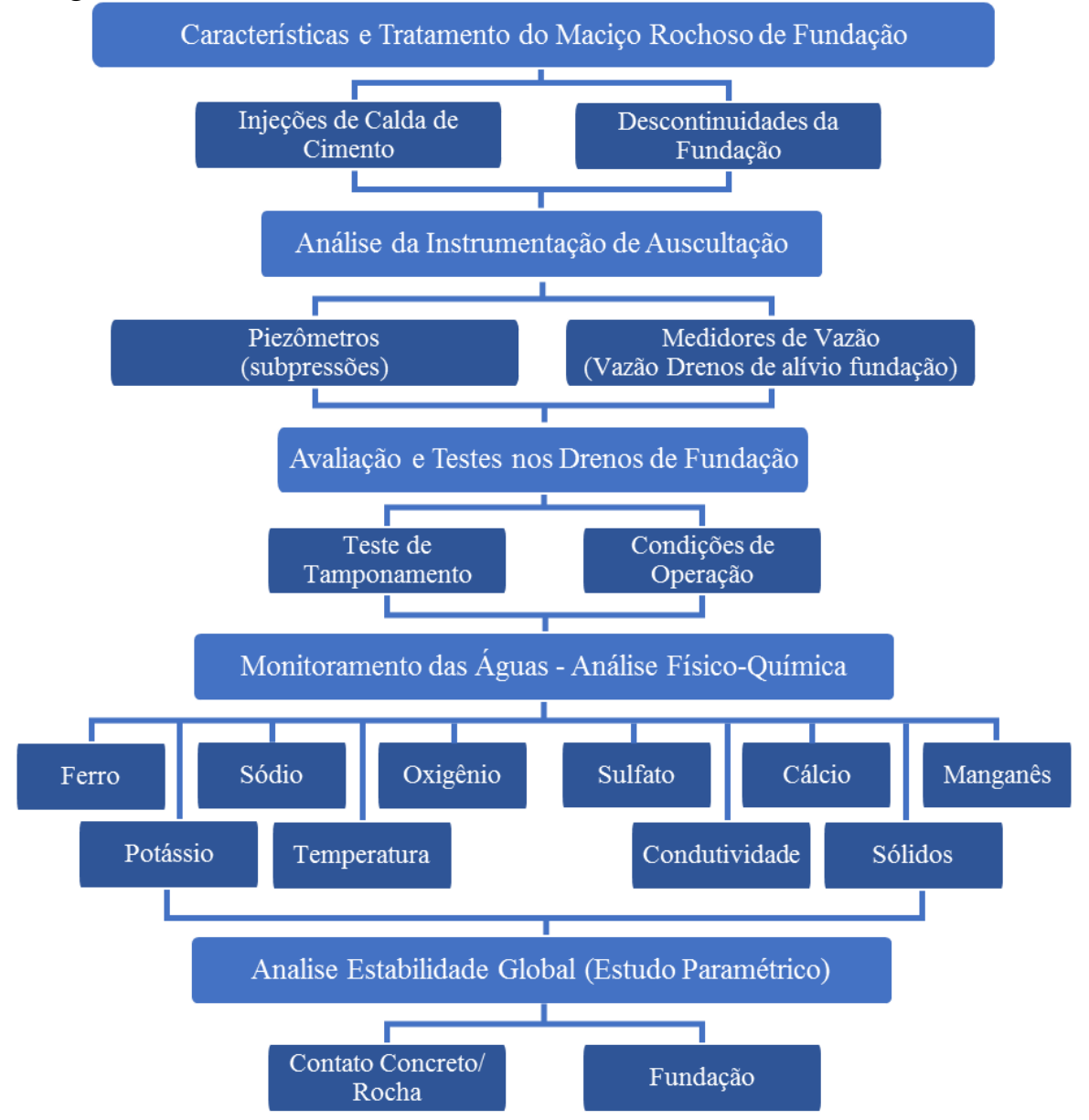

Fonte: do Autor (2020)

\subsection{CARACTERÍSTICAS E TRATAMENTO MACIÇO ROCHOSO DE FUNDAÇÃO DA BARRAGEM}

A caracterização geológica e geotécnica da fundação foi realizada a partir de uma análise minuciosa das investigações, sondagens e documentos que constam dos estudos de implantação e projetos básico e executivo do empreendimento.

Espera-se a partir desse levantamento/estudo um melhor entendimento da formação geológica da rocha de fundação das estruturas de concreto, a fim de subsidiar as outras etapas do presente trabalho, procurando-se associar o comportamento observado dos instrumentos de auscultação e drenos de fundação com a rocha de fundação. 


\subsection{ANÁLISE DA INSTRUMENTAÇÃO DE AUSCULTAÇÃO}

A análise da instrumentação foi realizada tendo por base o histórico das leituras dos instrumentos de auscultação instalados nas estruturas de concreto para medição das subpressões, vazões e deslocamentos durante as fases de enchimento do reservatório e operação, com leituras realizadas com frequência semanal.

O plano de instrumentação da PCH Mata Velha é composto por piezômetros, medidores de vazão, medidores triortogonais e extensômetros. A análise das leituras desses instrumentos e sua variação ao longo do tempo é uma ferramenta importante, devendo permitir um melhor entendimento quanto ao comportamento da fundação ao longo do tempo, considerando condições de carga diferentes, como por exemplo durante o enchimento do reservatório e o período de operação.

A partir da análise do comportamento da instrumentação e sua correlação com outras etapas do presente estudo, espera-se que seja possível elencar algumas hipóteses que pudessem ocorrer em relação ao comportamento observado na fundação, caracterizado pelas altas vazões pelos drenos de fundação e sua rápida redução, com ocorrência, também, de intensa carbonatação/colmatação dos drenos de fundação.

\subsection{TESTE DE TAMPONAMENTO DOS DRENOS DE FUNDAÇÃO}

O teste de tamponamento dos drenos de fundação consistiu no fechamento dos drenos de fundação da barragem de concreto, utilizando tampas roscáveis junto ao terminal de saída da água, de tal forma que os mesmos pudessem ser pressurizados.

O teste foi realizado em três etapas, tendo-se tamponado inicialmente os drenos dos Blocos 2 e 3 (Drenos 1 a 11), em uma segunda etapa foram tamponados os drenos dos Blocos 4 a 6 (Drenos 12 a 35), e por fim foram tamponados os demais drenos dos blocos 7 e 8 (Drenos 36 a $50)$.

Durante o tamponamento dos drenos, foram realizadas também leituras dos instrumentos de auscultação das estruturas de concreto.

Esta etapa tem por objetivo verificar a influência da cortina de drenagem nos instrumentos de auscultação, principalmente nos piezômetros instalados a partir da galeria de drenagem da Barragem Principal, uma vez que o tamponamento dos drenos deverá refletir em um aumento das subpressões medidas pelos piezômetros. 


\subsection{AVALIAÇÃO DAS CONDIÇÕES DE OPERAÇÃO DOS DRENOS DE FUNDAÇÃO}

A avaliação das condições de operação dos drenos de fundação foi realizada em duas fases. A segunda fase foi definida após as observações da primeira fase e ambas tiveram caráter investigativo.

$\mathrm{Na}$ primeira fase, inicialmente foi realizada a leitura de todos os instrumentos de auscultação das estruturas de concreto, a saber, piezômetros, medidores de vazão, extensômetros múltiplos de hastes e medidores triortogonais de junta entre blocos das estruturas de concreto.

Foi também realizada a medição de vazão dreno a dreno naqueles em que ocorria saída de água, empregando-se um recipiente graduado (Figura 85) e cronômetro, enquanto naqueles em que não ocorria a saída de água, foi realizada a medição do nível d'água, empregando-se o sensor de nível d'água, o qual é dotado de um torpedo metálico, conforme Figura 86.

Adicionalmente foi medida a profundidade de todos os drenos, empregando-se o mesmo sensor de nível d'água e anotando-se a profundidade máxima atingida, ou seja, até o fundo do tubo ou alguma obstrução que viesse impedir a passagem do torpedo.

Figura 85 - Leitura de vazão empregando-se o recipiente graduado.

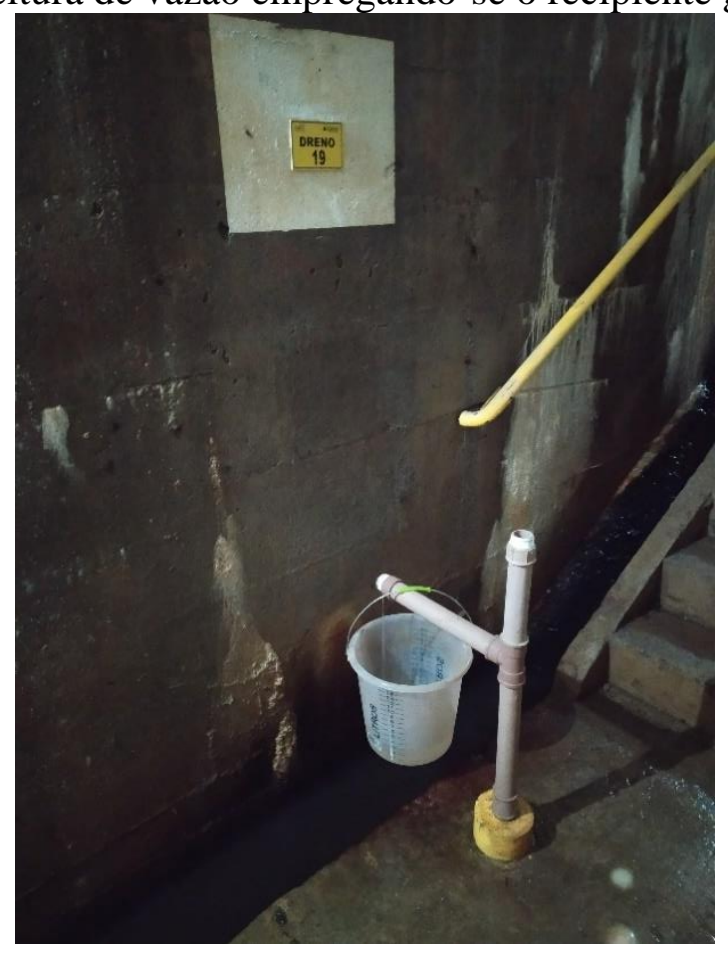

Fonte: do Autor (2019). 
Figura 86 - Medição de nível d'água e profundidade dos drenos de fundação. a) realização de leitura. b) Detalhe do sensor de nível d'água empregado, com torpedo metálico na extremidade inferior.
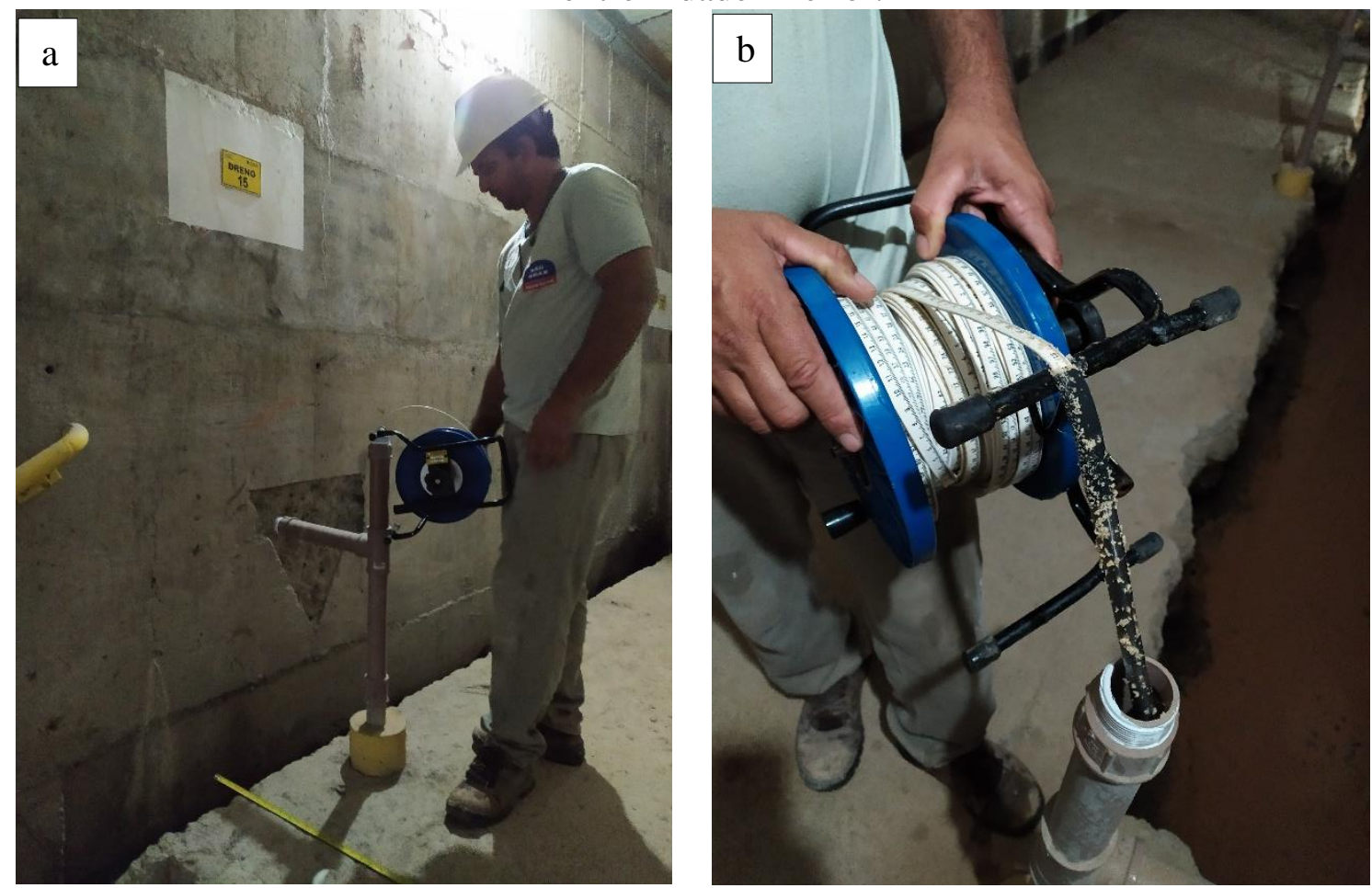

Fonte: do Autor (2019).

Para subsidiar as observações e permitir a visualização internamente às tubulações instaladas nos drenos de fundação, foi utilizado um endoscópio industrial constituído por uma sonda com iluminação própria, que permite visualizar, fotografar e filmar o interior de regiões confinadas.

$\mathrm{Na}$ primeira fase foram retiradas algumas tubulações internas dos drenos para avaliação/inspeção visual. Houve a tentativa, também, de lavagem das tubulações com jato de água sob pressão, utilizando máquina de limpeza de alta pressão, modelo J870 e marca JactoClean, de uso industrial.

Na segunda fase foi realizada também a medição de vazão, níveis d'água e profundidades dos drenos de fundação. Foram removidas as tubulações internas de drenos em que haviam sido observadas alguma obstrução. Para esta remoção das tubulações foi desenvolvido um sistema/estrutura metálica com talha elétrica. Para inspeção interna dos drenos, tanto antes como depois da remoção da tubulação interna, utilizou-se um Boroscópio, modelo END 23F50MHD, o qual permite tanto fotografas como filmar internamente ao furo com boa qualidade.

A avaliação das condições de operação dos drenos de fundação deve permitir uma melhor 
avaliação das condições internas dos drenos e tubulações instaladas internamente às perfurações, principalmente aquela realizada na segunda fase, empregando boroscópio com boa qualidade de imagem, assim como da observação das tubulações internas, após sua remolção.

\subsection{ANÁLISE FÍSICO-QUÍMICA DA ÁGUA}

As análises físico-químicas foram realizadas a partir da coletada de amostras de $300 \mathrm{ml} \mathrm{de}$ água em oito pontos: um no reservatório a 10 metros de profundidade, quatro na porção terminal dos drenos de fundação da barragem de concreto e três na porção terminal dos DHPs (drenos horizontais profundos) no talude da Casa de Força na margem direita, referente à fundação dos blocos 1 e 2 da barragem de concreto, conforme localização da Figura 87.

Figura 87 - Foto aérea com localização dos pontos de coleta de água. Os drenos de fundação da barragem (DR) estão localizados na galeria de drenagem.

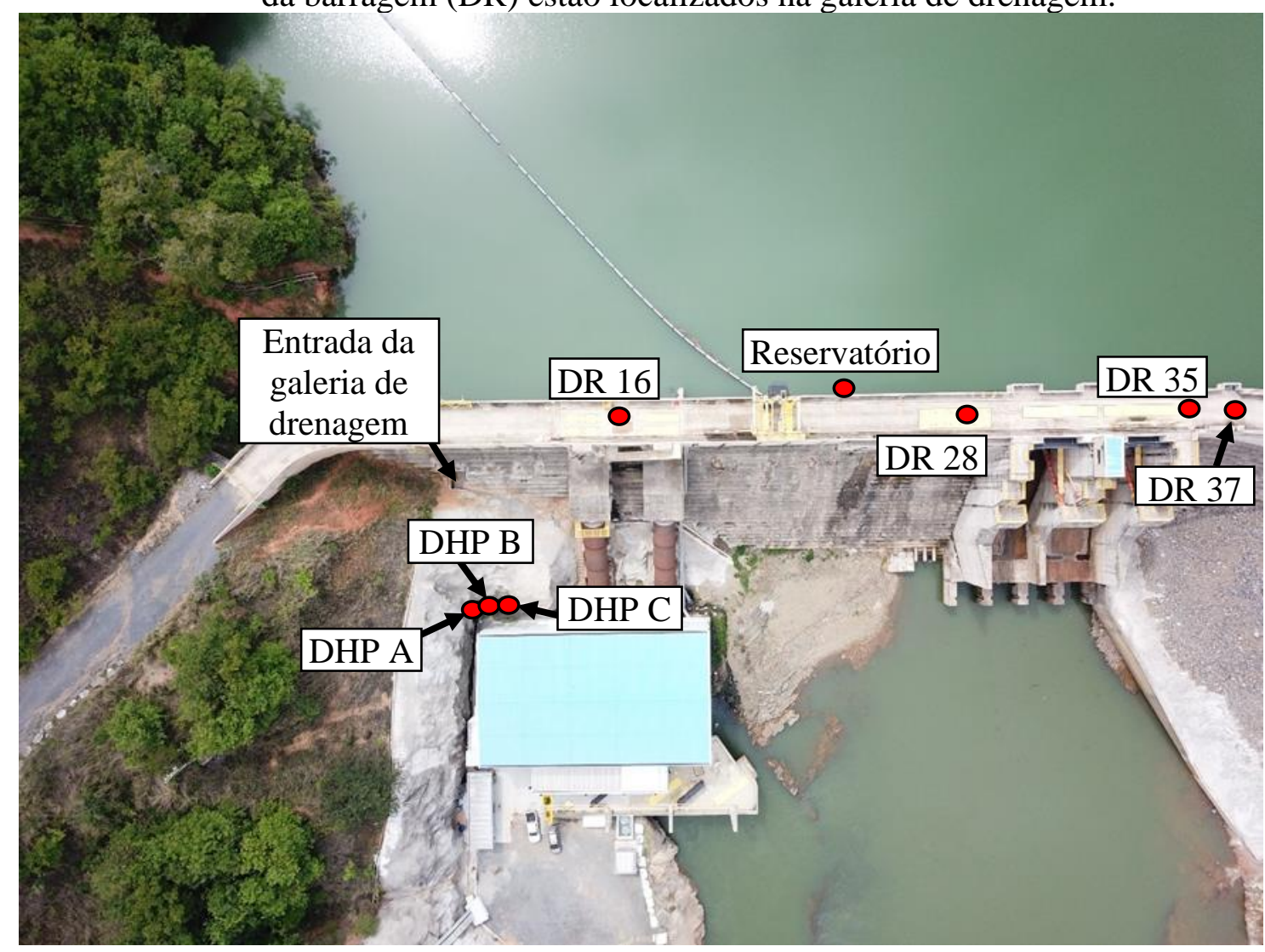

Fonte: do Autor (2020).

Tanto a amostragem como a análise em laboratório foram realizadas pela empresa Tommasi Ambiental, de Brasília-DF. Foram avaliados os seguintes parâmetros: $\mathrm{T}\left({ }^{\circ} \mathrm{C}\right)$, Condutividade, Oxigênio Dissolvido, Sulfato Total, Sólidos Dissolvidos Totais, Sólidos 
Suspensos Totais, Ferro Total, Manganês Total, Cálcio Total, Ferro Dissolvido, Ferro Particulado, Manganês Dissolvido, Manganês Particulado, Cálcio Dissolvido, Cálcio Particulado, Sódio Dissolvido, Sódio Particulado, Sódio Total, Potássio Dissolvido, Potássio Particulado e Potássio Total.

A partir da análise de água, espera-se poder correlacionar seus resultados às observações junto aos drenos de fundação (deposição de carbonato de cálcio e presença de finos). Está campanha de análise de água deverá ser um ponto de partida, inclusive para comparação com campanhas futuras.

\subsection{ANÁLISES DA ESTABILIDADE GLOBAL - MODELOS ANALÍTICOS}

Foram realizadas análises de estabilidade global empregando-se modelos analíticos, conforme critérios definidos pela Eletrobrás (2003), tendo por base os desenhos e relatórios de projeto, assim como as observações durante o período de construção, para definição da geometria das estruturas e demais considerações pertinentes.

Nas análises de estabilidade deverão ser avaliadas a implicação da obstrução e eventual perda de eficiência dos drenos, levando em conta tanto o contado concreto/rocha como a fundação, através das juntas de alívio no maciço rochoso de fundação, para a Condição de Carregamento Normal.

São realizadas análise paramétricas a fim de avaliar os Fatores de Segurança - FS para conjuntos de parâmetros distintos, considerando as estabilidades ao deslizamento, tombamento e flutuação, bem como as tensões na fundação.

\section{RESULTADOS}

\subsection{CARACTERÍSTICAS E TRATAMENTO DA FUNDAÇÃO DAS ESTRUTURAS DE CONCRETO}

\subsubsection{Regularização e Limpeza da Fundação}

A superfície da rocha de fundação foi regularizada por meio de enchimento com concreto de regularização ou por escavação. Após a escavação, a limpeza grossa foi realizada com a utilização de uma chapa metálica lisa à frente dos dentes da caçamba da escavadeira, 
com o objetivo de se evitar a escarificação e o relaxamento do material de fundação.

Foi realizada a remoção dos blocos de rocha que apresentavam preenchimento de material argiloso/siltoso entre eles, sendo a limpeza fina realizada utilizando-se de ar comprimido e água. Em zonas estreitas, onde houve necessidade de remover material, as depressões resultantes foram preenchidas com concreto dental. Ao final foi executada a regularização da fundação com concreto, com espessura mínima de $0,5 \mathrm{~m}$, a fim de permitir a execução do concreto compactado a rolo - CCR.

Figura 88 - Detalhe típico do tratamento superficial rigoroso.

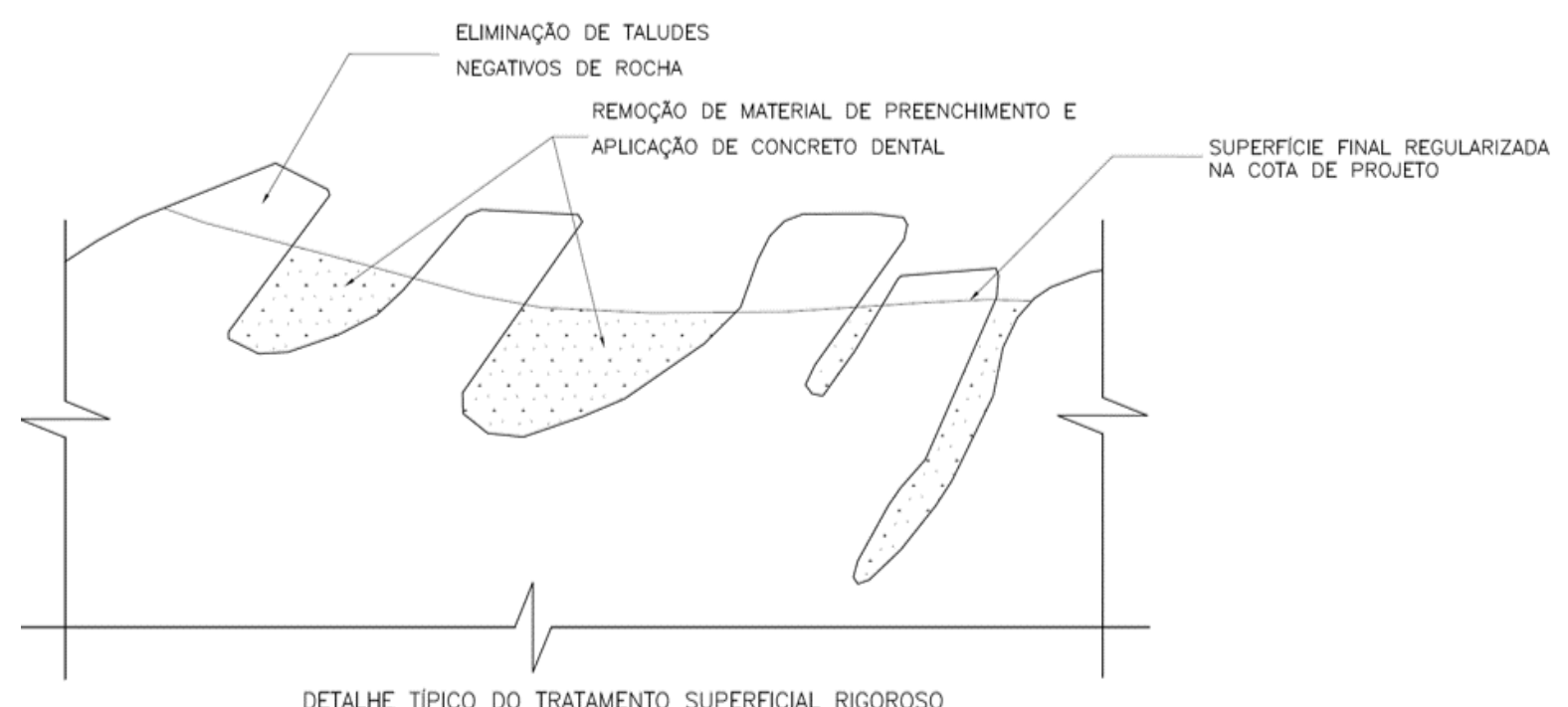

Fonte: adaptado de Mata Velha Energética S.A. (2016).

No geral a rocha de fundação ficou abaixo da elevação definida em projeto, o que é normal de ser observado nas obras de barragem.

$\mathrm{Na}$ margem direita, foram encontrados alguns vazios e pequenas cavernas, os quais foram preenchidos com concreto. São apresentadas fotos a seguir, tendo por base os registros do período de obras, procurando-se ilustrar algumas condições da rocha de fundação, limpeza e regularização da fundação com concreto, finalizando com o lançamento do concreto compactado a rolo - CCR (Figura 89 a Figura 96). 
Figura 89 - Vista da escavação na região da margem direita.

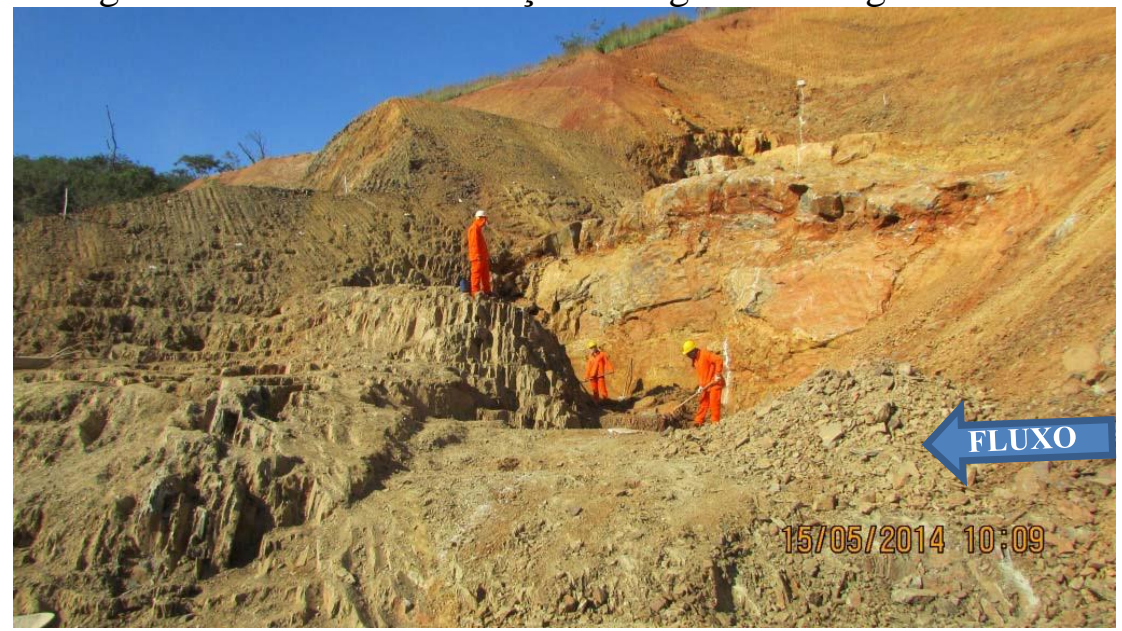

Fonte: Mata Velha Energética S.A. (2016).

Figura 90 - Fundação da barragem de CCR da margem direita e local com pequena caverna, nas proximidades da El. $620,00 \mathrm{~m}$.

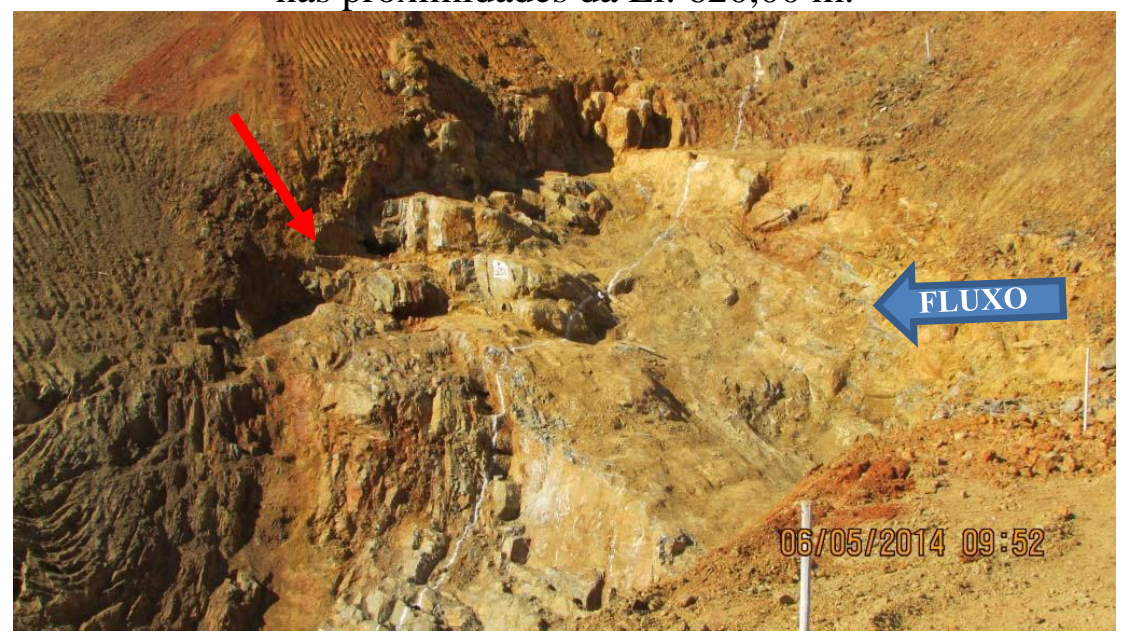

Fonte: Mata Velha Energética S.A. (2016).

Figura 91 - Detalhe da pequena caverna $(\sim 50 \mathrm{~cm})$, característica de regiões cársticas.

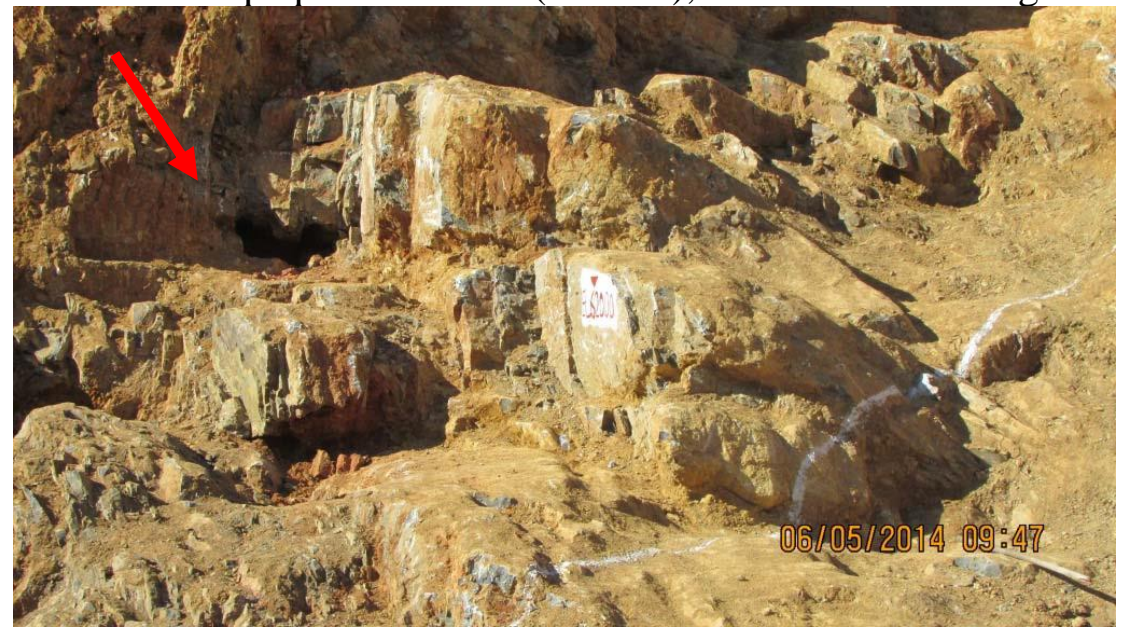

Fonte: Mata Velha Energética S.A. (2016). 
Foto 17 - Vista a partir da margem esquerda, observando-se a escavação do leito do rio, da região do vertedouro e da barragem margem direita.

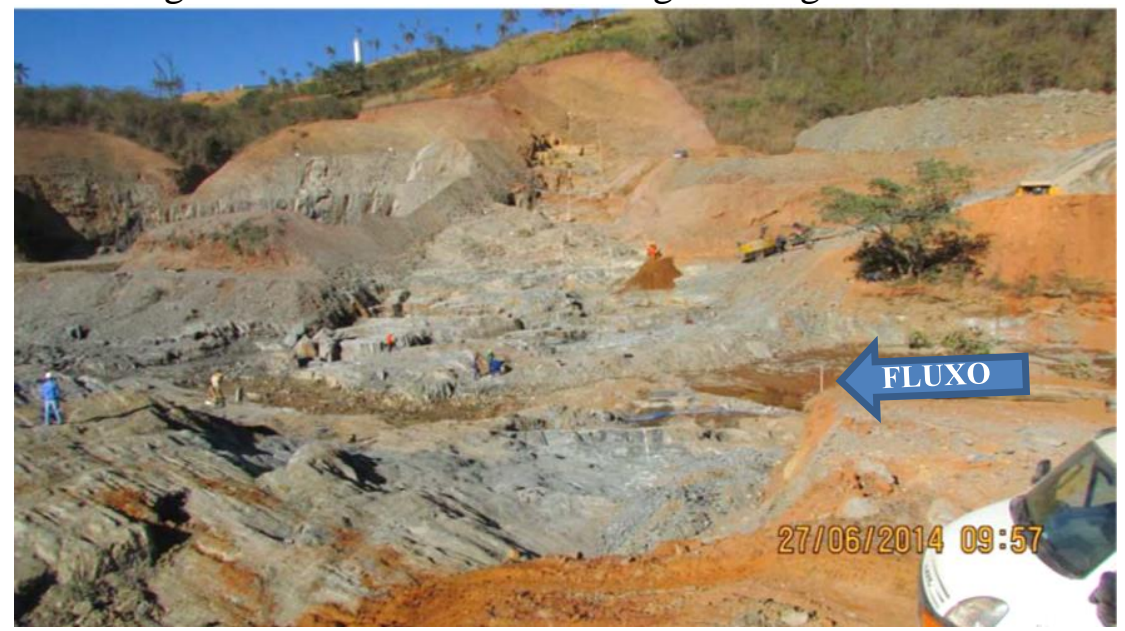

Fonte: Mata Velha Energética S.A. (2016).

Figura 92 - Limpeza e preparo de fundação na região da tomada d'água.

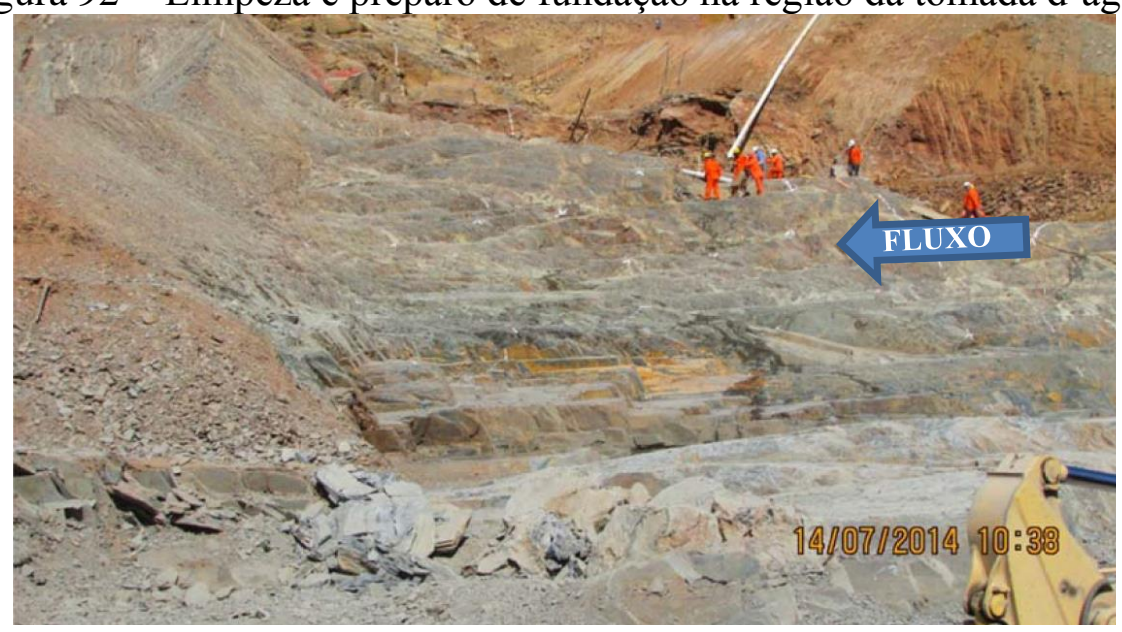

Fonte: Mata Velha Energética S.A. (2016).

Figura 93 - Vista da limpeza da fundação e região de regularização (seta) do vertedouro.

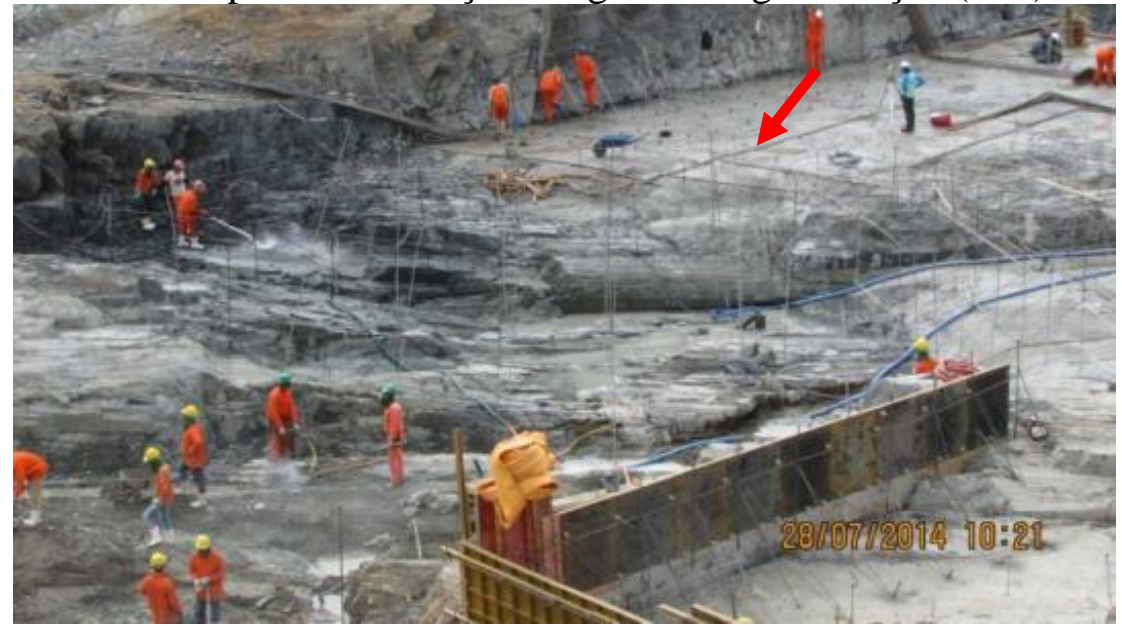

Fonte: Mata Velha Energética S.A. (2016). 
Figura 94 - Concreto de regularização da fundação da barragem margem direita.

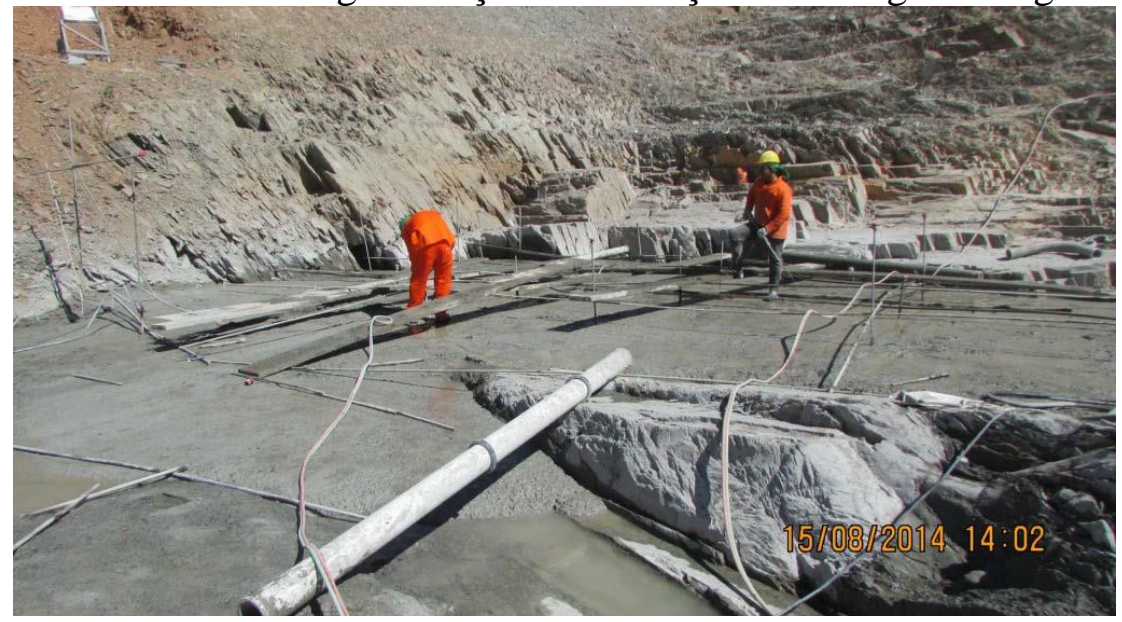

Fonte: Mata Velha Energética S.A. (2016).

Figura 95 - Vista da região da margem direita com fundação já regularizada.

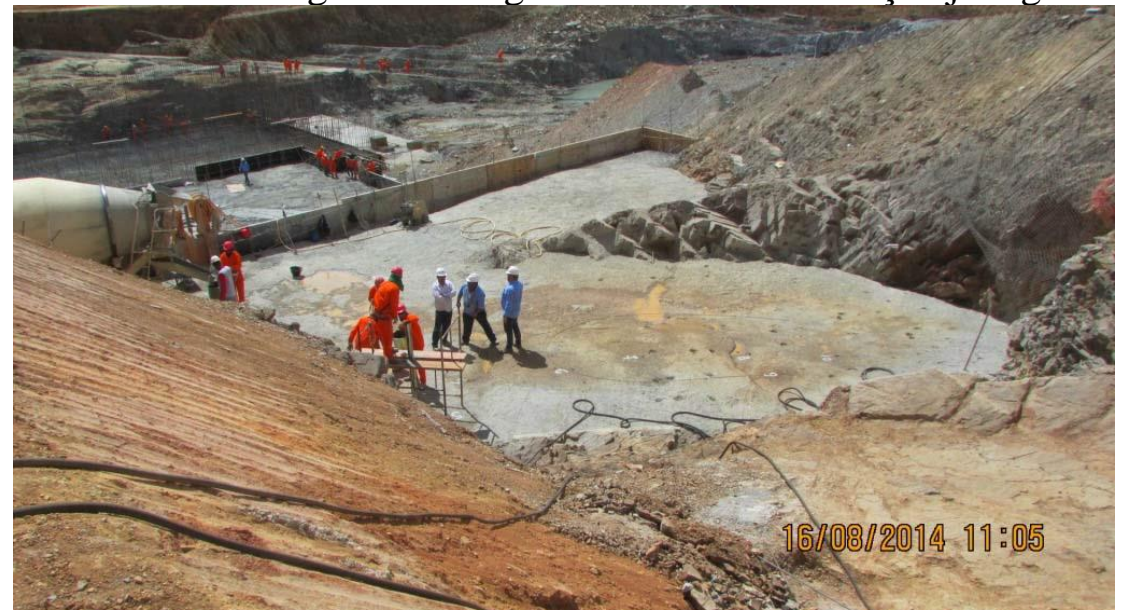

Fonte: Mata Velha Energética S.A. (2016).

Figura 96 - Vista da barragem a partir da margem direita, com lançamento do CCR.

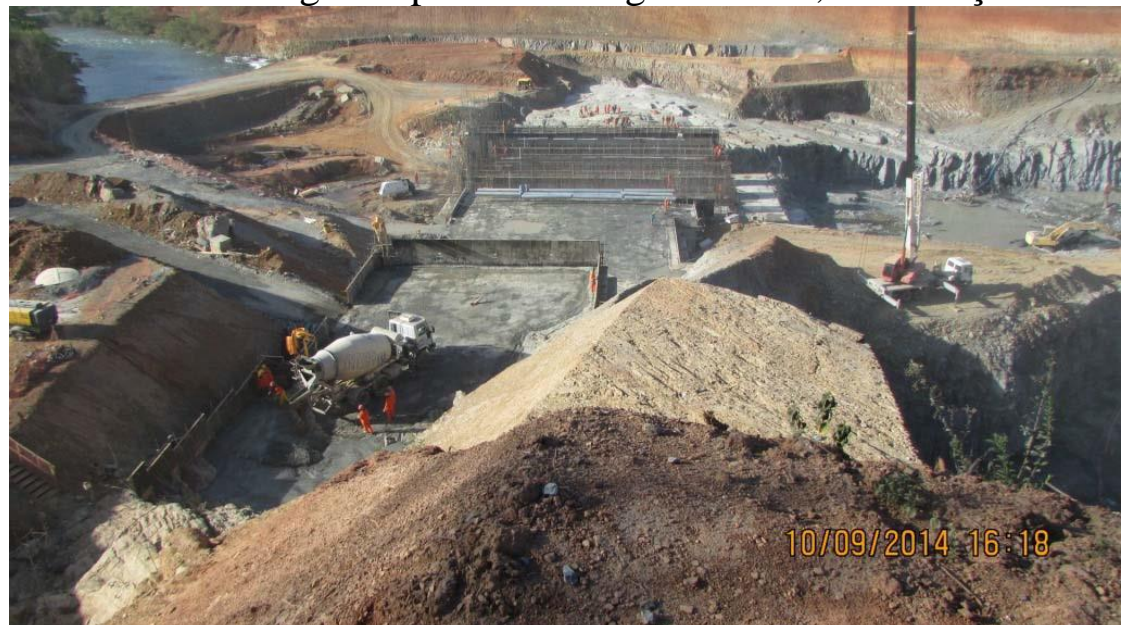

Fonte: Mata Velha Energética S.A. (2016). 


\subsubsection{Injeção da Fundação}

As injeções de calda de cimento para impermeabilização, as quais interceptaram tanto os metacalcáreos como os metasiltitos, seguiram o método de espaçamento divisional, no qual primeiro abrem-se os furos primários, a distâncias relativamente grandes uns dos outros $(6 \mathrm{~m})$. Após a sua injeção, são abertos furos secundários, a meia distância entre os primários, e injetados da mesma maneira. Posteriormente os furos terciários e assim por diante, até se atingir o grau de impermeabilização desejado, conforme esquemas de injeções da Figura 97.

Foram realizadas também, injeções de consolidação, as quais visam interceptar e preencher possíveis vazios cársticos identificados na faixa jusante da barragem da margem direita, espaçados a cada 3,0 m, conforme Figura 97.

Figura 97 - Esquema de injeção de calda de cimento: a) Impermeabilização em linha tripla; b) Impermeabilização em linha única; c) Consolidação.

a)

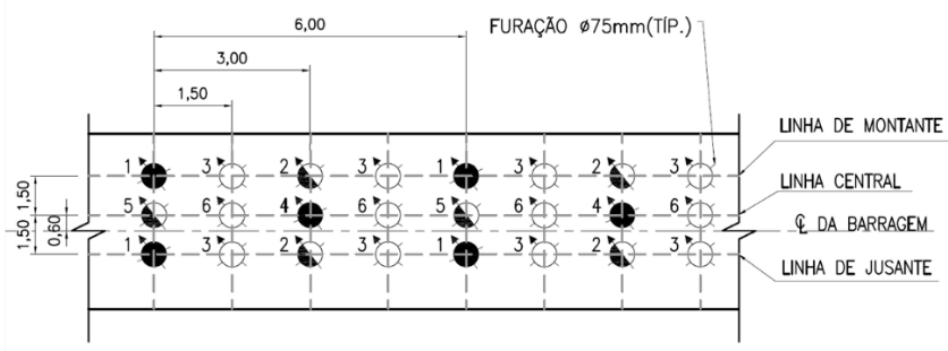

b)

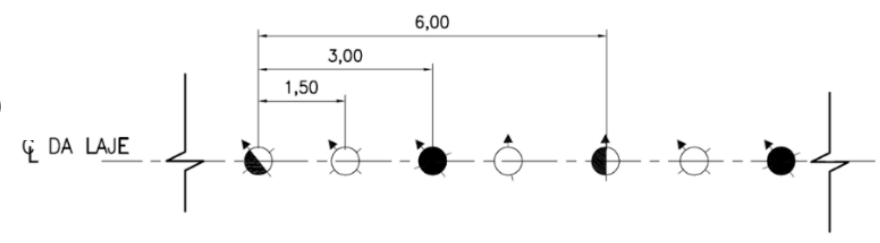

c)
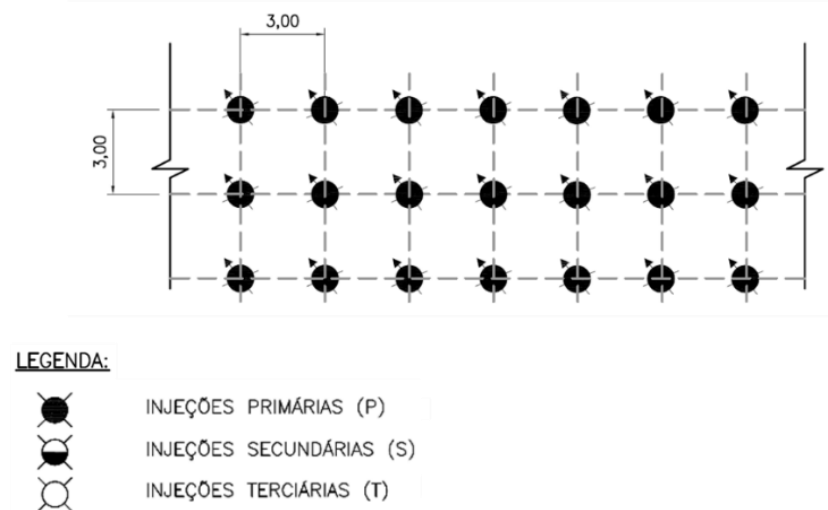

Fonte: Mata Velha Energética S.A. (2016).

O sistema de injeção foi realizado de tal forma que a calda de cimento pudesse ser introduzida em diferentes profundidades do furo, mediante o emprego de obturadores. Foi 
empregado traço predominante de A/C (Água/Cimento)=0,7, sendo eventualmente alterado para melhores resultados na penetração e preenchimento de vazios. Na Tabela 16 são apresentadas as relações do traço e a conversão em volume.

Tabela 16 - Traços A/C e volumes empregados.

\begin{tabular}{cc}
\hline Saco de cimento $(50 \mathrm{~kg})-16$ litros $(1 \mathrm{KG}=0,31 \mathrm{~L})$ \\
VOLUME/TRAÇO $(\mathrm{LITROS})$ \\
\hline $\mathrm{A} / \mathrm{C}=1,0$ & 66 calda \\
$\mathrm{A} / \mathrm{C}=0,8$ & 56 calda \\
$\mathrm{A} / \mathrm{C}=0,7$ & 51 calda \\
$\mathrm{A} / \mathrm{C}=0,6$ & 46 calda \\
$\mathrm{A} / \mathrm{C}=0,5$ & 41 calda \\
$\mathrm{A} / \mathrm{C}=0,4$ & 36 calda \\
\hline
\end{tabular}

Nota: $\mathrm{A} / \mathrm{C}=$ Água/Cimento.

Fonte: Mata Velha Energética S.A. (2016).

Para ilustração, na Figura 98 são apresentadas algumas seções típicas na margem direita, enquanto na Figura 99 são apresentadas fotos a partir da margem direita, durante a realização das injeção de consolidação (por gravidade) e de impermeabilização/cortina de injeção (sob pressão), a partir da laje de regularização

Figura 98 - Seções típicas das estruturas com as linhas de injeção triplas e de consolidação, na região da ombreira direita e tomada d'água.
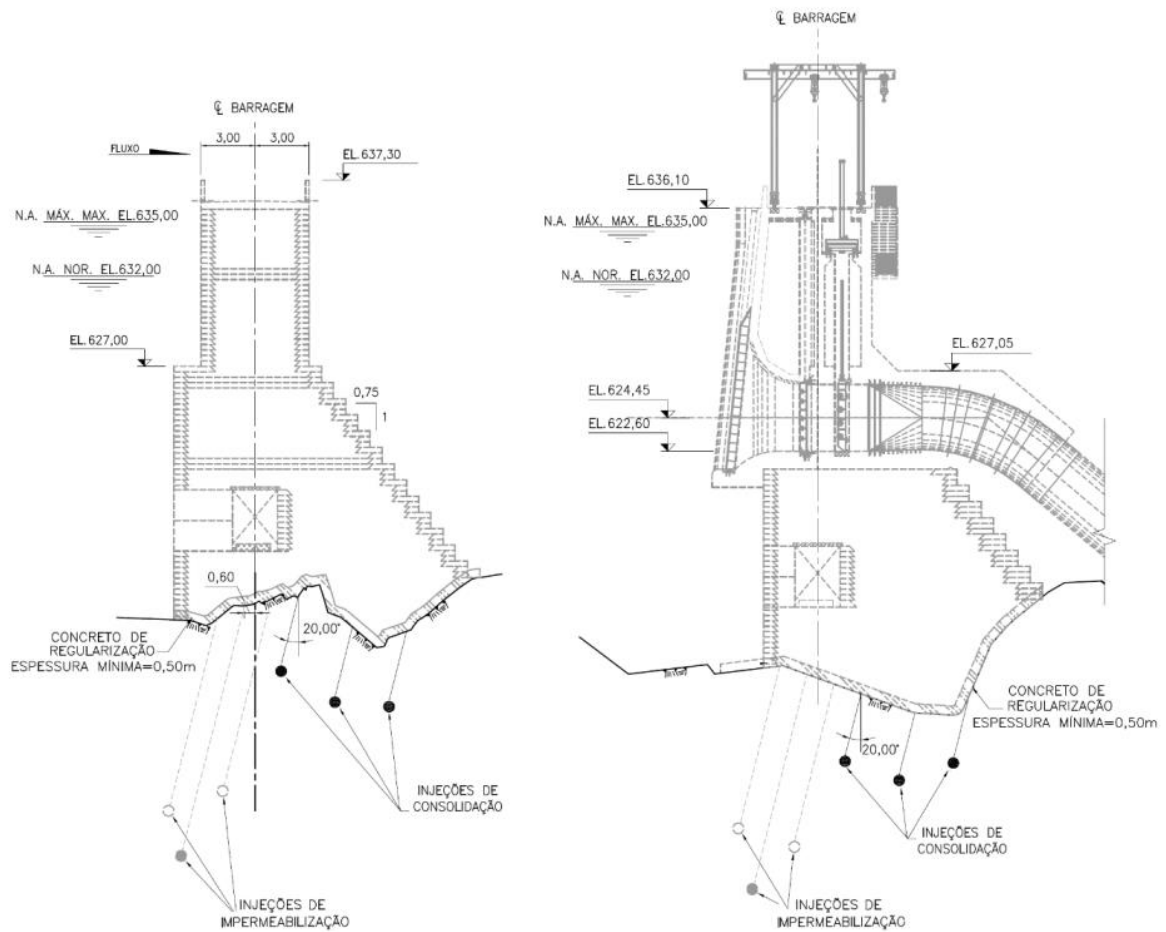

Fonte: Adaptado de Mata Velha Energética S.A. (2016). 
Figura 99 - Injeções de calda de cimento na margem direita: a) Trecho regularizado com furos das injeções de consolidação. d) Injeção de consolidação por gravidade. c) Execução de furos. d) Injeção de calda de cimento de impermeabilização sob pressão.

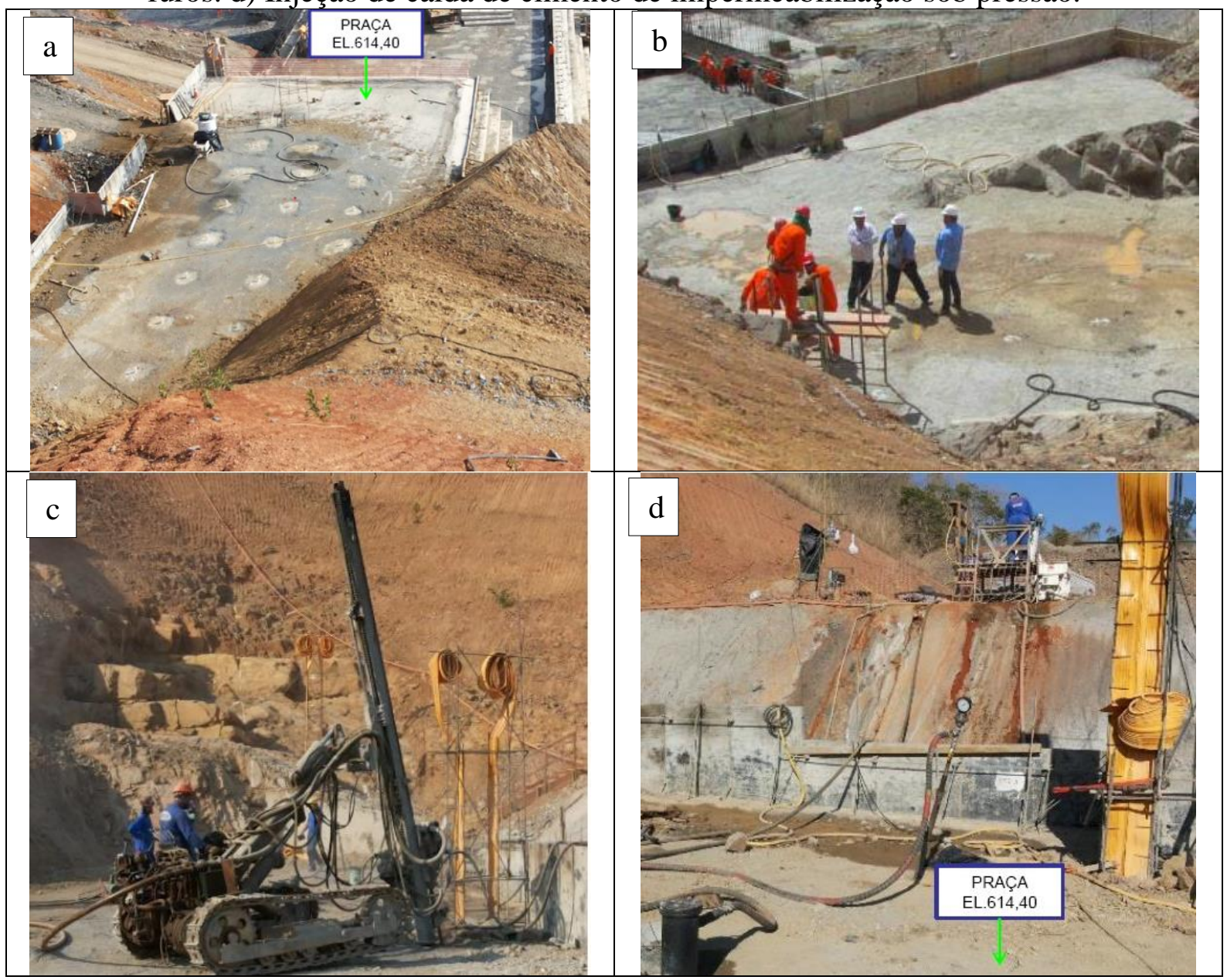

Fonte: Mata Velha Energética S.A. (2016).

Na parte alta da Margem Direita a linha de injeção foi tripla, com furos até a ordem quaternária na barragem de fechamento, com absorções baixas $<20 \mathrm{~kg} / \mathrm{m}$, porém com 3 passagens $>50 \mathrm{~kg} / \mathrm{m}$. Além das 3 linhas de injeção foram executadas injeções de consolidação a jusante, com absorções $>50 \mathrm{~kg} / \mathrm{m}$ e casos localizados de absorções $>500 \mathrm{~kg} / \mathrm{m}$.

As injeções também são em 3 linhas na área do Vertedouro e da Tomada de Água, complementadas com injeções a jusante que ainda contém trechos de grandes absorções $>500$ $\mathrm{kg} / \mathrm{m}$. A partir da Tomada de Água, as injeções prosseguem em linha única, indo até as terciárias. Na Figura 100 é possível visualizar a planta geral dos furos de injeção, com destaque para os furos de consolidação na margem direita já com indicação de consumo, e a seção longitudinal A-A, considerando as injeções dos furos das linhas mais a montante.

Na Figura 101 é apresentada a seção geológico-geotécnica com a sobreposição do 
consumo de calda de cimento das injeções, enquanto na Figura 102 é apresentada a seção do consumo de calda de cimento com a projeção da descontinuidades sub-horizontais mapeadas na fundação. A partir da sobreposição das descontinuidades sub-horizontais é possível observar que há relação entre os trechos com tomadas de calda elevadas e essas feições, onde vários trechos nos blocos 2 e 3 tiveram consumo $>500 \mathrm{~kg} / \mathrm{m}$. Nos blocos 4 a 8 as absorções já são de forma geral menores, corroborando a melhor qualidade do maciço nesse trecho, já não havendo consumos extremamente elevados $(>500 \mathrm{~kg} / \mathrm{m})$.

No geral, o consumo de calda de cimento por si só, já indica que o maciço rochoso tem passagens preferenciais de água, ou planos mais permeáveis de fluxo. Na Tabela 17 são apresentados os registros de obra, tendo por base as injeções de calda de cimento para impermeabilização e consolidação das estruturas de concreto.

Tabela 17 - Registro das injeções: comprimento perfurado e consumo de cimento.

\begin{tabular}{|c|c|c|c|c|}
\hline Estrutura & Estaca & $\begin{array}{l}\text { Comprimento } \\
\text { perfurado (m) }\end{array}$ & $\begin{array}{l}\text { Consumo de } \\
\text { cimento (ton) }\end{array}$ & $\begin{array}{c}\text { Absorção (*) } \\
(\mathrm{kg} / \mathrm{m})\end{array}$ \\
\hline $\begin{array}{l}\text { Barragem de Concreto Margem } \\
\text { Esquerda (Blocos } 7 \text { e } 8)\end{array}$ & $7+11,7$ a $9+19,6$ & 496 & 10 & 20 \\
\hline $\begin{array}{l}\text { Vertedouro e Adufas de Desvio } \\
\text { (Bloco 6) }\end{array}$ & $6+7,00$ a $7+11,7$ & 570 & 25 & 44 \\
\hline $\begin{array}{c}\text { Barragem de Concreto Margem } \\
\text { Direita e Tomada de Água (Blocos } \\
1 \text { a 5) }\end{array}$ & 0 a $6+7,00$ & 2413 & 80 & 33 \\
\hline $\begin{array}{c}\text { Furos de Consolidação } \\
\text { (Blocos } 1 \text { a 3) }\end{array}$ & - & 403 & 47 & 116 \\
\hline TOTAL & & 3.883 & 162 & 42 \\
\hline
\end{tabular}

Nota: (*) Absorção: Kg de cimento/metro perfurado.

Fonte: Mata Velha Energética S.A. (2016). 


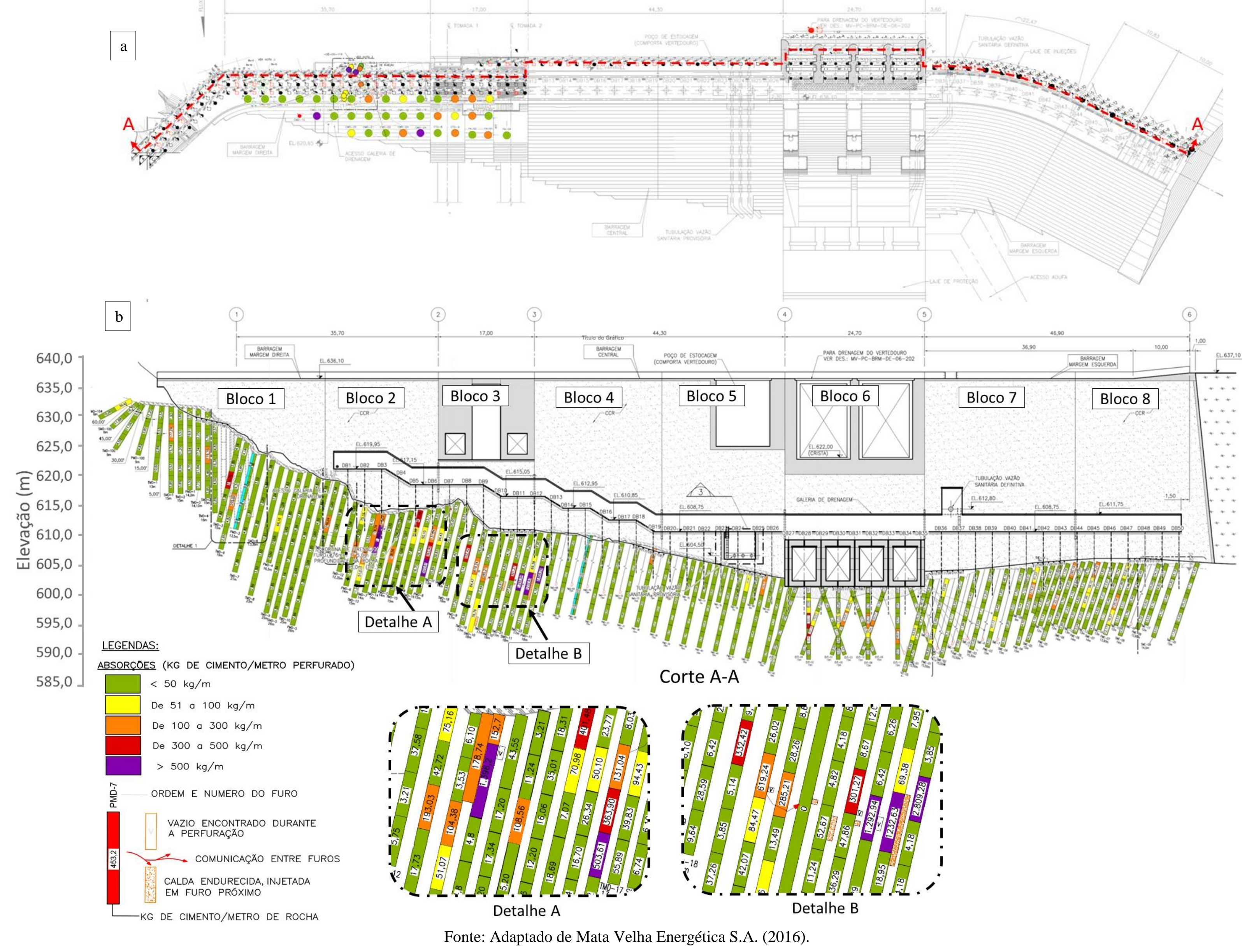

Fonte: Adaptado de Mata Velha Energética S.A. (2016). 


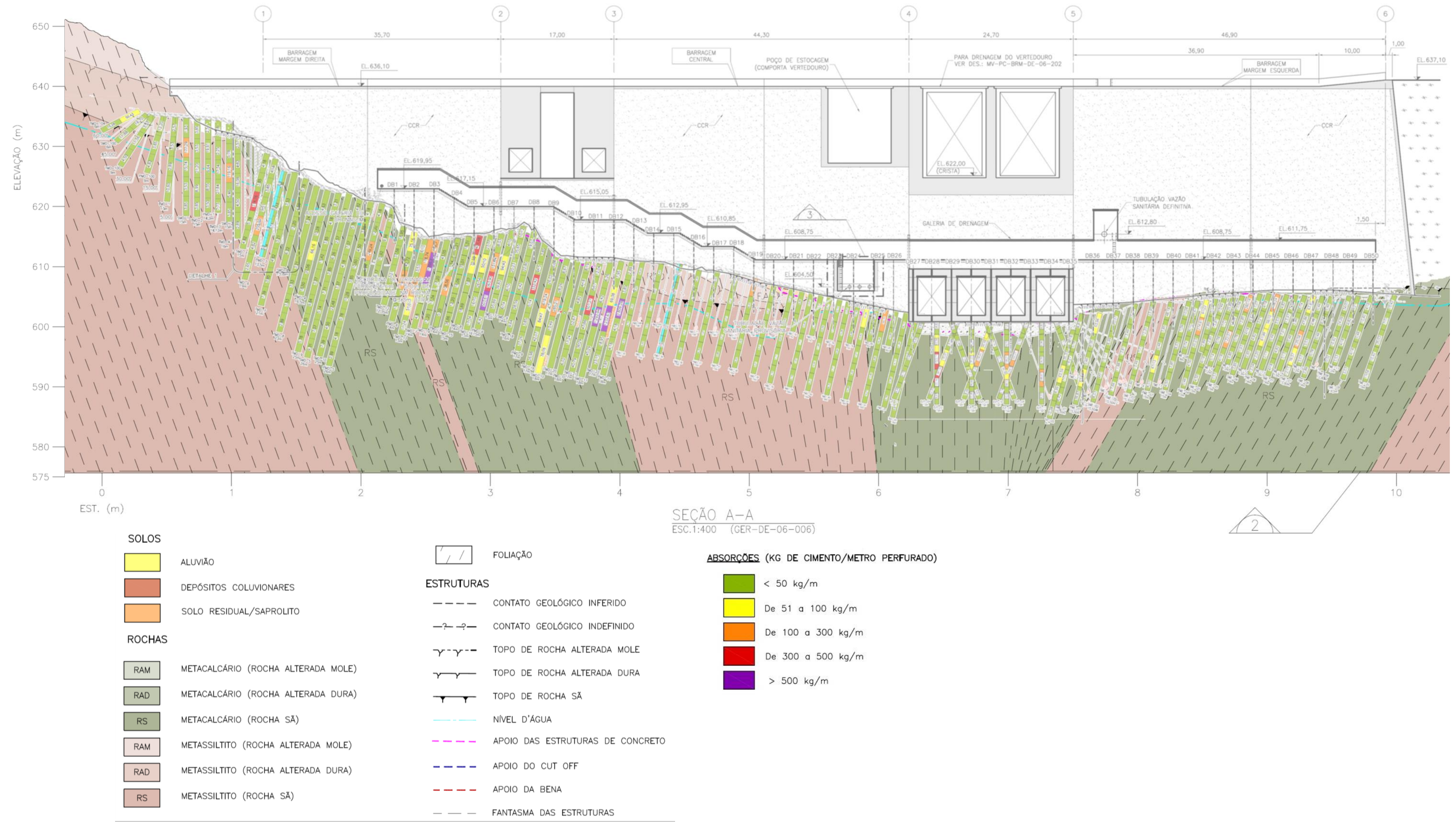

Fonte: Adaptado de Mata Velha Energética S.A. (2016). 


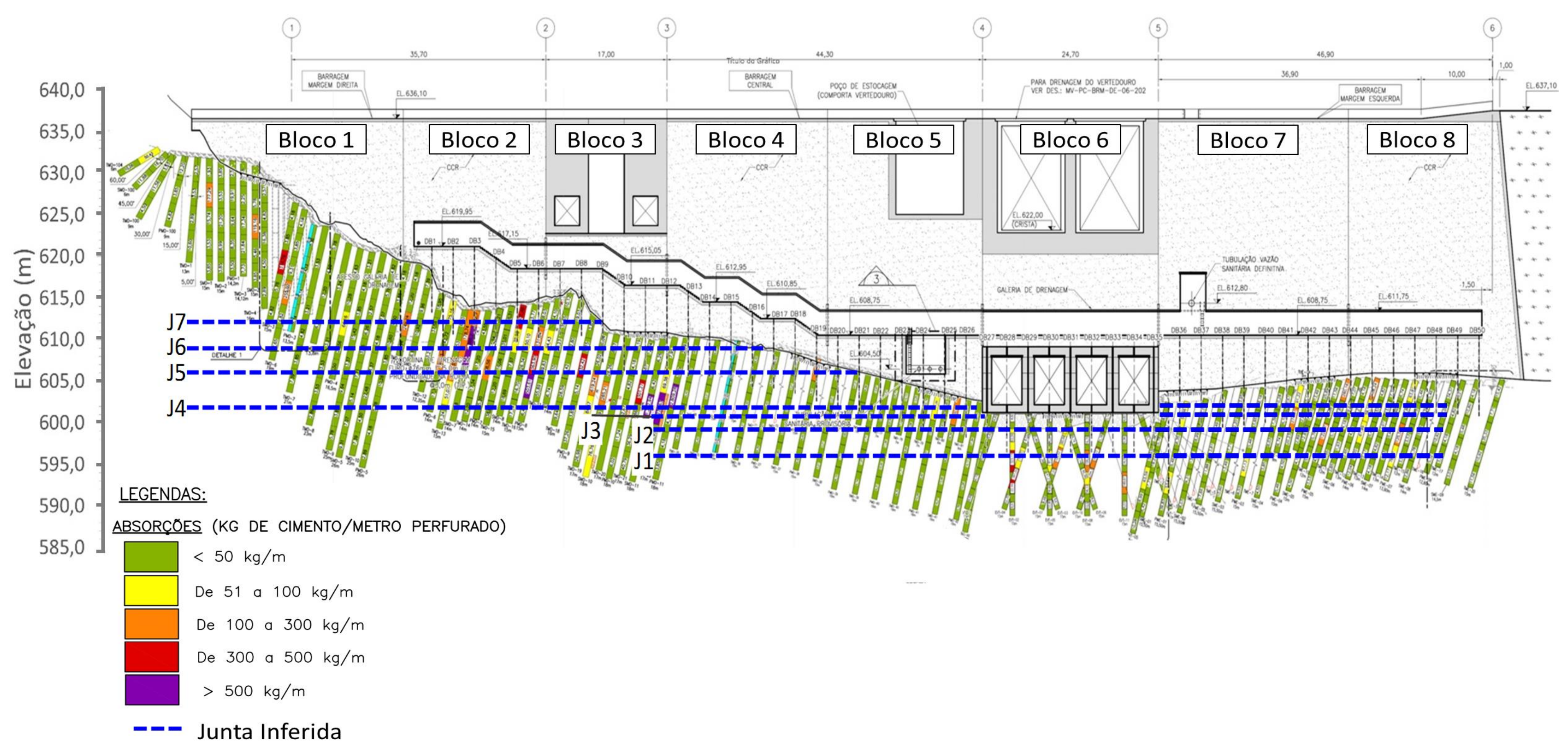

Fonte: Adaptado de Mata Velha Energética S.A. (2016) 


\subsection{ANÁLISE DA INSTRUMENTAÇÃO}

Neste item apresenta-se a análise da instrumentação de auscultação das estruturas de concreto da Barragem, considerando as observações nas fases de enchimento e primeiros anos de operação. Para a instrumentação da barragem em CCR e de suas fundações, foram instalados Piezômetros tipo standpipe, Medidores de Vazão, Marcos Superficiais, Medidores Triortogonais e Extensômetros Múltiplos de Haste, conforme apresentado no Quadro 6 e Figuras Figura 103 e Figura 104 seguir.

Quadro 6 - Lista de instrumentos instalados nas estruturas de concreto.

\begin{tabular}{|c|c|c|c|c|}
\hline Instrumento & Parâmetro & $\begin{array}{c}\text { Unidade de } \\
\text { Medida }\end{array}$ & Sigla & Quantidade \\
\hline $\begin{array}{c}\text { Piezômetros } \\
\text { Standpipe }\end{array}$ & $\begin{array}{c}\text { Subpressões no contato } \\
\text { concreto/rocha e maciço rochoso de } \\
\text { fundação }\end{array}$ & m.c.a. & PZ & 20 \\
\hline $\begin{array}{c}\text { Medidores de } \\
\text { Vazão }\end{array}$ & $\begin{array}{c}\text { Vazões através dos drenos de } \\
\text { fundação e infiltrações pela } \\
\text { estrutura de concreto }\end{array}$ & $1 /$ min & MV & $3(*)$ \\
\hline Marcos Superficiais & $\begin{array}{c}\text { Deslocamentos da estrutura de } \\
\text { concreto }\end{array}$ & $\mathrm{mm}$ & $\mathrm{MS}$ & $\mathbf{2}$ \\
\hline $\begin{array}{c}\text { Medidores } \\
\text { Triortogonais de } \\
\text { Junta Entre Blocos }\end{array}$ & $\begin{array}{c}\text { Deslocamentos diferenciais entre } \\
\text { blocos das estruturas de concreto } \\
\text { (deslizamento; recalque; } \\
\text { abertura/fechamento) }\end{array}$ & $\mathrm{mm}$ & $\mathrm{EH}$ & 5 \\
\hline $\begin{array}{c}\text { Extensômetros } \\
\text { Múltiplos de Haste }\end{array}$ & $\begin{array}{c}\text { Deslocamentos da fundação } \\
\text { (distensão/compressão) }\end{array}$ & $\mathrm{mm}$ & $\mathbf{3 7}$ \\
\hline \multicolumn{2}{|c|}{ TOTAL } & & 7 \\
\hline
\end{tabular}

Nota: (*) Um dos medidores foi instalado no talude externo da margem direita, a montante da Casa de Força. Fonte: Do Autor (2020). 
Figura 103 - Seção longitudinal e plano de instrumentação da barragem de concreto.

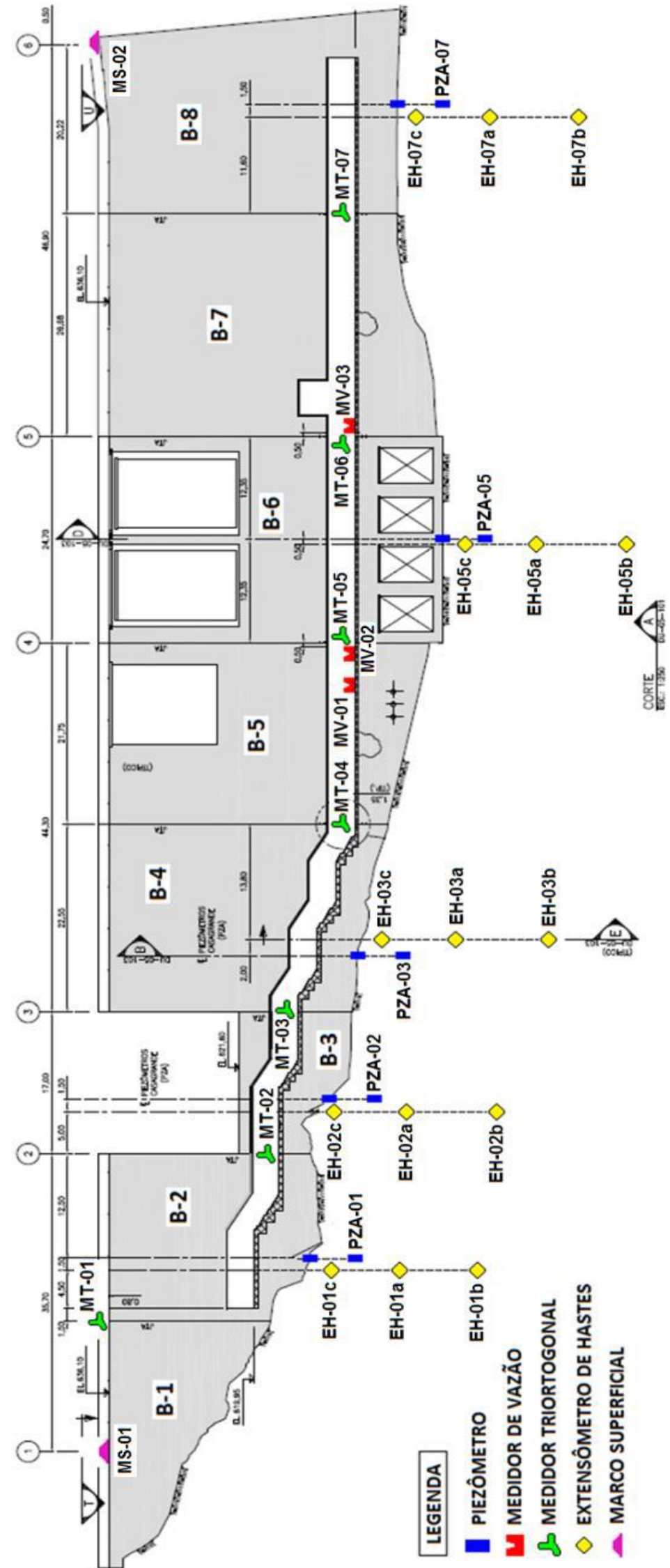

Fonte: Adaptado de Mata Velha Energética S.A. (2016). 
Figura 104 - Seção típica e posicionamento dos instrumentos.

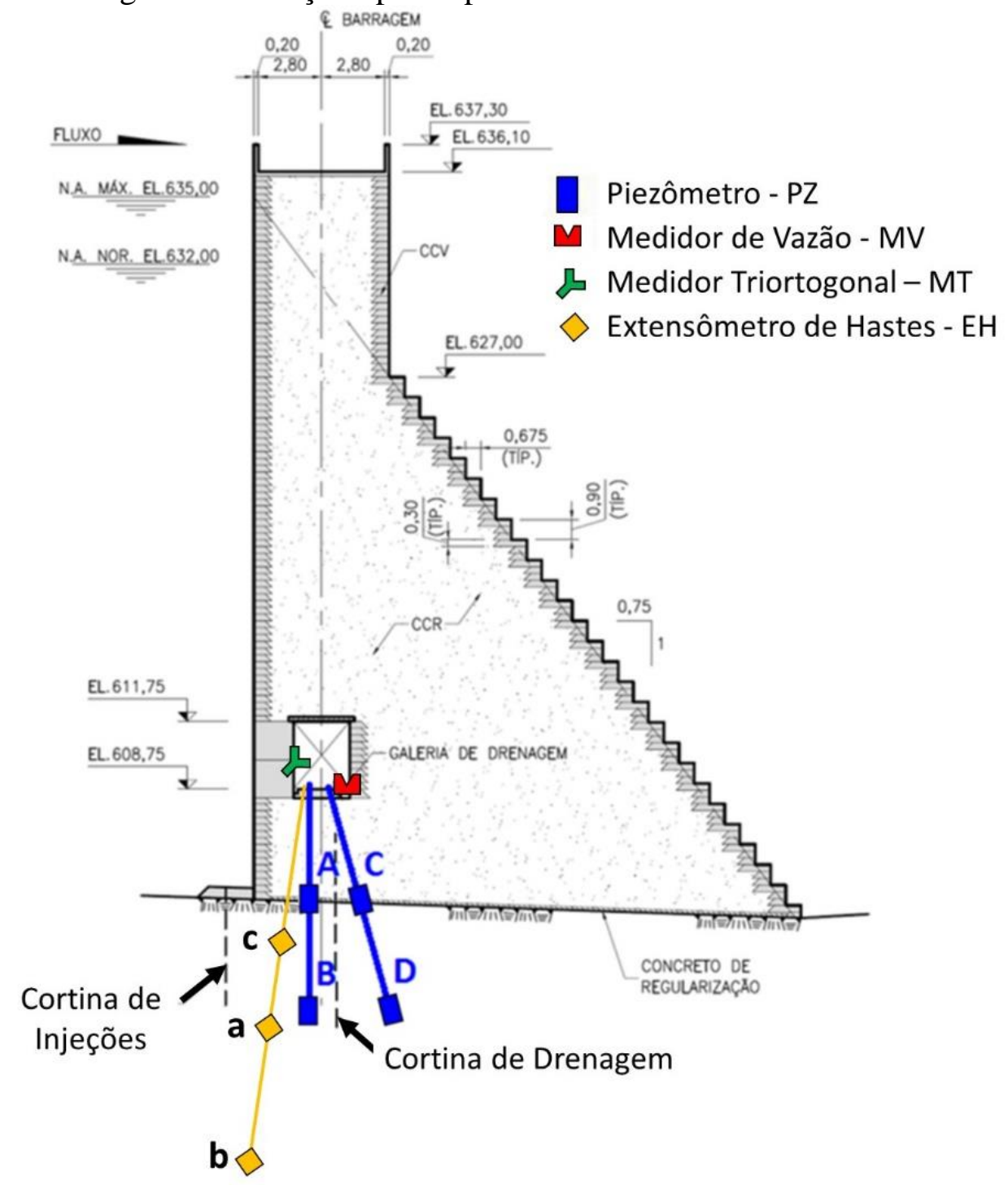

Fonte: Adaptado de Mata Velha Energética S.A. (2016).

\subsubsection{Piezômetros Standpipe (tubo aberto)}

Os Piezômetros standpipe - PZ foram instalados a partir da galeria de drenagem, em cinco seções distintas, a saber, nos blocos B-2, B-3, B-4, B-6 e B-8. Foram instalados 4 (quatro) piezômetros por seção, sendo dois mais profundos, e dois na interface concreto-rocha, como mostrado na Figura 105. 
Figura 105 - Seção típica com locação dos piezômetros.

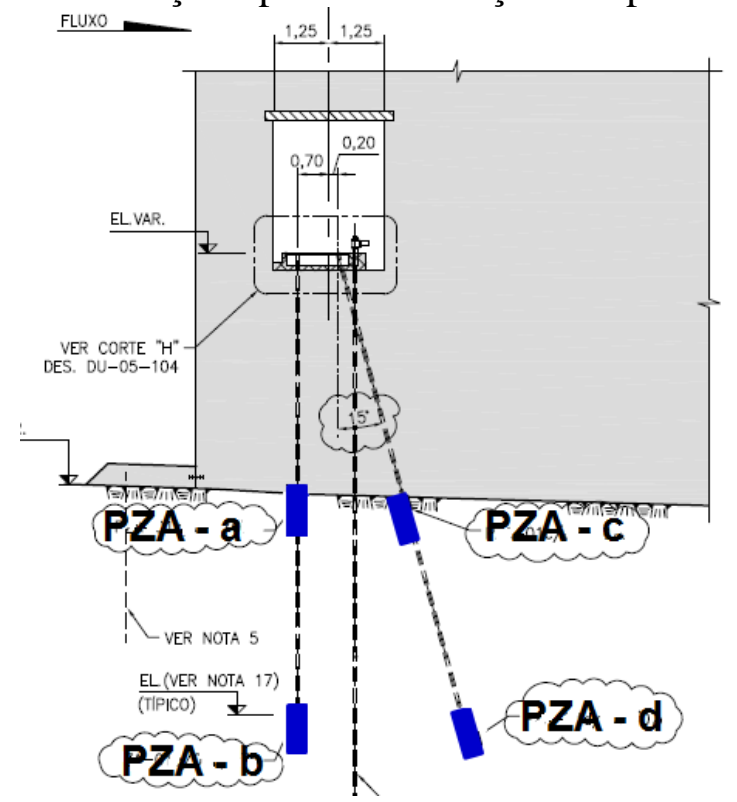

Fonte: Adaptado de 1384-MV-E-DE-B21-103-R100-R00).

Os PZ's foram instalados com o intuito de se avaliar as subpressões na fundação em rocha da das estruturas de concreto a montante (denominados "a" e "b") e a jusante da cortina de drenagem (denominados "c" e "d"). Dois piezômetros se encontram sempre com seus bulbos no contato concreto/rocha ("a" e "c"), enquanto os outros dois avaliam as subpressões em maior profundidade ("b" e "d"), com o bulbo um pouco acima da extremidade inferior da cortina de drenagem, ou pelo menos na mesma cota.

Em função do tipo de terminal utilizado para leitura dos piezômetros (Figura 106), dotado de várias conexões e apenas um manômetro para leitura de quatro piezômetros, julgase que as subpressões medidas ao final do enchimento não foram realistas, uma vez que, conforme as subpressões atingiam as cotas do piso da galeria, as mesmas passaram a se "estabilizar" (Figura 107). As subpressões provavelmente atingiram níveis mais elevados, as quais não puderam ser medidas de forma adequada. Na Figura 107 é apresentado o gráfico das leituras dos piezômetros do bloco 3, com a indicação da cota do piso da galeria e a projeção estimada das subpressões, considerando as leituras iniciais e uma correlação direta com os níveis do reservatório. 
Figura 106 - Vista do terminal dos piezômetros antes do enchimento, com várias conexões e apenas um manômetro para leitura de quatro piezômetros.

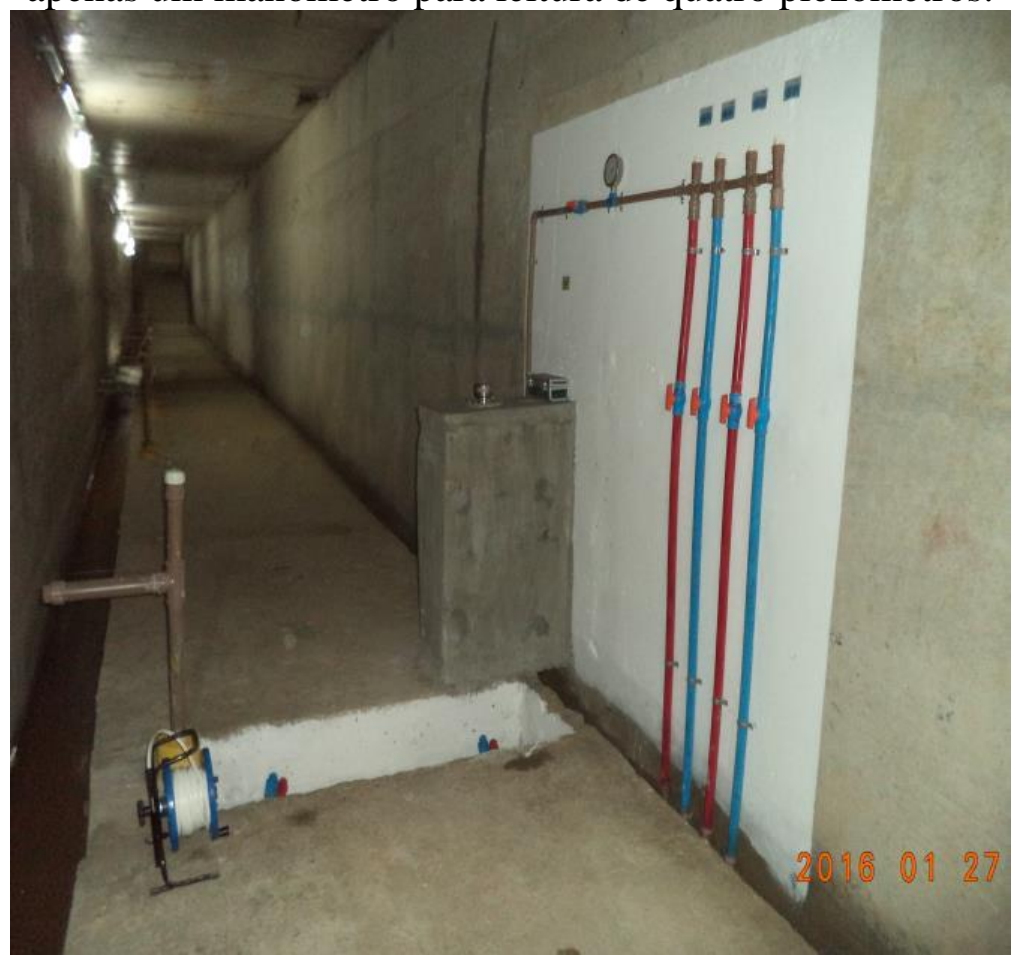

Fonte: Dumont (2016).

Figura 107 - Gráfico das leituras dos piezômetros localizados no Bloco B-4 da barragem de concreto durante o enchimento do reservatório. Em tracejado são indicadas as projeções possíveis das subpressões.

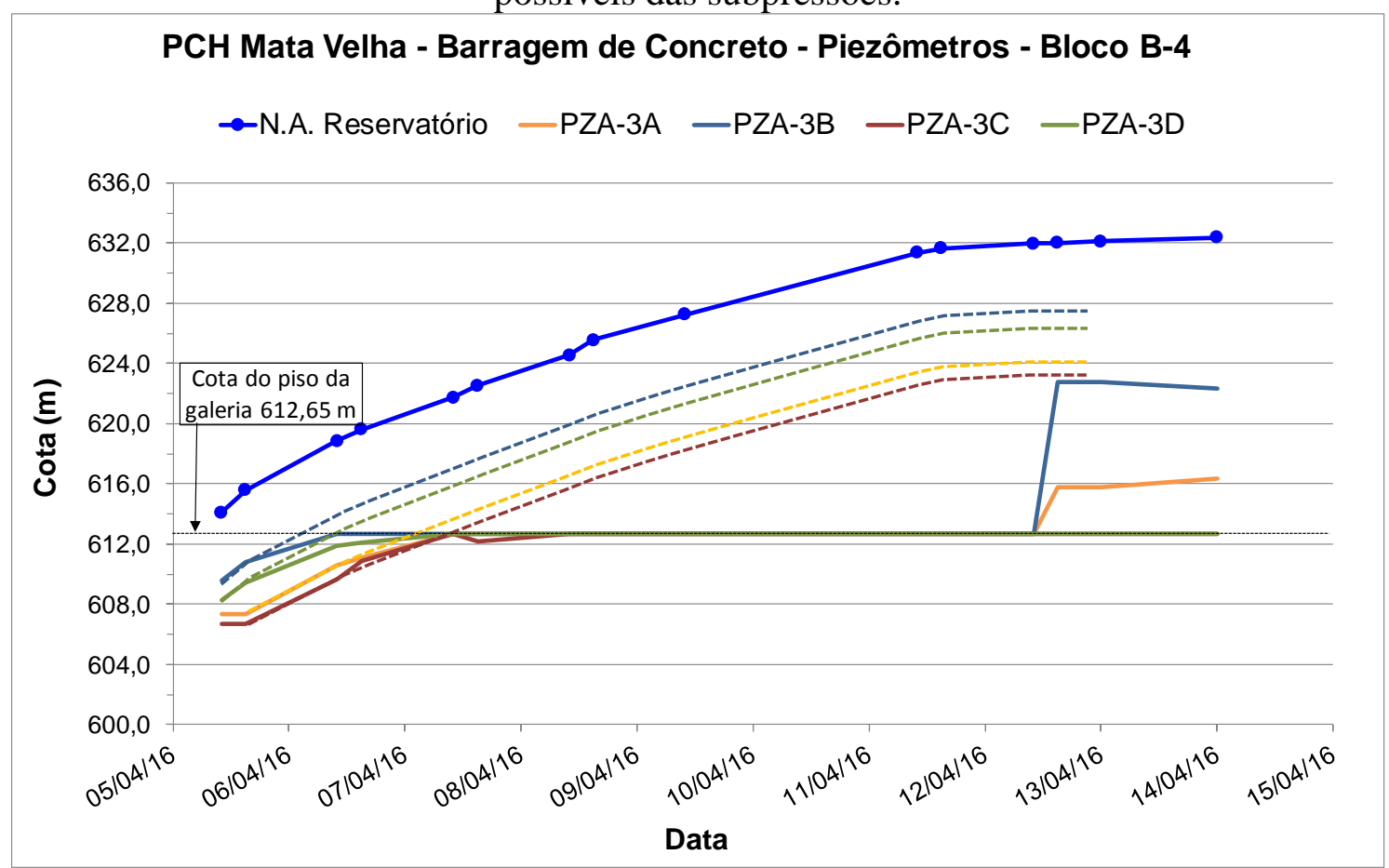

Fonte: do Autor (2020). 
Modificações junto aos terminais foram realizadas, os manômetros instalados nos piezômetros que não apresentavam carga foram removidos, verificando-se a cota do nível d'água em cada um deles. Posteriormente verificou-se a necessidade de instalação de mangueiras em alguns deles, para medição de níveis piezométricos até 2,0 $\mathrm{m}$ acima da cota dos respectivos tubos. Na Figura 108 são ilustrados os procedimentos de leitura que podem ser empregados, dependendo da subpressão.

Figura 108 - Exemplo dos tipos de leituras utilizadas nos piezômetros.

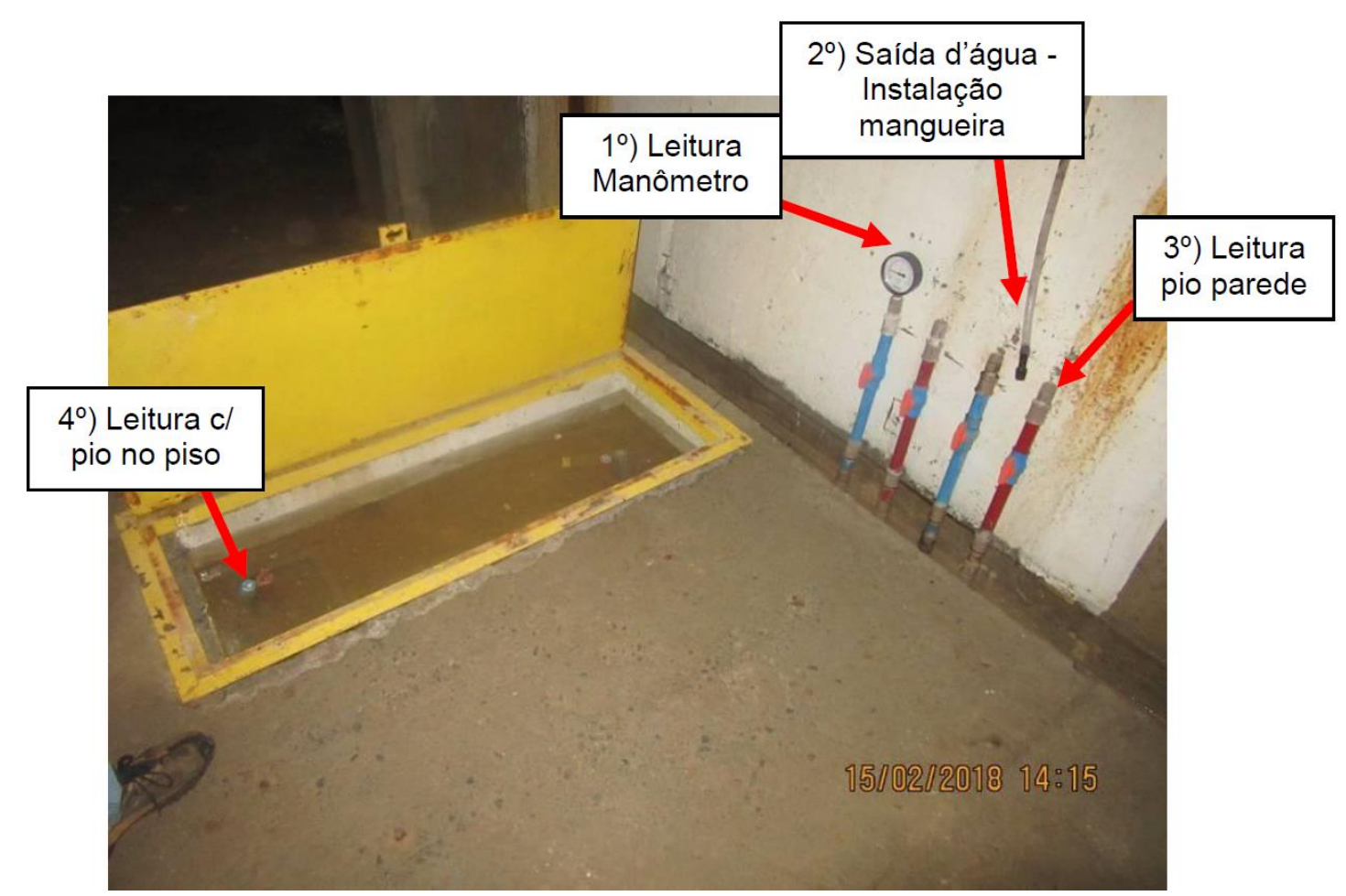

Fonte: do Autor (2019).

Todos os piezômetros responderam rapidamente ao enchimento do reservatório, sendo observadas as maiores subpressões geralmente nos piezômetros de montante (PZ-A e PZ-B), conforme seria de se esperar, entretanto, conforme comentado anteriormente julga-se que as subpressões máximas do enchimento não puderam ser registradas adequadamente. O que pode ser observado é que as subpressões, após um pico em função do enchimento do reservatório, apresentaram rápida redução. Como ilustração, na Figura 109 apresentam-se as cotas piezométricas (subpressões) medidas pelos piezômetros instalados no bloco B-3. Como a usina opera a fio d'água, o nível do reservatório praticamente não apresenta variações. 
Figura 109 - Gráfico das leituras dos piezômetros localizados no Bloco B-3 da barragem de concreto.

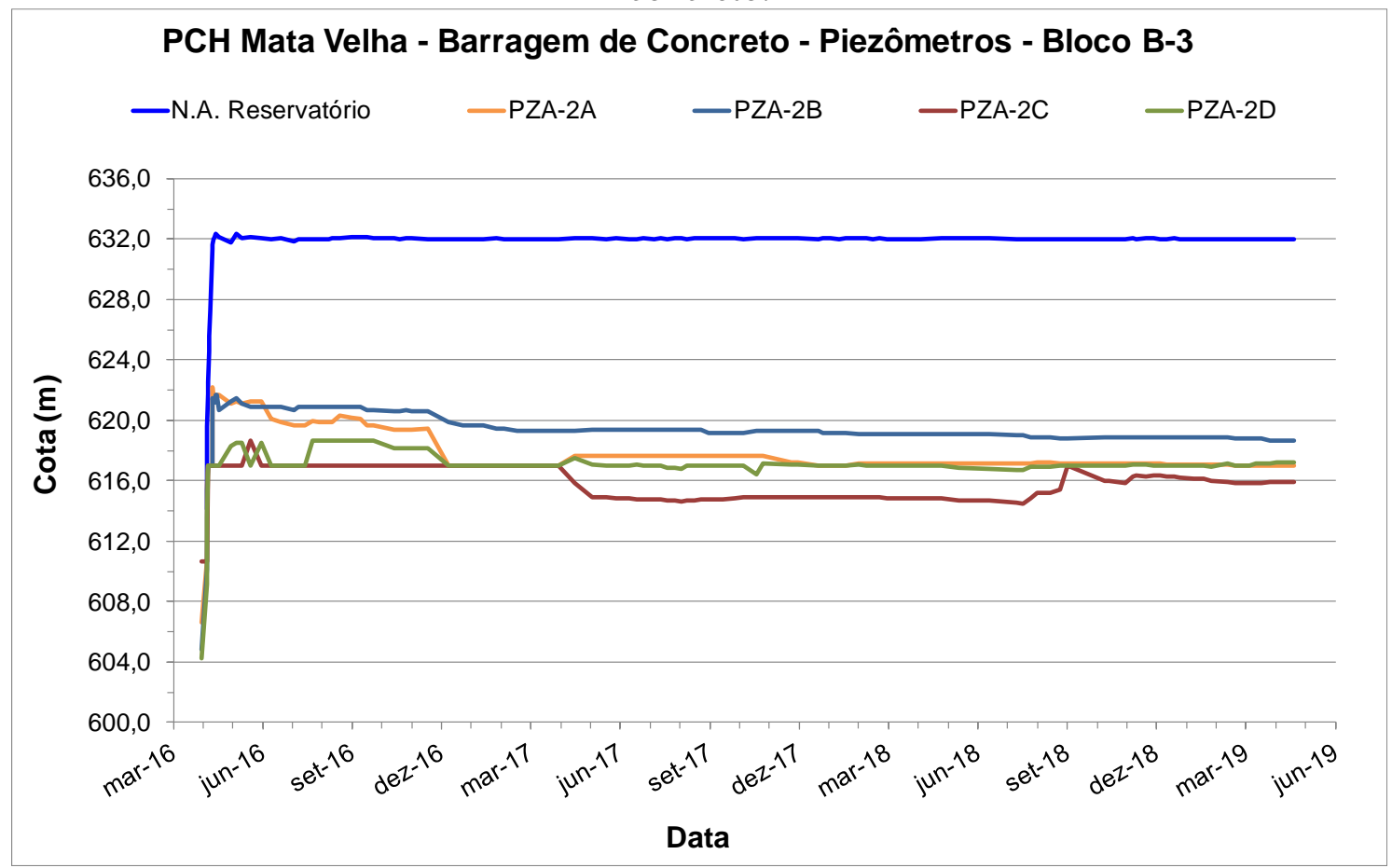

Fonte: do Autor (2019).

Na Figura 110 apresenta-se uma comparação dos níveis piezométricos medidos em 05/04/2019 com os Valores de Controle (Atenção e Alerta), tendo por base os estudos de estabilidade das estruturas de concreto, considerando os Casos de Carregamento Normal - CCN e Excepcional - CCE

Os piezômetros mantiveram-se sempre abaixo dos valores de controle, julga-se que após o pico das subpressões durante o enchimento houve rápida redução das mesmas, observando posteriormente, alguma redução lenta das supressões ao longo dos anos, em praticamente todos os piezômetros, 
Figura 110 - Comparação entre níveis piezométricos medidos (Abril/19) e Valores de Controle (Atenção e Alerta).

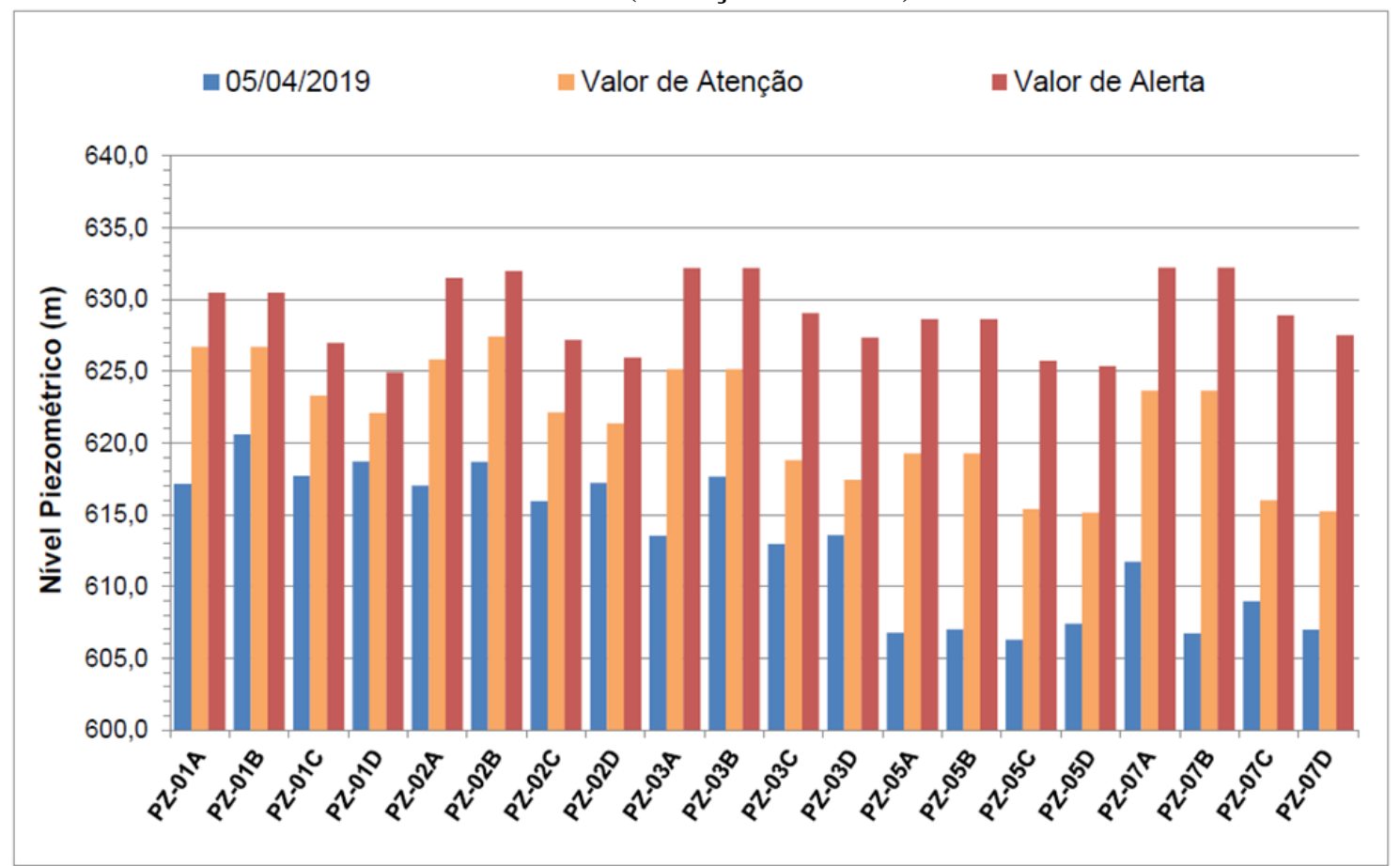

Fonte: do Autor (2019).

\subsubsection{Vazões de Drenagem - Medidores de Vazão}

Para medição das vazões pelos drenos e infiltrações da galeria de drenagem foram instalados inicialmente dois medidores de vazão do tipo triangular, os quais não englobavam as vazões dos drenos do bloco 6 (vertedouro) e não foram contabilizados no início das medições.

Durante o enchimento do reservatório, em Abril/2016, devido às altas vazões e dificuldades de esgotamento da galeria, os medidores ficaram afogados, conforme Figura 111. Assim, o sistema de esgotamento foi modificado, o que permitiu um melhor fluxo pelas canaletas. Foi adicionado um medidor de vazão, sendo necessária a mudança de fluxo da alguns medidores e de suas identificações. 
Figura 111 - Medidores de vazão afogados durante o enchimento do reservatório

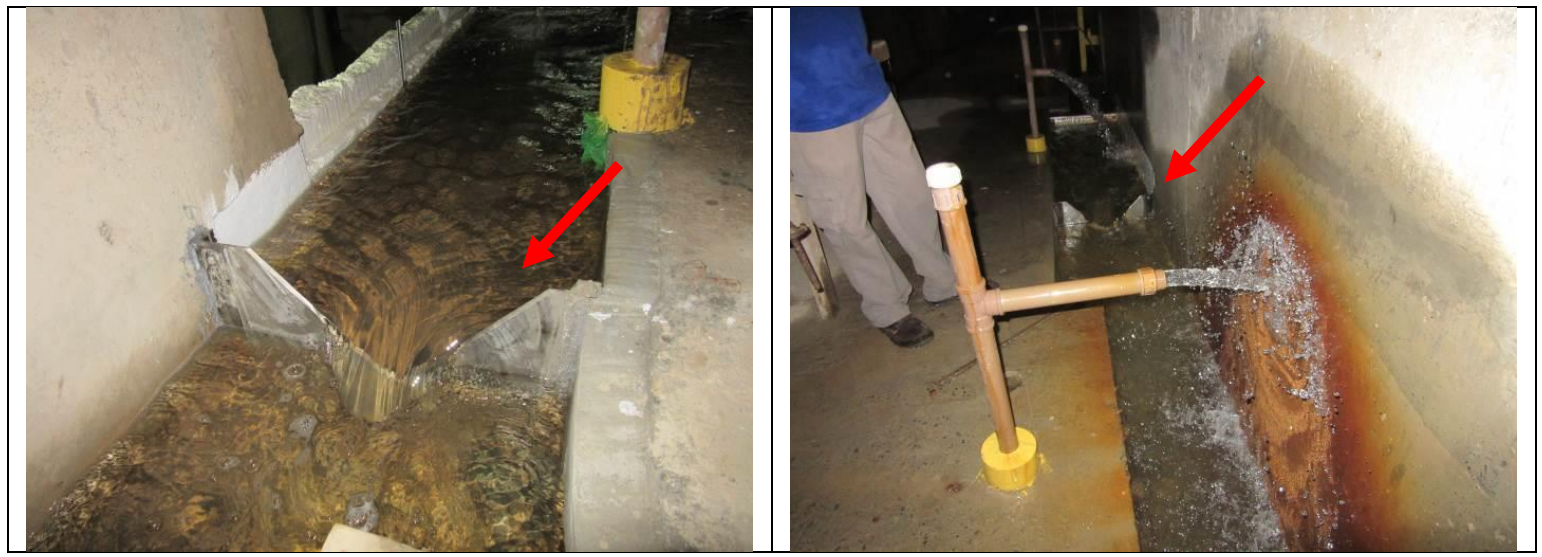

Fonte: do Autor (2016).

Após as modificações, foram definidos então 2 (dois) medidores de vazão na galeria de drenagem, sendo o MV-01 (MD) do tipo triangular e o MV-02 (ME) do tipo retangular, sendo que o MV-03 foi desativado em Dez/16 (Triangular).

Na Figura 112 apresenta-se o gráfico com as vazões da galeria de drenagem. Com o enchimento do reservatório as vazões totais, registradas pelos MV's 1 e 3 (antigo MV-02) atingiram valores de $1.577 \mathrm{1} / \mathrm{min}$. Observa-se que essa vazão não corresponde à vazão total da galeria, uma vez que havia um trecho com 30 m (bloco 6) sem medição de vazão. Tendo em vista o comprimento total da galeria de $\sim 137$ m e deixando de lado esse trecho sem medição, chega-se à vazão específica de $\sim 15$ 1/min/m, valor esse bastante elevado, quando comparado com valores de outras obras, acima do valor de Alerta (5,0 1/min/m).

As vazões, entretanto, passaram a diminuir de modo expressivo logo após o término do enchimento do reservatório, mantendo-se praticamente estabilizadas desde Jul/2017, ou seja, cerca de 1 ano e 3 meses após o pico do enchimento do reservatório

A vazão total atual galeria (MV-01 + MV-02) passou para valores da ordem de 130,0 $1 / \mathrm{min}$, que corresponde à vazão específica Qesp $=0,95 \mathrm{l} / \mathrm{min} / \mathrm{m}$, valor este que pode ser considerado adequado, abaixo do valor de Atenção $(2,0$ 1/min/m).

A título de exemplo apresenta-se na Figura 113 a redução de vazão no Dreno 35. Essa grande redução de vazão em apenas 1 ano e 3 meses não é comum, não tendo sido observada em outras barragens similares. 
Figura 112 - Gráfico das leituras dos Medidores de Vazão instalados na galeria de drenagem da barragem de concreto.

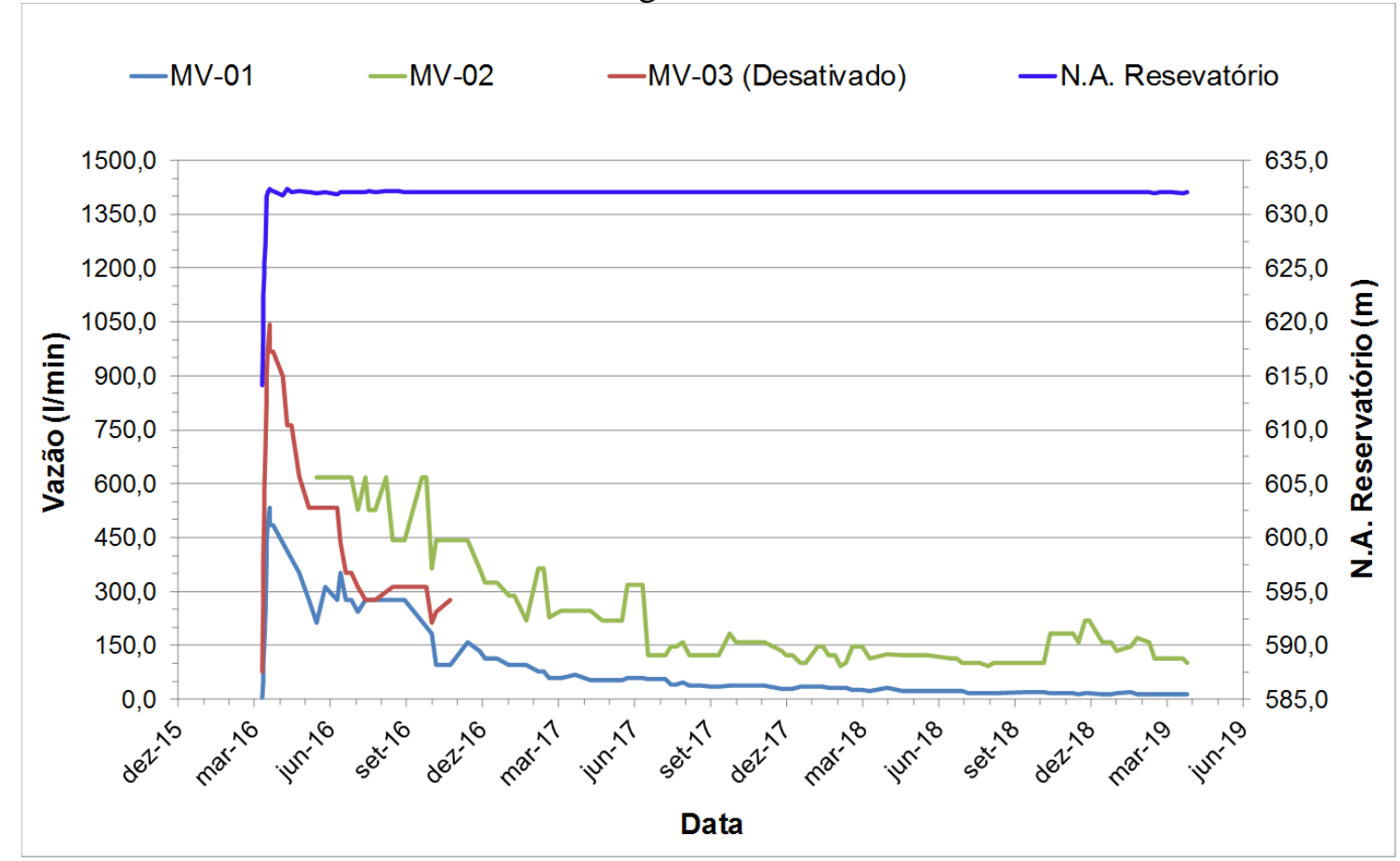

Fonte: do Autor (2019).

Figura 113 - Condição do dreno de fundação do Dreno 25 da barragem de concreto: a) Abril/2016 (pós enchimento); b) Abril/2017; c) Outubro/2017; d) Fevereiro/2018

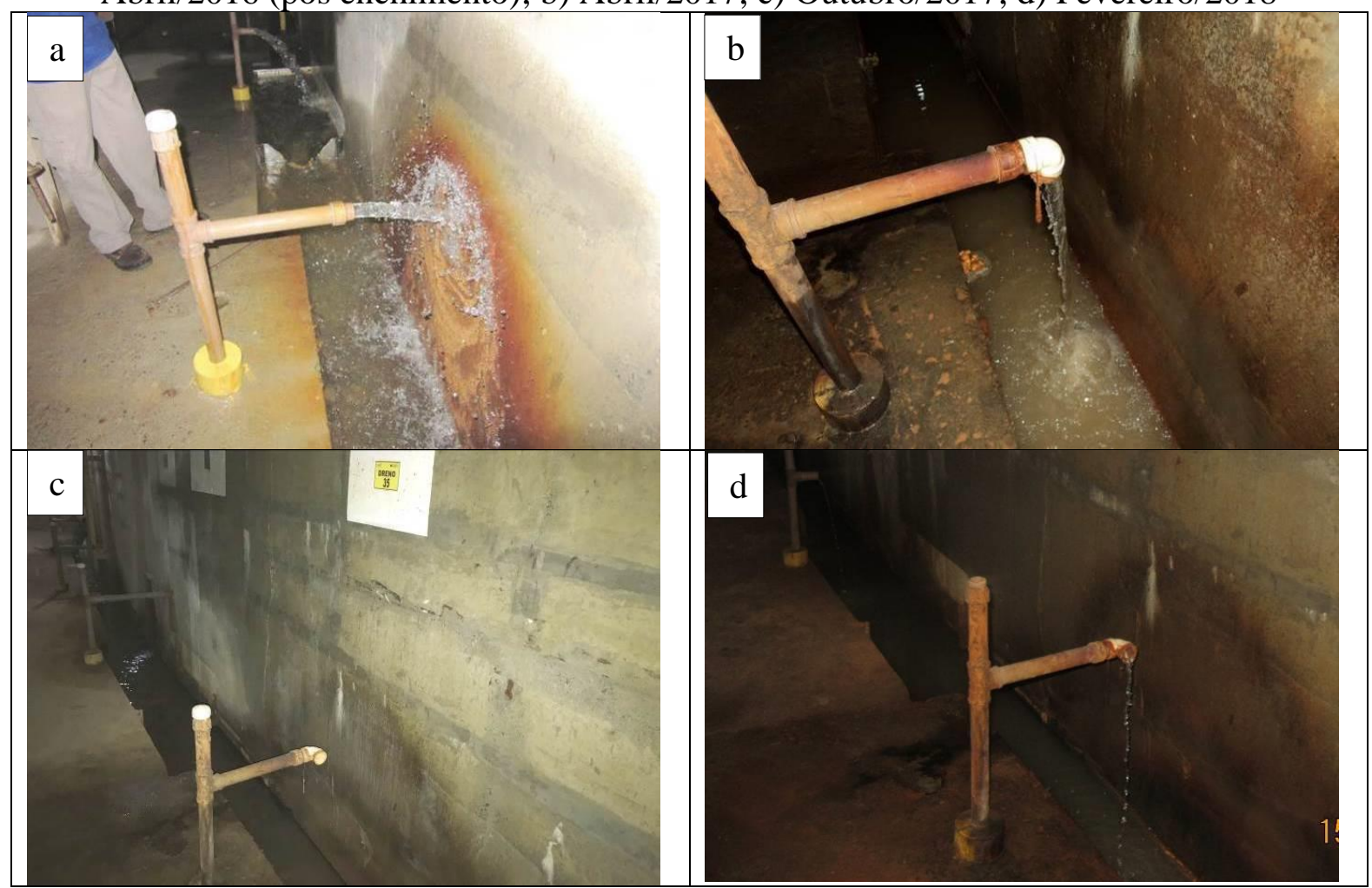

Fonte: do Autor (2020). 
Além das inspeções visuais junto às bocas dos drenos, foi realizada em Fev/18 a inspeção com câmera de TV em alguns drenos, verificando-se que alguns deles se encontravam com depósitos de carbonatos de magnitude considerável, conforme mostrado nas Figura 114.

Figura 114 - Depósitos de carbonato nos drenos: a) Conexão de dreno de fundação 6 meses após enchimento; b) Detalhe da saída de dreno de fundação com o depósito de carbonato, cerca de 1 ano após o enchimento. c) e d) Dreno do depósito de carbonato nas paredes, abaixo do nível d'água.

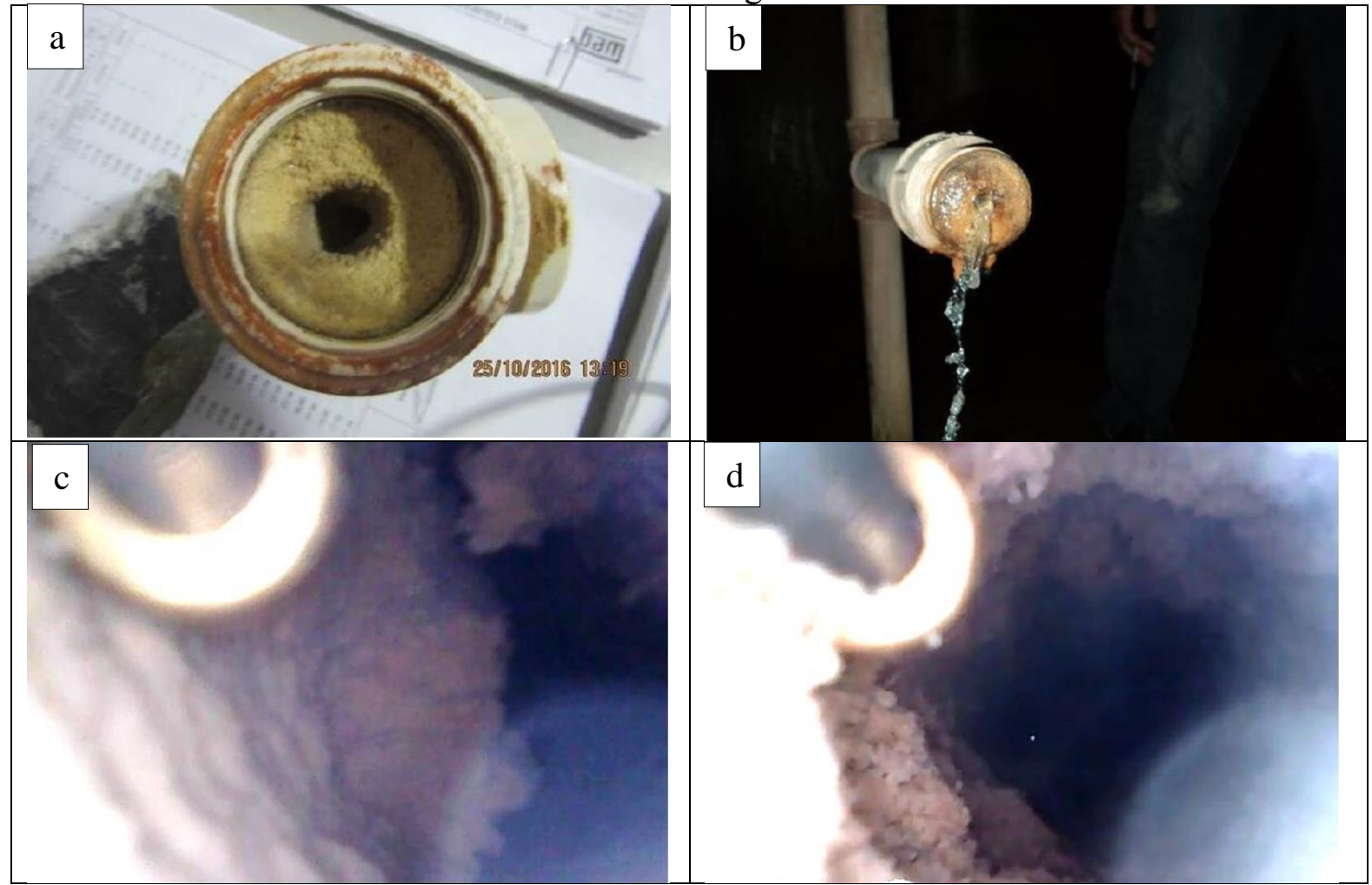

Fonte: do Autor (2020).

As altas vazões, inicialmente observadas através dos drenos de fundação da galeria, teriam ocorrido em função, aparentemente, das características do maciço rochoso de fundação, constituído essencialmente por meta-calcários e meta-siltitos, com comportamentos bastante peculiares.

Uma hipótese para a rápida redução das vazões poderia estar associada ao depósito de carbonato observada nos drenos de fundação, como uma possível influência, também, da origem geológica, formada por rochas calcáreas. Entretanto, a piezometria não indicou qualquer elevação das subpressões, pelo contrário, também mostrou alguma redução com o tempo, o que poderia ser associado à deposição de sólidos no fundo do reservatório ou processo de carbonatação dos caminhos de percolação pela rocha, ambos atuando no "fechamento" dos caminhos preferenciais de percolação na fundação. Outra hipótese poderia ser a formação de 
outros caminhos de percolação pelo maciço de fundação, em função de uma possível dissolução e carreamento de finos, aliviando assim a subpressão, com um fluxo pela fundação.

A carbonatação nos drenos de fundação chama atenção não apenas pela sua intensidade, mas também por ocorrer nos trechos abaixo do nível d'água, provavelmente em função do ar dissolvido na água e liberação de bolhas, ou funções ideais como pressão, $\mathrm{Ph}$, temperatura, etc.

Além dos medidores de vazão instalados na galeria de drenagem, foi instalado um medidor de vazão adicional para acompanhamento das vazões que percolavam a partir da rocha de fundação na ombreira direita e afloravam a montante/lateral da Casa de Força, conforme Figura 115.

Figura 115 - Foto aérea e local de instalação do medidor de vazão MV-4, para controle das infiltrações pelo talude de ombreira direita.

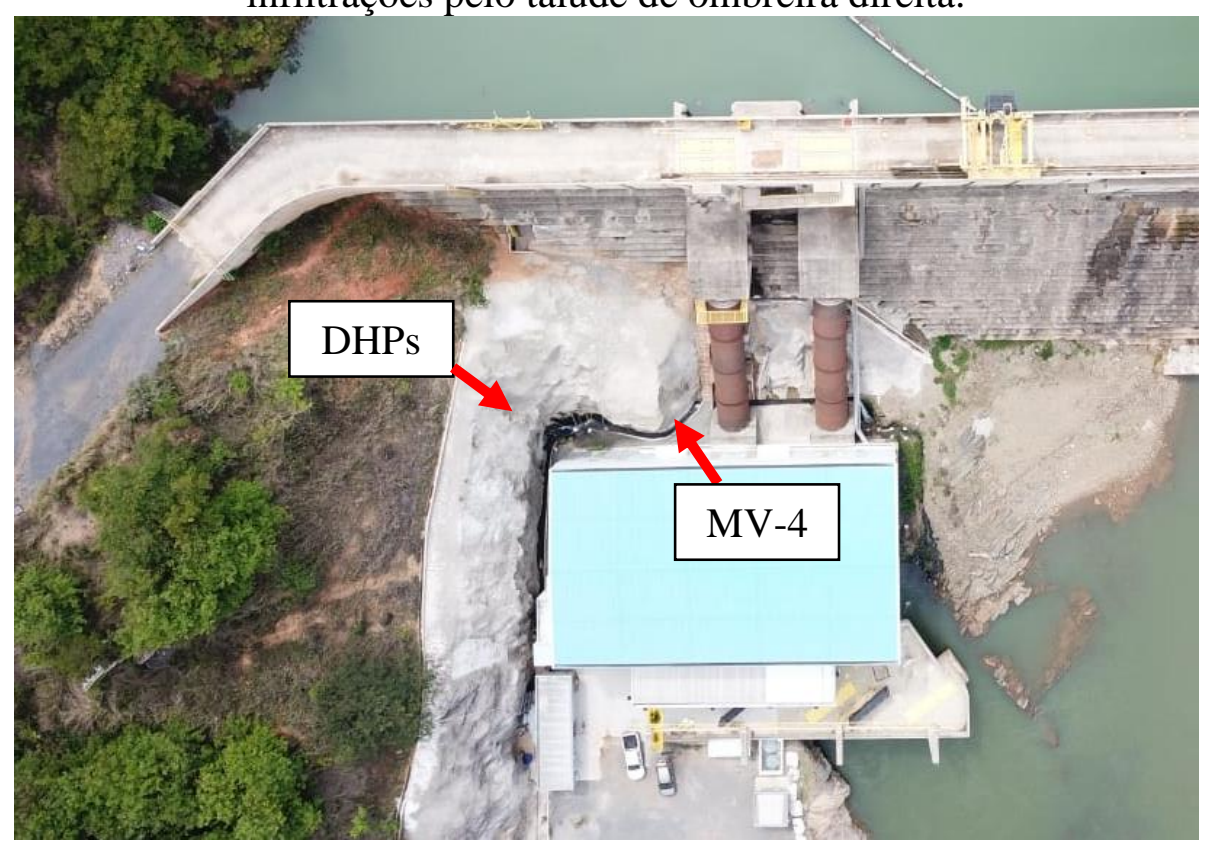

Fonte: do Autor (2020).

As vazões atingiram um máximo de 900 1/min reduzindo-se ao longo do tempo, até valores da ordem de 390 1/min. (Figura 116). Ressalta-se que o maciço rochoso da ombreira direita pode ser compreendido como a fundação dos blocos 1 e 2 da barragem de concreto. A redução de vazão apresentou a mesma intensidade das reduções observadas junto aos medidores de vazão da galeria. 
Figura 116 - Gráfico das leituras do Medidor de Vazão MV-4 instalado para controle da vazão pelo talude em rocha da ombreira direita.

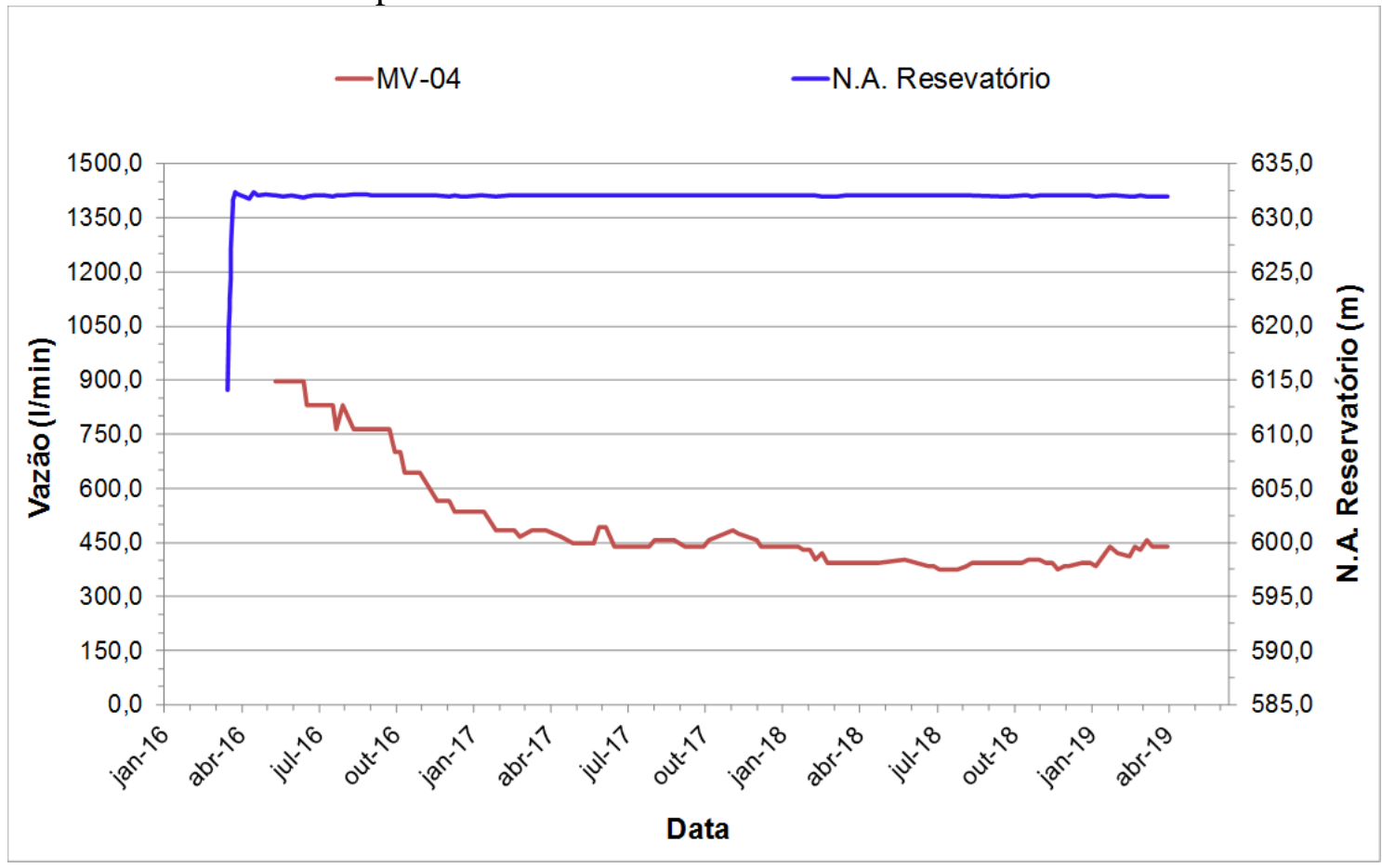

Fonte: do Autor (2019).

\subsubsection{Medidores Triortogonais de Junta entre Blocos da Estrutura de Concreto}

Os Medidores Triortogonais de Junta (Figura 117) foram instalados a cada junta de contração entre blocos da Barragem de Concreto, num total de 7 (sete) instrumentos, para acompanhar os deslocamentos diferenciais entre os blocos da barragem, nas três direções de interesse, a saber, "abertura ou fechamento da junta", "recalque diferencial entre blocos" e “deslizamento entre blocos".

Todos os medidores foram instalados na parede de montante da galeria de drenagem, a exceção do MT-01, instalado na crista, tendo em vista que a galeria não atingia a junta entre Blocos B-1/B-2.

Alguns medidores triortogonais, conforme observado nas Figura 118 a Figura 120 apresentaram rápida resposta ao enchimento do reservatório. O MT-01, instalado na crista da barragem, as maiores amplitudes de variação dos deslocamentos, principalmente no sentido de deslizamento horizontal, e de abertura/fechamento, com nítida influência da variação térmica (Figura 118). 
Figura 117 - Medidor triortogonal instalado na junta entre blocos, a partir da galeria de drenagem.

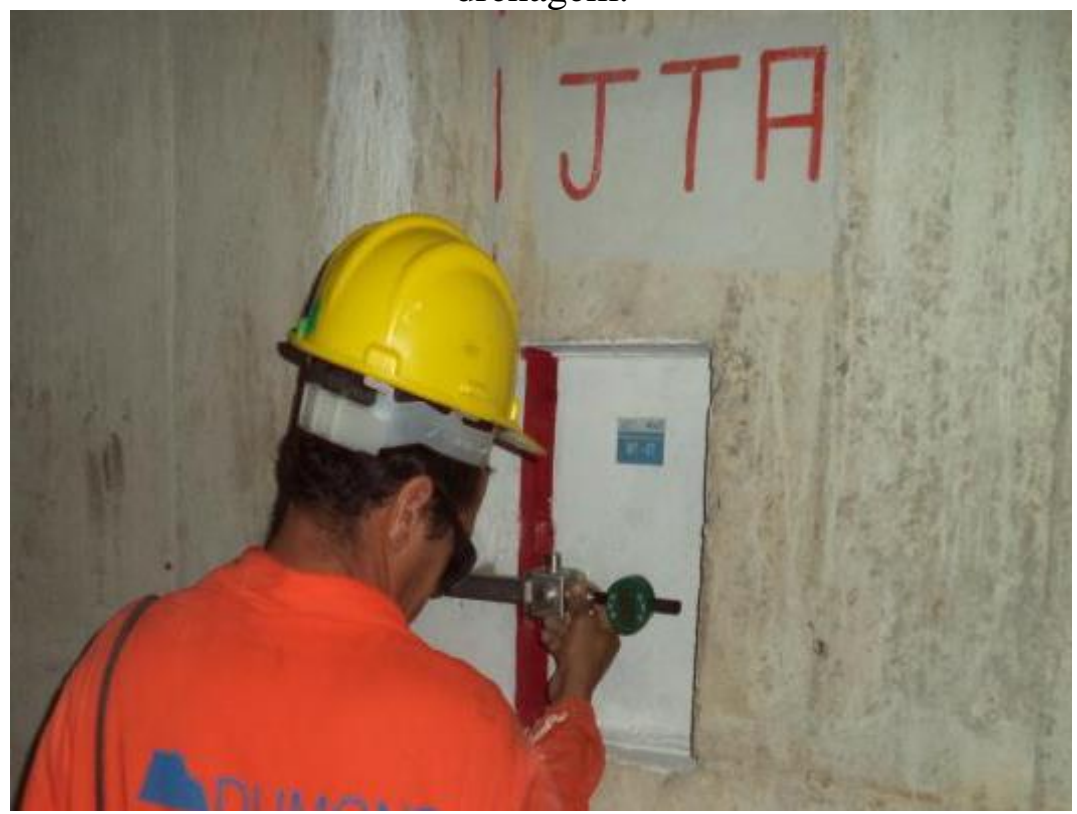

Fonte: Dumont (2016).

Figura 118 - Deslocamentos registrados junto ao medidor triortogonal de junta entre blocos MT-01, localizado na crista da barragem, na junta entre blocos B-1/B-2.

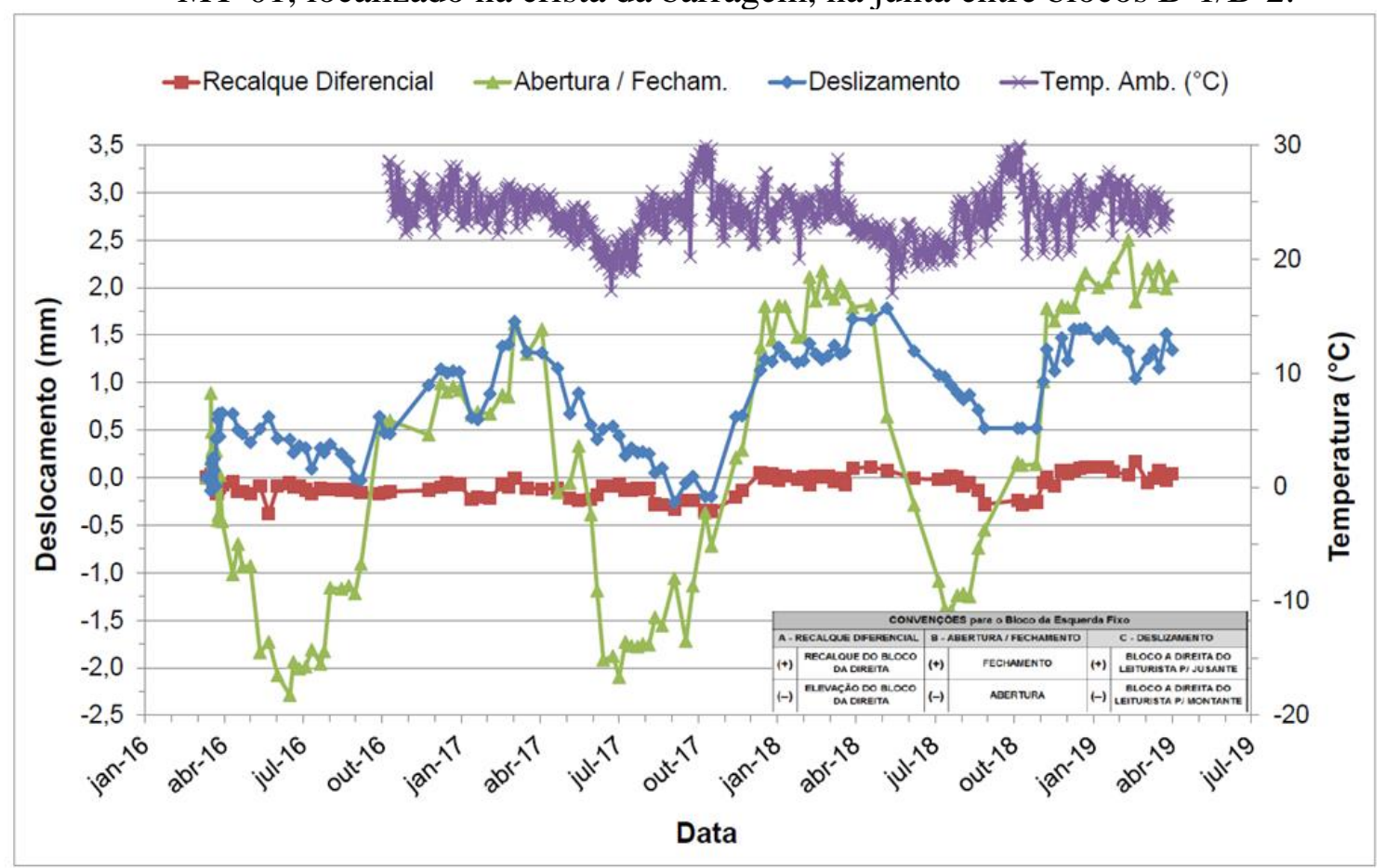

Fonte: do Autor (2019).

No MT-03 foram observados deslocamentos nas três direções referentes ao enchimento do reservatório, enquanto no MT-06, apenas deslocamentos de abertura/fechamento da junta. 
Os deslocamentos possuem certa influência da variação da temperatura, não estabilizados em relação aos deslocamentos de abertura/fechamento das juntas, conforme Figura 119 e Figura 120.

Já no caso dos MT's 4 e 7, praticamente não foram observados deslocamentos, tanto durante o enchimento, como no período operacional, o que está em concordância com o observado nas visitas de campo, onde não se constatou junta de contração no local, o que pode ocorrer em barragens CCR, devido à indução e método construtivo, nem sempre todas as juntas entre blocos são visualizadas nas paredes da galeria. O MT-2, por exemplo, teve sua posição trocada, não tendo sido medidos deslocamentos no período de enchimento do reservatório.

No Quadro 7, a seguir apresenta-se um resumo com os máximos valores medidos de cada Medidor Triortogonal. Os recalques diferenciais são de pequena magnitude em todos os Medidores Triortogonais, com deslocamentos inferiores a 0,7 mm, enquanto os deslizamentos apresentam valores inferiores a 0,5 mm, a exceção do MT-01 e MT-03, com valores da ordem de 1,7 mm. Já em termos de abertura e fechamento, são observados valores de até 3,89 mm. É natural que estes deslocamentos de abertura/fechamento sejam maiores que nas outras direções, conforme também observado em outras barragens de concreto.

Figura 119- Deslocamentos registrados junto ao medidor triortogonal de junta entre blocos MT-03, localizado na galeria de drenagem na junta dos Blocos B-3/B-4.

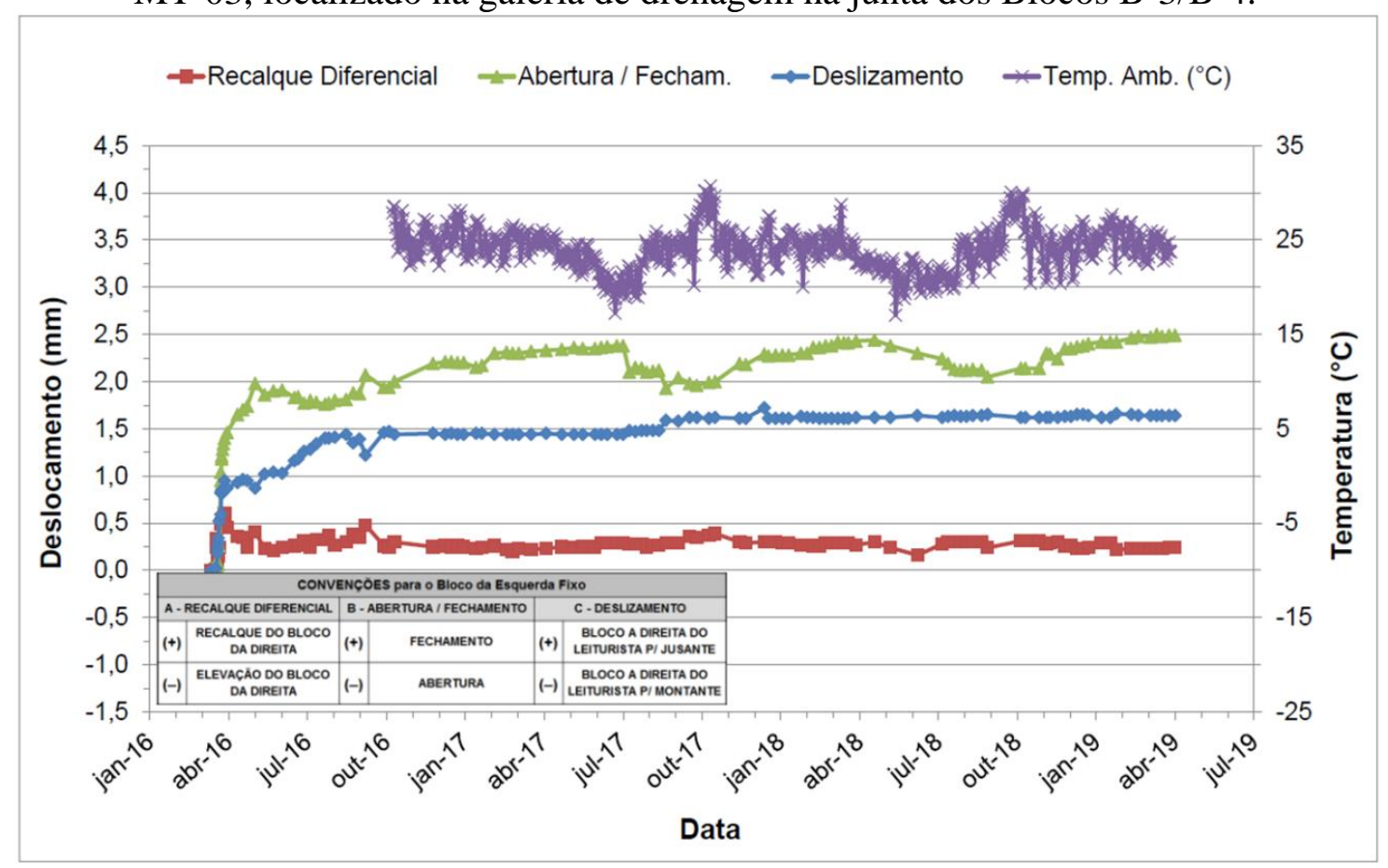

Fonte: do Autor (2019). 
Figura 120 - Deslocamentos registrados junto ao medidor triortogonal de junta entre blocos do MT-06 localizado na galeria de drenagem na junta dos Blocos B-6/B-7.

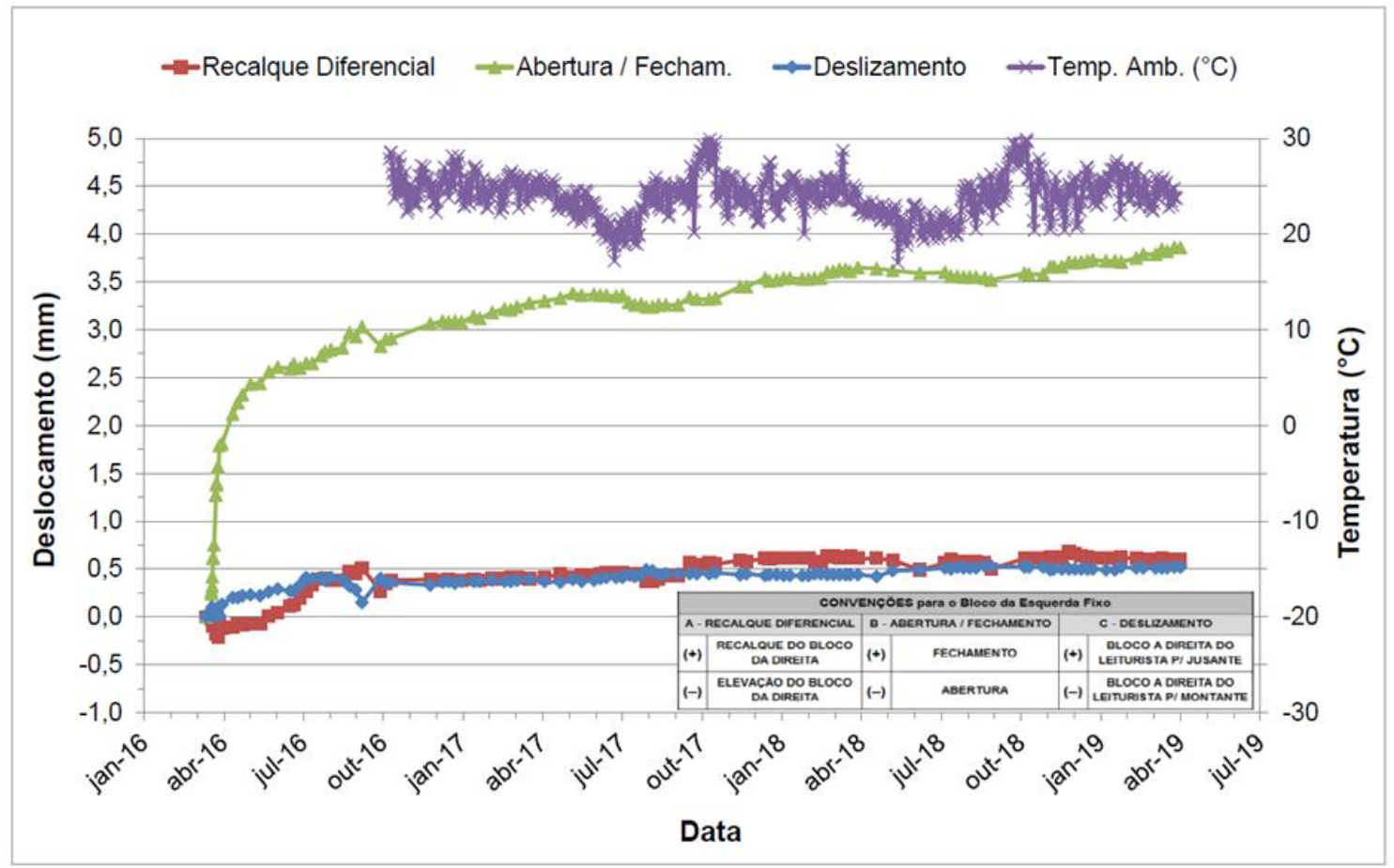

Fonte: do Autor (2019).

Quadro 7 - Síntese dos deslocamentos máximos medidos nos MTs até Abril/2019.

\begin{tabular}{|c|c|c|c|c|}
\hline \multirow{2}{*}{$\begin{array}{c}\text { Medidor } \\
\text { Triortogonal }\end{array}$} & \multirow{2}{*}{ Localização } & \multicolumn{3}{|c|}{ Leitura Máxima $(\mathbf{m m})$ até 05/04/2019 } \\
\cline { 3 - 5 } & & $\mathbf{A}$ & $\mathbf{B}$ & $\mathbf{C}$ \\
\cline { 3 - 5 } & Recalque Diferencial & Abertura / Fecham. & Deslizamento \\
\hline MT-01 & B-1 / B-2 & $-0,38$ & 2,50 & $\mathbf{1 , 7 8}$ \\
\hline MT-02 $\left(^{*}\right)$ & B-2 / B-3 & 0,19 & 0,42 & $-0,10$ \\
\hline MT-03 & B-3 / B-4 & 0,60 & 2,49 & $\mathbf{1 , 7 2}$ \\
\hline MT-04 & B-4 / B-5 & 0,34 & 0,31 & $-0,31$ \\
\hline MT-05 & B-5 / B-6 & 0,40 & 1,53 & $-0,33$ \\
\hline MT-06 & B-6 / B-7 & $\mathbf{0 , 6 8}$ & $\mathbf{3 , 8 9}$ & 0,52 \\
\hline MT-07 & B-7 / B-8 & 0,24 & 0,33 & $-0,17$ \\
\hline
\end{tabular}

Nota: $(*)$ Medidor deslocado de posição - leituras a partir de Mai/16.

Fonte: do Autor (2019).

\subsubsection{Extensômetros Múltiplos de Haste}

Os Extensômetros Múltiplos de Hastes foram instalados em 5 (cinco) seções ao longo da galeria de drenagem da Barragem Principal, a saber, nos blocos B-2, B-3, B-4, B-6 e B-8. Como pode ser visto na Figura 121 e Figura 122, cada extensômetro possui 3 (três) hastes instaladas em um mesmo furo, com inclinação de $5^{\circ}$ para montante, em profundidades diferentes, sendo elas:

$\checkmark$ Haste "b" (mais profunda) 20,0 m abaixo do contato C/R;

$\checkmark$ Haste "a" (intermediária) $\sim 10,0 \mathrm{~m}$ abaixo do contato C/R; 
$\checkmark$ Haste "c" (mais rasa) $\sim 2,0 \mathrm{~m}$ abaixo do contato C/R.

Figura 121 - Esquema típico de instalação dos Extensômetros de Hastes a partir da galeria

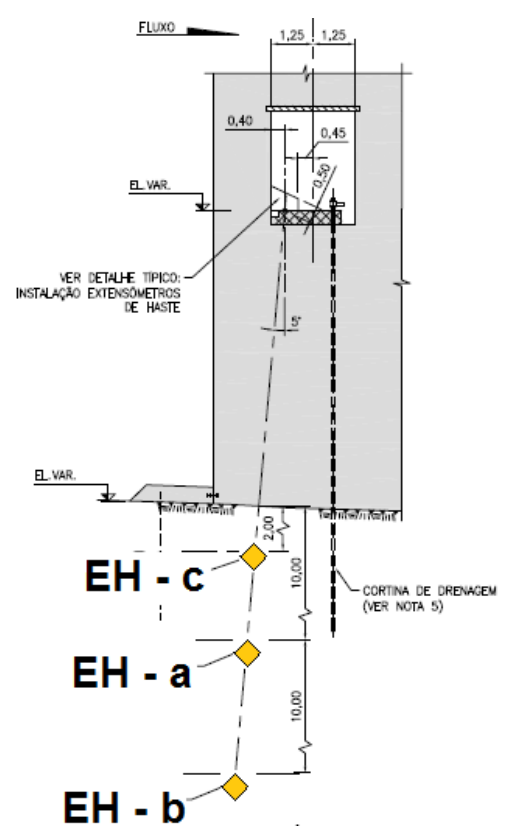

Fonte: Adaptado de Mata Velha Energética S.A. (2016).

Figura 122 - Detalhe das ancoragens, hastes e cabeça do extensômetro antes da instalação.

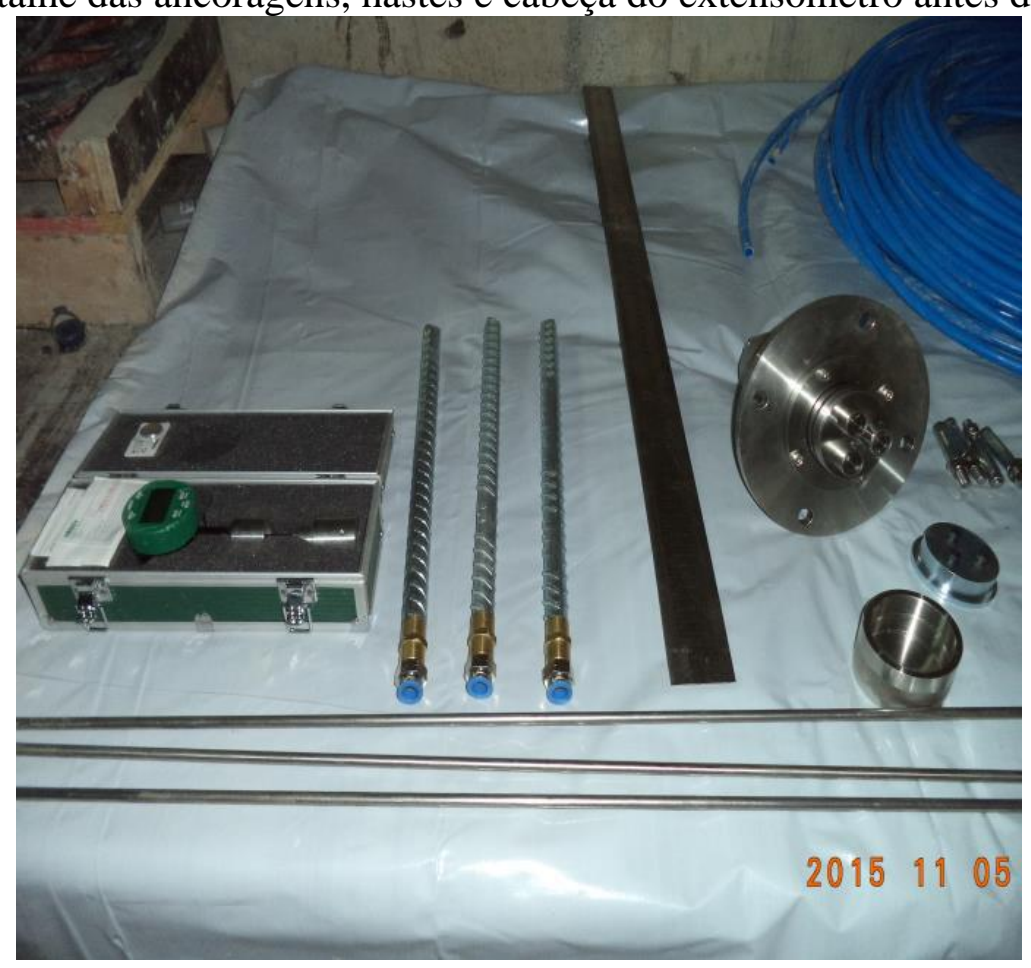

Fonte: Dumont (2016).

Durante o enchimento do reservatório foram observados deslocamentos de distensão, 
tendo sido bem mais intensos nos extensômetros da ombreira direita (EH's 1, 2 e 3), com estabilização alguns meses após o término do enchimento. O fato de se observar distensões maiores nas hastes mais profundas, leva a crer que este comportamento pode ter ocorrido em função do enchimento do reservatório e percolação pela fundação, gerando subpressão através dos caminhos de percolação ou em função de eventual acomodação da fundação no sentido de jusante, com maior influência em função da profunidade.

O EH-1 tem apresentado variações cíclicas, como reflexo das variações de temperatura (Figura 123). No EH-3 (Figura 124), o qual registrou os maiores deslocamentos, passou-se a observar completa estabilização desde Dez/2016.

Destaca-se que o enchimento foi relativamente rápido, subindo o reservatório da El. 614,11 m para a El. 632,00 m em 8 (oito) dias, com uma velocidade média de 2,24 m/dia, com reflexo direto nos registros dos extensômetros.

O EH-07, Figura 125, indicou uma tendência de compressão da haste "b" (mais profunda), antes do enchimento do reservatório, sem qualquer deslocamento das outras hastes, indicando uma compressão da camada entre as hastes "a" e "b". Durante o enchimento também se observou pequena distensão, mais claramente nas hastes "a" e "c". O EH-07 também apresentando um comportamento diferente daqueles instalados na ombreira direita, provavelmente em função da rocha de fundação nessa região. 
Figura 123 - Deslocamentos medidos pelo extensômetro de hastes EH-01.

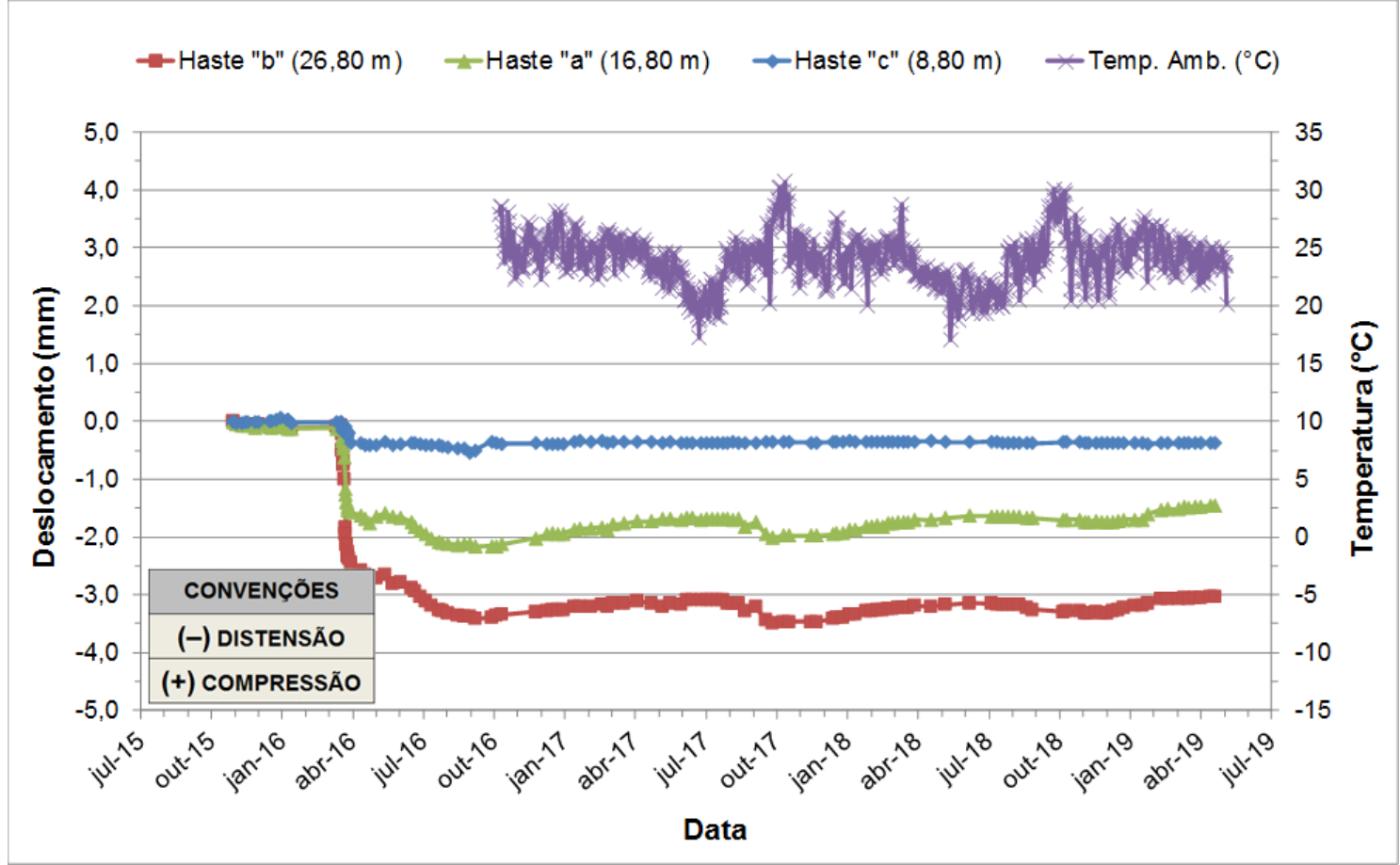

Fonte: do Autor (2019).

Figura 124 - Deslocamentos medidos pelo extensômetro de hastes EH-03.

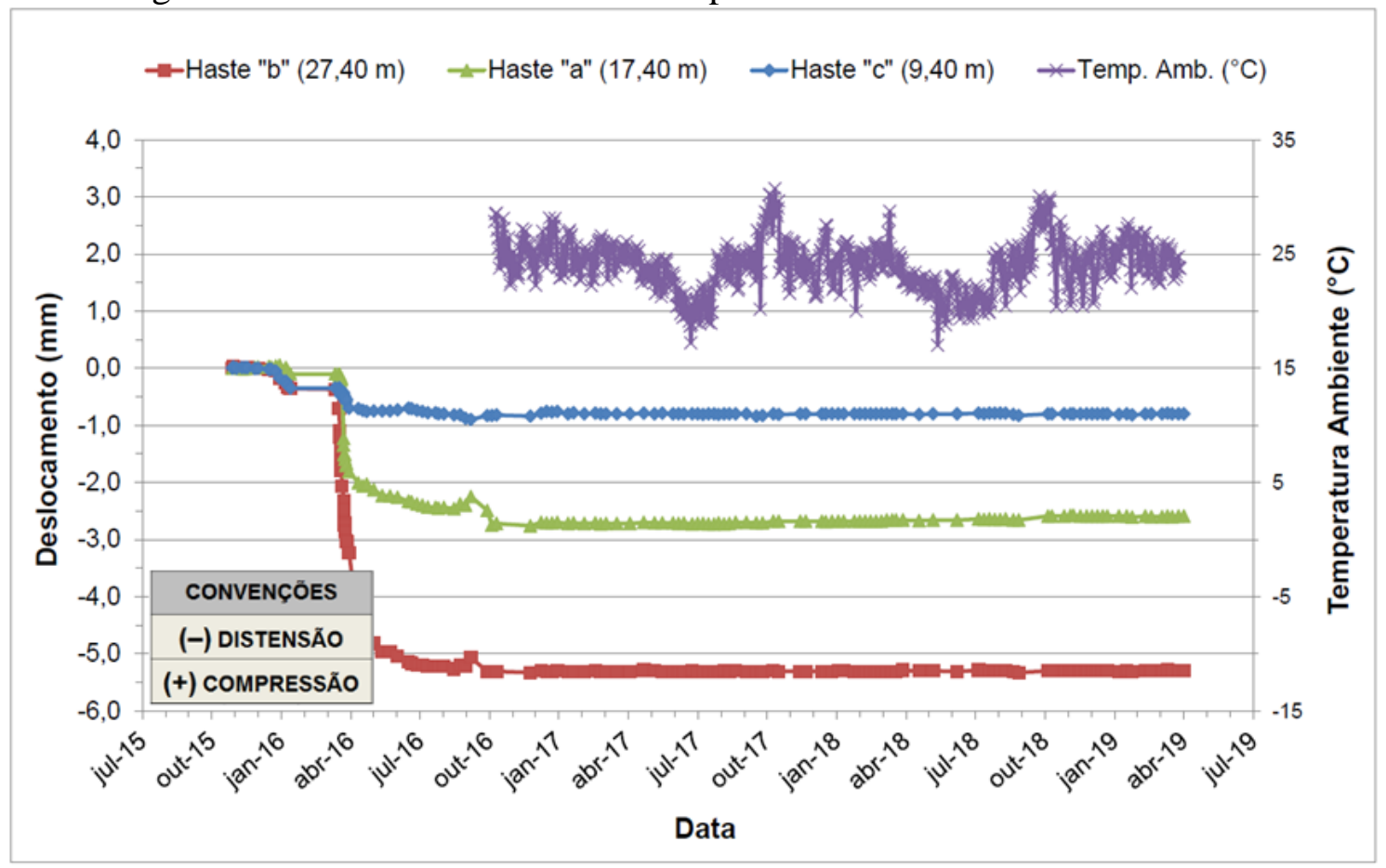

Fonte: do Autor (2019). 
Figura 125 - Deslocamentos medidos pelo extensômetro de hastes, com a haste " $b$ " indicando compressão durante o período construtivo.

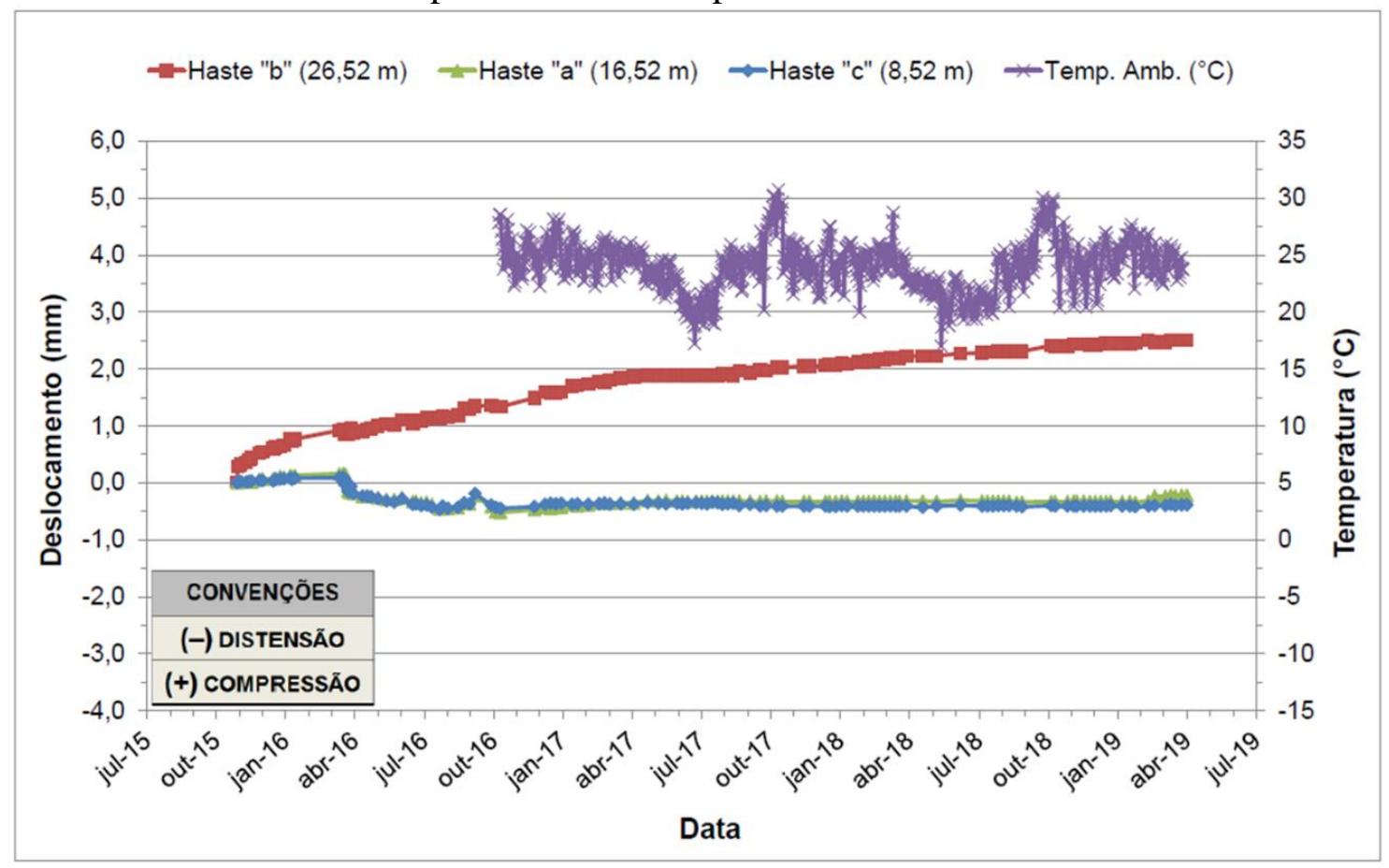

Fonte: do Autor (2019).

No Quadro 8 a seguir apresenta-se uma síntese com os deslocamentos medidos em cada uma das hastes dos 5 extensômetros até Abril/2019. Com relação aos deslocamentos da fundação, a comparação dos valores medidos pelos extensômetros com aqueles de outras barragens tipo gravidade, vem mostrar que mesmos apresentaram valores relativamente superiores, o que vem revelar que o maciço rochoso se apresenta mais deformável, provavelmente como reflexo das rochas metamórficas da fundação (meta-siltitos e metacalcários).

Quadro 8 - Deslocamentos máximos dos Extensômetros de Hastes até Abril/2019.

\begin{tabular}{|c|c|c|c|c|}
\hline \multirow[t]{2}{*}{ Localização } & \multirow{2}{*}{$\begin{array}{c}\text { Extensômetro } \\
\text { de Hastes }\end{array}$} & \multicolumn{3}{|c|}{$\begin{array}{l}\text { Leitura máxima até 05/04/2019 } \\
\qquad(\mathrm{mm})\end{array}$} \\
\hline & & Haste "b" & Haste "a" & Haste "c" \\
\hline Bloco B-2 & $\mathrm{EH}-01$ & $-3,49$ & $-2,17$ & $-0,55$ \\
\hline Bloco B-3 & $\mathrm{EH}-02$ & $-4,22$ & $-3,17$ & $-2,55$ \\
\hline Bloco B-4 & $\mathrm{EH}-03$ & $-5,33$ & $-2,76$ & $-0,90$ \\
\hline Bloco B-6 & $\mathrm{EH}-05$ & 0,68 & 0,76 & 0,68 \\
\hline Bloco B-8 & $\mathrm{EH}-07$ & 2,50 & $-0,52$ & $-0,47$ \\
\hline
\end{tabular}

Nota: Convenção de Sinais: (-) Distensão / (+) Recalque.

Fonte: do Autor (2019). 


\subsubsection{Marcos Superficiais}

Os 2 (dois) Marcos de Deslocamento Superficial instalados na crista da Barragem Principal em CCR, denominados MS-01 e MS-02, respectivamente nos blocos CL-1 e CL-8, têm por finalidade a determinação dos deslocamentos verticais e horizontais na crista da barragem,

Tendo em vista que estruturas de concreto costumam apresentar pequenos deslocamentos, da ordem de poucos milímetros, para a medição de tais valores seria necessária a utilização de aparelhos de alta precisão, sendo que o alto custo envolvido nestas medições não se justificaria para uma barragem deste porte, já tão bem instrumentada.

\subsection{TESTE DE TAMPONAMENTO DOS DRENOS DE FUNDAÇÃO}

Apesar da piezometria estar revelando subpressões aparentemente normais para a fundação da barragem em CCR, passou-se a julgar que poderia estar ocorrendo certa incompatibilidade entre a acentuada redução de vazão, como provável influência da carbonatação dos drenos de fundação, e o fato das subpressões não estarem aumentando.

Dessa forma, foram definidos os procedimentos básicos para a realização de testes de tamponamento dos drenos de fundação, o qual teve por objetivo verificar a influência da cortina de drenagem nos instrumentos de auscultação, principalmente nos piezômetros instalados na galeria de drenagem da Barragem Principal.

\subsubsection{Tamponamento dos Drenos}

O tamponamento dos drenos da galeria de drenagem foi realizado em três etapas, conforme planejado, tendo-se tamponado inicialmente os drenos dos Blocos 2 e 3 (Drenos 1 a 11), em uma segunda etapa foram tamponados os drenos dos Blocos 4 a 6 (12 a 35), e por fim foram tamponados os demais drenos dos blocos 7 e 8 (36 a 50), conforme indicado na Figura 126. 
Figura 126 - Planta galeria de drenagem da Barragem Principal com a locação dos drenos.

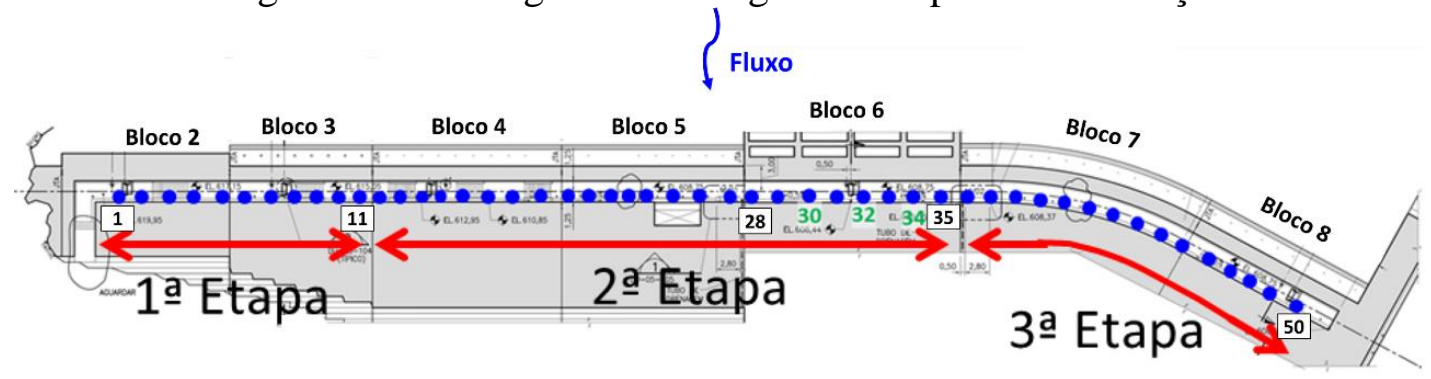

Fonte: do Autor (2019).

Para tamponamento dos drenos foi utilizada uma tampa rosqueável junto à saída do mesmo, conforme indicado na Figura 127 a seguir. Ressalta-se que na semana anterior ao teste foram realizados reparos nas bases de alguns drenos, a fim de evitar infiltrações quando do seu tamponamento.

Figura 127 - Dreno 33: a) antes do tamponamento com vazão; b) devidamente tamponado durante o teste.

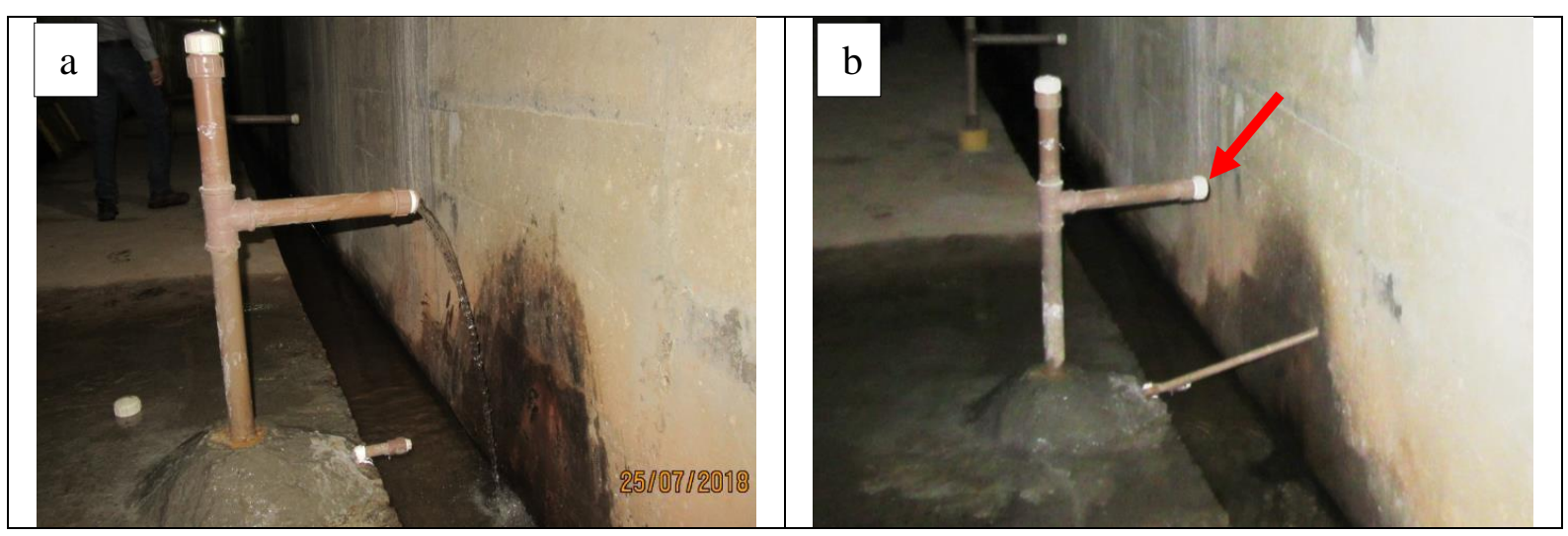

Fonte: do Autor (2019).

No primeiro dia, antes de iniciar o tamponamento dos drenos, foram realizadas leituras em todos os piezômetros, medidores de vazão, medidores triortogonais e extensômetros da galeria de drenagem.

O tamponamento dos drenos da primeira etapa se envolveu os Blocos 2 e 3, e as leituras nos piezômetros desses blocos após 15 e 30 minutos após o tamponamento. Foi previsto que a interrupção da atividade se daria caso mais de um piezômetro viesse atingir o valor de ATENÇÃO e apresentasse tendência de aumento em seu nível piezométrico. Tal situação, entretanto, não foi observada.

Foi realizado, na sequência, o tamponamento dos drenos da segunda etapa (blocos 4, 5 e 6), ou seja, com tamponamento dos drenos de 1 a 35. Foram realizadas leituras nos 
piezômetros dos Blocos 2 a 6, após cerca de 15 e 30 minutos desse tamponamento. Os níveis piezométricos medidos responderam ao tamponamento dos drenos, porém não atingiram valores de "Atenção".

$\mathrm{Na}$ terceira etapa foram tamponados os drenos dos Blocos 7 e 8 , ou seja, com tamponamento de todos os drenos (1 a 50), procedendo à leitura dos piezômetros após cerca de 15 e 30 minutos. Ao final dessa etapa foram realizadas leituras também nos Extensômetros e Medidores Triortogonais, assim como no medidor de vazão MV-4, localizado na base do talude da ombreira direita, lateral a Casa de Força.

A partir do tamponamento geral dos drenos, foram realizadas mais duas leituras com intervalos de 30 minutos. Como não foram observadas variações significativas as leituras seguintes passaram a ser mais espaçadas, sendo realizadas mais 3 leituras de hora em hora.

Visto que os níveis piezométricos se encontravam estabilizados, iniciou-se a remoção dos tampões nos drenos e realizadas leituras em todos os instrumentos da Barragem Principal. No segundo dia, nova leitura foi realizada em todos os instrumentos, não sendo detectas variações.

\subsubsection{Análise da Instrumentação Durante os Testes de Tamponamento}

Apresenta-se neste item uma análise da instrumentação de auscultação durante o teste de tamponamento dos drenos de fundação da Barragem Principal, enfatizando o comportamento dos piezômetros instalados no contato Concreto/Rocha e em profundidade na fundação.

Conforme Figura 128 foram instalados piezômetros no contato Concreto/Rocha e na Fundação, sendo dois a montante da cortina de drenagem e dois a jusante, com inclinação de $15^{\circ}$. Dessa forma o objetivo dos drenos foi o de aliviar as subpressões, principalmente da região a jusante, assim os piezômetros " $C$ " e " $D$ " de cada bloco seriam aqueles que deveriam responder mais ao teste de tamponamento de drenos. 
Figura 128 - Seção transversal com locação dos piezômetros e da cortina de drenagem.

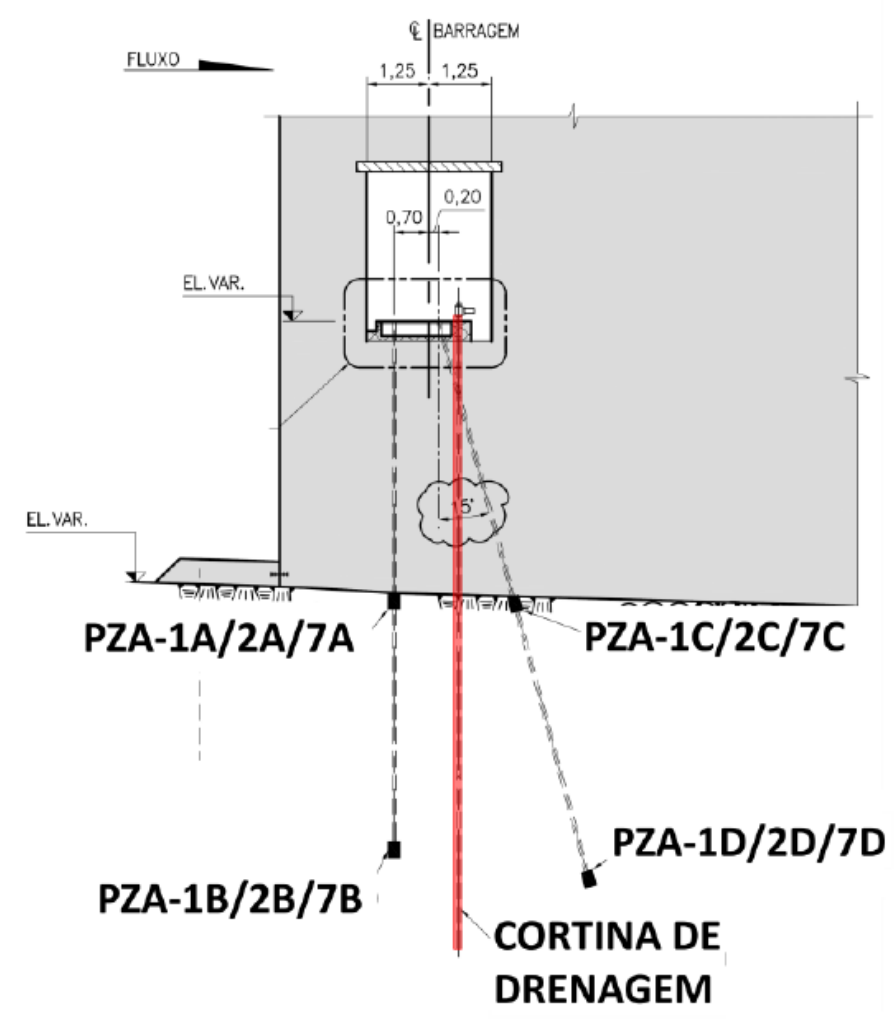

Fonte: Adaptado de Mata Velha Energética S.A (2016).

Os piezômetros dos Blocos 3 e 4 foram os que apresentaram as maiores variações condicionadas ao tamponamento dos drenos. Os piezômetros PZA-2B e PZA-2D (Bloco3) apresentaram elevação do nível piezométrico instantânea ao tamponamento dos drenos da primeira etapa, ambos situados em profundidade e não no contato $\mathrm{C} / \mathrm{R}$, conforme Figura 129. O primeiro apresentou uma elevação de aproximadamente 1,4 m.c.a., e o segundo um acréscimo de 2 m.c.a., ambos voltando aos níveis piezométricos iniciais após a retirada do tampão, ressaltando a resposta e eficiência da cortina de drenagem no alívio das subpressões neste bloco. 
Figura 129 - Variação dos níveis piezométricos de Bloco 3 da barragem de concreto no decorrer do teste de tamponamento.

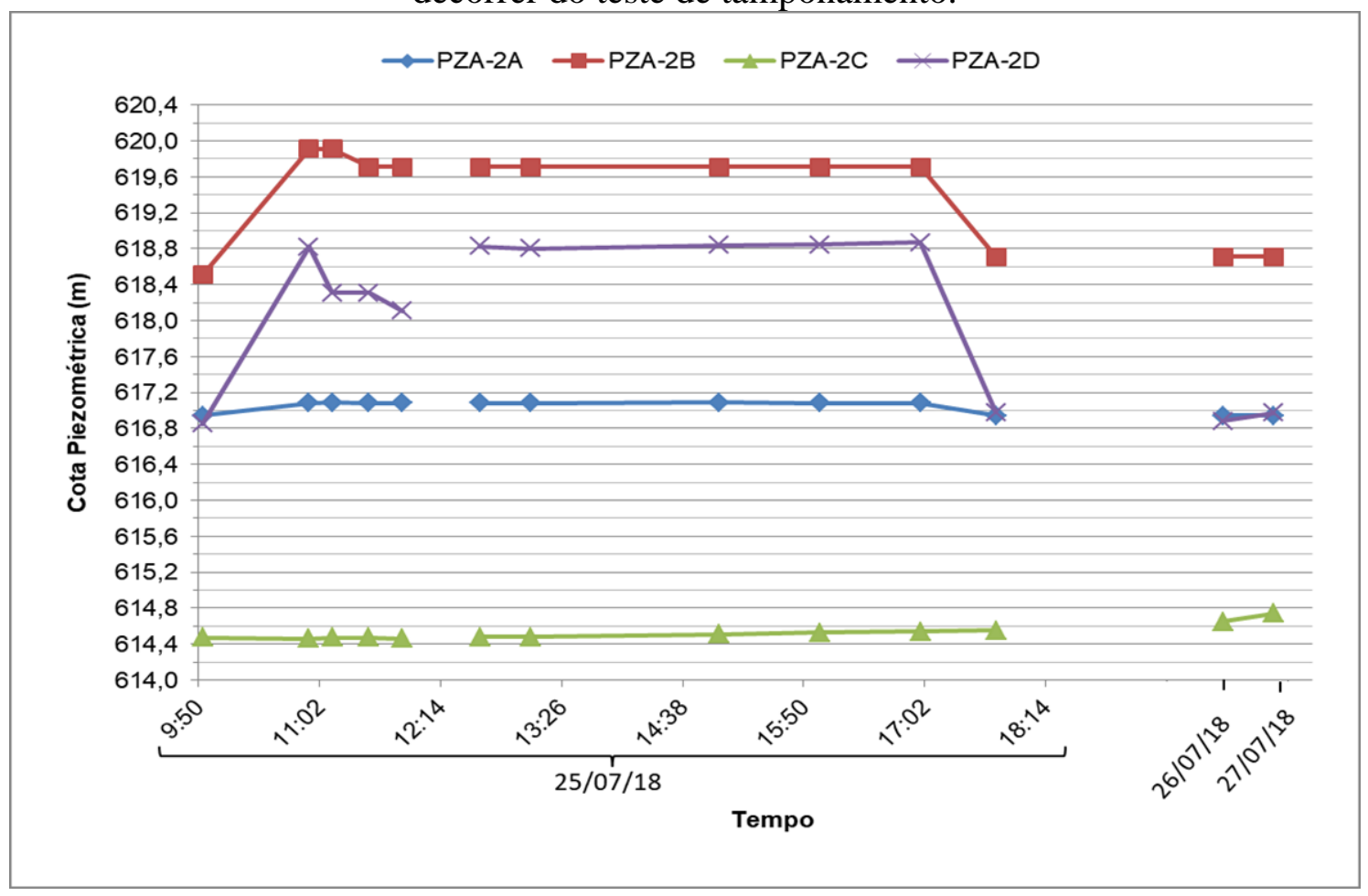

Fonte: do Autor (2019).

No Quadro 9 são apresentados os acréscimos máximos observados em cada piezômetro durante o teste de tamponamento dos drenos de fundação. Já na Figura 130 apresenta-se um gráfico de barras comparativo, para melhor visualização, com os níveis medidos e valores de Atenção calculados pela projetista. Os níveis piezométricos durante o teste foram bem inferiores aos valores de Atenção, com acréscimos máximos observados nos piezômetros do bloco 3 (Série 2B e 2D), com acréscimos máximos de 2,0 m.c.a.. 
Quadro 9 - Acréscimos máximos observados no decorrer do teste de tamponamento.

\begin{tabular}{|c|c|c|c|}
\hline Bloco & Piezômetro & Posição & Acréscimo Máximo (m) \\
\hline \multirow{4}{*}{ B1.2 } & PZA-1A & C/R mont. (*) & 0,43 \\
\cline { 2 - 4 } & PZA-1B & Fundação mont. & 0,62 \\
\cline { 2 - 4 } & PZA-1C & C/R jus. & 0,17 \\
\cline { 2 - 4 } & PZA-1D & Fundação jus. & 0,13 \\
\hline \multirow{5}{*}{ B1.3 } & PZA-2A & C/R mont. & 0,15 \\
\cline { 2 - 4 } & PZA-2B & Fundação mont. & 1,40 \\
\cline { 2 - 4 } & PZA-2C & C/R jus. & 0,28 \\
\cline { 2 - 4 } & PZA-2D & Fundação jus. & $\mathbf{2 , 0 2}$ \\
\hline \multirow{5}{*}{ B1.4 } & PZA-3A & C/R mont & 1,22 \\
\cline { 2 - 4 } & PZA-3B & Fundação mont. & 1,20 \\
\cline { 2 - 4 } & PZA-3C & C/R jus. & 0,95 \\
\cline { 2 - 4 } & PZA-3D & Fundação jus. & 0,50 \\
\hline \multirow{5}{*}{ B1.6 } & PZA-5A & C/R mont & 0,15 \\
\cline { 2 - 4 } & PZA-5B & Fundação mont. & 0,05 \\
\cline { 2 - 4 } & PZA-5C & C/R jus. & 0,05 \\
\cline { 2 - 4 } & PZA-5D & Fundação jus. & 0,44 \\
\hline \multirow{5}{*}{ B1.8 } & PZA-7A & C/R mont & 0,00 \\
\cline { 2 - 4 } & PZA-7B & Fundação mont. & 0,17 \\
\cline { 2 - 4 } & PZA-7C & C/R jus. & 0,82 \\
\cline { 2 - 4 } & PZA-7D & Fundação jus. & 0,23 \\
\hline
\end{tabular}

Fonte: Do autor (2019).

Figura 130 - Gráfico comparativo das subpressões medida durante o teste de tamponamento dos drenos.

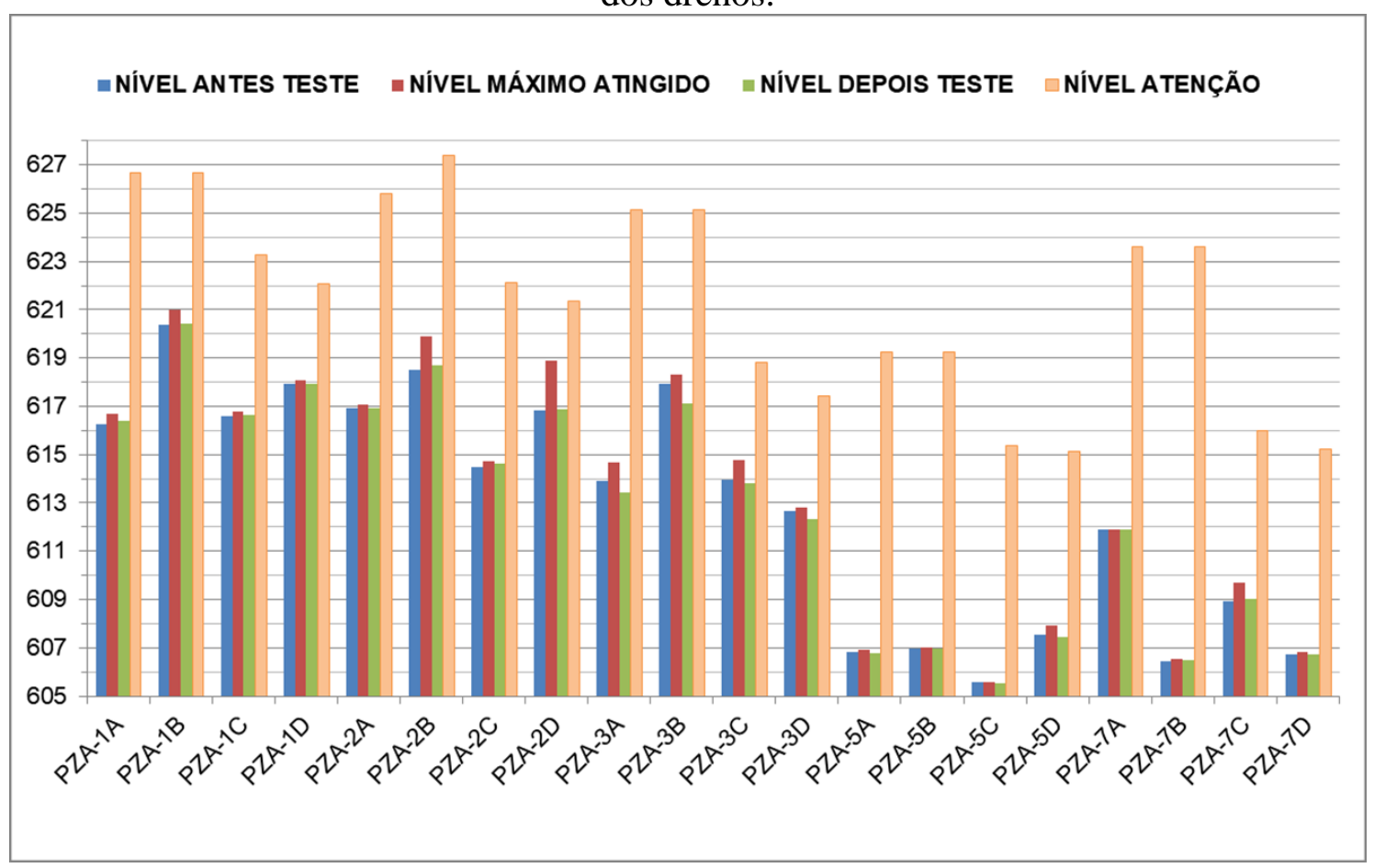

Fonte: do Autor (2019). 
Tendo por base a análise dos dados da instrumentação de auscultação da Barragem Principal da Pequena Central Hidrelétrica Mata Velha, durante as várias etapas do teste de tamponamento dos drenos de fundação, conclui-se que não houve um reflexo significativo nas subpressões na fundação, assim como nos deslocamentos medidos pelos extensômetros de hastes e medidores triortogonais de junta.

Como o reflexo em termos de subpressões foi mínimo, pois a maioria dos piezômetros do contato concreto-rocha, apresentaram variações inferiores a 0,5 mca após o tamponamento, seria de se esperar influências praticamente nulas nos deslocamentos da fundação (EH) assim como nos deslocamentos diferenciais entre blocos (MT).

De qualquer forma, as dúvidas com relação às repostas dos piezômetros puderam ser sanadas, ou seja, os piezômetros, no geral responderam ao teste de tamponamento dos drenos.

\subsection{AVALIAÇÃO DAS CONDIÇÕES DE OPERAÇÃO DOS DRENOS DE FUNDAÇÃO DAS ESTRUTURAS DE CONCRETO - TESTE 1}

Tento em vista a rápida redução das vazões a partir dos drenos de fundação da galeria de drenagem da Barragem Principal em CCR da Pequena Central Hidrelétrica Mata Velha, assim como os indícios da formação de carbonato internamente aos drenos, sem um reflexo direto na piezometria, foi realizada em Dez/2019 a avaliação das condições de operação dos drenos de fundação, assim como a tentativa de limpeza utilizando jato de água sob pressão e roto-rooter.

Incialmente foi realizada a leitura dos instrumentos (piezômetros, medidores triortogonais, extensômetros de hastes e medidores de vazão), assim como a leitura de profundidade, nível d’água e vazão dreno a dreno, conforme Figura 131.

Destaca-se que em alguns casos, mesmos não sendo possível a passagem do torpedo a pequena profundidade, havia certo fluxo, indicando alguma obstrução "parcial", talvez por carbonato, o que pôde ser constatado anteriormente quando da utilização câmera endoscópica.

Foram realizadas, também, a limpeza e investigação das tubulações instaladas internamente aos drenos. Essas investigações foram realizadas particularmente nos drenos obstruídos dos blocos 4 e 6 (Figura 132), assim como em outros blocos, nos quais foram observadas presença de carbonato nos drenos internamente. 
Figura 131 - Seção longitudinal com indicação das profundidades dos drenos e vazões.

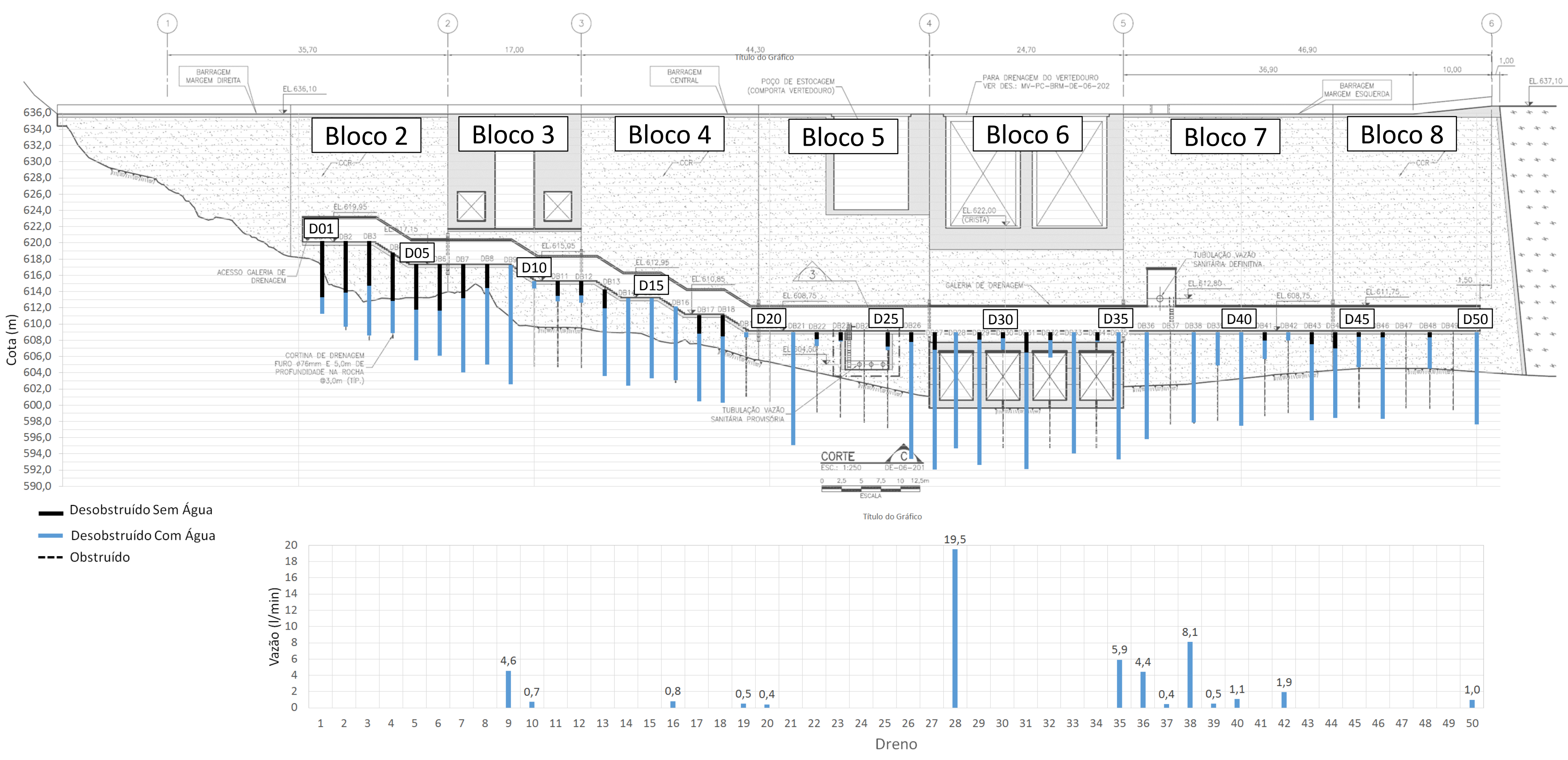

Fonte: Adaptado de Mata Velha Energética S.A. (2016). 
Figura 132 - Seção longitudinal da Barragem em CCR com locação dos instrumentos

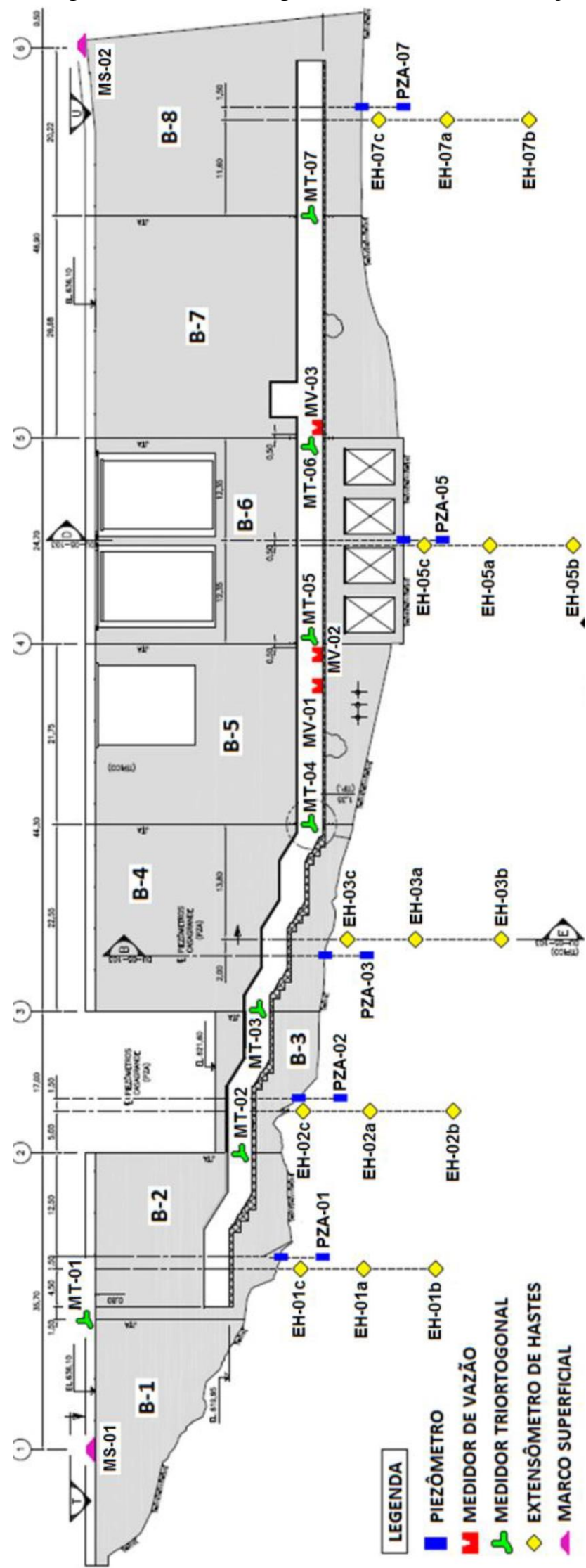

Fonte: Adaptado de Mata Velha Energética S.A. (2016). 


\subsubsection{Bloco 4 - Principais Observações}

No bloco 4 observou-se que os drenos 12 e 19 estavam obstruídos, sendo que nos demais drenos a profundidade era muito semelhante àquela do desenho "como construído", conforme Figura 131.

Dessa forma, tomou-se a decisão de atuar junto ao dreno 19, o qual apesar da obstrução, apresentava vazão de 0,51 1/min. Inicialmente foram utilizados jatos de água e ar sob pressão, sem sucesso. Foi então removido o terminal, observando-se então um emaranhado de tela e carbonato (Figura 133-a e Figura 133-b).

Com a remoção do emaranhado de tela notou-se que a tubulação interna ao furo se encontrava com sua seção bastante comprometida por carbonato, sendo realizada sua remoção do furo para verificação. A tubulação superior foi removida das demais, observando-se após seu corte carbonatação intensa em cerca de $1,10 \mathrm{~m}$, ou seja, nos primeiros 1,50 m a partir do piso (Figura 133-c e Figura 133-d), sendo os primeiros 0,55 m de carbonato bastante consolidado.

Junto à tela que reveste o tubo são observados, também, indícios de carbonato (Figura 133-e). Os tubos inferiores não apresentavam carbonatação acentuada, apenas pequenos pontos com carbonato mais arenoso, não consolidado (Figura 133-f). Removendo-se o tampão inferior do dreno de fundação, notou-se algum material mais fino, de cor cinza, possivelmente composto por um pó de pedra ou partículas decantadas, com algum material mais grosso.

Após a remoção da tubulação interna do dreno 19, a profundidade medida, em relação ao piso da galeria foi de $10,21 \mathrm{~m}$, a qual provavelmente refere-se à profundidade de projeto. Não foi possível, entretanto, a medição de vazão, porém não foi observado aumento significativo. 
Figura 133 - Verificação das condições do dreno 19 -Bloco 4: a) Remoção do terminal e emaranhado de tela (seta); b) Detalhe do carbonato junto ao terminal; .c) Carbonato junto à

tubulação abaixo do terminal (abaixo do piso). d) Carbonato em cerca de 1,1 m, com os primeiros 0,55 m bastante consolidados; e) Detalhe do carbonato junto à tela; f) Detalhe do carbonato em tubulação a cerca de $2,5 \mathrm{~m}$ de profundidade.

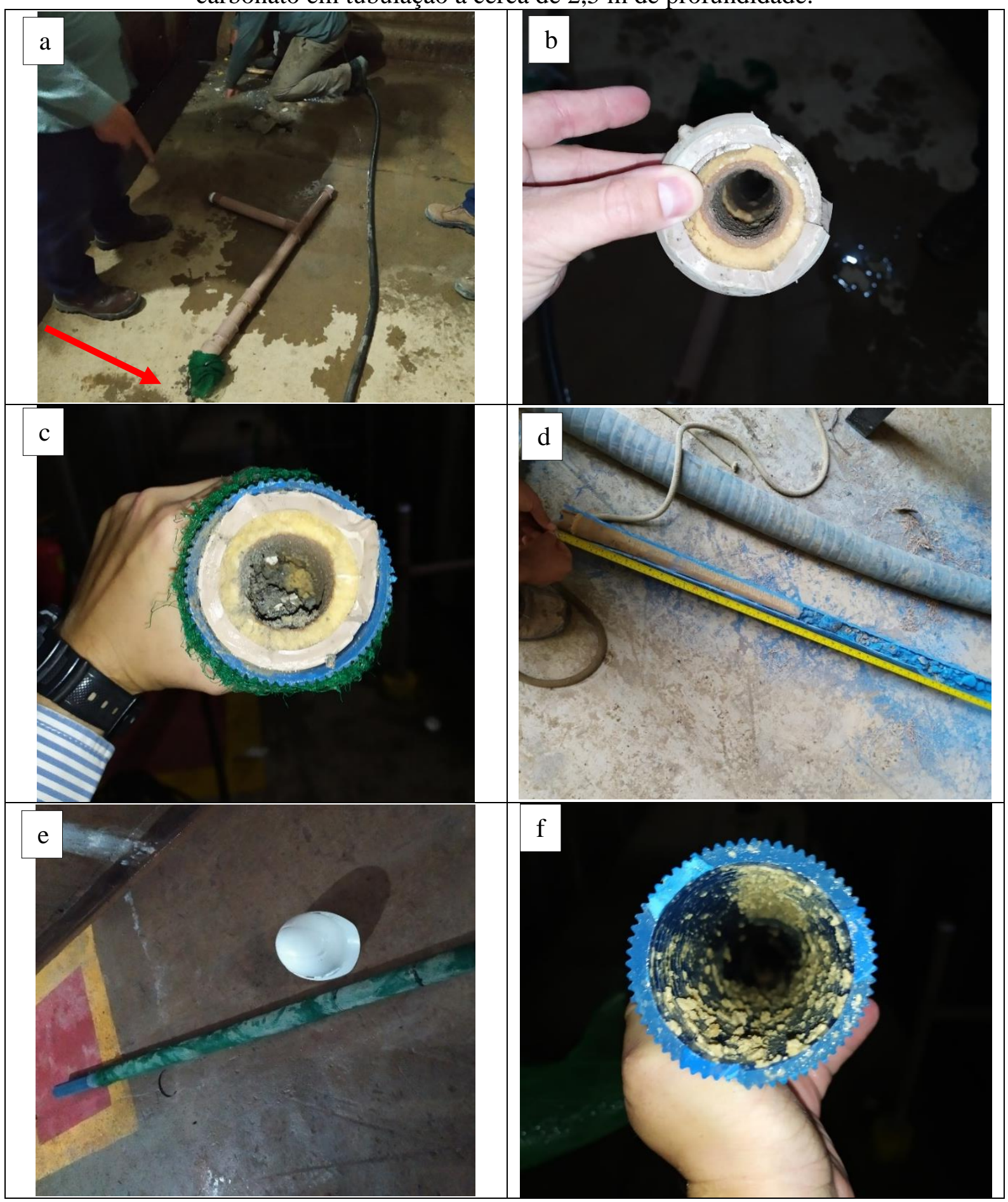

Fonte: do Autor (2019). 


\subsubsection{Bloco 6 - Principais Observações}

No Bloco 6 foi observado que os drenos em sua maioria atingem profundidades consideráveis, sendo as maiores observadas, conforme Figura 131. Os drenos 30, 32 e 33 não são dotados de terminal e suas profundidades em relação ao piso da galeria são bem inferiores aos demais drenos. A perfuração dos drenos da galeria precedeu o tamponamento das adufas de 3 das 4 adufas, não sendo então perfurados os drenos 30, 32 e 34, tendo em vista o vão das adufas quando da necessidade de perfuração.

\subsubsection{Outros Blocos - Principais Observações}

Tendo em vista a medição de profundidade dos drenos conforme Figura 131, tomou-se a decisão de tentar a desobstrução de alguns drenos com jato de água sob pressão e roto-rooter, assim como a "limpeza" de alguns drenos que teoricamente não estariam obstruídos.

No Bloco 5, foi utilizado jato de água sob pressão no dreno 23, cuja obstrução ocorria a 1,48 m a partir do topo no terminal, utilizando-se um balde em sua saída para coleta de material (Figura 134-a e Figura 134-b). Entretanto, mesmo removendo parcialmente o carbonato, não houve avanço em sua profundidade, julgando-se que foi removido apenas o carbonato menos consolidado das paredes.

Já no Dreno 24, a obstrução ocorria a $0,20 \mathrm{~m}$ do topo do terminal. A tentativa com jato de água não surtiu qualquer resultado. Decidiu-se então pela remoção da tubulação interna para avaliação.

O terminal encontrava-se bastante obstruído (Figura 134-c e Figura 134-d). A tentativa inicial de remoção da tubulação foi manual, entretanto, após grande dificultado utilizou-se uma talha improvisada. Mesmo com a talha foi possível remover apenas 2,30 m da tubulação, pois ocorria a ruptura da tubulação. Constatou-se que no trecho dos $2,30 \mathrm{~m}$, a tubulação encontravase totalmente obstruída por carbonato, observando-se, também, carbonato junto à tela que envolvia a tubulação (Figura 134-e Figura 134-f).

Destaca-se que durante a remoção da tubulação, não foi observada saída de água entre a tubulação e o furo. A impossibilidade de remoção da tubulação não permitiu observar se ocorria saída de água do furo. Tal observação seria importante para avaliar se há pressão internamente, uma vez que a tubulação estava totalmente obstruída. 
Figura 134 - Verificação das condições dos drenos do Bloco 5: a) Dreno 23- Condições iniciais com carbonato nas paredes; b) Dreno 23- material coletado; c) Dreno 24 - vista a partir do topo do terminal. D) Dreno 24 - carbonato removido do terminal. E) Dreno 24 carbonato junto à tela. F) Dreno 24 - Trecho da tubulação removido com 2,30 m, totalmente obstruída por carbonato.

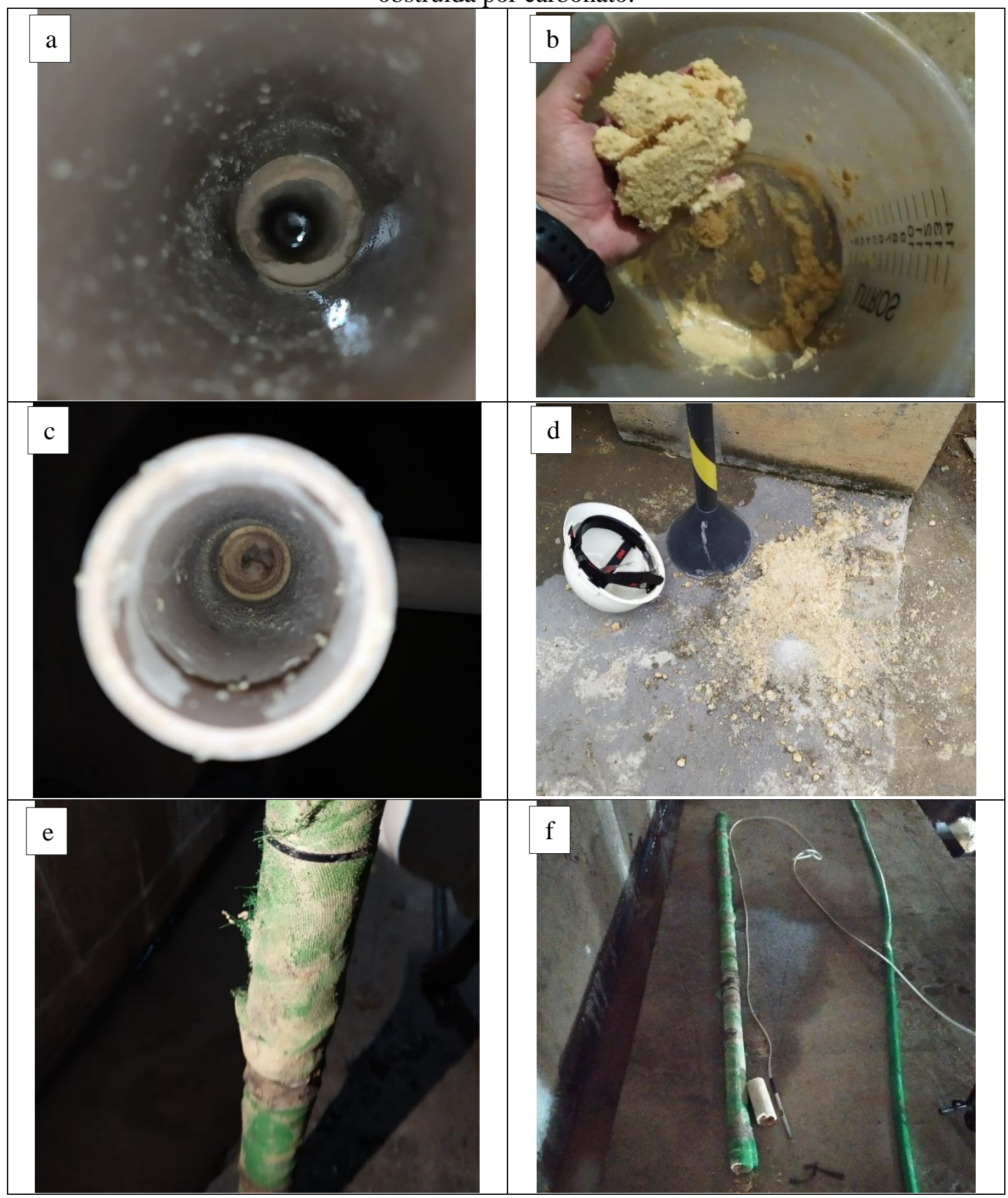

Fonte: do Autor (2019).

No Dreno 25, cuja profundidade medida foi de 2,53 m inicialmente, após o jato de água foi possível chegar à profundidade de 14,88 m. Entretanto com a câmera endoscópica foi 
possível observar que há formação de carbonato nas paredes, porém a redução da seção ainda permite a passagem do pio elétrico, devido ao seu diâmetro.

No bloco 7 foi realizada a limpeza nos drenos 37, 38 e 39. No dreno 37 (Figura 135-a e Figura 135-b), cuja profundidade inicial foi de 0,23 m, após limpeza a profundidade foi de 0,46 m, não sendo obtido melhores resultados.

No dreno 38, após inserido jato de água passou a sair água turva, com cor cinza, diminuindo conforme injeção de água, sem alteração na profundidade inicial.

No dreno 39 (Figura 135-c e Figura 135-d), cuja profundidade inicial foi de 4,44 m, após a utilização de água sob pressão e roto-rooter foi possível medir a profundidade de 13,85 m com o pio elétrico.

Figura 135 - Verificação das condições dos drenos do Bloco 7:. a) Dreno 37 - limpeza com jato de água; b) Dreno 37 - detalhe do material coletado; c) Dreno 39 - material coletado; d)

Dreno 39 - detalhe do material, com fragmento de maior tamanho.

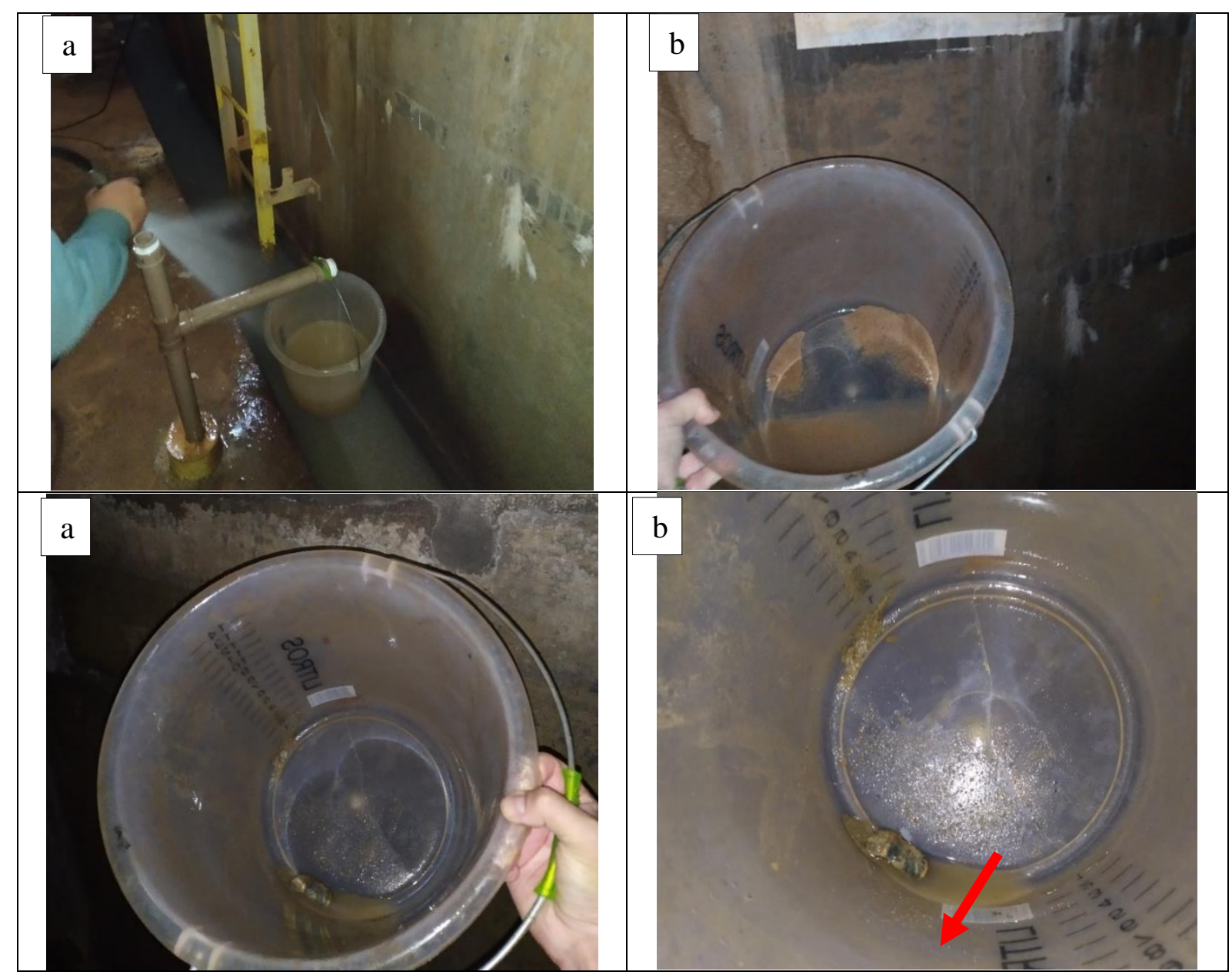

Fonte: do Autor (2019). 


\subsubsection{Comentários Gerais}

A medição de profundidade, nível d'água e vazão dos drenos da galeria de drenagem, assim como a realização limpeza e remoção de algumas tubulações internas dos drenos para análise, permitiu verificar que enquanto em alguns drenos ainda é possível a passagem do torpedo para medição de profundidade, outros encontram-se com intensa carbonatação, podendo ser considerados inoperantes.

Mesmo sendo possível a passagem do torpedo de medição de profundidade, o qual tem diâmetro da ordem de 1,0 cm, não é possível afirmar que não esteja ocorrendo a carbonatação interna da tubulação, mas talvez em intensidades menores, o que poderia ocorrer em função de condições especificas, que não levam à intensa formação do carbonato como naqueles totalmente obstruídos. Vale ressaltar que, conforme constatado em verificações anteriores, através da utilização de câmera endoscópica, em determinados drenos ocorre a formação de carbonato abaixo do nível d'água.

Fato é que cerca de um ano após o enchimento do reservatório, as vazões reduziram consideravelmente e foi possível observar drenos que inicialmente apresentavam alta vazão logo após o enchimento do reservatório e mesmo sem obstrução total (permitem passagem do torpedo de medição), tiveram redução visível de vazão, conforme observa-se nos drenos 35 e 36 (Figura 136).

Como os trabalhos realizados não permitiram uma desobstrução considerável dos drenos, não foram realizadas leituras nos instrumentos.

Figura 136 - Drenos 35 e 36, observando redução em relação a Abril/2016 (enchimento).

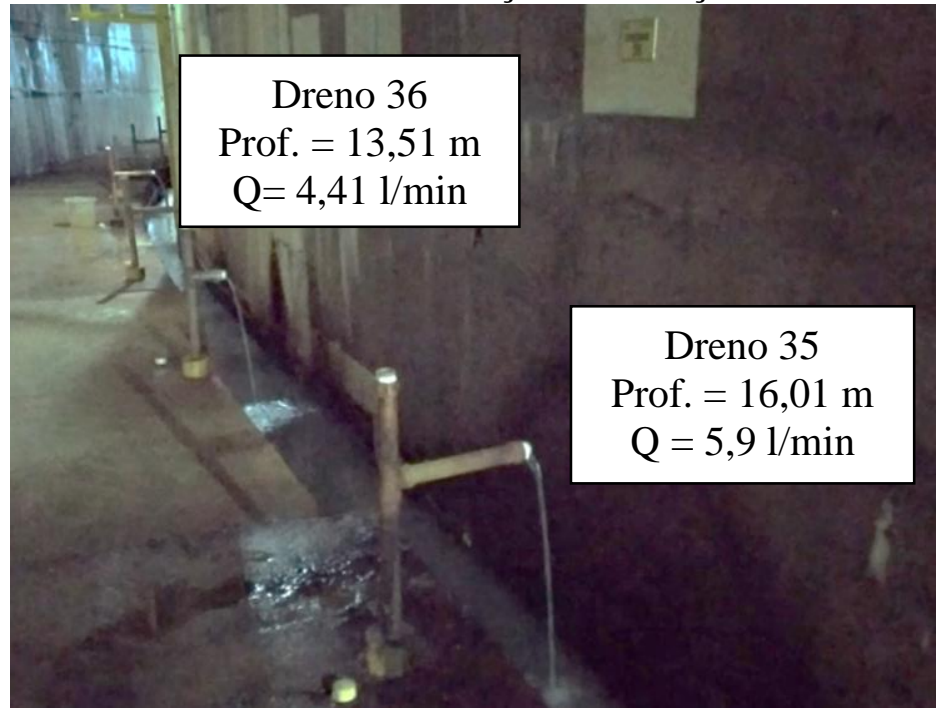

Fonte: do Autor (2019). 


\subsection{AVALIAÇÃO DAS CONDIÇÕES DE OPERAÇÃO DOS DRENOS DE FUNDAÇÃO DAS ESTRUTURAS DE CONCRETO - FASE 2}

Tento por base os resultados da avaliação das condições de operação dos drenos de fundação das estruturas de concreto, realizada em Dez/2019, sendo designada de Fase 1, procedeu-se a uma nova avaliação, designada de Fase 2, em Set/2020.

O principal fator que diferenciou os trabalhos realizados na Fase 2 refere-se à remoção das tubulações internas dos drenos de fundação para avaliação, utilizando-se um sistema com talha elétrica (Figura 137-a) assim como o fato de se utilizar um boroscópio de melhor qualidade, com melhor iluminação e qualidade de câmera (Figura 137-b).

Figura 137 - a) Sistema desenvolvido com talha elétrica para remoção da tubulação interna dos drenos. b) Boroscópio utilizado, Modelo END 23F50MHD.
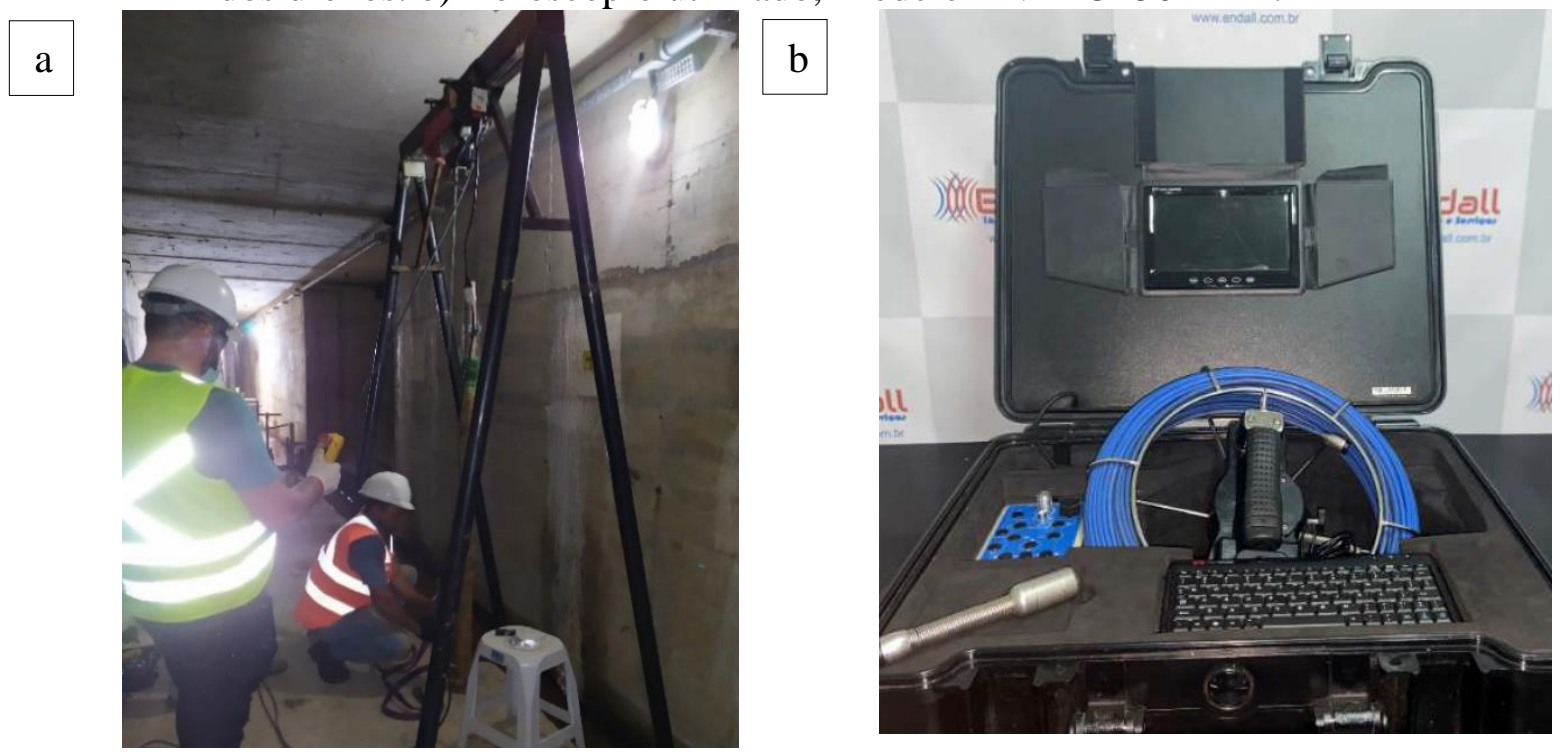

Fonte: Do autor (2020).

Na Fase 2, assim como na Fase 1, foi realizada a leitura de profundidade e vazão dreno a dreno antes da remoção das tubulações internas, cujos resultados são apresentados na Figura 138.

Não foi observada diferença relevante em relação aos valores medidos em Dez/2019. Nos drenos 12 e 39, nas medições de Set/2020 foi possível medir uma profundidade maior que em Dez/2019, o que pode ocorrer em função do posicionamento da sonda utilizada para medir a profundidade. Já nos drenos 19 e 24, as medições de profundidade foram realizadas após a remoção da tubulação. Em relação às vazões, os valores foram bem parecidos, destacando-se a redução de vazão no Dreno 28, passando de 19,5 1/min em Dez/2019 para 4,3 1/min em Set/2020. 
Figura 138 - Seção longitudinal com indicação das profundidades dos drenos e vazões, medidas em Dez/2019 (Fase 1) e Set/2020 (Fase 2)

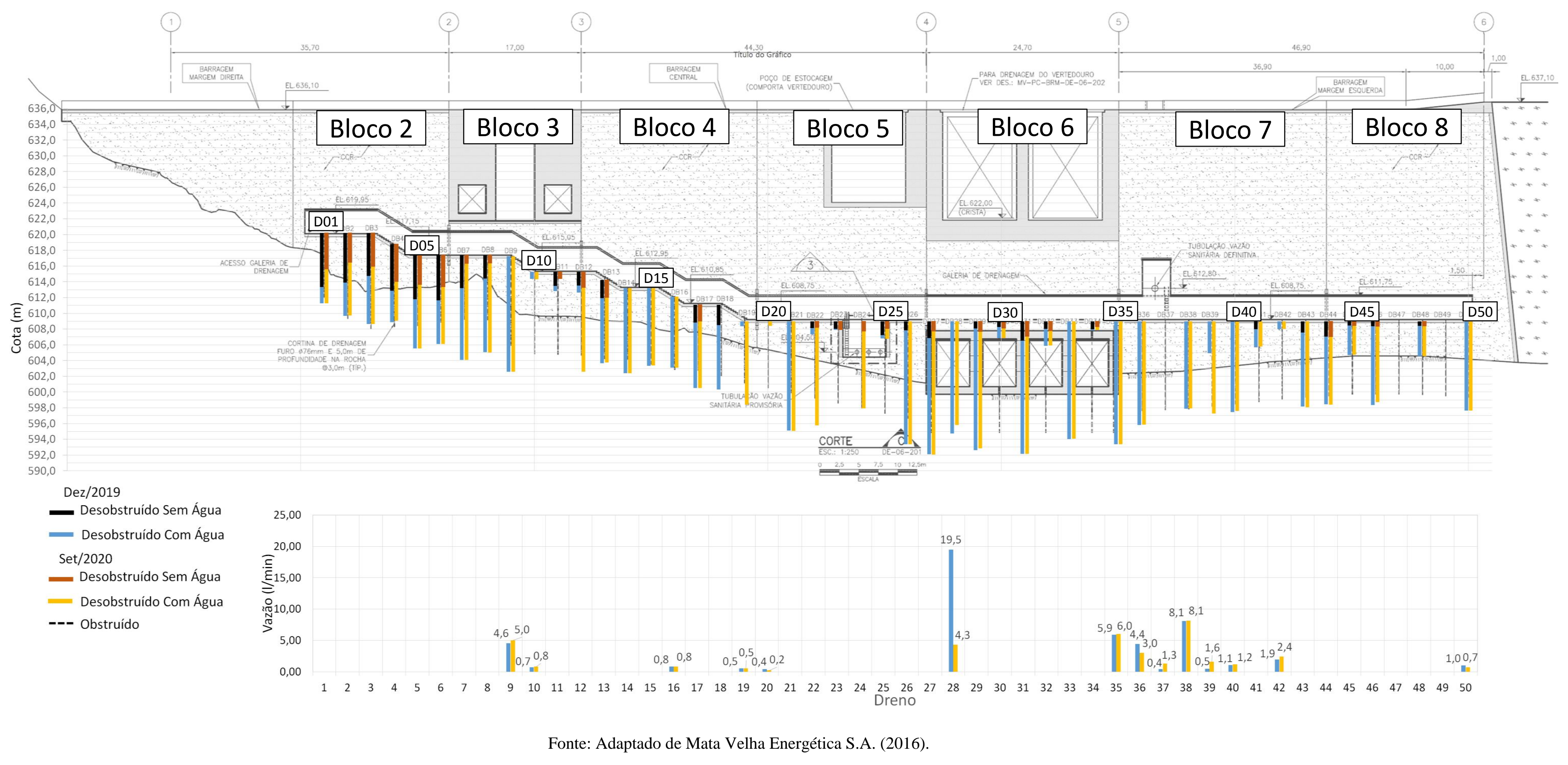




\subsubsection{Remoção das Tubulações Internas do Drenos}

Para remoção da tubulação interna procurou-se priorizar aqueles que apresentavam obstrução por carbonato, entretanto, mesmo após grandes esforços, algumas tubulações não puderam ser removidas. Os resultados em termos de drenos e comprimento da tubulação removida constam na Tabela 18.

Tabela 18 - Remoção de tubulação interna dos drenos.

\begin{tabular}{|c|c|c|}
\hline Dreno & $\begin{array}{l}\text { Tubulação interna } \\
\text { completamente removida }\end{array}$ & $\begin{array}{l}\text { Comprimento } \\
\text { do tubo removido }(\mathrm{m})\end{array}$ \\
\hline 10 & Sim & 10,4 \\
\hline 11 & $\operatorname{Sim}$ & 11,7 \\
\hline 18 & Não (tela de nylon enroscada) & 0,0 \\
\hline 20 & Sim & 11,9 \\
\hline 21 & Sim & 13,5 \\
\hline 23 & Sim & 13,5 \\
\hline 24 & Não (ruptura da tubulação) & 11,5 \\
\hline 25 & Sim & 14,3 \\
\hline 39 & Não $(*)$ & 6,8 \\
\hline 41 & Não (*) & 0,0 \\
\hline 42 & Não $(*)$ & 0,0 \\
\hline 43 & Não $(*)$ & 0,0 \\
\hline 45 & Sim & 10,4 \\
\hline 47 & Sim & 10,4 \\
\hline 48 & Sim & 10,6 \\
\hline 49 & Sim & 10,4 \\
\hline
\end{tabular}

Nota: (*) Dificuldades de remoção do concreto na base do terminal.

Fonte: do Autor (2020).

Nos drenos em que foi removida a tubulação, no geral foi observado carbonato retido na tela de nylon, assim como internamente aos drenos, com carbonato ora consolidado ora não consolidado, muito semelhante a areia, conforme Figura 139 a Figura 148. Alguns casos peculiares merecem observação: no dreno 11 foi observado material claro na parte superior da tubulação (Figura 140) ; nos drenos 23 e 45 foi observada a presença de material fino junto à 
tela (Figura 141 e Figura 146); no dreno 38 foi observada a saída de bolhas (Figura 144, as quais tem origem a cerca de 12,0 $\mathrm{m}$ de profundidade, conforme será visto mais adiante a partir da filmagem com boroscópio.

Figura 139 - Observações da remoção da tubulação do Dreno 10 - Bloco 3 da estrutura de concreto: a) Carbonato fechando a tubulação no trecho superior. b) trecho inferior da tubulação com carbonato junto às paredes.

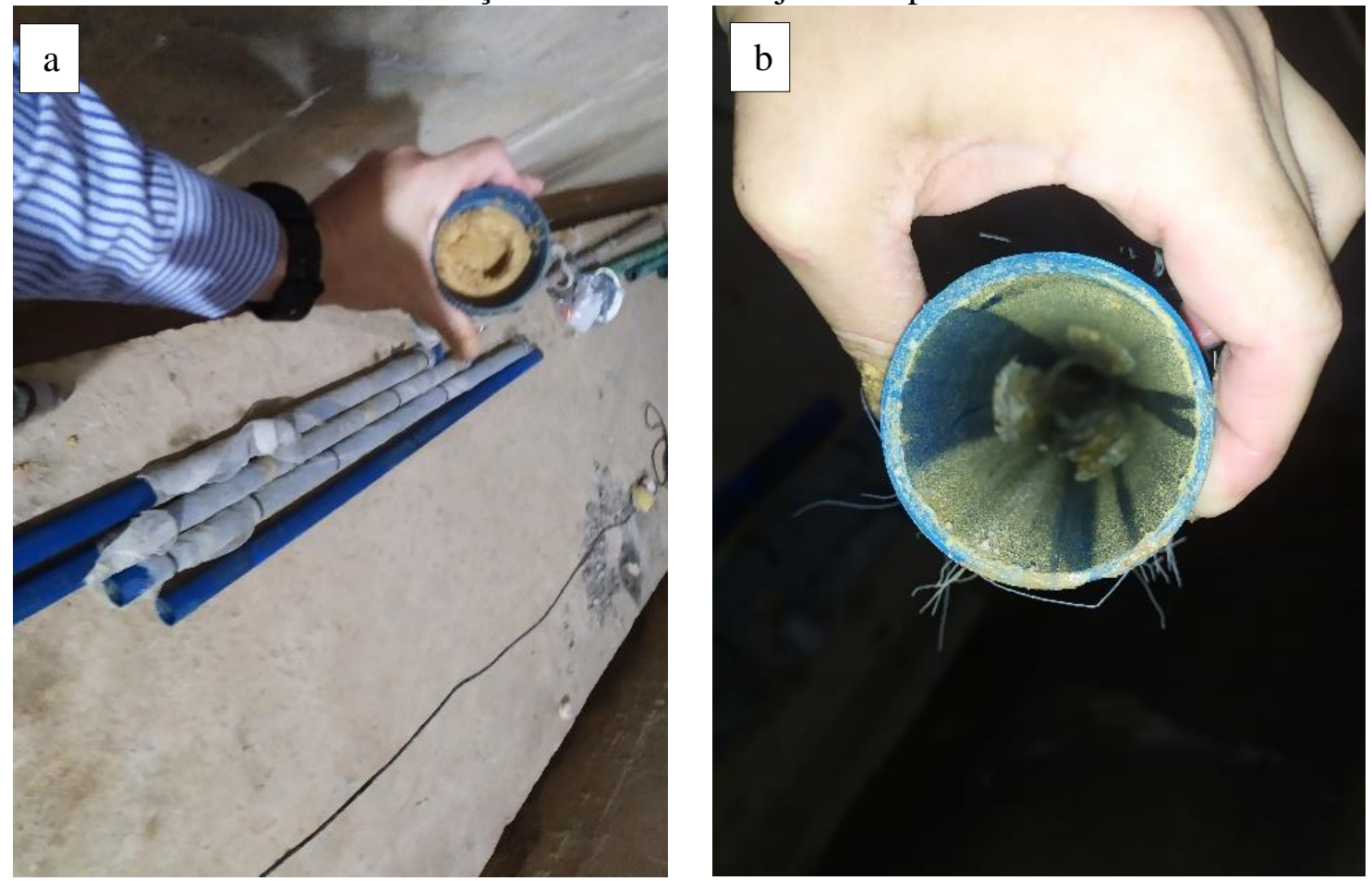

Fonte: do Autor (2020). 
Figura 140 - Observações da remoção da tubulação do Dreno 11- Bloco 3 da estrutura de concreto: a). Material branco e fino (seco) junto ao terminal, semelhante a cal. b) Material fechando a tubulação no trecho superior. c) Material de obstrução após remoção. d) Detalhe do material.

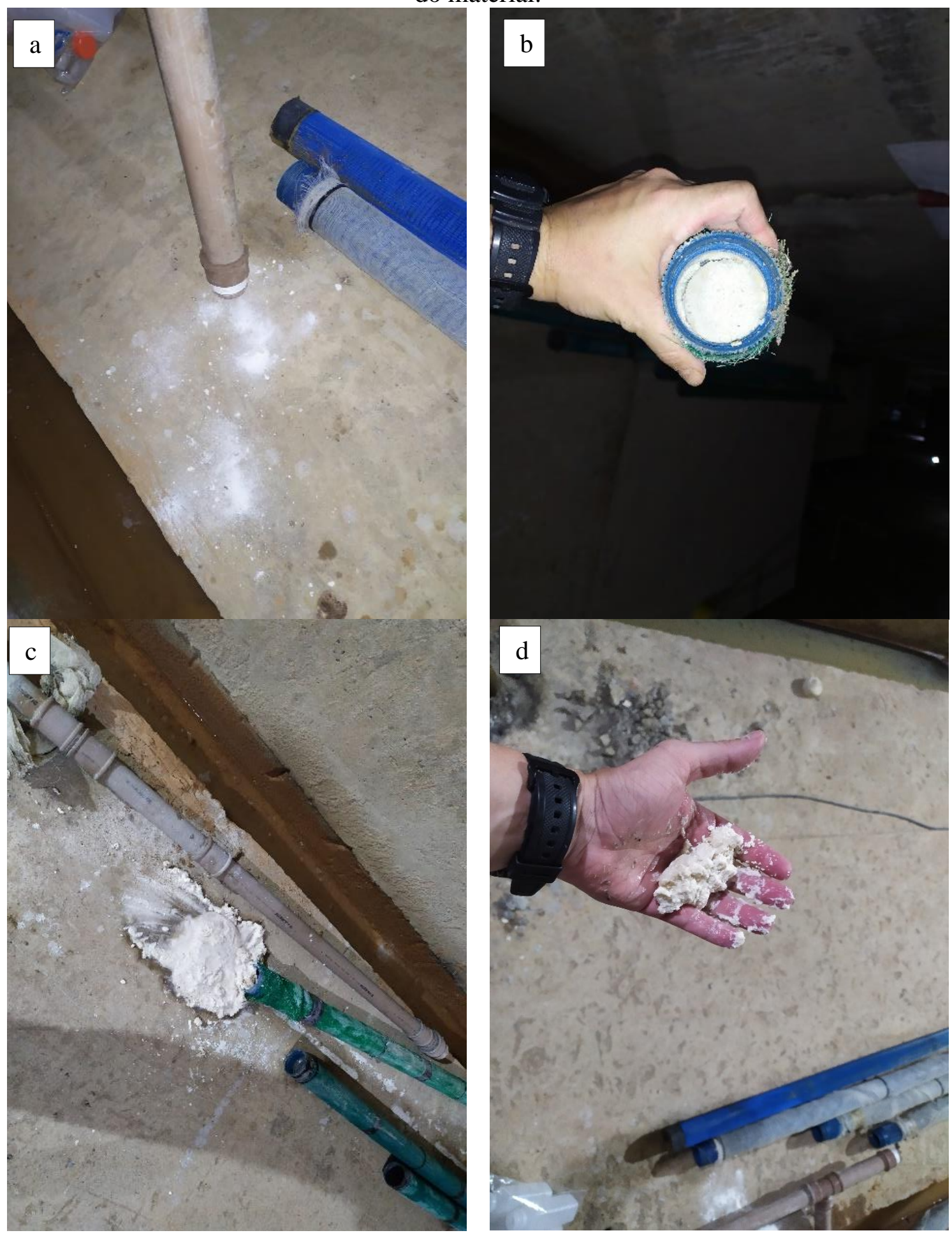

Fonte: do Autor (2020). 
Figura 141 - Observações da remoção da tubulação do Dreno 23 - Bloco 5 da estrutura de concreto: a) Material junto à tela de nylon. b) Detalhe do material fino junto à tela. c)Carbonato internamente à tubulação. d) "Cap" inferior com material fino acinzentado.
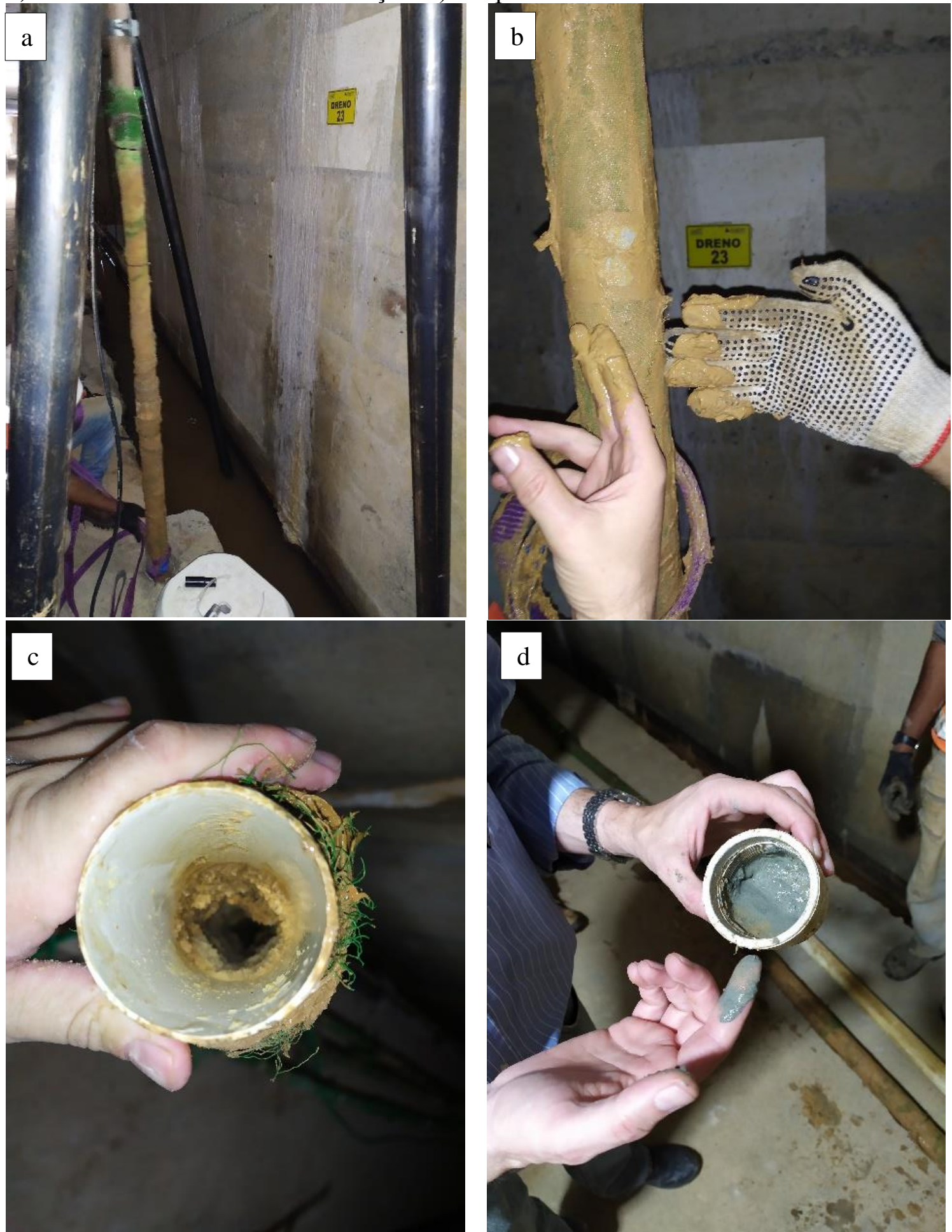

Fonte: do Autor (2020). 
Figura 142 - Observações da remoção da tubulação do Dreno 24 - Bloco 5 da estrutura de concreto: a) Carbonato junto à tela de nylon. b) Tubulação totalmente obstruída.
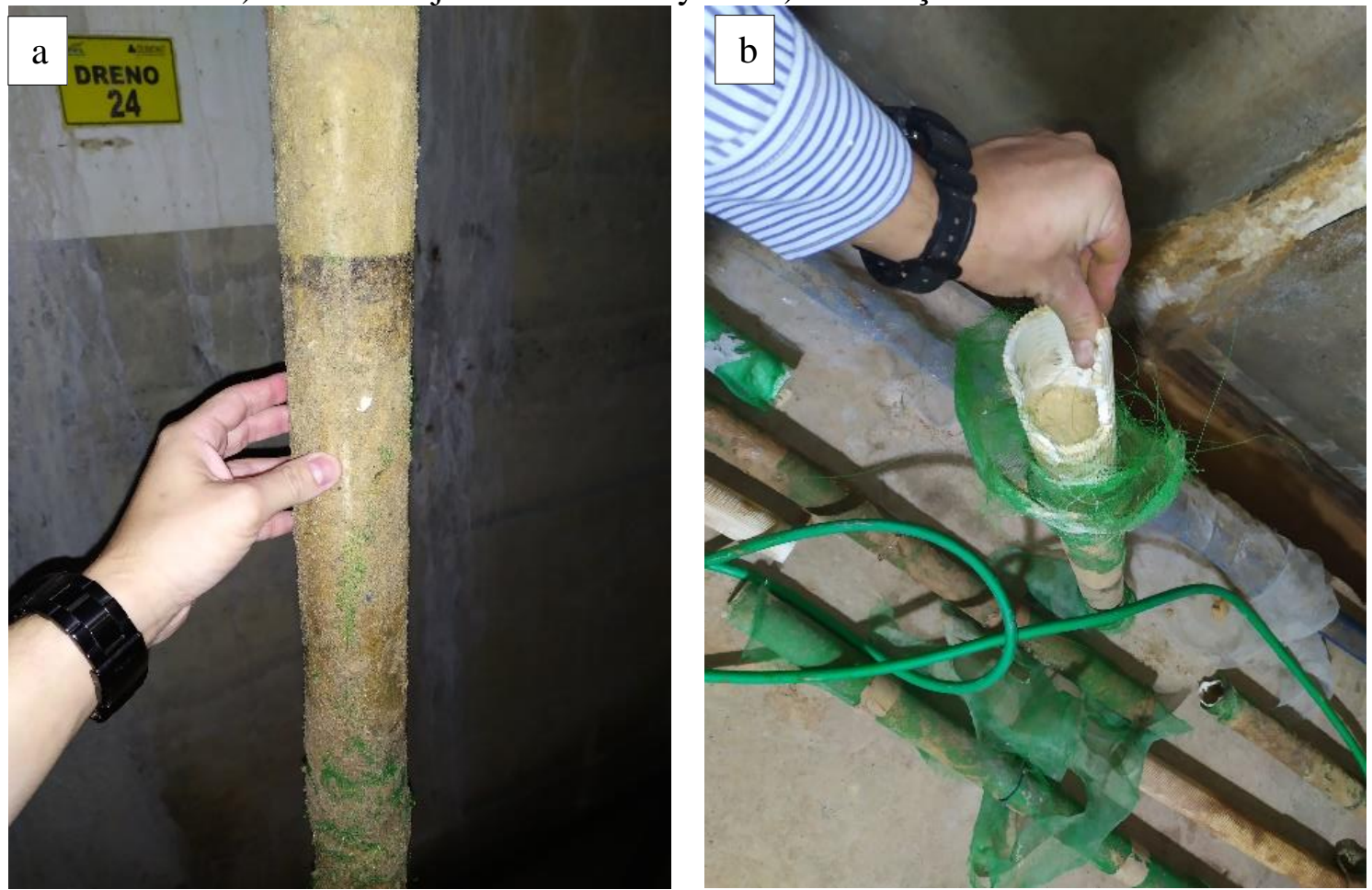

Fonte: do Autor (2020).

Figura 143 - Observações da remoção da tubulação do Dreno 25 - Bloco 5 da estrutura de concreto. a) Carbonato nas laterais bastante consolidado. b) Trechos com maior deposito de carbonato internamente.

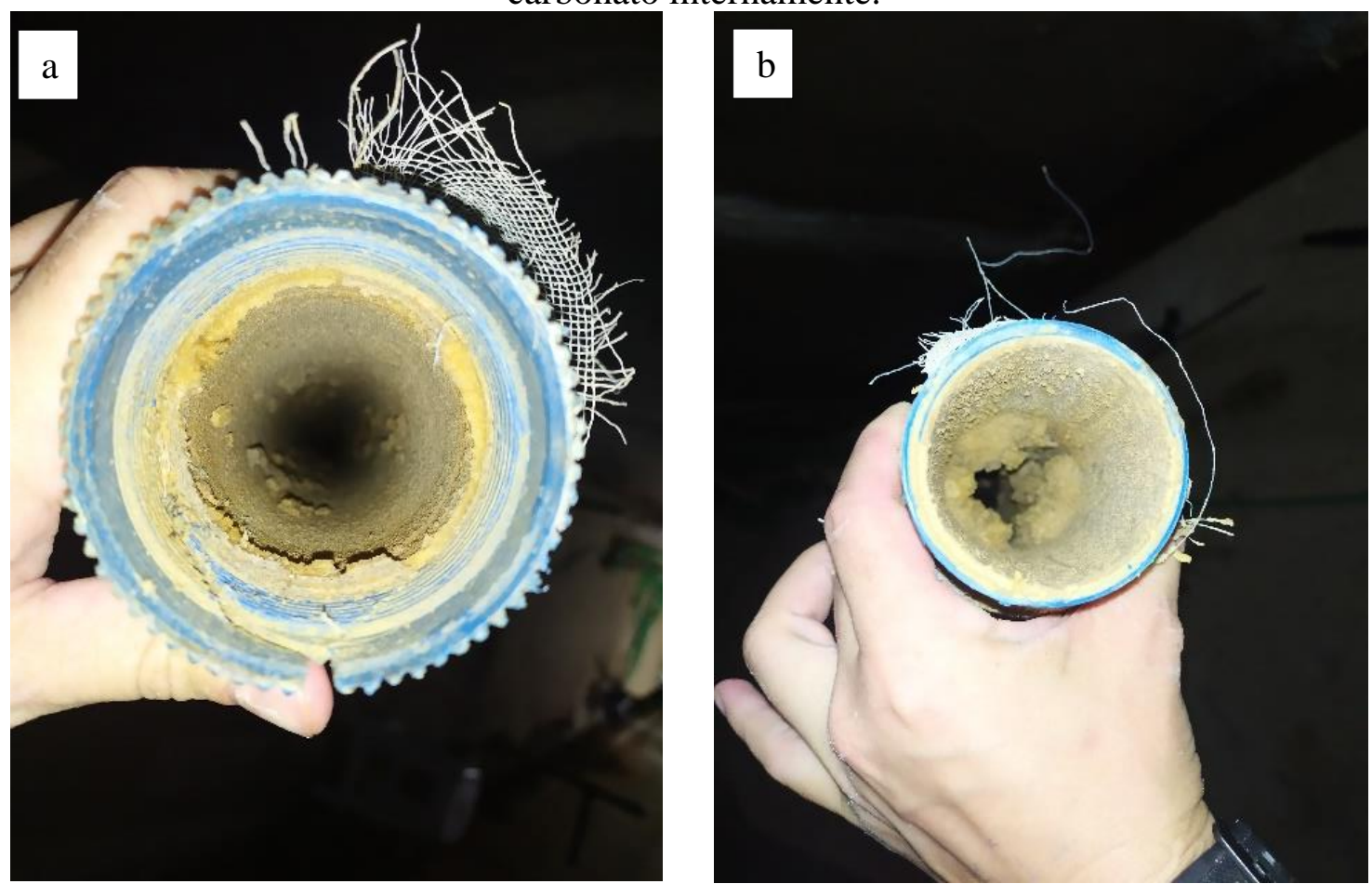

Fonte: do Autor (2020). 
Figura 144 - Observações da remoção da tubulação do Dreno 38- Bloco 7 da estrutura de concreto: a) Vista geral e vazão. b) Detalhe das bolhas de ar.
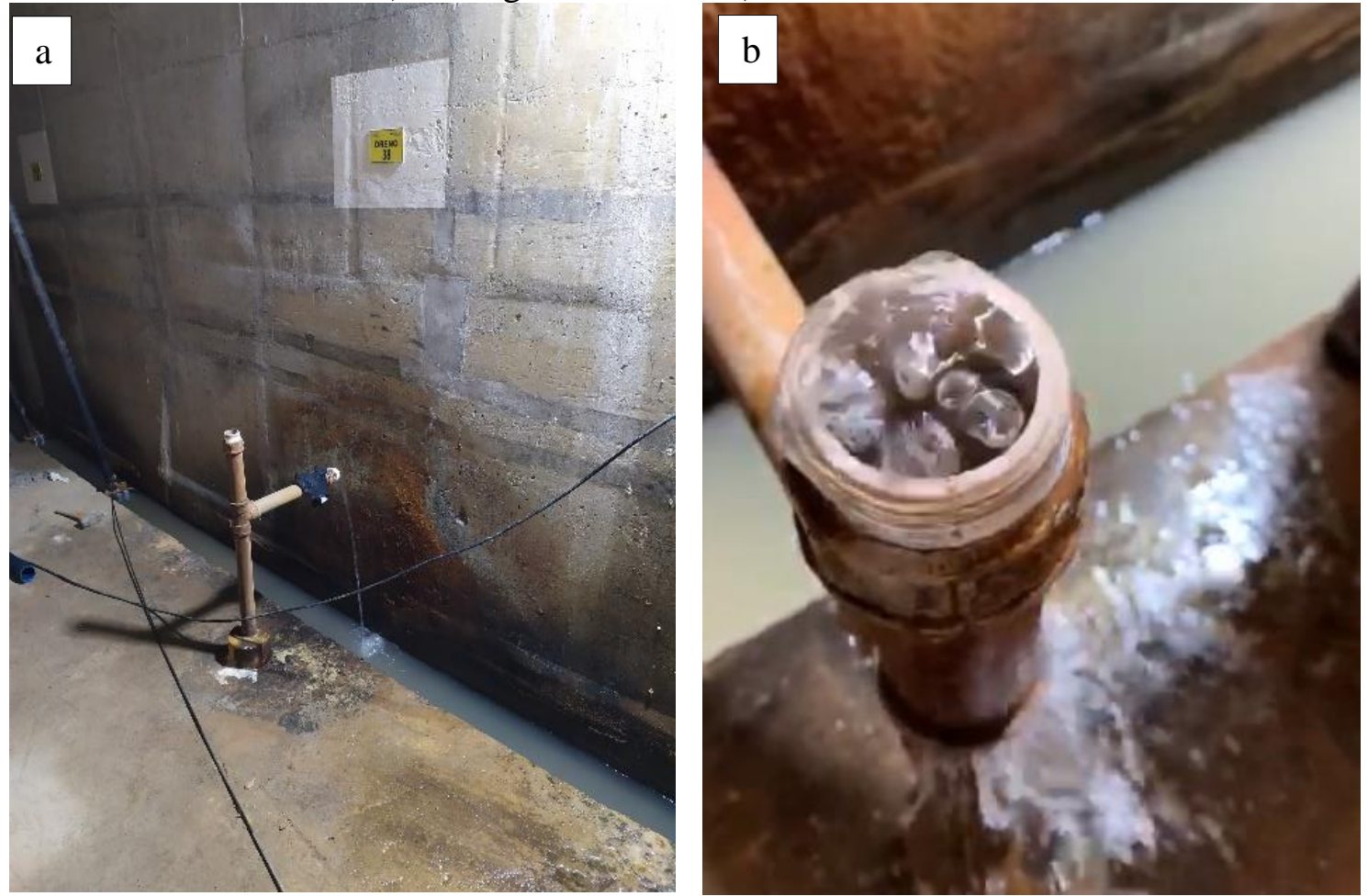

Fonte: do Autor (2020).

Figura 145 - Observações da remoção da tubulação do Dreno 42 - Bloco 7 da estrutura de concreto: a) Tubulação travada, impossibilitando a remoção. b) Carbonato terminal.

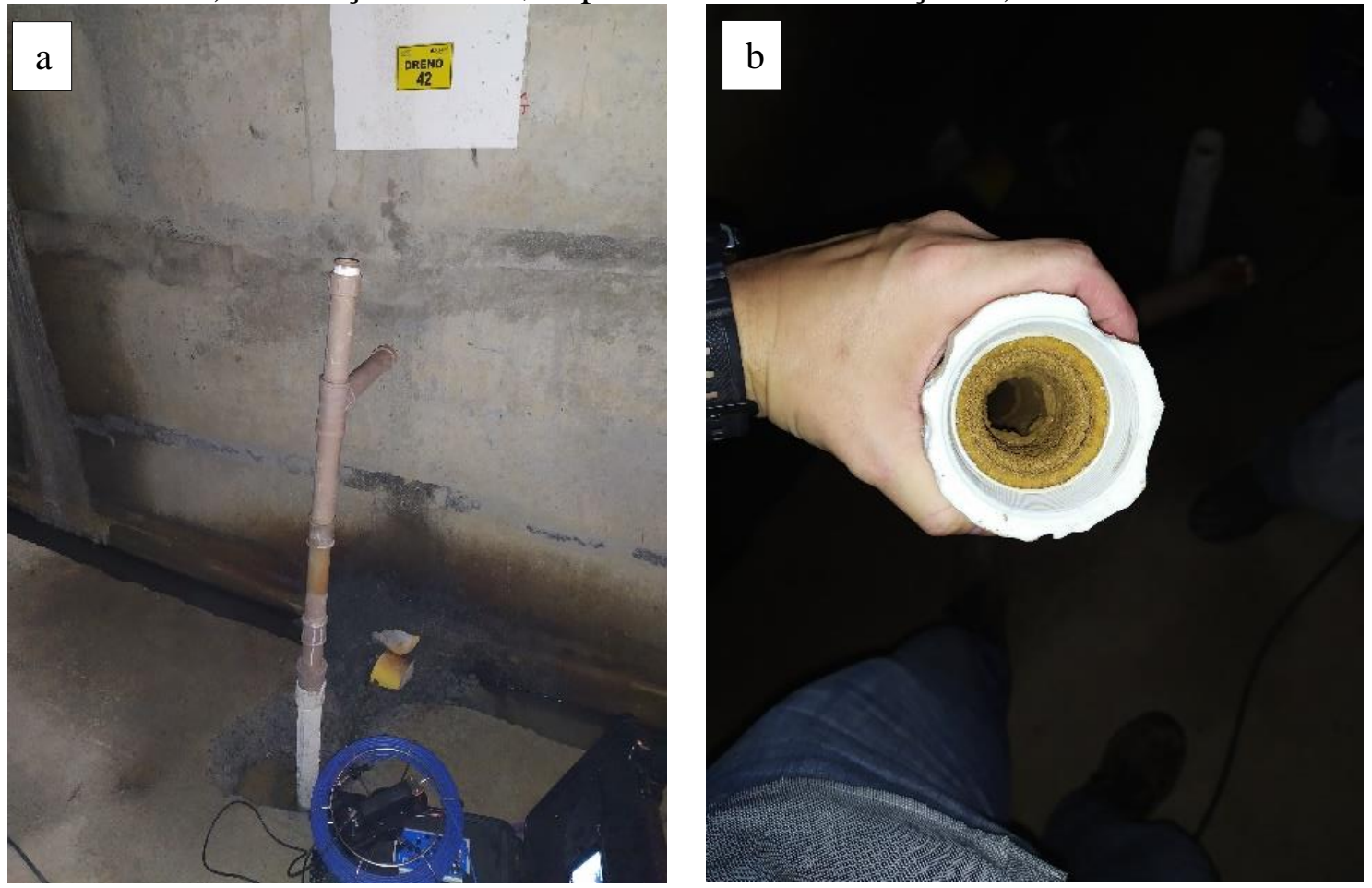

Fonte: do Autor (2020). 
Figura 146 - Observações da remoção da tubulação do Dreno 45 - Bloco 8 da estrutura de concreto: a) Tubulação sendo removida. b) Detalhe de material fino junto à tela de nylon.

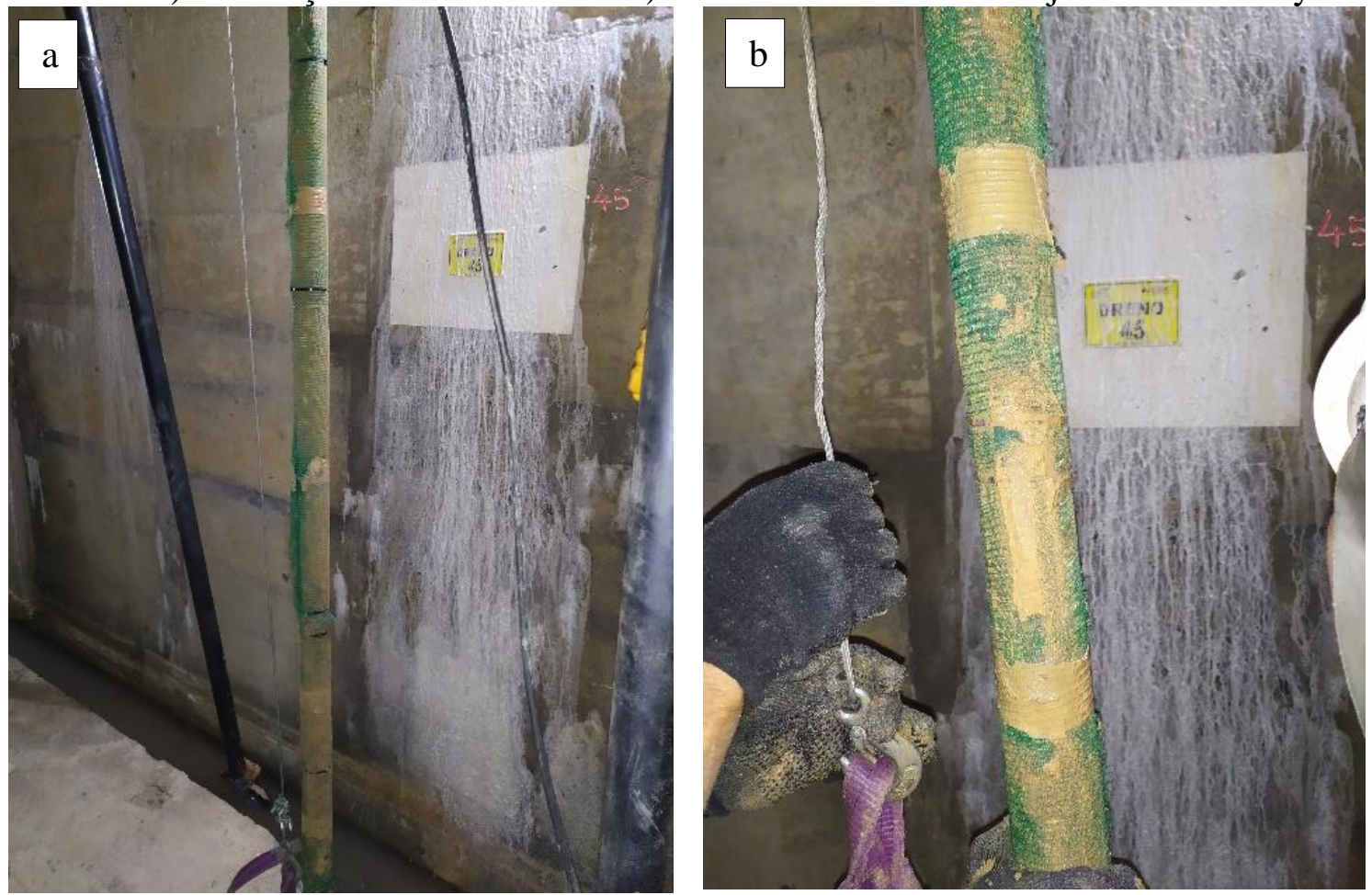

Fonte: do Autor (2020).

Figura 147 - Observações da remoção da tubulação do Dreno 47 - Bloco 8 da estrutura de concreto: a) Tubulação sendo removida. b) Detalhe do carbonato junto à tela.

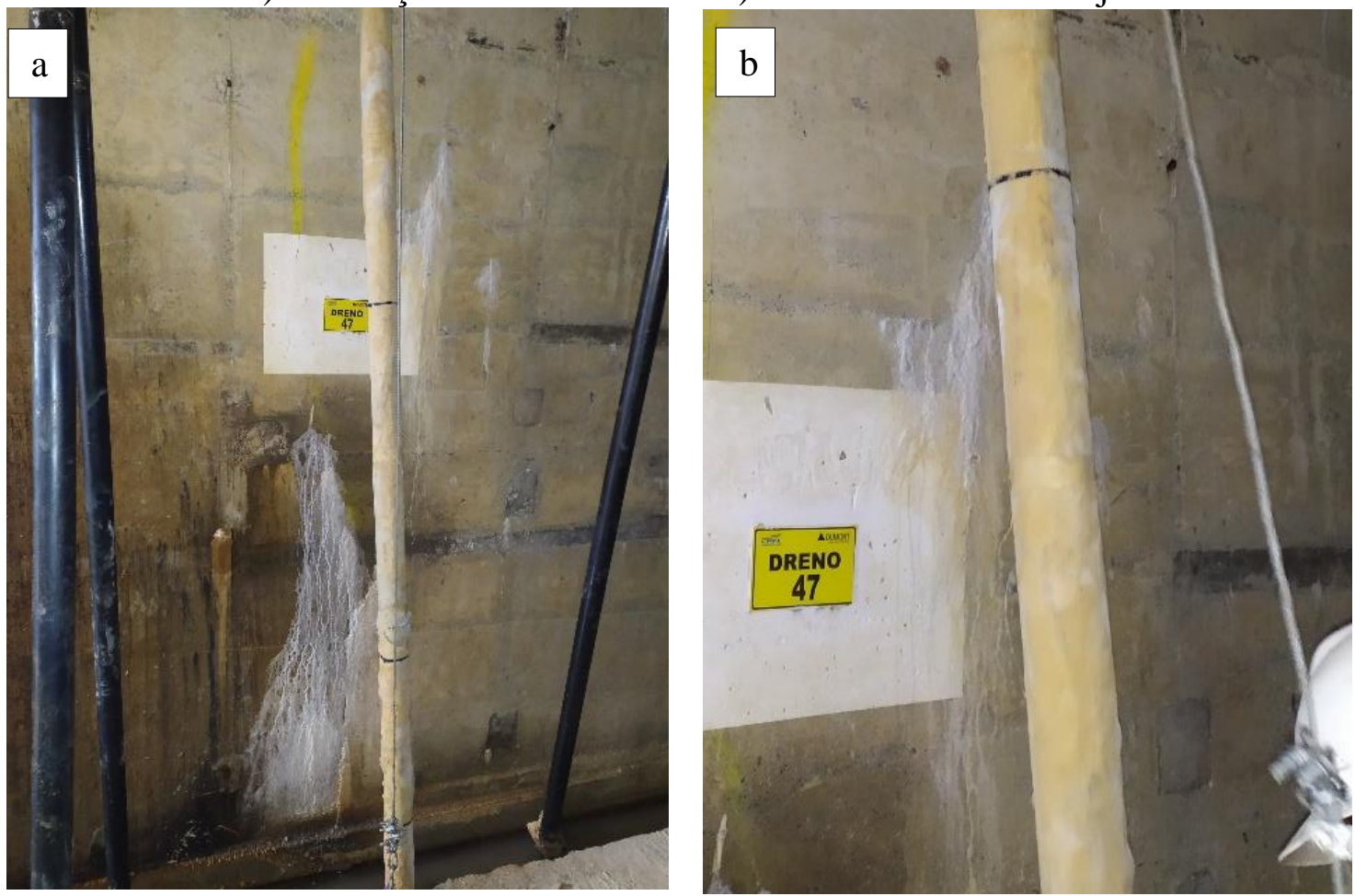

Fonte: do Autor (2020). 
Figura 148 - a) Tubulações removidas dos Drenos 45,43,49 e 48 (da esquerda para a direita). b) Detalhe das tubulações com material removido da tubulação do Dreno 48.
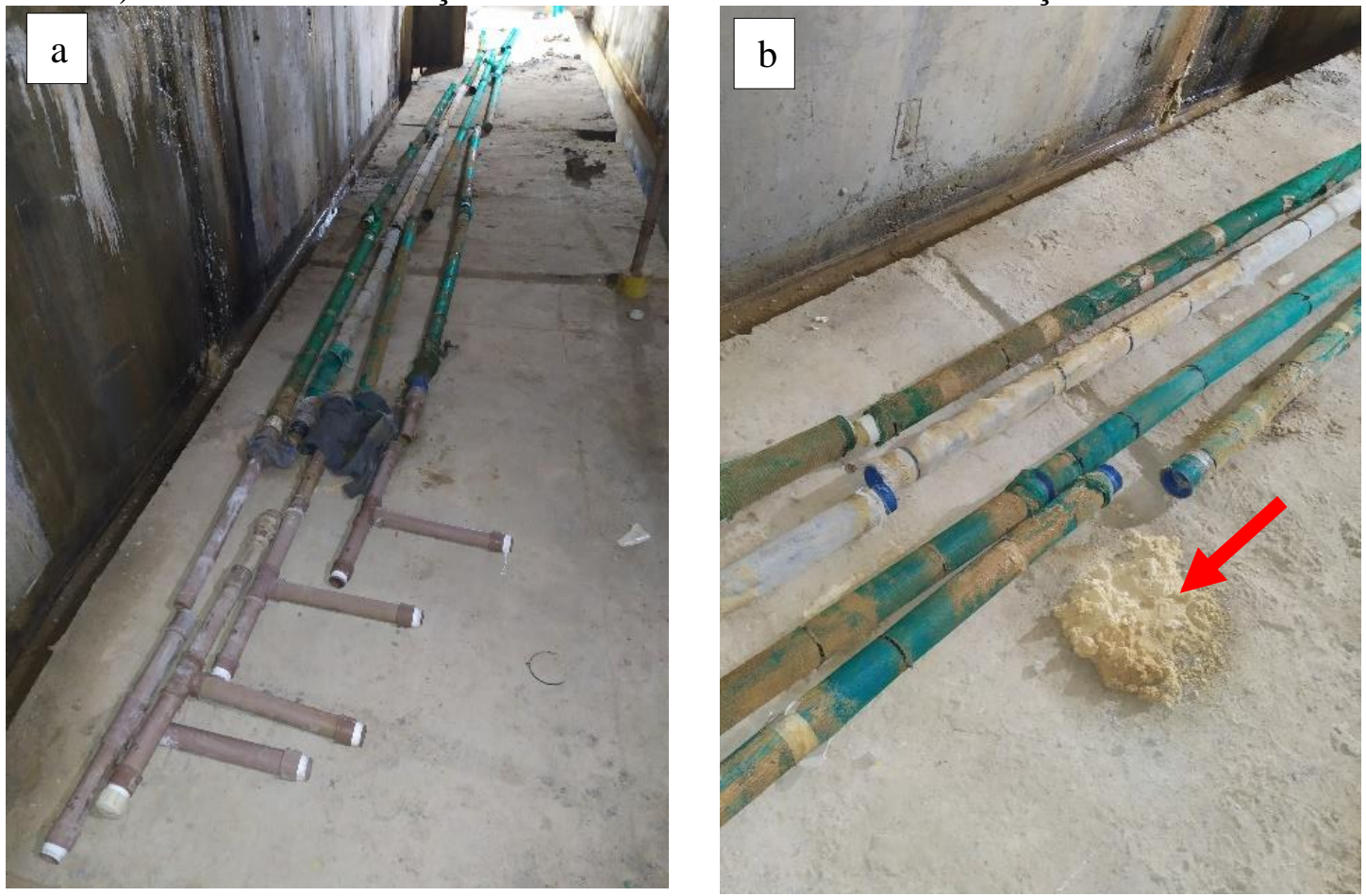

Fonte: do Autor (2020).

\subsubsection{Inspeção dos Furos e Tubulações Internas dos Drenos Utilizando Boroscópio}

Além da remoção das tubulações, utilizou-se a câmera endoscópica para inspeção dos drenos de fundação, em alguns casos internamente às tubulações ou após a remoção das mesmas, conforme Figura 149 a Figura 161

Alguns drenos apresentaram comportamento singular, cabendo as observações gerais, conforme a seguir:

Tubulações dos drenos com indícios de carbonato nas ranhuras internas das tubulações e algum carbonato depositado no fundo do furo (Drenos 1, 3, 5, 9, 12, 27, 29, 31, 33 e 44);

- Tubulação do dreno sem indícios de carbonato (Dreno 14);

- Tubulação do dreno com indícios de material biológico (Drenos 17, 28 e 50);

- Tubulações com carbonatação avançada, em alguns casos impedindo a passagem do tubo (Drenos 22, 23, 36, 37 e 40);

- Paredes do furo do Dreno com indícios de carbonato, após a remoção da tubulação (Dreno 19 e 21). 
Figura 149 - Registro da câmera endoscópica no Dreno 1, no Bloco 2 da estrutura de concreto: a) Indícios de carbonato junto às ranhuras internas da tubulação. b) Fundo do tubo com carbonato depositado.
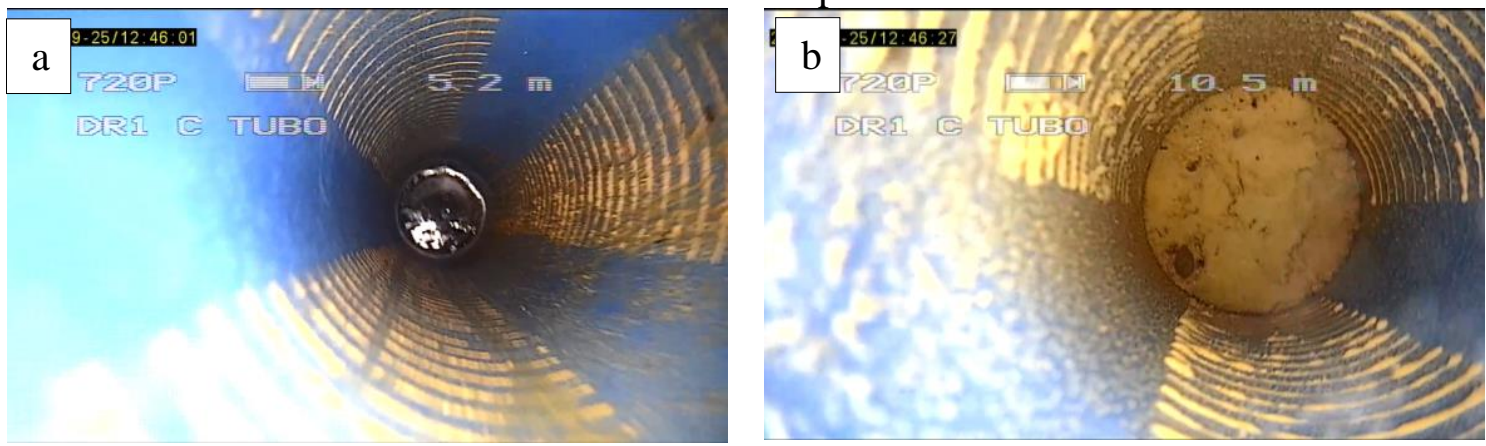

Fonte: Do autor (2020).

Figura 150 - Registro da câmera endoscópica nos Drenos 14 e 17, no Bloco 4 da estrutura de concreto: a) Dreno 14 sem indícios de carbonato. b) Dreno 17 com algum material no fundo do tubo.
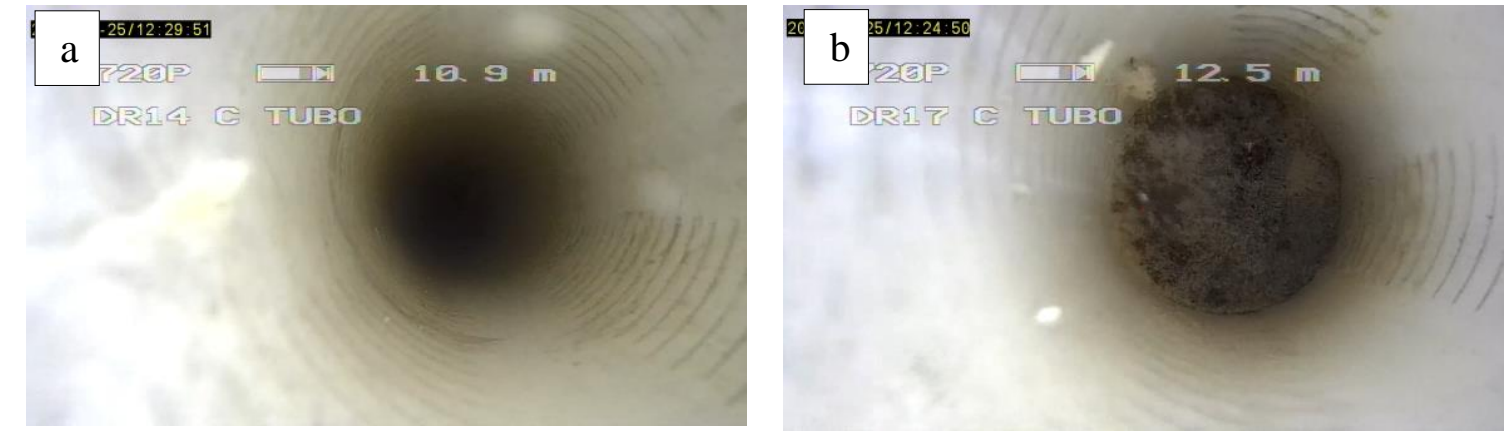

Fonte: do Autor (2020).

Figura 151 - Registro da câmera endoscópica nos Drenos 19 e 21, nos Blocos 4 e 5 da estrutura de concreto, após remoção da tubulação interna: a) Dreno 19 observando-se aspecto da rocha com material nas paredes. b) Dreno 21 aspecto da rocha.

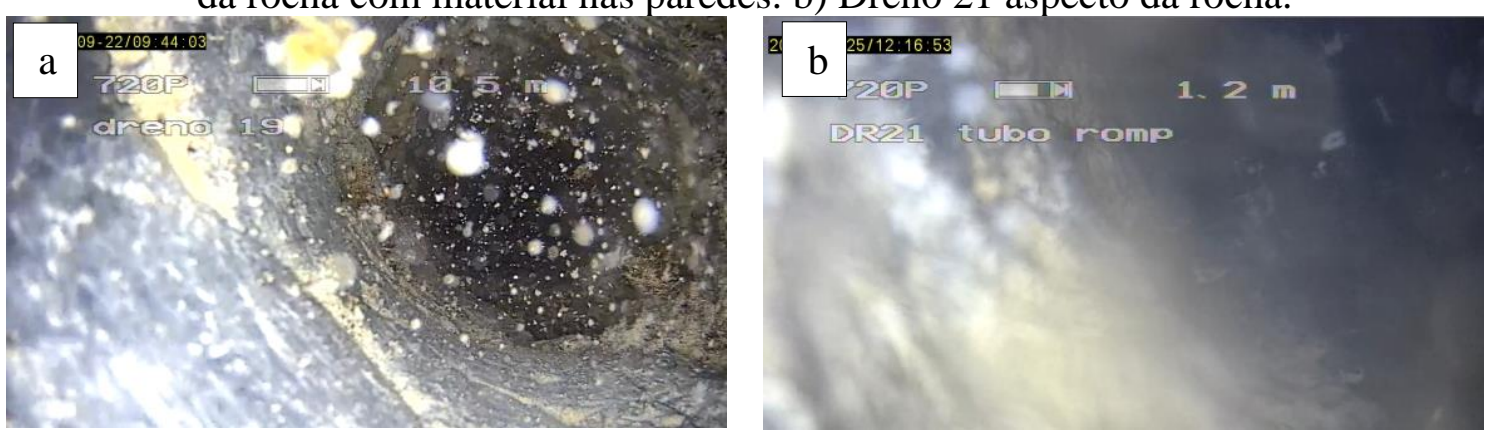

Fonte: do Autor (2020). 
Figura 152 - Registro da câmera endoscópica no Dreno 22 no Bloco 5 da estrutura de concreto. a) Trecho superior da tubulação. b) Carbonatação a cerca de 1,0 de profundidade. c) Intensa carbonatação a cerca de 1,6 m. d) Carbonatação impedindo a passagem do boroscópio, a cerca de $2,5 \mathrm{~m}$.
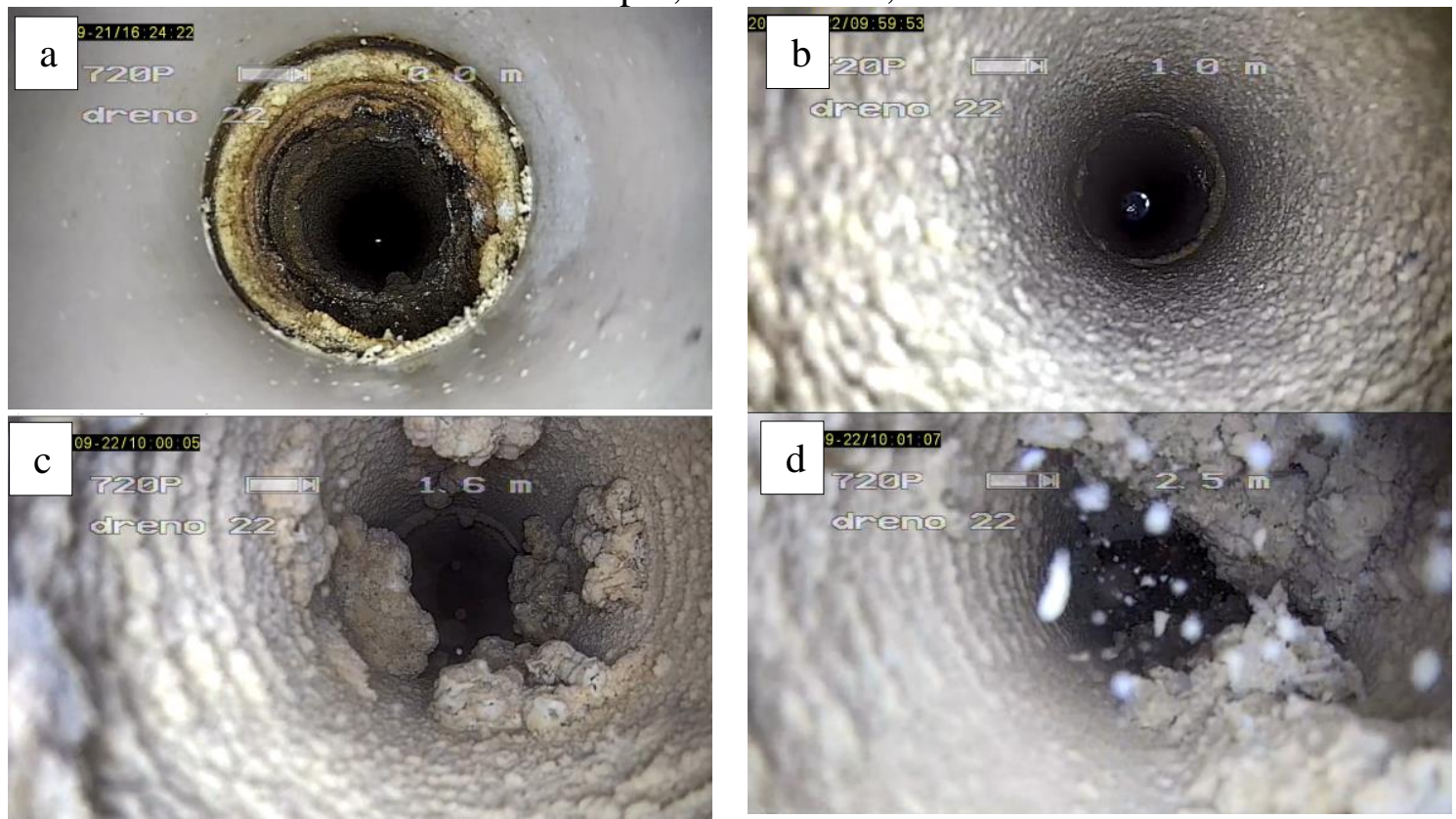

Fonte: do Autor (2020).

Figura 153 - Registro da câmera endoscópica no Dreno 23 no Bloco 5 da estrutura de concreto: a) Intensa carbonatação; b) Aspecto da rocha após remoção da tubulação.

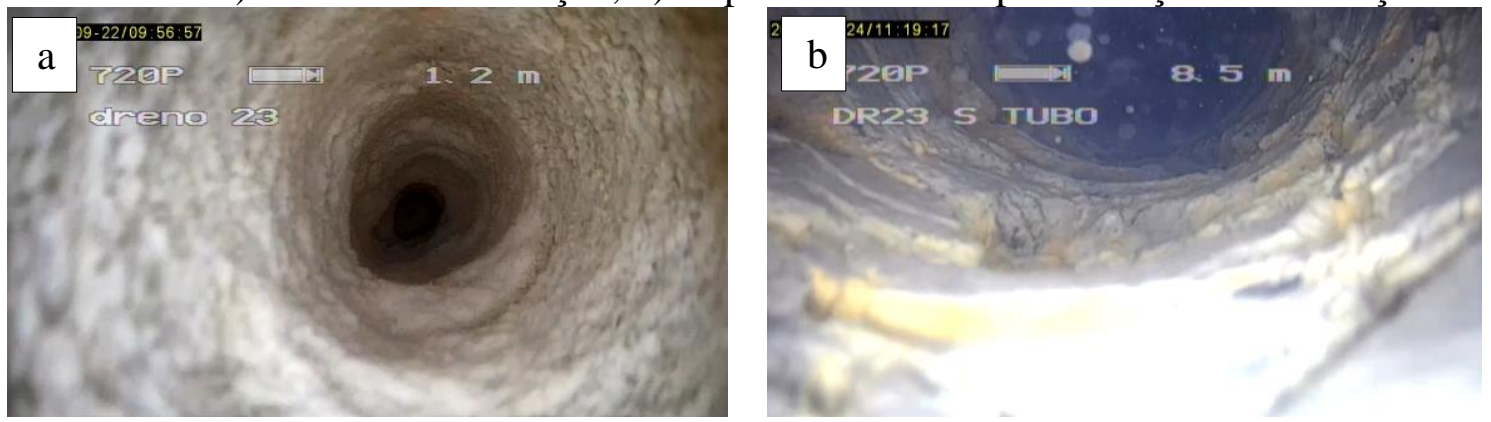

Fonte: do Autor (2020).

Figura 154 - Registro da câmera endoscópica nos Drenos 24 e 27, nos Blocos 5 e 6 da estrutura de concreto: a) Dreno 24 após remoção da tubulação interna; b) Dreno 27 com indícios de carbonato junto às ranhuras internas da tubulação.

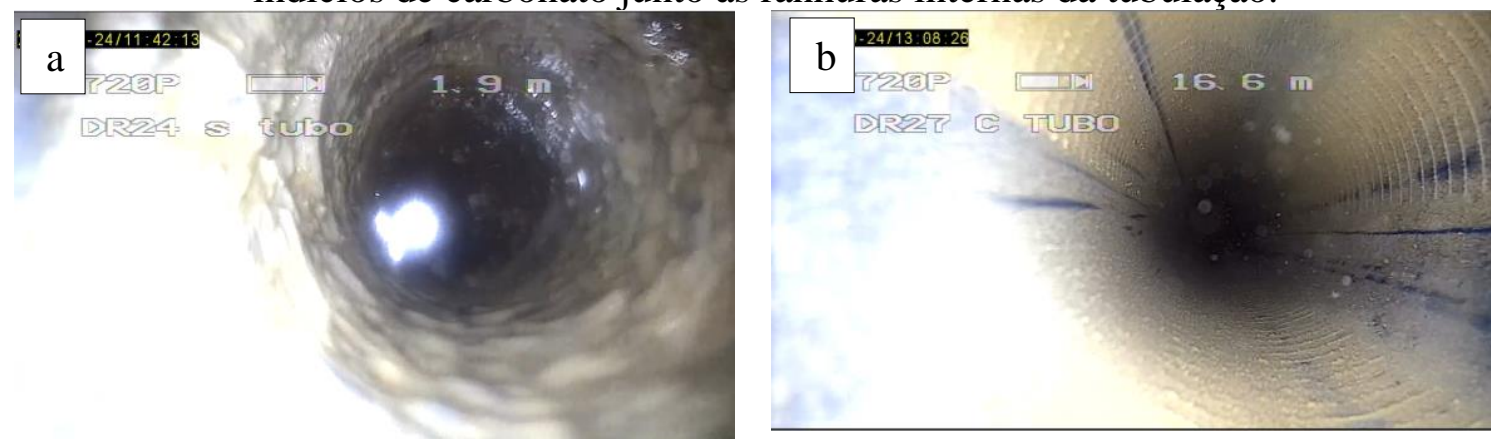

Fonte: do Autor (2020). 
Figura 155 - Registro da câmera endoscópica nos Drenos 28 e 33 no Bloco 6 da estrutura de concreto: a) Dreno 28 com material aparentemente de origem biológica; b) Dreno 33 com indícios de carbonato junto às ranhuras internas da tubulação.
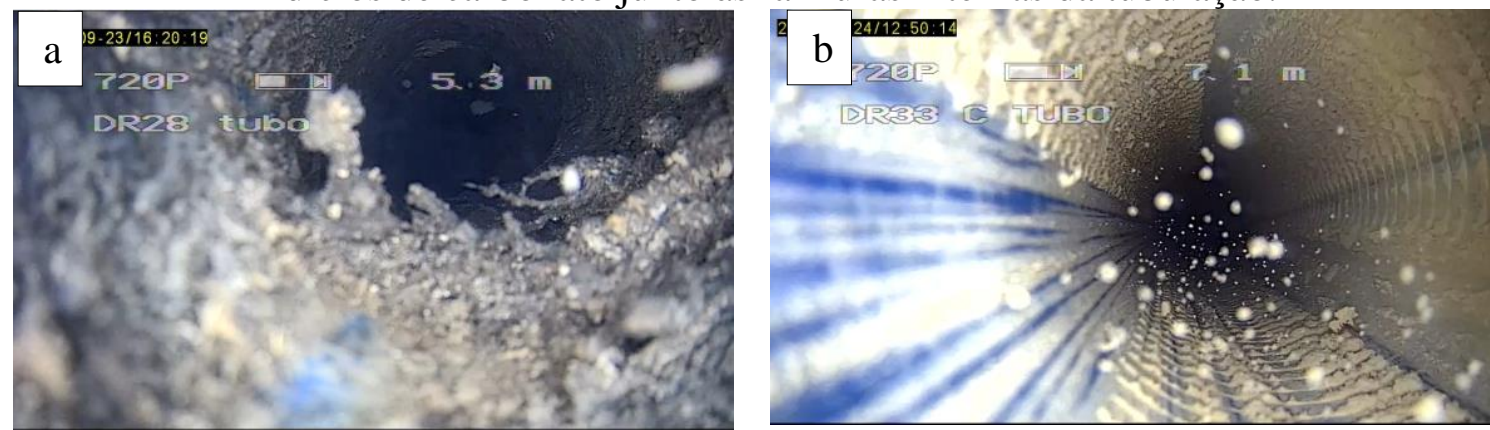

Fonte: do Autor (2020).

Figura 156 - Registro da câmera endoscópica nos Drenos 36 e 37 no Bloco 7 da estrutura de concreto: a) Dreno 36 com intensa carbonatação; b) Dreno 37 com intensa carbonatação

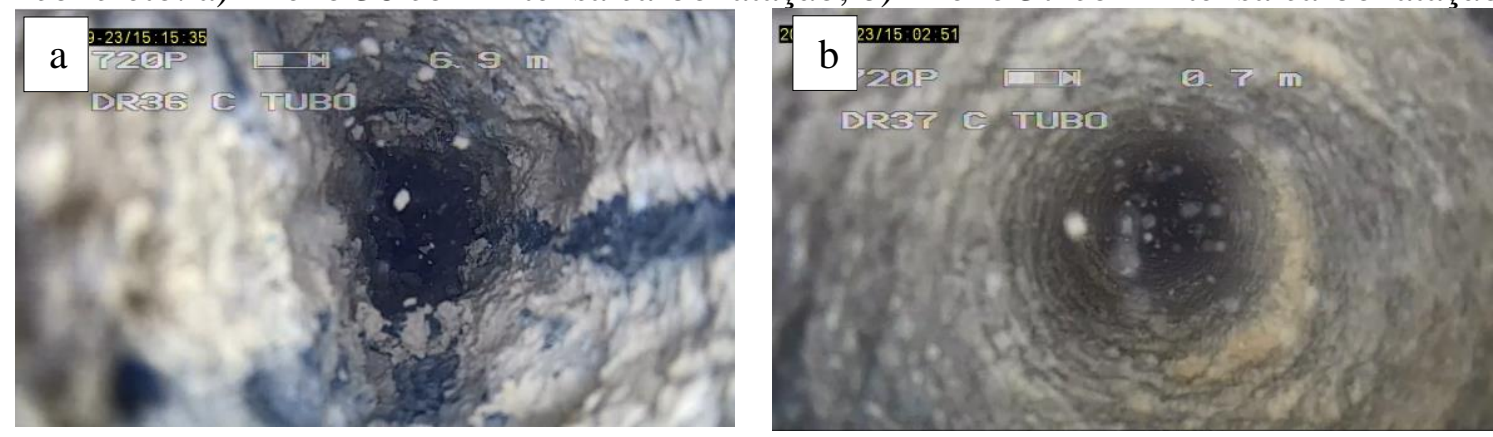

Fonte: do Autor (2020).

Figura 157 - Registro da câmera endoscópica no Dreno 38 no Bloco 7 da estrutura de concreto: a) Presença de bolhas de ar e material junto às ranhuras; b) Formação de bolhas de ar a cerca de $12 \mathrm{~m}$ de profundidade, observando carbonatação nas ranhuras abaixo.

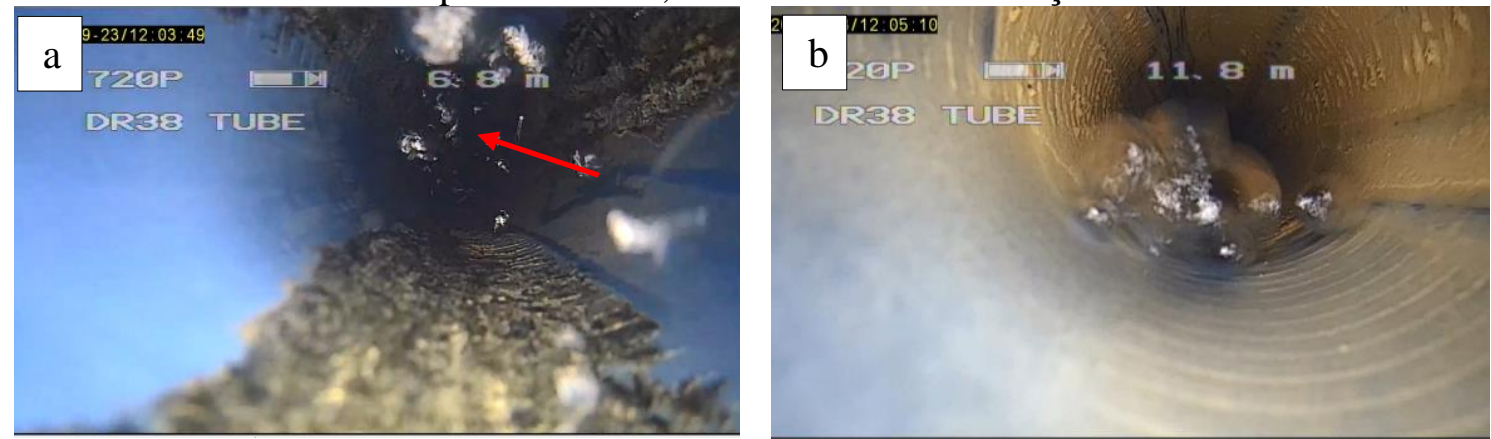

Fonte: do Autor (2020). 
Figura 158 - Registro da câmera endoscópica no Dreno 40 no Bloco 7 da estrutura de concreto: a) Intensa cabonatação a cerca de 1,7 m de profundidade; b) Carbonação menos intensa a cerca de $10,2 \mathrm{~m}$.
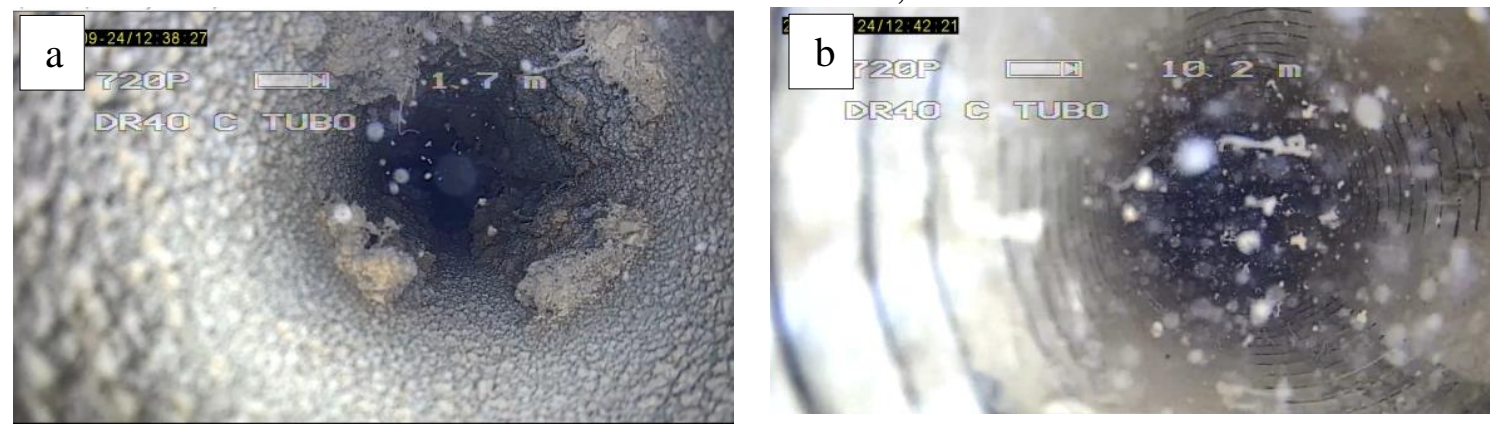

Fonte: do Autor (2020)

Figura 159 - Registro da câmera endoscópica nos Drenos 44 e 45 no Bloco 8 da estrutura de concreto: a) Dreno 44 com indícios de carbonato junto às ranhuras internas da tubulação; b) Dreno 45 após remoção da tubulação.
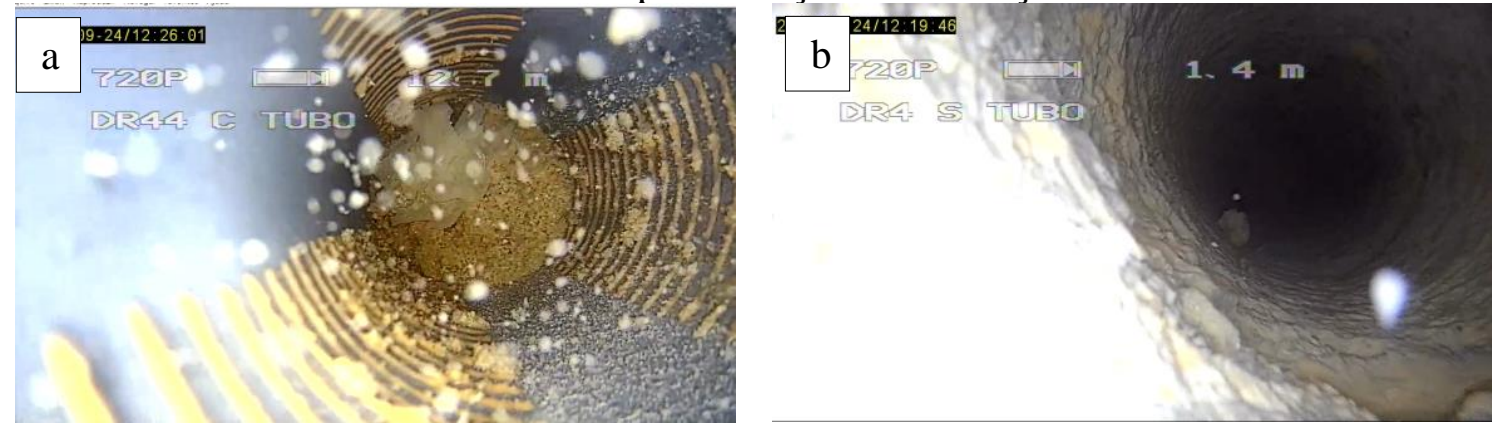

Fonte: do Autor (2020).

Figura 160 - Registro da câmera endoscópica nos Drenos 46 e 48 no Bloco 8 da estrutura de concreto: a) Dreno 46 com carbonato em suspensão em função descida do boroscópio; b)

Dreno 48 com carbonato.
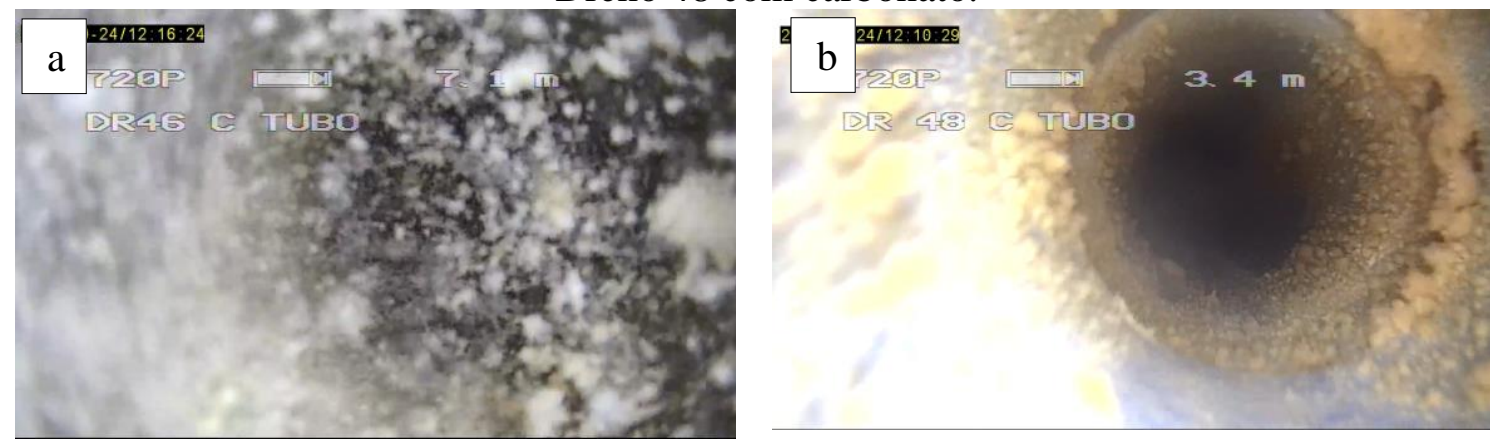

Fonte: do Autor (2020). 
Figura 161 - Registro da câmera endoscópica no Dreno 50 no Bloco 8 da estrutura de concreto: a) Trecho inicial do com carbonato; b) Material aparentemente de origem biológica, sem obstruir a tubulação, a cerca de 7,5 m.

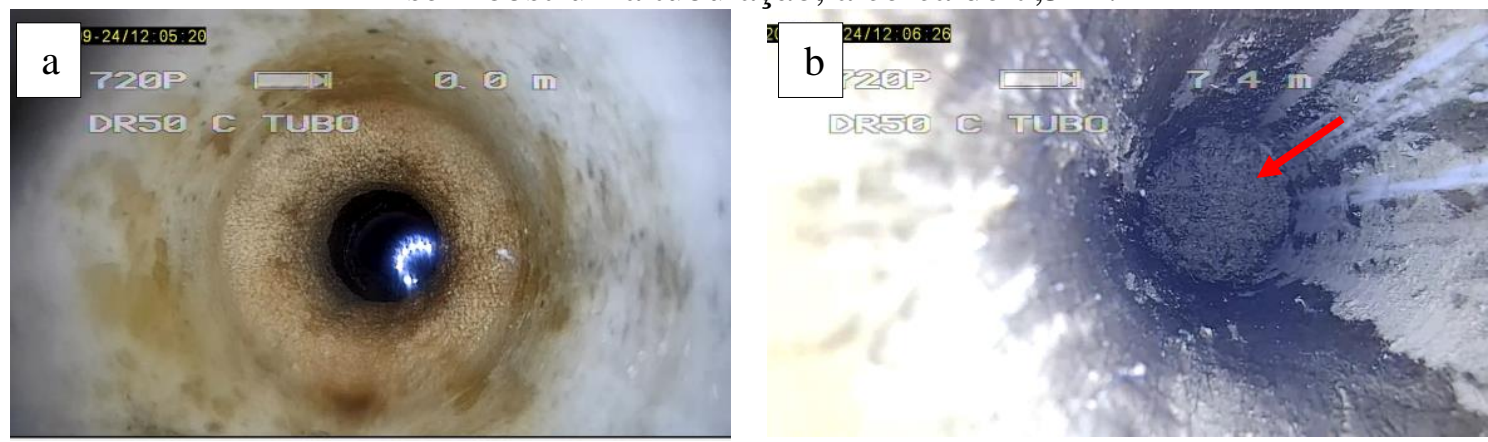

Fonte: do Autor (2020).

\subsubsection{Comentários Gerais}

Ao final dos trabalhos, como as tubulações removidas seriam descartadas, foram coletadas amostras dos materiais dos drenos, conforme Figura 162, para eventual análise ou comparação no futuro, caso necessário. Adicionalmente, deverão ser realizadas observações das canaletas, atentando-se para a deposição de material.

Figura 162 - Amostras coletadas dos drenos, para eventual análise.

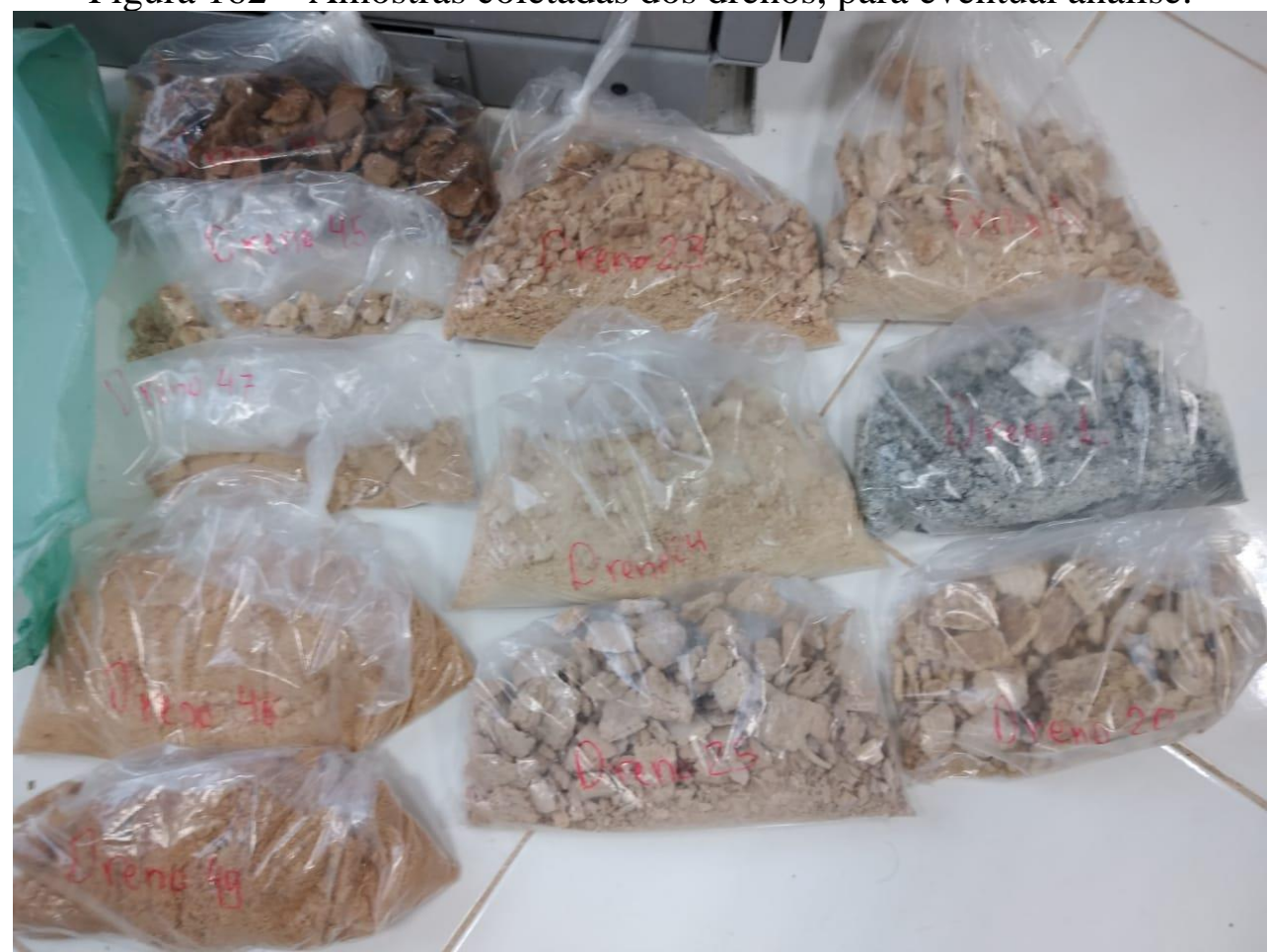

Fonte: do Autor (2020). 


\subsection{ANÁLISE FÍSICO-QUÍMICA DA ÁGUA}

Com a intenção de avaliar os materiais presentes na água dos drenos da barragem de concreto e outros pontos, foram coletadas amostras de $300 \mathrm{ml}$ de água em oito pontos:

1 no reservatório, a 10 metros de profundidade;

- 3 na porção terminal dos DHPs (drenos horizontais profundos) no talude da casa de força, na margem direita;

- 4 na porção terminal dos drenos de fundação da barragem de concreto.

As amostras foram coletadas e analisadas pela empresa Tommasi Ambiental, BrasíliaDF. Foram avaliados os seguintes parâmetros: $\mathrm{T}\left({ }^{\circ} \mathrm{C}\right)$, Condutividade, Oxigênio Dissolvido, Sulfato Total, Sólidos Dissolvidos Totais, Sólidos Suspensos Totais, Ferro Total, Manganês Total, Cálcio Total, Ferro Dissolvido, Ferro Particulado, Manganês Dissolvido, Manganês Particulado, Cálcio Dissolvido, Cálcio Particulado, Sódio Dissolvido, Sódio Particulado, Sódio Total, Potássio Dissolvido, Potássio Particulado e Potássio Total, conforme Tabela 19 e Figura 163 a Figura 166.

Os resultados obtidos na análise de $\mathrm{pH}$ apresentaram valores próximos da neutralidade, levemente ácidos para a maioria das amostras, que variaram entre 6,48 a 6,92, e mais alcalino $(\mathrm{pH} 7,7)$ para o dreno A (Figura 163-a).

As temperaturas médias obtidas no momento da coleta variaram entre $23,8^{\circ} \mathrm{C}$ e $21,6^{\circ} \mathrm{C}$, sendo a temperatura mais elevada coletada no reservatório (Figura 163-b).

A análise de condutividade demonstrou valores mais baixos nas amostras do reservatório, Dreno 28 e Dreno 37 com valores entre 22,1 $\mu \mathrm{S} / \mathrm{cm}$ e 42,6 $\mu \mathrm{S} / \mathrm{cm}$. Valores mais elevados foram encontrados nos demais pontos de coleta, variando entre 106,3 $\mu \mathrm{S} / \mathrm{cm}$ e 161,3 $\mu \mathrm{S} / \mathrm{cm}$ (Figura 163-c).

O nível de oxigênio dissolvido foi mais elevado no reservatório $(6,8 \mathrm{mg} / \mathrm{L})$ em comparação com os drenos que apresentaram níveis entre $2,3 \mathrm{mg} / \mathrm{L} \mathrm{e} 4,2 \mathrm{mg} / \mathrm{L}$ (Figura 163-d).

O ensaio de Sulfato total possui limite de quantificação de 1,0 mg/L e nenhuma amostra analisada apresentou valores superiores ao limite (Figura 163-e).

A presença de sólidos dissolvidos no reservatório da barragem apresentou níveis baixos $(26 \mathrm{mg} / \mathrm{L})$ em relação às amostras nos drenos, sendo este o menor valor. O Dreno 16 apresentou o maior valor (108 mg/L), seguidos dos Drenos C e B que apresentaram valores de $106 \mathrm{mg} / \mathrm{L}$ e $104 \mathrm{mg} / \mathrm{L}$, respectivamente. (Figura 163-f).

O ensaio de Sólidos Suspensos possui limite de quantificação de $10,0 \mathrm{mg} / \mathrm{L}$ e apenas a amostra relativa ao Dreno 37 apresentou valor superior ao limite, obtendo uma quantificação de $18 \mathrm{mg} / \mathrm{L}$ (Figura 164-a). 
A quantificação de Ferro Total apresentou níveis baixos no reservatório e Drenos A, B e C. Porém, os Drenos 16 e 35 apresentaram valores elevados, 0,575 mg/L e 0,653 mg/L, respectivamente (Figura 164-b).

O valor mais baixo de Manganês Total foi observado no reservatório $(0,033 \mathrm{mg} / \mathrm{L})$ e a maior quantificação foi obtida no Dreno $16 \mathrm{com} \mathrm{1,61} \mathrm{mg/L.} \mathrm{Os} \mathrm{demais} \mathrm{drenos} \mathrm{obtiveram}$ valores entre 0,126 mg/L e 0,54 mg/L (Figura 164-c).

A análise de Cálcio Total apresentou valores reduzidos apenas no reservatório (7,21 mg/L e no Dreno 28 (4,78). Os demais drenos apresentaram grande presença de Cálcio variando os valores entre $22 \mathrm{mg} / \mathrm{L}$ e 32,4 mg/L (Figura 164-d).

O Ferro Dissolvido foi observado em maiores concentrações nos Drenos 37, 35 e 16, com valores $0,126 \mathrm{mg} / \mathrm{L}, 0,088 \mathrm{mg} / \mathrm{L}$ e $0,073 \mathrm{mg} / \mathrm{L}$, respectivamente. Valores entre $0,024 \mathrm{mg} / \mathrm{L}$ e $0,036 \mathrm{mg} / \mathrm{L}$ foram observados nos Drenos 28, C e reservatório. Os Drenos A e B obtiveram valores inferiores ao limite de quantificação, que é de $0,01 \mathrm{mg} / \mathrm{L}$ (Figura 164-e).

A análise de Ferro Particulado demonstrou altas concentrações nos Drenos 16 e 35, com valores de 0,502 mg/L e 0,564mg/L, respectivamente, seguido pelo Dreno 28 (0,182 mg/L). Os demais drenos apresentaram valores abaixo de $0,044 \mathrm{mg} / \mathrm{L}$, sendo os Drenos B e C com quantidade abaixo do limite de quantificação de 0,01 mg/L (Figura 164-f).

O Manganês dissolvido teve maior concentração na amostragem do Dreno 16 (1,14 $\mathrm{mg} / \mathrm{L})$. Os Drenos 35, 37, A, B e C obtiveram valores intermediários entre 0,405 mg/L e 0,172 $\mathrm{mg} / \mathrm{L}$ e as concentrações mais baixas foram observadas no Reservatório $(0,021 \mathrm{mg} / \mathrm{L})$ e Dreno $28(0,041 \mathrm{mg} / \mathrm{L})$ (Figura 165-a)

O Manganês Particulado apresentou níveis similares ao Dissolvido, com o maior valor no Dreno $16(0,474 \mathrm{mg} / \mathrm{L})$, o menor no reservatório $(0,012 \mathrm{mg} / \mathrm{L})$ e os demais Drenos com concentrações entre 0,04 mg/L e 0,149 mg/L (Figura 165-b).

As concentrações de Cálcio Dissolvido foram, na maioria das amostras, elevadas, variando entre $11,1 \mathrm{mg} / \mathrm{L}$ e 23,9 mg/L, com exceção do Reservatório, com 2,95 mg/L e do Dreno 28 com 3,03 mg/L (Figura 165-c).

O Cálcio Particulado foi amostrado em menor concentração no Dreno 28 (1,75 mg/L) e em maior concentração nos Drenos A e B com 14,9 mg/L e 18,7 mg/L, respectivamente. Os demais valores variaram entre 4,26 mg/L e 6,68 mg/L (Figura 165-d).

A análise do Sódio Dissolvido demonstrou uma maior quantificação nos Drenos A, B e C (variação entre 4,09 mg/L e 4,87 mg/L) em relação aos demais pontos de amostragem que variaram entre $0,45 \mathrm{mg} / \mathrm{L}$ e $1,91 \mathrm{mg} / \mathrm{L}$ (Figura $165-$-e). 
O Sódio Particulado foi encontrado em maiores concentrações no Dreno A (2,06 mg/L) e Dreno B (1,63 mg/L) e em menores concentrações nos Drenos $16(0,24 \mathrm{mg} / \mathrm{L})$ e $37(0,15$ $\mathrm{mg} / \mathrm{L}$ ), estando indetectável no Dreno 35 (abaixo de 0,1 mg/L) (Figura 165-f).

Quantificações de Sódio Total evidenciaram uma maior concentração nos Drenos A, B e C (entre 5,73 mg/L e 6,22 mg/L) e os demais pontos de análise obtiveram valores entre 1,18 $\mathrm{mg} / \mathrm{L}$ e 2,15 mg/L (Figura 166-a).

O Potássio dissolvido apresentou-se em baixas concentrações nos Drenos 16 (0,66 $\mathrm{mg} / \mathrm{L})$ e A $(0,52 \mathrm{mg} / \mathrm{L})$ e nos demais pontos de coleta variou entre $0,92 \mathrm{mg} / \mathrm{L}$ e $1,32 \mathrm{mg} / \mathrm{L}$ (Figura 166-b).

Na análise do Potássio Particulado foi observado um pico de concentração no Dreno 28 $(1,68 \mathrm{mg} / \mathrm{L})$ e as demais amostras apresentaram valores inferiores a $0,38 \mathrm{mg} / \mathrm{L}$, estando abaixo do nível de quantificação no Dreno C (Figura 166-c).

Comportamento similar foi observado na quantificação de Potássio Total, com a maior concentração presente no Dreno $28(2,63 \mathrm{mg} / \mathrm{L})$ e as demais amostragens variaram entre 0,74 $\mathrm{mg} / \mathrm{L} \mathrm{e} 1,41 \mathrm{mg} / \mathrm{L}$ (Figura 166-d).

De uma forma geral, associando-se os resultados das análises físico-químicas aos processos de dissolução de rochas calcáreas e a carbonatação dos drenos de fundação, ficam as observações mais relevantes:

- O pH na água do reservatório é de 6,92, nas amostras dos drenos da galeria tem valor médio de 6,55 e nos drenos do talude da casa de força 7,11. Mesmo que a variação seja pequena, conceitualmente o $\mathrm{pH}$ da água do reservatório é praticamente neutro, passando a ligeiramente ácido na água coletada na galeria e ligeiramente básico quando aflora no talude da casa de força, podendo indicar um certo enriquecimento em bases (carbonato) durante o caminho de percolação;

- A temperatura da água nas amostras coletadas nos drenos da galeria é cerca de 1,5 graus mais baixa que no reservatório. Apesar de pequena, a diferença é favorável à dissolução do carbonato;

- A condutividade medida nas amostras de água dos drenos da parede de montante da casa de força e alguns drenos da galeria é cerca de 3 a 4 vezes maior que a água coletada no Reservatório. Nos drenos do talude da Casa de Força, a quantidade de sódio é cerca de 8 a 10 vezes maior que no reservatório, o que deve condicionar essa maior condutividade; 
- A quantidade de sólidos dissolvidos varia de $26 \mathrm{mg} / \mathrm{l}$ na água do reservatório para valores entre $70 \mathrm{mg} / \mathrm{l}$ e $108 \mathrm{mg} / \mathrm{l}$ nas amostras de água dos drenos, cerca de 3 a 4 vezes maior nestes, podendo ser associado à dissolução e carreamento de partículas finas da fundação (observado em outras fases de investigação);

- O cálcio dissolvido na água do reservatório tem uma concentração de 2,95 mg/l e nas amostras dos drenos da galeria e da parede da casa de força essa concentração varia entre 11,10 mg/l e 23,9 mg/l (a exceção do dreno 28), ou seja, de 3,8 a 8,1 vezes maior que na água do reservatório, indicando nitidamente que há dissolução de carbonatos no caminho de percolação. Este mesmo comportamento é observado nos teores de cálcio particulado e total;

Conforme Ruggeri (2004), a alta pressão da água no fundo do reservatório pode fazer com que o gás dióxido de carbono dissolvido se combine com a água para formar ácido carbônico (essa reação é sensível à pressão). À medida que mais ácido carbônico se forma, o $\mathrm{pH}$ da solução diminui (ou seja, aumenta a acidez). Uma solução com pH inferior a 8,2 pode dissolver o carbonato de cálcio (do concreto da barragem, cortina de injeção e rocha de fundação) formando bicarbonato de cálcio. O bicarbonato de cálcio é então transportado em solução à medida que a água flui para a fundação. Mas o bicarbonato de cálcio é instável e se a pressão da água diminuir (como ocorre quando a água flui para os drenos), isso causa a reversão da reação e o carbonato de cálcio dissolvido é depositado nos drenos. A taxa e a magnitude da diminuição da pressão afetam a densidade dos depósitos e a quantidade de precipitado que se forma. 
Tabela 19 - Resultados das análises físico-químicas.

\begin{tabular}{|c|c|c|c|c|c|c|c|c|c|c|}
\hline \multirow{2}{*}{ Análise } & \multirow{2}{*}{ Unidade } & \multirow{2}{*}{$\begin{array}{l}\text { Reserva- } \\
\text { tório }\end{array}$} & \multicolumn{4}{|c|}{$\begin{array}{c}\text { Galeria da Barragem de } \\
\text { Concreto }\end{array}$} & \multicolumn{3}{|c|}{$\begin{array}{l}\text { Talude da Casa de } \\
\text { Força }\end{array}$} & \multirow{2}{*}{$\begin{array}{c}\text { Limite de } \\
\text { Quantificação }\end{array}$} \\
\hline & & & $\begin{array}{l}\text { Dreno } \\
16\end{array}$ & $\begin{array}{l}\text { Dreno } \\
28\end{array}$ & $\begin{array}{l}\text { Dreno } \\
\mathbf{3 5}\end{array}$ & $\begin{array}{l}\text { Dreno } \\
37\end{array}$ & $\begin{array}{c}\text { DHP } \\
\text { A }\end{array}$ & $\begin{array}{c}\text { DHP } \\
\text { B }\end{array}$ & DHP C & \\
\hline $\mathrm{pH}$ & - & 6,92 & 6,51 & 6,56 & 6,48 & 6,64 & 7,7 & 6,76 & 6,88 & $2,00-12,00$ \\
\hline Temperatura & ${ }^{\circ} \mathrm{C}$ & 23,8 & 22,3 & 21,6 & 22,8 & 22,1 & 23,3 & 22,9 & 23 & 1,0 a 60,0 \\
\hline Condutividade & $\mu \mathrm{S} / \mathrm{cm}$ & 40,2 & 152,3 & 42,6 & 106,3 & 22,1 & 147,9 & 161,3 & 124,7 & 0,1 \\
\hline $\begin{array}{l}\text { Oxigênio } \\
\text { Dissolvido }\end{array}$ & $\mathrm{mg} / \mathrm{L}$ & 6,8 & 2,5 & 4,2 & 2,3 & 3,1 & 2,8 & 2,6 & 4,2 & 1,0 \\
\hline Sulfato Total & $\mathrm{mg} / \mathrm{L}$ & $<2,0$ & $<2,0$ & $<2,0$ & $<2,0$ & $<2,0$ & $<2,0$ & $<2,0$ & $<2,0$ & 2,0 \\
\hline $\begin{array}{c}\text { Sólidos } \\
\text { Dissolvidos } \\
\text { Totais }\end{array}$ & $\mathrm{mg} / \mathrm{L}$ & 26 & 108 & 36 & 72 & 70 & 98 & 105 & 106 & 10 \\
\hline $\begin{array}{c}\text { Sólidos } \\
\text { Suspensos Totais }\end{array}$ & $\mathrm{mg} / \mathrm{L}$ & $<10$ & $<10$ & $<10$ & $<10$ & 18 & $<10$ & $<10$ & $<10$ & 10 \\
\hline Ferro Total & $\mathrm{mg} / \mathrm{L}$ & 0,043 & 0,575 & 0,219 & 0,653 & 0,153 & 0,044 & $<0,01$ & 0,024 & 0,01 \\
\hline Manganês Total & $\mathrm{mg} / \mathrm{L}$ & 0,033 & 1,61 & 0,126 & 0,448 & 0,364 & 0,54 & 0,211 & 0,293 & 0,01 \\
\hline Cálcio Total & $\mathrm{mg} / \mathrm{L}$ & 7,21 & 26,2 & 4,78 & 23,8 & 22 & 26 & 32,4 & 30,6 & 0,1 \\
\hline Ferro Dissolvido & $\mathrm{mg} / \mathrm{L}$ & 0,029 & 0,073 & 0,036 & 0,088 & 0,126 & $<0,01$ & $<0,01$ & 0,024 & 0,01 \\
\hline Ferro Particulado & $\mathrm{mg} / \mathrm{L}$ & 0,013 & 0,502 & 0,182 & 0,564 & 0,034 & 0,044 & $<0,01$ & $<0,010$ & 0,01 \\
\hline $\begin{array}{l}\text { Manganês } \\
\text { Dissolvido }\end{array}$ & $\mathrm{mg} / \mathrm{L}$ & 0,021 & 1,14 & 0,041 & 0,3 & 0,265 & 0,405 & 0,172 & 0,183 & 0,01 \\
\hline $\begin{array}{l}\text { Manganês } \\
\text { Particulado }\end{array}$ & $\mathrm{mg} / \mathrm{L}$ & 0,012 & 0,474 & 0,085 & 0,149 & 0,099 & 0,135 & 0,04 & 0,11 & 0,01 \\
\hline Cálcio Dissolvido & $\mathrm{mg} / \mathrm{L}$ & 2,95 & 20,2 & 3,03 & 17,4 & 17 & 11,1 & 13,7 & 23,9 & 0,1 \\
\hline $\begin{array}{c}\text { Cálcio } \\
\text { Particulado }\end{array}$ & $\mathrm{mg} / \mathrm{L}$ & 4,26 & 6,01 & 1,75 & 6,31 & 4,97 & 14,9 & 18,7 & 6,68 & 0,1 \\
\hline Sódio Dissolvido & $\mathrm{mg} / \mathrm{L}$ & 0,45 & 1,91 & 0,45 & 1,17 & 1,32 & 4,16 & 4,09 & 4,87 & 0,1 \\
\hline Sódio Particulado & $\mathrm{mg} / \mathrm{L}$ & 0,72 & 0,24 & 0,91 & $<0,1$ & 0,15 & 2,06 & 1,63 & 0,94 & 0,1 \\
\hline Sódio Total & $\mathrm{mg} / \mathrm{L}$ & 1,18 & 2,15 & 1,36 & 1,26 & 1,48 & 6,22 & 5,73 & 5,81 & 0,1 \\
\hline $\begin{array}{l}\text { Potássio } \\
\text { Dissolvido }\end{array}$ & $\mathrm{mg} / \mathrm{L}$ & 0,93 & 0,66 & 0,93 & 1,05 & 1,32 & 0,52 & 0,92 & 1,13 & 0,1 \\
\hline $\begin{array}{l}\text { Potássio } \\
\text { Particulado }\end{array}$ & $\mathrm{mg} / \mathrm{L}$ & 0,19 & 0,36 & 1,68 & 0,12 & $<0,1$ & 0,22 & 0,38 & $<0,10$ & 0,1 \\
\hline Potássio Total & $\mathrm{mg} / \mathrm{L}$ & 1,12 & 1,02 & 2,62 & 1,17 & 1,41 & 0,74 & 1,3 & 1,13 & 0,1 \\
\hline
\end{tabular}

Notas: ${ }^{\circ} \mathrm{C}$ : Graus Celsius; $\mu \mathrm{S} / \mathrm{cm}$ : Micro-Siemens por Centímetro; mg/L: Miligrama por Litro.

Fonte: do Autor (2020). 
Figura 163 - Resultados das análises físico-químicas. a) pH. b) Temperatura. c) Condutividade. d) Oxigênio dissolvido. e) Sulfato Total. f) Sólidos dissolvidos.
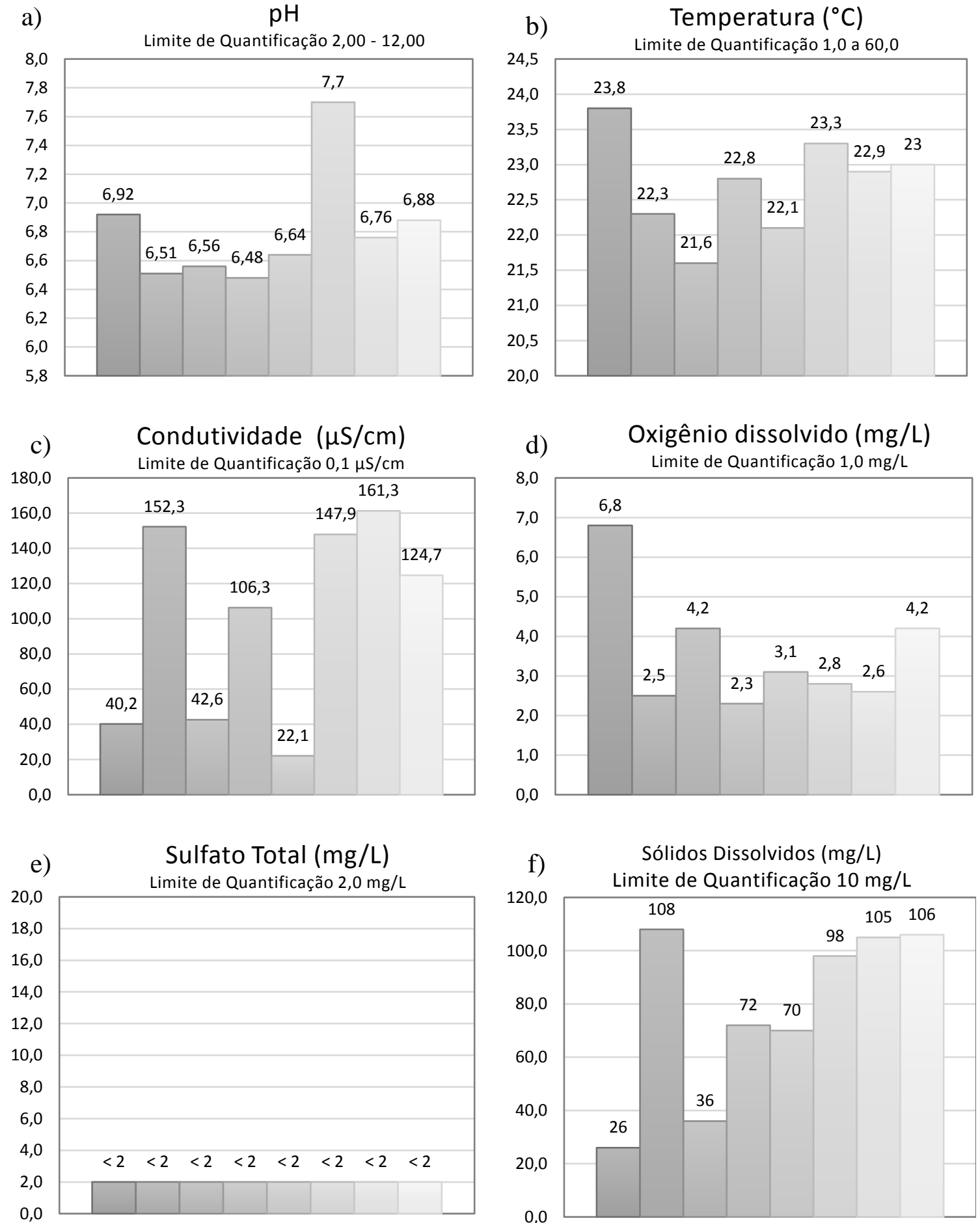

$\square$ Reservatório $\square$ Dreno $16 \square$ Dreno $28 \square$ Dreno $35 \square$ Dreno $37 \quad \square$ Dreno A $\square$ Dreno B $\square$ Dreno C

Fonte: do Autor (2020). 
Figura 164 - Resultados das análises físico-químicas. a) Sólidos suspensos. b) Ferro total. c) Manganês total. d) Cálcio total. e) Ferro dissolvido. f) Ferro particulado.
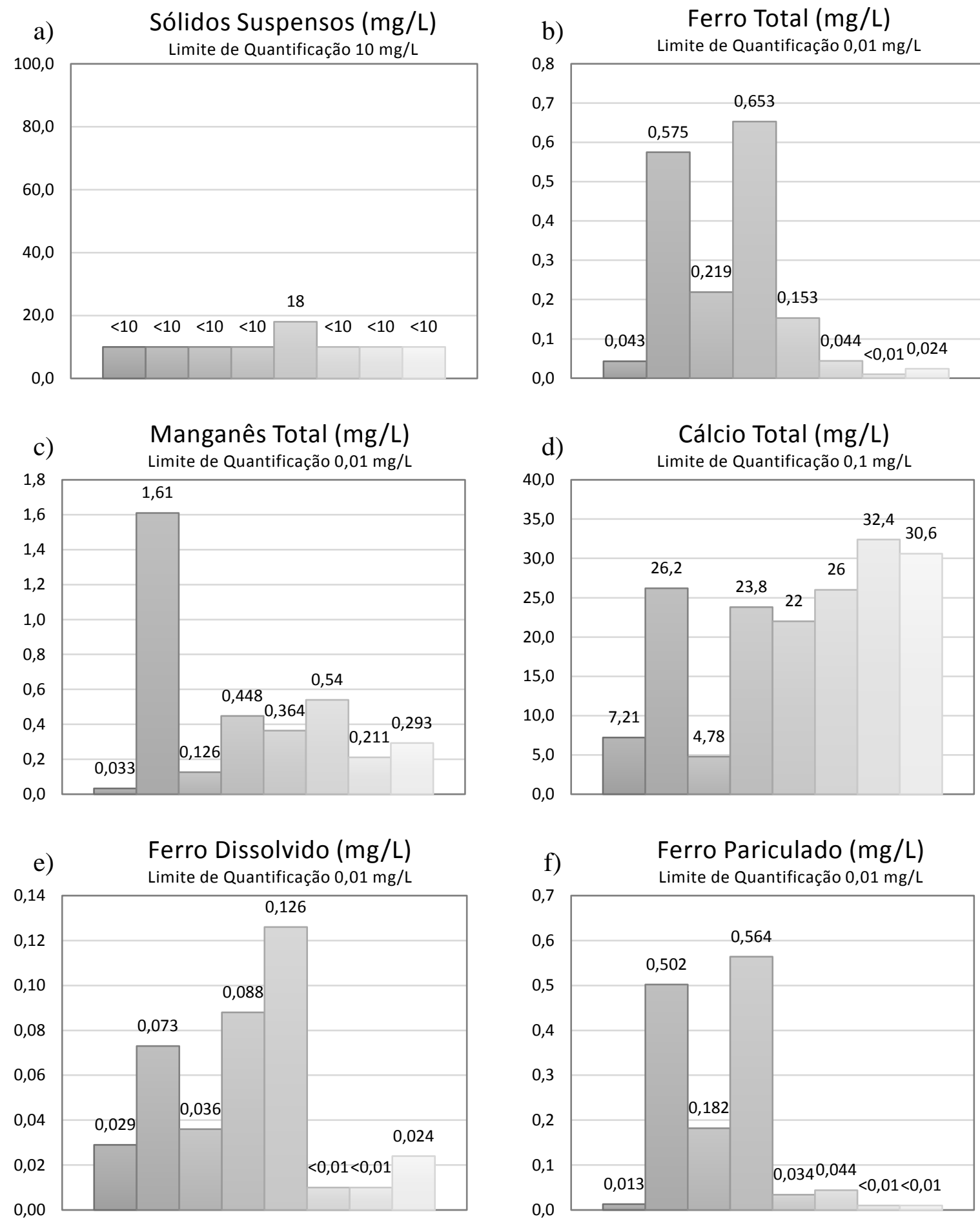

$\square$ Reservatório $\square$ Dreno $16 \square$ Dreno $28 \square$ Dreno $35 \square$ Dreno $37 \square$ Dreno A $\square$ Dreno B $\square$ Dreno C

Fonte: do Autor (2020). 
Figura 165 - Resultados das análises físico-químicas. a) Manganês dissolvido. b) Manganês particulado. c) Cálcio dissolvido. d) Cálcio particulado. e) Sódio Dissolvido. f) Sódio particulado.
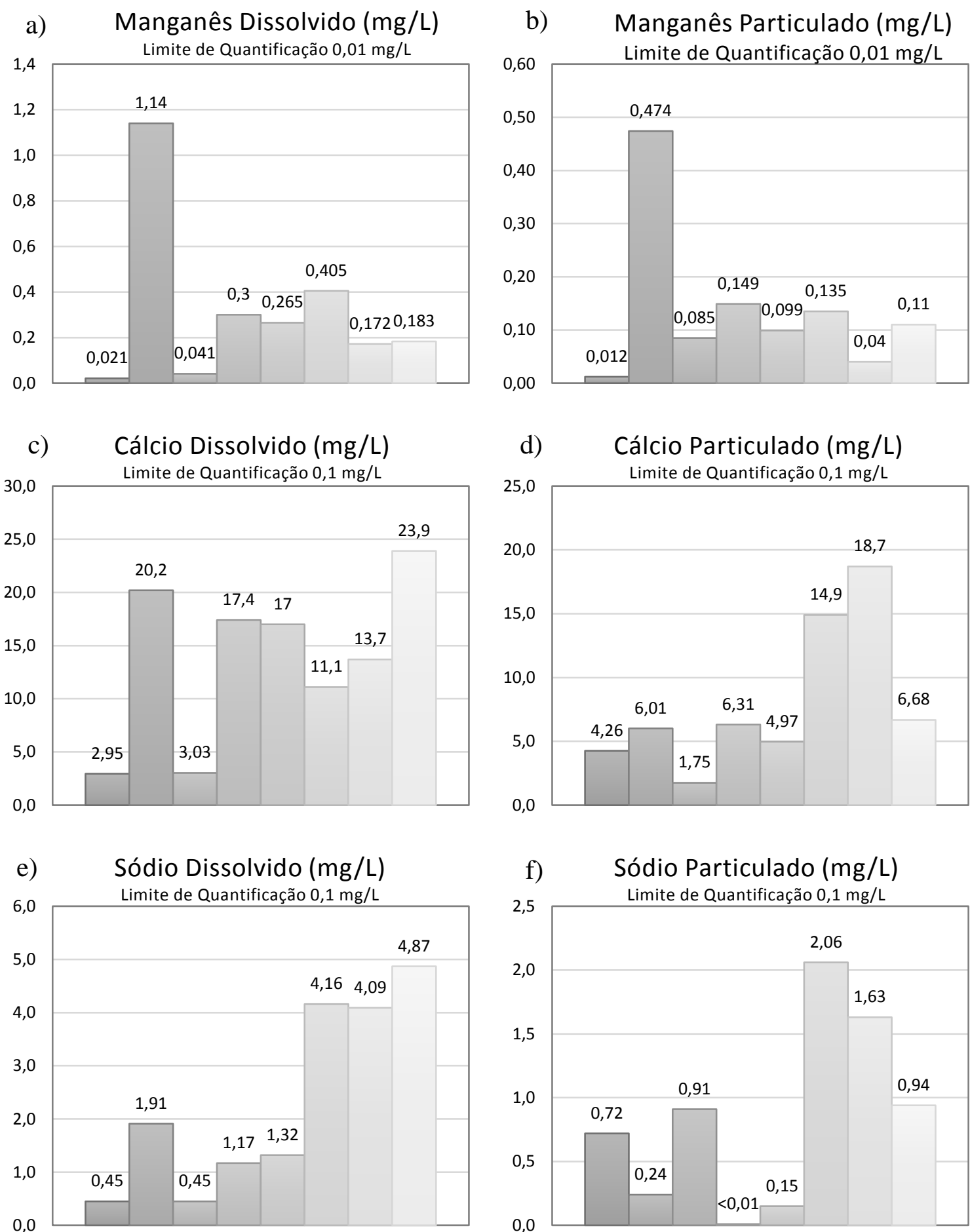

$\square$ Reservatório $\square$ Dreno $16 \square$ Dreno $28 \square$ Dreno $35 \square$ Dreno $37 \square$ Dreno A $\square$ Dreno B $\square$ Dreno C

Fonte: do Autor (2020). 
Figura 166 - Resultados das análises físico-químicas. a) Sódio total. b) Potássio dissolvido. c) Potássio particulado. d) Potássio particulado.
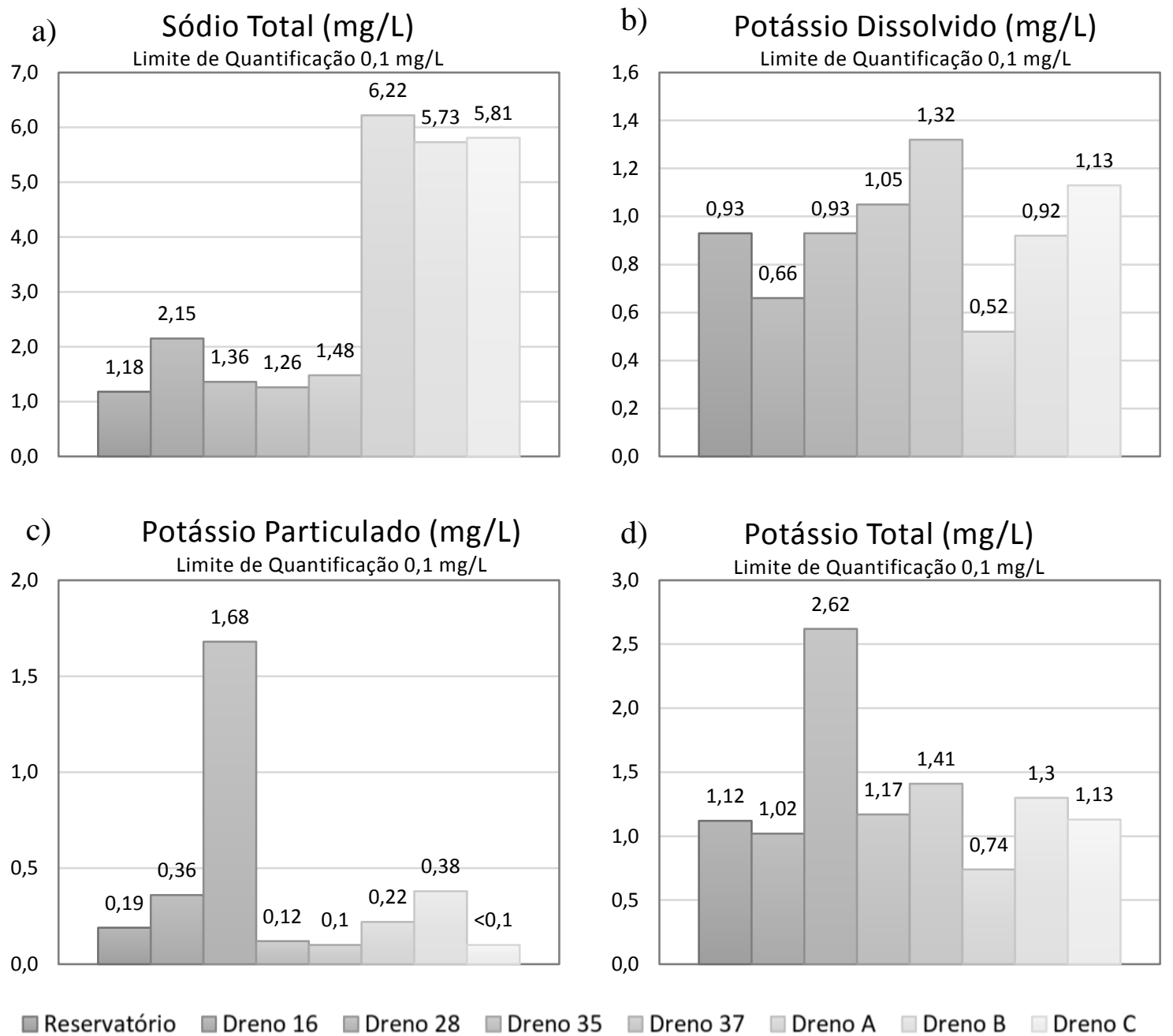

Fonte: do Autor (2020).

\subsection{COMPARAÇÃO DA SEÇÃO GEOLÓGICO GEOTÉCNICA E CONSUMO DE CALDA DE CIMENTO DAS CAMPANHAS DE INJEÇÃO COM AS MEDIÇÕES DE OBSTRUÇÃO DOS DRENOS}

Tendo em vista que o cálcio pode ser lixiviado do concreto da barragem, cortina de injeção e rocha de fundação, formando bicarbonato de cálcio, o qual se deposita nas paredes e obstruí os drenos, são apresentadas na Figura 168 e Figura 167, a sobreposição das medições de profundidade e vazões dos drenos (medição Dez/2019) e, respectivamente, os consumos de calda de cimento das injeções e seção geológica geotécnica. 
Figura 167 - Seção longitudinal geológica geotécnica e indicação das profundidades dos drenos e vazões (Medição Dez/2019)

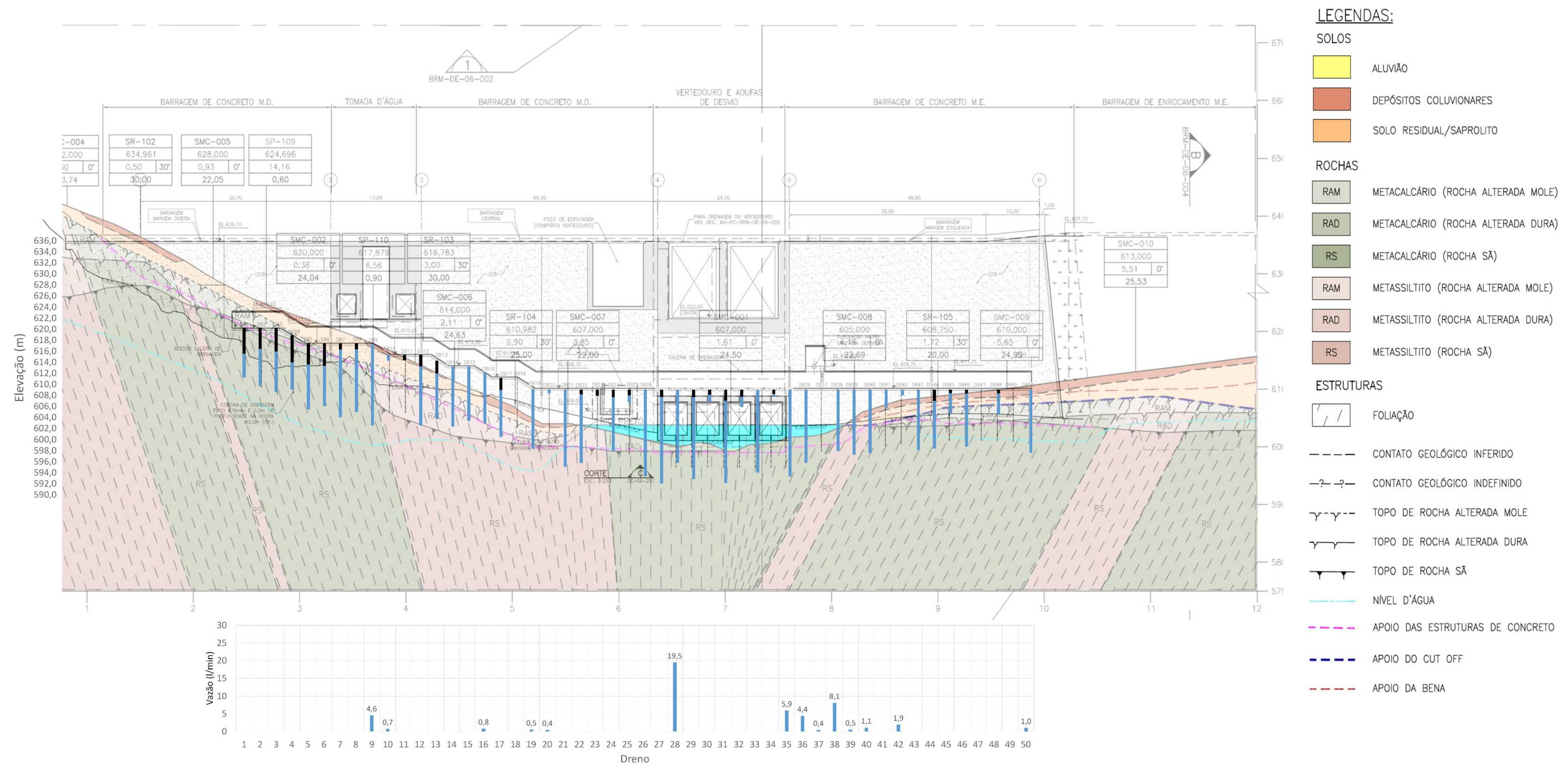

Fonte: Adaptado de Mata velha Energética S.A. (2016). 
Figura 168 - Seção longitudinal com consumo dos furos de impermeabilização e indicação das profundidades dos drenos e vazões (Medição Dez/2019)
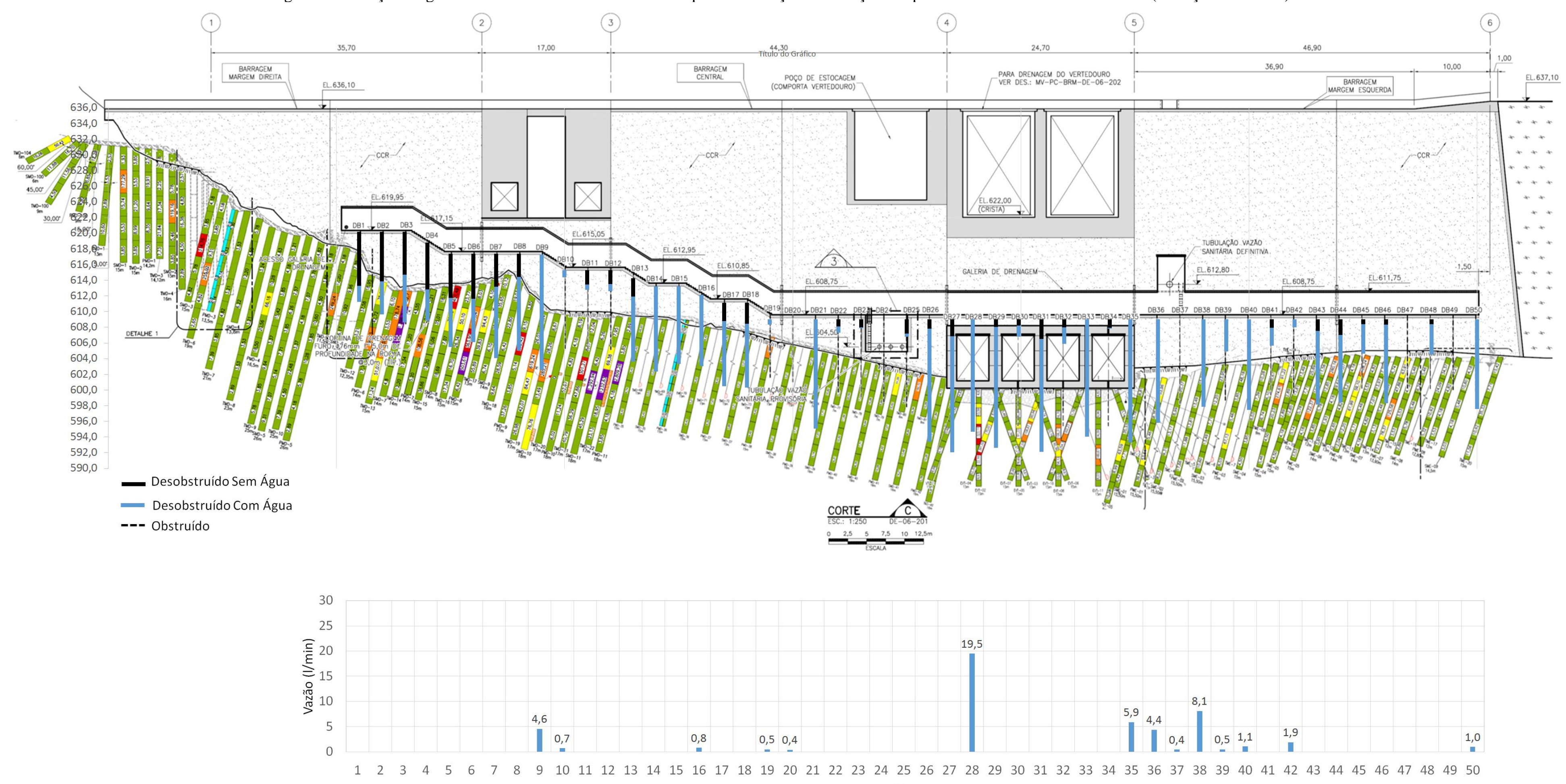

Dreno

Fonte: Adaptado de Mata velha Energética S.A. (2016). 
Nos dois casos, entretanto, não é possível observar alguma correlação que pudesse ser associada à obstrução dos drenos. Conforme RUGGERI, 2004, a taxa e a magnitude da redução da pressão afetam a densidade dos depósitos e a quantidade do precipitado que se forma. $\mathrm{O}$ tempo que um dreno leva para bloquear depende de muitos parâmetros: minerais solúveis em fundação e concreto, vazão, pH, etc. Ainda segundo RUGGERI, 2004, o caráter de um depósito muitas vezes muda com a localização. Os drenos podem ser severamente bloqueados em um trecho da barragem e completamente livres de depósitos em outro. Um único dreno pode ter depósitos que variam de macio a duro em todo ou em parte de seu comprimento

\subsection{ANÁLISES DA ESTABILIDADE DA BARRAGEM DE CONCRETO - MODELOS ANALÍTICOS}

As análises de estabilidade global foram realizadas empregando-se modelos analíticos, conforme critérios definidos pela Eletrobrás (2003), para o Caso de Carregamento Normal $\mathrm{CCN}$, que corresponde a todas as combinações de ações que apresentem grande probabilidade de ocorrência ao longo da vida útil da estrutura, durante a operação normal ou manutenção de rotina da obra, em condições hidrológicas normais.

Tendo por base os desenhos e demais informações de Mata Velha Energética S.A. (2016), assim como a posição das juntas na fundação conforme apresentado no item 4, foram definidas a geometria das estruturas e demais considerações pertinentes

Nas análises de estabilidade são avaliadas a implicação da obstrução e eventual perda de eficiência dos drenos, levando em conta tanto o contado concreto/rocha como a fundação, através das juntas de alívio no maciço rochoso de fundação. Foram realizadas análises paramétricas afim de avaliar os conjuntos de parâmetros necessários para obtenção dos Fatores de Seguranças - FS requeridos, considerando as estabilidades ao deslizamento, tombamento e flutuação, bem como as tensões na fundação.

Destaca-se que o presente trabalho não tem a intenção de definir os parâmetros geomecâcnicos da fundação, mas sim, através das análises de estabilidade, avaliar a sensibilidade através da variação destes parâmetros e a influência da cortina de drenagem na redução das subpressões.

A inoperância da cortina de drenagem geralmente é considerada no caso de Carregamento Excepcional - CCE, tendo em vista que a manutenção e limpeza dos drenos ao longo do período de operação deve ser realizada para que seja mantida a eficiência considerada para a condição CCN. No presente estudo, considerou-se a obstrução dos drenos para a o caso 
CCN, facilitando a comparação, com a condição de drenos operantes.

Em função da profundidade dos drenos, a qual atingiu $5 \mathrm{~m}$ a partir do contato concreto/rocha, a cortina de drenagem não atingiu as juntas mais profundas em determinadas seções, sendo avaliado, nestes casos, apenas a condição sem drenagem, em tudo semelhante ao caso para drenos inoperantes.

Na sequência é apresentado um resumo dos parâmetros utilizados e condições que implicam nos esforços aplicados pela e sobre a estrutura da barragem de concreto.

- Peso Específico dos Materiais

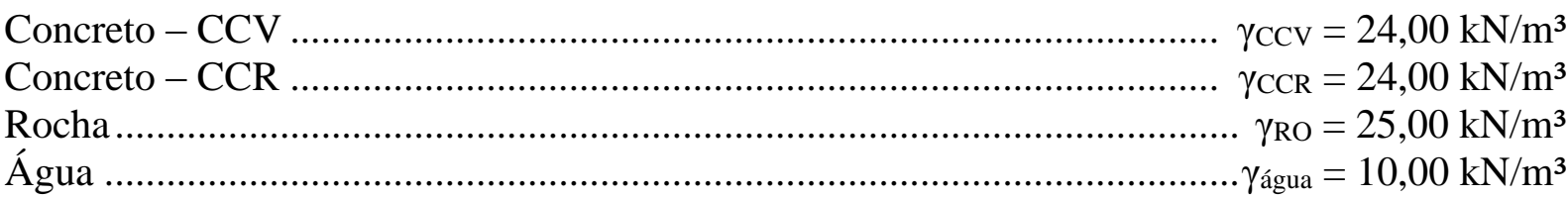

- Parâmetros Geomecânicos

Junta de Alívio

Ângulo de atrito $\varphi=15^{\circ} / 20^{\circ} / 25^{\circ} / 30^{\circ}$

Coesão a verificar

Contato Concreto/Rocha e Maciço Rochoso

Ângulo de atrito $\varphi=30^{\circ}$

Coesão $\mathrm{c}=400 \mathrm{kN} / \mathrm{m}^{2}$

- Níveis d'Água

Nível d’Água Montante $632,00 \mathrm{~m}$

Nível d'Água Jusante $601,94 \mathrm{~m}$

\subsubsection{Contato Concreto/Rocha}

A análise de estabilidade pelo contato concreto/rocha realizada para os blocos da Tomada de Água, Barragem da Margem Direita e Vertedouro, tendo sido realizadas simplificações da geometria junto ao contato, conforme esforços da Figura 169 e resultados do Quadro 10. 
Figura 169 - Ações atuantes junto ao contato concreto/rocha para as condições de drenos inoperantes e operantes: a) e b) Tomada d'Água; c) e d) Barragem Margem Direita; e) e f) Vertedouro.

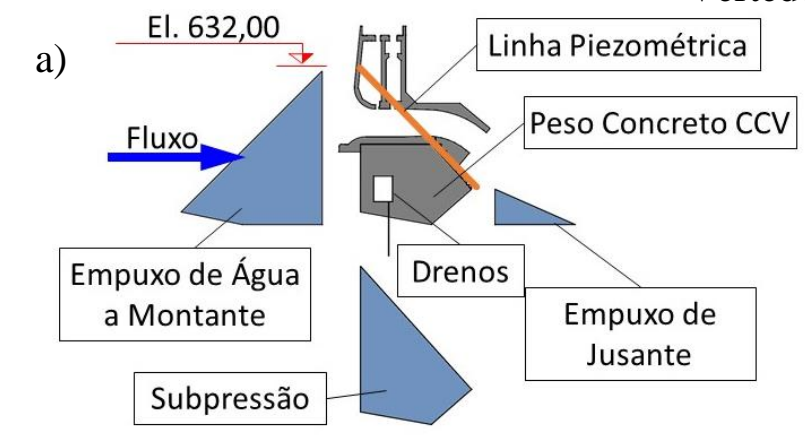

b)
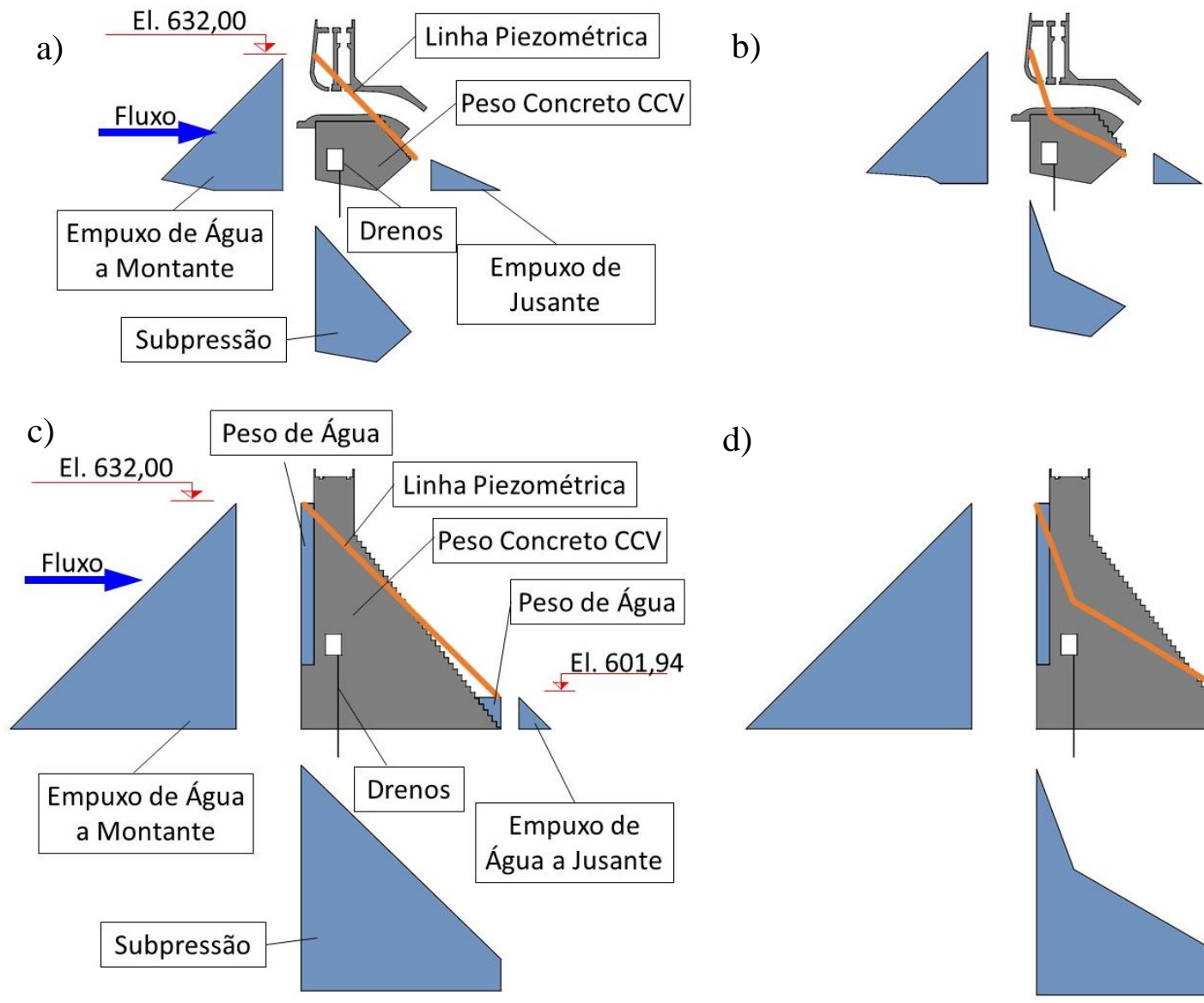

d)
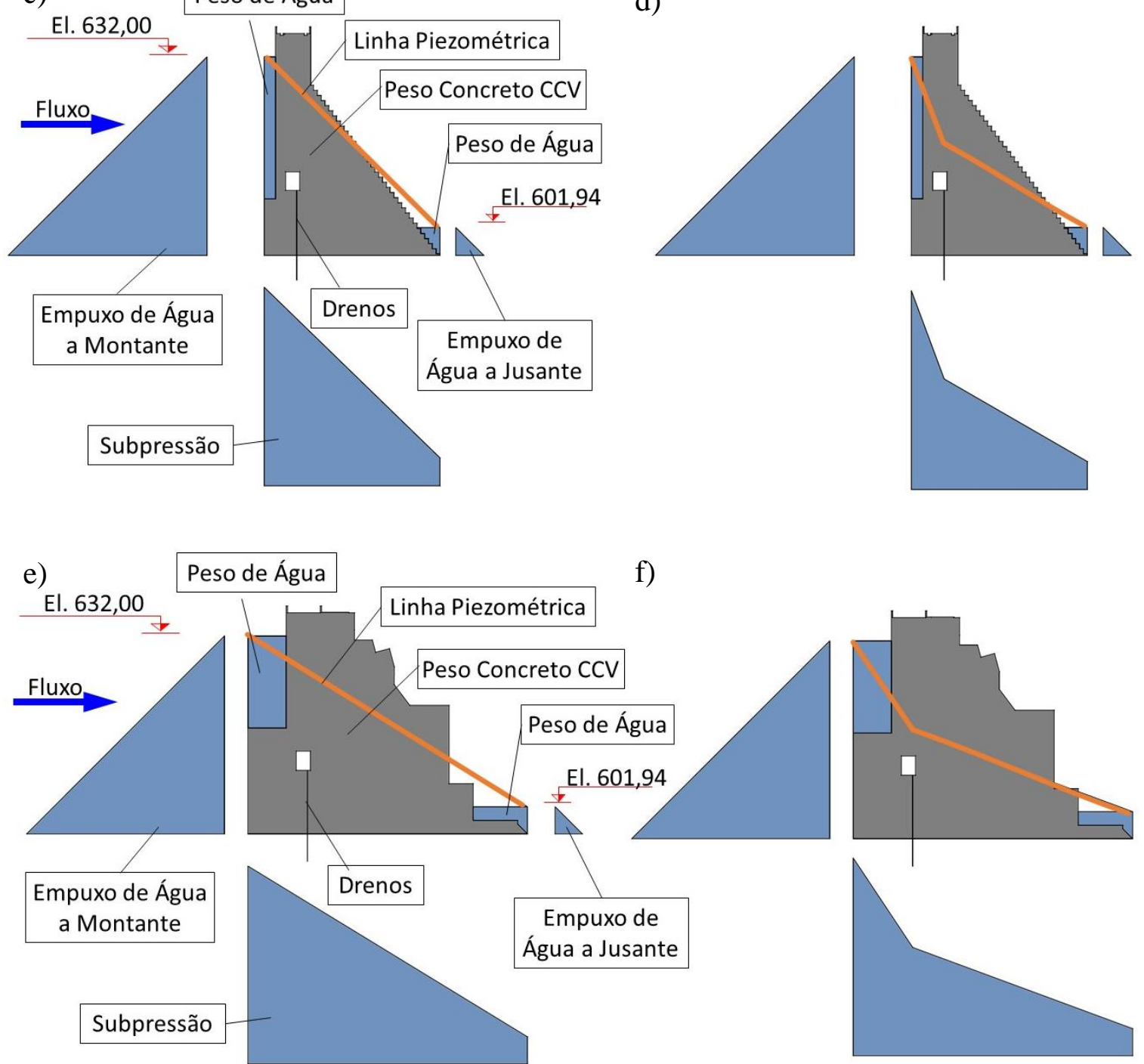

Fonte: do Autor (2021). 
Quadro 10 - Resultados da análise de estabilidade pelo contato concreto/rocha

\begin{tabular}{|c|c|c|c|c|}
\hline \multirow{2}{*}{ Bloco } & \multirow{2}{*}{ Condição } & \multicolumn{3}{|c|}{ Fator de Segurança - FS } \\
\cline { 3 - 5 } & & Flutuação & Tombamento & Deslizamento \\
\hline \multirow{2}{*}{ Tomada d'água } & Inoperantes & 2,45 & 1,58 & 10,28 \\
\cline { 2 - 5 } & Operantes & 3,47 & 1,98 & 11,65 \\
\hline \multirow{2}{*}{ Barragem da Margem Direita } & Inoperantes & 2,41 & 2,57 & 1,25 \\
\cline { 2 - 5 } & Operantes & 3,21 & 1,85 & 1,35 \\
\hline \multirow{2}{*}{ Vertedouro } & Inoperantes & 2,84 & 2,30 & 2,26 \\
\cline { 2 - 5 } & Operantes & 3,72 & 2,82 & 2,41 \\
\hline
\end{tabular}

Fonte: do Autor (2021).

Os resultados me termos de Fatores de Segurança mostram a importância da drenagem na redução das subpressões, resultando em Fatores de Segurança mais elevados, sendo mais sensíveis para as Condições de Flutuação e Tombamento. No caso da Tomada d'Água, em função da geometria junto à fundação, os resultados em termos de Fator de Segurança para o Deslizamento foram mais elevados que nos demais casos.

\subsubsection{Fundação}

Para análise da estabilidade pela fundação dos blocos da Tomada de Água, Barragem da Margem Direita e Vertedouro foram consideradas os planos indicados pelas Juntas de Alívio, J1 a J7.

Através de um estudo paramétrico, variando o ângulo de atrito no plano das juntas, foi calculada a coesão mínima necessária para estabilidade da estrutura, considerando os coeficientes de segurança recomendados nos Critérios de Projeto. Também foi realizado um estudo desconsiderando a coesão nos planos das Juntas de Alívio (Coesão = 0) e determinando o valor mínimo de ângulo de atrito de forma que os Coeficientes de Segurança ao Deslizamento encontrados atendessem os critérios recomendados.

As planilhas de cálculo utilizadas são apresentas no Apêndice A, ilustrando apenas os casos com ângulo de atrito $(\varphi)$ igual a $35^{\circ}$ pelas juntas na fundação, uma vez que as demais planilhas do estudo paramétrico são em tudo semelhantes.

Nas Figuras Figura 170 a Figura 173 são apresentadas as ações atuantes consideradas nos cálculos de estabilidade pela fundação, respectivamente dos blocos da Tomada de Água, Barragem da Margem Direita e Vertedouro, enquanto nos Quadros Quadro 11 a Quadro 13 são apresentados os resultados. 
Para os casos em que foram estudadas a superfície pelo contato concreto/rocha seguida da junta de alívio, adotou-se a simplificação junto ao contato concreto/rocha, facilitando as análises através das planilhas eletrônicas.

Figura 170 - Ações atuantes no bloco da Tomada d'Água: a) Junta J4; b) Junta J5; c) Junta J6, drenos inoperantes; d) Junta J6, drenos operantes; e) Junta J7, drenos inoperantes; f) Junta J7, drenos operantes.

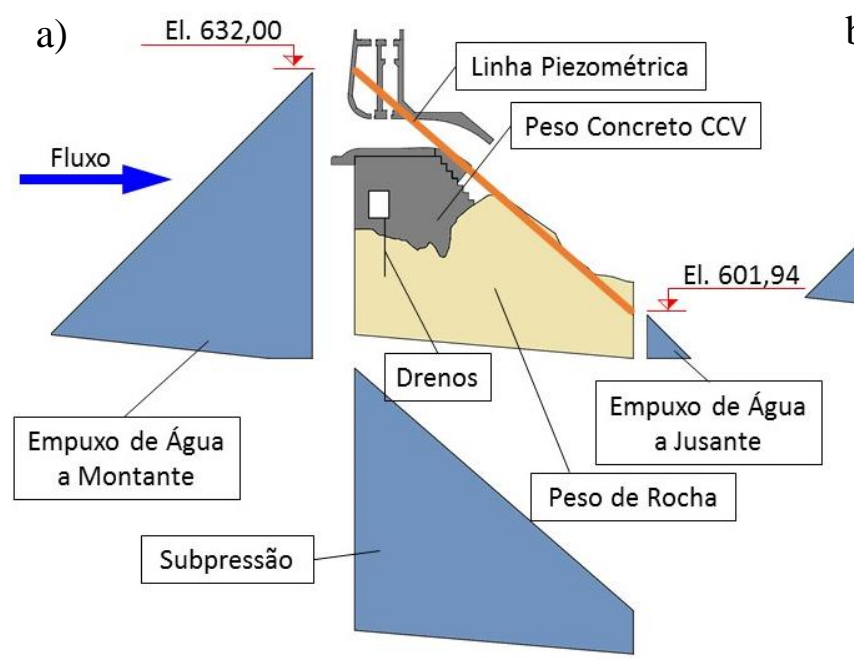

c)

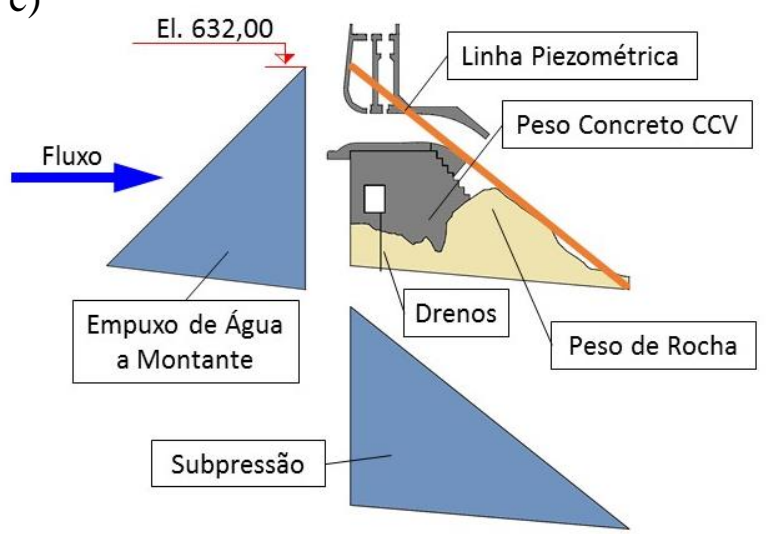

e)

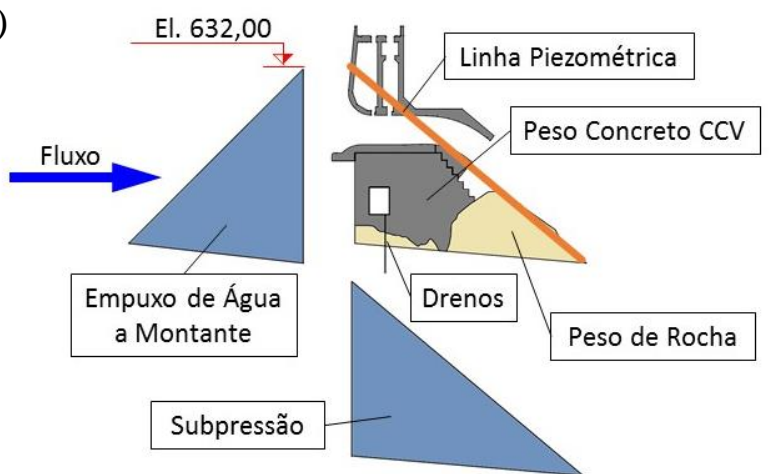

b)

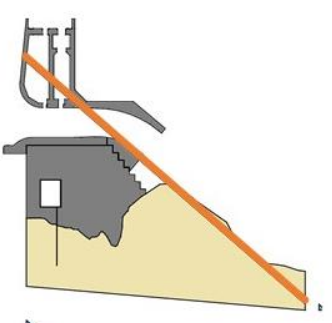

d)
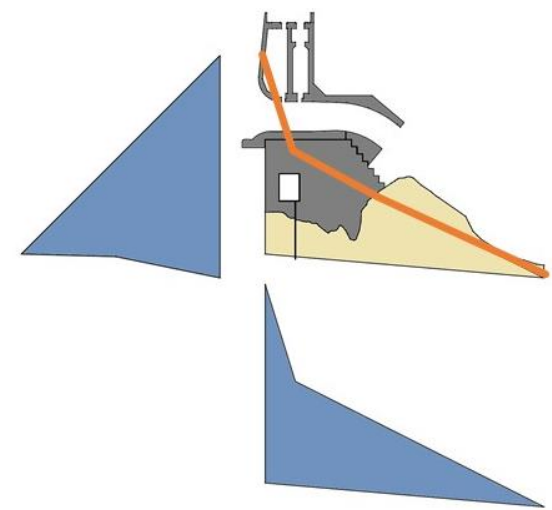

f)

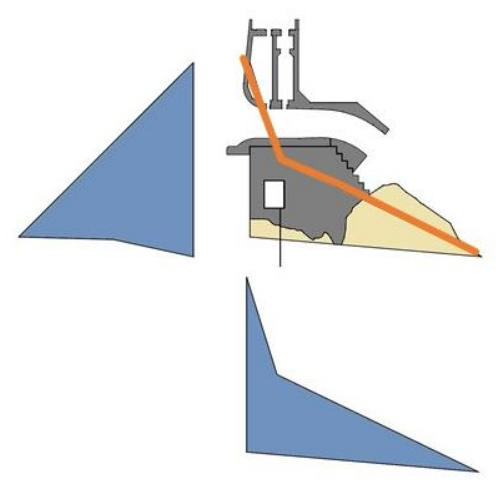

Fonte: do Autor (2021). 
Figura 171 - Ações atuantes no bloco da Barragem da Margem Direita: a) Junta J1, drenos inoperantes; b) Junta J1, drenos operantes; c) Junta J2, drenos inoperantes; d) Junta J2, drenos operantes; e) Junta J3, drenos inoperantes; f) Junta J3, drenos operantes;
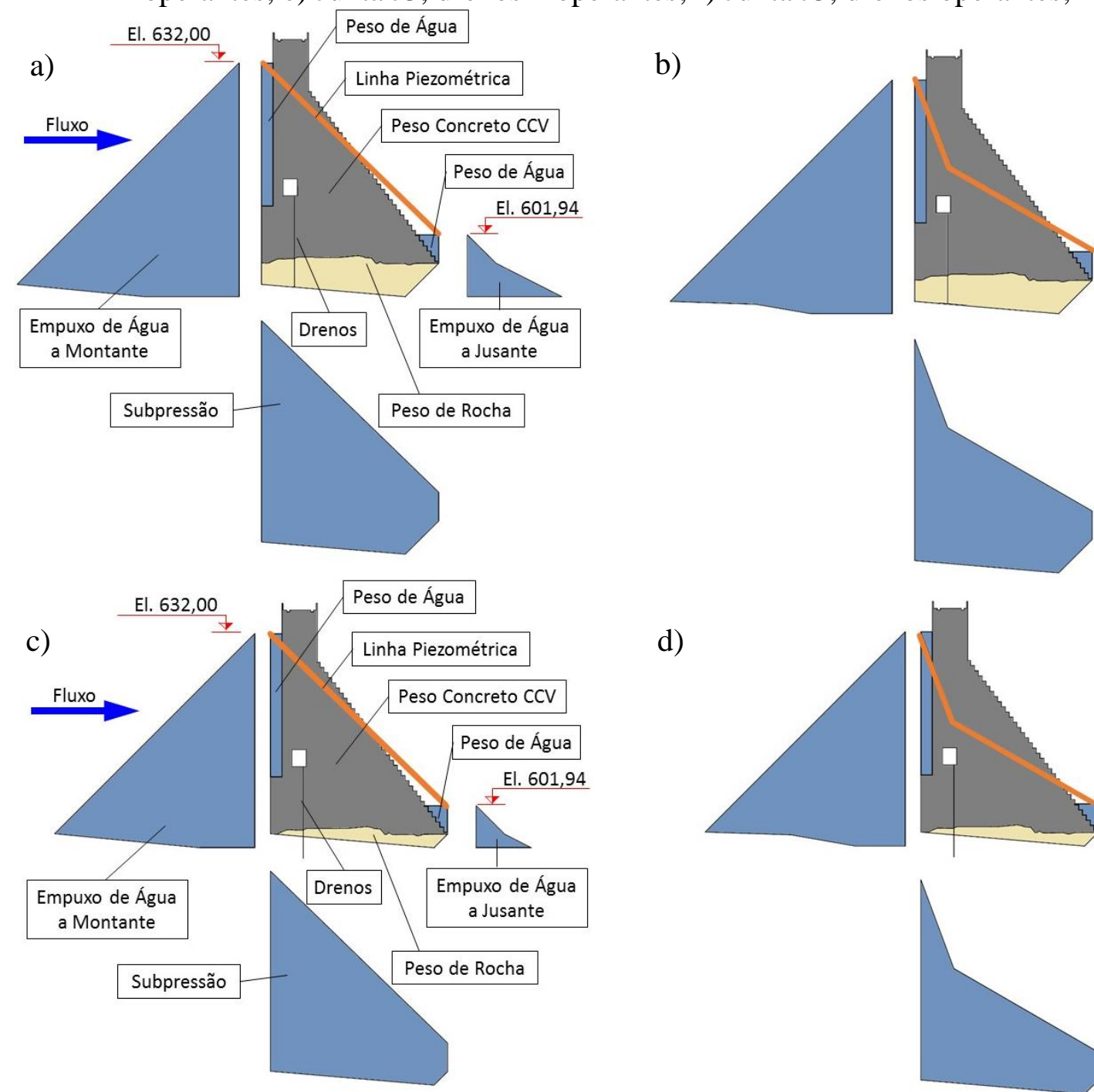

d)
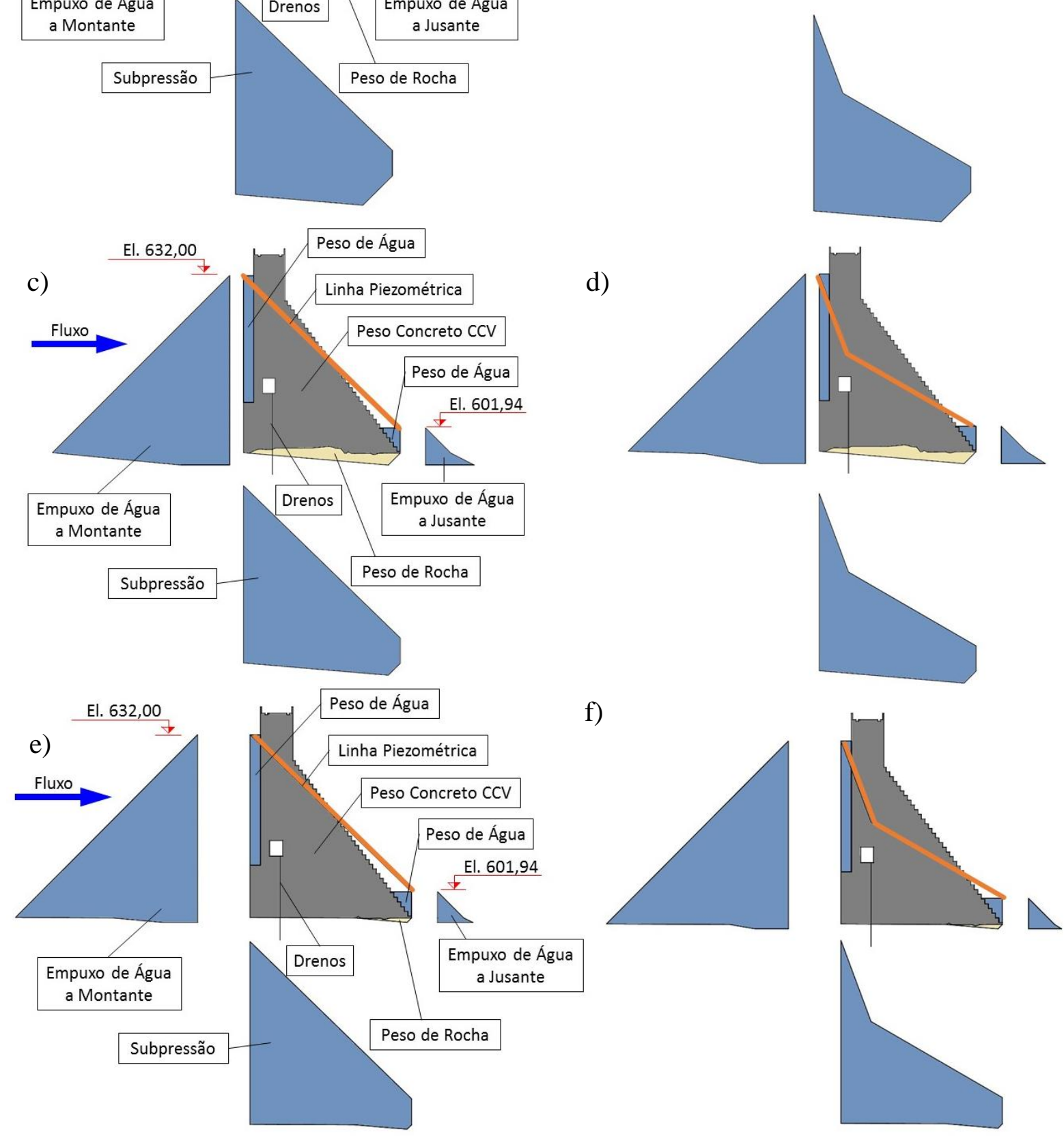

Fonte do Autor (2021). 
Quadro 11 - Resultados da análise de estabilidade pela fundação do bloco da Tomada de Água da Barragem de Concreto.

\begin{tabular}{|c|c|c|c|c|c|c|c|c|c|}
\hline \multirow{2}{*}{ Junta } & \multirow{2}{*}{ Condição } & \multirow{2}{*}{$\begin{array}{l}\text { Flutuação } \\
\text { FS }\end{array}$} & \multirow{2}{*}{$\begin{array}{l}\text { Tombamento } \\
\text { FS }\end{array}$} & \multicolumn{5}{|c|}{$\begin{array}{c}\text { Deslizamento }-\mathrm{c}\left(\mathrm{kN} / \mathrm{m}^{2}\right) \\
-\mathrm{FS}=1\end{array}$} & \multirow{2}{*}{$\begin{array}{c}\text { Deslizamento } \varphi\left(^{\circ}\right) \\
-\mathrm{FS}=1 \\
\mathrm{c}=0 \mathrm{kN} / \mathrm{m}^{2}\end{array}$} \\
\hline & & & & $\varphi=15^{\circ}$ & $\varphi=20^{\circ}$ & $\varphi=25^{\circ}$ & $\varphi=30^{\circ}$ & $\varphi=35^{\circ}$ & \\
\hline $\mathrm{J} 4$ & $(*)$ & 2,46 & 1,53 & 420 & 370 & 320 & 260 & 195 & 47 \\
\hline J5 & $(*)$ & 2,45 & 1,61 & 319 & 280 & 240 & 198 & 150 & 48 \\
\hline J6 & Operantes & 3,45 & 2,14 & 231 & 196 & 159 & 119 & 74 & 43 \\
\hline J6 & Inoperantes & 2,18 & 1,59 & 255 & 229 & 201 & 171 & 137 & 50 \\
\hline J7 & Operantes & 3,75 & 212 & 213 & 181 & 147 & 110 & 69 & 43 \\
\hline J7 & Inoperantes & 2,21 & 1,53 & 237 & 214 & 188 & 161 & 131 & 51 \\
\hline
\end{tabular}

(*) Não foi considerada drenagem, uma vez que os drenos não atingem a profundidade da junta.

Fonte: do Autor (2021).

Quadro 12 - Resultados da análise de estabilidade pela fundação do bloco da Barragem da Margem Direita.

\begin{tabular}{|c|c|c|c|c|c|c|c|c|c|}
\hline \multirow{2}{*}{ Junta } & \multirow{2}{*}{ Drenos } & \multirow{2}{*}{$\begin{array}{l}\text { Flutuação } \\
\text { FS }\end{array}$} & \multirow{2}{*}{$\begin{array}{c}\text { Tombamento } \\
\text { FS }\end{array}$} & \multicolumn{5}{|c|}{$\begin{array}{c}\text { Deslizamento }-\mathrm{c}\left(\mathrm{kN} / \mathrm{m}^{2}\right) \\
-\mathrm{FS}=1\end{array}$} & $\begin{array}{c}\text { Deslizamento } \varphi\left(^{\circ}\right) \\
-\mathrm{FS}=1\end{array}$ \\
\hline & & & & $\varphi=15^{\circ}$ & $\varphi=20^{\circ}$ & $\varphi=25^{\circ}$ & $\varphi=30^{\circ}$ & $\varphi=35^{\circ}$ & $\mathrm{c}=0 \mathrm{kN} / \mathrm{m}^{2}$ \\
\hline $\mathrm{J} 1$ & Operantes & 3,05 & 1,92 & 0 & 0 & 0 & 0 & 0 & 15 \\
\hline $\mathrm{J} 1$ & Inoperantes & 2,43 & 1,3 & 32 & 0 & 0 & 0 & 0 & 19 \\
\hline $\mathrm{J} 2$ & Operantes & 3,16 & 1,88 & 309 & 251 & 188 & 121 & 47 & 38 \\
\hline $\mathrm{J} 2$ & Inoperantes & 2,42 & 1,60 & 342 & 293 & 242 & 185 & 123 & 44 \\
\hline $\mathrm{J} 3$ & Operantes & 3,20 & 1,76 & 0 & 0 & 0 & 0 & 0 & 15 \\
\hline $\mathrm{J} 3$ & Inoperantes & 2,41 & 1,50 & 239 & 170 & 97 & 0 & 0 & 31 \\
\hline
\end{tabular}

Fonte: do Autor (2021).

Figura 172 - Ações atuantes na fundação no Bloco do Vertedouro, junta J1.

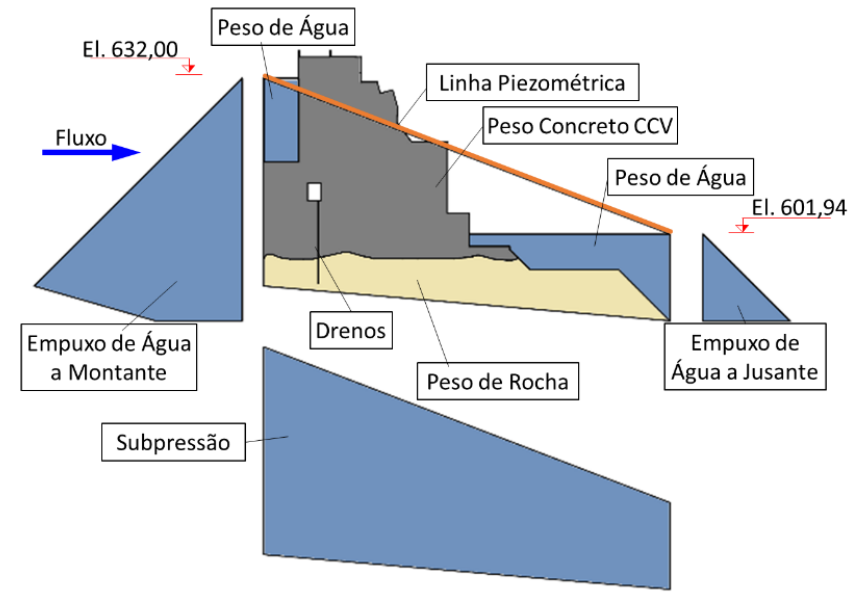

Fonte: do Autor (2021). 
Figura 173 - Ações atuantes no bloco do Vertedouro: a) Junta J2, drenos inoperantes; b) Junta J2, drenos operantes; c) Junta J3, drenos inoperantes; d) Junta J3, drenos operantes; e) Junta $\mathrm{J} 4$, drenos inoperantes; f) Junta J4, drenos operantes;
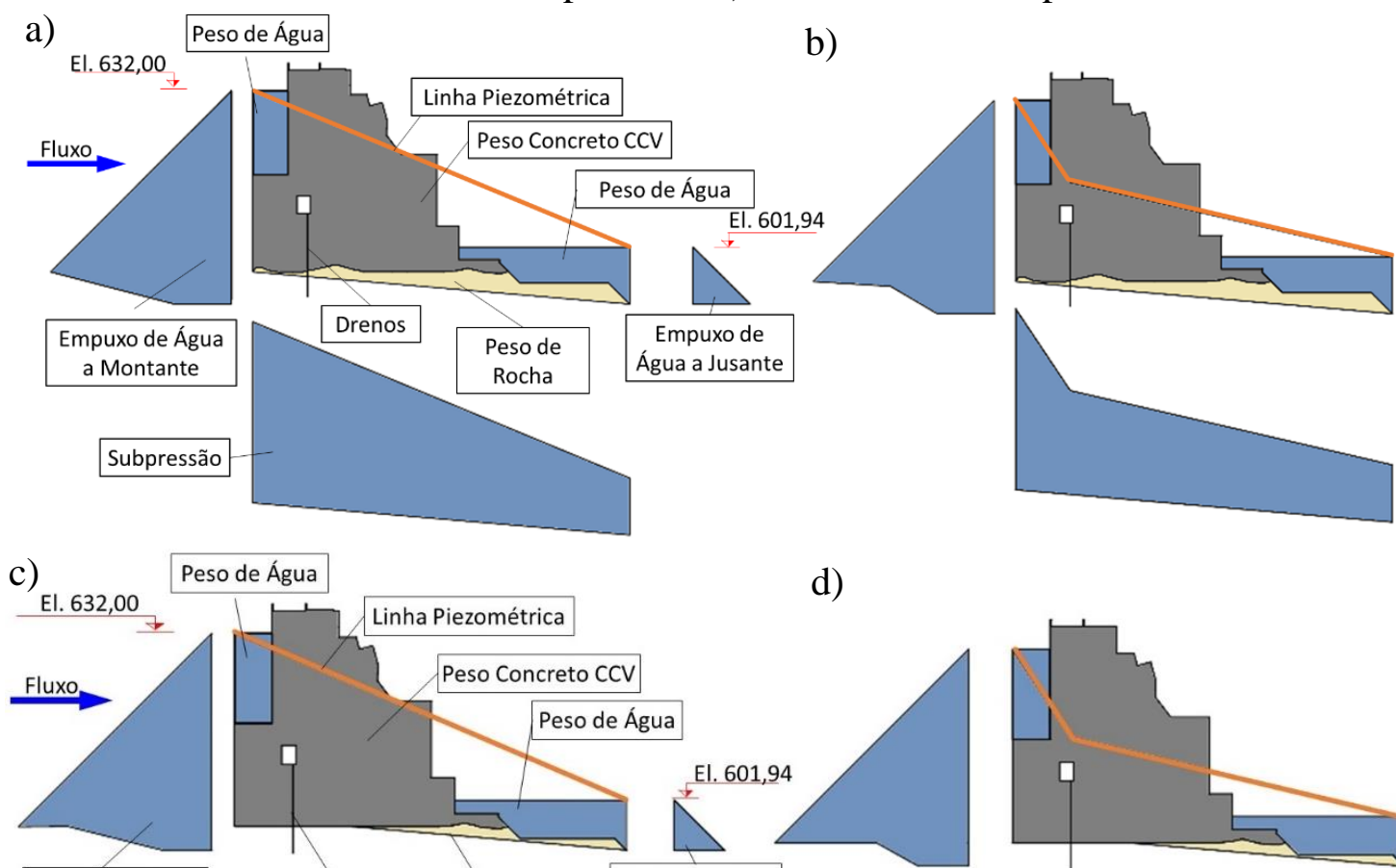

d)

Empuxo de Água a Montante

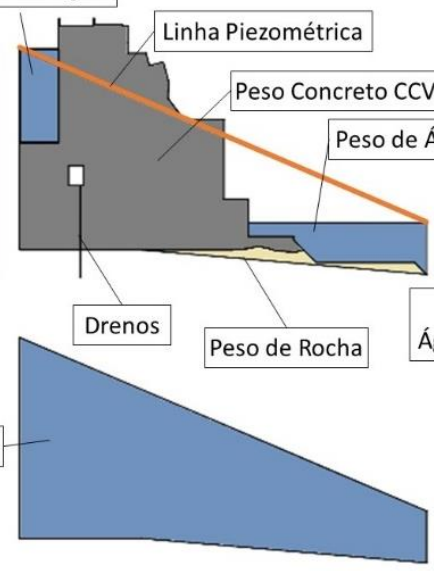

d)

Subpressão

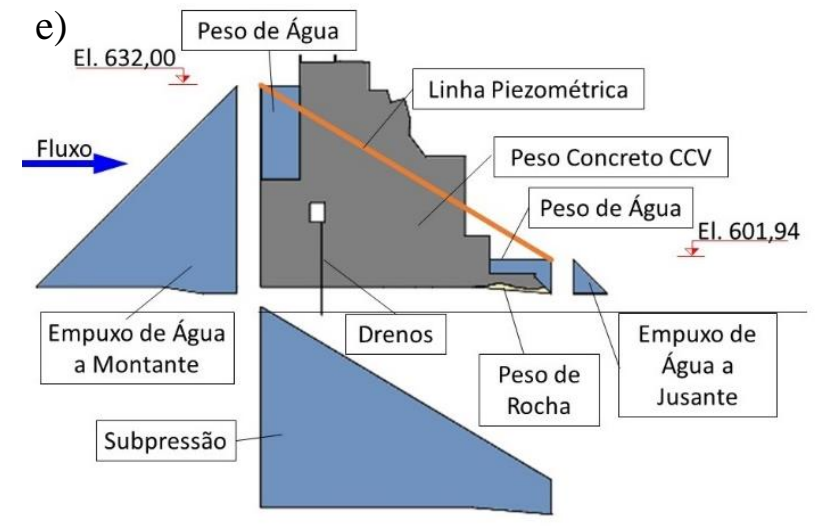

f)

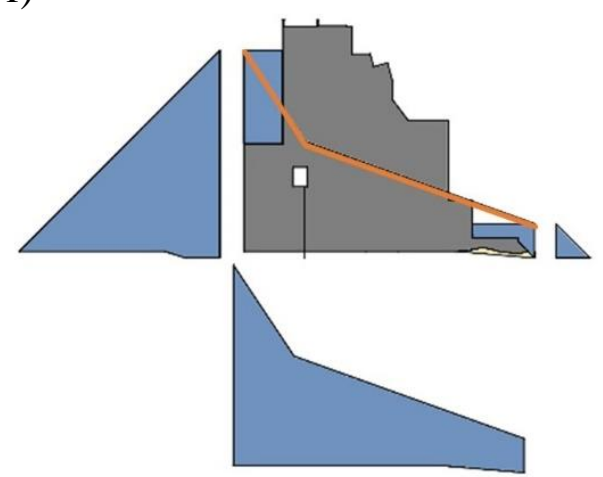

Fonte: do Autor (2021). 
Quadro 13 - Resultados da Análise de estabilidade pela fundação do bloco do Vertedouro.

\begin{tabular}{|c|c|c|c|c|c|c|c|c|c|}
\hline \multirow{2}{*}{ Junta } & \multirow{2}{*}{ Drenos } & \multirow{2}{*}{$\begin{array}{l}\text { Flutuação } \\
\text { FS }\end{array}$} & \multirow{2}{*}{$\begin{array}{c}\text { Tombamento } \\
\text { FS }\end{array}$} & \multicolumn{5}{|c|}{$\begin{array}{c}\text { Deslizamento }-\mathrm{c}\left(\mathrm{kN} / \mathrm{m}^{2}\right) \\
-\mathrm{FS}=1\end{array}$} & $\begin{array}{c}\text { Deslizamento } \varphi\left(^{\circ}\right) \\
-\mathrm{FS}=1\end{array}$ \\
\hline & & & & $\varphi=15^{\circ}$ & $\varphi=20^{\circ}$ & $\varphi=25^{\circ}$ & $\varphi=30^{\circ}$ & $\varphi=35^{\circ}$ & $\mathrm{c}=0 \mathrm{kN} / \mathrm{m}^{2}$ \\
\hline $\mathrm{J} 1$ & $(*)$ & 1,99 & 1,94 & 250 & 198 & 143 & 83 & 16 & 37 \\
\hline $\mathrm{J} 2$ & Operantes & 2,70 & 2,58 & 195 & 141 & 84 & 22 & 0 & 32 \\
\hline $\mathrm{J} 2$ & Inoperantes & 2,02 & 2,00 & 221 & 1 & 132 & 82 & 27 & 38 \\
\hline $\mathrm{J} 3$ & Operantes & 2,67 & 2,59 & 0 & 0 & 0 & 0 & 0 & 1 \\
\hline $\mathrm{J} 3$ & Inoperantes & 2,04 & 2,04 & 0 & 0 & 0 & 0 & 0 & 10 \\
\hline $\mathrm{J} 4$ & Operantes & 3,65 & 2,77 & 0 & 0 & 0 & 0 & 0 & 0 \\
\hline J4 & Inoperantes & 2,78 & 2,26 & 0 & 0 & 0 & 0 & 0 & 0 \\
\hline
\end{tabular}

(*) Não foi considerada drenagem, uma vez que os drenos não atingem a profundidade da junta.

Fonte: do Autor (2021).

As superfícies estudadas apresentaram tensões de compressão em toda a superfície da fundação, conforme critérios da Eletrobrás (2003), com exceção das seções do Vertedouro, para o caso estudados das Juntas $\mathrm{J} 2$ e $\mathrm{J} 3$, nas quais foi observada alguma tração a jusante, provavelmente em função da laje a jusante. Entretanto, conforme desenhos de Mata Velha Energética S.A. (2016), foram instalados nesses locais chumbadores, os quais devem absorver os esforços de tração a jusante.

Tendo por base os estudos paramétricos, observa-se que as seções da Tomada d'Água, dentre as estudadas, apresentaram a necessidade de conjuntos de parâmetros mais elevados para que fossem atendidos os Fatores de Segurança requeridos.

Nota-se também que a drenagem possui uma influência significativa na redução das subpressões, adotando-se as recomendações da Eletrobrás (2003), e consequentemente leva à necessidade de parâmetros com valores inferiores em comparação à condição com drenos inoperantes. Destaca-se, novamente, que para o caso de drenos inoperantes, considerou-se a Condições de Carregamento Normal - CCN e não a Condição de Carregamento Excepcional CCE, assumindo uma hipótese de que os drenos não seriam reperfurados e tal condição se manteria durante o período de operação

\section{DISCUSSÕES E CONCLUSÃO}

A Barragem da PCH foi construída em um domínio geológico de rochas metassedimentares, com intercalações de metasiltitos e metacalcáreos, com complexa 
estruturação geológica, caracterizada pela presença de sucessivos dobramentos e falhamentos tectônicos.

Como a região apresentava um maciço de rochas carbonáticas, foram realizados estudos de cavernas nas fases iniciais de investigação, os quais afastaram a hipótese de fuga d'água incontrolável ou alto custo de controle de água nesta região. À época foi relatada a eventual possibilidade de dissolução das fraturas no contato rocha/rocha e elevada permeabilidade do maciço, assim como de indícios de intercomunicação entre fraturas.

O maciço rochoso de fundação da área do aproveitamento poderia ser inserido em um contexto cárstico, tendo em vista a observação de vazios e pequenas cavernas durante as escavações e a presença de trechos com consumo elevado de calda de cimento das injeções de impermeabilização e consolidação, além das próprias observações durante o enchimento e período de operação, como intensa deposição de carbonato de cálcio junto aos drenos de fundação, resultados de análise físico-química água e etc.

As elevadas vazões pelos drenos de alívio da fundação das estruturas de concreto ao final do enchimento do reservatório ( 1600 1/min) e sua rápida redução para cerca de 130 1/min ao longo do primeiro ano de operação, assim como intenso processo de precipitação de carbonato de cálcio, obstruindo grande parte dos drenos, porém sem uma resposta nos piezômetros, no sentido de elevação da subpressão na fundação das estruturas, foram os principais motivos para o presente estudo,

Algumas hipóteses puderam ser levantadas e, de certa forma, algumas confrontadas ao decorrer dos estudos, sendo elas:

(a) Assim como os drenos de fundação, os piezômetros poderiam também estar obstruídos, ou com comportamento prejudicado, por carbonatação;

(b) Processo de carbonatação/colmatação, semelhante ao observado internamente aos drenos, poderia ocorrer na rocha de fundação, atuando no "fechamento" dos caminhos preferenciais de percolação na fundação.

(c) Sedimentos finos poderiam ter decantado do reservatório, com alguma deposição junto ao fundo do reservatório, atuando no "fechamento" dos caminhos preferenciais de percolação na fundação.

(d) A água pode ter "descoberto" novos caminhos para percolar, tendo em vista que o maciço de fundação é composto por rochas com complexa estruturação, afetadas pelo acamamento sedimentar, fraturas, dobramentos e falhamentos, com possível carreamento de finos e ou dissolução. 
No talude da ombreira direita foi observada também intensa percolação, com vazões máximas da ordem de 900 1/min, valores estes medidos logo após a instalação do medidor de vazão MV-4 na área a montante da Casa de Força, após cerca de 50 dias da finalização do enchimento do reservatório, com redução da vazão semelhante àquela observada na galeria de drenagem.

Os estudos realizados levam a crer que a circulação de água na fundação causou alterações nos caminhos de percolação através de processos de dissolução do carbonato e da remoção de finos (silte) ao longo das descontinuidades, o que pode ser corroborado pelas observações quando dos testes de operação dos drenos de fundação, quando se observou a presença de finos em alguns drenos, assim como a deposição de finos nas canaletas de drenagem da galeria.

Apesar dos testes de tamponamento terem indicado um reflexo na subpressão, as dúvidas com relação ao correto funcionamento dos piezômetros devido a uma possível carbonatação na região do bulbo, poderiam ser confrontadas com a instalação de novos piezômetros, tanto para monitorar a interface concreto/rocha quanto a fundação, nos níveis onde ocorrem as descontinuidades sub-horizontais. Naqueles piezômetros com níveis d'água abaixo do piso da galeria, poderiam ser realizados teste de recuperação ou testes de vida, para avaliação das permeabilidades do maciço no local de instalação desses instrumentos.

Os testes de remoção das tubulações internas dos drenos, principalmente aquelas tubulações com intensa deposição de carbontação, não teve influência no aumento de vazão, ou seja, mesmo com a remoção da tubulação, as vazões nos drenos não aumentaram. Com relação à carbonatação e eventual redução da eficiência dos drenos de fundação, poderiam ser realizados furos de sondagem intermediários aos drenos existentes, ou até mesmo em outros pontos da galeria. Caso esses furos, durante a perfuração, apresentem percolação para o interior da galeria com volume e pressão, será um indicativo que os furos da cortina de drenagem estão realmente obstruídos.

Nota-se que a análise físico-química da água, preferencialmente no caso de regiões cársticas, deve ser realizada desde o enchimento do reservatório, seguindo pela vida útil da barragem para que se possa acompanhar as concentrações de cálcio nos drenos de fundação, em comparação dos resultados das análises do reservatório. Particularmente no caso estudo, as análises de água, quanto aos sólidos carreados, também podem trazer informações relevantes, tende em vista a remoção de finos presente entre descontinuidades.

Novas sondagens a partir da galeria, ou a jusante da barragem, podem trazer 
informações interessantes principalmente em relação às descontinuidades/juntas de alívio na fundação, as quais foram extrapoladas a partir de observação das escavações. Ensaios de perda de água sob pressão e perfilagem óptica para determinação da atitude, abertura e preenchimento das descontinuidades, presença de vazios, estruturas geológicas, etc, podem melhorar as análises atuais e balizar recomendações de acompanhamento e ações no curto, médio e longo prazo.

Os resultados dos estudos de estabilidade para o contato concreto/rocha, assim como pelas juntas de alívio estimadas pela fundação, foram válidos no sentido de demonstrar a influência da cortina de drenagem no alívio das subpressões e a importância em mantê-la operante/ eficiente, assim como a sensibilidade em termos de variação dos parâmetros geomecânicos das juntas de alívio.

Ao longo da vida útil das barragens é importante que os registros dos instrumentos de auscultação sejam analisados frente as premissas e considerações de projeto, sendo de extrema importância também o acompanhamento do seu comportamento ao longo do tempo, associando, quando pertinente, observações de campo com a instrumentação ou mais de um instrumento para entendimento mais geral. Além disso há que se destacar a importância da documentação do empreendimento, tanto do período de projeto, como construção e também os registros de operação, para que se tenham subsídios para a realização de estudos e entendimento do comportamento das estruturas.

No caso de barragens de concreto, algumas atividades podem ser ainda inseridas dentro daquelas já consolidadas para seu acompanhamento e monitoramento. Juga-se que a profundidade dos drenos deve ser verificada antes do enchimento do reservatório, assim como durante o período de operação, adicionando a medição de vazão dreno a dreno, registrando-se semestralmente ou anualmente essas informações, o que permitirá avaliar eventuais reduções de profundidade e perda de eficiência da cortina de drenagem. A frequência de operações de limpeza e reperfuração dos drenos pode variar de empreendimento para empreendimento tendo em vista a perda de eficiência da cortina de drenagem e elevação dos níveis piezométricos.

No caso de piezômetros, pode-se estabelecer também a realização de testes de recuperação, procurando avaliar e comparar os resultados ao longo do tempo, o que poderia eventualmente revelar mau funcionamento do instrumento ou diferenças nas estimativas do coeficiente de permeabilidade no trecho instrumentado, mediante a determinação do tempo resposta "time lag" do instrumento.

Durante a execução das medições de profundidade e vazão dreno a dreno, assim como 
dos testes de recuperação dos piezômetros, também pode ser realizada a microfilmagem, empregando-se um bosroscópio, para avaliar manifestações patológicas com desencaixe de tubos, entupimento, carbonatação, queda de materiais, dentre outros

Uma rotina de análise de água ou, eventualmente, dos materiais presentes nos drenos de fundação podem melhorar o entendimento e monitoramento de condições que podem se mostrar prejudiciais à segurança e durabilidade das estruturas, podendo-se casos de barragens em regiões cársticas, com obstrução frequente dos drenos de fundação, em regiões de águas agressivas, com presença se ferro bactéria, sobre arenitos ou em que possa ocorrer carreamento de finos pela fundação, etc. 


\section{REFERÊNCIAS}

ABRAHÃO, Ricardo. Soft Rocks in Dam Foundation and Dam Sites. In: KANJI, Milton Assis; MANCHAO, He; RIBEIRO E SOUSA, Luís. Soft Rock Mechanics and Engineering, Cap. 24, p. 699-718, 2020.

ABRAHÃO, Ricardo; CRUZ, Paulo Teixeira da. Barragens e Reservatórios. In: OLIVEIRA, Antonio Manoel dos Santos; MONTICELI, João Jerônimo. Geologia de engenharia - Volume III, p. 10-37, 2018.

ABRAHÃO, Ricardo; DEGASPARE, José Carlos. Rebuilding Camará water supply dam. XV Colombian geotechnical congress \& II International specialized conference of soft rocks. Cartagena, 2016.

ALMEIDA, Marínis Maria de. Estudo tensão deformação de barragem de terra e enrocamento. Dissertação (Mestrado em Geotecnia) - Escola de Minas, Universidade Federal de Ouro Preto, Ouro Preto, p. 139, 2010.

ANA. Curso - Utilização do guia de diretrizes para a elaboração de projeto de barragens e revisão periódica - Instrumentação de Barragens e Revisão Periódica http://www.snisb.gov.br/portal/snisb/downloads/capacitacao/Arquivos_Cursos/curso-guia-dediretrizes-para-elaboracao-de-projeto-de-barragens-e-revisao-periodica-modulo-4-plano-demonitoramento-e-instrumentacao.pdf, p. 84. 2017

ANA. Manual do Empreendedor sobre Segurança de Barragens - Diretrizes Para Elaboração de Projeto de Barragens - Volume 5, Agência Nacional de Águas (Brasil) Ministério do Meio Ambiente, Brasília, p. 156, 2016.

ANA. Relatório de Segurança de Barragens 2018, Agência Nacional de Águas (Brasil) Ministério do Desenvolvimento Regional, Brasília, p. 103, 2019.

ANDRADE, Roberto Monteiro de. A drenagem nas fundações das estruturas hidráulicas: análise- interpretação-prática, Engevix, Rio de Janeiro, p. 437, 1982.

ASCE. Uplift in mansonry dams - Final report of the subcommittee on uplift in mansonry dams of the committee on mansonry dams of the power division, 1951, American Society of Civil Engineers, Transactions, Paper $n^{\circ} .2531,1952$

AZEVEDO, Maria da Penha Nogueira de. Barragens de Terra - Sistemas de Drenagem Interna. 2005. TCC (Graduação em Engenharia Civil) - Universidade Anhembi Morumbi, São Paulo, p. 96, 2005.

BARBOSA, Normando Perazzo; MENDONÇA, Ângelo Vieira; SANTOS, Celso Augusto Guimarães; LIRA, Belarmino Barbosa. Barragem de Camará. UNIVERSIDADE FEDERAL DA PARAÍBA - CENTRO DE TECNOLOGIA - João Pessoa. 2004.

BARTHOLOMEW, Charles Lewis. Failure of concrete dams. In: 6th ASDSO Annual 
Conference, Albuquerque, New Mexico, p. 428-445, 1989.

BEDMAR, Antonio Plata; ARAGUÁS, Luis Araguás. Detection and Prevention of Leaks from Dams, A.A. Balkema Publisher, p. 419, 2002.

BORGES, Antônio Augusto Finotti. Caracterização geomecânica de fundação de barragem de concreto em rocha branda. 2016. Dissertação (Mestrado em Engenharia Civil) COPPE/UFRJ, Universidade Federal do Rio de Janeiro, Rio de Janeiro, p. 99, 2016.

BRASIL. Lei $\mathbf{n}^{\mathbf{0}}$ 12.334, de 20 de setembro de 2010. Disponível em: http://www.planalto.gov.br/ccivil_03/_ato2007-2010/2010/lei/112334.htm. Acesso em: 07 dez. 2019, 2010

BRASIL. Senado Federal. Projeto de Lei $\mathbf{n}^{\mathbf{0}}$ 550/2019. Disponível em: https://www.camara.leg.br/proposicoesWeb/prop_mostrarintegra?codteor=1721856\&filename $=P L+550 / 2019$. Acesso em: 07 jun. 2020, 2019

BUREAU OF RECLAMATION. Design of Gravity Dams. United States Department of the interior - Bureau of Reclamation, Denver, p. 586, 1976.

BUREAU OF RECLAMATION. Design of Small Dams. United States Department Department of the Interior - Bureau of Reclamation - A Water Resources Technical Paper, Denver, EUA, p. 860, 1987.

BUREAU OF RECLAMATION. Ground Water Manual - A Water Resources - Technical Publication, 2nd edition, U.S. Department of the Interior, p. 690, 1995.

CALDAS, Silvio; LUZ, Gilson Machado da. Lições aprendidas com a instrumentação da UHE Tucuruí por ocasião do enchimento da $2^{\mathbf{a}}$ etapa. In: Seminário Nacional de Grandes Barragens, Porto de Galinhas, 2013.

CAMARGO, Wander Douglas Pires de. Estudo de acontecimentos históricos de ruptura de barragens. 2014. TCC (Graduação em Engenharia Civil) - Departamento Acadêmico de Construção Civil, Universidade Tecnológica Federal do Paraná, Campo Mourão, p.67, 2014.

COMIG. Mapa Geológico do Estado de Minas Gerais - escala 1:1.000.000, 2003. CPRM SERVIÇO GEOLÓGICO DO BRASIL. Mapa geológico do estado de Minas Gerais. Belo Horizonte: CPRM, 2003. Escala 1:1.000.000.

COMIG. Nota explicativa dos mapas geológico, metalogenéticos e de ocorrências minerais do estado de Minas Gerais - 1:1.000.000, 1994. Disponível em: < http://www.codemig.com.br/wp-

content/uploads/2016/08/nota_explicativa_mapa_geologico_1994.pdf>, Acesso em: 05 jul. 2020.

COSTA, Walter Duarte. Geologia de Barragens, Oficina de Textos, São Paulo, p. 352, 2012.

CRUZ, Paulo Teixeira da. As 100 Barragens Brasileiras: Casos históricos, materiais de construção e projeto. 2 ed. São Paulo: Oficina de Textos, p. 648, 2004. 
CRUZ, Paulo Teixeira da; MATERÓN, Bayardo; FREITAS JR., Manoel de Souza. Flow of Water Through Dams And Foundations, Second International Dam World, p. 1-14, 2015.

DEERE, D. U. Dams on rock foundations: some design questions. In: ROCK ENGINEERING FOR FOUNDATION \& SLOPES, ASCE - American Society of Civil Engineers, v.2, Nova York, p.55-86, 1977.

DOS SANTOS, Verlei Oliveira. Segurança de barragens de concreto: auscultação por instrumentação da barragem da UHE Dona Francisca - RS. 2018. Dissertação (Mestrado em Engenharia Civil) - Escola de Engenharia, Universidade Federal do Rio Grande do Sul, Porto Alegre, p. 295, 2018.

DUFFAUT, P. The Traps Behind the Failure of Malpasset Arch Dam, France, in 1959. Journal of Rock Mechanics and Geotechnical Engineering, v.5, n. 5, p. 335-341, 2013.

DUFFAUT, P.; LAROUZÉE, J. Geology, Engineering and Humanities: three sciences behind the Malpasset dam failure. Quarterly Journal of Engineering Geology and Hydrogeology, v. 52, p. 445-458, 2019.

EPRI - ELECTRIC POWER RESEARCH INSTITUTE. Uplift Pressures, Shear Strengths and Tensile Strengths for Stability Analysis of Concrete Gravity Dams. EPRI TR100345, Project 2917-05. Prepared by Stone and Webster Engineering Corp, Denver, Colorado, v. 1, p. 304, 1992.

\section{ELETROBRÁS. Critérios De Projeto Civil De Usinas Hidrelétricas. p. 278, 2003.}

FERC. Engineering Guidelines Risk-Informed Decision Making - Chapter R5 - Concrete Dam Analysis Arch, Gravity and Buttress Dams, p. 63, 2014.

FERNANDEZ Enrique, HERRERO Nieves, LARIO Javier, ORTIZ Isidoro, PEIRO Ramon, ROSSI Carlos - Introducción a la Geologia Karstica, Federación Española de Espeleologia, p. 202 1995;

FIEDLER, Bill; KELSIC, Rick; LABOON, John; MORFIN, Becky; MUNOZ, Rich; TURLINGTON, Gary; COOPER, Chuck. Drainage for Dams and Associated Structures, Civil Engineering and Geotechnical Services, Technical Services Center, Bureau of Reclamation, Denver, p. 416, 2004.

GIL, Euzébio José. Curso de segurança de barragens, Módulo I - Barragens: aspectos legais, técnicos e socioambientais, Unidade 8: Aspectos geológicos e geotécnicos. Brasília, 2013.

GOODMAN, Richard E.. On the Failure of Malpasset Dam. AEG Shlemon Specialty Conference: Dam Failures and Incidents, Association of Environmental and Engineering Geologists, Denver, 2013.

GRAÇA, Niarkios Luiz Santos de Salles. Validação da determinação de deslocamentos relativos em obras de engenharia obtidos com técnica geodésica e medidores triortogonais de junta. 2014. Dissertação (Mestrado em Ciências Geodésicas) - Departamento de Geomática, Setor de Ciências da Terra, Universidade Federal do Paraná, Curitiba p. 106, 2014. 
GRAÇA, Niarkios Luiz Santos de Salles; Faggion, Pedro Luis. Validação da determinação de deslocamentos relativos em barragens utilizando Topografia e Medidores Triortogonais de Junta. Revista Brasileira de Geomática. v.4, n. 2, p.89-98, 2016.

ISRM - International Society of Rock Mechanics. Rock characterization. Testing and monitoring. ISRM Suggested Methods. Ed. Brown, E. T. Commission on testing and monitoring. Pergamon Press, 1981.

JANSEN, Robert B., Dams and Public Safety, A Water Resources Technical Paper, U. S. Department of the Interior, Bureau of Reclamation, Denver, p. 332, 1983.

JENNINGS, Joseph Newell. An introduction to Systematic Geomorphology - Volume Seven - Karst. Australian National University Press, Canberra, 1971.

KANJI, Milton Assis. Parecer Técnico sobre as Causas da Ruptura da Barragem Camará - Resumo Executivo. São Paulo, p. 16, 2004.

KYLA, Justene Erich. Wolf Creek Dam: a case study of foundation remediation for dams built on Karst foundations, Missouri University of Science and Technology, 2013. Disponível em: 〈https://scholarsmine.mst.edu/masters_theses/5387>, Acesso em: 25 jun. 2020.

LARANJEIRA, Nina Paula Ferreira. A Plataforma Mista de Siliciclásticos e Carbonatos do Grupo Paranoá na região de Unaí, Minas Gerais. 1992. Dissertação (Mestrado em Geologia) Instituto de Geociências, Universidade de Brasília, Brasília, 1992.

LEVIS, Silvia Delattre. Verificação da eficácia dos sistemas de vedação e drenagem em fundações de barragens de concreto. 2006. Dissertação (Mestrado em Geotecnia) - Escola de Engenharia de São Carlos, Universidade de São Paulo, São Carlos, p. 186, 2006

LOMBARDI, Giovanni. Case histories of concrete dams (Structural cracks), Structural safety assessment of dams, International Centre for Mechanical Sciences - CISM, Udine, 2014.

LOPES, Marieli Biondo. Análise da eficiência do sistema de vedação da fundação em granito de uma barragem de concreto. 2015. Dissertação (Mestrado em Geotecnia) - Escola de Minas, Universidade Federal de Ouro Preto, p. 162, 2015.

MACHADO, William Gladstone de Freitas. Monitoramento de barragens de contenção de rejeitos da mineração. 2007. Dissertação (Mestrado em Engenharia Mineral) - Escola Politécnica, Universidade de São Paulo, São Paulo, p. 155, 2007.

MARANGON, Márcio. Tópicos em Geotecnia e Obras de Terra. Universidade Federal de Juiz de Fora - Departamento de Transportes e Geotecnia, Juiz de Fora, 2004.

MATA VELHA ENERGÉTICA S.A.. PCH Mata Velha - Projeto Básico Consolidado, 2011.

MAta Velha EnergétiCA S.A.. PCH Mata Velha - Projeto “Como Construído", 2016. 
MCCULLY, Patrick. When Things Fall Apart: The Techinical Failure of Large Dams. In: Silenced Rivers: The Ecology and Politics of Large Dams, 2001

MEIRELLES, Márcia Collares; GODOI, Cesar Schmidt; CORRÊA, Juliana Francisca; LOPES, Karina Guimarães. Compilação de dados de vazões de drenagem em diversas fundações de estruturas de concreto de UHE's, XXX Seminário Nacional De Grandes Barragens, Foz do Iguaçu, 2015

MILANOVIĆ, Petar. Catalog of engineering works in karst and their effects. In: Karst Aquifers - Characterization and Engineering (STEVANOVIĆ, Zoran). Professional Practice in Earth Science, Springer International Publishing Switzerland, p. 360-398, 2015.

MILANOVIĆ, Saša; VASIĆ, Ljiljana. 3D Conduit modelling of leakage below a dam situated in highly karstified rocks. In: STEVANOVIĆ, Zoran; KREŠIC, Neven; KUKURIĆ, Neno. Karst without boundaries, London, p. 321-336, 2016.

MINISTÉRIO DA INTEGRAÇÃO NACIONAL. Manual de Segurança e Inspeção de Barragens - Secretaria de Infraestrutura Hídrica, Brasília, p. 148, 2002.

NIEBLE, Carlos Manoel. Relatório de Diagnóstico do Sinistro da Barragem de Camará. São Paulo, 2004.

NIEBLE, Carlos Manoel. Riscos Geológico-Geotécnicos na Construção de Hidrelétricas O caso de Camará, Itapebi e Usinas no sul do Brasil. GEOSUL 2006 - V Simpósio de Prática de Engenharia Geotécnica da Região Sul, Porto Alegre, 2006.

NIGAM, P.S. Handbook Of Hydro Eletric Engineering - Nem Chand and Brothers, Roorkee, 1985 ;

OSAKO, Cláudio Issamy. A manutenção dos drenos nas fundações de barragens - O caso da usina hidrelétrica de Itaipu. 2002. Dissertação (Mestrado em Construção Civil), Universidade Federal do Paraná, Curitiba, 2002.

PILOTTI, Marco; MARANZONI, Andrea; TOMIROTTI, Massimo; VALERIO, Giulia.1923 Gleno Dam Break: Case Study and Numerical Modeling. Journal of Hydraulic Engineering, v. 137, n. 4, p. 480-492, 2011.

PORTO, Evangelista Caetano. Critério para determinação de vazões pela fundação de barragens com base nos ensaios de perda d'água: $O$ caso da Usina Hidrelétrica de Itaipu. 2002. Dissertação (Mestrado em Construção Civil), Universidade Federal do Paraná, Curitiba, p. 104, 2002

POSSAN, Edna. Curso de segurança de barragens, Módulo I - Barragens: aspectos legais, técnicos e socioambientais, Unidade 1: Barragens de Concreto, Brasília, 2015.

POUGATSCH, H.; MÜLLE, R.W.; SONDEREGGER, T.; KOBELT, A. Improvement of safety of Swiss dams on the basis of experience. In: SCHLEISS, Anton J.; BOES, Robert M. Dams and Reservoirs under Changing Challenges, A. Balkema Book, p. 145-152, 2011.

QUINTAS, Fernando Eduardo Geraldes. Planeamento da Construção de Barragens de 
Terra. 2002. Dissertação (Mestrado em Vias de Comunicação) - Faculdade de Engenharia, Universidade do Porto, Cidade do Porto, p. 181, 2002.

RHODES, J.A.; DIXON, N.A. Performance of foundation drain systems for concrete gravity dams, $12^{\circ}$ ICOLD, México, 1976.

RT-DU-RI-02/2016. Dumont Instrumentação de Barragens. Relatório Técnico Instrumentação das estruturas de concreto - fundações do vertedouro tomada d'água e barragem margem esquerda (BENA), 2016.

RUGGeRI, Giovanni. Uplift Pressures under Concrete Dams: Final Report. Working Group on Uplift Pressures under Concrete Dams. ICOLD European, 2004.

RYAN, K.K.; MORRIS, D.I.; MEISENHEIMER, J.K.. Evaluation and rehabilitation of clogged drains at concrete gravity drains, In: Waterpower '91, Proceedings of the International Conference on Hydropower - Denver, International Conference on Hydropower, American Society of Civil Engineers, New York, p. 1894-1903, 1991.

SANDRONI, Sandro Salvador. Notas para o Curso Geotecnica das Barragens - Capítulo 6, COPPE/UFRJ, Universidade Federal do Rio de Janeiro, Rio de Janeiro, 2006.

SCHNITTER, Nicholas J., A History of Dams - The Useful Pyramids. A.A. Balkema, Rotterdam, p. 282, 1994.

SILVEIRA, João Francisco Alves. Instrumentação e comportamento de fundações de barragens de concreto. Oficina de Textos. p. 313, 2003.

SILVEIRA, João Francisco Alves.; MANTESE, Arthur Couto Mantese; MELEGARI, Luis Fernado Pedrozo. Experiência na operação de limpeza de drenos de fundação em três barragens em CCR, XXXI Seminário Nacional de Grandes Barragens, Belo Horizonte, 2017.

SMIDERLE, Camila de Souza Dahm. Segurança de Barragens: Análise da Instrumentação da Barragem de Itaúba. 2014. Dissertação (Mestrado em Engenharia) - Escola de Engenharia, Universidade Federal do Rio Grande do Sul, Porto Alegre, p .224, 2014,

SOUZA, Tarcizo da Cruz Costa de. Análise de Estabilidade Global de Estruturas de Concreto em Usinas Hidrelétricas. 2018. Trabalho de Integração Multidisciplinar (Curso De Engenharia Civil) - Escola de Engenharia, Universidade Federal de Minas Gerais, Belo Horizonte, p. 116, 2018.

STEVANOVIĆ, Zoran; MILANOVIĆ, Petar. Engineering challenges, In: Karst, Acta Carsologica 44/3, Postojna, p. 381-399, 2015.

TECHNOS, Inc. Characterizing Karst and Pseudokarst, Technical Report, 2005.

TERZAGHI, Karl; PECK, Ralph Brazelton; MERSI, Gholamreza. Soil Mechanics in Engineering Practice, 3rd ed, Wiley-Interscience, p. 592, 1996

U.S. ARMY CORPS OF ENGINEERS. Design, Construction, and Maintenance of Relief Wells, Engineering Manual 1110-2-1914, USCAE - U.S. Army Corps of Engineer, 
Washington, p. 92, 1992.

U.S. ARMY CORPS OF ENGINEERS. Gravity Dam Design. Engineering and Design - EM 1110-2-2200, USCAE - U.S. Army Corps of Engineers, Washington, p. 88, 1995.

U.S. ARMY CORPS OF ENGINEERS. Wolf Creek Dam Concrete Diaphragm Walls Final Completion Reports Phases I and II, USCAE - U.S. Army Corps of Engineer, Nashville District, p. 403, 1988.

UOL. Dez dos maiores acidentes com barragens dos últimos anos ao redor do mundo, 2019- Disponível em: <https://www.bol.uol.com.br/listas/maiores-acidentes-com-barragensdos-ultimos-anos-ao-redor-do-mundo.htm>. Acesso em: 27 de out. 2019.

VELTROP, J., Water, Dams and Civilization, World Bank Technical Paper Number 115, 1991.

VOLKMER, Marian Vogt. Análise de subpressão em fundações rochosas e seus efeitos na estabilidade de barragens tipo gravidade. 2011. Dissertação (Mestrado em Geotecnia) Faculdade de Tecnologia, Universidade de Brasília, Brasília, p. 132, 2011.

WORLD COMISSION ON DAMS, Dams and Development. A new framework for decision making, The Report of the World Comission on Dams, Earthscan Publications, Londres, p. 446, 2000.

ZUCULIN, Sérgio. Curso de segurança de barragens Módulo II: Inspeção e Auscultação de Barragens, Unidade 2: Instrumentação de Barragens, Brasília, 2013.

ZUFFO, Monica Soares Resio. Metodologia para avaliação da segurança de barragens. 2005. Dissertação (Mestrado em Recursos Hídricos) - Faculdade de Engenharia Civil, Arquitetura e Urbanismo, Universidade Estadual de Campinas, Campinas, p. 192, 2005 
APÊNDICE A - PLANILHAS DE CÁLCULO DE ESTABILIDADE

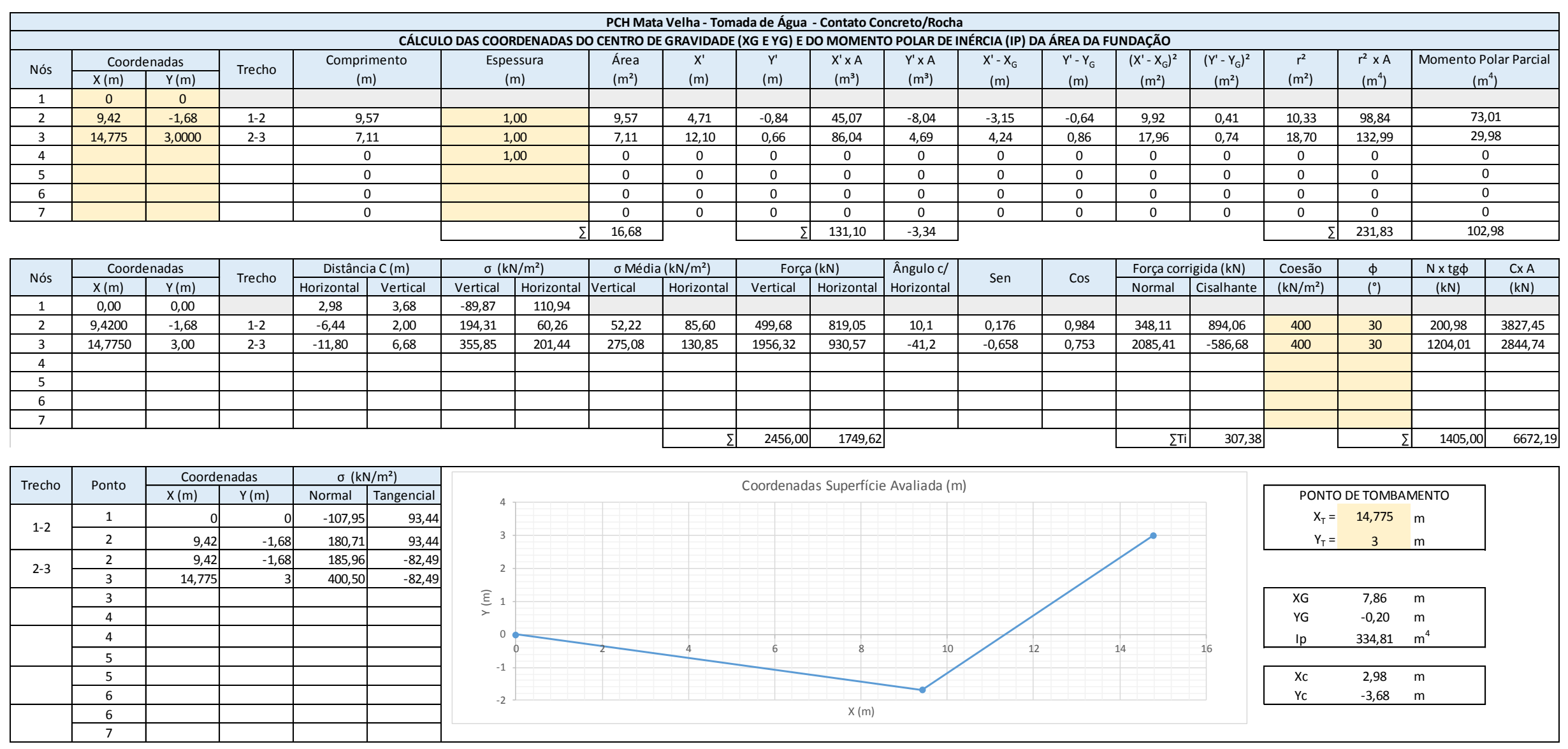

\begin{tabular}{|c|c|c|c|c|c|c|c|c|c|c|c|c|c|c|c|}
\hline \multicolumn{16}{|c|}{ PCH Mata Velha - Tomada de Água - Contato Concreto/Rocha } \\
\hline \multirow[b]{3}{*}{ ESFORÇOS } & & & CCN - DREN & PERAN & N.A. NORM & ALA MON & NTE (EL. 6 & OM) EA & UTE (EL. & & & & & & \\
\hline & \multirow{2}{*}{$\begin{array}{l}\text { Dire- } \\
\text { ção }\end{array}$} & \multirow{2}{*}{$\begin{array}{l}\text { VOLUME } \\
\left(\mathrm{m}^{3}\right)\end{array}$} & \multirow{2}{*}{$\begin{array}{l}\text { Peso Específico } \\
\left(\mathrm{kN} / \mathrm{m}^{3}\right)\end{array}$} & \multirow{2}{*}{\multicolumn{2}{|c|}{$\begin{array}{l}\text { FORÇA } \\
(\mathrm{kN})\end{array}$}} & \multirow{2}{*}{\multicolumn{2}{|c|}{ Coordenada $(\mathrm{m})$}} & \multicolumn{8}{|c|}{ EM RELAÇÃO AO PONTO DE TOMBAMENTO } \\
\hline & & & & & & & & \multicolumn{2}{|c|}{ Excentricidade } & \multicolumn{3}{|c|}{ Estabilizador ou Tombador } & \multirow{2}{*}{$\begin{array}{c}\text { Correç̃ão } \\
1 \\
\end{array}$} & \multicolumn{2}{|c|}{$\frac{\text { MOMENTO }}{(\mathrm{kN} . \mathrm{m})}$} \\
\hline Peso de Concreto - CCV & V & 173,0902 & 24,0 & $F_{1}=$ & $4.154,16$ & $\begin{array}{c}x \\
6,6132 \\
\end{array}$ & $\mathrm{r}$ & 8,16 & 0,00 & $\mathrm{E}$ & 0 & $\mathrm{E}$ & & $M_{1}=$ & $33.905,46$ \\
\hline Empuxo de Água a Montante & $\gg$ & 199,7994 & 10,0 & $\mathrm{~F}_{2}=$ & $1.997,99$ & & 5,38 & 0,00 & $-2,38$ & 0 & $\mathrm{~T}$ & $\mathrm{~T}$ & -1 & $\mathrm{M}_{2}=$ & $-4.752,63$ \\
\hline Subpressão & $\Lambda$ & 169,8169 & 10,0 & $\mathrm{~F}_{3}=$ & $1.698,17$ & 5,41 & & 9,36 & 0,00 & $T$ & 0 & $T$ & -1 & $M_{3}=$ & $-15.895,37$ \\
\hline \multirow[t]{9}{*}{ Empuxo Jusante } & $\ll$ & 24,8375 & 10,0 & $F_{4}=$ & 248,38 & & $-0,1169$ & 0,00 & 3,12 & 0 & $\mathrm{~T}$ & $\mathrm{~T}$ & -1 & $M_{4}=$ & $-774,16$ \\
\hline & & & & $F_{5}=$ & 0,00 & & & 0,00 & 0,00 & & & & & $M_{5}=$ & \\
\hline & & & & $F_{6}=$ & 0,00 & & & 0,00 & 0,00 & & & & & $M_{6}=$ & \\
\hline & & & & $F_{7}=$ & 0,00 & & & 0,00 & 0,00 & & & & & $M_{7}=$ & \\
\hline & & & & $F_{8}=$ & 0,00 & & & & & & & & & $M_{8}=$ & \\
\hline & & & & $F_{9}=$ & 0,00 & & & & & & & & & $M_{9}=$ & \\
\hline & & & & $\mathrm{F}_{10}=$ & 0,00 & & & & & & & & & $M_{10}=$ & \\
\hline & & & & $\mathrm{F}_{11}=$ & 0,00 & & & & & & & & & $\mathrm{M}_{11}=$ & \\
\hline & & & & & 0,00 & & & & & & & & & & \\
\hline
\end{tabular}

\begin{tabular}{|c|c|c|c|c|c|c|c|c|}
\hline \multirow{3}{*}{ ESFORÇOS } & \multicolumn{8}{|c|}{ EM RELAÇÃO AO CG DA FUNDAÇÃO } \\
\hline & \multicolumn{2}{|c|}{ Excentricidade } & \multirow{2}{*}{\multicolumn{3}{|c|}{ Estabilizador ou Tombador }} & \multirow{3}{*}{ Correção } & \multirow{2}{*}{\multicolumn{2}{|c|}{$\begin{array}{c}\text { MOMENTO } \\
(\mathrm{kN} . \mathrm{m})\end{array}$}} \\
\hline & $x_{G}-x$ & $Y_{G}-Y$ & & & & & & \\
\hline Peso de Concreto - CCV & 1,25 & 0,00 & $E$ & 0 & $E$ & & $\mathrm{M}_{1}=$ & $5.178,23$ \\
\hline Empuxo de Água a Montante & 0,00 & $-5,58$ & 0 & $\mathrm{~T}$ & $\mathrm{~T}$ & -1 & $\mathrm{M}_{2}=$ & $-11.147,14$ \\
\hline Subpressão & 2,45 & 0,00 & $\mathrm{~T}$ & 0 & $\mathrm{~T}$ & -1 & $M_{3}=$ & $-4.152,05$ \\
\hline \multirow[t]{9}{*}{ Empuxo Jusante } & 0,00 & $-0,08$ & 0 & E & $\mathrm{E}$ & 1 & $M_{4}=$ & 20,76 \\
\hline & & & & & & & $M_{s}=$ & \\
\hline & & & & & & & $M_{6}=$ & \\
\hline & & & & & & & $M_{7}=$ & \\
\hline & & & & & & & $\mathrm{NH}_{\mathrm{B}^{-}}$ & \\
\hline & & & & & & & $M_{g}=$ & \\
\hline & & & & & & & $M_{10}=$ & \\
\hline & & & & & & & $\mathrm{M}_{11}=$ & \\
\hline & & & & & & & & \\
\hline
\end{tabular}

\begin{tabular}{|c|c|c|c|c|c|c|c|c|}
\hline \multirow[b]{2}{*}{$\Sigma V=$} & \multirow[b]{2}{*}{$4154,1648 \mathrm{kN}$} & \multirow[b]{2}{*}{$\sum M_{E}=$} & \multirow{2}{*}{$33.905,46 \mathrm{kN} . \mathrm{m}$} & \multicolumn{5}{|c|}{ FLUTUAÇÃO - CSF } \\
\hline & & & & $\Sigma \mathrm{V}$ & \multirow[t]{2}{*}{2,45} & \multirow[t]{2}{*}{$>$} & \multirow[t]{2}{*}{1,3} & \multirow[t]{2}{*}{ ок } \\
\hline$\Sigma U=$ & $1698,169 \mathrm{kN}$ & $\sum M_{T}=$ & $21.422,16 \mathrm{kN} . \mathrm{m}$ & $\sum U$ & & & & \\
\hline$\Sigma V-\Sigma U=$ & $2455,9958 \mathrm{kN}$ & Momento Resultante & $12.483,30 \mathrm{kN} . \mathrm{m}$ & \multicolumn{5}{|c|}{ TOMBAMENTO - CST } \\
\hline$\sum T_{i, \text { MONAANE }}=$ & $1997,994 \mathrm{kN}$ & & & $\frac{\sum \mathrm{M}_{\mathrm{E}}}{\sum \mathrm{M}_{\mathrm{T}}}=$ & 1,58 & $>$ & 1,5 & ок \\
\hline$\sum \mathrm{T}_{\mathrm{i}, \text { USANEE }}=$ & & & & \multicolumn{5}{|c|}{ DESLIZAMENTO - CSD $\phi$ e CSD } \\
\hline Força Resultante & $1749,619 \mathrm{kN}$ & & & $\frac{N_{1} \times \operatorname{tg} \phi}{\operatorname{CSD}_{0} \times \sum \pi_{i}}+\frac{\sum \mathrm{C}_{1} \times \mathrm{Ai}^{-}}{\operatorname{CSD}_{c} \times \sum \pi}=$ & 10,28 & $>$ & 1,0 & ок \\
\hline
\end{tabular}




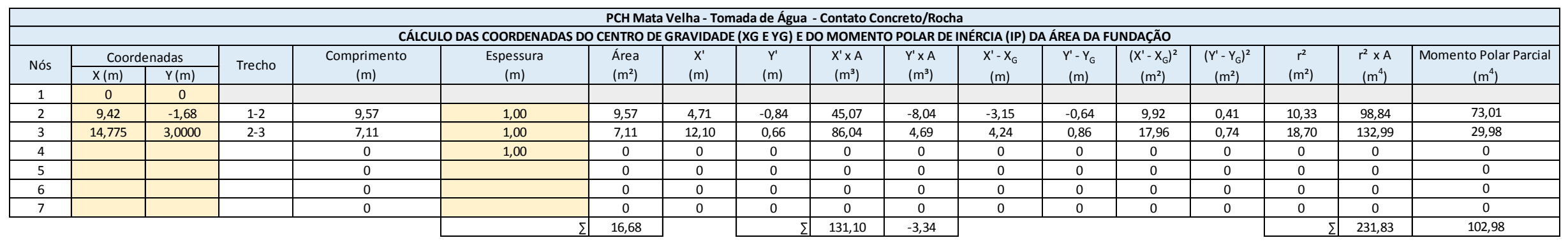

\begin{tabular}{|c|c|c|c|c|c|c|c|c|c|c|c|c|c|c|c|c|c|c|c|c|}
\hline \multirow{2}{*}{ Nós } & \multicolumn{2}{|c|}{ Coordenadas } & \multirow{2}{*}{ Trecho } & \multicolumn{2}{|c|}{ Distância C (m) } & \multicolumn{2}{|c|}{$\sigma\left(\mathrm{kN} / \mathrm{m}^{2}\right)$} & \multicolumn{2}{|c|}{$\sigma$ Média $\left(\mathrm{kN} / \mathrm{m}^{2}\right)$} & \multicolumn{2}{|c|}{ Força $(\mathrm{kN})$} & \multirow{2}{*}{$\begin{array}{l}\text { Ângulo c/ } \\
\text { Horizontal }\end{array}$} & \multirow{2}{*}{ Sen } & \multirow[b]{2}{*}{$\cos$} & \multicolumn{2}{|c|}{ Força corrigida (kN) } & \multirow{2}{*}{$\begin{array}{l}\text { Coesãa } \\
\left(\mathrm{kNN} / \mathrm{m}^{2}\right)\end{array}$} & \multirow{2}{*}{$\begin{array}{l}\phi \\
\left({ }^{\circ}\right) \\
\end{array}$} & \multirow{2}{*}{$\begin{array}{c}\mathrm{N} \times \mathrm{tg} \phi \\
(\mathrm{kN}) \\
\end{array}$} & \multirow{2}{*}{$\begin{array}{l}\mathrm{CXA} \\
(\mathrm{kN}) \\
\end{array}$} \\
\hline & $x(m)$ & $\mathrm{Y}(\mathrm{m})$ & & Horizontal & Vertical & Vertical & Horizontal & Vertical & Horizontal & Vertical & \begin{tabular}{|l|} 
Horizontal \\
\end{tabular} & & & & Normal & Cisalhante & & & & \\
\hline 1 & 0,00 & 0,00 & & 1,49 & 3,99 & $-41,41$ & 110,89 & & & & & & & & & & & & & \\
\hline 2 & 9,4200 & $-1,68$ & $1-2$ & $-7,93$ & 2,31 & 220,63 & 64,16 & 89,61 & 87,52 & 857,42 & 837,48 & 10,1 & 0,176 & 0,984 & $\begin{array}{ll}697,06 \\
\end{array}$ & 975,01 & 400 & 30 & 402,45 & 3827,45 \\
\hline 3 & 14,7750 & 3,00 & $2-3$ & $-13,29$ & 6,99 & 369,59 & 194,34 & 295,11 & 129,25 & 2098,77 & 919,21 & $-41,2$ & $-0,658$ & 0,753 & 2185,20 & $-688,98$ & 400 & 30 & 1261,63 & 2844,74 \\
\hline 4 & & & & & & & & & & & & & & & & & & & & \\
\hline 5 & & & & & & & & & & & & & & & & & & & & \\
\hline 6 & & & & & & & & & & & & & & & & & & & & \\
\hline 7 & & & & & & & & & & & & & & & & & & & & \\
\hline & & & & & & & & & $\Sigma$ & 2956,20 & $\begin{array}{l}1756,69 \\
\end{array}$ & & & & $\sum \mathrm{Ti}_{\mathrm{i}}$ & 286,03 & & $\Sigma$ & 1664,08 & 6672,19 \\
\hline
\end{tabular}
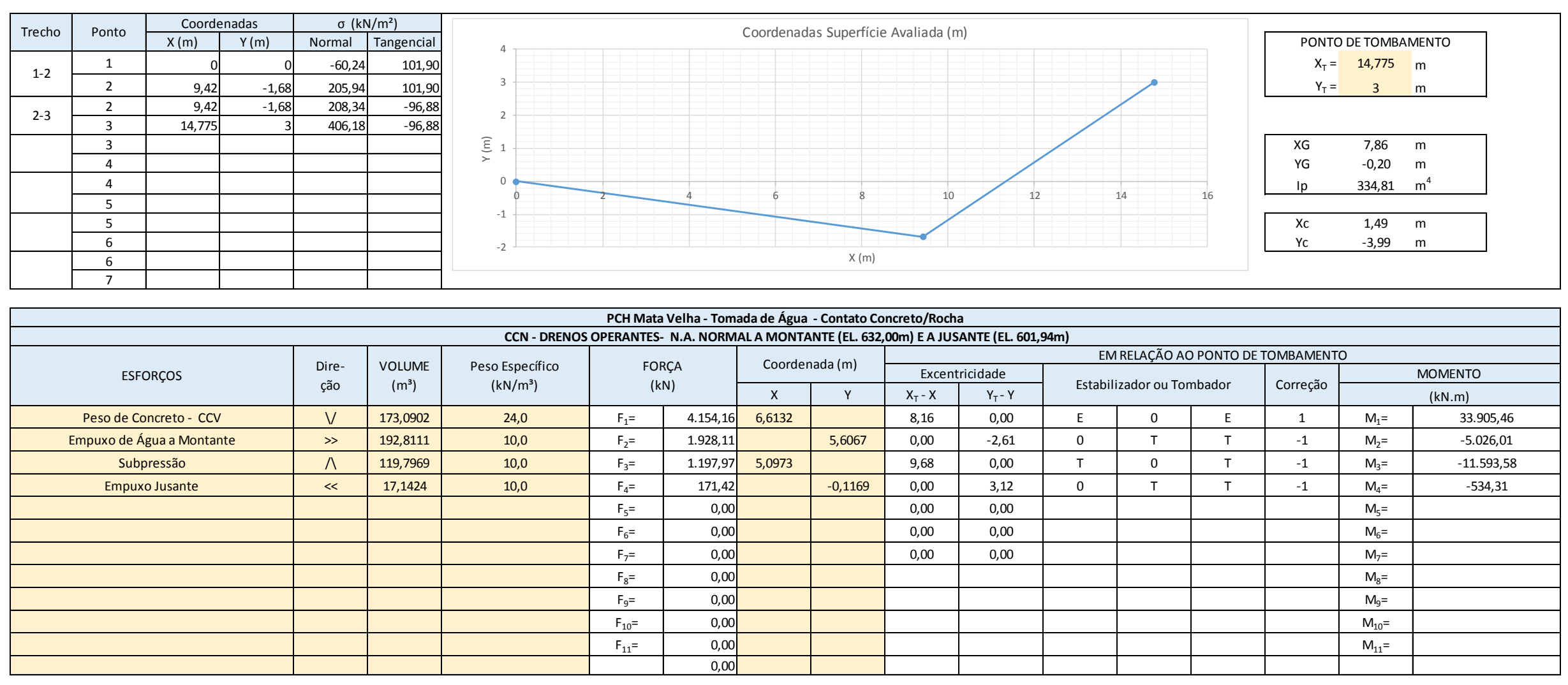

\begin{tabular}{|c|c|c|c|c|c|c|c|c|}
\hline \multirow{3}{*}{ ESFORÇOS } & \multicolumn{8}{|c|}{ EM RELAÇÃO AO CG DA FUNDAÇÃO } \\
\hline & \multicolumn{2}{|c|}{ Excentricidade } & \multirow{2}{*}{\multicolumn{3}{|c|}{ Estabilizador ou Tombador }} & \multirow{3}{*}{$\begin{array}{c}\text { Correção } \\
1\end{array}$} & \multirow{2}{*}{\multicolumn{2}{|c|}{$\frac{\text { MOMENTO }}{(\mathrm{kN} . \mathrm{m})}$}} \\
\hline & $x_{G}-x$ & $Y_{G}-Y$ & & & & & & \\
\hline Peso de Concreto - CCV & 1,25 & 0,00 & $E$ & 0 & $\mathrm{E}$ & & $M_{1}=$ & $5.178,23$ \\
\hline Empuxo de Água a Montante & 0,00 & $-5,81$ & 0 & $T$ & $T$ & -1 & $\mathrm{M}_{2}=$ & $-11.196,86$ \\
\hline Subpressão & 2,76 & 0,00 & $T$ & 0 & $T$ & -1 & $M_{3}=$ & $-3.309,29$ \\
\hline \multirow[t]{9}{*}{ Empuxo Jusante } & 0,00 & $-0,08$ & 0 & $\mathrm{E}$ & $\mathrm{E}$ & 1 & $\mathrm{M}_{4}=$ & 14,32 \\
\hline & & & & & & & $M_{5}=$ & \\
\hline & & & & & & & $M_{6}=$ & \\
\hline & & & & & & & $\mathrm{M}_{7}=$ & \\
\hline & & & & & & & $\mathrm{M}_{8}=$ & \\
\hline & & & & & & & $M_{g}=$ & \\
\hline & & & & & & & $M_{10}=$ & \\
\hline & & & & & & & $\mathrm{M}_{11}=$ & \\
\hline & & & & & & & & \\
\hline
\end{tabular}

\begin{tabular}{|c|c|c|c|c|c|c|c|c|}
\hline \multirow{2}{*}{$\Sigma V=$} & \multirow{2}{*}{$4154,1648 \mathrm{kN}$} & & & \multicolumn{5}{|c|}{ FLUTUAÇÃO - CSF } \\
\hline & & $\sum \mathrm{M}_{\mathrm{T}}=$ & $\begin{array}{l}33.903,46 \mathrm{kN} . \mathrm{m} \\
17.153,90 \mathrm{kN} . \mathrm{m}\end{array}$ & $\frac{\Sigma V}{\Sigma U}=$ & 3,47 & $>$ & 1,3 & ок \\
\hline$\Sigma V-\Sigma U=$ & $2956,1958 \mathrm{kN}$ & Momento Resultante & $16.751,56 \mathrm{kN} \cdot \mathrm{m}$ & \multicolumn{5}{|c|}{ TOMBAMENTO - CST } \\
\hline$\sum \mathrm{T}_{\mathrm{i}, \text { MONTANTE }}=$ & $1928,111 \mathrm{kN}$ & & & $\frac{\sum M_{E}}{\sum M_{T}}=$ & 1,98 & $>$ & 1,5 & ок \\
\hline$\sum \mathrm{T}_{\mathrm{i}, \text { USAANE }}=$ & $171,424 \mathrm{kN}$ & & & \multicolumn{5}{|c|}{ DESLIZAMENTO - CSD e CSD } \\
\hline Força Resultante & $1756,687 \mathrm{kN}$ & & & $\frac{N_{1} \times \operatorname{tg} \phi}{\operatorname{CSD}_{b} \times \sum \pi}+\frac{\sum C_{x} \times A_{i}}{\operatorname{CSD}_{c} \times \sum \pi}=$ & 11,65 & $>$ & 1,0 & ок \\
\hline
\end{tabular}




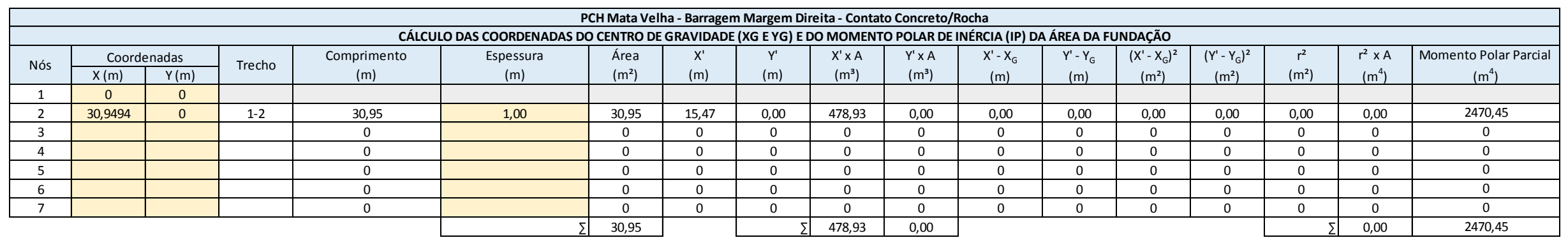

\begin{tabular}{|c|c|c|c|c|c|c|c|c|c|c|c|c|c|c|c|c|c|c|c|c|}
\hline \multirow{2}{*}{ Nós } & \multicolumn{2}{|c|}{ Coordenadas } & \multirow{2}{*}{ Trecho } & \multirow{2}{*}{\multicolumn{2}{|c|}{ Distância C (m) }} & \multicolumn{2}{|c|}{$\sigma\left(\mathrm{kN} / \mathrm{m}^{2}\right)$} & \multicolumn{2}{|c|}{$\sigma$ Média $\left(\mathrm{kN} / \mathrm{m}^{2}\right)$} & \multicolumn{2}{|c|}{ Força $(\mathrm{kN})$} & \multirow{2}{*}{$\begin{array}{l}\text { Ângulo c/ } \\
\text { Horizontal }\end{array}$} & \multirow[b]{2}{*}{ Sen } & \multirow[b]{2}{*}{$\cos$} & \multicolumn{2}{|c|}{ Força corrigida (kN) } & \multirow{2}{*}{$\begin{array}{l}\text { Coesão } \\
\left(\mathrm{kN} / \mathrm{m}^{2}\right) \\
\end{array}$} & \multirow{2}{*}{$\begin{array}{l}\phi \\
\left(^{\circ}\right) \\
\end{array}$} & \multirow{2}{*}{$\begin{array}{r}\mathrm{N} \times \operatorname{tg} \phi \\
(\mathrm{kN}) \\
\end{array}$} & \multirow{2}{*}{$\begin{array}{l}\mathrm{C} \times \mathrm{A} \\
(\mathrm{kN}) \\
\end{array}$} \\
\hline & $x(m)$ & $\mathrm{Y}(\mathrm{m})$ & & & & Vertical & Horizontal & Vertical & Horizontal & Vertical & Horizontal & & & & Normal & Cisalhante & & & & \\
\hline 1 & 0,00 & 0,00 & & $-11,37$ & 18,44 & 119,35 & 193,61 & & & & & & & & & & & & & \\
\hline 2 & 30,95 & 0,00 & $1-2$ & $-42,32$ & 18,44 & 444,36 & 193,61 & 281,86 & 193,61 & 8723,33 & 5992,00 & 0,0 & 0,000 & 1,000 & 8723,33 & 5992,00 & 400 & 30 & 5036,42 & 12379,76 \\
\hline 3 & & & & & & & & & & & & & & & & & & & & \\
\hline 4 & & & & & & & & & & & & & & & & & & & & \\
\hline 5 & & & & & & & & & & & & & & & & & & & & \\
\hline 6 & & & & & & & & & & & & & & & & & & & & \\
\hline 7 & & & & & & & & & $\Sigma$ & 8723,33 & 5992,00 & & & & $\sum \pi \mathrm{i}$ & 5992,00 & & 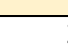 & 5036,42 & 12379,76 \\
\hline
\end{tabular}

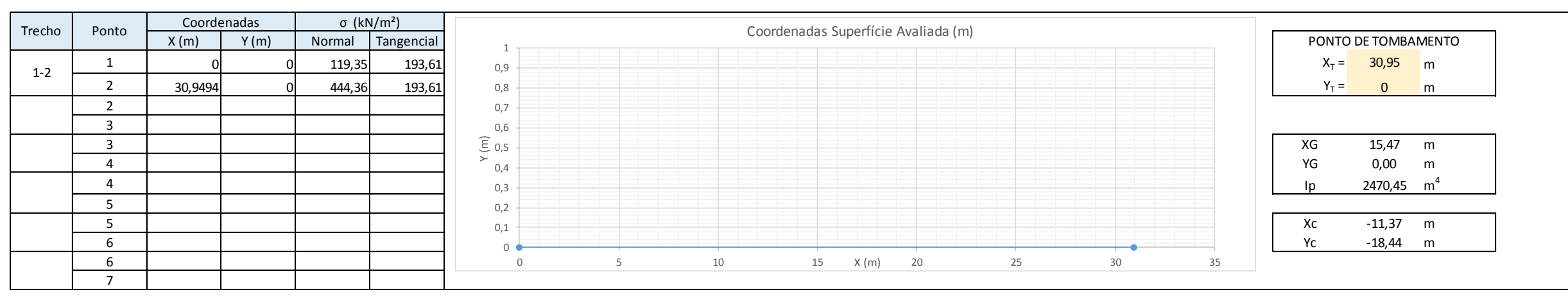

\begin{tabular}{|c|c|c|c|c|c|c|c|c|c|c|c|c|c|c|c|}
\hline \multirow{2}{*}{\multicolumn{16}{|c|}{$\begin{array}{l}\text { PCH Mata Velha - Barragem Margem Direita - Contato Concreto/Rocha } \\
\text { CCN - DRENOS INOPERANTES- N.A. NORMAL A MONTANTE (ELL. 632,00m) E A JUSANTE (EL. 601,94m) }\end{array}$}} \\
\hline & & & CCN - DREN & SERAN & N.A. NORN & LLAMON & NTE (EL. 6 & Om) EA & UTE (EL. & & & & & & \\
\hline \multirow{3}{*}{ ESFORÇOS } & \multirow{3}{*}{$\begin{array}{l}\text { Dire- } \\
\text { ção }\end{array}$} & \multirow{3}{*}{$\begin{array}{l}\text { VOLUME } \\
\left(\mathrm{m}^{3}\right)\end{array}$} & \multirow{3}{*}{$\begin{array}{l}\text { Peso Especifico } \\
\left(\mathrm{kN} / \mathrm{m}^{3}\right)\end{array}$} & \multirow{3}{*}{\multicolumn{2}{|c|}{$\begin{array}{l}\text { FORCA } \\
(\mathrm{kNN})\end{array}$}} & \multirow{2}{*}{\multicolumn{2}{|c|}{ Coordenada $(\mathrm{m})$}} & \multicolumn{8}{|c|}{ EM RELAÇÃO AO PONTO DE TOMBAMENTO } \\
\hline & & & & & & & & \multicolumn{2}{|c|}{ Excentricidade } & \multirow{2}{*}{\multicolumn{3}{|c|}{ Estabilizador ou Tombador }} & \multirow{3}{*}{$\begin{array}{c}\text { Correção } \\
1 \\
\end{array}$} & \multirow{2}{*}{\multicolumn{2}{|c|}{$\frac{\text { MOMENTO }}{(\mathrm{kN} . \mathrm{m})}$}} \\
\hline & & & & & & \multirow{2}{*}{$\begin{array}{c}x \\
11,0515 \\
\end{array}$} & \multirow[t]{2}{*}{ y } & $x_{T}-x$ & $Y_{T}-Y$ & & & & & & \\
\hline Peso de Concreto - CCV & $\mathrm{V}$ & 595,6836 & 24,0 & $F_{1}=$ & $14.296,41$ & & & 19,90 & 0,00 & $\mathrm{E}$ & 0 & E & & $M_{1}=$ & $284.468,46$ \\
\hline Empuxo de Água a Montante & $\gg$ & 611,2270 & 10,0 & $F_{2}=$ & $6.112,27$ & & 11,6555 & 0,00 & $-11,66$ & 0 & $\mathrm{~T}$ & $\mathrm{~T}$ & -1 & $\mathrm{M}_{2}=$ & $-71.241,56$ \\
\hline Subpressão & $\Lambda$ & 616,9752 & 10,0 & $\mathrm{~F}_{3}=$ & $6.169,75$ & 11,5854 & & 19,36 & 0,00 & $T$ & 0 & $T$ & -1 & $M_{3}=$ & $-119.471,08$ \\
\hline Peso de água a Montante & $\mathrm{V}$ & 49,9889 & 10,0 & $F_{4}=$ & 499,89 & 0,9996 & & 29,95 & 0,00 & $\mathrm{E}$ & 0 & $\mathrm{E}$ & 1 & $M_{4}=$ & $14.971,58$ \\
\hline Peso de Água a Jusante & V & 9,6788 & 10,0 & $F_{5}=$ & 96,79 & 29,6658 & & 1,28 & 0,00 & E & 0 & $\mathrm{E}$ & 1 & $M_{5}=$ & 124,24 \\
\hline \multirow[t]{7}{*}{ Empuxo de Água a Jusante } & $\ll$ & 12,0268 & 10,0 & $F_{6}=$ & 120,27 & & 1,6350 & 0,00 & $-1,64$ & 0 & $\mathrm{E}$ & $\mathrm{E}$ & 1 & $M_{6}=$ & 196,64 \\
\hline & & & & $F_{7}=$ & 0,00 & & & 0,00 & 0,00 & & & & & $M_{7}=$ & \\
\hline & & & & $F_{8}=$ & 0,00 & & & & & & & & & $M_{8}=$ & \\
\hline & & & & $F_{g}=$ & 0,00 & & & & & & & & & $M_{g}=$ & \\
\hline & & & & $F_{10}=$ & 0,00 & & & & & & & & & $M_{10}=$ & \\
\hline & & & & $\mathrm{F}_{11}=$ & 0,00 & & & & & & & & & $\mathrm{M}_{11}=$ & \\
\hline & & & & & 0,00 & & & & & & & & & & \\
\hline
\end{tabular}

\begin{tabular}{|c|c|c|c|c|c|c|c|c|}
\hline \multirow{3}{*}{ ESFORÇOS } & \multicolumn{8}{|c|}{ EM RELAÇÃO AO CG DA FUNDAÇÃO } \\
\hline & \multicolumn{2}{|c|}{ Excentricidade } & \multirow{2}{*}{\multicolumn{3}{|c|}{ Estabilizador ou Tombador }} & \multirow{3}{*}{$\begin{array}{c}\text { Correç̃o } \\
1\end{array}$} & \multirow{2}{*}{\multicolumn{2}{|c|}{$\begin{array}{c}\text { MOMENTO } \\
(\mathrm{kN} . \mathrm{m})\end{array}$}} \\
\hline & \multirow{2}{*}{$\frac{x_{G}-x}{4,42}$} & \multirow{2}{*}{$\frac{Y_{G}-Y}{0,00}$} & & & & & & \\
\hline Peso de Concreto - CCV & & & $\mathrm{E}$ & 0 & E & & $M_{1}=$ & $63.235,86$ \\
\hline Empuxo de Água a Montante & 0,00 & $-11,66$ & 0 & $\mathrm{~T}$ & $\mathrm{~T}$ & -1 & $M_{2}=$ & $-71.241,56$ \\
\hline Subpressão & 3,89 & 0,00 & $T$ & 0 & $\mathrm{~T}$ & -1 & $M_{3}=$ & $-23.996,02$ \\
\hline Peso de água a Montante & 14,48 & 0,00 & $\mathrm{E}$ & 0 & $\mathrm{E}$ & 1 & $M_{4}=$ & $7.235,94$ \\
\hline Peso de Água a Jusante & $-14,19$ & 0,00 & $T$ & 0 & T & -1 & $M_{5}=$ & $-1.373,53$ \\
\hline Empuxo de Água a Jusante & 0,00 & $-1,64$ & 0 & $E$ & $E$ & 1 & $M_{6}=$ & 196,64 \\
\hline & & & & & & & $\mathrm{M}_{7}=$ & \\
\hline & & & & & & & $M_{8}=$ & \\
\hline & & & & & & & $M_{g}=$ & \\
\hline & & & & & & & $M_{10}=$ & \\
\hline & & & & & & & $M_{11}=$ & \\
\hline & & & & & & & & \\
\hline
\end{tabular}

\begin{tabular}{|c|c|c|c|c|c|c|c|c|}
\hline \multirow{2}{*}{$\Sigma V=$} & \multirow{2}{*}{$14893,0834 \mathrm{kN}$} & & & \multicolumn{5}{|c|}{ FLUTUAÇÃO - CSF } \\
\hline & & $\sum \mathrm{M}_{\mathrm{T}}=$ & $190.712,64 \mathrm{kN} . \mathrm{m}$ & $\frac{\Sigma V}{\Sigma U}=$ & 2,41 & $>$ & 1,3 & ок \\
\hline$\Sigma V-\Sigma U=$ & $8723,3314 \mathrm{kN}$ & Momento Resultante & $109.048,28 \mathrm{kN} \cdot \mathrm{m}$ & \multicolumn{5}{|c|}{ TOMBAMENTO - CST } \\
\hline$\sum \mathrm{T}_{\mathrm{i}, \text { MONTANTE }}=$ & $6112,27 \mathrm{kN}$ & & & $\frac{\sum M_{E}}{\sum M_{T}}=$ & 1,57 & $>$ & 1,5 & ок \\
\hline$\sum \mathrm{T}_{\mathrm{i}, \text { USSANTE }}=$ & $120,268 \mathrm{kN}$ & & & \multicolumn{5}{|c|}{ DESLIZAMENTO - CSD $\phi$ e CSD $_{\mathrm{c}}$} \\
\hline Força Resultante & $10583,03 \mathrm{kN}$ & & & 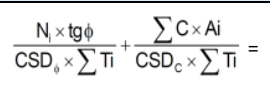 & 1,25 & $>$ & 1,0 & ок \\
\hline
\end{tabular}




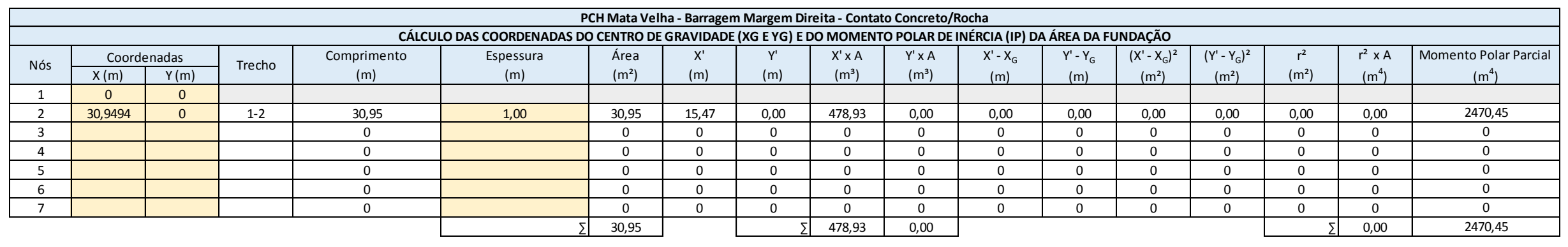

\begin{tabular}{|c|c|c|c|c|c|c|c|c|c|c|c|c|c|c|c|c|c|c|c|c|}
\hline \multirow{2}{*}{ Nós } & \multicolumn{2}{|c|}{ Coordenadas } & \multirow{2}{*}{ Trecho } & \multicolumn{2}{|c|}{ Distância C (m) } & \multicolumn{2}{|c|}{$\sigma\left(\mathrm{kN} / \mathrm{m}^{2}\right)$} & \multicolumn{2}{|c|}{$\sigma$ Média $\left(\mathrm{kN} / \mathrm{m}^{2}\right)$} & \multicolumn{2}{|c|}{ Força (kN) } & \multirow{2}{*}{$\begin{array}{l}\text { Ângulo c/ } \\
\text { Horizontal }\end{array}$} & \multirow{2}{*}{ Sen } & \multirow{2}{*}{$\cos$} & \multicolumn{2}{|c|}{ Força corrigida (kN) } & \multirow{2}{*}{$\begin{array}{c}\text { Coesão } \\
\left(\mathrm{kN} / \mathrm{m}^{2}\right)\end{array}$} & \multirow{2}{*}{$\begin{array}{l}\phi \\
\left({ }^{\circ}\right) \\
\end{array}$} & \multirow{2}{*}{$\begin{array}{c}\mathrm{N} \times \operatorname{tg} \phi \\
(\mathrm{kN})\end{array}$} & \multirow{2}{*}{$\begin{array}{l}\text { CXA } \\
(\mathrm{kNN}) \\
\end{array}$} \\
\hline & $x(m)$ & $Y(\mathrm{~m})$ & & Horizontal & Vertical & Vertical & Horizontal & Vertical & \begin{tabular}{|l|l} 
Horizontal \\
\end{tabular} & \begin{tabular}{|l|l} 
Vertical \\
\end{tabular} & Horizontal & & & & Normal & Cisalhante & & & & \\
\hline 1 & 0,00 & 0,00 & & $-23,58$ & 22,81 & 200,11 & 193,61 & & & & & & & & & & & & & \\
\hline 2 & 30,95 & 0,00 & $1-2$ & $-54,53$ & 22,81 & 462,78 & 193,61 & 331,44 & 193,61 & 10257,98 & 5992,00 & 0,0 & 0,000 & 1,000 & 10257,98 & 5992,00 & 400 & 30 & 5922,45 & 12379,76 \\
\hline 3 & & & & & & & & & & & & & & & & & & & & \\
\hline 4 & & & & & & & & & & & & & & & & & & & & \\
\hline 5 & & & & & & & & & & & & & & & & & & & & \\
\hline 6 & & & & & & & & & & & 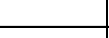 & & & & & & & & 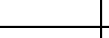 & \\
\hline 7 & & & & & & & & & & 10257.98 & 599200 & & & & $5 \mathrm{Ti}$ & 5992.00 & & $\Sigma$ & 5922.45 & 12379.76 \\
\hline
\end{tabular}

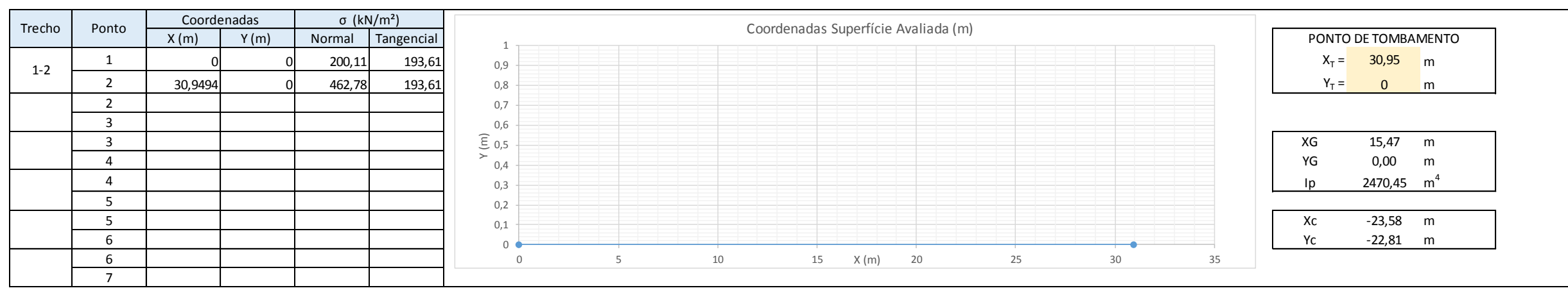

\begin{tabular}{|c|c|c|c|c|c|c|c|c|c|c|c|c|c|c|c|}
\hline \multicolumn{16}{|c|}{ PCH Mata Velha - Barragem Margem Direita - Contato Concreto/Rocha } \\
\hline \multirow{3}{*}{ ESFORÇOS } & \multirow{3}{*}{$\begin{array}{l}\text { Dire- } \\
\text { ção }\end{array}$} & \multirow{3}{*}{$\begin{array}{l}\text { VOLUME } \\
\left(\mathrm{m}^{3}\right)\end{array}$} & \multirow{3}{*}{$\begin{array}{c}\text { CCN - DREN } \\
\text { Peso Específico } \\
\left(\mathrm{kN} / \mathrm{m}^{3}\right)\end{array}$} & \multirow{3}{*}{\multicolumn{2}{|c|}{$\begin{array}{l}\text { FORÇA } \\
(\mathrm{kN})\end{array}$}} & \multirow{2}{*}{\multicolumn{2}{|c|}{ Coordenada (m) }} & \multirow{2}{*}{\multicolumn{8}{|c|}{ EM RELAÇÃO AO PONTO DE TOMBAMENTO }} \\
\hline & & & & & & & & \multicolumn{2}{|c|}{ Excentricidade } & \multirow{2}{*}{\multicolumn{3}{|c|}{ Estabilizador ou Tombador }} & \multirow{3}{*}{$\begin{array}{c}\text { Correç̃ão } \\
1\end{array}$} & \multirow{2}{*}{\multicolumn{2}{|c|}{$\frac{\text { MOMENTO }}{(\mathrm{kN} \mathrm{m})}$}} \\
\hline & & & & & & \multirow{2}{*}{$\begin{array}{c}x \\
11,0515\end{array}$} & \multirow[t]{2}{*}{ Y } & $x_{T}-x$ & $Y_{T}-Y$ & & & & & & \\
\hline Peso de Concreto - CCV & $\mathrm{V}$ & 595,6836 & 24,0 & $F_{1}=$ & $14.296,41$ & & & 19,90 & 0,00 & $\mathrm{E}$ & 0 & E & & $M_{1}=$ & $284.468,46$ \\
\hline Empuxo de Água a Montante & $\gg$ & 611,2270 & 10,0 & $\mathrm{~F}_{2}=$ & $6.112,27$ & & 11,6555 & 0,00 & $-11,66$ & 0 & $\mathrm{~T}$ & $\bar{T}$ & -1 & $\mathrm{M}_{2}=$ & $-71.241,56$ \\
\hline Subpressão & $\Lambda$ & 463,5103 & 10,0 & $\mathrm{~F}_{3}=$ & $4.635,10$ & 11,3713 & & 19,58 & 0,00 & $\mathrm{~T}$ & 0 & $\mathrm{~T}$ & -1 & $M_{3}=$ & $-90.746,51$ \\
\hline Peso de água a Montante & $\mathrm{V}$ & 49,9889 & 10,0 & $F_{4}=$ & \begin{tabular}{rl|}
499,89 \\
\end{tabular} & 0,9996 & & 29,95 & 0,00 & $\mathrm{E}$ & 0 & $\mathrm{E}$ & 1 & $M_{4}=$ & $14.971,58$ \\
\hline Peso de Água a Jusante & $\mathrm{V}$ & 9,6788 & 10,0 & $F_{5}=$ & 96,79 & 29,6658 & & 1,28 & 0,00 & $\mathrm{E}$ & 0 & $\bar{E}$ & 1 & $M_{5}=$ & 124,24 \\
\hline \multirow[t]{7}{*}{ Empuxo de Água a Jusante } & $\ll$ & 12,0268 & 10,0 & $F_{6}=$ & 120,27 & & 1,6350 & 0,00 & $-1,64$ & 0 & $\mathrm{E}$ & $\mathrm{E}$ & 1 & $M_{6}=$ & 196,64 \\
\hline & & & & $F_{7}=$ & 0,00 & & & 0,00 & 0,00 & & & & & $M_{7}=$ & \\
\hline & & & & $F_{8}=$ & 0,00 & & & & & & & & & $M_{8}=$ & \\
\hline & & & & $F_{9}=$ & 0,00 & & & & & & & & & $M_{9}=$ & \\
\hline & & & & $F_{10}=$ & 0,00 & & & & & & & & & $\mathrm{M}_{10}=$ & \\
\hline & & & & $\mathrm{F}_{11}=$ & 0,00 & & & & & & & & & $M_{11}=$ & \\
\hline & & & & & 0,00 & & & & & & & & & & \\
\hline
\end{tabular}

\begin{tabular}{|c|c|c|c|c|c|c|c|c|}
\hline \multirow{3}{*}{ ESFORÇOS } & \multicolumn{8}{|c|}{ EM RELAÇÃO AO CG DA FUNDAÇÃO } \\
\hline & \multicolumn{2}{|c|}{ Excentricidade } & \multirow{2}{*}{\multicolumn{3}{|c|}{ Estabilizador ou Tombador }} & \multirow{3}{*}{$\begin{array}{c}\text { Correç̃o } \\
1\end{array}$} & \multirow{2}{*}{\multicolumn{2}{|c|}{$\begin{array}{c}\text { MOMENTO } \\
(\mathrm{kN} . \mathrm{m})\end{array}$}} \\
\hline & \multirow{2}{*}{$\frac{x_{G}-x}{4,42}$} & \multirow{2}{*}{$\frac{Y_{G}-Y}{0,00}$} & & & & & & \\
\hline Peso de Concreto - CCV & & & $\mathrm{E}$ & 0 & E & & $M_{1}=$ & $63.235,86$ \\
\hline Empuxo de Água a Montante & 0,00 & $-11,66$ & 0 & $\mathrm{~T}$ & $\mathrm{~T}$ & -1 & $M_{2}=$ & $-71.241,56$ \\
\hline Subpressão & 4,10 & 0,00 & $T$ & 0 & $\mathrm{~T}$ & -1 & $M_{3}=$ & $-19.019,68$ \\
\hline Peso de água a Montante & 14,48 & 0,00 & $\mathrm{E}$ & 0 & $\mathrm{E}$ & 1 & $M_{4}=$ & $7.235,94$ \\
\hline Peso de Água a Jusante & $-14,19$ & 0,00 & $T$ & 0 & T & -1 & $M_{5}=$ & $-1.373,53$ \\
\hline Empuxo de Água a Jusante & 0,00 & $-1,64$ & 0 & $E$ & $E$ & 1 & $M_{6}=$ & 196,64 \\
\hline & & & & & & & $\mathrm{M}_{7}=$ & \\
\hline & & & & & & & $M_{8}=$ & \\
\hline & & & & & & & $M_{g}=$ & \\
\hline & & & & & & & $M_{10}=$ & \\
\hline & & & & & & & $M_{11}=$ & \\
\hline & & & & & & & & \\
\hline
\end{tabular}

\begin{tabular}{|c|c|c|c|c|c|c|c|c|}
\hline \multirow{2}{*}{$\Sigma V=$} & $14893,0834 \mathrm{kN}$ & & & \multicolumn{5}{|c|}{ FLUTUAÇÃO - CSF } \\
\hline & $4635,103 \mathrm{kN}$ & $\sum \mathrm{M}_{\mathrm{T}}=$ & $161.988,07 \mathrm{kN} . \mathrm{m}$ & $\frac{\Sigma V}{\Sigma U}=$ & 3,21 & $>$ & 1,3 & ок \\
\hline$\Sigma V-\Sigma U=$ & $10257,9804 \mathrm{kN}$ & Momento Resultante & $137.772,84 \mathrm{kN} \cdot \mathrm{m}$ & \multicolumn{5}{|c|}{ TOMBAMENTO - CST } \\
\hline$\sum \mathrm{T}_{\mathrm{i}, \text { MONTANTE }}=$ & $6112,27 \mathrm{kN}$ & & & $\frac{\sum M_{E}}{\sum M_{T}}=$ & 1,85 & $>$ & 1,5 & ок \\
\hline$\sum \mathrm{T}_{\mathrm{i}, \text { JUSANTE }}=$ & $120,268 \mathrm{kN}$ & & & \multicolumn{5}{|c|}{ DESLIZAMENTO - CSD $\phi$ e CSD $_{\mathrm{c}}$} \\
\hline Força Resultante & $11879,83 \mathrm{kN}$ & & & 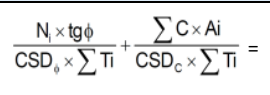 & 1,35 & $>$ & 1,0 & ок \\
\hline
\end{tabular}




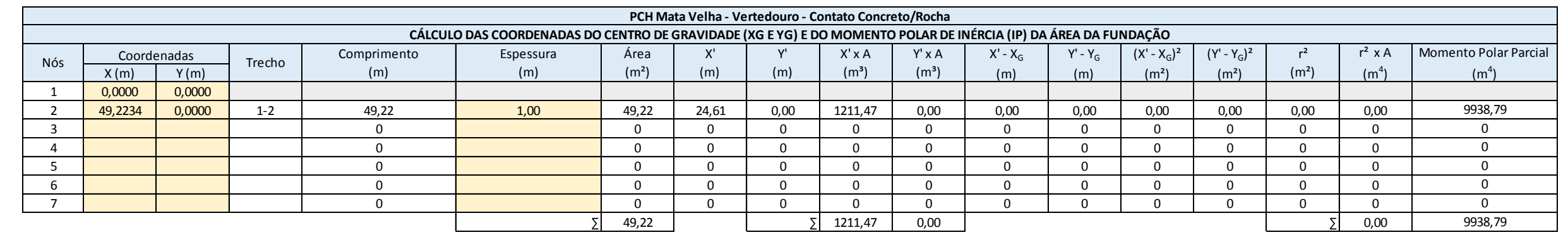

\begin{tabular}{|c|c|c|c|c|c|c|c|c|c|c|c|c|c|c|c|c|c|c|c|c|}
\hline \multirow[b]{2}{*}{ Nós } & \multicolumn{2}{|c|}{ Coordenadas } & \multirow[b]{2}{*}{ Trecho } & \multicolumn{2}{|c|}{ Distância C (m) } & \multicolumn{2}{|c|}{$\sigma\left(\mathrm{kN} / \mathrm{m}^{2}\right)$} & \multicolumn{2}{|c|}{$\sigma$ Média $\left(\mathrm{kN} / \mathrm{m}^{2}\right)$} & \multicolumn{2}{|c|}{ Forca $(\mathrm{kN})$} & \multirow{2}{*}{$\begin{array}{l}\begin{array}{l}\text { Anngulo cl } \\
\text { Horizontal }\end{array} \\
\end{array}$} & \multirow[b]{2}{*}{ Sen } & \multirow{2}{*}{$\cos$} & \multicolumn{2}{|c|}{ Força corrigida (kN) } & \multirow{2}{*}{$\begin{array}{l}\text { Coesãa } \\
\left(\mathrm{kN} / \mathrm{m}^{2}\right)\end{array}$} & \multirow{2}{*}{$\frac{\phi}{\left({ }^{\circ}\right)}$} & \multirow{2}{*}{$\frac{N \times \operatorname{tg} \phi}{(k N)}$} & \multirow{2}{*}{$\begin{array}{l}\mathrm{C} \times \mathrm{A} \\
(\mathrm{kN})\end{array}$} \\
\hline & $x(m)$ & $Y(m)$ & & Horizontal & Vertical & Vertical & Horizontal & Vertical & Horizontal & Vertical & Horizontal & & & & \begin{tabular}{|l|l|} 
Normal \\
\end{tabular} & Cisalhante & & & & \\
\hline 1 & 0,00 & 0,00 & & 109,31 & $-28,13$ & 469,72 & $\begin{array}{ll}120,88 \\
\end{array}$ & & & & & & & & & & & & & \\
\hline 2 & 49,22 & 0,00 & $1-2$ & 60,08 & $-28,13$ & 258,20 & 120,88 & 363,96 & 120,88 & 17915,32 & 5949,94 & 0,0 & 0,000 & 1,000 & 17915,32 & 5949,94 & 400 & 30 & 10343,42 & 19689,36 \\
\hline 3 & & & & & & & & & & & & & & & & & & & & \\
\hline 4 & & & & & & & & & & & & & & & & & & & & \\
\hline 5 & & & & & & & & & & & & & & & & & & & & \\
\hline 6 & & & & & & & & & & & & & & & & & & & & \\
\hline 7 & & & & & & & & & & & & & & & & & & & & \\
\hline & & & & & & & & & $\bar{\Sigma}$ & 17915,32 & 5949,94 & & & & $\sum \mathrm{TT}_{\mathrm{i}}$ & 5949,94 & & & 10343,42 & 19689,36 \\
\hline
\end{tabular}

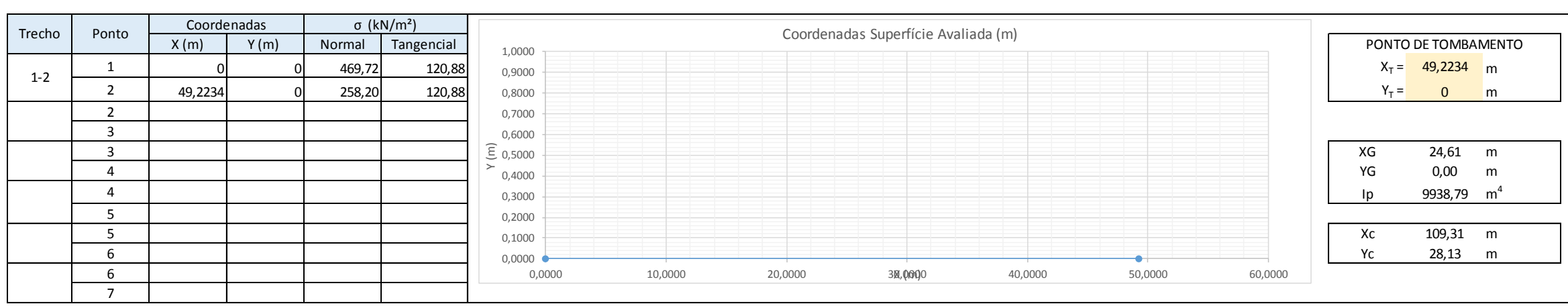

\begin{tabular}{|c|c|c|c|c|c|c|c|c|c|c|c|c|c|c|c|}
\hline \multicolumn{16}{|c|}{$\begin{array}{c}\text { PCH Mata Velha - Vertedouro - Contato Concreto/Rocha } \\
\text { CCN- DRENOS INOPERANTES- N A N }\end{array}$} \\
\hline \multirow[b]{3}{*}{ ESFORÇOS } & & & CCN - DRENO & PERAN T & N.A. NORMA & ALAMONT & VTE (EL. 63 & Im) EA & TE (EL. 6 & & & & & & \\
\hline & \multirow{2}{*}{$\begin{array}{l}\text { Dire- } \\
\text { ção }\end{array}$} & \multirow{2}{*}{$\begin{array}{c}\text { VOLUME } \\
\left(\mathrm{m}^{3}\right)\end{array}$} & \multirow{2}{*}{$\begin{array}{l}\text { Peso Especifico } \\
\qquad\left(\mathrm{kN} / \mathrm{m}^{3}\right)\end{array}$} & \multirow{2}{*}{\multicolumn{2}{|c|}{$\begin{array}{l}\text { FORCNA } \\
(\mathrm{kN})\end{array}$}} & \multirow{2}{*}{\multicolumn{2}{|c|}{ Coordenada $(\mathrm{m})$}} & \multicolumn{8}{|c|}{ EM RELAÇÃO AO PONTO DE TOMBAMENTO } \\
\hline & & & & & & & \multirow{2}{*}{$\mathrm{Y}$} & \multicolumn{2}{|c|}{ Excentricidade } & \multicolumn{3}{|c|}{ Estabilizador ou Tombador } & \multirow{2}{*}{ Correç̃o } & \multicolumn{2}{|c|}{$\frac{\text { MOMENTO }}{\text { (kN.m) }}$} \\
\hline Peso de Concreto - CCV & $\mathrm{V}$ & 1096,1962 & 24,0 & $\mathrm{~F}_{1}=$ & $26.308,71$ & \begin{tabular}{|c|}
$x$ \\
18,6982
\end{tabular} & & 30,53 & 0,00 & $\mathrm{E}$ & 0 & $\mathrm{E}$ & & $M_{1}=$ & $803.078,60$ \\
\hline Empuxo de Água a Montante & $\gg$ & 606,3385 & 10,0 & $F_{2}=$ & $6.063,39$ & & 11,6080 & 0,00 & $-11,61$ & 0 & $\mathrm{~T}$ & $\mathrm{~T}$ & -1 & $\mathrm{M}_{2}=$ & $-70.383,77$ \\
\hline Subpressão & $\Lambda$ & 974,2989 & 10,0 & $\mathrm{~F}_{3}=$ & $9.742,99$ & 18,3821 & & 30,84 & 0,00 & $T$ & 0 & $T$ & -1 & $M_{3}=$ & $-300.486,45$ \\
\hline Peso de água a Montante & $\mathrm{V}$ & 109,3500 & 10,0 & $\mathrm{~F}_{4}=$ & $1.093,50$ & 3,3750 & & 45,85 & 0,00 & $\mathrm{E}$ & 0 & E & 1 & $M_{4}=$ & $50.135,23$ \\
\hline Peso de Água a Jusante & $\mathrm{V}$ & 25,6105 & 10,0 & $F_{5}=$ & 256,11 & 44,8789 & & 4,34 & 0,00 & $\mathrm{E}$ & 0 & $\mathrm{E}$ & 1 & $M_{5}=$ & $1.112,65$ \\
\hline \multirow[t]{7}{*}{ Empuxo de Água a Jusante } & $\ll$ & 11,3450 & 10,0 & $F_{6}=$ & 113,45 & & 1,5878 & 0,00 & $-1,59$ & 0 & $E$ & $\mathrm{E}$ & 1 & $M_{6}=$ & 180,14 \\
\hline & & & & $F_{7}=$ & 0,00 & & & 0,00 & 0,00 & & & & & $\mathrm{M}_{7}=$ & \\
\hline & & & & $F_{8}=$ & 0,00 & & & & & & & & & $\mathrm{M}_{8}=$ & \\
\hline & & & & $F_{9}=$ & 0,00 & & & & & & & & & $M_{9}=$ & \\
\hline & & & & $F_{10}=$ & 0,00 & & & & & & & & & $\mathrm{M}_{10}=$ & \\
\hline & & & & $F_{11}=$ & 0,00 & & & & & & & & & $\mathrm{M}_{11}=$ & \\
\hline & & & & & 0,00 & & & & & & & & & & \\
\hline
\end{tabular}

\begin{tabular}{|c|c|c|c|c|c|c|c|c|}
\hline \multirow{3}{*}{ ESFORÇOS } & \multicolumn{8}{|c|}{ EM RELAÇÃO AO CG DA FUNDAÇÃO } \\
\hline & \multicolumn{2}{|c|}{ Excentricidade } & \multirow{2}{*}{\multicolumn{3}{|c|}{ Estabilizador ou Tombador }} & \multirow{3}{*}{$\begin{array}{c}\text { Correção } \\
1\end{array}$} & \multirow{2}{*}{\multicolumn{2}{|c|}{$\frac{\text { MOMENTO }}{(\mathrm{kN} . \mathrm{m})}$}} \\
\hline & $x_{G}-x$ & $Y_{G}-Y$ & & & & & & \\
\hline Peso de Concreto - CCV & 5,91 & 0,00 & $\mathrm{E}$ & 0 & E & & $M_{1}=$ & $155.576,55$ \\
\hline Empuxo de Água a Montante & 0,00 & $-11,61$ & 0 & $\mathrm{~T}$ & $T$ & -1 & $M_{2}=$ & $-70.383,77$ \\
\hline Subpressão & 6,23 & 0,00 & $T$ & 0 & $T$ & -1 & $M_{3}=$ & $-60.694,92$ \\
\hline Peso de água a Montante & 21,24 & 0,00 & E & 0 & $\mathrm{E}$ & 1 & $M_{4}=$ & $23.222,33$ \\
\hline Peso de Água a Jusante & $-20,27$ & 0,00 & $T$ & 0 & $T$ & -1 & $M_{5}=$ & $-5.190,53$ \\
\hline \multirow{6}{*}{ Empuxo de Água a Jusante } & 0,00 & $-1,59$ & 0 & $\mathrm{E}$ & $E$ & 1 & $M_{6}=$ & 180,14 \\
\hline & & & & & & & $M_{7}=$ & \\
\hline & & & & & & & $M_{8}=$ & \\
\hline & & & & & & & $M_{9}=$ & \\
\hline & & & & & & & $M_{10}=$ & \\
\hline & & & & & & & $M_{11}=$ & \\
\hline & & & & & & & & \\
\hline
\end{tabular}

\begin{tabular}{|c|c|c|c|c|c|c|c|c|}
\hline \multirow{2}{*}{$\Sigma V=$} & \multirow[b]{2}{*}{$27658,3138 \mathrm{kN}$} & \multirow[b]{2}{*}{$\sum M_{E}=$} & \multirow[b]{2}{*}{$854.506,61 \mathrm{kN} . \mathrm{m}$} & \multicolumn{5}{|c|}{ FLUTUAÇÃO - CSF } \\
\hline & & & & $\Sigma \mathrm{V}$ & \multirow{2}{*}{2,84} & \multirow{2}{*}{$>$} & \multirow{2}{*}{1,3} & \multirow{2}{*}{ ок } \\
\hline$\Sigma U=$ & $9742,989 \mathrm{kN}$ & $\sum M_{T}=$ & $370.870,22 \mathrm{kN} \cdot \mathrm{m}$ & $\sum U$ & & & & \\
\hline$\Sigma V-\Sigma U=$ & $17915,3248 \mathrm{kN}$ & Momento Resultante & $483.636,39 \mathrm{kN} \cdot \mathrm{m}$ & \multicolumn{5}{|c|}{ TOMBAMENTO - CST } \\
\hline$\sum T_{i}$, MontaANE $=$ & $6063,385 \mathrm{kN}$ & & & $\frac{\sum M_{E}}{\sum M_{T}}=$ & 2,30 & $>$ & 1,5 & ок \\
\hline$\sum \mathrm{T}_{\mathrm{i}, \text { UUSANTE }}=$ & $113,45 \mathrm{kN}$ & & & \multicolumn{5}{|c|}{ DESLIZAMENTO - CSD e CSD } \\
\hline Força Resultante & $5949,935 \mathrm{kN}$ & & & $\frac{N_{1} \times \operatorname{tg} \phi}{\mathrm{CSD}_{0} \times \sum \pi}+\frac{\sum \mathrm{C} \times \mathrm{Ai}^{2}}{\mathrm{CSD}_{\mathrm{c}} \times \sum \pi}=$ & 2,26 & $>$ & 1,0 & ок \\
\hline
\end{tabular}




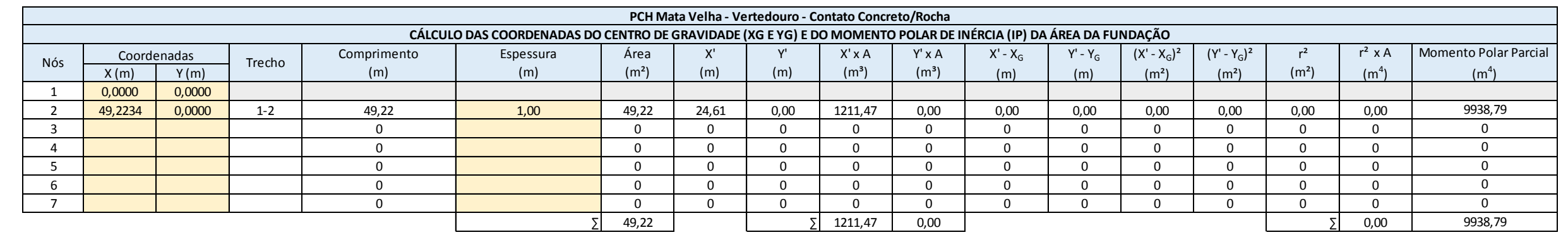

\begin{tabular}{|c|c|c|c|c|c|c|c|c|c|c|c|c|c|c|c|c|c|c|c|c|}
\hline \multirow[b]{2}{*}{ Nós } & \multicolumn{2}{|c|}{ Coordenadas } & \multirow[b]{2}{*}{ Trecho } & \multicolumn{2}{|c|}{ Distância C (m) } & \multicolumn{2}{|c|}{$\sigma\left(\mathrm{kN} / \mathrm{m}^{2}\right)$} & \multicolumn{2}{|c|}{$\sigma$ Média $\left(\mathrm{kN} / \mathrm{m}^{2}\right)$} & \multicolumn{2}{|c|}{ Forca $(\mathrm{kN})$} & \multirow{2}{*}{$\begin{array}{l}\begin{array}{l}\text { Anngulo cl } \\
\text { Horizontal }\end{array} \\
\end{array}$} & \multirow[b]{2}{*}{ Sen } & \multirow{2}{*}{$\cos$} & \multicolumn{2}{|c|}{ Força corrigida (kN) } & \multirow{2}{*}{$\begin{array}{l}\text { Coesão } \\
\left(\mathrm{kN} / \mathrm{m}^{2}\right)\end{array}$} & \multirow{2}{*}{$\frac{\phi}{\left({ }^{\circ}\right)}$} & \multirow{2}{*}{$\frac{N \times \operatorname{tg} \phi}{(k N)}$} & \multirow{2}{*}{$\begin{array}{l}\mathrm{CXA} \\
(\mathrm{kN})\end{array}$} \\
\hline & $x(m)$ & $Y(m)$ & & Horizontal & Vertical & Vertical & Horizontal & Vertical & Horizontal & Vertical & Horizontal & & & & \begin{tabular}{|l|l|} 
Normal \\
\end{tabular} & Cisalhante & & & & \\
\hline 1 & 0,00 & 0,00 & & 100,86 & $-22,44$ & 543,32 & $\begin{array}{ll}120,88 \\
\end{array}$ & & & & & & & & & & & & & \\
\hline 2 & 49,22 & 0,00 & $1-2$ & 51,63 & $-22,44$ & 278,15 & 120,88 & 410,73 & 120,88 & 20217,77 & 5949,94 & 0,0 & 0,000 & 1,000 & 20217,77 & 5949,94 & 400 & 30 & 11672,73 & 19689,36 \\
\hline 3 & & & & & & & & & & & & & & & & & & & & \\
\hline 4 & & & & & & & & & & & & & & & & & & & & \\
\hline 5 & & & & & & & & & & & & & & & & & & & & \\
\hline 6 & & & & & & & & & & & & & & & & & & & & \\
\hline 7 & & & & & & & & & & & & & & & & & & & & \\
\hline & & & & & & & & & $\bar{\Sigma}$ & 20217,77 & 5949,94 & & & & $\sum \mathrm{TT}_{\mathrm{i}}$ & 5949,94 & & & 11672,73 & 19689,36 \\
\hline
\end{tabular}

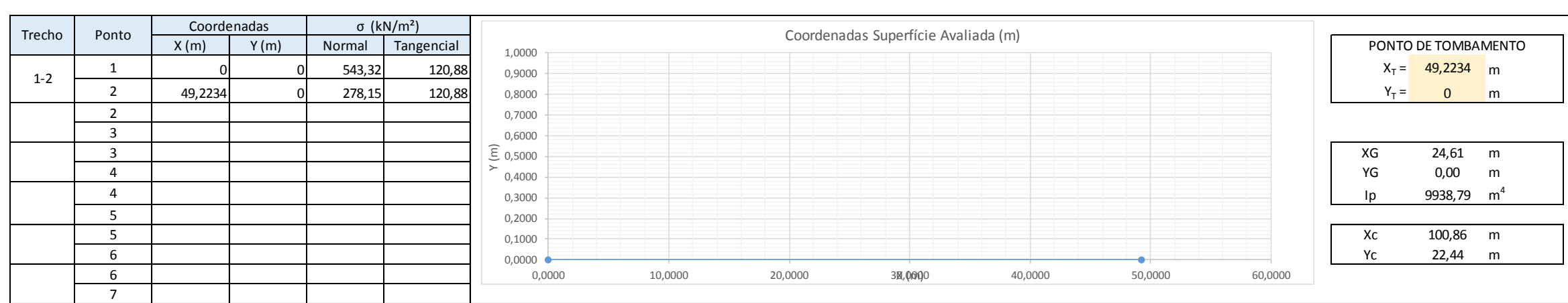

\begin{tabular}{|c|c|c|c|c|c|c|c|c|c|c|c|c|c|c|c|}
\hline \multicolumn{16}{|c|}{$\begin{array}{c}\text { PCH Mata Velha - Vertedouro - Contato Concreto/Rocha } \\
\text { CCN- DRENOS INOPERANTES- N A N }\end{array}$} \\
\hline \multirow[b]{3}{*}{ ESFORÇOS } & & & CCN - DRENO & PERAN T & N.A. NORMA & ALAMONT & VTE (EL. 63 & Im) EA & TE (EL. 6 & & & & & & \\
\hline & \multirow{2}{*}{$\begin{array}{l}\text { Dire- } \\
\text { ção }\end{array}$} & \multirow{2}{*}{$\begin{array}{c}\text { VOLUME } \\
\left(\mathrm{m}^{3}\right)\end{array}$} & \multirow{2}{*}{$\begin{array}{l}\text { Peso Específico } \\
\qquad\left(\mathrm{kN} / \mathrm{m}^{3}\right)\end{array}$} & \multirow{2}{*}{\multicolumn{2}{|c|}{$\begin{array}{l}\text { FORCNA } \\
(\mathrm{kN})\end{array}$}} & \multirow{2}{*}{\multicolumn{2}{|c|}{ Coordenada $(\mathrm{m})$}} & \multicolumn{8}{|c|}{ EM RELAÇÃO AO PONTO DE TOMBAMENTO } \\
\hline & & & & & & & \multirow{2}{*}{$\mathrm{Y}$} & \multicolumn{2}{|c|}{ Excentricidade } & \multicolumn{3}{|c|}{ Estabilizador ou Tombador } & \multirow{2}{*}{ Correção } & \multicolumn{2}{|c|}{$\frac{\text { MOMENTO }}{\text { (kN.m) }}$} \\
\hline Peso de Concreto - CCV & $\mathrm{V}$ & 1096,1962 & 24,0 & $\mathrm{~F}_{1}=$ & $26.308,71$ & \begin{tabular}{|c|}
$x$ \\
18,6982
\end{tabular} & & 30,53 & 0,00 & $\mathrm{E}$ & 0 & $\mathrm{E}$ & & $M_{1}=$ & $803.078,60$ \\
\hline Empuxo de Água a Montante & $\gg$ & 606,3385 & 10,0 & $F_{2}=$ & $6.063,39$ & & 11,6080 & 0,00 & $-11,61$ & 0 & $\mathrm{~T}$ & $\mathrm{~T}$ & -1 & $\mathrm{M}_{2}=$ & $-70.383,77$ \\
\hline Subpressão & $\Lambda$ & 744,0548 & 10,0 & $\mathrm{~F}_{3}=$ & $7.440,55$ & 17,9101 & & 31,31 & 0,00 & $T$ & 0 & $T$ & -1 & $M_{3}=$ & $-232.988,11$ \\
\hline Peso de água a Montante & $\mathrm{V}$ & 109,3500 & 10,0 & $\mathrm{~F}_{4}=$ & $1.093,50$ & 3,3750 & & 45,85 & 0,00 & $\mathrm{E}$ & 0 & E & 1 & $M_{4}=$ & $50.135,23$ \\
\hline Peso de Água a Jusante & $\mathrm{V}$ & 25,6105 & 10,0 & $F_{5}=$ & 256,11 & 44,8789 & & 4,34 & 0,00 & $\mathrm{E}$ & 0 & $\mathrm{E}$ & 1 & $M_{5}=$ & $1.112,65$ \\
\hline \multirow[t]{7}{*}{ Empuxo de Água a Jusante } & $\ll$ & 11,3450 & 10,0 & $F_{6}=$ & 113,45 & & 1,5878 & 0,00 & $-1,59$ & 0 & $E$ & $\mathrm{E}$ & 1 & $M_{6}=$ & 180,14 \\
\hline & & & & $F_{7}=$ & 0,00 & & & 0,00 & 0,00 & & & & & $\mathrm{M}_{7}=$ & \\
\hline & & & & $F_{8}=$ & 0,00 & & & & & & & & & $\mathrm{M}_{8}=$ & \\
\hline & & & & $F_{9}=$ & 0,00 & & & & & & & & & $M_{9}=$ & \\
\hline & & & & $F_{10}=$ & 0,00 & & & & & & & & & $\mathrm{M}_{10}=$ & \\
\hline & & & & $F_{11}=$ & 0,00 & & & & & & & & & $\mathrm{M}_{11}=$ & \\
\hline & & & & & 0,00 & & & & & & & & & & \\
\hline
\end{tabular}

\begin{tabular}{|c|c|c|c|c|c|c|c|c|}
\hline \multirow{3}{*}{ ESFORÇOS } & \multicolumn{8}{|c|}{ EM RELAÇÃO AO CG DA FUNDAÇÃO } \\
\hline & \multicolumn{2}{|c|}{ Excentricidade } & \multirow{2}{*}{\multicolumn{3}{|c|}{ Estabilizador ou Tombador }} & \multirow{2}{*}{ Correção } & \multirow{2}{*}{\multicolumn{2}{|c|}{ MOMENTO }} \\
\hline & & \multirow{2}{*}{$\begin{array}{l}Y_{G}-Y \\
0,00\end{array}$} & & & & & & \\
\hline Peso de Concreto - CCV & & & $\mathrm{E}$ & 0 & $\mathrm{E}$ & 1 & $M_{1}=$ & $155.576,55$ \\
\hline Empuxo de Água a Montante & 0,00 & $-11,61$ & 0 & $\bar{T}$ & $T$ & -1 & $\mathrm{M}_{2}=$ & $-70.383,77$ \\
\hline Subpressão & 6,70 & 0,00 & $\mathrm{~T}$ & 0 & $T$ & -1 & $M_{3}=$ & $-49.863,58$ \\
\hline Peso de água a Montante & 21,24 & 0,00 & E & 0 & $\mathrm{E}$ & 1 & $\mathrm{M}_{4}=$ & $23.222,33$ \\
\hline Peso de Água a Jusante & $-20,27$ & 0,00 & $T$ & 0 & $\mathrm{~T}$ & -1 & $\mathrm{M}_{\mathrm{s}}=$ & $-5.190,53$ \\
\hline \multirow[t]{7}{*}{ Empuxo de Água a Jusante } & 0,00 & $-1,59$ & 0 & $E$ & $\mathrm{E}$ & 1 & $M_{6}=$ & 180,14 \\
\hline & & & & & & & $\mathrm{M}_{7}=$ & \\
\hline & & & & & & & $M_{8}=$ & \\
\hline & & & & & & & $\mathrm{M}_{9}=$ & \\
\hline & & & & & & & $\mathrm{M}_{10}=$ & \\
\hline & & & & & & & $\mathrm{M}_{11}=$ & \\
\hline & & & & & & & & \\
\hline
\end{tabular}

\begin{tabular}{|c|c|c|c|c|c|c|c|c|}
\hline \multirow{2}{*}{$\Sigma V=$} & \multirow{2}{*}{$27658,3138 \mathrm{kN}$} & \multirow{2}{*}{$\sum M_{E}=$} & \multirow{2}{*}{ 854.506,61 kN.m } & \multicolumn{5}{|c|}{ FLUTUAÇÃO - CSF } \\
\hline & & & & $\Sigma \mathrm{V}$ & \multirow{2}{*}{3,72} & \multirow{2}{*}{$>$} & \multirow{2}{*}{1,3} & \multirow{2}{*}{ ок } \\
\hline$\Sigma U=$ & $7440,548 \mathrm{kN}$ & $\sum M_{T}=$ & $303.371,88 \mathrm{kN} . \mathrm{m}$ & $\sum U$ & & & & \\
\hline$\Sigma V-\Sigma U=$ & $20217,7658 \mathrm{kN}$ & Momento Resultante & $551.134,72 \mathrm{kN} \cdot \mathrm{m}$ & \multicolumn{5}{|c|}{ TOMBAMENTO - CST } \\
\hline$\sum T_{i}$, MontaANE $=$ & $6063,385 \mathrm{kN}$ & & & $\frac{\sum M_{E}}{\sum M_{T}}=$ & 2,82 & $>$ & 1,5 & ок \\
\hline$\sum \mathrm{T}_{\mathrm{i}, \text { JUSANTE }}=$ & $113,45 \mathrm{kN}$ & & & \multicolumn{5}{|c|}{ DESLIZAMENTO - CSD e CSD } \\
\hline Força Resultante & $5949,935 \mathrm{kN}$ & & & $\frac{N_{1} \times \operatorname{tg} \phi}{\operatorname{CSD}_{b} \times \sum \pi}+\frac{\sum \mathrm{C}_{0} \times \mathrm{Ai}^{2}}{\operatorname{CSD}_{\mathrm{c}} \times \sum \pi^{\pi}}=$ & 2,41 & $>$ & 1,0 & ок \\
\hline
\end{tabular}




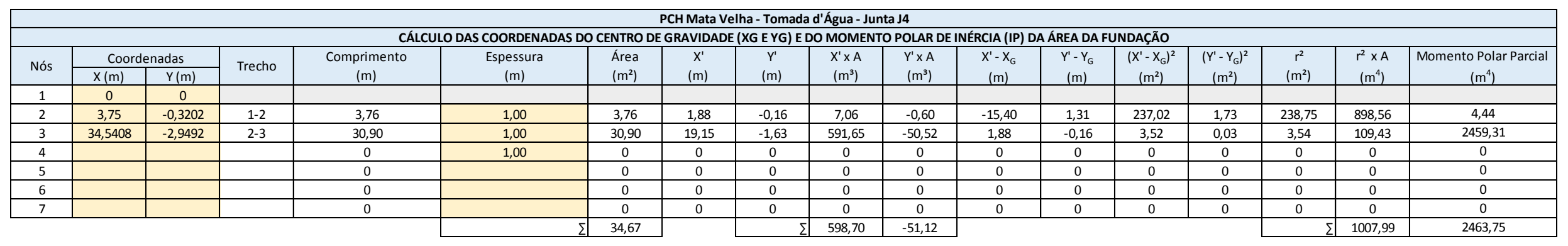

\begin{tabular}{|c|c|c|c|c|c|c|c|c|c|c|c|c|c|c|c|c|c|c|c|c|}
\hline \multirow{2}{*}{ Nós } & \multicolumn{2}{|c|}{ Coordenadas } & \multirow{2}{*}{ Trecho } & \multicolumn{2}{|c|}{ Distância C (m) } & \multicolumn{2}{|c|}{$\sigma\left(\mathrm{kN} / \mathrm{m}^{2}\right)$} & \multicolumn{2}{|c|}{$\sigma$ Média $\left(\mathrm{kN} / \mathrm{m}^{2}\right)$} & \multicolumn{2}{|c|}{ Força $(\mathrm{kN})$} & \multirow{2}{*}{$\begin{array}{l}\text { Ângulo c/ } \\
\text { Horizontal }\end{array}$} & \multirow{2}{*}{ Sen } & \multirow{2}{*}{$\cos$} & \multicolumn{2}{|c|}{ Força corrigida (kN) } & \multirow{2}{*}{$\begin{array}{l}\text { Coesão } \\
\left(\mathrm{kN} / \mathrm{m}^{2}\right)\end{array}$} & \multirow{2}{*}{$\begin{array}{l}\phi \\
\left({ }^{\circ}\right)\end{array}$} & \multirow{2}{*}{$\begin{array}{c}\frac{N \times \operatorname{tg} \phi}{(\mathrm{kN})} \\
\end{array}$} & \multirow{2}{*}{$\begin{array}{l}\mathrm{CXA} \\
(\mathrm{kN}) \\
\end{array}$} \\
\hline & $x(m)$ & $Y(m)$ & & Horizontal & Vertical & Vertical & Horizontal & Vertical & Horizontal & Vertical & \begin{tabular}{|l|} 
Horizontal \\
\end{tabular} & & & & Normal & Cisalhante & & & & \\
\hline 1 & 0,00 & 0,00 & & $-5,34$ & 14,95 & 65 & 182,12 & & & & & & & & & & & & & \\
\hline 2 & 3,75 & $-0,32$ & $1-2$ & $-9,09$ & 14,63 & 110,73 & 178,22 & 87,89 & 180,17 & 330,79 & 678,08 & 4,9 & 0,085 & 0,996 & 271,90 & 703,76 & 195 & 35 & 190,38 & 733,91 \\
\hline 3 & 34,54 & $-2,95$ & $2-3$ & $-39,88$ & 12,00 & 485,84 & 146,19 & 298,29 & 162,20 & 9217,95 & 5012,48 & 4,9 & 0,085 & 0,996 & 8758,11 & 5778,51 & 195 & 35 & 6132,49 & 6026,05 \\
\hline 4 & & & & & & & & & & & & & & & & & & & & \\
\hline 5 & & & & & & & & & & & & & & & & & & & & \\
\hline 6 & & & & & & & & & & & & & & & & & & & & \\
\hline 7 & & & & & & & & & & & & & & & & & & & & \\
\hline & & & & & & & & & & 9548,74 & 5690,57 & & & & $\sum \mathrm{ET}_{1}$ & 6482,28 & & $\Sigma$ & 6322,88 & 6759,96 \\
\hline
\end{tabular}

\begin{tabular}{|c|c|c|c|c|c|}
\hline \multirow{2}{*}{ Trecho } & \multirow{2}{*}{ Ponto } & \multicolumn{2}{|c|}{ Coordenadas } & \multicolumn{2}{|c|}{$\sigma\left(\mathrm{kN} / \mathrm{m}^{2}\right)$} \\
\hline & & $x(m)$ & $Y(m)$ & Normal & Tangencial \\
\hline \multirow{2}{*}{$1-2$} & 1 & 0 & 0 & 49,32 & \begin{tabular}{|l|}
186,99 \\
\end{tabular} \\
\hline & 2 & 3,75 & $-0,3202$ & 95,17 & 186,99 \\
\hline \multirow{10}{*}{$2-3$} & 2 & 3,75 & $-0,3202$ & 95,17 & 186,99 \\
\hline & 3 & 34,5408 & $-2,9492$ & 471,65 & 186,99 \\
\hline & 3 & & & & \\
\hline & 4 & & & & \\
\hline & 4 & & & & \\
\hline & 5 & & & & \\
\hline & 5 & & & & \\
\hline & 6 & & & & \\
\hline & 6 & & & & \\
\hline & 7 & & & & \\
\hline
\end{tabular}

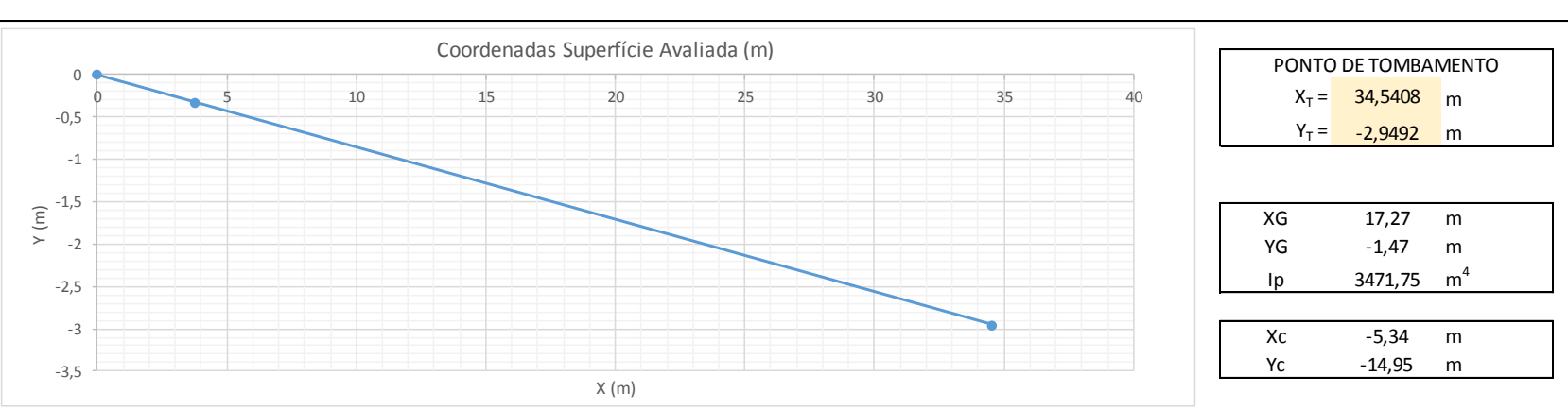

\begin{tabular}{|c|c|c|c|c|c|c|c|c|c|c|c|c|c|c|c|}
\hline \multirow{2}{*}{\multicolumn{16}{|c|}{$\begin{array}{l}\text { PCH Mata Velha - Tomada d'Água - Junta J4 } \\
\text { CCN - SEM DRENOS - N.A. NORMAL A MONTANTE (EL. 632,00m) E A JUSANTE (EL. 601,94m) }\end{array}$}} \\
\hline \multirow{3}{*}{ ESFORÇOS } & & & & & & \multirow{2}{*}{\multicolumn{2}{|c|}{ Coordenada $(\mathrm{m})$}} & \multirow{2}{*}{\multicolumn{8}{|c|}{ EM RELAÇÃO AO PONTO DE TOMBAMENTO }} \\
\hline & \multirow{2}{*}{$\begin{array}{l}\text { Dire- } \\
\text { ção }\end{array}$} & \multirow{2}{*}{$\begin{array}{l}\text { VOLUME } \\
\left(\mathrm{m}^{3}\right)\end{array}$} & \multirow{2}{*}{$\begin{array}{l}\text { Peso Especifico } \\
\left(\mathrm{kN} / \mathrm{m}^{3}\right)\end{array}$} & \multirow{2}{*}{\multicolumn{2}{|c|}{$\begin{array}{l}\text { FORÇA } \\
(\mathrm{kN})\end{array}$}} & & & & & & & & & & \\
\hline & & & & & & \multirow{2}{*}{$\begin{array}{c}x \\
6,7514 \\
\end{array}$} & \multirow[t]{2}{*}{$\mathrm{Y}$} & $x_{T}-x$ & $Y_{T}-Y$ & \multicolumn{3}{|c|}{ Estabilizador ou Tombador } & Correção & \multicolumn{2}{|c|}{$\frac{\text { MOMENTO }}{(\mathrm{kN} . \mathrm{m})}$} \\
\hline Peso de Concreto - CCV & V & 180,6800 & 24,0 & $F_{1}=$ & $4.336,32$ & & & 27,79 & 0,00 & E & 0 & E & 1 & $M_{1}=$ & $120.503,73$ \\
\hline Peso de Rocha & $\mathrm{V}$ & 470,0495 & 25,0 & $F_{2}=$ & $11.751,24$ & 16,9200 & & 17,62 & 0,00 & $\mathrm{E}$ & 0 & $\mathrm{E}$ & 1 & $M_{2}=$ & $207.066,21$ \\
\hline Empuxo de Água a Montante & $\gg$ & 583,5033 & 10,0 & $F_{3}=$ & $5.835,03$ & & 9,6852 & 0,00 & $-12,63$ & 0 & $T$ & $T$ & -1 & $M_{3}=$ & $-73.722,14$ \\
\hline Empuxo de Água Jusante & $\ll$ & 14,4468 & 10,0 & $F_{4}=$ & 144,47 & & $-1,1574$ & 0,00 & $-1,79$ & 0 & $\mathrm{E}$ & $\mathrm{E}$ & 1 & $M_{4}=$ & 258,86 \\
\hline \multirow[t]{8}{*}{ Subpressão } & $\Lambda$ & 653,8818 & 10,0 & $F_{5}=$ & $6.538,82$ & 13,1482 & & 21,39 & 0,00 & $T$ & 0 & $T$ & -1 & $M_{5}=$ & $-139.882,32$ \\
\hline & & & & $F_{6}=$ & 0,00 & & & 0,00 & 0,00 & & & & & $M_{6}=$ & \\
\hline & & & & $F_{7}=$ & 0,00 & & & 0,00 & 0,00 & & & & & $M_{7}=$ & \\
\hline & & & & $F_{8}=$ & 0,00 & & & & & & & & & $\mathrm{M}_{8}=$ & \\
\hline & & & & $F_{g}=$ & 0,00 & & & & & & & & & $M_{g}=$ & \\
\hline & & & & $F_{10}=$ & 0,00 & & & & & & & & & $M_{10}=$ & \\
\hline & & & & $\mathrm{F}_{11}=$ & 0,00 & & & & & & & & & $\mathrm{M}_{11}=$ & \\
\hline & & & & & 0,00 & & & & & & & & & & \\
\hline
\end{tabular}

\begin{tabular}{|c|c|c|c|c|c|c|c|c|}
\hline \multirow{3}{*}{ ESFORÇOS } & \multicolumn{8}{|c|}{ EM RELAÇÃO AO CG DA FUNDAÇÃO } \\
\hline & \multicolumn{2}{|c|}{ Excentricidade } & \multirow{2}{*}{\multicolumn{3}{|c|}{ Estabilizador ou Tombador }} & \multirow{3}{*}{$\begin{array}{c}\text { Correção } \\
1\end{array}$} & \multirow{2}{*}{\multicolumn{2}{|c|}{$\begin{array}{l}\text { MOMENTO } \\
(\mathrm{kN.m})\end{array}$}} \\
\hline & $x_{G}-x$ & $Y_{G}-Y$ & & & & & & \\
\hline Peso de Concreto - CCV & 10,52 & 0,00 & $\mathrm{E}$ & 0 & $\mathrm{E}$ & & $M_{1}=$ & $45.613,75$ \\
\hline Peso de Rocha & 0,35 & 0,00 & $\mathrm{E}$ & 0 & $\mathrm{E}$ & 1 & $M_{2}=$ & $4.117,63$ \\
\hline Empuxo de Água a Montante & 0,00 & $-11,16$ & 0 & $T$ & $T$ & -1 & $M_{3}=$ & $-65.117,84$ \\
\hline Empuxo de Água Jusante & 0,00 & $-0,32$ & 0 & $\mathrm{E}$ & $\mathrm{E}$ & 1 & $M_{4}=$ & 45,83 \\
\hline \multirow{8}{*}{ Subpressão } & 4,12 & 0,00 & $T$ & 0 & $T$ & -1 & $M_{5}=$ & $-26.954,31$ \\
\hline & & & & & & & $M_{6}=$ & \\
\hline & & & & & & & $\mathrm{M}_{7}=$ & \\
\hline & & & & & & & $M_{8}=$ & \\
\hline & & & & & & & $M_{g}=$ & \\
\hline & & & & & & & $M_{10}=$ & \\
\hline & & & & & & & $M_{11}=$ & \\
\hline & & & & & & & & \\
\hline
\end{tabular}

\begin{tabular}{|c|c|c|c|c|c|c|c|c|}
\hline \multirow[b]{2}{*}{$\Sigma V=$} & \multirow{2}{*}{$16087,5575 \mathrm{kN}$} & & & \multicolumn{5}{|c|}{ FLUTUAÇÃ̃ - CSF } \\
\hline & & $\sum \mathrm{M}_{\mathrm{T}}=$ & $213.604,46 \mathrm{kN} . \mathrm{m}$ & $\frac{\Sigma V}{\sum U}=$ & 2,46 & $>$ & 1,3 & ок \\
\hline$\Sigma V-\Sigma U=$ & $9548,7395 \mathrm{kN}$ & Momento Resultante & $114.224,34 \mathrm{kN} . \mathrm{m}$ & \multicolumn{5}{|c|}{ TOMBAMENTO - CST } \\
\hline$\sum \mathrm{T}_{\mathrm{i}, \text { MONTANIE }}=$ & $\begin{array}{l}5835,033 \mathrm{kN} \\
144,468 \mathrm{kN}\end{array}$ & & & $\frac{\sum M_{E}}{\sum M_{T}}=$ & 1,53 & $>$ & 1,5 & ок \\
\hline$\sum \mathrm{T}_{\mathrm{i}, \text { JUAANTE }}=$ & & & & \multicolumn{5}{|c|}{ DESLIZAMENTO - CSD $\phi$ e $\operatorname{CSD}_{\mathrm{c}}$} \\
\hline Força Resultante & $11115,80 \mathrm{kN}$ & & & $\frac{N_{N} \times \operatorname{tg} \phi}{\operatorname{CSD}_{b} \times \sum \pi}+\frac{\sum C_{0} \times A i}{\operatorname{CSD}_{c} \times \sum \pi}=$ & 1,00 & $>$ & 1,0 & ок \\
\hline
\end{tabular}

Fonte: Do autor (2021). 


\begin{tabular}{|c|c|c|c|c|c|c|c|c|c|c|c|c|c|c|c|c|c|}
\hline \multicolumn{18}{|c|}{ PCH Mata Velha - Tomada d'Água - Junta J5 } \\
\hline & & & \multirow[b]{2}{*}{ Trecho } & & \multirow[b]{2}{*}{$\begin{array}{l}\text { Espessura } \\
(\mathrm{m})\end{array}$} & \multirow{2}{*}{$\begin{array}{l}\text { Área } \\
\left(\mathrm{m}^{2}\right)\end{array}$} & \multirow{2}{*}{$\begin{array}{l}x^{\prime} \\
(m)\end{array}$} & \multirow{2}{*}{$\begin{array}{l}\left.\mathrm{y}^{\prime} \mathrm{EY}\right) \mathrm{t} \\
(\mathrm{m})\end{array}$} & \multirow{2}{*}{$\begin{array}{l}\text { MOMEN } \\
\mathrm{X}^{\prime} \times A \\
\left(\mathrm{~m}^{3}\right)\end{array}$} & \multirow{2}{*}{$\begin{array}{l}\text { OLAADE } \\
Y^{\prime} \times A \\
\left(m^{3}\right)\end{array}$} & \multirow{2}{*}{$\begin{array}{l}\frac{R^{R C A}\left(I^{\prime}\right)}{X^{\prime}-X_{G}} \\
(\mathrm{~m})\end{array}$} & \multirow{2}{*}{$\begin{array}{l}Y^{\prime}-Y_{G} \\
(m)\end{array}$} & \multirow[b]{2}{*}{$\begin{array}{c}\left(x^{\prime}-x_{6}\right)^{2} \\
\left(m^{2}\right)^{2}\end{array}$} & \multirow[b]{2}{*}{$\begin{array}{l}\left(Y^{\prime}-Y_{G}\right)^{2} \\
\left(m^{2}\right)\end{array}$} & & & \\
\hline Nós & \multicolumn{2}{|c|}{ Coordenadas } & & $\begin{array}{l}\text { Comprimento } \\
(\mathrm{m})\end{array}$ & & & & & & & & & & & $\begin{array}{c}r^{2} \\
\left(m^{2}\right)\end{array}$ & $\begin{array}{l}\mathrm{r}^{2} \times \mathrm{A} \\
\left(\mathrm{m}^{4}\right)\end{array}$ & $\begin{array}{c}\text { Momento Polar Parcial } \\
\left(\mathrm{m}^{4}\right)\end{array}$ \\
\hline 1 & 0 & 0 & & & & & & & & & & & & & & & \\
\hline 2 & 3,75 & $-0,3202$ & $1-2$ & 3,76 & 1,00 & 3,76 & 1,88 & $-0,16$ & 7,06 & $-0,60$ & $-15,40$ & 1,31 & 237,02 & 1,73 & 238,75 & 898,56 & 4,44 \\
\hline 3 & 34,5408 & $-2,9492$ & $2-3$ & 30,99 & 1,00 & 30,90 & 19,15 & 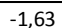 & 591,65 & $-50,52$ & $\begin{array}{l}1,88 \\
\end{array}$ & $-0,16$ & 3,52 & $\begin{array}{ll}0,03 \\
\end{array}$ & 3,54 & 109,43 & 2459,31 \\
\hline 4 & & & & 0 & 1,00 & 0 & 0 & 0 & 0 & 0 & 0 & 0 & 0 & 0 & 0 & 0 & 0 \\
\hline 5 & & & & 0 & & 0 & 0 & 0 & 0 & 0 & 0 & 0 & 0 & 0 & 0 & 0 & 0 \\
\hline 6 & & & & 0 & & 0 & 0 & 0 & 0 & 0 & 0 & 0 & 0 & 0 & 0 & 0 & 0 \\
\hline 7 & & & & 0 & & 0 & 0 & 0 & 0 & 0 & 0 & 0 & 0 & 0 & 0 & 0 & 0 \\
\hline & & & & & & 34,67 & & & 598,70 & $-51,12$ & & & & & $\sum$ & 1007,99 & 2463,75 \\
\hline
\end{tabular}

\begin{tabular}{|c|c|c|c|c|c|c|c|c|c|c|c|c|c|c|c|c|c|c|c|c|}
\hline \multirow{2}{*}{ Nós } & \multicolumn{2}{|c|}{ Coordenadas } & \multirow{2}{*}{ Trecho } & \multicolumn{2}{|c|}{ Distância C (m) } & \multicolumn{2}{|c|}{$\sigma\left(\mathrm{kN} / \mathrm{m}^{2}\right)$} & \multicolumn{2}{|c|}{$\sigma$ Média $\left(\mathrm{kN} / \mathrm{m}^{2}\right)$} & \multicolumn{2}{|c|}{ Forca $(\mathrm{kN})$} & \multirow{2}{*}{$\begin{array}{l}\text { Ângulo c/ } \\
\text { Horizontal }\end{array}$} & \multirow{2}{*}{ Sen } & \multirow{2}{*}{$\cos$} & \multicolumn{2}{|c|}{ Força corrigida (kN) } & \multirow{2}{*}{$\frac{\text { Coesão }}{\left(\mathrm{kN} / \mathrm{m}^{2}\right)}$} & \multirow{2}{*}{$\frac{\phi}{\left(0^{\circ}\right)}$} & \multirow{2}{*}{$\frac{\mathrm{N} \times \operatorname{tg} \phi}{(\mathrm{kN})}$} & \multirow{2}{*}{$\begin{array}{l}\mathrm{C} \times \mathrm{A} \\
\mathrm{kN})\end{array}$} \\
\hline & $X(m)$ & $Y(m)$ & & Horizontal & Vertical & $\begin{array}{l}\text { Vertical } \\
\end{array}$ & Horizontal & Vertical & Horizontal & Vertical | & \begin{tabular}{|l|} 
Horizontal \\
\end{tabular} & & & & Normal & Cisalhante & & & & \\
\hline 1 & 0,00 & 0,00 & & $-20,03$ & 23,90 & 110,83 & 132,23 & & & & & & & & & & & & & \\
\hline 2 & 3,75 & $-0,32$ & $1-2$ & $-23,78$ & 23,58 & 131,57 & 130,46 & 121,20 & 131,35 & 456,15 & 494,35 & 4,9 & 0,085 & 0,996 & 412,44 & 531,36 & 150 & 35 & 288,80 & 564,55 \\
\hline 3 & 34,54 & $-2,95$ & $2-3$ & $-54,58$ & 20,96 & 301,90 & 115,92 & 216,74 & 123,19 & 6697,74 & 3806,93 & 4,9 & 0,085 & 0,996 & 6349,59 & 4362,93 & 150 & 35 & 4446,03 & 4635,42 \\
\hline 4 & & & & & & & & & & & & & & & & & & & & \\
\hline 5 & & & & & & & & & & & & & & & & & & & & \\
\hline 6 & & & & & & & & & & & & & & & & & & & & \\
\hline 7 & & & & & & & & & & & & & & & & & & & & \\
\hline & & & & & & & & & & 7153,89 & 4301,28 & & & & $\sum \pi \mathrm{Ti}$ & 4894,29 & & $\Sigma$ & 4734,83 & 5199,97 \\
\hline
\end{tabular}

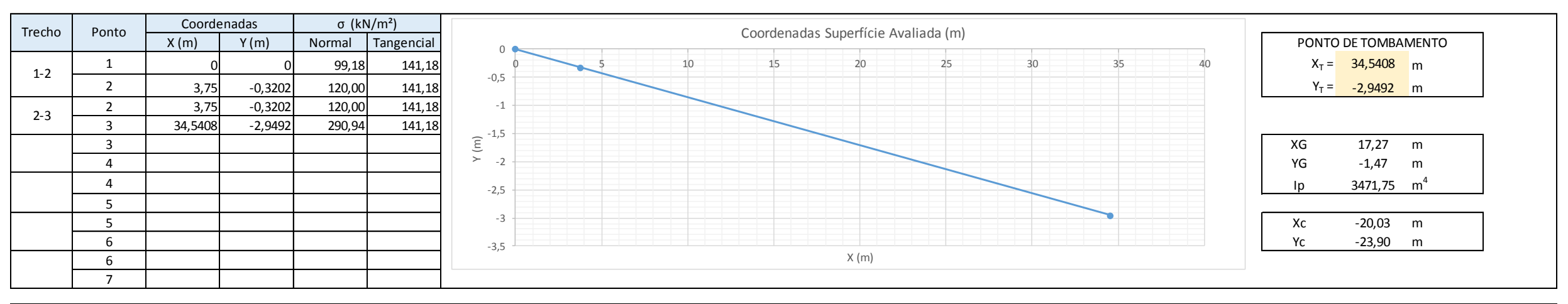

\begin{tabular}{|c|c|c|c|c|c|c|c|c|c|c|c|c|c|c|c|}
\hline \multicolumn{16}{|c|}{$\begin{array}{l}\text { PCH Mata Velha - Tomada d'Água - Junta J5 } \\
\end{array}$} \\
\hline \multirow{4}{*}{ ESFORÇOS } & & & CCN-S & NOS - & VORMALA & MONTANT & ELL. 632,0 & EAJUS: & E. 601,9 & & & & & & \\
\hline & \multirow{3}{*}{$\begin{array}{l}\text { Dire- } \\
\text { ção }\end{array}$} & \multirow{3}{*}{$\begin{array}{l}\text { VOLUME } \\
\left(\mathrm{m}^{3}\right)\end{array}$} & \multirow{3}{*}{$\begin{array}{l}\text { Peso Específico } \\
\left(\mathrm{kN} / \mathrm{m}^{3}\right)\end{array}$} & \multirow{3}{*}{\multicolumn{2}{|c|}{$\begin{array}{l}\text { FORÇA } \\
(\mathrm{kN})\end{array}$}} & \multirow{2}{*}{\multicolumn{2}{|c|}{ Coordenada $(\mathrm{m})$}} & \multicolumn{8}{|c|}{ EM RELAÇÃO AO PONTO DE TOMBAMENTO } \\
\hline & & & & & & & & \multicolumn{2}{|c|}{ Excentricidade } & \multirow{2}{*}{\multicolumn{3}{|c|}{ Estabilizador ou Tombador }} & \multirow{3}{*}{$\begin{array}{c}\text { Correção } \\
1\end{array}$} & \multirow{2}{*}{\multicolumn{2}{|c|}{$\begin{array}{l}\text { MOMENTO } \\
\text { (kN.m) }\end{array}$}} \\
\hline & & & & & & \multirow{2}{*}{$\begin{array}{c}x \\
6,7514\end{array}$} & \multirow[t]{2}{*}{$\mathrm{Y}$} & $x_{T}-X$ & 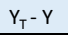 & & & & & & \\
\hline Peso de Concreto - CCV & $\mathrm{V}$ & 180,6800 & 24,0 & $F_{1}=$ & 4.336,32 & & & 27,79 & 0,00 & $\mathrm{E}$ & 0 & $\mathrm{E}$ & & $M_{1}=$ & $120.503,73$ \\
\hline Empuxo de Água a Montante & $\gg$ & 430,4112 & 10,0 & $F_{3}=$ & $4.304,11$ & & 8,2783 & 0,00 & $-11,23$ & 0 & $\mathrm{~T}$ & $\mathrm{~T}$ & -1 & $M_{3}=$ & $-48.324,42$ \\
\hline Empuxo de Água Jusante & $\ll$ & 0,2837 & 10,0 & $\mathrm{~F}_{4}=$ & 2,84 & & $-2,6981$ & 0,00 & $-0,25$ & 0 & $\mathrm{E}$ & $\mathrm{E}$ & 1 & $M_{4}=$ & 0,71 \\
\hline \multirow[t]{7}{*}{ Subpressão } & $\Lambda$ & 494,2351 & 10,0 & $F_{5}=$ & $4.942,35$ & 11,8167 & & 22,72 & 0,00 & $\mathrm{~T}$ & 0 & $T$ & -1 & $M_{5}=$ & $-112.310,48$ \\
\hline & & & & $F_{6}=$ & 0,00 & & & 0,00 & 0,00 & & & & & $M_{6}=$ & \\
\hline & & & & $F_{7}=$ & 0,00 & & & 0,00 & 0,00 & & & & & $M_{7}=$ & \\
\hline & & & & $F_{9}=$ & 0,00 & & & & & & & & & $\mathrm{M}_{9}=$ & \\
\hline & & & & $F_{10}=$ & 0,00 & & & & & & & & & $M_{10}=$ & \\
\hline & & & & $\mathrm{F}_{11}=$ & 0,00 & & & & & & & & & $M_{11}=$ & \\
\hline & & & & & 0,00 & & & & & & & & & & \\
\hline
\end{tabular}

\begin{tabular}{|c|c|c|c|c|c|c|c|c|}
\hline \multirow{3}{*}{ ESFORÇOS } & \multicolumn{8}{|c|}{ EM RELAÇÃO AO CG DA FUNDAÇÃO } \\
\hline & \multicolumn{2}{|c|}{ Excentricidade } & \multirow{2}{*}{\multicolumn{3}{|c|}{ Estabilizador ou Tombador }} & \multirow{3}{*}{$\begin{array}{c}\text { Correção } \\
1\end{array}$} & \multirow{2}{*}{\multicolumn{2}{|c|}{$\begin{array}{l}\text { MOMENTO } \\
(\mathrm{kN} \cdot \mathrm{m})\end{array}$}} \\
\hline & $x_{G}-x$ & $Y_{G}-Y$ & & & & & & \\
\hline Peso de Concreto - CCV & 10,52 & 0,00 & $\mathrm{E}$ & 0 & E & & $\mathrm{M}_{1}=$ & $45.613,75$ \\
\hline Peso de Rocha & 0,53 & 0,00 & $E$ & 0 & $\mathrm{E}$ & 1 & $\mathrm{M}_{2}=$ & $4.116,64$ \\
\hline Empuxo de Água a Montante & 0,00 & $-9,75$ & 0 & $\mathrm{~T}$ & $T$ & -1 & $\mathrm{M}_{3}=$ & $-41.977,60$ \\
\hline Empuxo de Água Jusante & 0,00 & 1,22 & 0 & $T$ & $T$ & -1 & $\mathrm{M}_{4}=$ & $-3,47$ \\
\hline \multirow[t]{8}{*}{ Subpressão } & 5,45 & 0,00 & $T$ & 0 & $T$ & -1 & $M_{5}=$ & $-26.954,10$ \\
\hline & & & & & & & $M_{6}=$ & \\
\hline & & & & & & & $\mathrm{M}_{7}=$ & \\
\hline & & & & & & & $M_{8}=$ & \\
\hline & & & & & & & $\mathrm{M}_{\mathrm{g}}=$ & \\
\hline & & & & & & & $M_{10}=$ & \\
\hline & & & & & & & $M_{11}=$ & \\
\hline & & & & & & & & \\
\hline
\end{tabular}

\begin{tabular}{|c|c|c|c|c|c|c|c|c|}
\hline \multirow{2}{*}{$\Sigma V=$} & \multirow{2}{*}{$12096,245 \mathrm{kN}$} & & & \multicolumn{5}{|c|}{ FLUTUAÇ̃̃̃ - CSF } \\
\hline & & $\Sigma M_{T}=$ & $\begin{array}{l}258.638,09 \mathrm{kN} \cdot \mathrm{m} \\
160.634,90 \mathrm{kN} \cdot \mathrm{m}\end{array}$ & $\frac{\Sigma V}{\Sigma U}=$ & 2,45 & $>$ & 1,3 & ок \\
\hline$\Sigma V-\Sigma U=$ & $7153,894 \mathrm{kN}$ & Momento Resultante & $98.003,20 \mathrm{kN} . \mathrm{m}$ & \multicolumn{5}{|c|}{ TOMBAMENTO - CST } \\
\hline$\sum \mathrm{T}_{\mathrm{i}, \text { MONTANTE }}=$ & $4304,112 \mathrm{kN}$ & & & $\frac{\sum \mathrm{M}_{E}}{\sum \mathrm{M}_{\mathrm{T}}}=$ & 1,61 & $>$ & 1,5 & ок \\
\hline$\sum \mathrm{T}_{\mathrm{i}, \text { USAANE }}=$ & $2,837 \mathrm{kN}$ & & & \multicolumn{5}{|c|}{ DESLIZAMENTO - CSD $\phi$ e CSD $_{c}$} \\
\hline Força Resultante & $4301,275 \mathrm{kN}$ & & & $\frac{N_{N} \times \operatorname{tg} \phi}{\operatorname{CSD}_{0} \times \sum \pi}+\frac{\sum C_{0} \times A_{i}}{\operatorname{CSD}_{c} \times \sum \pi}=$ & 1,00 & $>$ & 1,0 & ок \\
\hline
\end{tabular}

Fonte: Do autor (2021). 


\begin{tabular}{|c|c|c|c|c|c|c|c|c|c|c|c|c|c|c|c|c|c|}
\hline \multicolumn{18}{|c|}{ PCH Mata Velha - Tomada d'Água - Junta J6 } \\
\hline \multirow[b]{2}{*}{ Nós } & & & \multirow[b]{2}{*}{ Trecho } & \multirow{2}{*}{$\begin{array}{c}\text { Comprimento } \\
(\mathrm{m})\end{array}$} & \multirow[b]{2}{*}{$\begin{array}{l}\text { Espessura } \\
(\mathrm{m})\end{array}$} & \multirow{2}{*}{$\begin{array}{l}\text { Área } \\
\left(\mathrm{m}^{2}\right)\end{array}$} & \multirow{2}{*}{$\begin{array}{l}x^{\prime} \\
(m)\end{array}$} & \multirow{2}{*}{$\begin{array}{l}Y^{\prime} \\
(m)\end{array}$} & \multirow{2}{*}{$\begin{array}{l}\text { MOMEN } \\
\mathrm{X}^{\prime} \times A \\
\left(\mathrm{~m}^{3}\right)\end{array}$} & \multirow{2}{*}{$\begin{array}{l}\text { OLAADE } \\
Y^{\prime} \times A \\
\left(m^{3}\right)\end{array}$} & \multirow{2}{*}{$\begin{array}{l}\frac{R^{R C A}\left(I^{\prime}\right)}{X^{\prime}-X_{G}} \\
(\mathrm{~m})\end{array}$} & \multirow{2}{*}{$\begin{array}{l}Y^{\prime}-Y_{G} \\
(m)\end{array}$} & \multirow[b]{2}{*}{$\begin{array}{c}\left(x^{\prime}-x_{6}\right)^{2} \\
\left(m^{2}\right)^{2}\end{array}$} & \multirow[b]{2}{*}{$\begin{array}{l}\left(Y^{\prime}-Y_{G}\right)^{2} \\
\left(m^{2}\right)\end{array}$} & & & \\
\hline & \multicolumn{2}{|c|}{ Coordenadas } & & & & & & & & & & & & & $\begin{array}{c}r^{2} \\
\left(m^{2}\right)\end{array}$ & $\begin{array}{l}r^{2} \times A \\
\left(m^{4}\right)\end{array}$ & $\begin{array}{c}\text { Momento Polar Parcial } \\
\left(\mathrm{m}^{4}\right)\end{array}$ \\
\hline 1 & 0 & 0 & & & & & & & & & & & & & & & \\
\hline 2 & 3,75 & $-0,3202$ & $1-2$ & 3,76 & 1,00 & 3,76 & 1,88 & $-0,16$ & 7,06 & $-0,60$ & $-15,40$ & 1,31 & 237,02 & 1,73 & 238,75 & 898,56 & 4,44 \\
\hline 3 & 34,5408 & $-2,9492$ & $2-3$ & 30,99 & 1,00 & 30,90 & 19,15 & $-1,63$ & 591,65 & $-50,52$ & $\begin{array}{ll}1,88 \\
\end{array}$ & $-0,16$ & 3,52 & $\begin{array}{ll}0,03 \\
\end{array}$ & 3,54 & 109,43 & 2459,31 \\
\hline 4 & & & & 0 & 1,00 & 0 & 0 & 0 & 0 & 0 & 0 & 0 & 0 & 0 & 0 & 0 & 0 \\
\hline 5 & & & & 0 & & 0 & 0 & 0 & 0 & 0 & 0 & 0 & 0 & 0 & 0 & 0 & 0 \\
\hline 6 & & & & 0 & & 0 & 0 & 0 & 0 & 0 & 0 & 0 & 0 & 0 & 0 & 0 & 0 \\
\hline 7 & & & & 0 & & 0 & 0 & 0 & 0 & 0 & 0 & 0 & 0 & 0 & 0 & 0 & 0 \\
\hline & & & & & & 34,67 & & & 598,70 & $-51,12$ & & & & & $\sum$ & 1007,99 & 2463,75 \\
\hline
\end{tabular}

\begin{tabular}{|c|c|c|c|c|c|c|c|c|c|c|c|c|c|c|c|c|c|c|c|c|}
\hline \multirow{2}{*}{ Nós } & \multicolumn{2}{|c|}{ Coordenadas } & \multirow{2}{*}{ Trecho } & \multicolumn{2}{|c|}{ Distância C (m) } & \multicolumn{2}{|c|}{$\sigma\left(\mathrm{kN} / \mathrm{m}^{2}\right)$} & \multicolumn{2}{|c|}{$\sigma$ Média $\left(\mathrm{kN} / \mathrm{m}^{2}\right)$} & \multicolumn{2}{|c|}{ Forca $(\mathrm{kN})$} & \multirow{2}{*}{$\begin{array}{l}\text { Ângulo c/ } \\
\text { Horizontal }\end{array}$} & \multirow{2}{*}{ Sen } & \multirow{2}{*}{$\cos$} & \multicolumn{2}{|c|}{ Força corrigida (kN) } & \multirow{2}{*}{$\frac{\text { Coesão }}{\left(\mathrm{kN} / \mathrm{m}^{2}\right)}$} & \multirow{2}{*}{$\frac{\phi}{\left(0^{\circ}\right)}$} & \multirow{2}{*}{$\frac{\mathrm{N} \times \operatorname{tg} \phi}{(\mathrm{kN})}$} & \multirow{2}{*}{$\begin{array}{l}\mathrm{C} \times \mathrm{A} \\
\mathrm{kN})\end{array}$} \\
\hline & $X(m)$ & $Y(m)$ & & Horizontal & Vertical & $\begin{array}{l}\text { Vertical } \\
\end{array}$ & Horizontal & Vertical & Horizontal & Vertical | & \begin{tabular}{|l|} 
Horizontal \\
\end{tabular} & & & & Normal & Cisalhante & & & & \\
\hline 1 & 0,00 & 0,00 & & $-102,64$ & 82,24 & 124,28 & 99,58 & & & & & & & & & & & & & \\
\hline 2 & 3,75 & $-0,32$ & $1-2$ & $-106,39$ & 81,92 & 128,82 & 99,19 & 126,55 & 99,38 & 476,29 & 374,04 & 4,9 & 0,085 & 0,996 & 442,74 & 413,21 & 137 & 35 & 310,01 & 515,62 \\
\hline 3 & 34,54 & $-2,95$ & $2-3$ & $-137,18$ & 79,29 & 166,10 & 96,01 & 147,46 & 97,60 & 4556,96 & 3016,03 & 4,9 & 0,085 & 0,996 & 4283,85 & 3392,77 & 137 & 35 & 2999,59 & 4233,69 \\
\hline 4 & & & & & & & & & & & & & & & & & & & & \\
\hline 5 & & & & & & & & & & & & & & & & & & & & \\
\hline 6 & & & & & & & & & & & & & & & & & & & & \\
\hline 7 & & & & & & & & & & & & & & & & & & & & \\
\hline & & & & & & & & & & 5033,24 & 3390,07 & & & & $\sum \mathrm{Ti}$ & 3805,97 & & $\Sigma$ & 3309,60 & 4749,31 \\
\hline
\end{tabular}

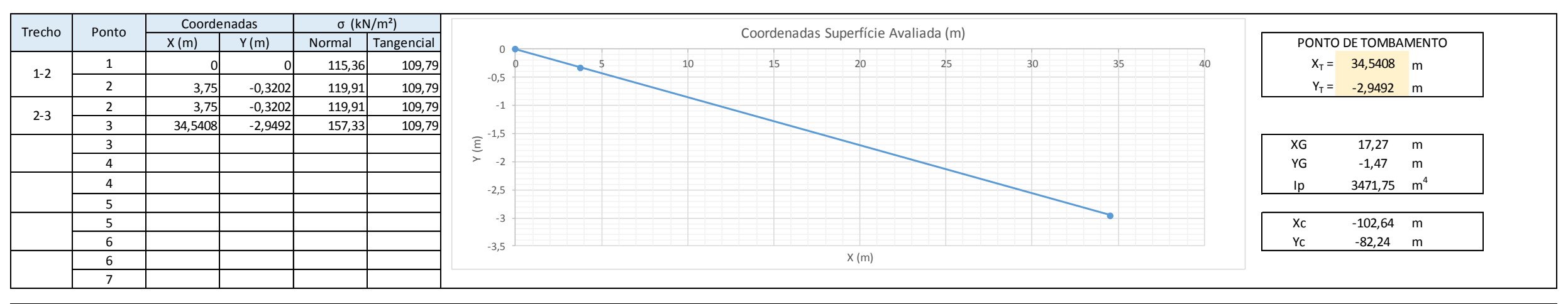

\begin{tabular}{|c|c|c|c|c|c|c|c|c|c|c|c|c|c|c|c|}
\hline \multicolumn{16}{|c|}{ PCH Mata Velha - Tomada d'Água - Junta J6 } \\
\hline \multirow{4}{*}{ ESFORÇOS } & & & CCN - DREN & PERAN & V.A. NORM & ALAMON & NTE (EL. 6 & OM) EA & TIE (EL. & & & & & & \\
\hline & \multirow{3}{*}{$\begin{array}{l}\text { Dire- } \\
\text { ção }\end{array}$} & \multirow{3}{*}{$\begin{array}{l}\text { VOLUME } \\
\left(\mathrm{m}^{3}\right)\end{array}$} & \multirow{3}{*}{$\begin{array}{l}\text { Peso Específico } \\
\left(\mathrm{kN} / \mathrm{m}^{3}\right)\end{array}$} & \multirow{3}{*}{\multicolumn{2}{|c|}{$\begin{array}{c}\text { FORCA } \\
(\mathrm{kN})\end{array}$}} & \multirow{2}{*}{\multicolumn{2}{|c|}{ Coordenada $(\mathrm{m})$}} & \multicolumn{8}{|c|}{ EM RELAÇÃO AO PONTO DE TOMBAMENTO } \\
\hline & & & & & & & & \multicolumn{2}{|c|}{ Excentricidade } & \multirow{2}{*}{\multicolumn{3}{|c|}{ Estabilizador ou Tombador }} & \multirow{3}{*}{$\begin{array}{c}\text { Correção } \\
1\end{array}$} & \multirow{2}{*}{\multicolumn{2}{|c|}{$\begin{array}{l}\text { MOMENTO } \\
(\mathrm{kN} . \mathrm{m})\end{array}$}} \\
\hline & & & & & & \multirow{2}{*}{\begin{tabular}{|c|}
$x$ \\
6,7514
\end{tabular}} & \multirow[t]{2}{*}{$\mathrm{Y}$} & $x_{T}-X$ & 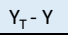 & & & & & & \\
\hline Peso de Concreto - CCV & $\mathrm{V}$ & 180,6800 & 24,0 & $F_{1}=$ & 4.336,32 & & & 27,79 & 0,00 & E & 0 & E & & $M_{1}=$ & $120.503,73$ \\
\hline Empuxo de Água a Montante & $\gg$ & 339,0066 & 10,0 & $F_{3}=$ & $3.390,07$ & & 7,2189 & 0,00 & $-10,17$ & 0 & $\mathrm{~T}$ & $\mathrm{~T}$ & -1 & $M_{3}=$ & $-34.470,53$ \\
\hline \multirow[t]{8}{*}{ Subpressão } & $\Lambda$ & 424,9526 & 10,0 & $F_{4}=$ & $4.249,53$ & 11,5136 & & 23,03 & 0,00 & $\mathrm{~T}$ & 0 & $\mathrm{~T}$ & -1 & $M_{4}=$ & $-97.854,69$ \\
\hline & & & & $F_{5}=$ & $\begin{array}{l}0,00 \\
\end{array}$ & & & 0,00 & 0,00 & & & & & $M_{5}=$ & \\
\hline & & & & $F_{6}=$ & 0,00 & & & 0,00 & 0,00 & & & & & $M_{6}=$ & \\
\hline & & & & $F_{7}=$ & 0,00 & & & 0,00 & 0,00 & & & & & $\mathrm{M}_{7}=$ & \\
\hline & & & & $F_{9}=$ & 0,00 & & & & & & & & & $\mathrm{M}_{9}=$ & \\
\hline & & & & $F_{10}=$ & 0,00 & & & & & & & & & $M_{10}=$ & \\
\hline & & & & $\mathrm{F}_{11}=$ & 0,00 & & & & & & & & & $\mathrm{M}_{11}=$ & \\
\hline & & & & & 0,00 & & & & & & & & & & \\
\hline
\end{tabular}

\begin{tabular}{|c|c|c|c|c|c|c|c|c|}
\hline \multirow{3}{*}{ ESFORÇOS } & \multicolumn{8}{|c|}{ EM RELAÇÃO AO CG DA FUNDAÇÃO } \\
\hline & \multicolumn{2}{|c|}{ Excentricidade } & \multirow{2}{*}{\multicolumn{3}{|c|}{ Estabilizador ou Tombador }} & \multirow{2}{*}{ Correção } & \multirow{2}{*}{\multicolumn{2}{|c|}{$\begin{array}{r}\text { MOMENTO } \\
\text { (kN.m) }\end{array}$}} \\
\hline & \multirow{2}{*}{$\frac{x_{6}-x}{10,52}$} & \multirow{2}{*}{$\frac{Y_{G}-Y}{0,00}$} & & & & & & \\
\hline Peso de Concreto - CCV & & & $\mathrm{E}$ & 0 & $E$ & 1 & $M_{1}=$ & $45.613,75$ \\
\hline Peso de Rocha & 0,83 & 0,00 & $\mathrm{E}$ & 0 & $\mathrm{E}$ & 1 & $\mathrm{M}_{2}=$ & $4.117,92$ \\
\hline Empuxo de Água a Montante & 0,00 & $-8,69$ & 0 & $\mathrm{~T}$ & $T$ & -1 & $\mathrm{M}_{3}=$ & $-29.471,56$ \\
\hline \multirow[t]{9}{*}{ Subpressão } & 5,76 & 0,00 & $T$ & 0 & $\mathrm{~T}$ & -1 & $M_{4}=$ & $-24.463,67$ \\
\hline & & & & & & & $M_{5}=$ & \\
\hline & & & & & & & $M_{6}=$ & \\
\hline & & & & & & & $\mathrm{M}_{7}=$ & \\
\hline & & & & & & & $M_{8}=$ & \\
\hline & & & & & & & $M_{9}=$ & \\
\hline & & & & & & & $\mathrm{M}_{10}=$ & \\
\hline & & & & & & & $M_{11}=$ & \\
\hline & & & & & & & & \\
\hline
\end{tabular}

\begin{tabular}{|c|c|c|c|c|c|c|c|c|}
\hline \multirow{2}{*}{$\Sigma V=$} & \multirow{2}{*}{$9282,77 \mathrm{kN}$} & & & \multicolumn{5}{|c|}{ FLUTUAÇÃO - CSF } \\
\hline & & $\Sigma M_{T}=$ & $\begin{array}{l}210.048,82 \mathrm{kN} \cdot \mathrm{m} \\
132.325,22 \mathrm{kN} \cdot \mathrm{m}\end{array}$ & $\frac{\Sigma V}{\Sigma U}=$ & 2,18 & $>$ & 1,3 & ок \\
\hline$\Sigma V-\Sigma U=$ & $5033,244 \mathrm{kN}$ & Momento Resultante & $77.723,61 \mathrm{kN} . \mathrm{m}$ & \multicolumn{5}{|c|}{ TOMBAMENTO - CST } \\
\hline \multirow[t]{2}{*}{$\sum \mathrm{T}_{\mathrm{i}, \text { USANTE }}=$} & $\begin{array}{r}3390,066 \mathrm{kN} \\
9,09495 \mathrm{E}-13 \mathrm{kN}\end{array}$ & & & $\frac{\sum \mathrm{M}_{\mathrm{E}}}{\sum \mathrm{M}_{\mathrm{T}}}=$ & 1,59 & $>$ & 1,5 & ок \\
\hline & & & & \multicolumn{5}{|c|}{ DESLIZAMENTO - CSDQ e CSD $D_{c}$} \\
\hline Força Resultante & $3390,066 \mathrm{kN}$ & & & $\frac{N_{N} \times \operatorname{tg} \phi}{\operatorname{CSD}_{0} \times \sum \pi}+\frac{\sum C_{0} \times A_{i}}{\operatorname{CSD}_{c} \times \sum \pi}=$ & 1,00 & $>$ & 1,0 & ок \\
\hline
\end{tabular}

Fonte: Do autor (2021). 


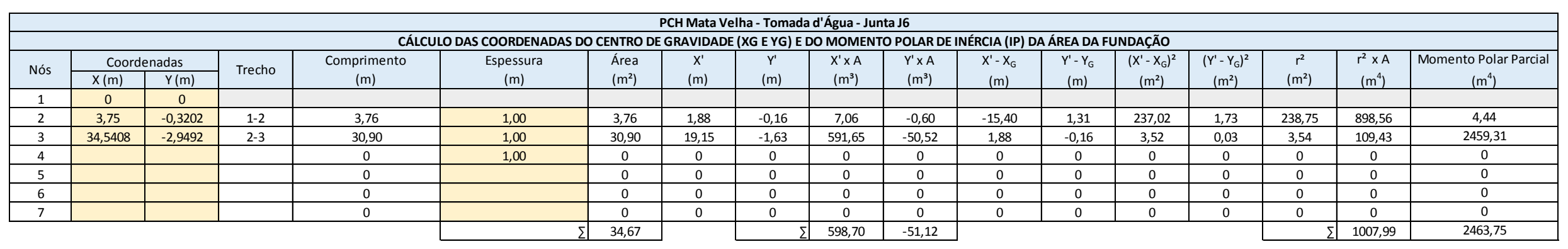

\begin{tabular}{|c|c|c|c|c|c|c|c|c|c|c|c|c|c|c|c|c|c|c|c|c|}
\hline \multirow{2}{*}{ Nós } & \multicolumn{2}{|c|}{ Coordenadas } & \multirow{2}{*}{ Trecho } & \multicolumn{2}{|c|}{ Distância C (m) } & \multicolumn{2}{|c|}{$\sigma\left(\mathrm{kN} / \mathrm{m}^{2}\right)$} & \multicolumn{2}{|c|}{$\sigma$ Média $\left(\mathrm{kN} / \mathrm{m}^{2}\right)$} & \multicolumn{2}{|c|}{ Forca $(\mathrm{kN})$} & \multirow{2}{*}{$\begin{array}{l}\text { Ângulo c/ } \\
\text { Horizontal }\end{array}$} & \multirow{2}{*}{ Sen } & \multirow{2}{*}{$\cos$} & \multicolumn{2}{|c|}{ Força corrigida (kN) } & \multirow{2}{*}{$\frac{\text { Coesão }}{\left(\mathrm{kN} / \mathrm{m}^{2}\right)}$} & \multirow{2}{*}{$\frac{\phi}{\left(0^{\circ}\right)}$} & \multirow{2}{*}{$\frac{\mathrm{N} \times \operatorname{tg} \phi}{(\mathrm{kN})}$} & \multirow{2}{*}{$\begin{array}{l}\mathrm{C} \times \mathrm{A} \\
\mathrm{kN})\end{array}$} \\
\hline & $X(m)$ & $Y(m)$ & & Horizontal & Vertical & $\begin{array}{l}\text { Vertical } \\
\end{array}$ & Horizontal & Vertical & Horizontal & Vertical | & \begin{tabular}{|l|} 
Horizontal \\
\end{tabular} & & & & Normal & Cisalhante & & & & \\
\hline 1 & 0,00 & 0,00 & & 246,21 & $-111,59$ & 204,58 & 92,72 & & & & & & & & & & & & & \\
\hline 2 & 3,75 & $-0,32$ & $1-2$ & 242,46 & $-111,91$ & 201,46 & 92,99 & 203,02 & 92,85 & 764,11 & 349,47 & 4,9 & 0,085 & 0,996 & 731,60 & 413,21 & 74 & 35 & 512,27 & 278,51 \\
\hline 3 & 34,54 & $-2,95$ & $2-3$ & 211,67 & $-114,54$ & 175,88 & 95,17 & 188,67 & 94,08 & 5830,51 & 2907,29 & 4,9 & 0,085 & 0,996 & 5562,04 & 3392,77 & 74 & 35 & 3894,59 & 2286,81 \\
\hline 4 & & & & & & & & & & & & & & & & & & & & \\
\hline 5 & & & & & & & & & & & & & & & & & & & & \\
\hline 6 & & & & & & & & & & & & & & & & & & & & \\
\hline 7 & & & & & & & & & & & & & & & & & & & & \\
\hline & & & & & & & & & & 6594,62 & 3256,75 & & & & $\sum \mathrm{Ti}$ & 3805,97 & & $\Sigma$ & 4406,86 & 2565,32 \\
\hline
\end{tabular}

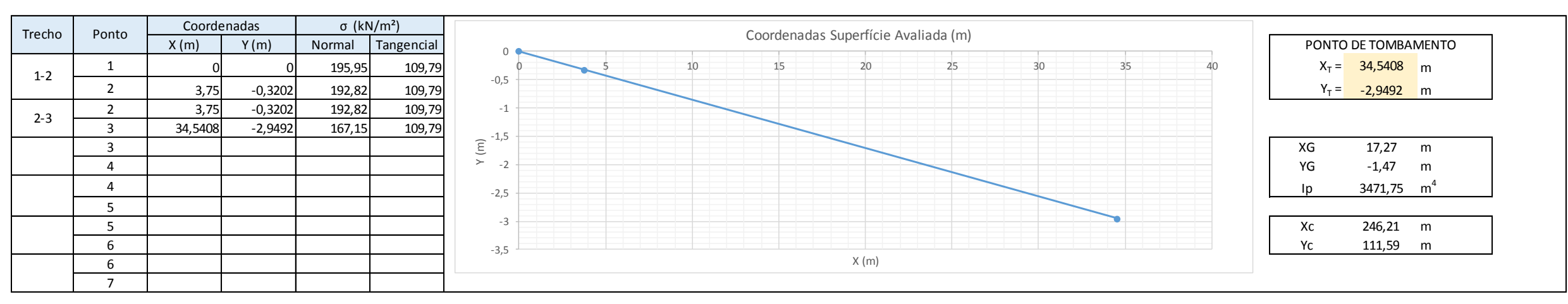

\begin{tabular}{|c|c|c|c|c|c|c|c|c|c|c|c|c|c|c|c|}
\hline \multicolumn{16}{|c|}{ PCH Mata Velha - Tomada d'Água - Junta J6 } \\
\hline \multirow{4}{*}{ ESFORÇOS } & & & CCN - DRE & ERANT & IA. NORMA & LAMONT & TE (EL. 63 & I) EAJU & TE (EL. 6 ( & & & & & & \\
\hline & \multirow{3}{*}{$\begin{array}{l}\text { Dire- } \\
\text { ção }\end{array}$} & \multirow{3}{*}{$\begin{array}{l}\text { VOLUME } \\
\left(\mathrm{m}^{3}\right)\end{array}$} & \multirow{3}{*}{$\begin{array}{l}\text { Peso Específico } \\
\left(\mathrm{kN} / \mathrm{m}^{3}\right)\end{array}$} & \multirow{3}{*}{\multicolumn{2}{|c|}{$\begin{array}{l}\text { FORCA } \\
(\mathrm{kN})\end{array}$}} & \multirow{2}{*}{\multicolumn{2}{|c|}{ Coordenada $(\mathrm{m})$}} & \multicolumn{8}{|c|}{ EM RELAÇÃO AO PONTO DE TOMBAMENTO } \\
\hline & & & & & & & & \multicolumn{2}{|c|}{ Excentricidade } & \multirow{2}{*}{\multicolumn{3}{|c|}{ Estabilizador ou Tombador }} & \multirow{2}{*}{ Correção } & \multirow{2}{*}{\multicolumn{2}{|c|}{$\begin{array}{c}\text { MOMENTO } \\
(\mathrm{kN} . \mathrm{m})\end{array}$}} \\
\hline & & & & & & \multirow{2}{*}{\begin{tabular}{|c|}
$x$ \\
6,7514
\end{tabular}} & \multirow[t]{2}{*}{$\mathrm{Y}$} & $x_{T}-x$ & $Y_{T}-Y$ & & & & & & \\
\hline Peso de Concreto - CCV & $\mathrm{V}$ & 180,6800 & 24,0 & $F_{1}=$ & $4.336,32$ & & & 27,79 & 0,00 & $\mathrm{E}$ & 0 & $\mathrm{E}$ & 1 & $M_{1}=$ & $120.503,73$ \\
\hline Empuxo de Água a Montante & $\gg$ & 325,6751 & 10,0 & $\mathrm{~F}_{3}=$ & $3.256,75$ & & 7,5590 & 0,00 & $-10,51$ & 0 & $\mathrm{~T}$ & $T$ & -1 & $\mathrm{M}_{3}=$ & $-34.222,59$ \\
\hline \multirow[t]{8}{*}{ Subpressão } & $\Lambda$ & 268,8151 & 10,0 & $F_{4}=$ & $2.688,15$ & 10,7876 & & 23,75 & 0,00 & $\mathrm{~T}$ & 0 & $\mathrm{~T}$ & -1 & $M_{4}=$ & $-63.852,19$ \\
\hline & & & & $F_{5}=$ & $\begin{array}{l}0,00 \\
\end{array}$ & & & 0,00 & 0,00 & & & & & $M_{5}=$ & \\
\hline & & & & $F_{6}=$ & 0,00 & & & 0,00 & 0,00 & & & & & $M_{6}=$ & \\
\hline & & & & $F_{7}=$ & 0,00 & & & 0,00 & 0,00 & & & & & $\mathrm{M}_{7}=$ & \\
\hline & & & & $F_{9}=$ & 0,00 & & & & & & & & & $M_{9}=$ & \\
\hline & & & & $F_{10}=$ & 0,00 & & & & & & & & & $M_{10}=$ & \\
\hline & & & & $\mathrm{F}_{11}=$ & 0,00 & & & & & & & & & $\mathrm{M}_{11}=$ & \\
\hline & & & & & \begin{tabular}{l|l}
0,00 \\
\end{tabular} & & & & & & & & & & \\
\hline
\end{tabular}

\begin{tabular}{|c|c|c|c|c|c|c|c|c|}
\hline \multirow{3}{*}{ ESFORÇOS } & \multicolumn{8}{|c|}{ EM RELAÇÃO AO CG DA FUNDAÇÃO } \\
\hline & \multicolumn{2}{|c|}{ Excentricidade } & \multirow{2}{*}{\multicolumn{3}{|c|}{ Estabilizador ou Tombador }} & \multirow{2}{*}{ Correção } & \multirow{2}{*}{\multicolumn{2}{|c|}{$\frac{\text { MOMENTO }}{(\mathrm{kN} . \mathrm{m})}$}} \\
\hline & $x_{G}-x$ & $Y_{G}-Y_{1}$ & & & & & & \\
\hline Peso de Concreto - CCV & 10,52 & 0,00 & $E$ & 0 & E & 1 & $M_{1}=$ & $45.613,75$ \\
\hline Peso de Rocha & 0,83 & 0,00 & $E$ & 0 & $\mathrm{E}$ & 1 & $\mathrm{M}_{2}=$ & $4.117,92$ \\
\hline Empuxo de Água a Montante & 0,00 & $-9,03$ & 0 & $\bar{T}$ & $T$ & -1 & $M_{3}=$ & $-29.420,21$ \\
\hline \multirow[t]{8}{*}{ Subpressão } & 6,48 & 0,00 & $T$ & 0 & $T$ & -1 & $M_{4}=$ & $-17.426,74$ \\
\hline & & & & & & & $M_{5}=$ & \\
\hline & & & & & & & $M_{6}=$ & \\
\hline & & & & & & & $\mathrm{M}_{7}=$ & \\
\hline & & & & & & & $M_{8}=$ & \\
\hline & & & & & & & $\mathrm{M}_{\mathrm{g}}=$ & \\
\hline & & & & & & & $M_{10}=$ & \\
\hline & & & & & & & $\mathrm{M}_{11}=$ & \\
\hline
\end{tabular}

\begin{tabular}{|c|c|c|c|c|c|c|c|c|}
\hline \multirow[b]{2}{*}{$\Sigma V=$} & \multirow[b]{2}{*}{$9282,77 \mathrm{kN}$} & \multirow[b]{2}{*}{$\sum M_{E}=$} & \multirow[b]{2}{*}{$210.048,82 \mathrm{kN} . \mathrm{m}$} & \multicolumn{5}{|c|}{ FLUTUAÇÃO - CSF } \\
\hline & & & & $\Sigma \mathrm{V}$ & \multirow{2}{*}{3,45} & \multirow{2}{*}{$>$} & \multirow{2}{*}{1,3} & \multirow{2}{*}{ ок } \\
\hline$\Sigma U=$ & $2688,151 \mathrm{kN}$ & $\sum M_{\mathrm{T}}=$ & $98.074,78 \mathrm{kN} \cdot \mathrm{m}$ & $\Sigma U$ & & & & \\
\hline$\Sigma V-\Sigma U=$ & $6594,619 \mathrm{kN}$ & Momento Resultante & $111.974,04 \mathrm{kN} \cdot \mathrm{m}$ & \multicolumn{5}{|c|}{ TOMBAMENTO - CST } \\
\hline$\sum \mathrm{T}_{\mathrm{i}, \text { MONTANTE }}=$ & $3256,751 \mathrm{kN}$ & & & $\frac{\sum M_{E}}{\sum M_{T}}=$ & 2,14 & $>$ & 1,5 & ок \\
\hline$\sum T_{i}$, USAANTE $=$ & 4,34/4/E-13 KIV & & & \multicolumn{5}{|c|}{ DESLIZAMENTO - CSDQ e CSD } \\
\hline Força Resultante & $3256,751 \mathrm{kN}$ & & & $\frac{N_{1} \times \operatorname{tg} \phi}{\operatorname{CSD}_{0} \times \sum \pi}+\frac{\sum \mathrm{C}_{0} \times \mathrm{Ai}}{\operatorname{CSD}_{c} \times \sum \pi}=$ & 1,00 & $>$ & 1,0 & ок \\
\hline
\end{tabular}

Fonte: Do autor (2021). 


\begin{tabular}{|c|c|c|c|c|c|c|c|c|c|c|c|c|c|c|c|c|c|}
\hline \multicolumn{18}{|c|}{$\begin{array}{l}\text { PCH Mata Velha - Tomada d'Água - Junta J7 } \\
\end{array}$} \\
\hline & & & & \multirow{2}{*}{$\begin{array}{l}\text { Comprimento } \\
(\mathrm{m})\end{array}$} & \multirow[b]{2}{*}{$\begin{array}{l}\text { Espessura } \\
(\mathrm{m})\end{array}$} & \multirow{2}{*}{$\begin{array}{l}\text { Área } \\
\left(\mathrm{m}^{2}\right)\end{array}$} & \multirow{2}{*}{$\begin{array}{l}x^{\prime} \\
(m)\end{array}$} & \multirow{2}{*}{$\begin{array}{l}Y^{\prime} E() \\
(m)\end{array}$} & \multirow{2}{*}{$\begin{array}{l}\text { MOMEN } \\
\mathrm{X}^{\prime} \times A \\
\left(\mathrm{~m}^{3}\right)\end{array}$} & \multirow{2}{*}{$\begin{array}{l}\text { OLAADE } \\
Y^{\prime} \times A \\
\left(m^{3}\right)\end{array}$} & \multirow{2}{*}{$\begin{array}{l}\frac{R^{R C A}\left(I^{\prime}\right)}{X^{\prime}-X_{G}} \\
(\mathrm{~m})\end{array}$} & \multirow{2}{*}{$\begin{array}{l}Y^{\prime}-Y_{G} \\
(m)\end{array}$} & \multirow[b]{2}{*}{$\begin{array}{c}\left(x^{\prime}-x_{6}\right)^{2} \\
\left(m^{2}\right)^{2}\end{array}$} & & & & \\
\hline Nós & \multicolumn{2}{|c|}{ Coordenadas } & Trecho & & & & & & & & & & & $\begin{array}{l}\left(Y^{\prime}-Y_{G}\right)^{2} \\
\left(m^{2}\right)\end{array}$ & $\begin{array}{c}r^{2} \\
\left(m^{2}\right)\end{array}$ & $\begin{array}{l}r^{2} \times A \\
\left(m^{4}\right)\end{array}$ & $\begin{array}{c}\text { Momento Polar Parcial } \\
\left(\mathrm{m}^{4}\right)\end{array}$ \\
\hline 1 & 0 & 0 & & & & & & & & & & & & & & & \\
\hline 2 & 3,75 & $-0,3202$ & $1-2$ & 3,76 & 1,00 & 3,76 & 1,88 & $-0,16$ & 7,06 & $-0,60$ & $-12,46$ & 1,06 & 155,35 & 1,13 & 156,48 & 588,93 & 4,44 \\
\hline 3 & 28,6775 & -2 & $2-3$ & 25,02 & 1,00 & 25,02 & 16,21 & $-1,38$ & 405,64 & $-34,64$ & 1,88 & $-0,16$ & 3,52 & 0,03 & 3,54 & 88,60 & 1304,93 \\
\hline 4 & & & & 0 & 1,00 & 0 & 0 & 0 & 0 & 0 & 0 & 0 & 0 & 0 & 0 & 0 & 0 \\
\hline 5 & & & & 0 & & 0 & 0 & 0 & 0 & 0 & 0 & 0 & 0 & 0 & 0 & 0 & 0 \\
\hline 6 & & & & 0 & & 0 & 0 & 0 & 0 & 0 & 0 & 0 & 0 & 0 & 0 & 0 & 0 \\
\hline 7 & & & & 0 & & 0 & 0 & 0 & 0 & 0 & 0 & 0 & 0 & 0 & 0 & 0 & 0 \\
\hline & & & & & & 28,78 & & & 412,70 & $-35,24$ & & & & & & 677,52 & 1309,37 \\
\hline
\end{tabular}

\begin{tabular}{|c|c|c|c|c|c|c|c|c|c|c|c|c|c|c|c|c|c|c|c|c|}
\hline \multirow{2}{*}{ Nós } & \multicolumn{2}{|c|}{ Coordenadas } & \multirow{2}{*}{ Trecho } & \multicolumn{2}{|c|}{ Distância C (m) } & \multicolumn{2}{|c|}{$\sigma\left(\mathrm{kN} / \mathrm{m}^{2}\right)$} & \multicolumn{2}{|c|}{$\sigma$ Média $\left(\mathrm{kN} / \mathrm{m}^{2}\right)$} & \multicolumn{2}{|c|}{ Forca $(\mathrm{kN})$} & \multirow{2}{*}{$\begin{array}{l}\text { Ângulo c/ } \\
\text { Horizontal }\end{array}$} & \multirow{2}{*}{ Sen } & \multirow{2}{*}{$\cos$} & \multicolumn{2}{|c|}{ Força corrigida (kN) } & \multirow{2}{*}{$\frac{\text { Coesão }}{\left(\mathrm{kN} / \mathrm{m}^{2}\right)}$} & \multirow{2}{*}{$\frac{\phi}{\left(0^{\circ}\right)}$} & \multirow{2}{*}{$\frac{\mathrm{N} \times \operatorname{tg} \phi}{(\mathrm{kN})}$} & \multirow{2}{*}{$\begin{array}{l}\mathrm{C} \times \mathrm{A} \\
\mathrm{kN})\end{array}$} \\
\hline & $X(m)$ & $\mathrm{Y}(\mathrm{m})$ & & Horizontal & Vertical & $\begin{array}{l}\text { Vertical } \\
\end{array}$ & Horizontal & Vertical & Horizontal & Vertical & \begin{tabular}{|l|} 
Horizontal \\
\end{tabular} & & & & Normal & Cisalhante & & & & \\
\hline 1 & 0,00 & 0,00 & & $-22,68$ & 26,88 & 79,96 & 94,76 & & & & & & & & & & & & & \\
\hline 2 & 3,75 & $-0,32$ & $1-2$ & $-26,43$ & 26,56 & 93,18 & 93,63 & 86,57 & 94,19 & 325,82 & 354,50 & 4,9 & 0,085 & 0,996 & 294,48 & 380,94 & 131 & 35 & 206,20 & 493,04 \\
\hline 3 & 28,68 & $-2,45$ & $2-3$ & $-51,36$ & 24,43 & 181,06 & 86,12 & 137,12 & 89,88 & 3430,54 & 2248,51 & 4,9 & 0,085 & 0,996 & 3226,82 & 2532,21 & 131 & 35 & 2259,44 & 3277,38 \\
\hline 4 & & & & & & & & & & & & & & & & & & & & \\
\hline 5 & & & & & & & & & & & & & & & & & & & & \\
\hline 6 & & & & & & & & & & & & & & & & & & & & \\
\hline 7 & & & & & & & & & & & & & & & & & & & & \\
\hline & & & & & & & & & & 3756,37 & 2603,02 & & & & $\sum \mathrm{Ti}$ & 2913,15 & & $\Sigma$ & 2465,64 & 3770,42 \\
\hline
\end{tabular}

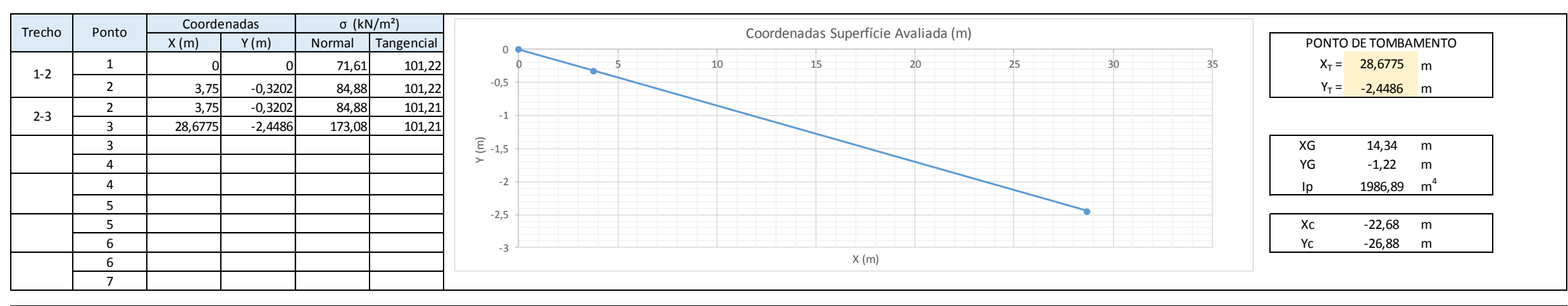

\begin{tabular}{|c|c|c|c|c|c|c|c|c|c|c|c|c|c|c|c|}
\hline \multicolumn{16}{|c|}{ PCH Mata Velha - Tomada d'Água - Junta J7 } \\
\hline \multirow{4}{*}{ ESFORÇOS } & & & CCN - DREN & PERAN & V.A. NORM & ALAMON & NTE (EL. 6 & OM) EA & TE(EL. & & & & & & \\
\hline & \multirow{3}{*}{$\begin{array}{l}\text { Dire- } \\
\text { ção }\end{array}$} & \multirow{3}{*}{$\begin{array}{l}\text { VOLUME } \\
\left(\mathrm{m}^{3}\right)\end{array}$} & \multirow{3}{*}{$\begin{array}{l}\text { Peso Específico } \\
\left(\mathrm{kN} / \mathrm{m}^{3}\right)\end{array}$} & \multirow{3}{*}{\multicolumn{2}{|c|}{$\begin{array}{l}\text { FORCA } \\
(\mathrm{kN})\end{array}$}} & \multirow{2}{*}{\multicolumn{2}{|c|}{ Coordenada (m) }} & \multicolumn{8}{|c|}{ EM RELAÇÃO AO PONTO DE TOMBAMENTO } \\
\hline & & & & & & & & \multicolumn{2}{|c|}{ Excentricidade } & \multirow{2}{*}{\multicolumn{3}{|c|}{ Estabilizador ou Tombador }} & \multirow{3}{*}{$\begin{array}{c}\text { Correção } \\
1\end{array}$} & \multirow{2}{*}{\multicolumn{2}{|c|}{$\begin{array}{l}\text { MOMENTO } \\
\text { (kN.m) }\end{array}$}} \\
\hline & & & & & & \multirow{2}{*}{\begin{tabular}{|c|}
$x$ \\
6,7514
\end{tabular}} & \multirow[t]{2}{*}{$\mathrm{Y}$} & $x_{T}-X$ & $Y_{T}-Y$ & & & & & & \\
\hline Peso de Concreto - CCV & $\mathrm{V}$ & 180,6800 & 24,0 & $\mathrm{~F}_{1}=$ & 4.336,32 & & & 21,93 & 0,00 & E & 0 & $\mathrm{E}$ & & $M_{1}=$ & $95.078,59$ \\
\hline Empuxo de Água a Montante & $\gg$ & 260,3015 & 10,0 & $\mathrm{~F}_{3}=$ & $2.603,02$ & & 6,3922 & 0,00 & $-8,84$ & 0 & $\mathrm{~T}$ & $T$ & -1 & $\mathrm{M}_{3}=$ & $-23.012,74$ \\
\hline \multirow[t]{8}{*}{ Subpressão } & $\Lambda$ & 310,0796 & 10,0 & $F_{4}=$ & $3.100,80$ & 9,5592 & & 19,12 & 0,00 & $\mathrm{~T}$ & 0 & $\mathrm{~T}$ & -1 & $M_{4}=$ & $-59.281,95$ \\
\hline & & & & $F_{5}=$ & $\begin{array}{l}0,00 \\
\end{array}$ & & & 0,00 & 0,00 & & & & & $M_{5}=$ & \\
\hline & & & & $F_{6}=$ & 0,00 & & & 0,00 & 0,00 & & & & & $M_{6}=$ & \\
\hline & & & & $F_{7}=$ & 0,00 & & & 0,00 & 0,00 & & & & & $M_{7}=$ & \\
\hline & & & & $F_{9}=$ & 0,00 & & & & & & & & & $M_{9}=$ & \\
\hline & & & & $F_{10}=$ & 0,00 & & & & & & & & & $M_{10}=$ & \\
\hline & & & & $\mathrm{F}_{11}=$ & 0,00 & & & & & & & & & $\mathrm{M}_{11}=$ & \\
\hline & & & & & 0,00 & & & & & & & & & & \\
\hline
\end{tabular}

\begin{tabular}{|c|c|c|c|c|c|c|c|c|}
\hline \multirow{3}{*}{ ESFORÇOS } & \multicolumn{8}{|c|}{ EM RELAÇÃO AO CG DA FUNDAÇÃO } \\
\hline & \multicolumn{2}{|c|}{ Excentricidade } & \multirow{2}{*}{\multicolumn{3}{|c|}{ Estabilizador ou Tombador }} & \multirow{3}{*}{$\begin{array}{c}\text { Correção } \\
1\end{array}$} & \multirow{2}{*}{\multicolumn{2}{|c|}{$\frac{\text { MOMENTO }}{(\mathrm{kN.m})}$}} \\
\hline & $x_{G}-x$ & $Y_{G}-Y$ & & & & & & \\
\hline Peso de Concreto - CCV & 7,59 & 0,00 & $E$ & 0 & E & & $M_{1}=$ & $32.901,18$ \\
\hline Peso de Rocha & $-2,09$ & 0,00 & $T$ & 0 & $T$ & -1 & $\mathrm{M}_{2}=$ & $-5.259,61$ \\
\hline Empuxo de Água a Montante & 0,00 & $-7,62$ & 0 & $T$ & $T$ & -1 & $M_{3}=$ & $-19.825,88$ \\
\hline \multirow[t]{8}{*}{ Subpressão } & 4,78 & 0,00 & $\mathrm{~T}$ & 0 & $T$ & -1 & $M_{4}=$ & $-14.820,41$ \\
\hline & & & & & & & $M_{5}=$ & \\
\hline & & & & & & & $M_{6}=$ & \\
\hline & & & & & & & $M_{7}=$ & \\
\hline & & & & & & & $M_{8}=$ & \\
\hline & & & & & & & $\mathrm{M}_{9}=$ & \\
\hline & & & & & & & $M_{10}=$ & \\
\hline & & & & & & & $M_{11}=$ & \\
\hline & & & & & & & & \\
\hline
\end{tabular}

\begin{tabular}{|c|c|c|c|c|c|c|c|c|}
\hline \multirow{2}{*}{$\Sigma V=$} & \multirow{2}{*}{$6857,1625 \mathrm{kN}$} & \multirow{2}{*}{$\sum M_{E}=$} & \multirow{2}{*}{$125.964,70 \mathrm{kN} \cdot \mathrm{m}$} & \multicolumn{5}{|c|}{ FLUTUAÇÃO - CSF } \\
\hline & & & & $\frac{\Sigma V}{\Sigma U}$ & 2,21 & $>$ & 1,3 & ок \\
\hline$\Sigma V-\Sigma U=$ & $3756,3665 \mathrm{kN}$ & Momento Resultante & $43.670,02 \mathrm{kN} \cdot \mathrm{m}$ & \multicolumn{5}{|c|}{ TOMBAMENTO - CST } \\
\hline$\sum T_{i, \text { MONTANTE }}=$ & $2603,015 \mathrm{kN}$ & & & $\frac{\sum M_{E}}{\sum M_{T}}=$ & 1,53 & $>$ & 1,5 & ок \\
\hline$\sum \mathrm{T}_{\mathrm{i}, \text { USAANE }}=$ & $4,54 / 4 / \mathrm{t}-13 \mathrm{kN}$ & & & \multicolumn{5}{|c|}{ DESLIZAMENTO - CSDQ e CSD } \\
\hline Força Resultante & $\begin{array}{r}2603,015 \mathrm{kN} \\
4570,12 \mathrm{kN}\end{array}$ & & & $\frac{N_{i} \times \operatorname{tg} \phi}{\operatorname{CSD}_{0} \times \sum \pi}+\frac{\sum \mathrm{C} \times A_{i}}{\operatorname{CSD}_{c} \times \sum \pi}=$ & 1,00 & $>$ & 1,0 & ок \\
\hline
\end{tabular}

Fonte: Do autor (2021). 


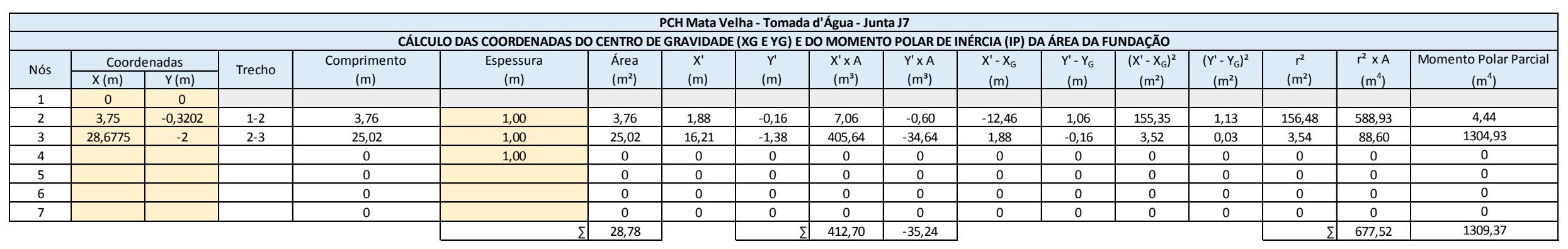

\begin{tabular}{|c|c|c|c|c|c|c|c|c|c|c|c|c|c|c|c|c|c|c|c|c|}
\hline \multirow{2}{*}{ Nós } & \multicolumn{2}{|c|}{ Coordenadas } & \multirow{2}{*}{ Trecho } & \multicolumn{2}{|c|}{ Distância C (m) } & \multicolumn{2}{|c|}{$\sigma\left(\mathrm{kN} / \mathrm{m}^{2}\right)$} & \multicolumn{2}{|c|}{$\sigma$ Média $\left(\mathrm{kN} / \mathrm{m}^{2}\right)$} & \multicolumn{2}{|c|}{ Forca $(\mathrm{kN})$} & \multirow{2}{*}{$\begin{array}{l}\text { Ângulo c/ } \\
\text { Horizontal }\end{array}$} & \multirow{2}{*}{ Sen } & \multirow{2}{*}{$\cos$} & \multicolumn{2}{|c|}{ Força corrigida (kN) } & \multirow{2}{*}{$\frac{\text { Coesão }}{\left(\mathrm{kN} / \mathrm{m}^{2}\right)}$} & \multirow{2}{*}{$\frac{\phi}{\left(0^{\circ}\right)}$} & \multirow{2}{*}{$\frac{\mathrm{N} \times \operatorname{tg} \phi}{(\mathrm{kN})}$} & \multirow{2}{*}{$\begin{array}{l}\mathrm{CXA} \\
(\mathrm{kN})\end{array}$} \\
\hline & $X(m)$ & $Y(m)$ & & Horizontal & Vertical & $\begin{array}{l}\text { Vertical } \\
\end{array}$ & Horizontal & Vertical & Horizontal & Vertical | & Horizontal & & & & Normal & Cisalhante & & & & \\
\hline 1 & 0,00 & 0,00 & & $-125,92$ & 70,77 & 156,91 & 88,19 & & & & & & & & & & & & & \\
\hline 2 & 3,75 & $-0,32$ & $1-2$ & $-129,67$ & 70,45 & 161,58 & 87,79 & 159,24 & 87,99 & 599,33 & 331,15 & 4,9 & 0,085 & 0,996 & 568,98 & 380,94 & 69 & 35 & 398,41 & 259,69 \\
\hline 3 & 28,68 & $-2,45$ & $2-3$ & $-154,60$ & 68,32 & 192,64 & 85,13 & 177,11 & 86,46 & 4430,94 & 2163,10 & 4,9 & 0,085 & 0,996 & 4230,85 & 2532,21 & 69 & 35 & 2962,47 & 1726,26 \\
\hline 4 & & & & & & & & & & & & & & & & & & & & \\
\hline 5 & & & & & & & & & & & & & & & & & & & & \\
\hline 6 & & & & & & & & & & & & & & & & & & & & \\
\hline 7 & & & & & & & & & & & & & & & & & & & & \\
\hline & & & & & & & & & & 5030,27 & 2494,25 & & & & $\sum \mathrm{Ti}$ & 2913,15 & & $\Sigma$ & 3360,88 & 1985,95 \\
\hline
\end{tabular}

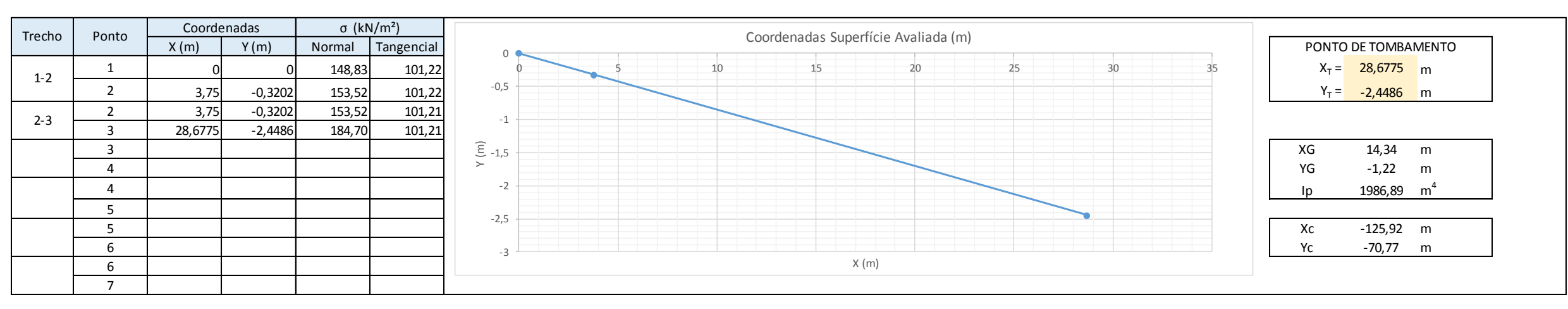

\begin{tabular}{|c|c|c|c|c|c|c|c|c|c|c|c|c|c|c|c|}
\hline \multicolumn{16}{|c|}{ PCH Mata Velha - Tomada d'Água - Junta J7 } \\
\hline \multirow{4}{*}{ ESFORÇOS } & & & CCN - DRE & ERANT & IA. NORMA & LAMONT & TE (EL. 63 & I) EAJU & FE(EL.C. & & & & & & \\
\hline & \multirow{3}{*}{$\begin{array}{l}\text { Dire- } \\
\text { ção }\end{array}$} & \multirow{3}{*}{$\begin{array}{l}\text { VOLUME } \\
\left(\mathrm{m}^{3}\right)\end{array}$} & \multirow{3}{*}{$\begin{array}{l}\text { Peso Específico } \\
\left(\mathrm{kN} / \mathrm{m}^{3}\right)\end{array}$} & \multirow{3}{*}{\multicolumn{2}{|c|}{$\begin{array}{l}\text { FORCA } \\
(\mathrm{kN})\end{array}$}} & \multirow{2}{*}{\multicolumn{2}{|c|}{ Coordenada $(\mathrm{m})$}} & \multicolumn{8}{|c|}{ EM RELAÇÃ̃ AO PONTO DE TOMBAMENTO } \\
\hline & & & & & & & & \multicolumn{2}{|c|}{ Excentricidade } & \multirow{2}{*}{\multicolumn{3}{|c|}{ Estabilizador ou Tombador }} & \multirow{2}{*}{ Correção } & \multirow{2}{*}{\multicolumn{2}{|c|}{$\begin{array}{l}\text { MOMENTO } \\
\text { (kN.m) }\end{array}$}} \\
\hline & & & & & & \multirow{2}{*}{\begin{tabular}{c|}
$x$ \\
6,7514
\end{tabular}} & \multirow[t]{2}{*}{$\mathrm{Y}$} & $x_{T}-x$ & $Y_{T}-Y$ & & & & & & \\
\hline Peso de Concreto - CCV & $\mathrm{V}$ & 180,6800 & 24,0 & $\mathrm{~F}_{1}=$ & $4.336,32$ & & & 21,93 & 0,00 & $\mathrm{E}$ & 0 & $\mathrm{E}$ & 1 & $M_{1}=$ & $95.078,59$ \\
\hline Empuxo de Água a Montante & $\gg$ & 249,4246 & 10,0 & $\mathrm{~F}_{3}=$ & $2.494,25$ & & 6,7112 & 0,00 & $-9,16$ & 0 & $\mathrm{~T}$ & $T$ & -1 & $\mathrm{M}_{3}=$ & $-22.846,79$ \\
\hline \multirow[t]{8}{*}{ Subpressão } & $\Lambda$ & 182,6895 & 10,0 & $F_{4}=$ & $1.826,90$ & 8,69 & & 19,99 & 0,00 & $T$ & 0 & $T$ & -1 & $\mathrm{M}_{4}=$ & $-36.519,63$ \\
\hline & & & & $F_{5}=$ & 0,00 & & & 0,00 & 0,00 & & & & & $M_{5}=$ & \\
\hline & & & & $F_{6}=$ & 0,00 & & & 0,00 & 0,00 & & & & & $M_{6}=$ & \\
\hline & & & & $F_{7}=$ & 0,00 & & & 0,00 & 0,00 & & & & & $\mathrm{M}_{7}=$ & \\
\hline & & & & $F_{9}=$ & 0,00 & & & & & & & & & $M_{9}=$ & \\
\hline & & & & $F_{10}=$ & 0,00 & & & & & & & & & $M_{10}=$ & \\
\hline & & & & $\mathrm{F}_{11}=$ & 0,00 & & & & & & & & & $\mathrm{M}_{11}=$ & \\
\hline & & & & & \begin{tabular}{l|l}
0,00 \\
\end{tabular} & & & & & & & & & & \\
\hline
\end{tabular}

\begin{tabular}{|c|c|c|c|c|c|c|c|c|}
\hline \multirow{3}{*}{ ESFORÇOS } & \multicolumn{8}{|c|}{ EM RELAÇÃO AO CG DA FUNDAÇÃO } \\
\hline & \multicolumn{2}{|c|}{ Excentricidade } & \multirow{2}{*}{\multicolumn{3}{|c|}{ Estabilizador ou Tombador }} & \multirow{2}{*}{ Correção } & \multirow{2}{*}{\multicolumn{2}{|c|}{$\frac{\text { MOMENTO }}{(\mathrm{kN} . \mathrm{m})}$}} \\
\hline & $x_{G}-x$ & $Y_{G}-Y_{1}$ & & & & & & \\
\hline Peso de Concreto - CCV & 7,59 & 0,00 & $E$ & 0 & E & 1 & $M_{1}=$ & $32.901,18$ \\
\hline Peso de Rocha & $-2,09$ & 0,00 & $\mathrm{~T}$ & 0 & $T$ & -1 & $\mathrm{M}_{2}=$ & $-5.259,61$ \\
\hline Empuxo de Água a Montante & 0,00 & $-7,94$ & 0 & $\bar{T}$ & $T$ & -1 & $M_{3}=$ & $-19.793,10$ \\
\hline \multirow[t]{8}{*}{ Subpressão } & 5,65 & 0,00 & $T$ & 0 & $T$ & -1 & $M_{4}=$ & $-10.324,24$ \\
\hline & & & & & & & $M_{5}=$ & \\
\hline & & & & & & & $M_{6}=$ & \\
\hline & & & & & & & $\mathrm{M}_{7}=$ & \\
\hline & & & & & & & $M_{8}=$ & \\
\hline & & & & & & & $\mathrm{M}_{\mathrm{g}}=$ & \\
\hline & & & & & & & $M_{10}=$ & \\
\hline & & & & & & & $\mathrm{M}_{11}=$ & \\
\hline
\end{tabular}

\begin{tabular}{|c|c|c|c|c|c|c|c|c|}
\hline \multirow{2}{*}{$\Sigma V=$} & \multirow[b]{2}{*}{$6857,1625 \mathrm{kN}$} & \multirow[b]{2}{*}{$\sum M_{E}=$} & \multirow{2}{*}{$125.964,70 \mathrm{kN} \cdot \mathrm{m}$} & \multicolumn{5}{|c|}{ FLUTUAÇÃ̃ - CSF } \\
\hline & & & & $\sum \mathrm{V}$ & \multirow{2}{*}{3,75} & \multirow[t]{2}{*}{$>$} & \multirow{2}{*}{1,3} & \multirow{2}{*}{ ок } \\
\hline$\Sigma U=$ & $1826,895 \mathrm{kN}$ & $\sum M_{T}=$ & $59.366,43 \mathrm{kN} . \mathrm{m}$ & $\sum U$ & & & & \\
\hline$\Sigma V-\Sigma U=$ & $5030,2675 \mathrm{kN}$ & Momento Resultante & $66.598,28 \mathrm{kN} \cdot \mathrm{m}$ & \multicolumn{5}{|c|}{ TOMBAMENTO - CST } \\
\hline$\sum T_{i}$, MONTANTE $=$ & $2494,246 \mathrm{kN}$ & & & $\frac{\sum \mathrm{M}_{\mathrm{E}}}{\sum \mathrm{M}_{\mathrm{T}}}=$ & 2,12 & $>$ & 1,5 & ок \\
\hline$\sum T_{i}$, JUSANTE $=$ & $4,54747 \mathrm{E}-13 \mathrm{kN}$ & & & \multicolumn{5}{|c|}{ DESLIZAMENTO - CSD e CSDD } \\
\hline Força Resultante & $2494,246 \mathrm{kN}$ & & & $\frac{\mathrm{N}_{\mathrm{N}} \times \operatorname{tg} \phi}{\mathrm{CSD}_{\bullet} \times \sum \pi}+\frac{\sum \mathrm{C} \times \mathrm{Ai}}{\mathrm{CSD}_{c} \times \sum \pi}=$ & 1,00 & $>$ & 1,0 & ок \\
\hline
\end{tabular}

Fonte: Do autor (2021). 


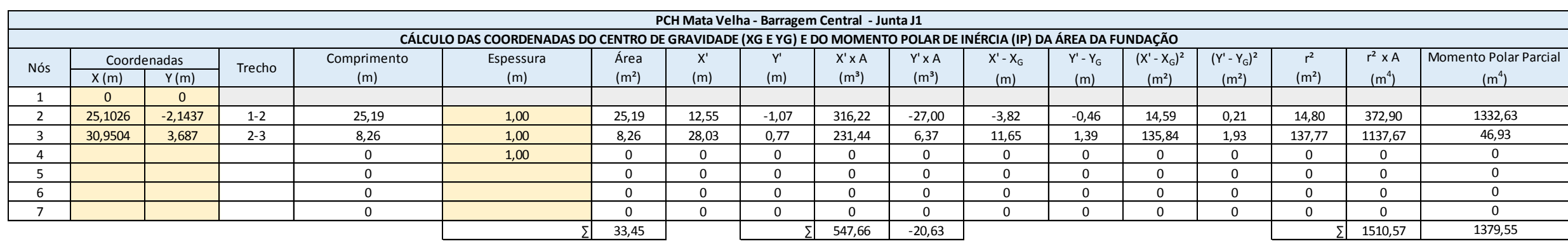

\begin{tabular}{|c|c|c|c|c|c|c|c|c|c|c|c|c|c|c|c|c|c|c|c|c|}
\hline \multirow{2}{*}{ Nós } & \multicolumn{2}{|c|}{ Coordenadas } & \multirow{2}{*}{ Trecho } & \multicolumn{2}{|c|}{ Distância C (m) } & \multicolumn{2}{|c|}{$\sigma\left(\mathrm{kN} / \mathrm{m}^{2}\right)$} & \multicolumn{2}{|c|}{$\sigma$ Média $\left(\mathrm{kN} / \mathrm{m}^{2}\right)$} & \multicolumn{2}{|c|}{ Força $(\mathrm{kN})$} & \multirow{2}{*}{$\begin{array}{l}\text { Ângulo c/ } \\
\text { Horizontal }\end{array}$} & \multirow{2}{*}{ Sen } & \multirow{2}{*}{$\cos$} & \multicolumn{2}{|c|}{ Força corrigida (kN) } & \multirow{2}{*}{$\begin{array}{l}\text { Coesão } \\
\left(\mathrm{kN} / \mathrm{m}^{2}\right)\end{array}$} & \multirow{2}{*}{$\frac{\phi}{\left({ }^{\circ}\right)}$} & \multirow{2}{*}{$\frac{\mathrm{N} \times \operatorname{tg} \phi}{(\mathrm{kN})}$} & \multirow{2}{*}{$\begin{array}{l}\mathrm{CXA} \\
(\mathrm{kN})\end{array}$} \\
\hline & $x(m)$ & $\mathrm{Y}(\mathrm{m})$ & & Horizontal & Vertical & $\begin{array}{l}\text { Vertical } \\
\end{array}$ & Horizontal & $\begin{array}{l}\text { Vertical } \\
\end{array}$ & Horizontal & \begin{tabular}{l|l|} 
Vertical \\
\end{tabular} & \begin{tabular}{|l|} 
Horizontal \\
\end{tabular} & & & & Normal & Cisalhante & & & & \\
\hline 1 & 0,00 & 0,00 & & $-1,92$ & 13,03 & 34,05 & 230,47 & & & & & & & & & & & & & \\
\hline 2 & 25,10 & $-2,14$ & $1-2$ & $-27,03$ & 10,89 & 478,06 & 192,55 & 256,05 & 211,51 & 6451,02 & 5328,72 & 4,9 & 0,085 & 0,996 & 5974,22 & 5858,29 & 0 & 35 & 4183,19 & 0,00 \\
\hline 3 & 30,95 & 3,69 & $2-3$ & $-32,88$ & 16,72 & 581,49 & 295,68 & 529,78 & 244,12 & 4374,88 & 2015,89 & $-44,9$ & $-0,706$ & 0,708 & 4521,39 & $-1661,43$ & 400 & 30 & 2610,43 & 3303,18 \\
\hline 4 & & & & & & & & & & & & & & & & & & & & \\
\hline 5 & & & & & & & & & & & & & & & & & & & & \\
\hline 6 & & & & & & & & & & & & & & & & & & & & \\
\hline 7 & & & & & & & & & & & & & & & & & & & & \\
\hline & & & & & & & & & & 10825,90 & 7344,61 & & & & $\Sigma \mathrm{Ti}$ & 4196,86 & & $\Sigma$ & 6793,62 & 3303,18 \\
\hline
\end{tabular}

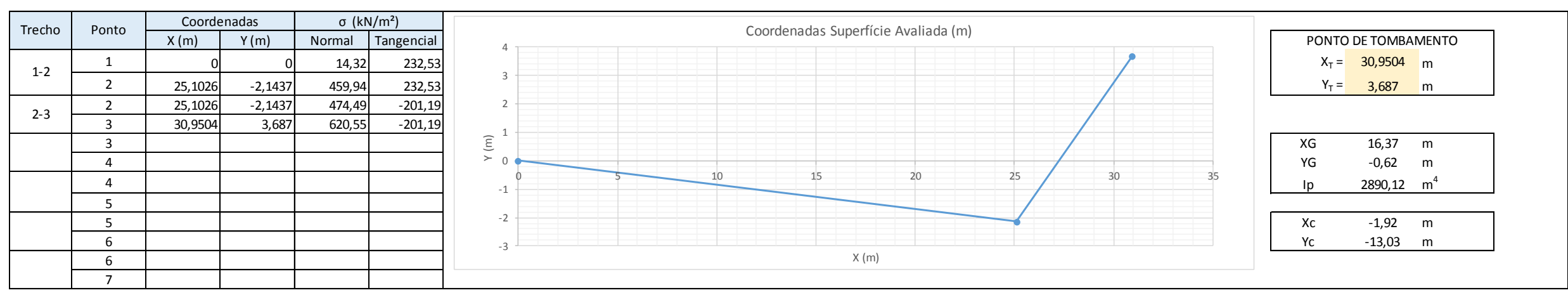

\begin{tabular}{|c|c|c|c|c|c|c|c|c|c|c|c|c|c|c|c|}
\hline \multirow{2}{*}{\multicolumn{16}{|c|}{$\begin{array}{l}\text { PCH Mata Velha - Barragem Central - Junta J1 } \\
\text { CCN - SEM DRENAGEM - N.A. NORMAL A MONTANTE (EL. 632,00m) E A JUSANTE (EL. 601,94m) }\end{array}$}} \\
\hline & & & & & & & & \multirow{2}{*}{\multicolumn{8}{|c|}{ EM RELAÇÃO AO PONTO DE TOMBAMENTO }} \\
\hline \multirow{2}{*}{ ESFORÇOS } & \multirow{2}{*}{$\begin{array}{l}\text { Dire- } \\
\text { ção }\end{array}$} & \multirow{2}{*}{$\begin{array}{l}\text { VOLUME } \\
\left(\mathrm{m}^{3}\right)\end{array}$} & \multirow{2}{*}{$\begin{array}{l}\text { Peso Específico } \\
\left(\mathrm{kN} / \mathrm{m}^{3}\right)\end{array}$} & \multirow{2}{*}{\multicolumn{2}{|c|}{$\begin{array}{l}\text { FORÇA } \\
(\mathrm{kN})\end{array}$}} & \multicolumn{2}{|c|}{ Coordenada $(\mathrm{m})$} & & & & & & & & \\
\hline & & & & & & \multirow{2}{*}{$\begin{array}{c}x \\
11,0732\end{array}$} & \multirow[t]{2}{*}{ Y } & $x_{T}-x$ & $Y_{T}-Y$ & \multicolumn{3}{|c|}{ Estabilizador ou Tombador } & Correção & \multicolumn{2}{|c|}{$\frac{\text { MOMENTO }}{(\mathrm{kN} . \mathrm{m})}$} \\
\hline Peso de Concreto - CCV & $\mathrm{V}$ & 581,2348 & 24,0 & $F_{1}=$ & $13.949,64$ & & & 19,88 & 0,00 & E & 0 & $\mathrm{E}$ & 1 & $M_{1}=$ & $277.279,69$ \\
\hline Empuxo de Água a Montante & $\gg$ & 809,5774 & 10,0 & $F_{3}=$ & $8.095,77$ & & 11,9009 & 0,00 & $-8,21$ & 0 & $\bar{T}$ & $T$ & -1 & $M_{3}=$ & $-66.497,88$ \\
\hline Subpressão & $\Lambda$ & 756,1977 & 10,0 & $F_{4}=$ & $7.561,98$ & 12,2498 & & 18,70 & 0,00 & $T$ & 0 & $T$ & -1 & $M_{4}=$ & $-141.413,51$ \\
\hline Peso de água a Montante & $\mathrm{V}$ & 49,9889 & 10,0 & $F_{5}=$ & 499,89 & 0,9996 & & 29,95 & 0,00 & $\mathrm{E}$ & 0 & $\mathrm{E}$ & 1 & $\mathrm{M}_{\mathrm{s}}=$ & $14.972,08$ \\
\hline $\begin{array}{l}\text { Peso de Água a Jusante } \\
\end{array}$ & $\mathrm{V}$ & 9,6795 & 10,0 & $F_{6}=$ & 96,80 & 29,6658 & & 1,28 & 0,00 & $\mathrm{E}$ & 0 & $\mathrm{E}$ & 1 & $M_{6}=$ & 124,34 \\
\hline \multirow[t]{5}{*}{ Empuxo de Água a Jusante } & $\ll$ & 75,1167 & 10,0 & $F_{7}=$ & 751,17 & & 1,0975 & 0,00 & 2,59 & 0 & $T$ & $\mathrm{~T}$ & -1 & $\mathrm{M}_{7}=$ & $-1.945,15$ \\
\hline & & & & $F_{9}=$ & 0,00 & & & & & & & & & $M_{9}=$ & \\
\hline & & & & $F_{10}=$ & 0,00 & & & & & & & & & $M_{10}=$ & \\
\hline & & & & $\mathrm{F}_{11}=$ & 0,00 & & & & & & & & & $M_{11}=$ & \\
\hline & & & & & 0,00 & & & & & & & & & & \\
\hline
\end{tabular}

\begin{tabular}{|c|c|c|c|c|c|c|c|c|}
\hline \multirow{3}{*}{ ESFORÇOS } & \multicolumn{8}{|c|}{ EM RELAÇÃO AO CG DA FUNDAÇÃO } \\
\hline & \multicolumn{2}{|c|}{ Excentricidade } & \multirow{2}{*}{\multicolumn{3}{|c|}{ Estabilizador ou Tombador }} & \multirow{3}{*}{$\begin{array}{c}\text { Correção } \\
1 \\
\end{array}$} & \multirow{2}{*}{\multicolumn{2}{|c|}{$\frac{\text { MOMENTO }}{(\mathrm{kN} \cdot \mathrm{m})}$}} \\
\hline & $x_{6}-x$ & $Y_{G}-Y$ & & & & & & \\
\hline Peso de Concreto - CCV & 5,30 & 0,00 & $\mathrm{E}$ & 0 & $E$ & & $M_{1}=$ & $73.909,55$ \\
\hline Peso de Rocha & $-0,05$ & 0,00 & $T$ & 0 & $T$ & -1 & $\mathrm{M}_{2}=$ & $-206,24$ \\
\hline Empuxo de Água a Montante & 0,00 & $-12,52$ & 0 & $\mathrm{~T}$ & $\mathrm{~T}$ & -1 & $M_{3}=$ & $-101.340,17$ \\
\hline Subpressão & 4,12 & 0,00 & $T$ & 0 & $T$ & -1 & $M_{4}=$ & $-31.168,31$ \\
\hline Peso de água a Montante & 15,37 & 0,00 & $\mathrm{E}$ & 0 & $\mathrm{E}$ & 1 & $M_{5}=$ & $7.684,25$ \\
\hline Peso de Água a Jusante & $-13,29$ & 0,00 & $T$ & 0 & $T$ & -1 & $M_{6}=$ & $-1.286,82$ \\
\hline \multirow[t]{5}{*}{ Empuxo de Agua a Jusante } & 0,00 & $-1,71$ & 0 & $\mathrm{E}$ & $\mathrm{E}$ & 1 & $M_{7}=$ & $1.287,70$ \\
\hline & & & & & & & $\mathrm{M}_{8}=$ & \\
\hline & & & & & & & $M_{9}=$ & \\
\hline & & & & & & & $M_{10}=$ & \\
\hline & & & & & & & $M_{11}=$ & \\
\hline & & & & & & & & \\
\hline
\end{tabular}

\begin{tabular}{|c|c|c|c|c|c|c|c|c|}
\hline \multirow[b]{2}{*}{$\Sigma V=$} & \multirow[b]{2}{*}{$18387,8742 \mathrm{kN}$} & \multirow[b]{2}{*}{$\sum M_{\mathrm{E}}=$} & \multirow[b]{2}{*}{$348.175,46 \mathrm{kN} . \mathrm{m}$} & \multicolumn{5}{|c|}{ FLUTUAÇÃO - CSF } \\
\hline & & & & $\Sigma \mathrm{V}$ & \multirow[b]{2}{*}{2,43} & \multirow[b]{2}{*}{$>$} & \multirow[b]{2}{*}{1,3} & \multirow{2}{*}{ ok } \\
\hline$\Sigma U=$ & $7561,977 \mathrm{kN}$ & $\sum M_{T}=$ & $209.856,53 \mathrm{kN} . \mathrm{m}$ & $\sum U$ & & & & \\
\hline$\Sigma V-\Sigma U=$ & $10825,8972 \mathrm{kN}$ & Momento Resultante & $138.318,93 \mathrm{kN} \cdot \mathrm{m}$ & \multicolumn{5}{|c|}{ TOMBAMENTO - CST } \\
\hline$\sum T_{i}$, MontaANE $=$ & $8095,774 \mathrm{kN}$ & & & $\frac{\sum M_{E}}{\sum M_{T}}=$ & 1,66 & $>$ & 1,5 & ок \\
\hline & $151,16 / \mathrm{kN}$ & & & \multicolumn{5}{|c|}{ DESLIZAMENTO - CSDQ e CSD ${ }_{\mathrm{c}}$} \\
\hline Força Resultante & $7344,607 \mathrm{kN}$ & & & $\frac{N_{1} \times \operatorname{tg} \phi}{\operatorname{CSD}_{6} \times \sum \pi}+\frac{\sum C_{x} \times A_{i}}{\operatorname{CSD}_{c} \times \sum \pi}=$ & 1,34 & $>$ & 1,0 & ок \\
\hline
\end{tabular}

Fonte: Do autor (2021). 


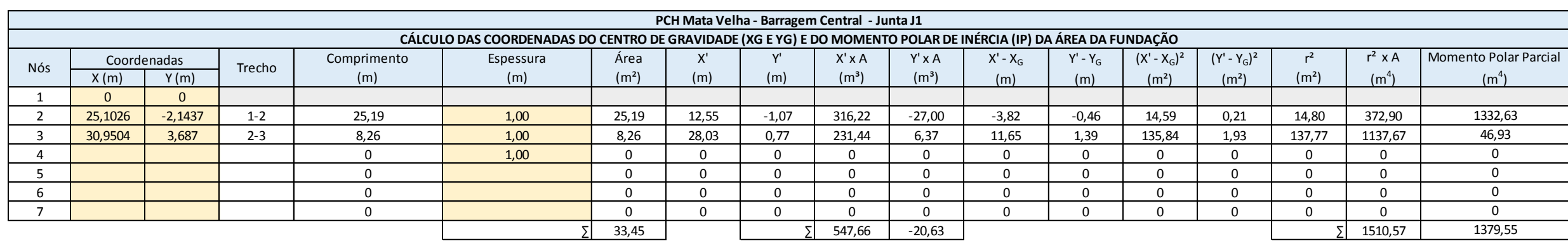

\begin{tabular}{|c|c|c|c|c|c|c|c|c|c|c|c|c|c|c|c|c|c|c|c|c|}
\hline \multirow{2}{*}{ Nós } & \multicolumn{2}{|c|}{ Coordenadas } & \multirow{2}{*}{ Trecho } & \multicolumn{2}{|c|}{ Distância C (m) } & \multicolumn{2}{|c|}{$\sigma\left(\mathrm{kN} / \mathrm{m}^{2}\right)$} & \multicolumn{2}{|c|}{$\sigma$ Média $\left(\mathrm{kN} / \mathrm{m}^{2}\right)$} & \multicolumn{2}{|c|}{ Força $(\mathrm{kN})$} & \multirow{2}{*}{$\begin{array}{l}\text { Ângulo c/ } \\
\text { Horizontal }\end{array}$} & \multirow{2}{*}{ Sen } & \multirow{2}{*}{$\cos$} & \multicolumn{2}{|c|}{ Força corrigida (kN) } & \multirow{2}{*}{$\begin{array}{l}\text { Coesão } \\
\left(\mathrm{kN} / \mathrm{m}^{2}\right)\end{array}$} & \multirow{2}{*}{$\frac{\phi}{\left({ }^{\circ}\right)}$} & \multirow{2}{*}{$\frac{\mathrm{N} \times \operatorname{tg} \phi}{(\mathrm{kN})}$} & \multirow{2}{*}{$\begin{array}{l}\mathrm{CXA} \\
(\mathrm{kN})\end{array}$} \\
\hline & $x(m)$ & $\mathrm{Y}(\mathrm{m})$ & & Horizontal & Vertical & $\begin{array}{l}\text { Vertical } \\
\end{array}$ & Horizontal & $\begin{array}{l}\text { Vertical } \\
\end{array}$ & Horizontal & \begin{tabular}{l|l|} 
Vertical \\
\end{tabular} & \begin{tabular}{|l|} 
Horizontal \\
\end{tabular} & & & & Normal & Cisalhante & & & & \\
\hline 1 & 0,00 & 0,00 & & $-7,44$ & 14,65 & 115,40 & 227,41 & & & & & & & & & & & & & \\
\hline 2 & 25,10 & $-2,14$ & $1-2$ & $-32,54$ & 12,51 & 505,01 & 194,14 & 310,20 & 210,77 & 7815,26 & 5310,25 & 4,9 & 0,085 & 0,996 & 7335,08 & 5955,98 & 0 & 35 & 5136,08 & 0,00 \\
\hline 3 & 30,95 & 3,69 & $2-3$ & $-38,39$ & 18,34 & 595,77 & 284,64 & 550,39 & 239,39 & 4545,09 & 1976,85 & $-44,9$ & $-0,706$ & 0,708 & 4614,36 & $-1809,27$ & 400 & 30 & 2664,10 & 3303,18 \\
\hline 4 & & & & & & & & & & & & & & & & & & & & \\
\hline 5 & & & & & & & & & & & & & & & & & & & & \\
\hline 6 & & & & & & & & & & & & & & & & & & & & \\
\hline 7 & & & & & & & & & & & & & & & & & & & & \\
\hline & & & & & & & & & & 12360,35 & 7287,10 & & & & $\Sigma \mathrm{Ti}$ & 4146,71 & & $\Sigma$ & 7800,18 & 3303,18 \\
\hline
\end{tabular}

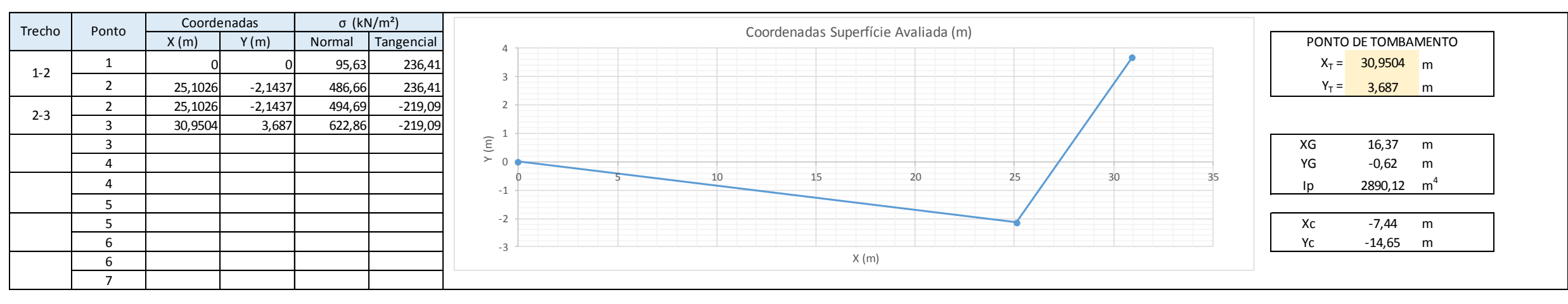

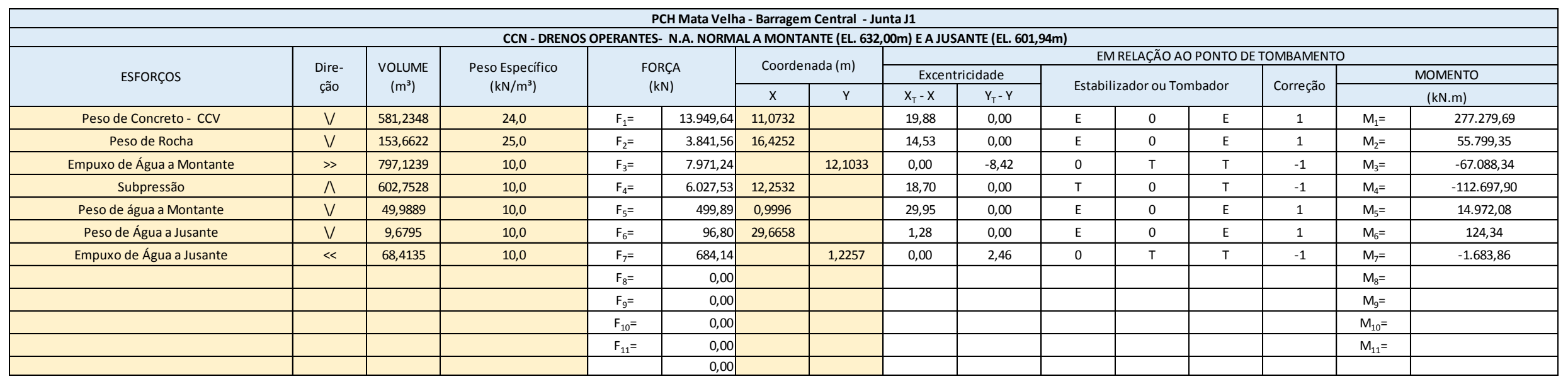

\begin{tabular}{|c|c|c|c|c|c|c|c|c|}
\hline \multirow{3}{*}{ ESFORŞOS } & \multicolumn{8}{|c|}{ EM RELAÇÃO AO CG DA FUNDAÇÃO } \\
\hline & \multicolumn{2}{|c|}{ Excentricidade } & \multirow{2}{*}{\multicolumn{3}{|c|}{ Estabilizador ou Tombador }} & \multirow{3}{*}{$\begin{array}{c}\text { Correção } \\
1 \\
\end{array}$} & \multirow{2}{*}{\multicolumn{2}{|c|}{$\frac{\text { MOMENTO }}{(\mathrm{kN.m})}$}} \\
\hline & $x_{G}-x$ & $Y_{G}-Y$ & & & & & & \\
\hline Peso de Concreto - CCV & 5,30 & 0,00 & $E$ & 0 & $\mathrm{E}$ & & $M_{1}=$ & $73.909,55$ \\
\hline Peso de Rocha & $-0,05$ & 0,00 & $T$ & 0 & $T$ & -1 & $\mathrm{M}_{2}=$ & $-206,24$ \\
\hline Empuxo de Água a Montante & 0,00 & $-12,72$ & 0 & $T$ & $\mathrm{~T}$ & -1 & $M_{3}=$ & $-101.394,66$ \\
\hline Subpressão & 4,12 & 0,00 & $\mathrm{~T}$ & 0 & $T$ & -1 & $M_{4}=$ & $-24.823,25$ \\
\hline Peso de água a Montante & 15,37 & 0,00 & $\mathrm{E}$ & 0 & $\mathrm{E}$ & 1 & $M_{5}=$ & $7.684,25$ \\
\hline Peso de Água a Jusante & $-13,29$ & 0,00 & $T$ & 0 & $T$ & -1 & $M_{6}=$ & $-1.286,82$ \\
\hline \multirow[t]{5}{*}{ Empuxo de Agua a Jusante } & 0,00 & $-1,84$ & 0 & $\mathrm{E}$ & $\mathrm{E}$ & 1 & $M_{7}=$ & $1.260,49$ \\
\hline & & & & & & & $\mathrm{M}_{8}=$ & \\
\hline & & & & & & & $M_{9}=$ & \\
\hline & & & & & & & $M_{10}=$ & \\
\hline & & & & & & & $\mathrm{M}_{11}=$ & \\
\hline & & & & & & & & \\
\hline
\end{tabular}

\begin{tabular}{|c|c|c|c|c|c|c|c|c|}
\hline \multirow{2}{*}{$\Sigma V=$} & \multirow{2}{*}{$18387,8742 \mathrm{kN}$} & \multirow{2}{*}{$\sum M_{E}=$} & & \multicolumn{5}{|c|}{ FLUTUAÇÃO - CSF } \\
\hline & & & $181.470,10 \mathrm{kN} . \mathrm{m}$ & $\frac{\Sigma V}{\sum U}=$ & 3,05 & $>$ & 1,3 & ок \\
\hline$\Sigma V-\Sigma U=$ & $12360,3462 \mathrm{kN}$ & Momento Resultante & $166.705,37 \mathrm{kN} \cdot \mathrm{m}$ & \multicolumn{5}{|c|}{ TOMBAMENTO - CST } \\
\hline$\sum \mathrm{T}_{\mathrm{i}, \text { MONTANTE }}=$ & $7971,239 \mathrm{kN}$ & & & $\frac{\sum M_{E}}{\sum M_{T}}=$ & 1,92 & $>$ & 1,5 & ок \\
\hline$\sum \mathrm{T}_{\mathrm{i}, \text { JUSANTE }}=$ & & & & \multicolumn{5}{|c|}{ DESLIZAMENTO - CSD } \\
\hline Força Resultante & $\begin{array}{l}7287,104 \mathrm{kN} \\
14348,52 \mathrm{kN}\end{array}$ & & & $\frac{N_{i} \times \operatorname{tg} \phi}{\operatorname{CSD}_{6} \times \sum \pi}+\frac{\sum \mathrm{C} \times \mathrm{Ai}^{2}}{\mathrm{CSD}_{c} \times \sum \pi}=$ & 1,52 & $>$ & 1,0 & ок \\
\hline
\end{tabular}

Fonte: Do autor (2021). 


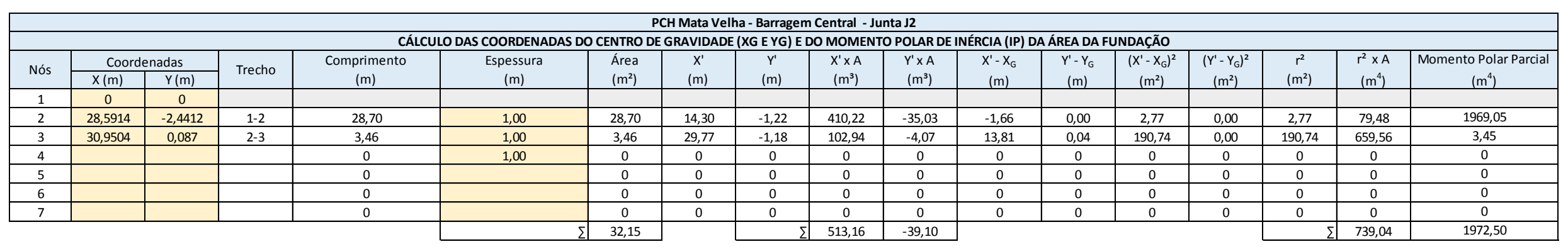

\begin{tabular}{|c|c|c|c|c|c|c|c|c|c|c|c|c|c|c|c|c|c|c|c|c|}
\hline \multirow{2}{*}{ Nós } & \multicolumn{2}{|c|}{ Coordenadas } & \multirow{2}{*}{ Trecho } & \multicolumn{2}{|c|}{ Distância C (m) } & \multicolumn{2}{|c|}{$\sigma\left(\mathrm{kN} / \mathrm{m}^{2}\right)$} & \multicolumn{2}{|c|}{$\sigma$ Média $\left(\mathrm{kN} / \mathrm{m}^{2}\right)$} & \multicolumn{2}{|c|}{ Forca $(\mathrm{kN})$} & \multirow{2}{*}{$\begin{array}{l}\text { Ângulo c/ } \\
\text { Horizontal }\end{array}$} & \multirow{2}{*}{ Sen } & \multirow{2}{*}{$\cos$} & \multicolumn{2}{|c|}{ Força corrigida (kN) } & \multirow{2}{*}{$\frac{\text { Coesão }}{\left(\mathrm{kN} / \mathrm{m}^{2}\right)}$} & \multirow{2}{*}{$\frac{\phi}{\left(0^{\circ}\right)}$} & \multirow{2}{*}{$\frac{\mathrm{N} \times \operatorname{tg} \phi}{(\mathrm{kN})}$} & \multirow{2}{*}{$\begin{array}{l}\mathrm{CxA} \\
\mathrm{kNN})\end{array}$} \\
\hline & $X(m)$ & $Y(m)$ & & Horizontal & Vertical & $\begin{array}{l}\text { Vertical } \\
\end{array}$ & Horizontal & Vertical & Horizontal & Vertical | & \begin{tabular}{|l|} 
Horizontal \\
\end{tabular} & & & & Normal & Cisalhante & & & & \\
\hline 1 & 0,00 & 0,00 & & $-9,13$ & 18,36 & 105,33 & 211,83 & & & & & & & & & & & & & \\
\hline 2 & 28,59 & $-2,44$ & $1-2$ & $-37,72$ & 15,92 & 435,15 & 183,67 & 270,24 & 197,75 & 7754,61 & 5674,53 & 4,9 & 0,085 & 0,996 & 7243,75 & 6313,66 & 123 & 35 & 5072,13 & 3529,54 \\
\hline 3 & 30,95 & 0,09 & $2-3$ & $-40,08$ & 18,45 & 462,36 & 212,83 & 448,76 & 198,25 & 1551,73 & 685,52 & $-47,0$ & $-0,731$ & 0,682 & 1559,84 & $-666,87$ & 400 & 30 & 900,57 & 1383,14 \\
\hline 4 & & & & & & & & & & & & & & & & & & & & \\
\hline 5 & & & & & & & & & & & & & & & & & & & & \\
\hline 6 & & & & & & & & & & & & & & & & & & & & \\
\hline 7 & & & & & & & & & & & & & & & & & & & & \\
\hline & & & & & & & & & & 9306,34 & 6360,05 & & & & $\sum \mathrm{Ti}$ & 5646,79 & & $\Sigma$ & 5972,70 & 4912,67 \\
\hline
\end{tabular}

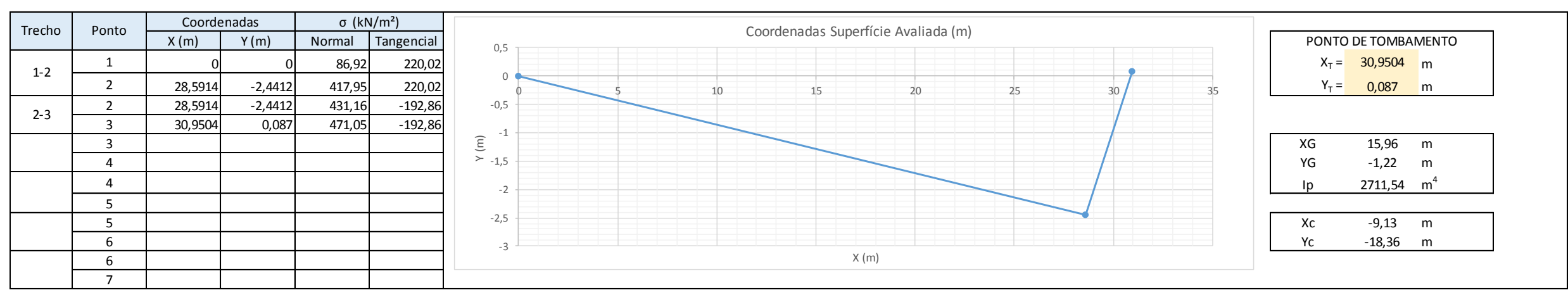

\begin{tabular}{|c|c|c|c|c|c|c|c|c|c|c|c|c|c|c|c|}
\hline \multicolumn{16}{|c|}{ PCH Mata Velha - Barragem Central - Junta J2 } \\
\hline \multirow{4}{*}{ ESFORÇOS } & & & CCN - DREN & PERAN & N.A. NORM & ALAMON & NTE (EL. 6 . & Om) EAJ & TIE (EL. & & & & & & \\
\hline & \multirow{3}{*}{$\begin{array}{l}\text { Dire- } \\
\text { ção }\end{array}$} & \multirow{3}{*}{$\begin{array}{l}\text { VOLUME } \\
\qquad\left(\mathrm{m}^{3}\right)\end{array}$} & \multirow{3}{*}{$\begin{array}{l}\text { Peso Específico } \\
\left(\mathrm{kN} / \mathrm{m}^{3}\right)\end{array}$} & \multirow{3}{*}{\multicolumn{2}{|c|}{$\begin{array}{c}\text { FORCA } \\
(\mathrm{kN})\end{array}$}} & \multirow{2}{*}{\multicolumn{2}{|c|}{ Coordenada $(\mathrm{m})$}} & \multicolumn{8}{|c|}{ EM RELAÇÃO AO PONTO DE TOMBAMENTO } \\
\hline & & & & & & & & \multicolumn{2}{|c|}{ Excentricidade } & \multirow{2}{*}{\multicolumn{3}{|c|}{ Estabilizador ou Tombador }} & \multirow{2}{*}{ Correção } & \multirow{2}{*}{\multicolumn{2}{|c|}{$\begin{array}{c}\text { MOMENTO } \\
(\mathrm{kN} . \mathrm{m})\end{array}$}} \\
\hline & & & & & & \multirow{2}{*}{$\begin{array}{c}x \\
11,0732\end{array}$} & \multirow[t]{2}{*}{$\mathrm{Y}$} & $x_{T}-x$ & $Y_{T}-Y$ & & & & & & \\
\hline Peso de Concreto - CCV & $\mathrm{V}$ & 581,2348 & 24,0 & $F_{1}=$ & $13.949,64$ & & & 19,88 & 0,00 & $\mathrm{E}$ & 0 & $\mathrm{E}$ & 1 & $M_{1}=$ & $277.279,69$ \\
\hline Empuxo de Água a Montante & $\gg$ & 665,6824 & 10,0 & $\mathrm{~F}_{3}=$ & $6.656,82$ & & 10,6207 & 0,00 & $-10,53$ & 0 & $\mathrm{~T}$ & $T$ & -1 & $\mathrm{M}_{3}=$ & $-70.120,99$ \\
\hline Subpressão & $\Lambda$ & 654,8431 & 10,0 & $F_{4}=$ & $6.548,43$ & 12,0650 & & 18,89 & 0,00 & $\mathrm{~T}$ & 0 & $\mathrm{~T}$ & -1 & $M_{4}=$ & $-123.669,74$ \\
\hline Peso de água a Montante & $\mathrm{V}$ & 49,9889 & 10,0 & $F_{5}=$ & $\begin{array}{l}499,89 \\
\end{array}$ & 0,9996 & & 29,95 & 0,00 & $E$ & 0 & $\mathrm{E}$ & 1 & $M_{5}=$ & $14.972,08$ \\
\hline Peso de Água a Jusante & $\mathrm{V}$ & 9,6795 & 10,0 & $F_{6}=$ & 96,80 & 29,6658 & & 1,28 & 0,00 & $E$ & 0 & $\mathrm{E}$ & 1 & $M_{6}=$ & 124,34 \\
\hline \multirow[t]{5}{*}{ Empuxo de Água a Jusante } & $\ll$ & 29,6770 & 10,0 & $F_{7}=$ & 296,77 & & $-0,1438$ & 0,00 & 0,23 & 0 & $T$ & $T$ & -1 & $\mathrm{M}_{7}=$ & $\begin{array}{ll}-68,49 \\
\end{array}$ \\
\hline & & & & $F_{9}=$ & 0,00 & & & & & & & & & $M_{9}=$ & \\
\hline & & & & $F_{10}=$ & 0,00 & & & & & & & & & $M_{10}=$ & \\
\hline & & & & $\mathrm{F}_{11}=$ & 0,00 & & & & & & & & & $M_{11}=$ & \\
\hline & & & & & 0,00 & & & & & & & & & & \\
\hline
\end{tabular}

\begin{tabular}{|c|c|c|c|c|c|c|c|c|}
\hline \multirow{3}{*}{ ESFORÇOS } & \multicolumn{8}{|c|}{ EM RELAÇÃO AO CG DA FUNDAÇÃO } \\
\hline & \multicolumn{2}{|c|}{ Excentricidade } & \multirow{2}{*}{\multicolumn{3}{|c|}{ Estabilizador ou Tombador }} & \multirow{3}{*}{$\begin{array}{c}\text { Correção } \\
1\end{array}$} & \multirow{2}{*}{\multicolumn{2}{|c|}{$\frac{\text { MOMENTO }}{(\mathrm{kN.m})}$}} \\
\hline & \multirow{2}{*}{$\begin{array}{l}x_{G}-x \\
4,89\end{array}$} & \multirow{2}{*}{$\frac{Y_{G}-Y}{0,00}$} & & & & & & \\
\hline Peso de Concreto - CCV & & & $E$ & 0 & E & & $M_{1}=$ & $68.168,26$ \\
\hline Peso de Rocha & $-1,24$ & 0,00 & $\mathrm{~T}$ & 0 & $T$ & -1 & $\mathrm{M}_{2}=$ & $-1.617,98$ \\
\hline Empuxo de Água a Montante & 0,00 & $-11,84$ & 0 & $T$ & $T$ & -1 & $M_{3}=$ & $-78.794,31$ \\
\hline Subpressão & 3,89 & 0,00 & $T$ & 0 & $T$ & -1 & $M_{4}=$ & $-25.505,76$ \\
\hline Peso de água a Montante & 14,96 & 0,00 & $\mathrm{E}$ & 0 & E & 1 & $M_{5}=$ & $7.478,51$ \\
\hline Peso de Agua a Jusante & $-13,71$ & 0,00 & $\mathrm{~T}$ & 0 & $\mathrm{~T}$ & -1 & $M_{6}=$ & $-1.326,66$ \\
\hline Empuxo de Água a Jusante & 0,00 & $-1,07$ & 0 & E & E & 1 & $M_{7}=$ & 318,17 \\
\hline & & & & & & & $M_{8}=$ & \\
\hline & & & & & & & $\mathrm{M}_{9}=$ & \\
\hline & & & & & & & $M_{10}=$ & \\
\hline & & & & & & & $\mathrm{M}_{11}=$ & \\
\hline
\end{tabular}

\begin{tabular}{|c|c|c|c|c|c|c|c|c|}
\hline \multirow[b]{2}{*}{$\Sigma V=$} & \multirow[b]{2}{*}{$15854,7742 \mathrm{kN}$} & & & \multicolumn{5}{|c|}{ FLUTUAÇÃO - CSF } \\
\hline & & $\sum \mathrm{M}_{\mathrm{T}}=$ & $193.859,22 \mathrm{kN} . \mathrm{m}$ & $\frac{\sum \mathrm{V}}{\sum \mathrm{U}}$ & 2,42 & $>$ & 1,3 & ок \\
\hline$\Sigma V-\Sigma U=$ & $9306,3432 \mathrm{kN}$ & Momento Resultante & $116.513,25 \mathrm{kN} . \mathrm{m}$ & \multicolumn{5}{|c|}{ TOMBAMENTO - CST } \\
\hline$\sum \mathrm{T}_{\mathrm{i}, \text { MONTANTE }}=$ & $6656,824 \mathrm{kN}$ & & & $\frac{\sum \mathrm{M}_{\mathrm{E}}}{\sum \mathrm{M}_{\mathrm{T}}}=$ & 1,60 & $>$ & 1,5 & ок \\
\hline$\sum T_{i}$, JUSANTE $=$ & & & & \multicolumn{5}{|c|}{ DESLIZAMENTO - CSD e CSDD } \\
\hline Força Resultante & $6360,054 \mathrm{kN}$ & & & $\frac{N_{N} \times \operatorname{tg} \phi}{\operatorname{CSD}_{6} \times \sum \pi}+\frac{\sum C_{0} \times A i}{\operatorname{CSD}_{c} \times \sum \pi}=$ & 1,00 & $>$ & 1,0 & ок \\
\hline
\end{tabular}

Fonte: Do autor (2021). 


\begin{tabular}{|c|c|c|c|c|c|c|c|c|c|c|c|c|c|c|c|c|c|}
\hline \multirow{2}{*}{\multicolumn{18}{|c|}{$\begin{array}{l}\text { PCH Mata Velha - Barragem Central - Junta J2 } \\
\text { CÁLCULO DAS COORDENADAS DO CENTRO DE GRAVIDADE (XG EYG) E DO MOMENTO POLAR DE INÉRCIA (IP) DA ÁREA DA FUNDAÇÃO }\end{array}$}} \\
\hline & & & & & & & & & & & & & & & & & \\
\hline Nós & \multicolumn{2}{|c|}{ Coordenadas } & Trecho & $\begin{array}{c}\text { Comprimento } \\
(\mathrm{m})\end{array}$ & $\begin{array}{l}\text { Espessura } \\
(\mathrm{m})\end{array}$ & $\begin{array}{l}\text { Área } \\
\left(m^{2}\right)\end{array}$ & $\begin{array}{l}x^{\prime} \\
(m)\end{array}$ & $\begin{array}{l}Y^{\prime} \\
(\mathrm{m})\end{array}$ & $\begin{array}{l}X^{\prime} \times A \\
\left(m^{3}\right)\end{array}$ & $\begin{array}{l}Y^{\prime} \times A \\
\left(m^{3}\right)\end{array}$ & $\begin{array}{l}x^{\prime}-x_{6} \\
(m)\end{array}$ & $\begin{array}{l}Y^{\prime}-Y_{G} \\
(m)\end{array}$ & $\begin{array}{c}\left(x^{\prime}-x_{6}\right)^{2} \\
\left(m^{2}\right)^{2}\end{array}$ & $\begin{array}{c}\left(Y^{\prime}-Y_{G}\right)^{2} \\
\left(m^{2}\right)^{2}\end{array}$ & $\begin{array}{c}r^{2} \\
\left(m^{2}\right)\end{array}$ & $\begin{array}{c}r^{2} \times A \\
\left(m^{4}\right)\end{array}$ & $\begin{array}{l}\text { Momento Polar Parcial } \\
\left(\mathrm{m}^{4}\right)\end{array}$ \\
\hline 1 & 0 & 0 & & & & & & & & & & & & & & & \\
\hline 2 & 28,5914 & $-2,4412$ & $1-2$ & 28,70 & 1,00 & 28,70 & 14,30 & $-1,22$ & 410,22 & $-35,03$ & $-1,66$ & 0,00 & 2,77 & 0,00 & 2,77 & 79,48 & 1969,05 \\
\hline 3 & 30,9504 & 0,087 & $2-3$ & 3,46 & 1,00 & 3,46 & 29,77 & $-1,18$ & 102,94 & \begin{tabular}{l|l}
$-4,07$ \\
\end{tabular} & 13,81 & 0,04 & 190,74 & 0 & 190,74 & 659,56 & 3,45 \\
\hline 4 & & & & 0 & 1,00 & 0 & 0 & 0 & 0 & 0 & 0 & 0 & 0 & 0 & 0 & 0 & 0 \\
\hline 5 & & & & 0 & & 0 & 0 & 0 & 0 & 0 & 0 & 0 & 0 & 0 & 0 & 0 & 0 \\
\hline 6 & & & & 0 & & 0 & 0 & 0 & 0 & 0 & 0 & 0 & 0 & 0 & 0 & 0 & 0 \\
\hline 7 & & & & 0 & & 0 & 0 & 0 & 0 & 0 & 0 & 0 & 0 & 0 & 0 & 0 & 0 \\
\hline & & & & & & 32,15 & & & 513,16 & $-39,10$ & & & & & & 739,04 & 1972,50 \\
\hline
\end{tabular}

\begin{tabular}{|c|c|c|c|c|c|c|c|c|c|c|c|c|c|c|c|c|c|c|c|c|}
\hline \multirow{2}{*}{ Nós } & \multicolumn{2}{|c|}{ Coordenadas } & \multirow{2}{*}{ Trecho } & \multicolumn{2}{|c|}{ Distância C (m) } & \multicolumn{2}{|c|}{$\sigma\left(\mathrm{kN} / \mathrm{m}^{2}\right)$} & \multicolumn{2}{|c|}{$\sigma$ Média $\left(\mathrm{kN} / \mathrm{m}^{2}\right)$} & \multicolumn{2}{|c|}{ Forca $(\mathrm{kN})$} & \multirow{2}{*}{$\begin{array}{l}\text { Ângulo c/ } \\
\text { Horizontal }\end{array}$} & \multirow{2}{*}{ Sen } & \multirow{2}{*}{$\cos$} & \multicolumn{2}{|c|}{ Força corrigida (kN) } & \multirow{2}{*}{$\frac{\text { Coesão }}{\left(\mathrm{kN} / \mathrm{m}^{2}\right)}$} & \multirow{2}{*}{$\frac{\phi}{\left(0^{\circ}\right)}$} & \multirow{2}{*}{$\frac{\mathrm{N} \times \operatorname{tg} \phi}{(\mathrm{kN})}$} & \multirow{2}{*}{$\begin{array}{l}\mathrm{C} \times \mathrm{A} \\
\mathrm{kN})\end{array}$} \\
\hline & $X(m)$ & $Y(m)$ & & Horizontal & Vertical & $\begin{array}{l}\text { Vertical } \\
\end{array}$ & Horizontal & Vertical & Horizontal & Vertical | & Horizontal & & & & Normal & Cisalhante & & & & \\
\hline 1 & 0,00 & 0,00 & & $-19,85$ & 21,83 & 186,90 & 205,55 & & & & & & & & & & & & & \\
\hline 2 & 28,59 & $-2,44$ & $1-2$ & $-48,44$ & 19,39 & 456,08 & 182,56 & 321,49 & 194,05 & 9225,32 & 5568,46 & 4,9 & 0,085 & 0,996 & 8718,16 & 6333,10 & 47 & 35 & 6104,52 & 1348,69 \\
\hline 3 & 30,95 & 0,09 & $2-3$ & $-50,80$ & 21,92 & 478,29 & 206,36 & 467,19 & 194,46 & 1615,46 & 672,42 & $-47,0$ & $-0,731$ & 0,682 & 1593,74 & $-722,40$ & 400 & 30 & 920,15 & 1383,14 \\
\hline 4 & & & & & & & & & & & & & & & & & & & & \\
\hline 5 & & & & & & & & & & & & & & & & & & & & \\
\hline 6 & & & & & & & & & & & & & & & & & & & & \\
\hline 7 & & & & & & & & & & & & & & & & & & & & \\
\hline & & & & & & & & & & 10840,79 & 6240,89 & & & & $\sum \mathrm{Ti}$ & 5610,70 & & $\Sigma$ & 7024,66 & 2731,82 \\
\hline
\end{tabular}

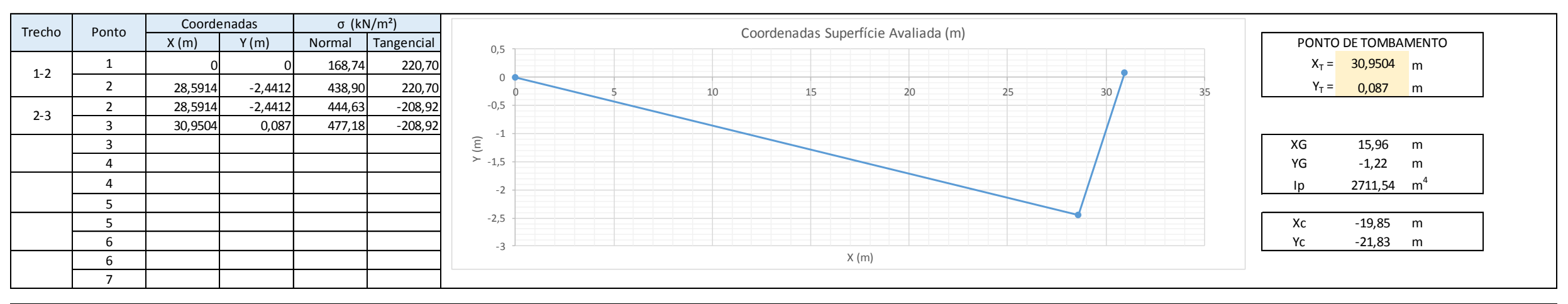

\begin{tabular}{|c|c|c|c|c|c|c|c|c|c|c|c|c|c|c|c|}
\hline \multicolumn{16}{|c|}{ PCH Mata Velha - Barragem Central - Junta J2 } \\
\hline \multirow{4}{*}{ ESFORÇOS } & & & CCN - DRE & ERANT & N.A. NORM & LAMONT & TE (EL. 63 & I) EAJ & TE (EL. 6 - & & & & & & \\
\hline & \multirow{3}{*}{$\begin{array}{l}\text { Dire- } \\
\text { ção }\end{array}$} & \multirow{3}{*}{$\begin{array}{l}\text { VOLUME } \\
\left(\mathrm{m}^{3}\right)\end{array}$} & \multirow{3}{*}{$\begin{array}{l}\text { Peso Específico } \\
\left(\mathrm{kN} / \mathrm{m}^{3}\right)\end{array}$} & \multirow{3}{*}{\multicolumn{2}{|c|}{$\begin{array}{l}\text { FORCA } \\
(\mathrm{kN})\end{array}$}} & \multirow{2}{*}{\multicolumn{2}{|c|}{ Coordenada $(\mathrm{m})$}} & \multicolumn{8}{|c|}{ EM RELAÇÃO AO PONTO DE TOMBAMENTO } \\
\hline & & & & & & & & \multicolumn{2}{|c|}{ Excentricidade } & \multirow{2}{*}{\multicolumn{3}{|c|}{ Estabilizador ou Tombador }} & \multirow{3}{*}{$\begin{array}{c}\text { Correção } \\
1\end{array}$} & \multirow{2}{*}{\multicolumn{2}{|c|}{$\begin{array}{l}\text { MOMENTO } \\
\text { (kN.m) }\end{array}$}} \\
\hline & & & & & & \multirow{2}{*}{$\begin{array}{c}x \\
11,0732 \\
\end{array}$} & \multirow[t]{2}{*}{$\mathrm{Y}$} & $x_{T}-X$ & $Y_{T}-\mathrm{Y}$ & & & & & & \\
\hline Peso de Concreto - CCV & $\mathrm{V}$ & 581,2348 & 24,0 & $F_{1}=$ & $13.949,64$ & & & 19,88 & 0,00 & $\mathrm{E}$ & 0 & $\mathrm{E}$ & & $M_{1}=$ & $277.279,69$ \\
\hline Empuxo de Água a Montante & $\gg$ & 652,6732 & 10,0 & $F_{3}=$ & $6.526,73$ & & 10,8532 & 0,00 & $-10,77$ & 0 & $\mathrm{~T}$ & $\mathrm{~T}$ & -1 & $M_{3}=$ & $-70.268,10$ \\
\hline Subpressão & $\Lambda$ & 501,3989 & 10,0 & $F_{4}=$ & $5.013,99$ & 12,0146 & & 18,94 & 0,00 & $\mathrm{~T}$ & 0 & $\mathrm{~T}$ & -1 & $M_{4}=$ & $-94.943,89$ \\
\hline Peso de água a Montante & $\mathrm{V}$ & 49,9889 & 10,0 & $F_{5}=$ & $\begin{array}{l}499,89 \\
\end{array}$ & 0,9996 & & 29,95 & 0,00 & $E$ & 0 & $\mathrm{E}$ & 1 & $M_{5}=$ & $14.972,08$ \\
\hline Peso de Água a Jusante & $\mathrm{V}$ & 9,6795 & 10,0 & $F_{6}=$ & 96,80 & 29,6658 & & 1,28 & 0,00 & $E$ & 0 & $E$ & 1 & $M_{6}=$ & 124,34 \\
\hline \multirow[t]{5}{*}{ Empuxo de Água a Jusante } & $\ll$ & 28,5844 & 10,0 & $F_{7}=$ & 285,84 & & $-0,0859$ & 0,00 & 0,17 & 0 & $\mathrm{~T}$ & $\mathrm{~T}$ & -1 & $\mathrm{M}_{7}=$ & $-49,42$ \\
\hline & & & & $F_{9}=$ & 0,00 & & & & & & & & & $\mathrm{M}_{9}=$ & \\
\hline & & & & $F_{10}=$ & 0,00 & & & & & & & & & $M_{10}=$ & \\
\hline & & & & $\mathrm{F}_{11}=$ & 0,00 & & & & & & & & & $M_{11}=$ & \\
\hline & & & & & 0,00 & & & & & & & & & & \\
\hline
\end{tabular}

\begin{tabular}{|c|c|c|c|c|c|c|c|c|}
\hline \multirow{3}{*}{ ESFORÇOS } & \multicolumn{8}{|c|}{ EM RELAÇÃO AO CG DA FUNDAÇÃO } \\
\hline & \multicolumn{2}{|c|}{ Excentricidade } & \multirow{2}{*}{\multicolumn{3}{|c|}{ Estabilizador ou Tombador }} & \multirow{3}{*}{$\begin{array}{c}\text { Correção } \\
1\end{array}$} & \multirow{2}{*}{\multicolumn{2}{|c|}{$\frac{\text { MOMENTO }}{(\mathrm{kN.m})}$}} \\
\hline & \multirow{2}{*}{$\begin{array}{l}x_{G}-x \\
4,89\end{array}$} & \multirow{2}{*}{$\frac{Y_{G}-Y}{0,00}$} & & & & & & \\
\hline Peso de Concreto - CCV & & & $E$ & 0 & E & & $M_{1}=$ & $68.168,26$ \\
\hline Peso de Rocha & $-1,24$ & 0,00 & $T$ & 0 & $T$ & -1 & $\mathrm{M}_{2}=$ & $-1.617,98$ \\
\hline Empuxo de Água a Montante & 0,00 & $-12,07$ & 0 & $\bar{T}$ & $T$ & -1 & $M_{3}=$ & $-78.771,92$ \\
\hline Subpressão & 3,95 & 0,00 & $T$ & 0 & $T$ & -1 & $M_{4}=$ & $-19.781,90$ \\
\hline Peso de água a Montante & 14,96 & 0,00 & $\mathrm{E}$ & 0 & $\mathrm{E}$ & 1 & $M_{5}=$ & $7.478,51$ \\
\hline Peso de Agua a Jusante & $-13,71$ & 0,00 & $T$ & 0 & $\mathrm{~T}$ & -1 & $M_{6}=$ & $-1.326,66$ \\
\hline Empuxo de Água a Jusante & 0,00 & $-1,13$ & 0 & $\mathrm{E}$ & E & 1 & $M_{7}=$ & 323,01 \\
\hline & & & & & & & $\mathrm{M}_{8}=$ & \\
\hline & & & & & & & $\mathrm{M}_{9}=$ & \\
\hline & & & & & & & $M_{10}=$ & \\
\hline & & & & & & & $M_{11}=$ & \\
\hline & & & & & & & & \\
\hline
\end{tabular}

\begin{tabular}{|c|c|c|c|c|c|c|c|c|}
\hline \multirow{2}{*}{$\Sigma V=$} & \multirow{2}{*}{$15854,7742 \mathrm{kN}$} & & & \multicolumn{5}{|c|}{ FLUTUAÇÃO - CSF } \\
\hline & & $\sum M_{T}=$ & $\begin{array}{l}310.372,47 \mathrm{kN} \cdot \mathrm{m} \\
165.261,42 \mathrm{kN} \cdot \mathrm{m}\end{array}$ & $\frac{\Sigma V}{\Sigma U}=$ & 3,16 & $>$ & 1,3 & ок \\
\hline$\Sigma V-\Sigma U=$ & $10840,7852 \mathrm{kN}$ & \multirow[t]{4}{*}{ Momento Resultante } & \multirow[t]{4}{*}{$145.111,05 \mathrm{kN} . \mathrm{m}$} & \multicolumn{5}{|c|}{ TOMBAMENTO - CST } \\
\hline $\begin{array}{c}\sum T_{i, \text { MONTANTE }}= \\
\sum T_{i, J \text { USANTE }}=\end{array}$ & $\begin{array}{l}6526,732 \mathrm{kN} \\
285,844 \mathrm{kN}\end{array}$ & & & $\frac{\sum M_{E}}{\sum M_{T}}=$ & 1,88 & $>$ & 1,5 & ок \\
\hline$\sum \mathrm{T}_{\mathrm{i}, \text { USANTE }}=$ & & & & \multicolumn{5}{|c|}{ DESLIZAMENTO - CSDQ e CSD ${ }_{c}$} \\
\hline Força Resultante & $6240,888 \mathrm{kN}$ & & & $\frac{N_{N} \times \operatorname{tg} \phi}{\operatorname{CSD}_{0} \times \sum \pi}+\frac{\sum C_{0} \times A_{i}}{\operatorname{CSD}_{c} \times \sum \pi}=$ & 1,00 & $>$ & 1,0 & ок \\
\hline
\end{tabular}

Fonte: Do autor (2021). 


\begin{tabular}{|c|c|c|c|c|c|c|c|c|c|c|c|c|c|c|c|c|c|}
\hline \multicolumn{18}{|c|}{ PCH Mata Velha - Barragem Central - Junta J3 } \\
\hline \multirow[b]{2}{*}{ Nós } & & & \multirow[b]{2}{*}{ Trecho } & & \multirow[b]{2}{*}{$\begin{array}{l}\text { Espessura } \\
(\mathrm{m})\end{array}$} & \multirow{2}{*}{$\begin{array}{l}\text { Área } \\
\left(\mathrm{m}^{2}\right)\end{array}$} & \multirow{2}{*}{$\begin{array}{l}\text { AVVIDAD } \\
X^{\prime} \\
(\mathrm{m})\end{array}$} & \multirow{2}{*}{$\begin{array}{l}\text { E EYG) } \\
Y^{\prime} \\
(\mathrm{m})\end{array}$} & \multirow{2}{*}{$\begin{array}{l}\text { MOMEN } \\
\mathrm{X}^{\prime} \times A \\
\left(\mathrm{~m}^{3}\right)\end{array}$} & \multirow{2}{*}{$\begin{array}{l}\text { OLLARD } \\
Y^{\prime} \times A \\
\left(m^{3}\right)\end{array}$} & \multirow{2}{*}{$\begin{array}{l}\frac{R^{R C A}\left(I^{\prime}\right)}{X^{\prime}-X_{G}} \\
(\mathrm{~m})\end{array}$} & \multirow{2}{*}{$\begin{array}{l}\text { R'ADAF } \\
\begin{array}{l}Y^{\prime}-Y_{G} \\
(m)\end{array}\end{array}$} & \multirow[b]{2}{*}{$\begin{array}{c}\left(x^{\prime}-x_{6}\right)^{2} \\
\left(m^{2}\right)^{2}\end{array}$} & \multirow[b]{2}{*}{$\begin{array}{l}\left(Y^{\prime}-Y_{G}\right)^{2} \\
\left(m^{2}\right)\end{array}$} & \multirow[b]{2}{*}{$\begin{array}{c}r^{2} \\
\left(m^{2}\right)\end{array}$} & & \multirow{2}{*}{$\begin{array}{c}\text { Momento Polar Parcial } \\
\left(\mathrm{m}^{4}\right)\end{array}$} \\
\hline & \multicolumn{2}{|c|}{ Coordenadas } & & $\begin{array}{c}\text { Comprimento } \\
(\mathrm{m})\end{array}$ & & & & & & & & & & & & $\begin{array}{l}\mathrm{r}^{2} \times \mathrm{A} \\
\left(\mathrm{m}^{4}\right)\end{array}$ & \\
\hline 1 & 0 & 0 & & & & & & & & & & & & & & & \\
\hline 2 & 20,0591 & $-0,0882$ & $1-2$ & 20,06 & 1,00 & 20,06 & 10,03 & $-0,04$ & 201,19 & $-0,88$ & $-5,63$ & 0,17 & 31,66 & 0,03 & 31,69 & 635,74 & 672,61 \\
\hline 3 & 30,0909 & $-0,9446$ & $2-3$ & 10,07 & 1,00 & 10,07 & 25,08 & $-0,52$ & 252,46 & $-5,20$ & 9,42 & $-0,30$ & $\begin{array}{l}88,71 \\
\end{array}$ & $\begin{array}{ll}0,09 \\
\end{array}$ & $\begin{array}{l}88,80 \\
\end{array}$ & 894,03 & 85,05 \\
\hline 4 & 30,95 & $-0,09$ & $3-4$ & 1,21 & 1,00 & 1,21 & 30,52 & $-0,52$ & 37,06 & $-0,63$ & 14,86 & $-0,30$ & 220,94 & 0,09 & 221,03 & 268,38 & 0,15 \\
\hline 5 & & & & 0 & & 0 & 0 & 0 & 0 & 0 & 0 & 0 & 0 & 0 & 0 & 0 & 0 \\
\hline 6 & & & & 0 & & 0 & 0 & 0 & 0 & 0 & 0 & 0 & 0 & 0 & 0 & 0 & 0 \\
\hline 7 & & & & 0 & & 0 & 0 & 0 & 0 & 0 & 0 & 0 & 0 & 0 & 0 & 0 & 0 \\
\hline & & & & & & 31,34 & & & 490,71 & $-6,71$ & & & & & & 1798,16 & 757,82 \\
\hline
\end{tabular}

\begin{tabular}{|c|c|c|c|c|c|c|c|c|c|c|c|c|c|c|c|c|c|c|c|c|}
\hline \multirow{2}{*}{ Nós } & \multicolumn{2}{|c|}{ Coordenadas } & \multirow{2}{*}{ Trecho } & \multicolumn{2}{|c|}{ Distância C (m) } & \multicolumn{2}{|c|}{$\sigma\left(\mathrm{kN} / \mathrm{m}^{2}\right)$} & \multicolumn{2}{|c|}{$\sigma$ Média $\left(\mathrm{kN} / \mathrm{m}^{2}\right)$} & \multicolumn{2}{|c|}{ Força $(\mathrm{kN})$} & \multirow{2}{*}{$\begin{array}{l}\text { Ângulo c/ } \\
\text { Horizontal }\end{array}$} & \multirow{2}{*}{ Sen } & \multirow{2}{*}{$\cos$} & \multicolumn{2}{|c|}{ Forca corrigida $(\mathrm{kN})$} & \multirow{2}{*}{$\begin{array}{l}\text { Coesão } \\
\frac{\left(\mathrm{kN} / \mathrm{m}^{2}\right)}{2}\end{array}$} & \multirow{2}{*}{$\begin{array}{l}\phi \\
\left({ }^{\circ}\right) \\
\end{array}$} & \multirow{2}{*}{$\frac{\mathrm{N} \times \operatorname{tg} \phi}{(\mathrm{kN})}$} & \multirow{2}{*}{$\begin{array}{l}\mathrm{C} \times \mathrm{A} \\
(\mathrm{kN}) \\
\end{array}$} \\
\hline & $x(m)$ & $Y(m)$ & & Horizontal & Vertical & Vertical & Horizontal & Vertical & Horizontal & Vertical & Horizontal & & & & \begin{tabular}{|l|l|} 
Normal \\
\end{tabular} & Cisalhante & & & & \\
\hline 1 & 0,00 & 0,00 & & $-11,76$ & 19,96 & 120,66 & 204,86 & & & & & & & & & & & & & \\
\hline 2 & 20,06 & $-0,09$ & $1-2$ & $-31,81$ & 19,87 & 326,56 & 203,96 & 223,61 & 204,41 & 4485,46 & 4100,28 & 0,3 & 0,004 & 1,000 & 4467,39 & 4119,97 & 400 & 30 & 2579,25 & 8023,72 \\
\hline 3 & 30,09 & $-0,94$ & $2-3$ & $-41,85$ & 19,01 & 429,53 & 195,16 & 378,04 & 199,56 & 3806,26 & 2009,23 & 4,9 & 0,085 & 0,996 & 3621,56 & 2325,71 & 0 & 35 & 2535,85 & 0,00 \\
\hline 4 & 30,95 & $-0,09$ & 3-4 & $-42,71$ & 19,87 & 438,35 & 203,97 & 433,94 & 199,57 & 526,91 & 242,32 & $-44,9$ & $-0,706$ & 0,708 & 544,14 & $-200,66$ & 400 & 30 & 314,16 & 485,70 \\
\hline 5 & & & & & & & & & & & & & & & & & & & & \\
\hline 6 & & & & & & & & & & & & & & & & & & & & \\
\hline 7 & & & & & & & & & & & & & & & & & & & & \\
\hline & & & & & & & & & & 8818,63 & 6351,84 & & & & $\sum \mathrm{Ti}$ & 6245,01 & & $\Sigma$ & 5429,25 & 8509,42 \\
\hline
\end{tabular}

\begin{tabular}{|c|c|r|r|r|r|}
\hline \multirow{2}{*}{ Trecho } & \multirow{2}{*}{ Ponto } & \multicolumn{2}{|c|}{ Coordenadas } & \multicolumn{2}{|c|}{$\sigma\left(\mathrm{kN} / \mathrm{m}^{2}\right)$} \\
\cline { 3 - 6 } & \multicolumn{1}{|c|}{$\mathrm{X}(\mathrm{m})$} & \multicolumn{1}{|c|}{$\mathrm{Y}(\mathrm{m})$} & \multicolumn{2}{|c|}{ Normal } & Tangencial \\
\hline \multirow{2}{*}{$1-2$} & 1 & 0 & 0 & 119,76 & 205,39 \\
\cline { 2 - 6 } & 2 & 20,0591 & $-0,0882$ & 325,66 & 205,39 \\
\hline \multirow{2}{*}{$2-3$} & 2 & 20,0591 & $-0,0882$ & 308,03 & 230,99 \\
\hline \multirow{3}{*}{$3-4$} & 3 & 30,0909 & $-0,9446$ & 411,37 & 230,99 \\
\hline & 3 & 30,0909 & $-0,9446$ & 441,90 & $-165,26$ \\
\hline & 4 & 30,9504 & $-0,0869$ & 454,36 & $-165,26$ \\
\hline & 4 & & & 0,00 & 0,00 \\
\cline { 2 - 6 } & 5 & & & & \\
\hline & 5 & & & & \\
\cline { 2 - 6 } & 6 & & & & \\
\hline & 6 & & & & \\
\hline & 7 & & & & \\
\hline
\end{tabular}
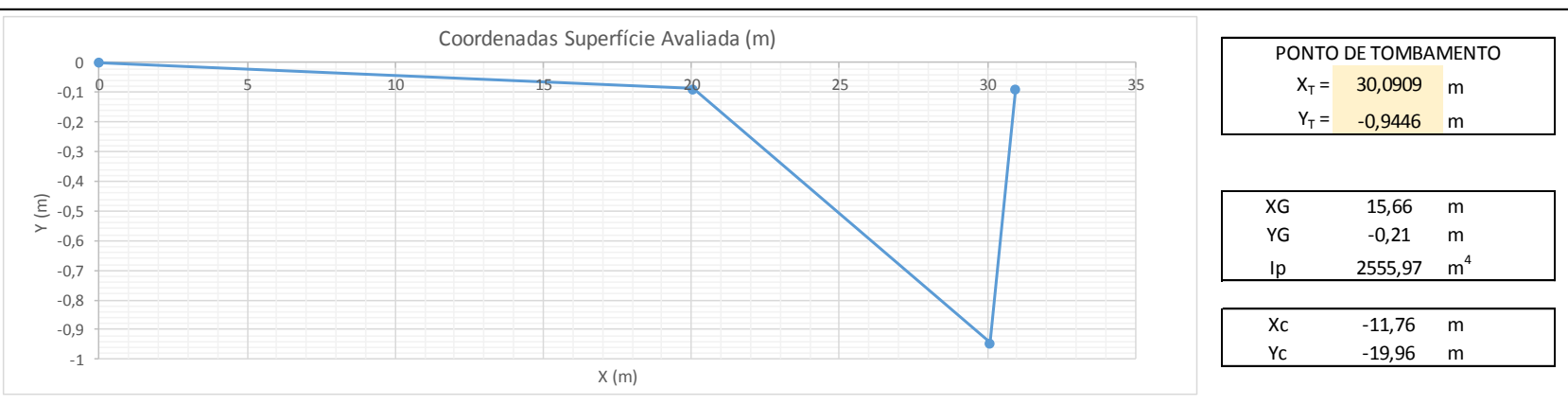

\begin{tabular}{|c|c|c|c|c|c|c|c|c|c|c|c|c|c|c|c|}
\hline \multicolumn{16}{|c|}{ PCH Mata Velha - Barragem Central - Junta J3 } \\
\hline \multirow[b]{3}{*}{ ESFORÇOS } & & & CCN - DREN & ERAN & N.A. NORN & ALAMON & VTE (EL. 6 . & OM) EA & TIE (EL. & & & & & & \\
\hline & \multirow{2}{*}{$\begin{array}{c}\text { Dire- } \\
\text { ção }\end{array}$} & \multirow{2}{*}{$\begin{array}{l}\text { VOLUME } \\
\left(\mathrm{m}^{3}\right)\end{array}$} & \multirow{2}{*}{$\begin{array}{l}\text { Peso Específico } \\
\left(\mathrm{kN} / \mathrm{m}^{3}\right)\end{array}$} & \multirow{2}{*}{\multicolumn{2}{|c|}{$\begin{array}{l}\text { FORÇA } \\
(\mathrm{kN})\end{array}$}} & \multirow{2}{*}{\multicolumn{2}{|c|}{ Coordenada $(\mathrm{m})$}} & \multicolumn{8}{|c|}{ EM RELAÇÃO AO PONTO DE TOMBAMENTO } \\
\hline & & & & & & & & \multicolumn{2}{|c|}{ Excentricidade } & \multicolumn{3}{|c|}{ Estabilizador ou Tombador } & \multirow{2}{*}{ Correção } & \multicolumn{2}{|c|}{$\begin{array}{c}\text { MOMENTO } \\
\text { (kN.m) }\end{array}$} \\
\hline Peso de Concreto - CCV & $\mathrm{V}$ & 597,9175 & 24,0 & $F_{1}=$ & $14.350,02$ & $\begin{array}{c}\mathrm{X} \\
11,0878 \\
\end{array}$ & $\mathrm{Y}$ & 19,00 & 0,00 & $\mathrm{E}$ & 0 & $\mathrm{E}$ & & $M_{1}=$ & $272.694,87$ \\
\hline Empuxo de Água a Montante & $\gg$ & 652,6732 & 10,0 & $F_{3}=$ & $6.526,73$ & & 10,8532 & 0,00 & $-11,80$ & 0 & $\mathrm{~T}$ & $\mathrm{~T}$ & -1 & $\mathrm{M}_{3}=$ & $-77.001,08$ \\
\hline Subpressão & $\Lambda$ & 623,4915 & 10,0 & $\mathrm{~F}_{4}=$ & $6.234,92$ & 11,7245 & & 18,37 & 0,00 & $\mathrm{~T}$ & 0 & $\mathrm{~T}$ & -1 & $M_{4}=$ & $-114.512,94$ \\
\hline Peso de água a Montante & $\mathrm{V}$ & 49,9889 & 10,0 & $\mathrm{~F}_{5}=$ & $\begin{array}{l}499,89 \\
\end{array}$ & 0,9996 & & 29,09 & 0,00 & $E$ & 0 & $E$ & 1 & $M_{5}=$ & $14.542,42$ \\
\hline Peso de Água a Jusante & $\mathrm{V}$ & 9,6795 & 10,0 & $F_{6}=$ & 96,80 & 29,6658 & & 0,43 & 0,00 & $\mathrm{E}$ & 0 & $\mathrm{E}$ & 1 & $M_{6}=$ & 41,15 \\
\hline \multirow[t]{5}{*}{ Empuxo de Água a Jusante } & $\ll$ & 17,4895 & 10,0 & $F_{7}=$ & 174,90 & & 0,9687 & 0,00 & $-1,91$ & 0 & $\mathrm{E}$ & $E$ & 1 & $M_{7}=$ & 334,63 \\
\hline & & & & $F_{9}=$ & 0,00 & & & & & & & & & $M_{9}=$ & \\
\hline & & & & $\mathrm{F}_{10}=$ & 0,00 & & & & & & & & & $M_{10}=$ & \\
\hline & & & & $\mathrm{F}_{11}=$ & 0,00 & & & & & & & & & $M_{11}=$ & \\
\hline & & & & & 0,00 & & & & & & & & & & \\
\hline
\end{tabular}

\begin{tabular}{|c|c|c|c|c|c|c|c|c|}
\hline \multirow{3}{*}{ ESFORÇOS } & \multicolumn{8}{|c|}{ EM RELAÇÃO AO CG DA FUNDAÇÃO } \\
\hline & \multicolumn{2}{|c|}{ Excentricidade } & \multirow{2}{*}{\multicolumn{3}{|c|}{ Estabilizador ou Tombador }} & \multirow{3}{*}{$\begin{array}{c}\text { Correção } \\
1\end{array}$} & \multirow{2}{*}{\multicolumn{2}{|c|}{$\frac{\text { MOMENTO }}{(\mathrm{kN} . \mathrm{m})}$}} \\
\hline & & \multirow{2}{*}{$\frac{Y_{G}-Y}{0,00}$} & & & & & & \\
\hline Peso de Concreto - CCV & & & $E$ & 0 & E & & $M_{1}=$ & $65.562,88$ \\
\hline Peso de Rocha & $-11,48$ & 0,00 & $T$ & 0 & $T$ & -1 & $\mathrm{M}_{2}=$ & $-1.226,65$ \\
\hline Empuxo de Água a Montante & 0,00 & $-11,07$ & 0 & $\bar{T}$ & $T$ & -1 & $M_{3}=$ & $-72.233,27$ \\
\hline Subpressão & 3,93 & 0,00 & $T$ & 0 & $T$ & -1 & $M_{4}=$ & $-24.516,53$ \\
\hline Peso de água a Montante & 14,66 & 0,00 & $\mathrm{E}$ & 0 & $\mathrm{E}$ & 1 & $M_{5}=$ & $7.326,89$ \\
\hline Peso de Agua a Jusante & $-14,01$ & 0,00 & $T$ & 0 & $\mathrm{~T}$ & -1 & $M_{6}=$ & $-1.356,02$ \\
\hline Empuxo de Água a Jusante & 0,00 & $-1,18$ & 0 & $\mathrm{E}$ & E & 1 & $M_{7}=$ & 206,86 \\
\hline & & & & & & & $\mathrm{M}_{8}=$ & \\
\hline & & & & & & & $\mathrm{M}_{9}=$ & \\
\hline & & & & & & & $M_{10}=$ & \\
\hline & & & & & & & $M_{11}=$ & \\
\hline & & & & & & & & \\
\hline
\end{tabular}

\begin{tabular}{|c|c|c|c|c|c|c|c|c|}
\hline \multirow{2}{*}{$\Sigma V=$} & \multirow{2}{*}{$15053,5465 \mathrm{kN}$} & & & \multicolumn{5}{|c|}{ FLUTUAÇÃO - CSF } \\
\hline & & $\Sigma M_{T}=$ & $\begin{array}{l}287.928,60 \mathrm{kN} \cdot \mathrm{m} \\
191.514,02 \mathrm{kN} \cdot \mathrm{m}\end{array}$ & $\frac{\Sigma V}{\Sigma U}=$ & 2,41 & $>$ & 1,3 & ок \\
\hline$\Sigma V-\Sigma U=$ & $8818,6315 \mathrm{kN}$ & Momento Resultante & $96.414,58 \mathrm{kN} . \mathrm{m}$ & \multicolumn{5}{|c|}{ TOMBAMENTO - CST } \\
\hline$\sum \mathrm{T}_{\mathrm{i}, \text { MONTANTE }}=$ & $6526,732 \mathrm{kN}$ & & & $\frac{\sum \mathrm{M}_{E}}{\sum \mathrm{M}_{\mathrm{T}}}=$ & 1,50 & $>$ & 1,5 & ок \\
\hline$\sum \mathrm{T}_{\mathrm{i}, \text { USAANE }}=$ & $174,895 \mathrm{kN}$ & & & \multicolumn{5}{|c|}{ DESLIZAMENTO - CSD $\phi$ e CSD $_{c}$} \\
\hline Força Resultante & $6351,837 \mathrm{kN}$ & & & $\frac{N_{N} \times \operatorname{tg} \phi}{\operatorname{CSD}_{0} \times \sum \pi}+\frac{\sum C_{0} \times A_{i}}{\operatorname{CSD}_{c} \times \sum \pi}=$ & 1,03 & $>$ & 1,0 & ок \\
\hline
\end{tabular}

Fonte: Do autor (2021). 


\begin{tabular}{|c|c|c|c|c|c|c|c|c|c|c|c|c|c|c|c|c|c|}
\hline \multicolumn{18}{|c|}{ PCH Mata Velha - Barragem Central - Junta J3 } \\
\hline \multirow[b]{2}{*}{ Nós } & & & \multirow[b]{2}{*}{ Trecho } & & \multirow[b]{2}{*}{$\begin{array}{l}\text { Espessura } \\
(\mathrm{m})\end{array}$} & \multirow{2}{*}{$\begin{array}{l}\text { Área } \\
\left(\mathrm{m}^{2}\right)\end{array}$} & \multirow{2}{*}{$\begin{array}{l}\text { AVVIDAD } \\
X^{\prime} \\
(\mathrm{m})\end{array}$} & \multirow{2}{*}{$\begin{array}{l}\text { E EYG) } \\
Y^{\prime} \\
(\mathrm{m})\end{array}$} & \multirow{2}{*}{$\begin{array}{l}\text { MOMEN } \\
\mathrm{X}^{\prime} \times A \\
\left(\mathrm{~m}^{3}\right)\end{array}$} & \multirow{2}{*}{$\begin{array}{l}\text { OLLARD } \\
Y^{\prime} \times A \\
\left(m^{3}\right)\end{array}$} & \multirow{2}{*}{$\begin{array}{l}\frac{R^{R C A}\left(I^{\prime}\right)}{X^{\prime}-X_{G}} \\
(\mathrm{~m})\end{array}$} & \multirow{2}{*}{$\begin{array}{l}\text { R'ADAF } \\
\begin{array}{l}Y^{\prime}-Y_{G} \\
(m)\end{array}\end{array}$} & \multirow[b]{2}{*}{$\begin{array}{c}\left(x^{\prime}-x_{6}\right)^{2} \\
\left(m^{2}\right)^{2}\end{array}$} & \multirow[b]{2}{*}{$\begin{array}{l}\left(Y^{\prime}-Y_{G}\right)^{2} \\
\left(m^{2}\right)\end{array}$} & \multirow[b]{2}{*}{$\begin{array}{c}r^{2} \\
\left(m^{2}\right)\end{array}$} & & \multirow{2}{*}{$\begin{array}{c}\text { Momento Polar Parcial } \\
\left(\mathrm{m}^{4}\right)\end{array}$} \\
\hline & \multicolumn{2}{|c|}{ Coordenadas } & & $\begin{array}{c}\text { Comprimento } \\
(\mathrm{m})\end{array}$ & & & & & & & & & & & & $\begin{array}{l}\mathrm{r}^{2} \times \mathrm{A} \\
\left(\mathrm{m}^{4}\right)\end{array}$ & \\
\hline 1 & 0 & 0 & & & & & & & & & & & & & & & \\
\hline 2 & 20,0591 & $-0,0882$ & $1-2$ & 20,06 & 1,00 & 20,06 & 10,03 & $-0,04$ & 201,19 & $-0,88$ & $-5,63$ & 0,17 & 31,66 & 0,03 & 31,69 & 635,74 & 672,61 \\
\hline 3 & 30,0909 & $-0,9446$ & $2-3$ & 10,07 & 1,00 & 10,07 & 25,08 & $-0,52$ & 252,46 & $-5,20$ & 9,42 & $-0,30$ & $\begin{array}{l}88,71 \\
\end{array}$ & $\begin{array}{ll}0,09 \\
\end{array}$ & $\begin{array}{l}88,80 \\
\end{array}$ & 894,03 & 85,05 \\
\hline 4 & 30,95 & $-0,09$ & $3-4$ & 1,21 & 1,00 & 1,21 & 30,52 & $-0,52$ & 37,06 & $-0,63$ & 14,86 & $-0,30$ & 220,94 & 0,09 & 221,03 & 268,38 & 0,15 \\
\hline 5 & & & & 0 & & 0 & 0 & 0 & 0 & 0 & 0 & 0 & 0 & 0 & 0 & 0 & 0 \\
\hline 6 & & & & 0 & & 0 & 0 & 0 & 0 & 0 & 0 & 0 & 0 & 0 & 0 & 0 & 0 \\
\hline 7 & & & & 0 & & 0 & 0 & 0 & 0 & 0 & 0 & 0 & 0 & 0 & 0 & 0 & 0 \\
\hline & & & & & & 31,34 & & & 490,71 & $-6,71$ & & & & & & 1798,16 & 757,82 \\
\hline
\end{tabular}

\begin{tabular}{|c|c|c|c|c|c|c|c|c|c|c|c|c|c|c|c|c|c|c|c|c|}
\hline \multirow{2}{*}{ Nós } & \multicolumn{2}{|c|}{ Coordenadas } & \multirow{2}{*}{ Trecho } & \multicolumn{2}{|c|}{ Distância C (m) } & \multicolumn{2}{|c|}{$\sigma\left(\mathrm{kN} / \mathrm{m}^{2}\right)$} & \multicolumn{2}{|c|}{$\sigma$ Média $\left(\mathrm{kN} / \mathrm{m}^{2}\right)$} & \multicolumn{2}{|c|}{ Forca $(\mathrm{kN})$} & \multirow{2}{*}{\begin{tabular}{|l|} 
Anngulo cl \\
Horizontal
\end{tabular}} & \multirow{2}{*}{ Sen } & \multirow{2}{*}{$\cos$} & \multicolumn{2}{|c|}{ Força corrigida $(\mathrm{kN})$} & \multirow{2}{*}{$\begin{array}{l}\text { Coesão } \\
\frac{\left(\mathrm{kN} / \mathrm{m}^{2}\right)}{2}\end{array}$} & \multirow{2}{*}{$\begin{array}{l}\phi \\
\left({ }^{\circ}\right) \\
\end{array}$} & \multirow{2}{*}{$\frac{\mathrm{N} \times \operatorname{tg} \phi}{(\mathrm{kN})}$} & \multirow{2}{*}{$\begin{array}{l}\frac{C \times A}{(k N)} \\
\end{array}$} \\
\hline & $x(m)$ & $Y(m)$ & & Horizontal & Vertical & Vertical & Horizontal & Vertical & Horizontal & Vertical & Horizontal & & & & Normal & Cisalhante & & & & \\
\hline 1 & 0,00 & 0,00 & & $-24,31$ & 23,47 & 200,91 & 193,97 & & & & & & & & & & & & & \\
\hline 2 & 20,06 & $-0,09$ & $1-2$ & $-44,37$ & 23,38 & 366,72 & 193,24 & 283,82 & 193,61 & 5693,14 & 3883,59 & 0,3 & 0,004 & 1,000 & 5676,01 & 3908,58 & 400 & 30 & 3277,04 & 8023,72 \\
\hline 3 & 30,09 & $-0,94$ & $2-3$ & $-54,40$ & 22,52 & 449,64 & 186,16 & 408,18 & 189,70 & 4109,66 & 1909,97 & 4,9 & 0,085 & 0,996 & 3932,31 & 2252,61 & 0 & 35 & 2753,43 & 0,00 \\
\hline 4 & 30,95 & $-0,09$ & 3-4 & $-55,26$ & 23,38 & 456,74 & 193,25 & 453,19 & 189,71 & 550,29 & 230,35 & $-44,9$ & $-0,706$ & 0,708 & 552,23 & $-225,65$ & 400 & 30 & 318,83 & 485,70 \\
\hline 5 & & & & & & & & & & & & & & & & & & & & \\
\hline 6 & & & & & & & & & & & & & & & & & & & & \\
\hline 7 & & & & & & & & & & & & & & & & & & & & \\
\hline & & & & & & & & & & 10353,08 & 6023,90 & & & & $\sum T \mathrm{Ti}$ & 5935,54 & & $\Sigma$ & 6349,30 & 8509,42 \\
\hline
\end{tabular}

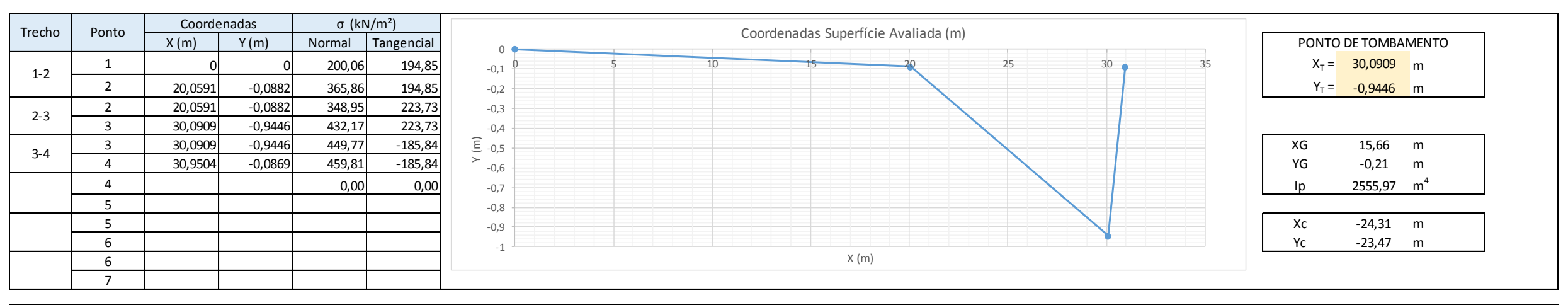

\begin{tabular}{|c|c|c|c|c|c|c|c|c|c|c|c|c|c|c|c|}
\hline \multicolumn{16}{|c|}{ PCH Mata Velha - Barragem Central - Junta J3 } \\
\hline \multirow{4}{*}{ ESFORÇOS } & & & CCN - DRE & ERANT & N.A. NORM & LAMONT & TE (EL. 63 & I) EAJ & TE (EL. 6 - & & & & & & \\
\hline & \multirow{3}{*}{$\begin{array}{l}\text { Dire- } \\
\text { ção }\end{array}$} & \multirow{3}{*}{$\begin{array}{l}\text { VOLUME } \\
\left(\mathrm{m}^{3}\right)\end{array}$} & \multirow{3}{*}{$\begin{array}{l}\text { Peso Específico } \\
\left(\mathrm{kN} / \mathrm{m}^{3}\right)\end{array}$} & \multirow{3}{*}{\multicolumn{2}{|c|}{$\begin{array}{l}\text { FORCA } \\
(\mathrm{kN})\end{array}$}} & \multirow{2}{*}{\multicolumn{2}{|c|}{ Coordenada $(\mathrm{m})$}} & \multicolumn{8}{|c|}{ EM RELAÇÃ̃ AO PONTO DE TOMBAMENTO } \\
\hline & & & & & & & & \multicolumn{2}{|c|}{ Excentricidade } & \multirow{2}{*}{\multicolumn{3}{|c|}{ Estabilizador ou Tombador }} & \multirow{3}{*}{$\begin{array}{c}\text { Correção } \\
1\end{array}$} & \multirow{2}{*}{\multicolumn{2}{|c|}{$\begin{array}{l}\text { MOMENTO } \\
\text { (kN.m) }\end{array}$}} \\
\hline & & & & & & \multirow{2}{*}{$\begin{array}{c}x \\
11,0878 \\
\end{array}$} & \multirow[t]{2}{*}{$\mathrm{Y}$} & $x_{T}-X$ & $Y_{T}-\mathrm{Y}$ & & & & & & \\
\hline Peso de Concreto - CCV & $\mathrm{V}$ & 597,9175 & 24,0 & $F_{1}=$ & $14.350,02$ & & & 19,00 & 0,00 & $\mathrm{E}$ & 0 & $\mathrm{E}$ & & $M_{1}=$ & $272.694,87$ \\
\hline Empuxo de Água a Montante & $\gg$ & 619,7101 & 10,0 & $F_{3}=$ & $6.197,10$ & & 11,4656 & 0,00 & $-12,41$ & 0 & $\mathrm{~T}$ & $\mathrm{~T}$ & -1 & $M_{3}=$ & $-76.907,26$ \\
\hline Subpressão & $\Lambda$ & 470,0463 & 10,0 & $F_{4}=$ & $4.700,46$ & 11,5588 & & 18,53 & 0,00 & $\mathrm{~T}$ & 0 & $\mathrm{~T}$ & -1 & $M_{4}=$ & $-87.109,45$ \\
\hline Peso de água a Montante & $\mathrm{V}$ & 49,9889 & 10,0 & $\mathrm{~F}_{5}=$ & 499,89 & 0,9996 & & 29,09 & 0,00 & $E$ & 0 & $\mathrm{E}$ & 1 & $M_{5}=$ & $14.542,42$ \\
\hline Peso de Água a Jusante & $\mathrm{V}$ & 9,6795 & 10,0 & $F_{6}=$ & 96,80 & 29,6658 & & 0,43 & 0,00 & $E$ & 0 & $E$ & 1 & $M_{6}=$ & 41,15 \\
\hline \multirow[t]{5}{*}{ Empuxo de Água a Jusante } & $\ll$ & 17,3198 & 10,0 & $F_{7}=$ & 173,20 & & 0,9847 & 0,00 & $-1,93$ & 0 & $E$ & $\mathrm{E}$ & 1 & $\mathrm{M}_{7}=$ & 334,15 \\
\hline & & & & $F_{9}=$ & 0,00 & & & & & & & & & $\mathrm{M}_{9}=$ & \\
\hline & & & & $F_{10}=$ & 0,00 & & & & & & & & & $M_{10}=$ & \\
\hline & & & & $\mathrm{F}_{11}=$ & 0,00 & & & & & & & & & $M_{11}=$ & \\
\hline & & & & & 0,00 & & & & & & & & & & \\
\hline
\end{tabular}

\begin{tabular}{|c|c|c|c|c|c|c|c|c|}
\hline \multirow{3}{*}{ ESFORÇOS } & \multicolumn{8}{|c|}{ EM RELAÇÃO AO CG DA FUNDAÇÃO } \\
\hline & \multicolumn{2}{|c|}{ Excentricidade } & \multirow{2}{*}{\multicolumn{3}{|c|}{ Estabilizador ou Tombador }} & \multirow{3}{*}{$\begin{array}{c}\text { Correção } \\
1\end{array}$} & \multirow{2}{*}{\multicolumn{2}{|c|}{$\frac{\text { MOMENTO }}{(\mathrm{kN.m})}$}} \\
\hline & & \multirow{2}{*}{$\frac{Y_{G}-Y}{0,00}$} & & & & & & \\
\hline Peso de Concreto - CCV & & & $E$ & 0 & E & & $M_{1}=$ & $65.562,88$ \\
\hline Peso de Rocha & $-11,48$ & 0,00 & $T$ & 0 & $T$ & -1 & $\mathrm{M}_{2}=$ & $-1.226,65$ \\
\hline Empuxo de Água a Montante & 0,00 & $-11,68$ & 0 & $\bar{T}$ & $T$ & -1 & $M_{3}=$ & $-72.380,25$ \\
\hline Subpressão & 4,10 & 0,00 & $T$ & 0 & $T$ & -1 & $M_{4}=$ & $-19.261,72$ \\
\hline Peso de água a Montante & 14,66 & 0,00 & $\mathrm{E}$ & 0 & $E$ & 1 & $M_{5}=$ & $7.326,89$ \\
\hline Peso de Agua a Jusante & $-14,01$ & 0,00 & $T$ & 0 & $\mathrm{~T}$ & -1 & $M_{6}=$ & $-1.356,02$ \\
\hline Empuxo de Água a Jusante & 0,00 & $-1,20$ & 0 & $\mathrm{E}$ & E & 1 & $M_{7}=$ & 207,63 \\
\hline & & & & & & & $\mathrm{M}_{8}=$ & \\
\hline & & & & & & & $\mathrm{M}_{9}=$ & \\
\hline & & & & & & & $M_{10}=$ & \\
\hline & & & & & & & $M_{11}=$ & \\
\hline & & & & & & & & \\
\hline
\end{tabular}

\begin{tabular}{|c|c|c|c|c|c|c|c|c|}
\hline \multirow{2}{*}{$\Sigma V=$} & \multirow{2}{*}{$15053,5465 \mathrm{kN}$} & & & \multicolumn{5}{|c|}{ FLUTUAÇÃO - CSF } \\
\hline & & $\sum M_{T}=$ & $164.016,71 \mathrm{kN} \cdot \mathrm{m}$ & $\frac{\Sigma V}{\Sigma U}=$ & 3,20 & $>$ & 1,3 & ок \\
\hline$\Sigma V-\Sigma U=$ & $10353,0835 \mathrm{kN}$ & \multirow[t]{4}{*}{ Momento Resultante } & \multirow[t]{4}{*}{$123.911,41 \mathrm{kN} . \mathrm{m}$} & \multicolumn{5}{|c|}{ TOMBAMENTO - CST } \\
\hline $\begin{array}{c}\sum T_{i, \text { MONTANTE }}= \\
\sum T_{i, J \text { USANTE }}=\end{array}$ & $\begin{array}{l}6197,101 \mathrm{kN} \\
173,198 \mathrm{kN}\end{array}$ & & & $\frac{\sum \mathrm{M}_{\mathrm{E}}}{\sum \mathrm{M}_{\mathrm{T}}}=$ & 1,76 & $>$ & 1,5 & ок \\
\hline$\sum \mathrm{T}_{\mathrm{i}, \text { USANTE }}=$ & & & & \multicolumn{5}{|c|}{ DESLIZAMENTO - CSDQ e CSD $D_{c}$} \\
\hline Força Resultante & $6023,903 \mathrm{kN}$ & & & $\frac{N_{N} \times \operatorname{tg} \phi}{\operatorname{CSD}_{0} \times \sum \pi}+\frac{\sum C_{0} \times A_{i}}{\operatorname{CSD}_{c} \times \sum \pi}=$ & 1,19 & $>$ & 1,0 & ок \\
\hline
\end{tabular}

Fonte: Do autor (2021). 


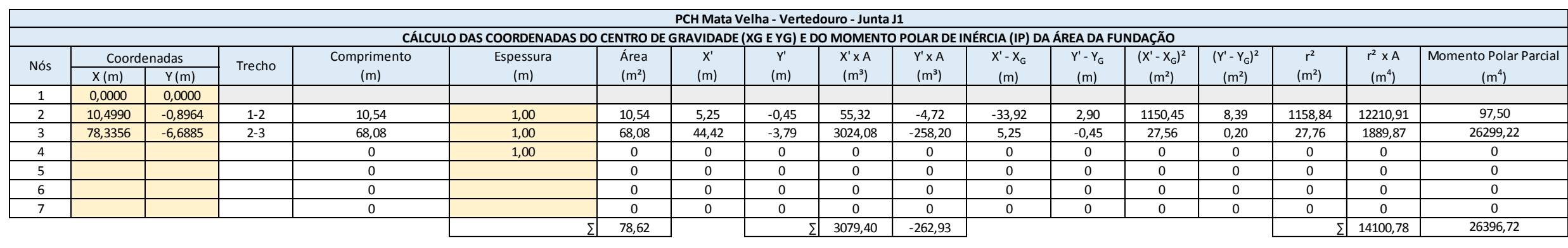

\begin{tabular}{|c|c|c|c|c|c|c|c|c|c|c|c|c|c|c|c|c|c|c|c|c|}
\hline \multirow{2}{*}{ Nós } & \multicolumn{2}{|c|}{ Coordenadas } & \multirow{2}{*}{ Trecho } & \multicolumn{2}{|c|}{ Distância C (m) } & \multicolumn{2}{|c|}{$\sigma\left(\mathrm{kN} / \mathrm{m}^{2}\right)$} & \multicolumn{2}{|c|}{$\sigma$ Média $\left(\mathrm{kN} / \mathrm{m}^{2}\right)$} & \multicolumn{2}{|c|}{ Força (kN) } & \multirow{2}{*}{$\begin{array}{l}\text { Ângulo c/ } \\
\text { Horizontal }\end{array}$} & \multirow{2}{*}{ Sen } & \multirow{2}{*}{$\cos$} & \multicolumn{2}{|c|}{ Força corrigida (kN) } & \multirow{2}{*}{$\begin{array}{l}\frac{\text { Coesão }}{\left(\mathrm{kN} / \mathrm{m}^{2}\right)} \\
\end{array}$} & \multirow{2}{*}{$\frac{\phi}{\left.l^{\circ}\right)}$} & \multirow{2}{*}{$\frac{\mathrm{N} \times \operatorname{tg} \phi}{(\mathrm{kN})}$} & \multirow{2}{*}{$\begin{array}{l}\mathrm{CXA} \\
(\mathrm{kN})\end{array}$} \\
\hline & $x(m)$ & $Y(m)$ & & Horizontal & Vertical & Vertical & Horizontal & Vertical & Horizontal & Vertical & Horizontal & & & & Normal & Cisalhante & & & & \\
\hline 1 & 0,00 & 0,00 & & 84,03 & $-14,01$ & 526,95 & 87,85 & & & & & & & & & & & & & \\
\hline 2 & 10,50 & $-0,90$ & $1-2$ & 73,53 & $-14,91$ & 461,11 & 93,47 & 494,03 & 90,66 & 5205,66 & 955,29 & 4,9 & 0,085 & 0,996 & 5105,52 & 1394,68 & 16 & 35 & 3574,93 & 168,60 \\
\hline 3 & 78,34 & $-6,69$ & $2-3$ & 5,70 & $-20,70$ & 35,71 & 129,79 & 248,41 & 111,63 & 16912,67 & 7600,18 & 4,9 & 0,085 & 0,996 & 16204,78 & 9011,45 & 16 & 35 & 11346,71 & 1089,33 \\
\hline 4 & & & & & & & & & & & & & & & & & & & & \\
\hline 5 & & & & & & & & & & & & & & & & & & & & \\
\hline 6 & & & & & & & & & & & & & & & & & & & & \\
\hline 7 & & & & & & & & & & & & & & & & & & & & \\
\hline & & & & & & & & & & 22118,33 & 8555,48 & & & & $\sum \pi \mathrm{Ti}$ & 10406,13 & & & 14921,63 & 1257,93 \\
\hline
\end{tabular}

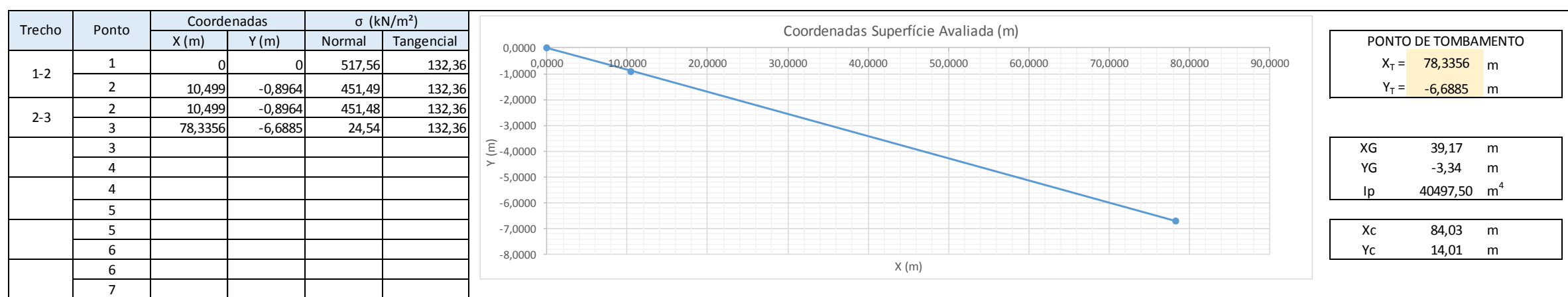

\begin{tabular}{|c|c|c|c|c|c|c|c|c|c|c|c|c|c|c|c|}
\hline \multicolumn{16}{|c|}{ PCH Mata Velha - Vertedouro - Junta J1 } \\
\hline \multirow{4}{*}{ ESFORÇOS } & & & CCN-SEN & AGEM - & NORMAL & AMONTAN & ELLL 632,0 & EAJUSA & (EL. 601 & & & & & & \\
\hline & \multirow{3}{*}{$\begin{array}{l}\text { Dire- } \\
\text { ção }\end{array}$} & \multirow{3}{*}{$\begin{array}{l}\text { VOLUME } \\
\left(\mathrm{m}^{3}\right)\end{array}$} & \multirow{3}{*}{$\begin{array}{l}\text { Peso Específico } \\
\left(\mathrm{kN} / \mathrm{m}^{3}\right)\end{array}$} & \multirow{3}{*}{\multicolumn{2}{|c|}{$\begin{array}{l}\text { FORÇA } \\
(\mathrm{kN})\end{array}$}} & \multirow{2}{*}{\multicolumn{2}{|c|}{ Coordenada $(\mathrm{m})$}} & \multicolumn{8}{|c|}{ EM RELAÇÃO AO PONTO DE TOMBAMENTO } \\
\hline & & & & & & & & \multicolumn{2}{|c|}{ Excentricidade } & \multirow{2}{*}{\multicolumn{3}{|c|}{ Estabilizador ou Tombador }} & \multirow{2}{*}{ Correç̃a } & \multirow{2}{*}{\multicolumn{2}{|c|}{$\frac{\text { MOMENTO }}{(\mathrm{kN} . \mathrm{m})}$}} \\
\hline & & & & & & \multirow{2}{*}{$\begin{array}{c}x \\
18,7469 \\
\end{array}$} & \multirow[t]{2}{*}{ Y } & $x_{T}-x$ & $Y_{T}-Y_{1}$ & & & & & & \\
\hline Peso de Concreto - CCV & $\mathrm{V}$ & 1087,0195 & 24,0 & $F_{1}=$ & $26.088,47$ & & & 59,59 & 0,00 & $\mathrm{E}$ & 0 & $\mathrm{E}$ & 1 & $M_{1}=$ & $1.554 .577,89$ \\
\hline Empuxo de Água a Montante & $\gg$ & 996,2577 & 10,0 & $\mathrm{~F}_{3}=$ & $9.962,58$ & & 10,2737 & 0,00 & $-16,96$ & 0 & $T$ & $\mathrm{~T}$ & -1 & $\mathrm{M}_{3}=$ & $-168.987,22$ \\
\hline Subpressão & $\Lambda$ & $2.229,5350$ & 10,0 & $F_{4}=$ & $22.295,35$ & 33,8072 & & 44,53 & 0,00 & $T$ & 0 & $T$ & -1 & $M_{4}=$ & $-992.776,26$ \\
\hline Peso de água a Montante & V & 109,3500 & 10,0 & $F_{5}=$ & $1.093,50$ & 3,3750 & & 74,96 & 0,00 & $\mathrm{E}$ & 0 & $\mathrm{E}$ & 1 & $M_{5}=$ & $81.969,42$ \\
\hline Peso de Água a Jusante & V & 273,6497 & 10,0 & $F_{6}=$ & $2.736,50$ & 64,1209 & & 14,21 & 0,00 & $\mathrm{E}$ & 0 & $\mathrm{E}$ & 1 & $M_{6}=$ & $38.898,48$ \\
\hline \multirow[t]{5}{*}{ Empuxo de Água a Jusante } & $\ll$ & 140,7102 & 10,0 & $F_{7}=$ & $1.407,10$ & & $-1,0967$ & 0,00 & $-5,59$ & 0 & $\mathrm{E}$ & $\mathrm{E}$ & 1 & $\mathrm{M}_{7}=$ & $7.868,23$ \\
\hline & & & & $F_{9}=$ & 0,00 & & & & & & & & & $M_{9}=$ & \\
\hline & & & & $\mathrm{F}_{10}=$ & 0,00 & & & & & & & & & $M_{10}=$ & \\
\hline & & & & $\mathrm{F}_{11}=$ & 0,00 & & & & & & & & & $\mathrm{M}_{11}=$ & \\
\hline & & & & & 0,00 & & & & & & & & & & \\
\hline
\end{tabular}

\begin{tabular}{|c|c|c|c|c|c|c|c|c|}
\hline \multirow{3}{*}{ ESFORÇOS } & \multicolumn{8}{|c|}{ EM RELAÇÃO AO CG DA FUNDAÇÃO } \\
\hline & \multicolumn{2}{|c|}{ Excentricidade } & \multirow{2}{*}{\multicolumn{3}{|c|}{ Estabilizador ou Tombador }} & \multirow{3}{*}{$\begin{array}{c}\text { Correção } \\
1 \\
\end{array}$} & \multirow{2}{*}{\multicolumn{2}{|c|}{$\begin{array}{l}\text { MOMENTO } \\
(\mathrm{kN} \cdot \mathrm{m})\end{array}$}} \\
\hline & $x_{G}-x$ & $Y_{G}-Y$ & & & & & & \\
\hline Peso de Concreto - CCV & 20,42 & 0,00 & $\mathrm{E}$ & 0 & $\mathrm{E}$ & & $M_{1}=$ & $532.750,03$ \\
\hline Peso de Rocha & 0,16 & 0,00 & $\mathrm{E}$ & 0 & $\mathrm{E}$ & 1 & $\mathrm{M}_{2}=$ & $2.372,89$ \\
\hline Empuxo de Água a Montante & 0,00 & $-13,62$ & 0 & $\mathrm{~T}$ & $T$ & -1 & $\mathrm{M}_{3}=$ & $-135.669,72$ \\
\hline Subpressão & 5,36 & 0,00 & $\mathrm{~T}$ & 0 & $\mathrm{~T}$ & -1 & $M_{4}=$ & $-119.516,48$ \\
\hline Peso de água a Montante & 35,79 & 0,00 & $\mathrm{E}$ & 0 & E & 1 & $M_{5}=$ & $39.139,43$ \\
\hline Peso de Água a Jusante & $-24,95$ & 0,00 & $T$ & 0 & $T$ & -1 & $M_{6}=$ & $-68.284,08$ \\
\hline \multirow[t]{6}{*}{ Empuxo de Água a Jusante } & 0,00 & $-2,25$ & 0 & $\mathrm{E}$ & E & 1 & $\mathrm{M}_{7}=$ & $3.162,51$ \\
\hline & & & & & & & $M_{8}=$ & \\
\hline & & & & & & & $M_{9}=$ & \\
\hline & & & & & & & $M_{10}=$ & \\
\hline & & & & & & & $M_{11}=$ & \\
\hline & & & & & & & & \\
\hline
\end{tabular}

\begin{tabular}{|c|c|c|c|c|c|c|c|c|}
\hline & & & & \multicolumn{5}{|c|}{ FLUTUAÇÃO - CSF } \\
\hline$\Sigma U=$ & $22295,35 \mathrm{kN}$ & $\sum M_{T}=$ & $1.161 .763,49 \mathrm{kN} . \mathrm{m}$ & $\frac{\Sigma V}{\sum U}=$ & 1,99 & $>$ & 1,3 & ok \\
\hline$\Sigma V-\Sigma U=$ & $22118,3275 \mathrm{kN}$ & Momento Resultante & $1.091 .668,99 \mathrm{kN} . \mathrm{m}$ & \multicolumn{5}{|c|}{ TOMBAMENTO - CST } \\
\hline $\begin{array}{c}\sum \mathrm{T}_{\mathrm{i}, \text { MONTANTE }}= \\
\sum \mathrm{T}_{\mathrm{i}, \text { JUSANTE }}=\end{array}$ & $9962,577 \mathrm{kN}$ & & & $\frac{\sum M_{E}}{\sum M_{T}}=$ & 1,94 & $>$ & 1,5 & ок \\
\hline & & & & \multicolumn{5}{|c|}{ DESLIZAMENTO - CSDQ e CSD $D_{C}$} \\
\hline Força Resultante & $8555,475 \mathrm{kN}$ & & & $\frac{N_{N} \times \operatorname{tg} \phi}{\operatorname{CSD}_{0} \times \sum \pi}+\frac{\sum \mathrm{C} \times \mathrm{Ai}}{\mathrm{CSD}_{\mathrm{c}} \times \sum \pi}=$ & 1,00 & $>$ & 1,0 & ок \\
\hline
\end{tabular}

Fonte: Do autor (2021). 


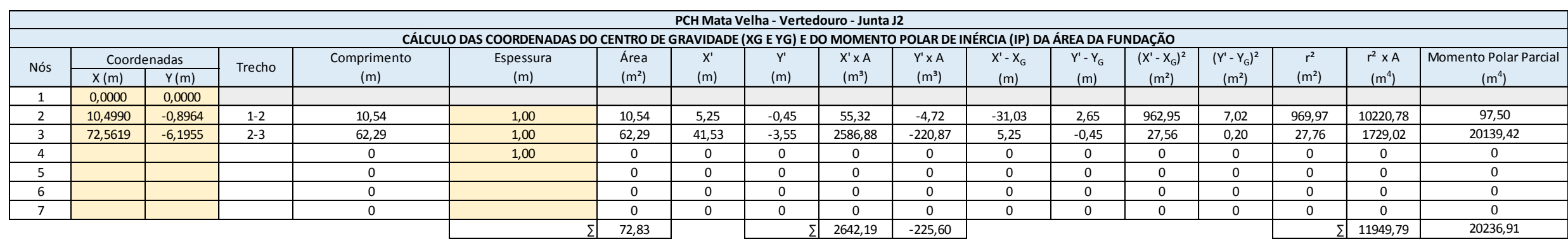

\begin{tabular}{|c|c|c|c|c|c|c|c|c|c|c|c|c|c|c|c|c|c|c|c|c|}
\hline \multirow{2}{*}{ Nós } & \multicolumn{2}{|c|}{ Coordenadas } & \multirow{2}{*}{ Trecho } & \multicolumn{2}{|c|}{ Distância C (m) } & \multicolumn{2}{|c|}{$\sigma\left(\mathrm{kN} / \mathrm{m}^{2}\right)$} & \multicolumn{2}{|c|}{$\sigma$ Média $\left(\mathrm{kN} / \mathrm{m}^{2}\right)$} & \multicolumn{2}{|c|}{ Força $(\mathrm{kN})$} & \multirow{2}{*}{\begin{tabular}{|l|}
$\begin{array}{l}\text { Anngulo o/ } \\
\text { Horizontal }\end{array}$ \\
\end{tabular}} & \multirow[b]{2}{*}{ Sen } & \multirow{2}{*}{$\cos$} & \multicolumn{2}{|c|}{$\begin{array}{l}\text { Força corrigida }(\mathrm{kN}) \\
\end{array}$} & \multirow{3}{*}{$\begin{array}{l}\text { Coesão } \\
\left(\mathrm{kN} / \mathrm{m}^{2}\right)\end{array}$} & \multirow{2}{*}{$\frac{\phi}{\left(^{\circ}\right)}$} & \multirow{2}{*}{$\begin{array}{c}\mathrm{N} \times \mathrm{tg} \phi \\
(\mathrm{kN})\end{array}$} & \multirow{2}{*}{$\begin{array}{l}\mathrm{CXA} \\
(\mathrm{kN}) \\
\end{array}$} \\
\hline & $x(m)$ & $Y(m)$ & & \begin{tabular}{|l|} 
Horizontal \\
\end{tabular} & Vertical & Vertical & Horizontal & Vertical & Horizontal & Vertical & Horizontal & & & & Normal & Cisalhante & & & & \\
\hline 1 & 0,00 & 0,00 & & 69,07 & $-10,19$ & 492,03 & 72,60 & & & & & & & & & & & & & \\
\hline 2 & 10,50 & $-0,90$ & $1-2$ & 58,57 & $-11,09$ & 417,23 & 78,98 & 454,63 & 75,79 & 4790,51 & 798,61 & 4,9 & 0,085 & 0,996 & 4705,21 & 1203,24 & 27 & 35 & 3294,62 & 284,50 \\
\hline 3 & 72,56 & $-6,20$ & $2-3$ & $-3,49$ & $-16,39$ & $-24,89$ & 116,73 & 196,17 & 97,86 & 12219,27 & 6095,40 & 4,9 & 0,085 & 0,996 & 11656,41 & 7112,83 & 27 & 35 & 8161,91 & 1681,80 \\
\hline 4 & & & & & & & & & & & & & & & & & & & & \\
\hline 5 & & & & & & & & & & & & & & & & & & & & \\
\hline 6 & & & & & & & & & & & & & & & & & & & & \\
\hline 7 & & & & & & & & & & & & & & & & & & & & \\
\hline & & & & & & & & & & 17009,78 & 6894,00 & & & & $\sum \pi \mathrm{Ti}$ & 8316,07 & & & 11456,53 & 1966,30 \\
\hline
\end{tabular}

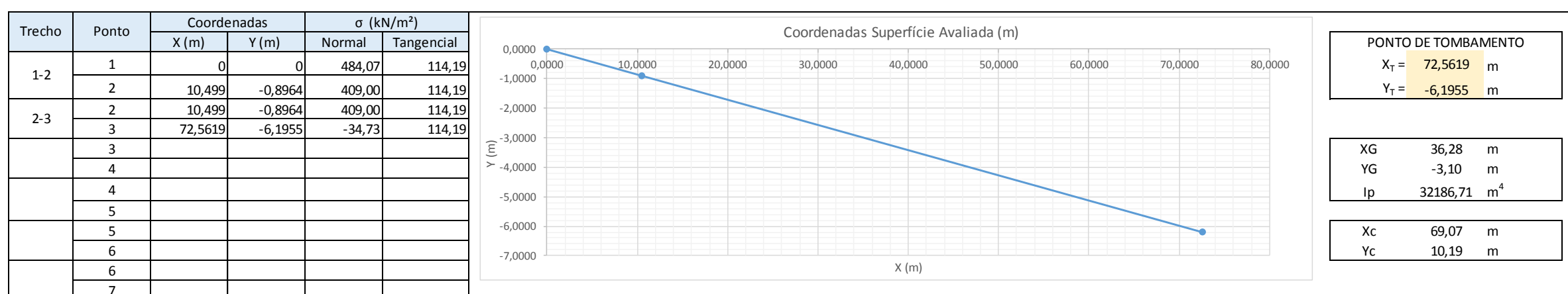

\begin{tabular}{|c|c|c|c|c|c|c|c|c|c|c|c|c|c|c|c|}
\hline \multicolumn{16}{|c|}{ PCH Mata Velha - Vertedouro - Junta J2 } \\
\hline \multirow{4}{*}{ ESFORÇOS } & & & CCN-DRENC & ERANT & N.A. NORMA & ALA MONT & UTE (EL. 6 & OM) EAJ & TE (EL. 6 G & & & & & & \\
\hline & \multirow{3}{*}{$\begin{array}{l}\text { Dire- } \\
\text { ção }\end{array}$} & \multirow{3}{*}{$\begin{array}{l}\text { VOLUME } \\
\left(\mathrm{m}^{3}\right)\end{array}$} & \multirow{3}{*}{$\begin{array}{l}\text { Peso Específico } \\
\left(\mathrm{kN} / \mathrm{m}^{3}\right)\end{array}$} & \multirow{3}{*}{\multicolumn{2}{|c|}{$\begin{array}{c}\text { FORÇA } \\
(\mathrm{kN})\end{array}$}} & \multirow{2}{*}{\multicolumn{2}{|c|}{ Coordenada (m) }} & \multicolumn{8}{|c|}{ EM RELAÇÃO AO PONTO DE TOMBAMENTO } \\
\hline & & & & & & & & \multicolumn{2}{|c|}{ Excentricidade } & \multirow{2}{*}{\multicolumn{3}{|c|}{ Estabilizador ou Tombador }} & \multirow{2}{*}{ Correç̃a } & \multirow{2}{*}{\multicolumn{2}{|c|}{$\frac{\text { MOMENTO }}{(\mathrm{kN} . \mathrm{m})}$}} \\
\hline & & & & & & \multirow{2}{*}{$\begin{array}{c}x \\
18,7469 \\
\end{array}$} & \multirow[t]{2}{*}{ Y } & $x_{T}-x$ & $Y_{T}-Y$ & & & & & & \\
\hline Peso de Concreto - CCV & $\mathrm{V}$ & 1087,0195 & 24,0 & $F_{1}=$ & $26.088,47$ & & & 53,82 & 0,00 & $E$ & 0 & $\mathrm{E}$ & 1 & $\mathrm{M}_{1}=$ & $1.403 .950,91$ \\
\hline Empuxo de Água a Montante & $\gg$ & 749,9216 & 10,0 & $\mathrm{~F}_{3}=$ & $7.499,22$ & & 8,9349 & 0,00 & $-15,13$ & 0 & $T$ & $\mathrm{~T}$ & -1 & $\mathrm{M}_{3}=$ & $-113.466,14$ \\
\hline Subpressão & $\Lambda$ & 1664,1457 & 10,0 & $F_{4}=$ & $16.641,46$ & 29,9888 & & 42,57 & 0,00 & $T$ & 0 & $T$ & -1 & $M_{4}=$ & $-708.478,41$ \\
\hline Peso de água a Montante & V & 109,3500 & 10,0 & $F_{5}=$ & $1.093,50$ & 3,3750 & & 69,19 & 0,00 & $\mathrm{E}$ & 0 & $\mathrm{E}$ & 1 & $M_{5}=$ & $75.655,88$ \\
\hline Peso de Água a Jusante & V & 193,4606 & 10,0 & $F_{6}=$ & $1.934,61$ & 59,3426 & & 13,22 & 0,00 & $\mathrm{E}$ & 0 & $\mathrm{E}$ & 1 & $M_{6}=$ & $25.574,14$ \\
\hline \multirow[t]{5}{*}{ Empuxo de Água a Jusante } & $\ll$ & 60,5211 & 10,0 & $F_{7}=$ & 605,21 & & $-2,5282$ & 0,00 & $-3,67$ & 0 & $\mathrm{E}$ & $\mathrm{E}$ & 1 & $\mathrm{M}_{7}=$ & $2.219,49$ \\
\hline & & & & $F_{9}=$ & 0,00 & & & & & & & & & $M_{9}=$ & \\
\hline & & & & $\mathrm{F}_{10}=$ & 0,00 & & & & & & & & & $M_{10}=$ & \\
\hline & & & & $\mathrm{F}_{11}=$ & 0,00 & & & & & & & & & $\mathrm{M}_{11}=$ & \\
\hline & & & & & 0,00 & & & & & & & & & & \\
\hline
\end{tabular}

\begin{tabular}{|c|c|c|c|c|c|c|c|c|}
\hline \multirow{3}{*}{ ESFORÇOS } & \multicolumn{8}{|c|}{ EM RELAÇÃO AO CG DA FUNDAÇÃO } \\
\hline & \multicolumn{2}{|c|}{ Excentricidade } & \multirow{2}{*}{\multicolumn{3}{|c|}{ Estabilizador ou Tombador }} & \multirow{3}{*}{$\begin{array}{c}\text { Correção } \\
1 \\
\end{array}$} & \multirow{2}{*}{\multicolumn{2}{|c|}{$\begin{array}{c}\text { MOMENTO } \\
(\mathrm{kN} . \mathrm{m})\end{array}$}} \\
\hline & $x_{6}-x$ & $Y_{G}-Y$ & & & & & & \\
\hline Peso de Concreto - CCV & 17,53 & 0,00 & $\mathrm{E}$ & 0 & $\mathrm{E}$ & & $M_{1}=$ & $457.436,53$ \\
\hline Peso de Rocha & $-5,49$ & 0,00 & $T$ & 0 & $T$ & -1 & $\mathrm{M}_{2}=$ & $-24.911,86$ \\
\hline Empuxo de Água a Montante & 0,00 & $-12,03$ & 0 & $T$ & $T$ & -1 & $M_{3}=$ & $-90.235,34$ \\
\hline Subpressão & 6,29 & 0,00 & $\mathrm{~T}$ & 0 & $\mathrm{~T}$ & -1 & $M_{4}=$ & $-104.710,56$ \\
\hline Peso de água a Montante & 32,91 & 0,00 & $E$ & 0 & $E$ & 1 & $\mathrm{M}_{\mathrm{s}}=$ & $35.982,66$ \\
\hline Peso de Água a Jusante & $-23,06$ & 0,00 & $\mathrm{~T}$ & 0 & $\mathrm{~T}$ & -1 & $M_{6}=$ & $-44.615,20$ \\
\hline \multirow[t]{6}{*}{ Empuxo de Água a Jusante } & 0,00 & $-0,57$ & 0 & $\mathrm{E}$ & $\mathrm{E}$ & 1 & $M_{7}=$ & 344,69 \\
\hline & & & & & & & $M_{8}=$ & \\
\hline & & & & & & & $M_{g}=$ & \\
\hline & & & & & & & $M_{10}=$ & \\
\hline & & & & & & & $\mathrm{M}_{11}=$ & \\
\hline & & & & & & & & \\
\hline
\end{tabular}

\begin{tabular}{|c|c|c|c|c|c|c|c|c|}
\hline & & & & \multicolumn{5}{|c|}{ FLUTUAÇÃO - CSF } \\
\hline$\Sigma U=$ & $16641,457 \mathrm{kN}$ & $\sum M_{T}=$ & $821.944,55 \mathrm{kN} \cdot \mathrm{m}$ & $\frac{\Sigma V}{\sum U}=$ & 2,02 & $>$ & 1,3 & ok \\
\hline$\Sigma V-\Sigma U=$ & $17009,782 \mathrm{kN}$ & Momento Resultante & $825.065,95 \mathrm{kN} . \mathrm{m}$ & \multicolumn{5}{|c|}{ TOMBAMENTO - CST } \\
\hline$\sum \mathrm{T}_{\mathrm{i}, \text { MONTANTE }}=$ & $7499,216 \mathrm{kN}$ & & & $\frac{\sum \mathrm{M}_{\mathrm{E}}}{\sum \mathrm{M}_{\mathrm{T}}}=$ & 2,00 & $>$ & 1,5 & ок \\
\hline & & & & \multicolumn{5}{|c|}{ DESLIZAMENTO - CSDQ e CSD $D_{C}$} \\
\hline Força Resultante & $6894,005 \mathrm{kN}$ & & & 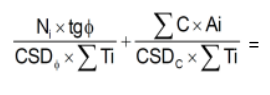 & 1,00 & $>$ & 1,0 & ок \\
\hline
\end{tabular}

Fonte: Do autor (2021). 


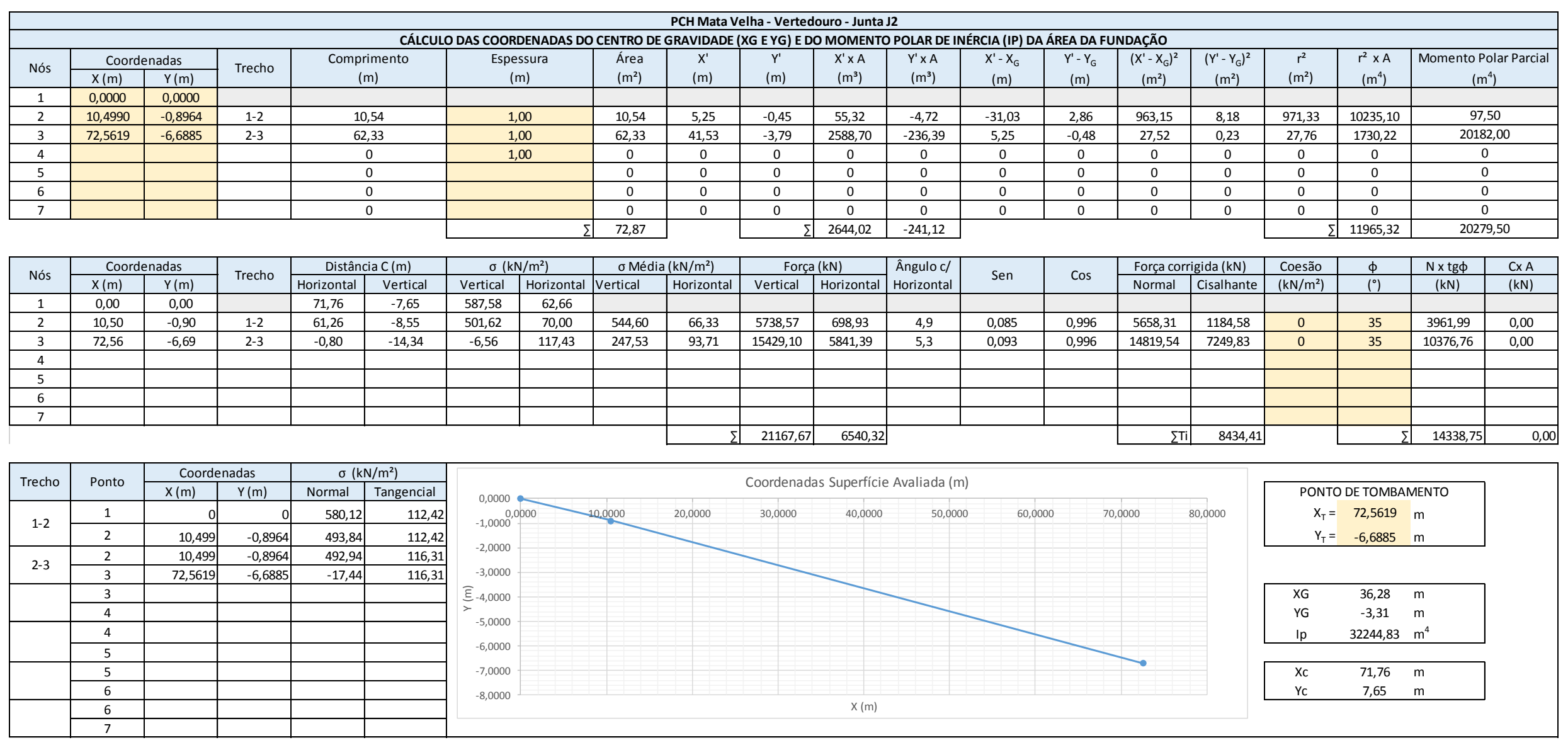

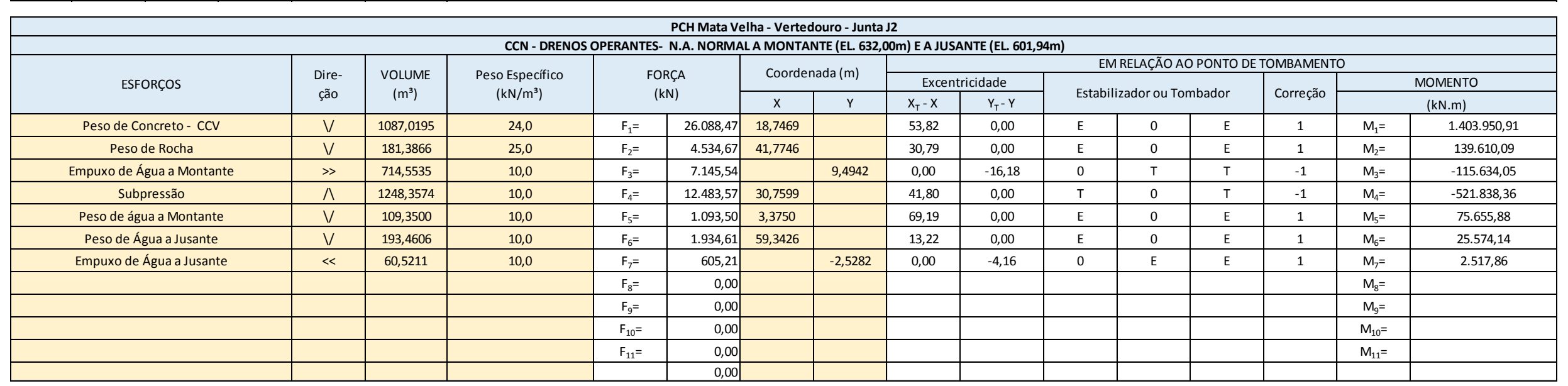

\begin{tabular}{|c|c|c|c|c|c|c|c|c|}
\hline \multirow{3}{*}{ ESFORÇOS } & \multicolumn{8}{|c|}{ EM RELAÇÃO AO CG DA FUNDAÇÃO } \\
\hline & \multicolumn{2}{|c|}{ Excentricidade } & \multirow{2}{*}{\multicolumn{3}{|c|}{ Estabilizador ou Tombador }} & \multirow{3}{*}{\begin{tabular}{|c|} 
Correção \\
1
\end{tabular}} & \multirow{2}{*}{\multicolumn{2}{|c|}{$\frac{\text { MOMENTO }}{(\mathrm{kN} \cdot \mathrm{m})}$}} \\
\hline & $x_{6}-x$ & $Y_{G}-Y$ & & & & & & \\
\hline Peso de Concreto - CCV & 17,54 & 0,00 & $\mathrm{E}$ & 0 & $\mathrm{E}$ & & $\mathrm{M}_{1}=$ & $457.519,00$ \\
\hline Peso de Rocha & $-5,49$ & 0,00 & $\mathrm{~T}$ & 0 & $\mathrm{~T}$ & -1 & $\mathrm{M}_{2}=$ & $-24.897,52$ \\
\hline Empuxo de Água a Montante & 0,00 & $-12,80$ & 0 & $\mathrm{~T}$ & $\mathrm{~T}$ & -1 & $\mathrm{M}_{3}=$ & $-91.484,72$ \\
\hline Subpressão & 5,52 & 0,00 & $\mathrm{~T}$ & 0 & $\mathrm{~T}$ & -1 & $\mathrm{M}_{4}=$ & $-68.961,91$ \\
\hline Peso de água a Montante & 32,91 & 0,00 & $\mathrm{E}$ & 0 & $E$ & 1 & $M_{5}=$ & $35.986,11$ \\
\hline Peso de Água a Jusante & $-23,06$ & 0,00 & $\mathrm{~T}$ & 0 & $\mathrm{~T}$ & -1 & $M_{6}=$ & $-44.609,09$ \\
\hline \multirow[t]{6}{*}{ Empuxo de Agua a Jusante } & 0,00 & $-0,78$ & 0 & $\mathrm{E}$ & $\mathrm{E}$ & 1 & $\mathrm{M}_{7}=$ & 472,46 \\
\hline & & & & & & & $\mathrm{M}_{8}=$ & \\
\hline & & & & & & & $\mathrm{M}_{9}=$ & \\
\hline & & & & & & & $\mathrm{M}_{10}=$ & \\
\hline & & & & & & & $\mathrm{M}_{11}=$ & \\
\hline & & & & & & & & \\
\hline
\end{tabular}

\begin{tabular}{|ccc|}
\hline Momento Resultante & $264.024,33$ & $\mathrm{kN} . \mathrm{m}$ \\
Alfa & 72,83 & \\
e & 11,92 & \\
e1 & 37,13 & \\
kv & 8,19 & \\
\hline
\end{tabular}

\begin{tabular}{|c|c|c|c|c|c|c|c|c|}
\hline \multirow[b]{2}{*}{$\Sigma V=$} & \multirow[b]{2}{*}{$33651,239 \mathrm{kN}$} & & & \multicolumn{5}{|c|}{ FLUTUAÇÃO - CSF } \\
\hline & & $\sum M_{T}=$ & $\begin{array}{r}1.647 .308,87 \mathrm{kN} . \mathrm{m} \\
637.472,41 \mathrm{kN} \cdot \mathrm{m}\end{array}$ & $\frac{\Sigma V}{\sum U}=$ & 2,70 & $>$ & 1,3 & ок \\
\hline$\Sigma V-\Sigma U=$ & $21167,665 \mathrm{kN}$ & Momento Resultante & $1.009 .836,46 \mathrm{kN} . \mathrm{m}$ & \multicolumn{5}{|c|}{ TOMBAMENTO - CST } \\
\hline$\sum T_{i, \text { MONTANTE }}=$ & $7145,535 \mathrm{kN}$ & & & $\frac{\sum \mathrm{M}_{\mathrm{E}}}{\sum \mathrm{M}_{\mathrm{T}}}=$ & 2,58 & $>$ & 1,5 & ок \\
\hline$\sum T_{i}$, USAANTE $=$ & $603,211 \mathrm{KN}$ & & & \multicolumn{5}{|c|}{ DESLIZAMENTO - CSD e CSD } \\
\hline Força Resultante & $\begin{array}{l}6540,324 \mathrm{kN} \\
22155,04 \mathrm{kN}\end{array}$ & & & $\frac{N_{1} \times \operatorname{tg} \phi}{\operatorname{CSD}_{b} \times \sum \pi}+\frac{\sum C_{1} \times A i}{\operatorname{CSD}_{c} \times \sum \pi}=$ & 1,13 & $>$ & 1,0 & ок \\
\hline
\end{tabular}

Fonte: Do autor (2021). 


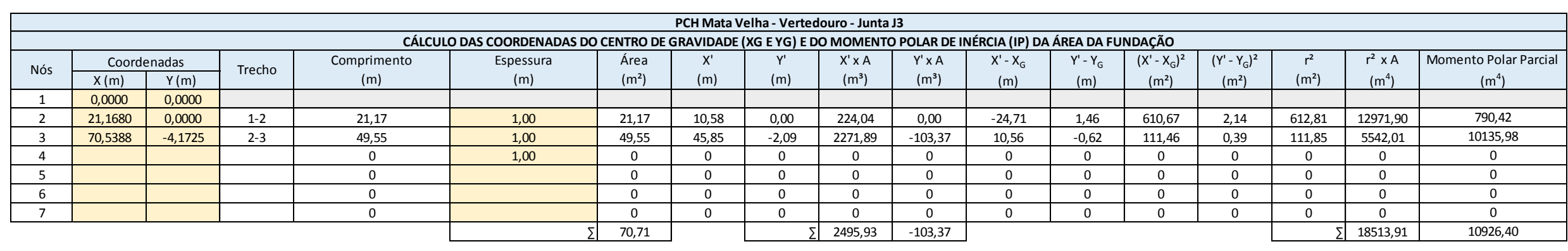

\begin{tabular}{|c|c|c|c|c|c|c|c|c|c|c|c|c|c|c|c|c|c|c|c|c|}
\hline \multirow{2}{*}{ Nós } & \multicolumn{2}{|c|}{ Coordenadas } & \multirow{2}{*}{ Trecho } & \multicolumn{2}{|c|}{ Distância C (m) } & \multicolumn{2}{|c|}{$\sigma\left(\mathrm{kN} / \mathrm{m}^{2}\right)$} & \multicolumn{2}{|c|}{$\sigma$ Média $\left(\mathrm{kN} / \mathrm{m}^{2}\right)$} & \multicolumn{2}{|c|}{ Força $(\mathrm{kN})$} & \multirow{2}{*}{$\begin{array}{l}\text { Ângulo c/ } \\
\text { Horizontal }\end{array}$} & \multirow{2}{*}{ Sen } & \multirow{3}{*}{$\cos$} & \multicolumn{2}{|c|}{ Força corrigida (kN) } & \multirow{2}{*}{$\begin{array}{l}\text { Coesão } \\
\left(\mathrm{kN} / \mathrm{m}^{2}\right)\end{array}$} & \multirow{3}{*}{$\begin{array}{l}\phi \\
\left({ }^{\circ}\right) \\
\end{array}$} & \multirow{2}{*}{$\frac{N \times \operatorname{tg} \phi}{(\mathrm{kN})}$} & \multirow{2}{*}{$\frac{\mathrm{C} \times \mathrm{A}}{(\mathrm{kN})}$} \\
\hline & $x(m)$ & $Y(m)$ & & Horizontal & Vertical & Vertical & Horizontal & Vertical & Horizontal & \begin{tabular}{l|l} 
Vertical \\
\end{tabular} & Horizontal & & & & Normal & Cisalhante & & & & \\
\hline 1 & 0,00 & 0,00 & & 63,75 & $-10,20$ & 494,40 & 79,10 & & & & & & & & & & & & & \\
\hline 2 & 21,17 & 0,00 & $1-2$ & 42,59 & $-10,20$ & 330,24 & 79,10 & 412,32 & 79,10 & 8728,00 & 1674,43 & 0,0 & 0,000 & 1,000 & 8728,00 & 1674,43 & 400 & 30 & 5039,11 & 8467,20 \\
\hline 3 & 70,54 & $-4,17$ & $2-3$ & $-6,79$ & $-14,37$ & $-52,62$ & 111,46 & 138,81 & 95,28 & 6877,72 & 4720,85 & 4,8 & 0,084 & 0,996 & 6455,73 & 5283,28 & 0 & 35 & 4520,35 & 0,00 \\
\hline 4 & & & & & & & & & & & & & & & & & & & & \\
\hline$\frac{5}{6}$ & & & & & & & & & & & & & & & & & & & & \\
\hline 7 & & & & & & & & & & & & & & & & & & & & \\
\hline & & & & & & & & & & 15605,72 & 6395,29 & & & & $\sum T i$ & 6957,71 & & & 9559,46 & 8467,20 \\
\hline
\end{tabular}

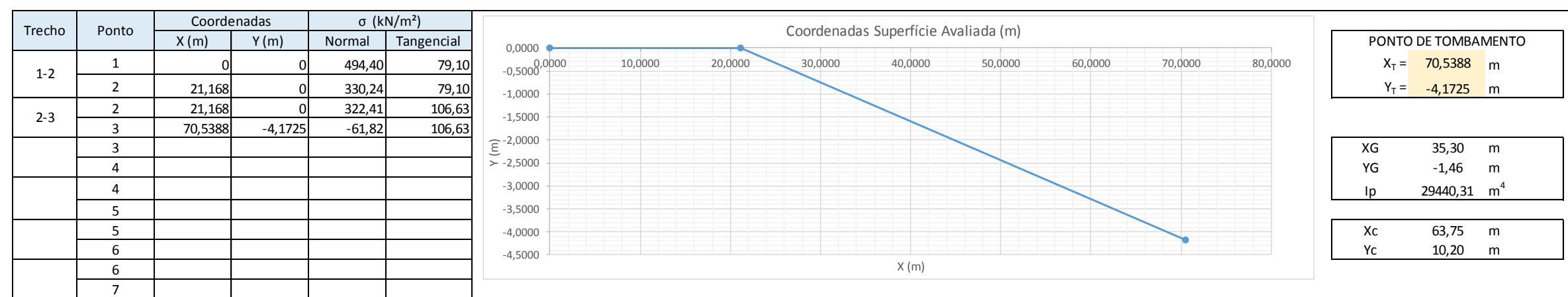

\begin{tabular}{|c|c|c|c|c|c|c|c|c|c|c|c|c|c|c|c|}
\hline \multicolumn{16}{|c|}{$\begin{array}{l}\text { PCH Mata Velha - Vertedouro - Junta } 33 \\
\end{array}$} \\
\hline \multirow{4}{*}{ ESFORÇOS } & & & CCN - DRENC & ERANT & V.A. NORMA & ALAMONT & UTE (EL. 632 & OM)EAJ & 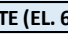 & & & & & & \\
\hline & \multirow{3}{*}{$\begin{array}{l}\text { Dire- } \\
\text { ção }\end{array}$} & \multirow{3}{*}{$\begin{array}{l}\text { VOLUME } \\
\left(\mathrm{m}^{3}\right)\end{array}$} & \multirow{3}{*}{$\begin{array}{l}\text { Peso Específico } \\
\left(\mathrm{kN} / \mathrm{m}^{3}\right)\end{array}$} & \multirow{3}{*}{\multicolumn{2}{|c|}{$\begin{array}{c}\text { FORÇA } \\
(\mathrm{kN})\end{array}$}} & \multirow{2}{*}{\multicolumn{2}{|c|}{ Coordenada $(\mathrm{m})$}} & \multirow{2}{*}{\multicolumn{2}{|c|}{ Excentricidade }} & \multirow{2}{*}{\multicolumn{4}{|c|}{ EM RELAÇÃO AO PONTO DE TOMBAMENT }} & \multirow{2}{*}{\multicolumn{2}{|c|}{ MOMENTO }} \\
\hline & & & & & & & & & & & & & & & \\
\hline & & & & & & \multirow{2}{*}{$\frac{x}{18,6982}$} & \multirow[t]{2}{*}{ Y } & \multirow{2}{*}{$\frac{X_{T}-X}{51,84}$} & \multirow{2}{*}{$\begin{array}{l}Y_{T}-Y \\
0,00\end{array}$} & \multicolumn{3}{|c|}{ Estabilizador ou Tombador } & \multirow{2}{*}{$\frac{\text { Correção }}{1}$} & \multicolumn{2}{|c|}{$(\mathrm{kN} . \mathrm{m})$} \\
\hline Peso de Concreto - CCV & $\mathrm{V}$ & 1096,1962 & 24,0 & $F_{1}=$ & $26.308,71$ & & & & & $\mathrm{E}$ & 0 & $\mathrm{E}$ & & $M_{1}=$ & $1.363 .859,25$ \\
\hline Peso de Rocha & $\mathrm{V}$ & 58,9460 & 25,0 & $\mathrm{~F}_{2}=$ & $1.473,65$ & 48,4685 & & 22,07 & 0,00 & $\mathrm{E}$ & 0 & $\mathrm{E}$ & 1 & $\mathrm{M}_{2}=$ & $32.523,90$ \\
\hline Empuxo de Água a Montante & $\gg$ & 679,8382 & 10,0 & $\mathrm{~F}_{3}=$ & $6.798,38$ & & 10,2051 & 0,00 & $-14,38$ & 0 & $T$ & $T$ & -1 & $\mathrm{M}_{3}=$ & $-97.744,42$ \\
\hline Subpressão & $\Lambda$ & 1500,2635 & 10,0 & $F_{4}=$ & $15.002,64$ & 28,2663 & & 42,27 & 0,00 & $T$ & 0 & $T$ & -1 & $M_{4}=$ & $-634.198,89$ \\
\hline Peso de água a Montante & V & 109,3500 & 10,0 & $F_{5}=$ & $1.093,50$ & 3,3750 & & 67,16 & 0,00 & $\mathrm{E}$ & 0 & $\mathrm{E}$ & 1 & $M_{5}=$ & $73.443,62$ \\
\hline Peso de Água a Jusante & V & 173,2492 & 10,0 & $F_{6}=$ & $1.732,49$ & 57,9145 & & 12,62 & 0,00 & $\mathrm{E}$ & 0 & $\mathrm{E}$ & 1 & $M_{6}=$ & $21.871,50$ \\
\hline \multirow[t]{5}{*}{ Empuxo de Água a Jusante } & $\ll$ & 40,3097 & 10,0 & $F_{7}=$ & 403,10 & & $-1,1795$ & 0,00 & $-2,99$ & 0 & $E$ & $\mathrm{E}$ & 1 & $\mathrm{M}_{7}=$ & $1.206,47$ \\
\hline & & & & $F_{9}=$ & 0,00 & & & & & & & & & $M_{9}=$ & \\
\hline & & & & $\mathrm{F}_{10}=$ & 0,00 & & & & & & & & & $M_{10}=$ & \\
\hline & & & & $\mathrm{F}_{11}=$ & 0,00 & & & & & & & & & $\mathrm{M}_{11}=$ & \\
\hline & & & & & 0,00 & & & & & & & & & & \\
\hline
\end{tabular}

\begin{tabular}{|c|c|c|c|c|c|c|c|c|}
\hline \multirow{3}{*}{ ESFORÇOS } & \multicolumn{8}{|c|}{ EM RELAÇÃO AO CG DA FUNDAÇÃO } \\
\hline & \multicolumn{2}{|c|}{ Excentricidade } & \multirow{2}{*}{\multicolumn{3}{|c|}{ Estabilizador ou Tombador }} & \multirow{3}{*}{$\begin{array}{c}\text { Correção } \\
1 \\
\end{array}$} & \multirow{2}{*}{\multicolumn{2}{|c|}{$\begin{array}{l}\text { MOMENTO } \\
\text { (kN.m) }\end{array}$}} \\
\hline & $x_{6}-x$ & $Y_{G}-Y$ & & & & & & \\
\hline Peso de Concreto - CCV & 16,60 & 0,00 & $\mathrm{E}$ & 0 & $\mathrm{E}$ & & $M_{1}=$ & $436.659,92$ \\
\hline Peso de Rocha & $-13,17$ & 0,00 & $\mathrm{~T}$ & 0 & $T$ & -1 & $\mathrm{M}_{2}=$ & $-19.412,03$ \\
\hline Empuxo de Água a Montante & 0,00 & $-11,67$ & 0 & $\mathrm{~T}$ & $T$ & -1 & $\mathrm{M}_{3}=$ & $-79.315,67$ \\
\hline Subpressão & 7,03 & 0,00 & $\mathrm{~T}$ & 0 & $T$ & -1 & $M_{4}=$ & $-105.460,16$ \\
\hline Peso de água a Montante & 31,92 & 0,00 & E & 0 & E & 1 & $M_{5}=$ & $34.905,33$ \\
\hline Peso de Água a Jusante & $-22,62$ & 0,00 & $\mathrm{~T}$ & 0 & $T$ & -1 & $M_{6}=$ & $-39.186,82$ \\
\hline \multirow[t]{6}{*}{ Empuxo de Água a Jusante } & 0,00 & $-0,28$ & 0 & $\mathrm{E}$ & E & 1 & $\mathrm{M}_{7}=$ & 113,77 \\
\hline & & & & & & & $M_{8}=$ & \\
\hline & & & & & & & $M_{9}=$ & \\
\hline & & & & & & & $M_{10}=$ & \\
\hline & & & & & & & $M_{11}=$ & \\
\hline & & & & & & & & \\
\hline
\end{tabular}

\begin{tabular}{|c|c|c|c|c|c|c|c|c|}
\hline \multirow[b]{2}{*}{$\Sigma V=$} & & & & \multicolumn{5}{|c|}{ FLUTUAÇÃO - CSF } \\
\hline & $15002,635 \mathrm{kN}$ & $\sum M_{T}=$ & $731.943,31 \mathrm{kN} . \mathrm{m}$ & $\frac{\Sigma V}{\Sigma U}=$ & 2,04 & $>$ & 1,3 & ок \\
\hline$\Sigma V-\Sigma U=$ & $15605,7158 \mathrm{kN}$ & Momento Resultante & $760.961,43 \mathrm{kN} . \mathrm{m}$ & \multicolumn{5}{|c|}{ TOMBAMENTO - CST } \\
\hline$\sum T_{i}$, MONTANE $=$ & $6798,382 \mathrm{kN}$ & & & $\frac{\sum M_{E}}{\sum M_{T}}=$ & 2,04 & $>$ & 1,5 & ок \\
\hline$\sum T_{i}$, USANTE $=$ & & & & \multicolumn{5}{|c|}{ DESLIZAMENTO - CSDQ e CSD $D_{c}$} \\
\hline Força Resultante & $6395,285 \mathrm{kN}$ & & & $\frac{N_{2} \times \operatorname{tg} \phi}{\operatorname{CSD}_{b} \times \sum \pi}+\frac{\sum \mathrm{C}_{x} \mathrm{Ai}}{\operatorname{CSD}_{\mathrm{c}} \times \sum \pi}=$ & 1,32 & $>$ & 1,0 & ок \\
\hline
\end{tabular}

Fonte: Do autor (2021). 


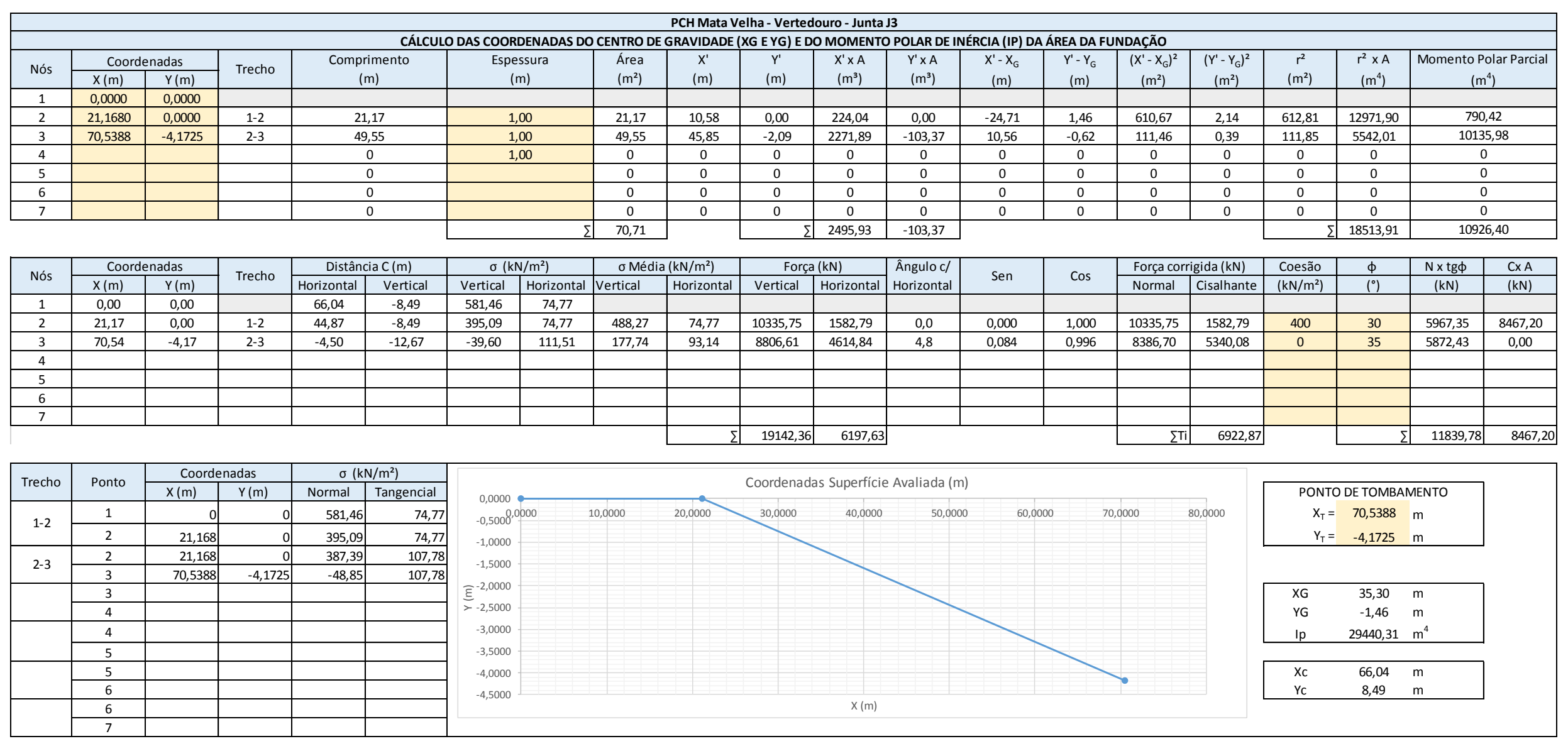

\begin{tabular}{|c|c|c|c|c|c|c|c|c|c|c|c|c|c|c|c|}
\hline \multicolumn{16}{|c|}{ PCH Mata Velha - Vertedouro - Junta J3 } \\
\hline \multirow{4}{*}{ ESFORÇOS } & & & CCN - DRENC & ERANTE & 1.A. NORMA & AMONTA & TE(EL. 632 , & n)EAJ & E(EL. 60 & & & & & & \\
\hline & \multirow{3}{*}{$\begin{array}{l}\text { Dire- } \\
\text { ção }\end{array}$} & \multirow{3}{*}{$\begin{array}{l}\text { VOLUME } \\
\left(\mathrm{m}^{3}\right)\end{array}$} & \multirow{3}{*}{$\begin{array}{l}\text { Peso Específico } \\
\left(\mathrm{kN} / \mathrm{m}^{3}\right)\end{array}$} & \multirow{3}{*}{\multicolumn{2}{|c|}{$\begin{array}{c}\text { FORÇA } \\
(\mathrm{kN})\end{array}$}} & \multirow{2}{*}{\multicolumn{2}{|c|}{ Coordenada $(\mathrm{m})$}} & \multicolumn{8}{|c|}{ EM RELAÇÃOO AO PONTO DE TOMBAMENTO } \\
\hline & & & & & & & & \multicolumn{2}{|c|}{ Excentricidade } & \multirow{2}{*}{\multicolumn{3}{|c|}{ Estabilizador ou Tombador }} & \multirow{2}{*}{ Correção } & \multirow{2}{*}{\multicolumn{2}{|c|}{$\frac{\text { MOMENTO }}{(\mathrm{kN} \cdot \mathrm{m})}$}} \\
\hline & & & & & & \multirow{2}{*}{\begin{tabular}{|l|}
$x$ \\
18,6982 \\
\end{tabular}} & \multirow[t]{2}{*}{$\mathrm{Y}$} & $x_{T}-x$ & $\mathrm{Y}_{T}-\mathrm{Y}$ & & & & & & \\
\hline Peso de Concreto - CCV & $\mathrm{V}$ & 1096,1962 & 24,0 & $\mathrm{~F}_{1}=$ & $26.308,71$ & & & 51,84 & 0,00 & $\mathrm{E}$ & 0 & $\mathrm{E}$ & 1 & $M_{1}=$ & $1.363 .859,25$ \\
\hline Empuxo de Água a Montante & $\gg$ & 660,0724 & 10,0 & $\mathrm{~F}_{3}=$ & $6.600,72$ & & 10,5511 & 0,00 & $-14,72$ & 0 & $\mathrm{~T}$ & $\mathrm{~T}$ & -1 & $M_{3}=$ & $-97.186,42$ \\
\hline Subpressão & $\Lambda$ & 1146,5987 & 10,0 & $F_{4}=$ & $\begin{array}{l}11.465,99 \\
\end{array}$ & 28,7913 & & 41,75 & 0,00 & $T$ & 0 & $T$ & -1 & $M_{4}=$ & $-478.676,29$ \\
\hline Peso de água a Montante & V & 109,3500 & 10,0 & $F_{5}=$ & \begin{tabular}{|l|}
$1.093,50$ \\
\end{tabular} & 3,3750 & & 67,16 & 0,00 & $\mathrm{E}$ & 0 & $\mathrm{E}$ & 1 & $M_{5}=$ & $73.443,62$ \\
\hline Peso de Água a Jusante & V & 173,2492 & 10,0 & $F_{6}=$ & $1.732,49$ & 57,9145 & & 12,62 & 0,00 & $\mathrm{E}$ & 0 & $\mathrm{E}$ & 1 & $M_{6}=$ & $21.871,50$ \\
\hline \multirow[t]{5}{*}{ Empuxo de Água a Jusante } & $\ll$ & 40,3097 & 10,0 & $F_{7}=$ & 403,10 & & $-1,1795$ & 0,00 & $-2,99$ & 0 & $\mathrm{E}$ & $\mathrm{E}$ & 1 & $M_{7}=$ & $1.206,47$ \\
\hline & & & & $F_{9}=$ & 0,00 & & & & & & & & & $M_{9}=$ & \\
\hline & & & & $F_{10}=$ & 0,00 & & & & & & & & & $\mathrm{M}_{10}=$ & \\
\hline & & & & $\mathrm{F}_{11}=$ & 0,00 & & & & & & & & & $\mathrm{M}_{11}=$ & \\
\hline & & & & & 0,00 & & & & & & & & & & \\
\hline
\end{tabular}

\begin{tabular}{|c|c|c|c|c|c|c|c|c|}
\hline \multirow{3}{*}{ ESFORÇOS } & \multicolumn{8}{|c|}{ EM RELAÇÃO AO CG DA FUNDAÇÃO } \\
\hline & \multicolumn{2}{|c|}{ Excentricidade } & \multirow{2}{*}{\multicolumn{3}{|c|}{ Estabilizador ou Tombador }} & \multirow{3}{*}{$\begin{array}{c}\text { Correção } \\
1 \\
\end{array}$} & \multirow{2}{*}{\multicolumn{2}{|c|}{$\begin{array}{l}\text { MOMENTO } \\
(\mathrm{kN.m})\end{array}$}} \\
\hline & $x_{6}-x$ & $Y_{G}-Y$ & & & & & & \\
\hline Peso de Concreto - CCV & 16,60 & 0,00 & $\mathrm{E}$ & 0 & $\mathrm{E}$ & & $M_{1}=$ & $436.659,92$ \\
\hline Peso de Rocha & $-13,17$ & 0,00 & $\bar{T}$ & 0 & $\bar{T}$ & -1 & $\mathrm{M}_{2}=$ & $-19.412,03$ \\
\hline Empuxo de Água a Montante & 0,00 & $-12,01$ & 0 & $\mathrm{~T}$ & $T$ & -1 & $\mathrm{M}_{3}=$ & $-79.293,48$ \\
\hline Subpressão & 6,50 & 0,00 & $T$ & 0 & $T$ & -1 & $M_{4}=$ & $-74.579,85$ \\
\hline Peso de água a Montante & 31,92 & 0,00 & $\mathrm{E}$ & 0 & $\mathrm{E}$ & 1 & $M_{5}=$ & $34.905,33$ \\
\hline Peso de Água a Jusante & $-22,62$ & 0,00 & $T$ & 0 & $T$ & -1 & $M_{6}=$ & $-39.186,82$ \\
\hline \multirow[t]{6}{*}{ Empuxo de Água a Jusante } & 0,00 & $-0,28$ & 0 & $\mathrm{E}$ & $\mathrm{E}$ & 1 & $M_{7}=$ & 113,77 \\
\hline & & & & & & & $M_{8}=$ & \\
\hline & & & & & & & $M_{9}=$ & \\
\hline & & & & & & & $M_{10}=$ & \\
\hline & & & & & & & $M_{11}=$ & \\
\hline & & & & & & & & \\
\hline
\end{tabular}

\begin{tabular}{|c|c|c|c|c|c|c|c|c|}
\hline & & & & \multicolumn{5}{|c|}{ FLUTUAÇÃO - CSF } \\
\hline$\Sigma U=$ & $11465,987 \mathrm{kN}$ & $\sum M_{T}=$ & $575.862,71 \mathrm{kN} . \mathrm{m}$ & $\frac{\Sigma V}{\sum U}=$ & 2,67 & $>$ & 1,3 & ок \\
\hline$\Sigma V-\Sigma U=$ & $19142,3638 \mathrm{kN}$ & Momento Resultante & $917.042,02 \mathrm{kN} . \mathrm{m}$ & \multicolumn{5}{|c|}{ TOMBAMENTO - CST } \\
\hline$\sum \mathrm{T}_{\mathrm{i}, \text { MONTANTE }}=$ & $6600,724 \mathrm{kN}$ & & & $\frac{\sum \mathrm{M}_{\mathrm{E}}}{\sum \mathrm{M}_{\mathrm{T}}}=$ & 2,59 & $>$ & 1,5 & ок \\
\hline$\sum T_{i}$, USANTE $=$ & & & & \multicolumn{5}{|c|}{ DESLIZAMENTO - CSDQ e CSD $D_{c}$} \\
\hline Força Resultante & $6197,627 \mathrm{kN}$ & & & $\frac{\mathrm{N} \times \operatorname{tg} \phi}{\mathrm{CSD}_{b} \times \sum \pi}+\frac{\sum \mathrm{C} \times \mathrm{Ai}}{\mathrm{CSD}_{\mathrm{c}} \times \sum \pi}=$ & 1,55 & $>$ & 1,0 & ок \\
\hline
\end{tabular}

Fonte: Do autor (2021). 


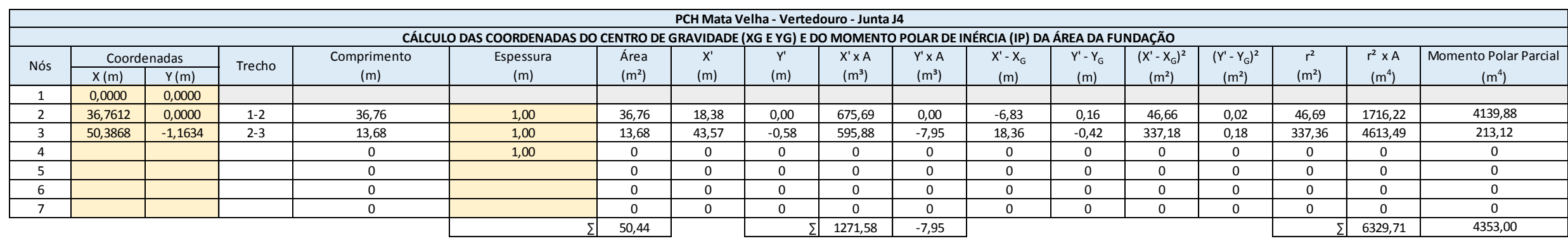

\begin{tabular}{|c|c|c|c|c|c|c|c|c|c|c|c|c|c|c|c|c|c|c|c|c|}
\hline \multirow{2}{*}{ Nós } & \multicolumn{2}{|c|}{ Coordenadas } & \multirow{2}{*}{ Trecho } & \multicolumn{2}{|c|}{ Distância C (m) } & \multicolumn{2}{|c|}{$\sigma\left(\mathrm{kN} / \mathrm{m}^{2}\right)$} & \multicolumn{2}{|c|}{$\sigma$ Média $\left(\mathrm{kN} / \mathrm{m}^{2}\right)$} & \multicolumn{2}{|c|}{ Força $(\mathrm{kN})$} & \multirow{2}{*}{$\begin{array}{l}\text { Ângulo c/ } \\
\text { Horizontal }\end{array}$} & \multirow{2}{*}{ Sen } & \multirow{2}{*}{$\cos$} & \multicolumn{2}{|c|}{ Força corrigida $(\mathrm{kN})$} & \multirow{2}{*}{$\frac{\text { Coesão }}{\left(\mathrm{kN} / \mathrm{m}^{2}\right)}$} & \multirow{2}{*}{$\phi$} & \multirow{2}{*}{$\frac{\mathrm{N} \times \operatorname{tg} \phi}{(\mathrm{kN})}$} & \multirow{2}{*}{$\begin{array}{l}\mathrm{CXA} \\
(\mathrm{kN})\end{array}$} \\
\hline & $x(m)$ & $Y(m)$ & & Horizontal & Vertical & Vertical & Horizontal & Vertical & Horizontal & Vertical & Horizontal & & & & Normal & Cisalhante & & & & \\
\hline 1 & 0,00 & 0,00 & & 98,72 & $-24,51$ & 475,93 & 118,15 & & & & & & & & & & & & & \\
\hline 2 & 36,76 & 0,00 & $1-2$ & 61,96 & $-24,51$ & 298,71 & 118,15 & 387,32 & 118,15 & 14238,23 & 4343,17 & 0,0 & 0,000 & 1,000 & 14238,23 & 4343,17 & 400 & 30 & 8220,45 & 14704,48 \\
\hline 3 & 50,39 & $-1,16$ & $2-3$ & 48,34 & $-25,67$ & 233,02 & 123,75 & 265,87 & 120,95 & 3635,75 & 1654,01 & 4,9 & 0,085 & 0,996 & 3481,86 & 1957,32 & 0 & 35 & 2438,02 & 0,00 \\
\hline 4 & & & & & & & & & & & & & & & & & & & & \\
\hline 5 & & & & & & & & & & & & & & & & & & & & \\
\hline 6 & & & & & & & & & & & & & & & & & & & & \\
\hline 7 & & & & & & & & & & & & & & & & & & & & \\
\hline & & & & & & & & & $\Sigma$ & \begin{tabular}{|l|l|}
17873,98 \\
\end{tabular} & 5997,18 & & & & $\sum \mathrm{TT}_{\mathrm{i}}$ & 6300,49 & & 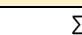 & \begin{tabular}{|l|}
10658,47 \\
\end{tabular} & \begin{tabular}{|l|l}
14704,48 \\
\end{tabular} \\
\hline
\end{tabular}

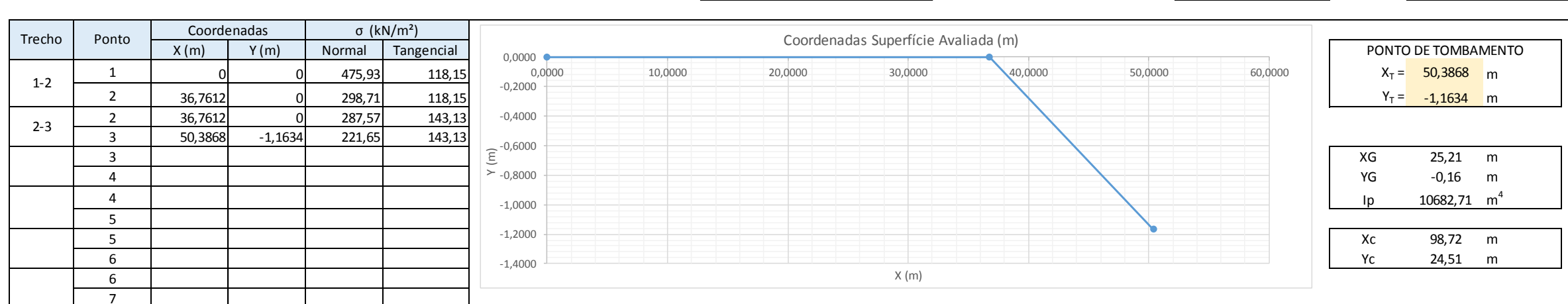

\begin{tabular}{|c|c|c|c|c|c|c|c|c|c|c|c|c|c|c|c|}
\hline \multirow{2}{*}{\multicolumn{16}{|c|}{$\begin{array}{l}\text { PCH Mata Velha - Vertedouro - Junta J4 } \\
\text { CCN - DRENOS INOPERANTES- N.A. NORMAL A MONTANTE (ELL. 632,00m) E A JUSANTE (EL. 601,94m) }\end{array}$}} \\
\hline & & & & & & & & & & \multirow{2}{*}{\multicolumn{6}{|c|}{ EM RELAÇÃO AO PONTO DE TOMBAMENTO }} \\
\hline \multirow{2}{*}{ ESFORÇOS } & \multirow{3}{*}{$\begin{array}{l}\text { Dire- } \\
\text { ção }\end{array}$} & \multirow{3}{*}{$\begin{array}{l}\text { VOLUME } \\
\left(\mathrm{m}^{3}\right)\end{array}$} & \multirow{3}{*}{$\begin{array}{l}\text { Peso Especifico } \\
\left(\mathrm{kN} / \mathrm{m}^{3}\right)\end{array}$} & \multirow{3}{*}{\multicolumn{2}{|c|}{$\begin{array}{l}\text { FORÇA } \\
(\mathrm{kN})\end{array}$}} & \multirow{2}{*}{\multicolumn{2}{|c|}{ Coordenada $(\mathrm{m})$}} & \multirow{2}{*}{\multicolumn{2}{|c|}{ Excentricidade }} & & & & & & \\
\hline & & & & & & & & & & \multirow{2}{*}{\multicolumn{3}{|c|}{ Estabilizador ou Tombador }} & \multirow[t]{2}{*}{ Correç̃a } & \multirow{2}{*}{\multicolumn{2}{|c|}{$\frac{\text { MOMENTO }}{(\mathrm{kN} . \mathrm{m})}$}} \\
\hline Peso de Concreto - CCV & & & & & & \multirow{2}{*}{$\frac{X}{18,6982}$} & \multirow{2}{*}{$\mathrm{Y}$} & \multirow{2}{*}{\begin{tabular}{|l|}
$X_{T}-X$ \\
31,69
\end{tabular}} & \multirow{2}{*}{$\frac{Y_{T}-Y}{0,00}$} & & & & & & \\
\hline Peso de Concreto - CCV & $\mathrm{V}$ & 1096,1962 & 24,0 & $F_{1}=$ & $26.308,71$ & & & & & $\mathrm{E}$ & 0 & $\mathrm{E}$ & 1 & $M_{1}=$ & $833.686,15$ \\
\hline Peso de Rocha & V & 8,2402 & 25,0 & $F_{2}=$ & 206,01 & 44,1582 & & 6,23 & 0,00 & $\mathrm{E}$ & 0 & $\mathrm{E}$ & 1 & $M_{2}=$ & $1.283,12$ \\
\hline Empuxo de Água a Montante & $\gg$ & 617,2817 & 10,0 & $\mathrm{~F}_{3}=$ & $6.172,82$ & & 11,3929 & 0,00 & $-12,56$ & 0 & $T$ & $T$ & -1 & $M_{3}=$ & $-77.507,74$ \\
\hline Subpressão & $\Lambda$ & 1005,2522 & 10,0 & $\mathrm{~F}_{4}=$ & $10.052,52$ & 19,0297 & & 31,36 & 0,00 & $\mathrm{~T}$ & 0 & $\mathrm{~T}$ & -1 & $M_{4}=$ & $-315.217,94$ \\
\hline Peso de água a Montante & $\mathrm{V}$ & 109,3500 & 10,0 & $F_{5}=$ & $1.093,50$ & 3,3750 & & 47,01 & 0,00 & $\mathrm{E}$ & 0 & $\mathrm{E}$ & 1 & $M_{5}=$ & $51.407,40$ \\
\hline Peso de Água a Jusante & $\mathrm{V}$ & 31,8290 & 10,0 & $F_{6}=$ & 318,29 & 45,8213 & & 4,57 & 0,00 & $\mathrm{E}$ & 0 & $\mathrm{E}$ & 1 & $M_{6}=$ & $1.453,15$ \\
\hline \multirow[t]{6}{*}{ Empuxo de Água a Jusante } & $\ll$ & 17,5635 & 10,0 & $\mathrm{~F}_{7}=$ & 175,64 & & 0,8122 & 0,00 & $-1,98$ & 0 & $\mathrm{E}$ & $\mathrm{E}$ & 1 & $\mathrm{M}_{7}=$ & 346,98 \\
\hline & & & & $F_{8}=$ & 0,00 & & & & & & & & & $\mathrm{M}_{8}=$ & \\
\hline & & & & $F_{9}=$ & 0,00 & & & & & & & & & $M_{9}=$ & \\
\hline & & & & $\mathrm{F}_{10}=$ & 0,00 & & & & & & & & & $\mathrm{M}_{10}=$ & \\
\hline & & & & $F_{11}=$ & 0,00 & & & & & & & & & $\mathrm{M}_{11}=$ & \\
\hline & & & & & 0,00 & & & & & & & & & & \\
\hline
\end{tabular}

\begin{tabular}{|c|c|c|c|c|c|c|c|c|c|c|c|}
\hline \multirow{3}{*}{ ESFORŞOS } & \multicolumn{8}{|c|}{ EM RELAÇÃO AO CG DA FUNDAÇÃO } & \multirow{4}{*}{$\begin{array}{l}\text { Momento Resultante } \\
\text { Alfa }\end{array}$} & \multirow{4}{*}{$\begin{array}{c}51.498,94 \\
71,45\end{array}$} & \multirow[b]{3}{*}{$\mathrm{kN} \cdot \mathrm{m}$} \\
\hline & \multicolumn{2}{|c|}{ Excentricidade } & \multirow{2}{*}{\multicolumn{3}{|c|}{ Estabilizador ou Tombador }} & \multirow{3}{*}{$\begin{array}{c}\text { Correção } \\
1\end{array}$} & \multirow{2}{*}{\multicolumn{2}{|c|}{$\begin{array}{l}\text { MOMENTO } \\
(\mathrm{kN} . \mathrm{m}) \\
\end{array}$}} & & & \\
\hline & $x_{6}-x$ & $Y_{G}-Y$ & & & & & & & & & \\
\hline Peso de Concreto - CCV & 6,51 & 0,00 & $E$ & 0 & $\mathrm{E}$ & & $M_{1}=$ & $171.355,66$ & & & \\
\hline Peso de Rocha & $-18,95$ & 0,00 & $T$ & 0 & $T$ & -1 & $\mathrm{M}_{2}=$ & $-3.903,12$ & e & 2,73 & \\
\hline Empuxo de Água a Montante & 0,00 & $-11,55$ & 0 & $T$ & $T$ & -1 & $\mathrm{M}_{3}=$ & $-71.299,87$ & e1 & 77,54 & \\
\hline Subpressão & 6,18 & 0,00 & $T$ & 0 & $T$ & -1 & $M_{4}=$ & $-62.142,35$ & $\mathrm{kv}$ & 4,82 & \\
\hline Peso de água a Montante & 21,84 & 0,00 & $\mathrm{E}$ & 0 & $\mathrm{E}$ & 1 & $M_{s}=$ & $23.878,18$ & & & \\
\hline Peso de Água a Jusante & $-20,61$ & 0,00 & $T$ & 0 & $T$ & -1 & $M_{6}=$ & $-6.559,90$ & & & \\
\hline \multirow[t]{5}{*}{ Empuxo de Agua a Jusante } & 0,00 & $\begin{array}{l}-0,97 \\
-0,97\end{array}$ & $\frac{1}{0}$ & $\mathrm{E}$ & $\mathrm{E}$ & 1 & $\mathrm{M}_{7}=$ & 170,35 & & & \\
\hline & & & & & & & $M_{8}=$ & & & & \\
\hline & & & & & & & $M_{9}=$ & & & & \\
\hline & & & & & & & $\mathrm{M}_{11}=$ & & & & \\
\hline & & & & & & & & & & & \\
\hline
\end{tabular}

\begin{tabular}{|c|c|c|c|c|c|c|c|c|}
\hline \multirow{2}{*}{$\Sigma V=$} & \multirow{2}{*}{$27926,5038 \mathrm{kN}$} & \multirow{2}{*}{$\sum M_{\varepsilon}=$} & & \multicolumn{5}{|c|}{ FLUTUAÇÃO - CSF } \\
\hline & & & $\begin{array}{l}888.176,81 \mathrm{kN} \cdot \mathrm{m} \\
392.725,68 \mathrm{kN} \cdot \mathrm{m}\end{array}$ & $\frac{\sum V}{\sum U}=$ & 2,78 & $>$ & 1,3 & ок \\
\hline$\Sigma V-\Sigma U=$ & $17873,9818 \mathrm{kN}$ & Momento Resultante & $495.451,13 \mathrm{kN} . \mathrm{m}$ & \multicolumn{5}{|c|}{ TOMBAMENTO - CST } \\
\hline \multirow{2}{*}{$\sum \mathrm{T}_{\mathrm{i}, \text { USAANE }}=$} & $\begin{array}{l}6172,817 \mathrm{kN} \\
175,635 \mathrm{kN}\end{array}$ & & & $\frac{\sum M_{E}}{\sum M_{T}}=$ & 2,26 & $>$ & 1,5 & ок \\
\hline & & & & \multicolumn{5}{|c|}{ DESLIZAMENTO - CSD e CSD ${ }_{c}$} \\
\hline Força Resultante & $\begin{array}{l}5997,182 \mathrm{kN} \\
18853,26 \mathrm{kN}\end{array}$ & & & $\frac{N \times \operatorname{tg} \phi}{\operatorname{CSD}_{b} \times \sum \pi_{i}}+\frac{\sum \mathrm{C} \times A i}{\operatorname{CSD}_{c} \times \sum \pi}=$ & 1,91 & $>$ & 1,0 & ок \\
\hline
\end{tabular}

Fonte: Do autor (2021). 


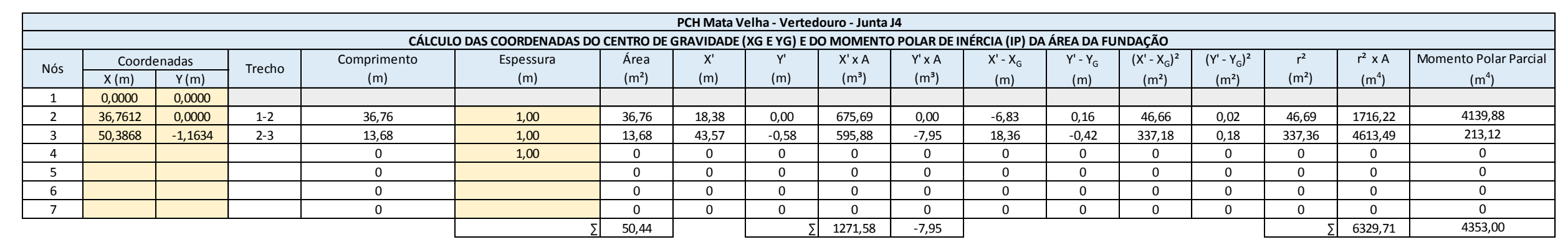

\begin{tabular}{|c|c|c|c|c|c|c|c|c|c|c|c|c|c|c|c|c|c|c|c|c|}
\hline \multirow{2}{*}{ Nós } & \multicolumn{2}{|c|}{ Coordenadas } & \multirow{2}{*}{ Trecho } & \multicolumn{2}{|c|}{ Distância C (m) } & \multicolumn{2}{|c|}{$\sigma\left(\mathrm{kN} / \mathrm{m}^{2}\right)$} & \multicolumn{2}{|c|}{$\sigma$ Média $\left(\mathrm{kN} / \mathrm{m}^{2}\right)$} & \multicolumn{2}{|c|}{ Força $(\mathrm{kN})$} & \multirow{2}{*}{$\begin{array}{l}\begin{array}{l}\text { Angulo c/ } \\
\text { Horizontal }\end{array} \\
\end{array}$} & \multirow{2}{*}{ Sen } & \multirow{2}{*}{$\cos$} & \multicolumn{2}{|c|}{ Força corrigida (kN) } & \multirow{2}{*}{$\begin{array}{l}\text { Coesão } \\
\left(\mathrm{kN} / \mathrm{m}^{2}\right)\end{array}$} & \multirow{2}{*}{$\begin{array}{l}\phi \\
\left(^{\circ}\right) \\
\end{array}$} & \multirow{2}{*}{$\frac{\mathrm{N} \times \operatorname{tg} \phi}{(\mathrm{kN})}$} & \multirow{2}{*}{$\begin{array}{l}\mathrm{CXA} \\
(\mathrm{kN})\end{array}$} \\
\hline & $X(m)$ & $Y(m)$ & & \begin{tabular}{|l|} 
Horizontal \\
\end{tabular} & Vertical & Vertical & Horizontal & Vertical & Horizontal & Vertical & \begin{tabular}{|l|} 
Horizontal \\
\end{tabular} & & & & Normal & Cisalhante & & & & \\
\hline 1 & 0,00 & 0,00 & & \begin{tabular}{|l|}
93,07 \\
\end{tabular} & $-19,86$ & 551,16 & 117,60 & & & & & & & & & & & & & \\
\hline 2 & 36,76 & 0,00 & $1-2$ & 56,31 & $-19,86$ & 333,46 & 117,60 & 442,31 & 117,60 & 16259,79 & 4323,02 & 0,0 & 0,000 & 1,000 & 16259,79 & 4323,02 & 400 & 30 & 9387,60 & 14704,48 \\
\hline 3 & 50,39 & $-1,16$ & $2-3$ & 42,68 & $-21,02$ & 252,76 & 124,49 & 293,11 & 121,04 & 4008,34 & 1655,28 & 4,9 & 0,085 & 0,996 & 3852,99 & 1990,28 & 0 & 35 & 2697,89 & 0,00 \\
\hline 4 & & & & & & & & & & & & & & & & & & & & \\
\hline 5 & & & & & & & & & & & & & & & & & & & & \\
\hline 6 & & & & & & & & & & & & & & & & & & & & \\
\hline 7 & & & & & & & & & & & & & & & & & & & & \\
\hline & & & & & & & & & & 20268,14 & 5978,30 & & & & $\sum \pi \mathrm{i}$ & 6313,30 & & & 12085,49 & 14704,48 \\
\hline
\end{tabular}

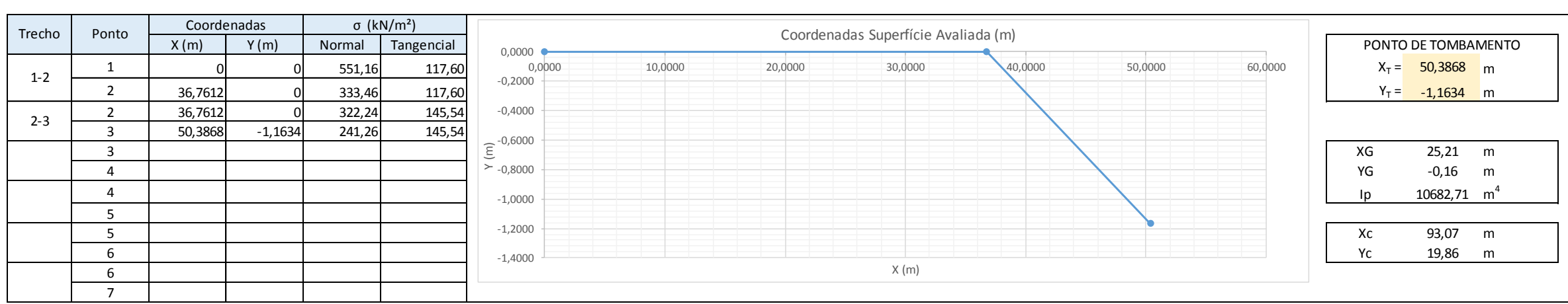

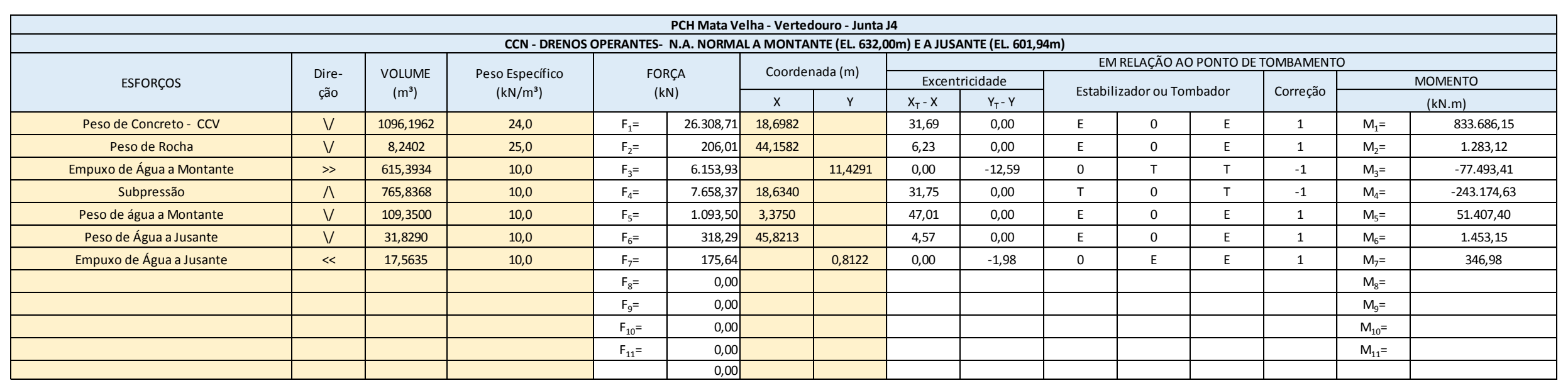

\begin{tabular}{|c|c|c|c|c|c|c|c|c|}
\hline \multirow{3}{*}{ ESFORÇOS } & \multicolumn{8}{|c|}{ EM RELAÇÃO AO CG DA FUNDAÇÃO } \\
\hline & \multicolumn{2}{|c|}{ Excentricidade } & \multirow{2}{*}{\multicolumn{3}{|c|}{ Estabilizador ou Tombador }} & \multirow{2}{*}{ Correção } & \multirow{2}{*}{\multicolumn{2}{|c|}{$\begin{array}{l}\frac{\text { MOMENTO }}{(\mathrm{kN} \cdot \mathrm{m})} \\
\end{array}$}} \\
\hline & $x_{6}-x$ & $Y_{G}-Y$ & & & & & & \\
\hline Peso de Concreto - CCV & 6,51 & 0,00 & $\mathrm{E}$ & 0 & $\mathrm{E}$ & 1 & $\mathrm{M}_{1}=$ & $171.355,66$ \\
\hline Peso de Rocha & $-18,95$ & 0,00 & $\mathrm{~T}$ & 0 & $\mathrm{~T}$ & -1 & $\mathrm{M}_{2}=$ & $-3.903,12$ \\
\hline Empuxo de Água a Montante & 0,00 & $-11,59$ & 0 & $\mathrm{~T}$ & $\mathrm{~T}$ & -1 & $M_{3}=$ & $-71.304,53$ \\
\hline Subpressão & 6,58 & 0,00 & $\mathrm{~T}$ & 0 & $\mathrm{~T}$ & -1 & $M_{4}=$ & $-50.372,67$ \\
\hline Peso de água a Montante & 21,84 & 0,00 & $E$ & 0 & $\mathrm{E}$ & 1 & $M_{5}=$ & $23.878,18$ \\
\hline Peso de Água a Jusante & $-20,61$ & 0,00 & $\mathrm{~T}$ & 0 & $\mathrm{~T}$ & -1 & $\mathrm{M}_{6}=$ & $-6.559,90$ \\
\hline \multirow[t]{5}{*}{ Empuxo de Agua a Jusante } & 0,00 & $-0,97$ & 0 & $E$ & $\mathrm{E}$ & 1 & $\mathrm{M}_{7}=$ & 170,35 \\
\hline & & & & & & & $\mathrm{M}_{8}=$ & \\
\hline & & & & & & & $M_{9}=$ & \\
\hline & & & & & & & $\mathrm{M}_{10}=$ & \\
\hline & & & & & & & $\mathrm{M}_{11}=$ & \\
\hline & & & & & & & & \\
\hline
\end{tabular}

\begin{tabular}{|c|c|c|c|c|c|c|c|c|}
\hline \multirow[b]{2}{*}{$\Sigma V=$} & \multirow[b]{2}{*}{$27926,5038 \mathrm{kN}$} & \multirow[b]{2}{*}{$\sum M_{E}=$} & \multirow[b]{2}{*}{$888.176,81 \mathrm{kN} . \mathrm{m}$} & \multicolumn{5}{|c|}{ FLUTUAÇÃ̃ - CSF } \\
\hline & & & & $\Sigma \mathrm{V}$ & \multirow[b]{2}{*}{3,65} & \multirow[b]{2}{*}{$>$} & \multirow[b]{2}{*}{1,3} & \multirow[b]{2}{*}{ ок } \\
\hline$\Sigma U=$ & $7658,368 \mathrm{kN}$ & $\sum M_{T}=$ & $320.668,04 \mathrm{kN} \cdot \mathrm{m}$ & $\sum U$ & & & & \\
\hline$\Sigma V-\Sigma U=$ & $20268,1358 \mathrm{kN}$ & Momento Resultante & $567.508,77 \mathrm{kN} . \mathrm{m}$ & \multicolumn{5}{|c|}{ TOMBAMENTO - CST } \\
\hline$\sum T_{i}$, MONTANTE $=$ & $6153,934 \mathrm{kN}$ & & & $\frac{\sum \mathrm{M}_{\mathrm{E}}}{\sum \mathrm{M}_{\mathrm{T}}}=$ & 2,77 & $>$ & 1,5 & ок \\
\hline$\sum T_{i}$, USANTE $=$ & $1 / 3,635 \mathrm{KN}$ & & & \multicolumn{5}{|c|}{ DESLIZAMENTO - CSD $\phi$ e CSD } \\
\hline Força Resultante & $5978,299 \mathrm{kN}$ & & & $\frac{\mathrm{N} \times \operatorname{tg} \phi}{\mathrm{CSD}_{b} \times \sum \pi}+\frac{\sum \mathrm{C} \times \mathrm{Ai}}{\mathrm{CSD}_{\mathrm{c}} \times \sum \pi}=$ & 2,05 & $>$ & 1,0 & ок \\
\hline
\end{tabular}

Fonte: Do autor (2021). 